\title{
Hydraulic Research \\ in the United States
}

1964

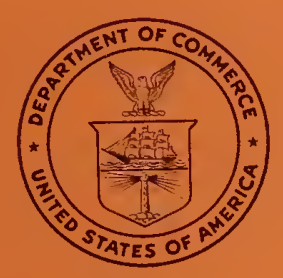

United States Department of Commerce

National Bureau of Standards

Miscellaneous Publication 261 


\section{THE NATIONAL BUREAU OF STANDARDS}

The National Bureau of Standards is a principal focal point in the Federal Government for assuring maximum application of the physical and engineering sciences to the advancement of technology in industry and commerce. Its responsibilities include development and maintenance of the national stand. ards of measurement, and the provisions of means for making measurements consistent with those standards; determination of physical constants and properties of materials; development of methods for testing materials, mechanisms, and structures, and making such tests as may be necessary, particularly for government agencies; cooperation in the establishment of standard practices for incorporation in codes and specifications; advisory service to government agencies on scientific and technical problems; invention and development of devices to serve special needs of the Government; assistance to industry, business, and consumers in the development and acceptance of commercial standards and simplified trade practice recommendations; administration of programs in cooperation with United States business groups and standards organizations for the development of international standards of practice; and maintenance of a clearinghouse for the collection and dissemination of scientific, technical, and engineering information. The scope of the Bureau's activities is suggested in the following listing of its four Institutes and their organizational units.

Institute for Basic Standards. Electricity. Metrology. Heat. Radiation Physics. Mechanics. Applied Mathematics. Atomic Physics. Physical Chemistry. Laboratory Astrophysics.* Radio Standards Laboratory: Radio Standards Physics; Radio Standards Engineering.** Office of Standard Reference Data.

Institute for Materials Research. Analytical Chemistry. Polymers. Metallurgy. Inorganic Materials. Reactor Radiations. Cryogenics. ${ }^{* *}$ Office of Standard Reference Materials.

Central Radio Propagation Laboratory.** Ionosphere Research and Propagation. Troposphere and Space Telecommunications. Radio Systems. Upper Atmosphere and Space Physics.

Institute for Applied Technology. Textiles and Apparel Technology Center. Building Research. Industrial Equipment. Information Technology. Performance Test Development. Instrumentation. Transport Systems. Office of Technical Services. Office of Weights and Measures. Office of Engineering Standards. Office of Industrial Services.

* NBS Group, Joint Institute for Laboratory Astrophysics at the University of Colorado.

** Located at Boulder, Colorado. 


\title{
Hydraulic Research in the United States
}

1964

\author{
(Including Contributions from Canadian Laboratories)
}

Edited by Helen K. Middleton

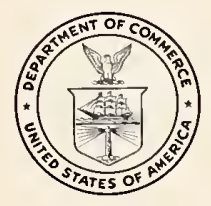

National Bureau of Standards Miscellaneous Publication 261

Issued August 14, 1964

For sale by the Superintendent of Documents, U.S. Government Printing Office Washington, D.C., 20402 - Price \$1.25 
Library of Congress Catalog Card Number : 34-3323 


\section{FOREWORD}

The information contained in this publication was complied from reports by the various hydraulic and hydrologic laboratories in the United States and Canada. The cooperation of these agencies is greatly appreciated. The National Bureau of Standards cannot assume responsibility for the completeness of this publication. We must depend upon reporting laboratorles for the completeness of the coverage of their own programs, as well as upon new laboratories engaged in hydraulics to bring their activities to our attention.

Projects are numbered and the number once assigned is repeated for identification purposes until a project is completed. The numbers 4893 and above refer to projects reported for the first time. All projects are in active state, unless otherwise noted under $(f)$.

The National Bureau of Standards does not maintain a flile of reports or detailed information regarding the research projects reported by other organizations. Such information may be obtained from the correspondent listed under (c) or immediately following the title of the organization reporting the work. It is of course understood that any laboratory submitting reports on its work will be willing to supply information to properly qualified inquirers.

A similar bulletin, "Hydraulic Research," complled and published by the International Association for Hydraulic Research, contains information on hydraulic research being conducted in foreign countries. This bulletin is edited by Professor H. J. Schoemaker, Director of the Hydraulic Laboratory at the Technical University of Delft, Netherlands, and Secretary of the International Association for Hydraulic Research. Coples may be obtalned from the Secretary at $\$ 6.00$ each (postage included). 
Foreword...................................... 111

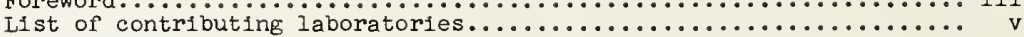

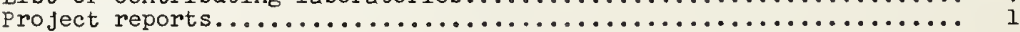

subject index......................................... 205

Key to Projects

(a) Number and title of project

b) Project conducted for

c) Correspondent

(d) Nature of project

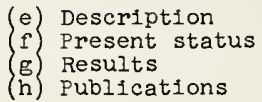


ARIZONA, UNIVERSITY OF

Dept. of C1vil Engrg., Tucson, Ar1z., 85721

Dr. Emmett M. Laursen, Head

ARKANSAS, UNIVERSITY OF

Agrlcultural Expt. Station, Fayetteville, Ark.

Prof. Kyle Engler, Head

Agricultural Engineering Dept.

ARKANSAS, UNIVERSITY OF

C1vil Engineering Dept., Fayetteville, Ark.

Prof. L. R. Heiple, Head

BOLT BERANEK AND NEWMAN, INC.

50 Moulton Street, Cambridge, Mass. 02138

Dr. John E. Ffowes Williams

BROOKLYN, POLYTECHNIC INSTITUTE OF

333 Jay Street, Brooklyn, New York 11201

Prof. Matthew W. Stewart, civil Engrg.

CALIFORNIA INSTITUTE OF TECHNOLOGY

Englneering Division, Pasadena 4, Calif

Prof. Milton S. Plesset, Applied Mechanics

CALIFORNIA INSTITUTE OF TECHNOLOGY

Hydrodynamics Laboratory, Pasadena, Cal1f.

Professor T. Y. Wu

CALIFORN IA INSTITUTE OF TECHNOLOGY

W. M. Keck Laboratory of Hydraulics and

Water Resources, Pasadena 4, Calif.

Dr. Vito A. Vanon1, Professor of Hydraulics

CALIFORNIA, UNIVERSITY OF

College of Agriculture, Davis, Cal1f.

Prof. Robert H. Burgy, Acting Chairman

Department of Irrigation

CALIFORNIA, UNIVERSITY OF

College of Engineering, Berkeley 4, Calif.

Prof. J. W. Johnson, Hydraullc Engineering

CALIFORNIA, UNIVERSITY OF

Dept. of Naval Architecture, Berkeley 4, Cal1f. Prof. H. A. Schade, Cha1rman

CARNEGIE INSTITUTE OF TECHNOLOGY

Dept. of Clvil Engrg., P1ttsburgh, Pa. 15213

Dr. T. E. Stelson, Head

CATHOLIC UNIVERSITY OF AMERICA, THE

Dept. of Clvil Engineering, Wash., D. C. 20017

Prof. Frank A. Biberstein, Head

COASTAL ENGINEERING RESEARCH CENTER (see U.S. Government)

COLORADO STATE UNIVERSITY

Hydraulics Laboratory

Clvil Engrg. Section, Fort Collins, Colo. 80521

Dr. D. B. Simons, Acting Chief

COLORADO, UNIVERSITY OF

Engineering Experiment Sta., Boulder, Colo.

Dr. K. D. Timmerhaus, Director

CORNELL AERONAUTICAL LABORATORY, INC.

Applied Mechanics Department

P. O. Box 235, Buffalo, N. Y. 14221

Dr. Irving C. Statler, Head

CORNELL UNIVERSITY

School of C1vil Englneering, Dept. of

Hydraulics and Hydraul1c Engrg., Ithaca, N. Y. Dr. J. A. Liggett

DAVID TAYLOR MODEL BASIN (see U.S. Government)

DELAWARE, UNIVERSITY OF

Dept. of C1vil Englneering, Newark, Del.

Dr. D. L. Dean, Chairman

DEIAWARE, UNIVERSITY OF

Dept. of Mech. Engineering, Newark, Del.

Dr. James P. Hartnett, Chairman

1 FLORIDA, UNIVERSITY OF

Engineering and Industrial Exp. Station

Coastal Engineerlng Lab., Galnesville, Fla. Dr. Per Bruun, Head

5

GEORGIA INSTITUTE OF TECHNOLOGY

Englneering Experlment Sta., Atlanta, Ga. 30332

Mr. R. E. St1emke, Director

6 GRUMMAN A IRCRAFT ENGTNEERING CORP.

Research Dept., Fluid Mechanics Section

Bethpage, L. I., New York

96

HOUSTON, UNIVERSITY OF

Dept. of Chemical Engineering

Cullen Boulevard, Houston 4, Texas

6 Prof. A. E. Dukler

IDAHO, UNIVERSITY OF

Engrg. Experiment Sta., Moscow, Idaho 83843

6 Dean Allen S. Janssen, Director

IIT RESEARCH INSTITUTE

10 West 35th St., Ch1cago 13, Ill.

7 Mr. H. B. Karplus

ILLINOIS STATE WATER SURVEY DIVISION

Box 232, Urbana, Illino1s

6 Mr. Wililam C. Ackermann, Chlef

ILLINOIS STATE WATERWAYS DIVISION

Dept. of Public Works and Bullding

201 West Monroe St., Springfield, Ill. 62706

$9 \mathrm{Mr}$. John C. Gulllou, chief Waterway Engr.

ILLINOIS, UNIVERSITY OF

Dept. of Agricultural Engrg., Urbana, Ill.

Dr. Frank B. Lanham, Head

ITINOIS, UNIVERSTTY OF

C1vil Engineering Dept., Urbana, Ill.

Dr. V. T. Chow, Prof. Hydraulic Engineering

ILLINOIS, UNIVERSITY OF

Dept. of Theoretical and Applied Mechanics

214 Talbot Laboratory, Urbana, Ill.

16 Prof. T. J. Dolan, Head

IOWA INSTITUTE OF HYDRAULIC RESEARCH

University of Iowa, Iowa City, Iowa

17 Dr. Hunter Rouse, Director

IOWA STATE UNIVERSITY

Dept. of Agricultural Engrg., Ames, Iowa

Dr. Clarence Bockhop, Head

IOWA STATE UNIVERSITY

18 Dept. of Agronomy, Ames, Iowa

Prof. Don Kirkhar

IOWA UNIVERSITY

Iowa C1ty, Iowa (see. Iowa Institute of

24 Hydraul1c Research)

JOHNS HOPKINS UNIVERSITY, THE

Applied Physics Lab., S1lver Spring, Md. 20910

96 Mr. R. E. Gibson, Director

JOHNS HOPKINS UNIVERSITY, THE

School of Englneering, Baltimore 18, Md.

Dr. John C. Geyer, Chairman

25 Dept. of Sanitary Engrg, and water Resources

KANSAS, UNIVERSITY OF

Dept. of Engrg. Mechanics and Aerospace Engrg.

Lawrence, Kansas

Dr. Kenneth C. Deemer, Chairman

25 IEHIGH UNIVERSITY

Department of Clvil Engineering

Fritz Engineering Lab., Bethlehem, $\mathrm{Pa}$.

26

Prof. W. J. Eney, Head of Dept. and Laboratory

LOUISIANA STATE UNIVERSITY AND A AND M COLIEGE Agricultural Engrg. Dept., Baton Rouge 3, La.

Mr. Harold T. Barr, Head 
MASSACHUSETTS INSTITUTE OF TECHNOLOGY

Dept. of Civil and Sanitary Engineering

Cambridge 39, Mass.

Dr. Arthur T. Ippen, Head, Hydrodynamics Lab.

MASSACHUSETTS INSTITUTE OF TECHNOLOGY

Dept. of Mechanical Englneering

Cambridge 39, Mass.

Prof. Ascher H. Shapiro, In Charge

Fluid Mechanics Division

MASSACHUSETTS, UNIVERSITY OF

School of Englneering, Amherst, Mass.

Prof. E. E. Lindsey, Acting Dean

MICHIGAN, UNIVERSITY OF

Dept. of Civil Engineering

320 W. Engrg. Bldg., Ann Arbor, Mich. 48104

Prof. E. F. Brater

MINNESOTA, UNIVERSITY OF

Minneapolis, Minn. (see St. Anthony Falls

Hydraulic Laboratory).

MINNESOTA, UNIVERSITY OF

Agricultural Expt. Station, St. Paul 1, Minn.

Prof. A. J. Schwantes, Head

MONTANA STATE COLIEGE

Agricultural Expt. Sta., Bozeman, Mont. 59715

Mr. Charles C. Bowman, Head

Agricultural Engineering Dept.

NEBRASKA, UNIVERSITY OF

Hydrodynamics Laboratory

Dept. of Engineering Mechanics

Lincoln 8, Nebraska

Dr. T. Sarpkaya

NEW YORK UNIVERSITY

Carpenter Sanitary Engrg. Research Lab.

New York 53, New York

Dr. WIlliam E. Dobbins, Director

NEW YORK UNIVERSITY

Dept. of Chem1cal Engrg., Bronx 53, N. Y.

Prof. John Happel, Chalrman

NEW YORK UNIVERSITY

College of Engineering

Dept. of Meteorology and Oceanography

University Heights, New York 53, N. Y.

NORTH CAROLINA STATE OF THE UNIVERSITY OF

NORTH CAROLINA

Dept. of Engrg. Research, Rale1gh, N. C.

Prof. N. W. Connor, Director, Engrg. Research

NORTH DAKOTA STATE UNIVERSITY

Agricultural Engrg. Dept., Fargo, No. Dak.

$\mathrm{Mr}$. W. J. Promersberger, Chalman

NORTHWESTERN UNIVERSITY

The Technological Institute, Evanston, Ill.

Dean Harold B. Gotaas

NOTRE DAME, UNIVERSITY OF

School of Engineering, Notre Dame, Ind. 46556

Dr. Norman R. Gay, Dean

OHIO AGRICULTURAL EXPERIMENT STATION

Dept. of Agricultural Engrg., Wooster, ohio 43210

Mr. R. E. Stewart, Chalman

OHIO AGRICULTURAL EXPERIMENT STATION

Dept. of Agronomy, Wooster, Oh10 43210

Mr. G. W. Volk, Chalman

OKLAHOMA STATE UNIVERSITY

Agricultural Engrg. Dept., St1llwater, Okla. 74075

Prof. E. W. Schroeder, Head

OREGON STATE COLIEGE

Hydraulics Lab., Dept. of Civil Engineering

Corvallis, oregon

Dr. Charles E. Behlke

PENNSYLVANIA STATE UNIVERSITY

Dept. of Civil Engrg., Hydraulies Laboratory

University Park, Pennsylvania 16802

Prof. Sam shulits, Head

PENNSYLVANIA STATE UNIVERSITY

Ordnance Research Lab., University Park, Pa. 16801

Dr. John C. Johnson, Director

PRINCETON UNIVERSITY

School of Engineerling and Applied Sclence

Princeton, New Jersey

Prof. Lucien M. Brush, Jr.

PURDUE UNIVERSITY

54 Lafayette, Ind. 47907

Prof. George E. Spencer, Head

PURDUE UNIVERSITY

55 Dept. of Agronomy, Lafayette, Ind. 47907

Dr. J. P. Peterson, Head

PURDUE UNIVERSITY

Chemical Engrg. Dept., Lafayette, Ind. 47907

Dr. Brage Golding, Head

PURDUE UNIVERSITY

C1v1l Engrg. Dept., Lafayette, Ind. 47907

Prof. K. B. Woods, Head

PURDUE UNIVERSITY

School of Electrical Engrg., Lafayette, Ind. 47907

D. F. Jones, Head

PURDUE UNIVERSITY

Jet Propulsion Center, Lafayette, Ind. 47907

Dr. Maurice J. Zucrow, Director

PURDUE UNIVERSITY

School of Mechanical Engineering

Lafayette, Ind. 47907

Dr. R. J. Grosh, Head

59 PURDUE UNIVERSITY

School of Mech. Engrg., Automat1c Control Lab.

W. Lafayette, Ind. 47907

Dr. Rufus oldenburger, Head

57 ST. ANTHONY FALLS HYDRAULIC LABORATORY

University of Minnesota

Miss. River at Third Ave., S. E.

Minneapolis, Minn. 55455

58 Prof. Edward Silberman, Acting Director

SCRIPPS INSTITUTION OF OCEANOGRAPHY

University of California San Diego

Ia Jolla, Calif. 92038

59 The Director

SOUTH CAROIINA, UNIVERSITY OF

C1v1l Engrg. Dept., Columbia, S. C. 29201

Dr. Harold Flinsch, Head

SOUTHWEST RESEARCH INSTITUTE

Dept. of Mechanical Sciences

San Antonio, Texas 78206

59 Dr. H. Norman Abramson, Director

STANFORD UNIVERSTTY

Dept. of Civil Engineering, Stanford, Calif.

60 Prof. Ray K. Linsley, Exec. Head

Hydraulic Laboratory

STEVENS INSTITUTE OF TECHNOLOGY

Davidson Laboratory

711 Hudson St., Hoboken, New Jersey

Dr. J. P. Bresiln, Director

61 ROBERT TAGGART INCORPORATED

400 Arlington Blvd., Falls Church, Va.

Mr. Robert Taggart

TEXAS A AND M COLEEGE

of oceanography

college station, Texas

Dr. Dale F. Le1pper, Head

TEXAS, UNIVERSITY OF

Dept. of C1vil Engrg., Austin 12, Texas

Dr. Walter L. Moore, Directing Head

THERM ADVANCED RESEARCH, INC.

100 Hudson Circle, Ithaca, N. Y.

Dr. A. Ritter, President 
UTAH STATE UNIVERSITY

Engineering Expt. Sta., Logan, Utah 84321

Dr. Vaughn E. Hansen, Director

VIDYA DIVISION, Itek Corp.

Applied Mechanics Department

1450 Page M1ll Road, Palo Alto, Cal1f. 94304

Mr. S. B. Spangler, Mgr.

WASHINGTON STATE UNIVERSITY

The R. I. Albrook Hydraulic Lab., Pullman, Wash.

Dr. E. Roy Tinney, Head

WASH INGTON, UNIVERSITY OF

Dept. Of Civil Engrg., Seattle, wash. 98105

Prof. Charles H. Norris, Chalman

WASHINGTON, UNIVERSITY OF

Fisheries Research Inst1tute, Seattle 5, Wash.

Dr. William F. Royce, Director

U. S. ARMY ENGINEER WATERWAYS EXPERIMENT STATION (see U. S. Government)

WEBB INSTITUTE OF NAVAL ARCHITECTURE

Crescent Beach Road

Glen Cove, I. I., New York 11542

Mr. Edward V. Lewis, Asst. to the Pres.

WISCONSIN, UNIVERSITY OF

Hydraulics and Sanitary Engrg. Laboratories

Dept. of Civil Engrg., Madison, Wis. 53706

Dr. Armo T. Lenz, Chaírman

WOODS HOLE OCEANOGRAPHIC INSTITUTION

Woods Hole, Mass.

Dr. Paul M. Fye, Director

WORCESTER POLYTECHNIC INSTITUTE

Alden Hydraul ic Laboratory

Worcester, Mass. 01609

Prof. I. J. Hooper, Director

\section{U. S. GOVERNMENT AGENCIES}

DEPARTMENT OF AGRICUITURE

AGRICULTURAL RESEARCH SERVICE, SOIl and

Water Conservation Research Division

CORN BELT BRANCH

108 Solls Bldg., St. Paul, Minn.

Dr. C. A. Van Doren, Branch Chief

NORTHEAST BRANCH

Plant Industry Station, Beltsville, Md.

Mr. W. W. Pate, Branch Chief

NORTHERN PIAINS BRANCH

323 South College Avenue, P. O. Box 758

Fort Collins, Colorado

Dr. C. E. Evans, Branch Chief

NORTHWEST BRANCH

306 No. 5th St., Box 2724 , Bolse, Idaho

Dr. J. S. Robins, Branch Ch1ef

SOUTHERN BRANCH

Univ. of Georgia, Box 1309, Athens, Ga.

Mr. Russell Woodburn, Branch Ch1ef

SOUTHERN PLAINS BRANCH

220 Urban Bldg., 804 Ryan st., Amar1llo, Tex.

Dr. J. R. Johnston, Branch Chief

SOUTHWEST BRANCH

3730 Elizabeth St., Box 2325, Riverside, Calif. Mr. W. W. Donnan, Chief

FOREST SERVICE

CENTRAL STATES FOREST EXPERIMENT STATION

111 old Federal Bldg., Columbus 15, Ohio

Mr. R. D. Lane, Director

INTERMOUNTAIN FOREST AND RANGE EXPT. STATION

Forest Service Bldg., Ogden, Utah

Mr. Joseph F. Pechanec, Director
85 LAKE STATES FOREST EXPT. STATION

St. Paul Campus, University of Minn.

St. Paul 1, Minn.

Dr. Murlyn B. Dickerman, Director
97

89
NORTHEASTERN FOREST EXPERIMENT STATION

Dr. Ralph W. Marquis, Director

NORTHERN FOREST EXPERIMENT STATION

Mr. Richard M. Hurd, Director

PACIFIC NORTHWEST FOREST AND RANGE EXPT. STA.

Mr. Philip A. Brieglab, Director

PACIFIC SOUTHWEST FOREST AND RANGE EXPT. STA.

Mr. John R. McGulre, Dírector

ROCKY MOUNTAIN FOREST AND RANGE EXPT. STA.

221 Forestry Bldg., Fort Collins, Colo.

Mr. Raymond Price, Director

SOUTHEASTERN FOREST EXPERIMENT STATION

P. O. Box 2570, A sheville, N. C. 28802

Dr. Thos. F. Mclintock, Director

SOUTHERN FOREST EXPERIMENT STATION

T-10210 Federal Bldg., 701 Loyola Ave.

New Orleans, La. 70113

Mr. W. M. Zillgitt, Director

DEPARTMENT OF THE ARMY, CORPS OF ENGINEERS

COASTAL ENGINEERING RESEARCH CENTER

5201 Little Falls Road, N. W.

washington, D. C. 20016

The Director

U. S. ARMY ENGINEER DISTRICT, PORTLAND

628 Pittock Block, Portland, Oregon 97205

The District Engineer

U. S. ARMY ENGINEER DISTRICT, ST. PAUL

1217 U. S. Post office and Customhouse

st. Paul 1 , Minn.

The District Engineer

U. S. ARMY ENGTNEER WATERWAYS EXPT. STATION

P. 0. Box 631, V1cksburg, MIss. 39181

The Director

\section{DEPARTMENT OF COMMERCE}

BUREAU OF PUBLIC ROADS

Div. of Hydraulic Research, Wash., D. C. 20235

Mr. Carl F. Izzard, Chlef

NATIONAL BUREAU OF STANDARDS

Fluid Mechanics Section, Wash., D. C. 200234

Dr. G. B. Schubauer, Chief

WEATHER BUREAU

Hydrologic Services Division

Washington, D. C. 20235

Mr. William E. Hiatt, Chief

DEPARTMENT OF THE INTERIOR

GEOLOGICAI SURVEY

. Whosh., D. C. 20242

Dr. Luna B. Leopold, Chief Hydraulic Engineer

BUREAU OF MINES

Morgantown Coal Research Center, P. O. Box 880

Collins Ferry Road, Morgantown, W. Va.

Dr. L. L. Hirst, Research Director

BUREAU OF RECIAMATION

Division of Engineering Laboratories

Denver Federal Center, Denver, Colo. 80225

$\mathrm{Mr}$. Grant Bloodgood, Chief Engineer

DEPARTMENT OF THE NAVY

DAVID TAYLOR MODEL BASIN

Washington, D. C. 20007

The Commanding officer and Director 
U. S. NAVAI BOILER AND TURBINE LABORATORY

Naval Base, Philadelphia 12, Pa.

The Director

U. S. NAVAL ORDNANCE LABORATORY

White Oak, Silver Spring, Md. 20910

The Commander

U. S. NAVAL ORDNANCE TEST STATION

$3203 \mathrm{E}$. Foothill Boulevard

Pasadena 8, Calif.

The Commander

OFFICE OF NAVAL RESEARCH

Fluid Dynamics Branch, Wash., D. C. 20360

Mr. Ralph D. Cooper, Head

TENNESSIE VALIEY AUTHORITY

Engineering Laboratory, Box 37, Norris, Tenn.

Mr. Rex A. Elder, Director

TENNESSEE VALLEY AUTHORITY

Hydraulic Data Branch, Knoxville, Tenn. 37902

Mr. James W. Beverage, Chief

CANADIAN IABORATORIES

H. G. ACRES AND COMPANY, ITD. Niagara Falls, Canada

Mr. I. W. McCaig, Hydraulic Engineer

ALBERTA, UNIVERSITY OF

Department of Civil Engrg., Edmonton, Canada

Prof. T. Blench, Head

BRITISH COLUNBIA, UNIVERSITY OF

Hydraulic Iab., Vancouver 8, Canada

Prof. J. H. Muir, Head

Dept. of Civil Engineering
(

Prof. Raymond Boucher, Head

189

189

197

620 University Ave., Toronto 2, Canada

Mr. J. B. Bryce, Hydraulic Engineer

LASALLE HYDRAULIC LABORATORY

0250 St. Patrick street

LaSalle, P. Q., Canada

191

Mr. E. Pariset, Director

MANITOBA, UNIVERSITY OF

Dept. of Civil Engrg., Winnipeg, Canada

192

MCGILI UNIVERSITY

Dept. of Civil Engrg. and Applied Mechanics

194 2, P. Q., Canada

Dr. A. J. Reynolds

NATIONAL RESEARCH COUNCIL

Division of Mechanical Engineering

Montreal Road, Ottawa 2, Canada

Dr. D. C. MacPhail, Director

ONTARIO AGRICULTURAL COLLEGE

Dept. of Engineering Science, Guelph, Canada

Prof. C. E. G. Downing, Head

QUEEN'S UNIVERSITY

203

Dept. of Civil Engrg., Kingston, Ontario, Canada

197

Dr. A. Brebner, Chairman

TORONTO, UNIVERSITY OF

Dept. of Mechanical Engrg., Toronto 5, Canada

203 


\section{UNIVERSITY OF ARIZONA.}

(4619) A STUDY OF THE MECHANICS OF UNSATURATED FLOW OF WATER IN SOILS.

(b) Agricultural Experiment Station.

(c) Dr. D. D. Evans, Dept. of Agricultural Chemistry and Solls, Univ. of Arizona, Tucson, Arizona.

(d) Laboratory Investigation.

(e) An effort is being made to discover all the physical processes occurring during soll water movement.

(g) The movement of a liquid water flow through solls has been shown to consist of no less than five distinct processes: viscous flow of the liquid phase, evaporation of water at the liquid flow, combined diffusion and viscous flow of water vapor ahead of the advancing liquid, sorption of water vapor by the medium, and cyclic heat flow due to thermal gradients and evaporation. A method of distinguishing liquid from vapor movement of water in solls was developed.

(h) "Temperature Fluctuations at a Wetting Front II. The Effect of Initial Water Content of the Medium on the Magnitude of the Temperature Fluctuations, "Duwayne M. Anderson, Garrison Sposito, and A. Linville. Soll Sc1. Amer. Proc. 27:367-369, 1963. "Temperature Fluctuations at a wetting Front III. Apparent Activation Energies for Water movement in the Iiquid and Vapor Phases," Duwayne M. Anderson, A. Linville, and Garrison Sposito. Soll Sci. Soc. Amer. Proc. (in press).

"Rate of Water Vapor Adsorption by Degassed Arizona Bentonite," Duwayne M. Anderson, and Garrison Sposito. Nature 199:1085-1086, 1963.

(4620) EFFECT OF CROP COVER ON EFFICIENCY OF SPRINKIER IRRIGATION UNDER VARYING CLIMATIC AND OPERATING CONDITIONS.

(b) Agricultural Experiment Station.

(c) Mr. Kenneth R. Frost, Department of Agricultural Engineering, Univ. of Arizona, Tuscon, Arlzona.

(d) Laboratory for theory and design.

(e) Precise water balance of growing crops under sprinkler application of irrigation water. Crops are grown in a tank of soll 12 feet in diameter and 2 feet deep. Instrumentation permits measurement of loss or gain of 0.005 inches of water on the area of the tank. Measurements permit evaluation of loss or gain of water from dew, rain, irrigation, evaporation, and transpiration on crops at any stage of growth and as functions of ambient atmospheric conditions.

(g) Evapotranspiration during sprinkling is approxinately equal to that during nonsprinkling periods since evaporation from wet follage replaces nomal transpiration. Daily evapotranspiration ranges from 6-8 times the one-hour evapotranspiration at the period of peak rates.

cloud cover reduces evapotranspiration by one-third from that at full-run under the same vapor pressure deficit.

(h) "Factors Affecting Evapotranspiration Losses During Sprinkling," by K. R. Frost. Transactions of the American Society of Agricultural Engineers, Vol. 7, 1964 (in press).

(4621) SPRINKIER IRRIGATION STUDIES UNDER ARID SOUTHWESTERN CONDITIONS.

(b) Agricultural Experiment Station.

(c) Mr. Kenneth R. Frost, Department of Agricuitural Engineering, Univ. of Arizona, Tuscon, Arizona.

(d) Field investigation for design data.

(e) Investigation of the use of sprinkler application of irrigation water in production of Arizona crops. Irrigation efficlencles under sprinkling as compared to efficiencies under surface applications. Irrigation scheduling and system design for sprinkler application of water. Crop ylelds per unit of land and per unit of water as functions of method of water application, soll type, irrigation schedules, and crop species and variety.

(g) Fleld tests on citrus, cotton, grains, and legumes indicate increased crop production per unit of water applied when water is applied by sprinklers rather than by surface methods. Results vary with crop and soll texture. On coarse textured solls water savings of $50 \%$ have been achleved by sprinkling.

(h) "Sprinkler Irrigation," H. C. Schwalen and K. R. Frost, Arizona Ägricultural Experiment Station, Bulletin No. A-24, 1963. "Twelve Years of Sprinkler Irrigation Research," K. R. Frost, Progressive Agriculture in Arizona 15 (1): 12-13, 1963.

(4622) GROUND WATER SUPPLIES.

(b) Agricultural Experiment Station, The Univ. of Arlzona; City of Tucson; and the Pima County.

(c) Prof. Harold C. Schwalen, Department of Agricultural Engineering, Univ. of Arizona, Tucson, Arizona.

(e) Detailed continuing groundwater inventory of selected basins in Arizona including at present the Santa Cruz from Nogales to Red Rock, Avra, Altar, Little Chino, Reddington Area of the San Pedro. Groundwater contour maps are prepared annually. Speciflc yields storage coefficients and transmissibilities are determined from well tests. An electric analog of the Tucson groundwater basin is being developed.

(g) Groundwater elevation data has been developed for all areas studied. Volumetric unwatering estimates have been prepared. Water balance estimates have been prepared for the Tucson Metropolitan, sahuarita Districts, and Cortaro Districts. Open files are maintained from which current ground water level data is avallable for any location in the area studied.

(h) "Upper Santa Cruz Valley", H. C. Schwalen, Water Resources Report No. 12, Annual Report on Groundwater in Arizona. Spring 1962 to Spring 1963. (in press) Arizona State Land Department, 1963 .

"Avra-Marana Area", H. C. Schwalen, Water Resources Report No. 12, Annual Report on Groundwater in Arizona. Spring 1962 to Spring 1963. (in press) Arizona State Land Department, 1963.

"Chino Valley", H. C. Schwalen, water Resources Report No. 12, Annual Report on Groundwater in Arizona. Spring 1962 to Spring 1963. (in press) Arizona State Land Department, 1963.

(4623) CHARACTERISTICS OF SEGMENTAL ORIFICES.

(b) Departmental.

(c) Dr. E. M. Laursen, Department of Civil Engineering, Univ, of Arizona, Tucson, Ariz.

(d) Laboratory investigation for development.

(e) The segment of a circle as a metering device has some advantages. The discharge and loss characteristics of such a constriction in a plpe was studied.

(f) Completed.

(g) The discharge and loss coefficients as a function of the relative size and the Reynolds number were determined.

(h) "Characteristics of Segmental Orifices," by Norman H. Perry, M.S. Thesis, Dept. of Civil Engineering, The University of Arlzona, 1963.

(4624) HYDROLOGIC CHARACTERISTICS OF A GROUNDWATER BASIN 
(b) City of Tucson and Pima County through a cooperative agreement with the Agricultural Engineering Department, Arizona Agricultural Experiment station.

(c) Mr. John Ferris, Department of Geology, Univ. of Arizona, Tucson, Arizona.

(d) Analytical, laboratory, and field investigations for development, operation, design and theory, for Doctoral dissertation.

(e) Attempts are being made to determine the hydrologic characteristics - specific yield and/or storage coefficient and transmissibility -- of the groundwater basin in the Santa cruz Valley near Tucson, Arizona. Well tests are being made at sites where observation wells are available. Water budget analyses are being used in connection with mathematical models. A passive element electric analog model is being developed.

(g) Well tests made during the past two years indicate that realistic values of specific yield and/or storage coefficlent are not obtained from such tests in the Santa cruz Valley. Values of transmissibility are more consistent and reasonable.

\section{(4625) CRITICAL TRACTIVE FORCE OF UNIFORM SANDS.}

(b) Departmental in cooperation with the U. S. Geological Survey.

(c) Dr. Emmett M. Laursen; Department of Civil Engineering, Univ. of Ariz., Tucson, Arlzona.

(d) Analytical and laboratory investigation related to theory.

(e) Analytic and experimental attempts to relate the average boundary shear to the inclpient movement of sediment particles composing the boundary.

(g) The experimental data plot on a Shield's diagram as two parallel lines for the laminar and turbulent cases. Both cases extend over the range usually considered the transition between a laminar sub-layer and fully rough turbulent flow. An approximate analysis lends credibility to the experimental results.

(h) "Critical Tractive Force of Uniform Sands," by Jimmy F. Harp, Ph. D. Dissertation, Dept. of Clvil Engineering, The University of Arizona, 1963.

\section{(4626) SCOUR AT RELIEF BRIDGES.}

(b) Departmental in cooperation with the U. S. Geological Survey.

(c) Dr. Emmett M. Laursen, Department of Civil Engineering, Univ. of Ariz., Tucson, Ariz.

(d) Laboratory investigation related to theory and design.

(e) To find the effect of sediment size and velocity of flow on the limiting depths of clear-water scour in simple relief-bridge geometries. First, the case of the long contraction will be studied, then the case of the long gradually-contracting channel. The last case to be studied will involve various simple abrupt contractions.

Throughout the experiments, examination of the assumptions of the analysis of Dr. E. M. Laursen will be made and also of the time dependency of depth of scour insorar as feasible.

(g) Equipment has been constructed and the experimental program has been started.

(h) "An Analysis of Relief Bridge Scour," by E. M. Laursen, Journal of the Hydraulics Division, ASCE, Vol. 89, No. HY3, May 1963.

(4627) A STUDY OF PARTIALLY SATURATED FLOW IN SANDEPOXY RESIN COLUNNS.

(b) Departmental.

(c) Professor Richard L. Sloane; Department of Civil Engineering, Univ, of Arizona, Tucson, Arizona.

(d) Laboratory investigation related to theory.

(e) The flow of water through soils often tares place under conditions of partially saturated flow. The prediction of fluid distribution and pressure under conditions of partially saturated flow is important to those interested in the problem of recharge to the ground water table from water applied to the surface of the earth.

This study of partially saturated flow will make use of vertical columns made of sand grains cemented together with epoxy resin. The use of this type of sand colurns will result in a model for which properties such as void ratio and particle arrangement will remaln constant during a series of tests.

(4628) RADIOCARBON AS A TRACER IN WATER SUPPLY PROBLEMS.

(b) Research Corporation unrestricted venture grant and Geochronology Dept. funds.

(c) Dr. Paul E. Damon, project leader; Geochronology Laboratories, Univ. of Arizona, Tucson, Arizona.

(d) Laboratory and field research.

(e) The study of ground water movement through aquifers has been limited by the slow rate of movement of the subsurface waters. Thus, if a tracer is introduced, only Iimited information is obtainable between the times of spiking and observation. However, radiocarbon (C-14) has been naturally introduced into ground water reservoirs continuously throughout geologic time and, consequently, movement which has taken place during the last 45,000 years may be studied. In addition nuclear technology is now producing radiocarbon at a greater rate than nature and so this artificially produced radiocarbon may also be used to trace recent water movements. Furthermore, it represents a potential hazard to health and therefore it is essential to monitor the increment for the safety of the community.

We propose to monitor the present carbon-14 content of surface water and organic matter in the Southwest and to measure the radiocarbon content of subsurface waters. The source of the carbon in water will be determined by $\mathrm{c}^{12} / \mathrm{c}^{13}$ measurements. This data will be related to ground water hydrologic problems such as the rate of laminar flow through aquifers, their permeability, the source and rate of recharge, paleoclimatology radioactive contamination in water supplies, and the waste disposal problem.

(g) So far the results of the carbon-14 dating of water have continued to be reasonable in that flow rates and storage times agree with informed estimates. The increase in the carbon-14 content of the biosphere resulting from Nuclear technology has been monitored. This increase, which amounted to $50 \%$ in April 1963, can be used to trace meteoric waters accumulated during the last 10 years. Sewage from the Tucson disposal plant has increased very little, probably due to mixirg with cellulose, petroleum products and equilibration with older ground waters used to flush the system.

(h) Arizona Radiocarbon Dates IV, P. E. Damon, I. Long, and J. J. Sigalove, Radiocarbon, V. 5, p. 283-301, 1963 .

\section{(4629) CURRENT METER DEVELOPMENT.}

(b) U.S.G.S. Ground Water Branch and departmental.

(c) Mr. E. H. Cordes, Univ, of Ariz., Tucson, Ariz.

(d) Design and development for field use; master thesis.

(e) This project will entail the design and operation of a current meter to measure the vertical velocity component in a pumping well. The velocity profile can then be applied to study transmisibility of ground water aquifers.

(4630) DEVELOPMENT OF HYDRAULIC MODELS ANALOGOUS TO SUBSURFACE GEOLOGIC CONDITIONS FOR STUDYING AND DEMONSTRATING THE CHARACTERISTICS OF GROUND WATER MOVEMENT. 
(b) National Sclence Foundation.

(c) Dr. John W. Harshbarger, Dept. of Geology, University of Arizona, Tucson, Arizona.

(d) Laboratory investigation, design, development and operation.

(e) The purpose of the project is to clarify the characteristics of laminar flow in groundwater movement in a manner which will enable a visual flow net analysis. Hydraulic models are belng developed which consist of consolidated media simulating sedimentaxy rock, enclosed in a water-tight case with a transparent side. Basic geolog1c structures and lithologies can be synthesized and colored inks can be inserted into the flow system of the model, forming visible flow lines. These flow ilnes can then be observed and analyzed in order to better understand the pattern of laminar groundwater flow as controlled by geologic factors. A few of the empirical model experiments which are belng camied out include: 1) Refraction of flow bands across lithologic interfaces. 2) continuity of flow around and through highly permeable and impermeable lenses of different 11thologles. 3) Flow net systems caused by a single pumping well. 4) Flow-net system of mutual interference of depression cones caused by pumping multiple wells. 5) Artesian aquifer systems. 6) Infiltration phenomenon.

Models are being developed for use in education in science and hydrology at the college and university level.

(g) Models consisting of plexiglass cases containing artiflclally consolidated porous media which can be arranged in a nearly infinite variety of geologic structures and hydrologic situations have been developed. A w1de variety of these models have been constructed and through their use it has become possible for the college student to obtain a clear description and understanding of previously concelved groundwater theorles.

(h) "Groundwater: Flow Toward an Effluent stream," Jay H. Lehr, sclence, Vol. 140, No. 3573, June 21, 1963 .

"Development of Groundwater Flow Models Simulating Subsurface Geologic and Hydrologic Cond1tions," Journal of Geological Education, Dec. 1963

"Model Analys1s of Water Table Drawdown surrounding Pumping Wells," Journal of Soll and Water Conservation, Vol. 18, No. 5, Sept.-Oct. 1963.

"Groundwater Fl ow Around and Through Lenticular Beds," Joumal of the Water pollution Control Federation, Dec. 1963. "Development of Hydraulic Models Analogous to Subsurface Geolog1c Conditions for Studying and Demonstrating the Characteristics of Groundwater Movement," Jay H. Lehr, F1nal Report to NSF New Laboratory Equipment Program, July 1, 1963.

(4631) GROUND WATER HYDROLOGY OF THE WESTERN DESERT, U.A.R.

(b) In cooperation with General Desert Development Authority, Calro, U.A.R.

(c) Moh. H. I. Salem, Univ. of Ar1z., Tucson, Ar1z.

(d) Analytical study of fleld data; operation and development; for doctoral dissertation.

(e) An electric analog model of the subsurface geologic and hydrologic conditions of the western desert of the U.A.R., Lybla, Sudan and Tehad is being constructed. Presently the area of recharge is in the high regions of Tehad and of Darfur in the Sudan. Ground water $1 \mathrm{~s}$ discharged into the N1le and 1 nto the Qattera Depression. The distribution of the fundamental differential equations in the system will be determined taking into consideration the boundary conditions. It is hoped that the equations can be solved with the use of the electric analog model. The effects on the Ground Water system due to changed boundary conditions such as the completion of the Aswan High Dam (The N1le 1 s expected to recharge water to the aquifer after the dam is completed) or the initiation of the Qattera depression project, w111 be included in the general analysis of the western desert.

\section{(4632) ENERGY BALANCE OF DESERT REGIONS.}

(b) Departmental project.

(c) Dr. William D. Sellers, Inst. of Atmospherlc Physics, Univ. of Arizona, Tucson, Arizona.

(d) Fleld investigation for testing of new equipment.

(e) Project 1 s to accurately measure all components of the energy balance over various types of desert surfaces. Emphasis is placed on measuring the heat used for evaporation.

(g) Evaporation rates measured in the dry stream channel of Walnut Gulch in S.E. Arlzona over an 18-day period in october 1961 were high enough to indicate that natural recharge of the water table $1 \mathrm{~s}$ negligible when the watertable is 48 to 90 $\mathrm{cm}$ below the surface. For dry solls evaporation rates appear to decrease with 1 ncreasing wind speed; the reverse $1 \mathrm{~s}$ true for wet solls. Practically all the radiative energy 1ncident on short grass is used for evaporation.

(h) No new publications.

(4633) PHYSICS OF CONVECTIVE CLOUDS AND CLOUD MODIFICATION.

(b) National Science Foundation. Also, some assistance by U. S. Weather Bureau and U. S. Forest Service.

(c) Dr. Louis J Battan, Inst1tute of Atmospherlc Physics, Univ. of Artzona, Tucson, Arizona.

(d) Fleld Investigations of the physics of convective clouds and the effects of cloud seeding with silver lodide.

(e) The program involves detalied observations of convective clouds during the summer by means of radar, a pair of high resolution cameras. A network of recording rain gages is employed to measure rainfall. Cloud seeding is conducted with airborne silverlodide generators. A carefully controlled randomization scheme 1 s employed to decide on which days to seed. The results are analyzed statistically. In addition a physical evaluation 1 s made to uncover information about the fundamental nature of cloud and precipitation formation.

(g) To date the experiments have ralled to show that cloud seeding with silver lodide can Increase ralnfall from the convective clouds commonly observed in the summer in the vicinity of Tucson. The analyses suggest that the quantity of rainfall does not depend on the 1ce nuclel properties of the alr. This result leads to the inference that seeding w1th 1ce nucle1 (such as silver lodide particles) is not likely to be successful in increasing rainfall.

(h) "Some Observations of Vertical Velocities and Precipltation Sizes in a Thunderstorm", by Louls J. Battan, Proceedings of the Tenth Weather Radar Conference, American Meteorological Soclety, Boston, Mass., Apri1, 1963. (Accepted for publication in the Journal of Applied Meteorology of the American Meteorological Society.)

"A New Pulsed-Doppler Radar for Cloud observations," by John B. Theiss and A. Rlchard Kassander, Jr. Proceedings of the Tenth Weather Radar Conference, Amerlcan Meteorologlcal Soclety, Boston, Mass., Apr11 1963.

"The Vertical Velocities of Angel Echoes," by Louis J. Battan, Proceedings of the Tenth Weather Radar Conference, Amerlcan Meteorological Soc1ety, Boston, Mass, April 1963. 
(4634) REDUCTION OF EVAPORATION LOSSES BY USING MONOMOLECULAR FITMS.

(b) U. S. Bureau of Reclamation, Procter and Gamble Co. and Institute.

(c) C. Brent Cluff, Institute of Water Utilization, Univ. of Ariz., Tucson, A rizona.

(d) Laboratory and field; operation, development and theory.

(e) For the U. S. Bureau of Reclamation the project has the following objectives: (1) To determine at one or more field sites the advisability of using the long-chain alcohols n-eicosanol and n-docosanol for the supression of evaporation from small reservoirs in arid regions.

(2) To determine the optimum concentrations of long-chain normal alcohols and emulsifiers in emulsions, the optimum concentration of long-chain normal alcohols in solutions and the relative merits of each.

(3) To determine the optimum spacing of dispensing tubes and rate of dispensing of emulsions and solutions through gravity flow and pressure-type dispensers as functions of wind velocities and reservoir area for reservolrs up to ten acres in size.

(4) To determine the sultability of commercial humidity transducers as means of estimating evaporation savings at small reservoirs. For the Procter and Gamble co. tests are being conducted in an effort to obtain a commerclally acceptable scheme for reduction of evaporation on stock ponds and small reservolrs using tallow and longer chain alcohols.

(g) Results to date indicate that the most promising method of maximizing evaporation savings on small reservolrs is the windactivated dispensing of n-eicosanol and $n$-docosanol in the form of an emulsion. Savings of 22 per cent over a one-month period were attained on a small test pond using this method. Savings up to 10 per cent were attained during the same period simply by treating, once a day, an identical pond with powdered material.

(h) C. Brent Cluff and Howard Goldstein, "Monomolecular Film Reduces Evaporation", Progressive Agriculture in Arizona, Vol. XV, No. 3, College of Agriculture, Univ. of Ariz., Tucson, May-June 1963.

Sol D. Resnick and C. Brent Cluff, "Evaporation Reduction Investigations on Small Reservoirs", Paper presented at the American Soclety of Civil Engineers Second Water Resources Engineering Conference, Milwaukee, Wisconsin, May 13, 1963. Available from Institute of Water Utilization.

(4635) INVESTIGATION OF SITES, METHODS, AQUIFER DETERIORATION CONTROL, AND EFFECTS OF ARTIFICIAL GROUND WATER RECHARGE OF ALLUVIAL BASINS TYPICAL OF THE ARID SOUTHWEST UNITED STATES.

(b) Institute.

c) Dr. L. G. Wilson, Institute of Water

Utilization, University of Arizona,

Tucson, Arizona.

(d) Laboratory and field; operation and development.

(e) (1) To evaluate various methods of artificial ground water recharge under arid land cond1tions.

(2) To evaluate in laboratory and field various types of flocculants and grassland filters for removal of suspended and colloldal material from recharge water and for relative costs.

(3) To determine the effect on the aquifer and ground water of recharging sediment laden flood water.

(4) To evaluate the status of ground water recharge practices in a water conservation and disposal program using saline industrial effluent.

(5) To evaluate the effect of quality of industrial effluent on the quality of native groundwater subsequent to recharge. (6) To evaluate the efficiency of grassland filters for post treatment of reclaimed sewage effluent in a program to conserve and expand the uses of such effluent.

(7) To evaluate the moderating influence on the neutron scattering method of soll moisture evaluation of various packing materlals around access tubing during installation in coarse geologic material.

(8) To evaluate the effects produced by organic matter additions to surface soil on soll properties influencing recharge rates; and to determine the nature of the by products of microbial metabolism producing such effects.

(g) Experiments were conducted to determine the factors involved in the utilization of grass filters for sediment reduction in flood water. All tests were conducted using coastal and common bermuda grasses. It was found that flow rate, infiltration rate, length of grass plots, initial turbidity, and helght and stage of development of grass were all interrelated factors in removal of sediment.

(4637) EFFECT OF FIRE AND RESIDUAL ASH ON VEGETATION-SOIL-WATER REIATIONS IN SELECTED PONDEROSA PINE STANDS.

(b) Dept. of Watershed Management in cooperation with U. S. Bureau of Indian Affairs, White Mt. Apache Tribe.

(c) Prof. P. B. Rowe and Mr. Malcolm J. Zwolinshi, Dept. of Watershed Management, Univ, of Arizona, Tucson, Ariz.

(d) Analytical, laboratory and field investigation; basic and applied.

(e) The study will include a series of laboratory and fleld experiments to evaluate the influences of wild fire and controlled burning on the chemical and physical properties of a forest soil as these may affect the basic processes of surface and soil water movements Laboratory studies will be carried on to determine changes in the structure, pore space, and chemical characteristics of the soll due to burning of the ground cover. Field studies employing North Fork type infiltrometers, soll and soil molsture sampling will be carried on to supplement and extend the results of the laboratory studies.

(g) Preliminary studies and literature review indicate conflicting and inconclusive evidence of the effects of fire and ash residue on water-soil relations.

(5152) DISPOSITION OF SUMMER RAINFALL IN PONDEROSA PINE STANDS AS INFLUENCED BY VEGETATION DENSITY AND RELATED PHYSIOGRAPHIC FACTORS.

(b) Departmental in cooperation with U. S. Burea of Indian Affairs, White Mt. Apache Tribe.

(c) Prof. P. B. Rowe and Mr. Howard G. Halverson, Dept. of Watershed Management, Univ. of Arizona, Tucson, Arizona.

(d) Analytical, field and laboratory investigations; basic and applied.

(e) Study aimed at evaluating effects of density of vegetation stocking on the disposition of summer rainfall in Ponderosa pine stands, and at developing methods of predicting effects of regulated stocking (stand management) on water yield. Three 0.6 plots are used in the study; one with the dense 40-60 year old pine stand undisturbed; one with a similar pine stand heavily thinned; and one with the deep rooted woody and forb vegetation completely removed. Measurements include complete soll vegetation inventories, and those of climate, soll moisture, evapotranspiration, vegetation and allied factors needed in evaluating effects of the treatments studied in the processes influencing soll-water relations, tree growth and water yield. 
(5153) ANALYSIS OF IRRIGATION PUMPING EFFICIENCIES AND COSTS.

(b) Agricultural Experiment Station, Univ. of Arizona and Bureau of Reclamation, Phoenix Development office, Region 3.

(c) Dr. C. D. Busch, Dept. of Agricultural Eng1neering, Univ. of Arizona, Tucson, Arizona.

(d) Field investigation for the design, operation and development.

(e) Fifty-four wells located in Central Arizona were measured for lift, discharge, and power input. Fixed and variable costs were also collected. This data is being used to determine the costs and efficiencies of pumping irrigation water so that current practice may be assessed and future practices estimated.

(f) Initiated June 1963.

(5154) EVALUATION OF SUB-SURFACE IRRIGATION WITH PLASTIC PIPE.

(b) Agricultural Experiment Station.

(c) Dr. C. D. Busch, Dept. Of Agricultural Engineering, University of Arizona, Tucson, Arizona.

(d) Theoretical and field investigations.

(e) Investigation of the nature of molsture movement and crop response to irrigation supplied by buried perforated plastic pipe. Plots with sub-surface irrigation and sprinkler irrigation have been instrumented for metered water delivery and irrigation by soil moisture stress. Bermuda grass is the indicator crop. The experiment compares the two irrigation systems on a basis of water use. Model work is planned to describe moisture movement.

(h) "Comparison of Sprinkler and Subsurface Irrigation of Bermuda Grass", C. D. Busch, Report on Turfgrass Research, Agricultural Experiment Station, Univ. of Arizona, (in press) 1963.

(5155) STORM FLOW IN A STREET NETWORK.

(b) Departmental

(c) Dr. Emmett M. Laursen, Dept. of Civil Engineering, The Univ, of Arizona, Tucson, Arizona.

(d) Analytical investigation for design.

(e) Development of a simple methodology to compute approximate backwater curves for storm flows in a street network.

(5156) ELECTRIC ANALOG OF THE GROUND WATER SYSTEM IN CHAJ DOAH, PAKISTAN.

(b) Departmental in cooperation with the water and soils investigation division of west Pakistan.

(c) Maqsood Ali Shah Gilani, c/o U.S.G.S./G.W., P. O. Box 4070, Tucson, Arizona, U.S.A.

(d) Laboratory investigations correlated to field studies; for Master's Thesis.

(e) Since the start of canal investigation in West Pakistan, the ground water levels have been rising. This has produced water-logging and excessive soll salinity in much of the arld and semi-arid areas. Militons of acres of land have thus been forced out of cultivation. To reclaim the affected land and to check the further deterioration of irrigated lands, investigations were started by government of West Pakistan. Field data obtained in one of the affected areas, known as Chaj Doah, comprising of about 5,000 square miles is being used to construct an electric analog model for the purpose of studying the cause and effect relationships.

(5157) THE IDEAL FLOW FIELD IN A SMALL WATERSHED AND ITS RELATION TO THE DRA INAGE NETWORK.

(b) Departmental.

(c) Mr. John J. Hickey, Box 9, Dept. of Geology, University of Arizona, Tucson, Arizona.

(d) Experimental, for Master's thesis. (e) Assuming that the surface of a basin at any particular time may be described by $\nabla^{2} \phi=0$ it is proposed to determine if the areal position of tributaries in a small

"homogeneous" vatershed can be shown to be a function of the flow fleld in the watershed at any particular time in its history.

(5158) A TRANSPARENT MATRIX SYSTEM FOR THREE DIMENSIONAL HYDRAULIC FLOW MODELS.

(b) National Science Foundation.

(c) Dr. Jay H. Lehr, Dept. of Geology, Univ. of Arizona, Tucson, Arizona.

(d) Laboratory investigation, design, development and operation.

(e) The purpose of this project is to develop a transparent porous media system capable of demonstrating the laminar flow of ground water movement. When a colorless porous media is saturated by a colorless liquid with the same index of refraction, in a closed system of optimum size, a high degree of transparency will be attained. In order to produce flow in the system a hydraulic gradient will be imposed upon 1t. Colored dyes will be introduced so that the fluid movement may be visually observed.

Experimentation with various immersion liquids, porous media, light source and dyes will be a necessary part of the project. Once developed, this system could be used in the construction of hydraulic flow models where the characteristics of three dimensional laminar flow analogous to groundwater movement, may be studied.

(5159) EFFECTS OF PHREATOPHYTE REMOVAL ON STREAMFLOW AND TOTAL WATER YIELD.

(b) Departmental and U. S. Bureau of Reclamation, with cooperative assistance of the U. S. Bureau of Indian Affairs, San Carlos Apache Tribe; U. S. Geology Survey; and U. S. Forest Service.

(c) Prof. P. B. Rowe, and Messrs. Loyd 0. Barnett and John M. Tromble, Dept. of Watershed Management, Univ. of Arizona, Tucson, Arizona.

(d) Analytical, field and laboratory investigations; basic and applied.

(e) Study designed to evaluate effects of phreatophytes on streamflow and water yleld in typical canyon bottom reaches, and the effects of phreatophyte removal or other potential management practices on these yields. The study site is situated on salt Creek a tributary to the Gila River on the headwaters of the Coolidge Reservoir and includes dense stands of salt cedar, mesquite, and assoclated species. Three channel cross section 700 to 900 feet long and 200 to 300 feet wide will be used for specific studies of the hydrologic processes. One cross section will be used as the control and two for treatments. Experimental data will include detalled vegetation, soll, and water inventorles; and measurements of climate, soil moisture, evapotranspiration, surface and subsurface flows, water table fluctuations and allied factors influencing water yields.

UNIVERSITY OF ARKANSAS, Agricultural Experiment Station.

(2255) GROUND WATER, RESOURCES AND RECHARGE, IN THE RICE GROWING AREA OF ARKANSAS.

(b) Arkansas Agricultural Experiment Station cooperative with U. S. Geological Survey and U. S. Corps of Engineers.

(c) Prof. Kyle Engler, Head of Agricultura Engineering Dept., University of Arkansas, Fayettevilie, Arkansas.

(d) Basic and applied research.

(e) The straight 26-inch sand-packed recharge 
well has been tested for one year an results have not proved completely satisfactory. Main difficulties encountered arise in duplicating test condition under fleld situations. The sand packed well seemed to filter out plugging material but redevelopment proved more difficult than in the gravel packed well. Separan AP-30 was tried but proved unsatisfactory for conditions as encountered in this test. A slow gravel fliter has been constmucted and will be tested as a means of clarifying recharge water during the winter and spring of $1960-61$.

(h) U. S. Geological Survey Water Supply Papers available from the office of the Superintendent of Documents, U. S. Government Printing office, Washington, D. C. 20402: "Artificlal Recharge of Ground Water--Grand Prairie Region, Arkansas," Kyle Engler, F. H. Bayley $3 \mathrm{rd}$, and R. T. Sniegockl, $1615-\mathrm{A}, 1963,32 \mathrm{pp}$.

"Equipment and Controls Used in Studies of Artificial Recharge in the Grand Prairie Region Arkansas" R. T. Sniegocki, F. A. Bayley 3rd, and Kyle Engler, 1615-C, 1963, 39 pp.

"Principles of Siphons with Respect to the Artificlal-Recharge Studies in the Grand Prairie Region Arkansas," R. T. Snlegocki and J. E. Reed, 1615-D, 1963, 19 pp.

"Geochemical Aspects of Artificlal Recharge in the Grand Prairie Region Arkansas," R. T. Sniegock1, 1615-E, 1963, 41 pp.

"A Fleld Method for Measurement of Infiltration," A. I. Johnson, 1544-F, 1963, 27 pp.

\section{UNIVERSITY OF ARKANSAS, Civil Engineering Dept.}

\section{(4068) TURBUIENT FLOW IN POROUS MEDIA.}

(b) U. S. Public Health Service.

(c) Prof. John C. Ward, Assistant Professor of Civil Englneering, University of Arkansas, Fayetteville, Arkansas.

(d) The project is experimental and theoretical and is classified as basic research with definite practical applications.

(e) Determination of the relationship between permeability of a porous media and its geometric mean size and geometric standard deviation. This will allow the calculation of the permeability of a porous media from a sieve analysis of the media.

(g) The relationship between the permeability of a porous media and its geometric mean size and geometric standard deviation has been determined for spherical particles.

\section{POLYTECHNIC INSTITUTE OF BROOKLYN}

\section{(4071) DIFFUSION OF SUBMERGED JETS.}

(b) Laboratory project.

(c) Prof. Matthew W. Stewart, Assoc. Prof. of Civil Englneering, Polytechnic Institute of Brooklym, 333 Jay st., Brooklyn, N. Y. 11201

(d) Experimental, basic research for master's thesis.

(e) To determine the diffusion of a circular water jet discharging vertically upward into a stream of water moving horizontally.

(f) Preliminary study completed.

g) Colored water was discharged vertically through a 1/2-1nch dlameter tube into a horlzontally moving stream of water. Jet trajectories were determined photographically for various ratios of stream to jet velocity.

(h) Thesis available on loan.

(5166) OPEN CHANNEL TRANSITIONS.

(b) Laboratory Project

(c) Prof. Matthew W. Stewart, Polytechnic Inst of Brooklyn, 333 Jay St., Brooklyn, N. Y. ilzol. (d) Literature study for Master's project.

(e) A study of the design of open channel transitions.

(f) Suspended.

CALIFORNIA INSTITUTE OF TECHNOLOGY, DIVIsion of Engineering and Applied Science.

(1548) PROBLEMS IN HYDRODYNAMICS.

(b) Office of Naval Research, Dept. of the Navy.

(c) Prof. Milton S. Plesset, Calif. Inst. of Tech., Pasadena, California.

(d) Theoretical and experimental; basic research.

(e) Studies of cavitating and noncavitating flow; dymamic behavior of cavitation bubbles; theoretical studies of cavitation damage.

(h) "Bubble Dynamics" by M. S. Plesset, Div. of Eng. and Applied Sclence, Calif. Inst. of Tech. Report No. 85-23, Feb. 1963.

"The collapse of a Spherical Cavity in a Compressible Liquid" by Robert Hickling and M. S. Plesset. Div of Eng. and Applied Science, Calif. Inst. of Tech. Report No. 85-24, March 1963.

"Radiation Due to the Radial Motion of a conducting Sphere in a Magnetic Field" by Giulio Venezlan, DIV. of Eng. and Applied Science, Calif. Inst. of Tech. Report No. 85-25, June 1963.

"A General Analysis of the stability of Superposed Fluids" by M. S. Plesset and DinYu Hsieh, Div. of Eng. and Applied Sclence, Calif. Inst. of Tech. Report No. 85-26, oct. 1963 .

"The Pulsation Method for Generating Cavitation Damage" by M. S. Plesset, Jour. of Basio Engineering, Sept. 1963, pp. 360-364, Trans. of the ASME.

"Effects of Thermal conduction in Sonoluminescence," by Robert Hickling, Jour. of the Acous. Soc. of Amer. Vol. 35, No. 7, pp. 967-974, July 1963 .

"Bubble Dynamics" Cavitation in Real Fluids, by M. S. Plesset, Elsevier Publishing Co., Amsterdam (in press).

"Collapse and Rebound of a Spherical Bubble in Water" by Robert Hickling and $M$. S

Plesset, Physics of Fluids, Dec. 1963.

CALIFORNIA INSTITUTE OF TECHNOLOGY, W. M. Keck Laboratory of Hydraulics and Water Resources.

(3670) TURBULENCE AND PARTICLE ENTRAINMENT IN SETTLING TANKS.

(b) U. S. Public Health Service.

(c) Prof. Vito A. Vanoni, Calif. Inst. of Tech., Pasadena, California.

(d) Experimental research.

e) Flow in a settling tank is simulated by introducing water with a low turbulence level and uniform velocity into a flume 15 feet long with the bed covered by $a$ thin layer of sediment. As the flow proceeds into the flume, a boundary layer develops and becomes progressively thicker. The entrainment of particles is observed visually and the corresponding shear stress is deduced from measured velocity profiles.

(f) Experiments have been completed and the report is being prepared.

(g) Data on critical shear stress for entraining fine sand particles of diameters of $0.1 \mathrm{~mm}$ and smaller have been observed.

(3671) EVALUATION OF FORMULAS FOR THE TRANSPORT RATE OF SEDIMENT BY ALLUVIAL STREAMS.

(b) Laboratory project.

(c) Prof. Vito A. Vanoni, Calif. Inst. of Tech., Pasadena, Calif.

(d) Analytical research using published data.

(e) The sediment discharge calculated by several well-known formulas is compared 
with actual measured sediment discharges in natural streams. The results are presented as graphs of sediment discharge against water discharge.

(f) Project is continuing.

(4075) MECHANICS OF FLOW IN SAND-BED CHANNELS AT VERY LOW RATES OF SEDIMENT TRANSPORT.

(b) National Sclence Foundation.

(c) Prof. V. A. Vanoni or N. H. Brooks, Calif. Inst. of Tech., Pasadena, Callformia.

(d) Experimental and theoretical research.

(e) Observations are made (1) of the development of dunes with time on a sand bed with flows which produce low rates of sediment transport and of the resulting changes in flow resistance as the dunes grow and (2) on the mechanism of entrainment of sediment by lowing water.

(f) Project is continuing.

(4076) PRECISION TILTING FLUME.

(b) National Science Foundation.

(c) Prof. Vito A. Vanoni and Prof. Norman H. Brooks, Calif. Inst. of Tech., Pasadena, California.

(d) Development of facilities.

e) The flume which is 40 meters 10 g, 110 cent1meters wide, and 50 centimeters deep is mounted on a rigid supporting structure carried on jacks. Water is circulated by pumps with variable speed drives for controlling the flow rate. The slope of the flume can be adjusted continuously without intemupting an experiment, up to a maximum of 2 per cent. The flume system can produce programmed unsteady flow and will be equipped with convenient recording equipment for observing such flows. It is designed as a general purpose facllity for studies of open channel flow problems such as sediment transportation, boundary layers, and wave propagation in shear flow.

(g) The flume has been erected and $1 \mathrm{~s}$ being adjusted and calibrated.

(4561) DYNAMICS OF DENSITY-STRATIFIED RESERVOIRS.

(b) U. S. Public Health Service (research grant).

(c) Prof. Norman H. Brooks, Callf. Inst. of Tech., Pasadena, Calif.

(d) Basic theoretical and experimental research. e) In reservolrs having density variation with depth, the patterm of flow toward an outlet may be quite different from the flow in a homogeneous reservolr. The withdrawal pattern has been studied experimentally in a laboratory tank of water having a linear density profile induced e1ther by dissolved salt or heat. Application will ultimately be in management of water quality in rivers by selective withdrawal from reservolrs.

(g) At very low Reynolds numbers there is a distinct "withdrawal layer" extending upstream at the level of the outlet. Fluid above and below this layer is not withdrawn through the outlet. Results of two-dimensional experiments agree with a theoretical analysis based on the laminar boundary layer equations and the diffusion equation for the substance causing density variation.

(h) "Viscous Stratifled Flow Towards a Line Sink," Robert C. Y. Koh, Ph. D. thesis, Dec., 1963, (also to be issued as a laboratory report).

(5013) DYNAMICS OF DENSITY-STRATIFIED GROUND-WATER FLOW .

(b) Laboratory project.

(c) Prof. Norman H. Brooks, Calif. Inst. of Tech., Pasadena, Calif.

(d) Basic theoretical and experimental research, including doctoral theses.

(e) Slight density variations often affect ground- water flow patterns. Water which is recharged artiflclally may not $m i x$ readily with native waters but develops density stratiflcation in the aquifer. Studies will be made of problems such as overturning of unstably layered systems, flow due to sources of buoyancy and effects of density difference on fluid dispersion in flow through porous media.

(5014) WAVE INDUCED OSCILLATIONS OF SMALI MOORED VESSELS.

(b) Dept. of the Army, Corps of Englneers.

c) Prof. Fredric Ralchlen and Prof. Vito A. Vanoni, Calif. Inst. of Tech., Pasadena, calif.

(d) Experimental and theoretical research.

e) Serious ship and dock damage can be caused bo wave induced oscillations of moored vessels. The ship and 1ts mooring system constitute a dynamic system capable of resonant oscilla tions. The specific a1m of this research is to investigate experimentally and theoretically the response of an 1dealized system consisting of prismatic bodies moored to floating platforms under the action of standing and progressive waves.

CALIFORNIA INSTITUTE OF TECHNOLOGY, Hydrodynam1es Laboratory.

(2746) HYDRODYNAMICS OF SUBMERGED BODIES AND WATER WAVES.

(b) Bureau of Weapons, Dept. of the Navy.

c) Prof. A. J.Acosta, T. Y. Wu and T. Kiceniuk, Hydrodynamics Laboratory, California Inst. of Technology, Pasadena, Califormia.

(d) Experimental and theoretical investigation.

(e) Detalled 1nvestigations of the basic hydrodynamic phenomena concerning the water waves and the motion of submerged bodies, including the various aspects of unsteady flow, partial and supercavitating regime, wakes and turbulent mixing. A new twodimensional test section has been incorporated into the H1gh Speed Water Tunnel that permits more precise measurements to be made on the characteristics of 2 dimensional cavitating and fully wetted hydrofolls and struts. Present work includes the determination of the gravity effect on cavity flow (in cooperation with Prof. R. E. Street $(4219)$,) the estimation of strut and gap interferences in fully wetted and fully cavitated flows, tunnel interference effects in cavity flows and related problems.

(h) "An Experimental Investigation of a Fully Cavitating Two-Dimensional Flat Plate Hydrofoll near a Free Surface," T. E. Dawson, and T. R. Bate, Hydrodynamics Laboratory Report El18-12, Division of Engineering, Califormia Institute of Technology, September 1962 .

"A Two-Dimensional Leg for the High Speed Water Tunnel" T. Kiceniuk, submitted for the A.S.M.E. symposium on Cavitation Facilities, May 1964 .

(3377) THEORETICAL STUDIES IN HYDRODYNAMICS.

(b) Office of Naval Research, Dept. of the Navy.

c) Prof. T. Y. Wu, California Institute of Technology, Pasadena, California.

(d) Theoret1cal; basic research.

(e) Studies of hydrodynamles of free surface flows; water waves, wake and cavity flows; principle of fish propulsion; flows through porous media.

(h) "A Wake Model for Free-Streamline Flow Theory Part 1. Fully and Partially Developed Wake Flows and Cavity Flows Past an Oblique Flat Plate," by T. Y. Wu, J. of Fluid Mechanics, Vol. 13, part 2, 161-181, 1962. (Also, Calif. Institute of Technology Engrg. Division Report No. 97-2, September 1961.) 
"Flow Through a Heavily Loaded Actuator Disc," by T. Y. Wu, Schiffstechnik Bd. 9, 134-138, Heft 47 , 1962. (Invited paper, symposium on Ship Theories, University of Hamburg, Germany, 1962.

"Accelerated Swimming of a Waving Plate," by T. Y. Wu, Invited paper, Proc. of Fourth Symposium on Naval Hydrodynamics, August 1962 , Wa shington, D. C.

"Small Time Behavior of Unsteady Cavity Flows," by D. P. Wang and T. Y. Wu, Arch. Rat. Mech. Anal., Vol. 14, No. 2, 127-152, 1963. (Also California Institute of Technology Engrg. Division Report No. 97-3, March 1963.) "A Wake Model for Free-Streamline Flow Theory Part II. Cavity Flows Past obstacles of Arbitrary Profile," by T. Y. Wu and D. P. Wang, Accepted to appear in the J. of Fluid Mechanics. California Institute of Tech. Engrg. Division Report No. 97-4, May 1963. "Dispersion of Water Waves," by T. Y. Wu, J. Geophys. Res., Vol. 68, No. 4, $1195-97$, February 1963

\section{(3378) HYDRODYNAMICS OF TURBOMACH INES}

(b) Office of Naval Research, Dept. of the Navy.

(c) Prof: A. J. Acosta, Hydrodynamics Lab., California Institute of Technology, Pasadena, California.

(d) Experimental and Theoretical basic research. Several problems concerning the flow of liquids through cascades have been studied to obtain more information for the design of propellers and pumps. Linear free-streamline theory has been used to determine the characteristics of cavitating flat plate cascades as well as cascades composed of other simple profiles such as wedge, planarconvex, etc.

The effect of contraction of the meridional streamlines through a rotor or stator on the cascade flow has been studied with a quasitwo-dimensional theory. The effect of such contraction on, for example, the lift coefficient of a cascade of moderate solidity is somewhat different than previously thought. It is hoped to carry out an experimental verification of these predictions in the near future.

Plans were made to carry out a few, exper1ments on cavitating cascades. As a preliminary step, experiments were made on an isolated two-dimensional, planar-convex hydrofoil. At moderate angles of attack, partial cavitation developed on the leading edge as usual but as the pressure was reduced and the cavity thereby lengthened, a condition developed in which a steady, large amplitude oscillation in cavity length and lift force took place. Force oscillograms and motion pictures are being analyzed to determine the exact cause of this phenomenon.

(h) "Flow Past a Partially Cavitating Cascade of Flat Plate Hydrofolls," R. B. Wade. Englneering Division Report 79.4, Jan. 1963. "Some Unsteady Effects in Cavitating Flow," A. J. Acosta and R. B. Wade. Film Report 79.5 .

"Note on the Application of Cascade Theory to Design of Axial-Flow Pumps," H. D. Linhardt and A. J. Acosta. Presented at annual ASME winter meeting, 1962, paper 62-WA-222.

(4073) STUDIES IN VENTILATING FLOWS AND MODEL SCALING.

(b) Bureau of Ships and Office of Naval Research, Dept. of the Navy.

(c) Prof. T. Y. Wu, Prof. A. J. Acosta, Calif. Institute of Technology, Pasadena, Calif

(d) Both theoretical and experimental, basic research.

(e) Theoretical and experimental studies are being carried out to investigate the basic principle, underlying mechanism and scale effect assoclated with the ventilating flow past submerged or surface piercing bodies and lifting surfaces. The problems under investigation include: Incipient ventilation of submerged hydrofoll; ventilation through a trailing vortex core; ventilation and entrainment process; ventilation of surface-plercing struts; and scaling problems.

(h) "An Approximate Numerical Scheme for the Theory of Cavity Flows Past Obstacles of Arbitrary Profile," by T. Y. Wu and D. P. Wang, ASME Annual Meeting, November 17-22, 1963, Paper No. 63-WA-133. California Inst. of Technology Engrg. Division Report No. $111-1$, July 1963 .

"Measurements of the Free Water Surface Displacements Due to a Submerged Hydrofnil of Moderate Aspect Rat1o," by J. BrentJes, Calif. Institute of Technology, Hydro. Lab. Internal Memo. No. E-110.3M. February 1962.

(5035) FORCES ACTING ON A BODY DURING WATER EXIT.

(b) Bureau of Weapons, Dept, of the Navy.

c) Prof. A. T. Ellis and Dr. J. G. Waugh, Calif. Institute of Technology, Pasadena, Calif.

(d) Experimental and theoretical investigation. Basic research.

(e) To assess the validity of theories for deter mining added mass in the presence of a free surface and hydrodynamic effects on missiles in the neighborhood of, or approaching a free surface. To provide experimental data on surface effects on missiles of simple mathematical conflguration under conditions of cavitating flow which might be used as a basis for further theoretical developments.

(g) Water exit theory has been extended for computation of forces acting on a sphere accelerated vertically upward from rest at arbitrary depths below the surface where brief intervals of time are considered. An experimental technique has been developed. for accelerating the sphere by an electromagnetic field. Measurements of the force applied to the sphere are made remotely to insure against hydrodynamic interference. Tris is done by measuring the force reaction on the coll used to accelerate the sphere. A variable atmosphere wave tank has been constructed to study the underwater and waterexit behavior of small missiles under varyirg degrees of cavitation and in the presence of different wave flelds. The tank is constmucted almost entirely of two inch thick lucite sheets which is non-magnetic and electrically non-conducting. This mode of construction was chosen in order to avoid spurious effects in determing the force exerted on electromagnetically accelerated missiles by measuring the equal and opposite reactive force on the wire coll.

(h) "The Variable Atmosphere Wave Tank," by J. G. Waugh and A. T. Ellis. Manuscript has been submitted to the ASME for presentation at a symposium on cavitation facilities and techniques, May 1964, and publication in a cavitation facilities handbook.

(5036) HYDRODYNAMIC AND THERMODYNAMIC PARAMETERS AF'FECTING CAVITATION BUBBLE GROWTH AND COLLAPSE

(b) Office of Naval Research, Dept. of the Navy.

c) Prof. A. T. Ellis and D. B. J. S. Barnard, California Institute of Technology, Pasadena, California

(d) Experimental and theoretical investigation.

(e) A Blow-down water Tunnel has been constructed with glass lining and a $2-3 / 4$ inch square working section to study cavitation bubble growth and collapse. Velocities of over a hundred feet per second are avallable for periods of 5 seconds or for longer times at lower velocities.

special photographic instrumentation has been developed for recording bubble behavior. This includes a repetitively pulsed ruby laær light source. Plctures have been taken at a rate of over one million per second at magnifications of $25 \mathrm{x}$ and exposure times of $2 \times 10^{-8}$ seconds. Theory is being developed for the collapse of a bubble in a moving stream near a rigid wall.

(g) Patent application has been made for the pulsed 
laser light source.

(h) "A New Approach to the study of Cavitation," by A. T. Ellis, M. E. Slater, and M. E. Fourney. Proceedings of the symposium on Cavitation of the Internation Association for Hydraulic Research, Senda1, Japan, Sept. 1962. "Application of a Ruby Laser to High-Speed Photography," by A. T. Ellis and M. E. Fourney. Proceedings of the Institute of Electrical and Electronics Englneers, Vol. 51, No. 6, pp. 942-943, June 1963.

"The Unsteady Flow Cavitation Tunnel at the California Institute of Technology," by B. J. S. Barnard, A. T. Ellis, and M. E. Slater, submitted to the ASME for presentation at a symposium on cavitation facilities and techniques, May 1964, and publication in a cavitation facilities handbook.

UNIVERSITY OF CALIFORNIA, College of Agriculture, Department of Irrigation.

(23) HYDROLOGY OF IRRIGATION SUPPLIES IN CALIFORNIA.

(b) University of California.

(c) Prof. R. H. Burgy and Mr. D. C. Lew1s, Dept. of Irrigation, Univ. of Calif., Davis, California.

(d) Experimental and fleld investigation. applied research.

(e) Hydrologic investigations of mountain watersheds are being conducted on pilot watersheds in three areas of the state. Measurements are being made of rainfall, surface runoff, erosion, and groundwater storage and outflow. The hydrologic effect of vegetative conversions on the watersheds is under longrange stidy. Radioactive tracers are used to study groundwater movement and depth of rooting of trees. A neutron moisture meter is used to measure moisture content in the soll and rock above the water table. Micrometeorological techniques and equipment are being tested to provide an independent evaluation of evapotranspiration from the study watersheds.

(h) "Water Use by Native Vegetation and Hydrologic studies", by D. C. Lewis and R. H. Burgy, Annual Report No. 4, 1962-63, Dept. of Irrigation, Univ. of Calif., Davis, Calif.

(1819) DRAINAGE IN REIATION TO IRRIGATION.

(b) University of California.

(c) Dr. J.N. Luthin and Mr. R. V. Worstell, University of California, Davis, California.

(d) Basic and applied research.

(e) An equation developed for the location of drains in land overlying an artesian aquifer has been solved with the IBM 7090. New curves have been prepared relating the spacing of the drains to the depth to the artesian layer and to the pressure head in the artesian layer. The drainage of sloping land has been studied. An equation has been developed in cooperation with Dr. P. Schmid of the Swiss Forest Research Station for the shape of the water table that $1 \mathrm{~s}$ in equilibrium with the rainfall. A paper has been submitted to the Journal of Geophysical Research.

Computer programs have been written in cooperation with Dr. George Taylor of the Ohio State University on the shape of the water table in equilibrium with rainfall on sloping land. The computer solutions take into account the flow in the capillary fringe. The seepage surface emerges as part of the solution.

(h) "The Use of Electronic Computers to Solve Subsurface Drainage Problems", by G. S. Taylor and J. N. Luthin, Hilgardia 34(12); $543-558,1963$.

(4086) MISCIBLE AND IMMISCIBIE FLUID DISPLACEMENTS IN REIATION TO SOLUTE MOVENENT IN SOIL AND
OTHER POROUS MATERIAL.

(b) University of California

c) Drs. J.W. Biggar and D. R. Nielsen, Dept. of Irrigation University of California, Davis, California.

(d) Theoretical and experimental; basic and applied.

(e) The simultaneous transport of fluids and solutes through porous media is under investigation. The mixing and spreading of the fluids in the medium, the interaction of the fluids with each other and the medium have been studied. The work will help define the nature of the porous structure of materials, and the coupling between velocity and diffusion in thedispersion process. Leaching phenomena, disposal of industrial and radioactive wastes, and the movement of pesticides in soll water depend upon the dispersion process.

(b) Mathematical models of dispersion previously reported have been compared with experimental data obtained from studies on soil, glass beads, sandstone and sand columns. More recently the effects of the density and viscosity of the fluigs on the mixing has been studied using $\mathrm{Cl}^{36}$ and glass bead medium. Leaching Phenomenon, disposal of industrial and radioactive wastes and the movement of pesticides in soll water involve dispersion processes.

(h) "Miscible Displacement: IV. Mixing in Glass Beads." D. R. Nielsen and J. W. Biggar. Soil Sc1. Soc. Amer. Proc. 27:10-13, 1963. "Miscible Displacement: V. Exchange Processes." J. W. Biggar and D. R. Nielsen. soll Sci. Soc. Amer. Proc. Nov.-Dec. 1963.

\section{(4087) DYNAMIC PROJECT PLANNING.}

(b) University of California.

(c) Dr. V. H. Scott, Department of Irrigation, University of California, Davis, California. (d) Developmental design.

(e) This study is to develop an approach to the engineering aspects of project planning of Irrigation projects particularly adaptable for such areas where (I) water requirements whether for irrigation or other uses are supplied through pumping from wells, and (2) where problems of increased cost of pumping due to lowering the water wells, deterioration of water quality, and/or reduo tion in yield of wells due to depletion of avallable ground water supply occur.

(g) Detalled analysis has shown that dynamic project planning is a satisfactory eng1neering technique when applied to situations where development of water facilities $1 \mathrm{~s}$ undertaken for presently unused water supplies in areas with a ground water deficiency.

(4088) IRROTATIONAL FLOW OVER A VERTICAL, SHARPCRESTED WEIR.

(b) University of California.

(c) Dr. Theodor S. Strelkoff, Dept. of Irrigation, University of California, Davis, Calif.

(d) Theoretical, basic research.

(e) A digital computer is used to carry out the approximate numerical solution of an exact integral equation, derived by conformal mapping and singularity distribution, and describing the two-dimensional flow over weirs ranging in height from zero to infinity. Project being extended to other geometries and to flows with given degree of rotationality.

(g) Approximate flow profiles and discharge coefficients have been obtained for weirs of head-to-height ratio $0.1,0.25,0.50$, $1.15,2.11,3.02,4.36$.

(h) "Irrotational Flow Over Weirs," by Theodor S. Strelkoff, PhD. Thesis, state Univ. of Iowa, June, 1962 . 
(b) University of California.

c) Dr. V.H. Scott, Department of Irrigation, University of California, Davis, California.

(d) Theoretical and field research including doctoral thesis research.

(e) To consider the influence of a decreasing discharge rate in developing a general solution for unsteady flow to wells. Such a solution is of Importance in calculating the transmissibility and storage coefficients of an aquifer from short-time pumping tests, and in water supply and dralnage problems where seasonal water requirements vary or a certain schedule of pumping is to be followed. Field tests are being used to check the theory.

(g) A general analytical solution has been developed for unsteady flow of groundwater to a well having a decreasing discharge rate. A graphical solution has been proposed to determine the aquifer characteristics from pumping test data. The graphical solution requires the numerical computation and tabulation of a mathematical function called the "varlable well function". Values of this function have been determined.

(h) "Nonsteady Flow for Wells with Decreasing Discharge," by M. Abu-zied and V. H. Scott. A. S. C. E. Proc., Jour. Hyd. D1v. 89(HY3): 119-132, May 1963 .

(5142) VARIABLE FLOW UNDER A VERTICAL GATE.

(b) University of California.

(c) Dr. Theodor S. Strelkoff, Dept. of Irrigation, Univ. of Calif., Davis, Callfornia.

(d) Experimental, theoretical; basic research, for Ph. D, dissertation.

(e) Time-dependent flows under sluice gate moving vertically in 1ts own plane are belng studied In a laboratory flume. A numerical, quasisteady, potential-flow analysis is being developed to complement the experimental investigation.

(5143) PROFILE OF A WETTING FRONT ADVANCING IN AN IRRIGATION BORDER.

(b) UnIversity of California.

(c) Dr. Theodor S. Strelkoff, Dept. of Irrigation, Univ, of Calif., Davis, Callf.

(d) Experimental, theoretical; applied research for M. S. and M. E. theses.

(e) Th1s is a special case of surge on a dry bed. Vegetation is simulated in a laboratory flume by an array of unfformly distributed vertical rods set into the bottom. Flow is introduced at the head end, and the passage of the wave through the rods is measured by electrical depth gauges. A theoretical expression describing an established such flow is being tested.

(5144) UNSTEADY FLOW IN OPEN CHANNELS.

(b) University of Callfornia.

(c) Dr. Theodor S. Strelkoff, Dept. of Irrigation, Univ. of Calif., Davis, Calif.

(d) Theoretical; basic research.

(e) A computer-implemented numerical solution is being developed for the one-dimensional continuity, momentum, and energy equations of unsteady flow in canals of arbitrary crosssectional form. A method is sought which will permit automatic tracking of spontaneously formed shock-discontinuities in the profile. Under investigation is a method of "smearing" the shocks by introducing Into every positive wave of the continuous solution an energy loss equivalent to that occurring in a discontinuity of comparable geometry

(g) An effective computer program has been developed for gradually varlable flow without discontinuities, with arbitrary initial and boundary conditions of depth and velocity.

(5145) NONLINEAR ANALYSIS OF HYDROLOGIC SYSTEMS.

(b) University of California. (c) Dr. J. Amorocho, Dept. of Irrigation, Un1v. of Calif., Davis, California.

(d) Theoretical and experimental investigation; basic and applied research.

(e) (1) Studies on the mathematical theory of nonlinear systems with lumped and with distributed parameters. (2) Characterization of time- and space-varlable rainfall distributions. (3) Development of methods for the establishment of nonlinear inflow-outflow relationships for natural catchments.

(4) Laboratory and fleld application of (3) above.

(g) Experiments completed to date on laboratory catchments under simulated rain reveal large departures from the conditions of linearity and Invarlance implicit in the "unit hydrograph" concept, and suggest that similar behavior can be expected in natural watersheds. A new approach in the analysis suggested and approxımate procedures applicable to floods due to uniformly distributed storms have been developed. Further development of mathematical theory of nonlinear systems is under way.

Statistical procedures for the mathematical characterization of storms from data on California watersheds are belng tested.

(h) "Nonlinear Analysis of Hydrologic Systems," J. Amorocho, G. T. Orlob, Sanitary Engin. Research Lab., Univ. of California, Berkeley. Water Resources Center Contribution No. 4, 147 pages, Nov. 1961 .

"Measures of the IInearity of Hydrologic Systems," J. Amorocho. Jour. Geophys. Res. $68(8): 2237-2249$, April 15, 1963.

(5146) THE EFFICIENCY OF ENERGY DISSIPATORS.

(b) University of Callfomla.

(c) Dr. J. Amorocho, Dept. of Irrigation, Univ. of Calif., Davis, Calif.

(d) Theoretical and experimental investigation; applled research.

(e) Development of analytical criteria for the efficiency of energy dissipating stmuctures In terms of the characteristics of the flow stream delivered and the shear stresses over the boundary of the recelving channels. Experimental evaluation of efflciencies from hydraulic model data.

(g) "Energy efflclency" and "shear efflciency" criteria have been developed as means of evaluating: (1) The effectiveness of a structure in dissipating energy; and (2) the scouring potential of the outflowing water. Experiments with a vortex-type energy disslpator 1llustrate the application of these criteria for designs based on hydraulic model investigations.

(h) "The Efflciency of Energy Dissipators," $J$. Amorocho. Paper presented at the ASCE Water Resources Englneering Conference, MIlwaukee, May 1, 1963.

(5147) ENERGY DISSIPATORS FOR CULVERT OUTLETS.

(b) Dept. of Water Resources, State of Calif.

c) Dr. J. Amorocho, Dept. of Irrigation, Univ. of California, Davis, Calif.

(d) Hydraulic model Investigations.

(e) Development of energy dissipating outlet stmuctures for cross-dralnage culverts under the California canal.

(5148) THERMALITO DIVERSION DAM MODEL STUDTES.

(b) Dept. of Water Resources, State of Calif.

c) Dr. J. Amorocho, Dept. of Irrigation, Univ. of California, Davis, Calif.

(d) Hydraulic model studies.

(e) Investigation of the effect of approach fleld geometry of the discharge capacity of a gated overflow structure; study of downstream scour and conflguration of tallwater flow patterns. Purpose of study was to serve as guide in design of major component of California water development program.

(f) Completed.

g) Effects of the asymmetry of the approach flow 
on the discharge of the overflow section were evaluated. Changes in various features of the overflow structure and the tall water area were tested and studied in detall.

(h) "Thermal1to Diversion Dam Model Studies," $\mathrm{J}$. Amorocho and Alan Babb. Dept. of Irrigation, Univ. of Calif., Davis, October 1963.

UNIVERSITY OF CALIFORNIA, Dept. of C1V11 Engineering, Fluid Mechanics Laboratory.

(1554) SEA WATER CONVERSION RESEARCH.

(b) State of California.

(c) Prof. Everett D. Howe, Coordinator Saline Water Conversion Research, University of Calif., 1301 south $46 \mathrm{th}$ Street, Richmond, California.

(d) Experimental, theoretical, field investigation and pilot plant; basic research, applied research, design, and operation.

(e) The purpose of this project is to discover whether there is avallable any method for the large-scale, low-cost demineralization of sea water. The project includes a number of investigations, of whish the following have been active during 1961-62: (1) Multiple effect rotating evaporator; (2) evaporation by immiscible fluld heat transfer; (3) vacuum flash distillation (low temperature difference method); (4) solar dist11lation; (5) electrodialysis tests; (6) freeze-separation; (7) 1on exchange; (8) blologlcal studies; (9) capillary control of vapor transfer gaps; (10) reverse osmosis pilot plant; (11) thermodynamic and economic analysis; (12) experimental heat transfer studies; (13) transport phenomena near a liquid-vapor interface; and (14) fundamental studies of corrosion processes. Investigations are belng carrled on at the Berkeley, Los Angeles and San Diego Campuses.

(g) Detalled results may be obtalned from the progress reports and publications listed under (h) below. This project has been active since $1951-52$ and previous summaries have listed all reports prior to July 1962.

(h) The following reports and publications have been issued during the period since July 1962 and summarize the work to date: UNIVERSITY OF CALIFORNIA AT LOS ANGEIES:* "A Contribution to the Theory of ThermoEconomics," Robert Evans, Dept. of Englneering Report No. 62-36, $125 \mathrm{pp}$. August 1962 . "Design, Development, and Testing of a 500 Gallon per Day Osmotic Sea Water Desalinization Cell," S. Loeb and F. MIlstein, Dept. of Englneering Report No. $62-52,63$ pp., Nov. 1.962.

"The Thermo-Economics of Sea-Water Conversion," Myron Tribus and Robert Evans, Dept. of Englneering Report No. 62-53, 241 pp., February 1963.

"Sea Water Demineralization by Means of a Semipermeable Membrane," $\mathrm{S}$. Loeb, Dept. of Englneering Report No.' $62-61,26$ pp., Dec. 1962 .

"Aqueous Oxygen Corrosion of Armco Iron Effect of Chloride Ions on Potentiostatic Phenomena In $\mathrm{H}_{2} \mathrm{SO}_{4}$, R. J. Toblas and $\mathrm{K}$. Nobe, Dept. of Engineering Report No. $63-11,56$ pp., Febmary 1963.

"Saline Water Research Progress Summary July 1, 1962 - December 31, 1962," Dept. of Engineering Report No. 63-15, 71 pp., March 1963.

"Brackish Water Desalination by an Osmot1c Membrane," S. Loeb and S. Manjlkian, Dept. of Englneering Report No. 63-22, 11 pp., May 1963.

"Aqueous Oxygen Corrosion of Iron. Transient and Steady State Galvanostatic Phenomena in $\mathrm{H}_{2} \mathrm{SO}_{4}$, "F. M. Donahue and $\mathrm{K}$. Nobe, Dept. of Engineering Report No. 63-24, 43 pp., May 1963.

"Sea Water Demineralization oy Means of a Semiperneable Membrane," S. Loeb, Dept. of Engineering Report No. $63-32,28$ pp., July 1963 .
UNIVERSITY OF CALIFORNIA, BERKELEY**

"The Optimum Temperature for the operation of a Non-Scaling Mult1-Stage Flash Evaporata Plant," L. H. MacLeod et al., Sea Water Conversion Laboratory Report No. 63-1, 42 pp., January 1963.

"Removal of Scale-Forming const1tuents from Saline Water by Ion Exchange - Equilibrium Conditions," Gerhard Klein et al., Sea

Water Conversion Laboratory Report No. 63-2, $66 \mathrm{pp} .$, February 1963.

"Berkeley Progress Report for the S1x-Month Period Ending December 31, 1962," Sea Water Conversion Laboratory Report No. 63-3, 44 pp., February 1963.

"Experimental Study of Some Baslc Parameters in Electrodialysis," P. M. Rapier et al., Sea Water Conversion Laboratory Report No. $63-4,43 \mathrm{pp} .$, Apr11 1963.

"Condensing Heat Transfer in Steam-A1r Mixtures in Turbulent Flow - Reynolds Number Relationships, " P. B. Stewart and S. E. Hurd, Sea Water Conversion Laboratory Report No. $63-5,43$ pp., June 1963.

"Sea Water Evaporation by Direct Contact Heat Transfer," C. R. Wilke et al., Sea Water Conversion Laboratory Report No. 63-6, 34 pp. August 1963.

"Sea Water Conversion Research at the Un1v. of California," E. D. Howe, Proceedings Desalination Research Conference, National Academy of Sclences--National Research Counc1l Publication 942, Washington, D. C., pp. 107-118, 1963 .

"The Distiliation of Sea Water and other Low-Temperature Applications of Solar Energy! E. D. Howe, Chapter 12 in book, Introduction to the Utilization of Solar Energy, MicGrawHill Book Company, Inc., A. M. Zarem and Duane D. Erway, editors, pp. ?95-313, 1963. "Simple Method Determines Brine Cnncentrations," Susan Welner, Chemlcal Englneering, Vol. 70, No. 12, pp. 238-240, June 10, 1963. "Fresh Water for the Future," E. D. Howe, Californla Monthly, Vol. LXXIV, No. 1, pp. 12-15, October 1963.

*Requests for coples should be directed to: Institute of Industrial Cooperation, Dept. of Englneering, Univ. of California, Los Angeles, Calif.

* Requests for coples should be directed to: Sea Water Conversion Laboratory, Univ. of Callfornia, 1301 South 46 th street, Richmond, California.

\section{(1823) TRANSPORT OF COASTAL SEDIMENT.}

(b) Beach Erosion Board, U. S. Army, Washington, D. C.

(d) Experimental, basic research.

(e) To obtain experimental information on the criterion for initial and general movement of bottom sediment by wave action. Prototype conditions of the relative motion of water and bed were simulated by use of an osc1llating plate in still water. Sediment transport by actual waves in flume with and without superimposed uni-directional flow has been measured for comparison with the results on moving bottom.

(f) Continued.

(g) A transport theory has been establlshed for bed-load motion very similar to that of H. A. Elnstein for river flows. It appears to describe all avallable measurements with good accuracy.

(h) "Transportation of Bed Material due to Wave Action" by George Kalkanis, Tech. Rept. HEL-2-4 to the U. S. Beach Erosion Board, February 1963. "Hydrodynamies of sediment Motion" by H. A. Einste1n, presented at the IUGG meeting at Berkeley, August 1963, Oceanography Section.

\section{(2265) FORCES ON ACCEIERATED CYLINDERS.}

(b) U. S. Navy, C1vil Englneerlng Laboratory, Port Hueneme, Calif., and National Sclence 
Foundation; laboratory project.

(c) Prof.A. D. K. Lalrd, 109 Mechanics Bldg., Univ. of California, Berkeley 4, Calif.

(d) Experimental and theoretical, basic research. Measurement and prediction of drag coefficients and flow configurations about cylinders during accelerated motion in fluids as related to wave forces as cylinders including effects of support flexibllity.

(h) "Groups of Vertical Cylinders oscillating in Water" by A. D. K. Lalrd and R. P. Warren, Proc. ASCE, Vol. 89, No. EM 1, Feb. 1963.

(2505) EFFECT OF SEDIMENT DISTRIBUTION IN STREAM CHANNELS.

(b) University project.

d) Experimental; basic research.

(e) Alluvial flows in channels with artificially secured banks are studied systematically for their tendency to meander as expressed by the development of alternate bars. It is the aim of this study to develop criteria for stability.

(f) Experimental work concluded.

g) The 1mportant parameters seem to be the Froude's number, the depth-width ratio and the size and uniformity of the bed sediment. The uneven distribution of friction between banks and bed $1 \mathrm{~s}$ of prime importance.

(h) Publication is in preparation.

(3385) ELECTRIC FLOOD MODEL.

(b) U. S. Corps Englneers, Kansas City Dist.

(c) Prof. J. A. Harder, Hesse Hall, Univ. of Callf., Berkeley, Calif.

(d) Experimental; design and development.

(e) Using analog model techniques a simulator for the Kansas RIver and its tributaries has been developed. Purpose is to provide a rapid and convenient means of estimating the effects of reservoir operation and rainfall distribution on flood stages. All pertinent hydraulic variables will be under operator's control, and a flood routing procedure completed each $1 / 60$ second.

(r) Completed. Electric Flood Model now in operation in U. S. Corps of Engineers District office, Kansas C1ty, Missourl.

(h) "Analog Models for Flood Control Systems," by J. A. Harder, Journal of the Hydraulics Div., Proceedings ASCE, Vol. 88, No. HY2, March 1962.

(3673) JET PUMP FOR SEDIMENT.

(b) Paclfic Coast Englneering co.

d) Experimental design.

e) The use of a jet pump as a booster pump at the end of the ladder of a suction dredge is studied.

(f) Design study completed.

(g) Two dredges w1th jet pump boosters completed successfully sand removal to 200 foot depths to uncover bedrock for placement of the Akosombo Dam, Volta River, Ghana. one dredge with jet pump booster now undergoing exhaustive field tests.

(3674) INVESTIGATIONS OF BOUNDARY LAYERS ALONG FLUID INTERFACES.

(b) National Sclence Foundation.

d) Experimental; basic research.

e) To study the stability, shear and disturbances along an interface.

(g) The comparison of the methods used in studying the stabllity of streamlined (laminar) flow near interfaces between real flulds showed that a wave pattern is always superimposed over the flow. If such a disturbance is selfsustaining at the interface it causes interfaclal waves or mixing of the flulds. If such a wave is self-sustaining, in one of the rluids near the Interface it leads to turbulence in that fluid, similar to a boundary layer near a solid boundary.
Experiments and analyses were completed of the flow of alr over water, colder and hotter than the air, and normal air flow over water to check Miles' stability theory using statistical techniques (Tukey's). Miles' shear theory seems to predict the phase angle-frequency component relationship for frequencies lower than the frequency assoclated with the maximum energy density.

(3675) CLAY TRANSPORT.

(b) National Science Foundation.

(c) Mr. R. B. Krone, DIv. Of Hydraulic and Sanitary Engineering, Univ. of California, Berkeley, California.

(d) Experimental and theoretical; basic research.

(e) A continuation and generalization of (3382) to various types of clays. The effect of flocculation and concentration of clay on flows, and the deposition and scour of these sediments are studied systematically.

(f) Near completion.

(g) Viscometer measurements on suspensions of clayey sediment from 5 sources are ylelding rheological characteristics of sediment flocs and floc aggregates, including shear strengths. Rheological measurements on consolidating sediments are also in progress. A 1000-ft. channel and clrculating system is completed and instrumented to determine friction factors of flowing sediment suspensions in order to study flow-bed interaction during deposition and scour. Friction measurements show that bed is roughened by sudden increases in flow.

(3677) ANNULAR NOZZLE GROUND EFFECT MACHINE.

(b) Offlce of Naval Research, Dept. of the Navy.

(c) Prof: R. L. Wiegel, Dept. of Clvil Engrg., Univ. of Calif., Berkeley, California.

(d) Experimental; applied research.

(e) Alrborne vehicles supported by annular jets have a lift considerably in excess of that due to the jet momentum when operating in a region close to the ground. The dynamic lift, bending moment, wave resistance, base pressures, and 1ntake pressures are being measured for such a vehicle operating over both calm water and water with surface gravity waves present.

(f) Completed.

(g) Much information has been obtained on the response of the model vehicle to surface water waves. In regard to wave-making resistance a noticeable nonuniformity of jet momentum has been measured.

(h) "Research on Annular Nozzle Type Ground Effect Machine Operating over Water: Water Surface Configuration" by J. D. Cumming, IER Tech. Rept. 187-3, 82 pp., Sept. 1963. "Research on Annular Nozzle Type Ground Effect Machine operating over Water: Preliminary Study of Alr Flow Patterns" by J. D. Cumming, IER Tech. Rept. 187-6, Sept. 1963.

"Research on Annular Nozzle Type Ground Effect Machine Operating over Water; Operation Over Waves ${ }^{11}$ by R. L. Wlegel, et al, IER Tech. Rept. 187-7, 77 pp., Sept. 1963. "Research on Annular Nozzle Type Ground Effect Machine Operating Over Water: Annular Distribution of Jet Momentum" by J. D. CummIng, IER Tech. Rept. 187-8, Sept. 1963.

(3678) OCEAN SEWER OUTFALLS.

(b) U. S. Public Health Service.

(d) Basic research.

(e) Th1s study $1 \mathrm{~s}$ concermed w1th the varlous phenomena involved in the diffusion of sewage at the discharge end of an ocean sewer outfall.

(g) Phases investigated to date have involved mixing resulting from jet action and surface wind waves. The effects of wind 
and waves on surface dispersion have been studied in a laboratory wind-wave flume. Measurements of the shape of the dispersion plume have been obtained under various wind and wave conditions, and the influence of some of the wave characteristics on the eddy diffusion coefficient has been noted.

(h) "Turbulent Mixing Phenomena of Ocean Outfalls," by Richard $\mathrm{J}$. Frankel and James D. Cumming, Univ. of Calif., IER, Tech. Rept. HEL-3-1, 109 pp., Febmary 1963.

(4077) NEARSHORE SEDIMENT MOVEMENT.

(b) National science Foundation.

d) Experimental (laboratory and field).

e) The objective of this investigation is to determine the overall sand balance for selected localities and to explain changes quantitatively. Special consideration is given to sediment conditions at the mouths of large sediment-carrying rivers, submarine canyon heads, and major headlands.

(h) "A Critical Appraisal of the Techniques Using Naturally occurring Radioactive Minerals as Littoral Tracers," by Kenneth H. Huston, Hyd. Engin. Lab. Rept. HEL-4-1.

"Sediment scour at Structures," by M. M. Abou-Selda, Hyd. Engin. Lab. Rept. HEL-4-2. "A Restudy of Bottom Sediments Near the Entrance of Golden Gate," by Byron Schatz, Hyd. Engin. Lab. Rept. HEL-4-3.

(4078) BEACH BACKGROUND RADIOACTIVITY.

(b) Atomic Energy Commission, Washington, D. C.

d) Field observations and theoretical considerations.

(e) Purpose of project is to measure variations in background radioactivity of beaches along the California coast with the object of determining the normal background, its seasonal variations and varlation in radioactivity from place to place at any one time.

(g) The dilution in concentration of naturally radioactive sediments away from a source has proved of value in establishing the predominant direction of littoral drift.

(h) "The Relationship between Watershed Geology and Beach Radioactivity," by J.R. Byerly, Beach Erosion Board Tech. Memo. No. 135, August 1963.

"Beach Sand Radioactivity, Source, Transportation, and Deposition studies," by John Cherry, George Gordon, and Moshe Gablinger, Hyd. Engin. Lab. Report HEL-5-2, July 1963 .

(4081) RECHARGE OF WASTES IN UNDERGROUND FORMATIONS.

(b) Livermore Radiation Lab., Livemore, Calif.

d) Experimental; basic and applied research.

(e) This study 1 s deslgned to evaluate the hydraulics of fluid flow from a surface basin into underlying aquifers. Results are expected to assist in fleld studies of disposal of Industrial wastes, brines, and radioactive materials.

(h) "Radial Flow Behavior of Artificial Recharge from Surface Cavities," by D. K. Sunada and D. K. Todd, Hydraulic Laboratory, Univ. of Calif., Berkeley, 57 pp., 1963.

(4032) CAVITATION IN A VENTURI.

(b) Laboratory project.

(c) Prof. H. W. Iversen, Dept. of Mech. Engrg., University of Calif., Berkeley, California.

(d) Experimental and theoretical basic research.

(e) Macroscopic nature of cavitation formation and collapse with inter-relationships of head losses on collapse and with liquids of different vaporization properties.

(B) Tests with water over a 60 degree $F$ 200 degree $F$ range of temperature are completed. Analysis in progress.
(4562) ANALYSIS OF NONLINEAR SYSTEMS.

(b) Laboratory project.

(c) Prof. J.A. Harder, Hesse Hall, Univ. of California, Berkeley, Calif.

(d) Theoretical; basic research.

(e) Given a sufficiently long record of the input and output of a stationary system that may include nonlinearities, the purpose is to develop a predictor for arbitrary inputs.

(g) Computer program is written that has enabled close prediction of the output of an experimental nonlinear system to a sine wave having an amplitude and frequency well within the limits of the random input used to develop the predictor.

(h) "Nonlinear Analysis of Hydraulic Englneering Systems," by S. L. Jacoby, Ph.D. thesis, Univ. of California, Berkeley, June 1962.

(4563) CLAY-SUSPENSION FILTRATION .

(b) Livermore Radiation Laboratory, Livermore, California.

(d) Experimental; basic and applied research.

(e) Study of the movement of clay suspensions through coarse porous medla and through fissured rock.

(f) Completed.

(n) "Flow of Clay Suspensions through Fractures," by I. Zafrani and D. K. Todd, Hydraul1C Laboratory, Univ. of Calif., Berkeley, $31 \mathrm{pp}, 1963$.

(4564) FLOW OF SAND-WATER MIXTURES IN PIPES.

(b) University project - thesis project.

d) Experimental.

(e) To define flow parameters and to design measuring equipment for the two-phase flows.

(g) A piece of experimental equipment has been designed to malntain various sustained flows of water-sand mixtures. Two solutions were investigated for combined flow-rate and concentration meters.

(h) "Investigation on a Two-Phase Problem in Closed Pipes," by W. H. Graf, Ph.D. Thesis and Report HEL-2-2 of the Hyd. Engln. Lab. Univ. of Callfornia, Berkeley.

"Experimental Apparatus Studies sediment Transport in Closed Conduits," by $\mathrm{H}$. A. Einstein and W. H. Graf, Civil Engineering, Vol. 33, No. 10, pp. 52-53, october 1963.

(4565) MATHEMATICAL MODELS FOR FLOOD ROUTING.

(b) U. S. Corps of Engineers, Omaha District office.

(c) Prof. J.A. Harder, Hesse Hall, Univ. of California, Berkeley, Calif.

(d) Theoretical; basic research.

(e) Varlous models are being fitted to experimental floods induced by splllway releases from reservolrs on the Missourl River.

(g) Principal limitation has been found to be accuracy of channel data.

(4566) PROGRESSIVE WAVES AT SPILLWAYS.

(b) Laboratory project.

(c) Hyaraulic Laboratory, Hesse Hall, Univ. of Calif., Berkeley 4, California.

(d) Experimental.

(e) Laboratory studies were made of the progressive waves generated downstream from spillways. Splliways studied included the hydraulic pump in both a horizontal and sloping channel and a flip-bucket.

(f) Completed.

(h) "Wave Action at Sp1llways," by M. M. AbouSelda, Jour. Hyd. Div. ASCE, pp. 133-152, May 1963.

(4568) SIGNIFICANCE OF VORTICITY IN TURBUEENT FLUID FLOWS.

(b) University project; thesis.

d) Theoretical. 
(e) A basic attempt to define turbulence. Some new characteristics of flows were developed describlng the onset and malntenance of turbulence.

(4569) STUDY OF PERSISTENT POLYMOLECULAR STRUCTURES OF WATER.

(b) Laboratory project

(c) Mr. R. B. Krone, D1v. of Hydraulic and Sanitary Engineering, Univ. of California, Berkeley, California.

(d) Basic theoretical - experimental.

(e) Investigations of thermal properties, surface characteristics, and of X-ray diffraction patterns are studied to provide information on properties of water in bulk and near interfaces.

(g) Relations between temperature and viscosity, specific heat, and speciflc volume have been found, and a tentative system of persistent structures has been developed that account for observed properties of water.

(4929) AQUIFER ANALYSIS BY SLUG TESTS OF WELLS.

(b) Laboratory project.

d Experimental; applied research.

(e) Study of the limitations, procedural problems, and validity under varlous field conditions of the slug test method of evaluating aquifer constants.

\section{(4930) COASTAL SAND MOVEMENT.}

(b) Corps of Englneers, U. S. Army, Coastal Engineering Research Center.

(d) Experimental; laboratory and field.

(e) This investigation is concerned with the transportation of sand by both wind and waves.

(h) "Calculation Procedure for Sand Transport by W1nd on Natural Beaches," by Abdel-Latif Kad1b, Hyd. Lab. Rept. HEL-2-6, October 1963.

(4931) EDDY DIFFUSION AND MASS TRANSFER IN OPEN CHANNEL FLOW.

(b) Laboratory project.

c) Prof.G.T. Orlob, Dept. of Civil Engin., Unıv. of California, Berkeley, Callf.

(d) Experimental; applied research-for doctoral thesis.

(e) This investigation was concerned with the eddy diffusion in open channel parallel two-dimensional turbulent shear flow. The diffusion in the vertical was studied by using sodium chlorlde mixed with alcohol as a tracer. The tracer was injected uniformly across the flow from a line source at the water surface at a steady rate. The purpose of this investigation was: (1) To deternine the diffusion coefficient in the vertical and to relate the diffusion coefflcient to some parameters of the flow: depth, velocity, rate of energy dissipation, etc.; (2) to compare the diffusion coefficient and the momentum transfer coefflcient based on Prandtl mixing length theory; (3) to find a general solution to the problem of line source at the water surface in turbulent shear flow; and (4) to compare between lateral. longitudinal and vertical diffusion coefflclents in open channel flow. (f) Completed.

g) The following results can be derived from this investigation: (1) The diffusion coefficlent had a minimum value near the boundarles and maximum value at mid-depth of the flow with askewed distribution toward the rough boundary. (2) The mean value of the observed diffusion coefflclent was approximately equal to the mean value of the computed momentum transfer coefficlents based on Prandtl mixing length theory. The two coefficients differ in their distribution in the vertical. (3) The diffusion coefficient was found to be related to the rate of energy dissipation per unit mass and the depth of the flow, whlch gave an experimental verification to Kolomogoroff similarity principle. (4) The mixing zone width in the vertical was found to be a parabolic function of the time at large distances from the source. (5) The longltudinal diffusion coefficient was found to be higher than the diffusion coefficlents in the lateral, and vertical for a glven flow condition.

(h) "Eddy Diffusion and Mass Transfer in Open Channel Flow," by A. Al-Saffar, Ph.D. Thesis, Univ. of California, Berkeley, October 1963.

(4932) GROUND WATER BASIN MANAGEMENT.

(b) Laboratory project.

(d) Experimental and theoretical; applied research.

(e) Study of the physical conditions within a basin so that ground water levels at any point can be predicted for any future time for given recharge and discharge conditions. Subsequently, study of alternate methods for operating the basin to obtain an economically optimal system.

(4933) HYDRAULIC SYSTEMS ANALYSIS.

(b) California Department of Water Resources.

c) Prof. J. A. Harder, Hesse Hall, Univ. of Callfornia, Berkeley, Calif.

(d) Experimental; applied research and design

(e) Analog model and digital computer methods are being used to predict salinity, tidal amplitudes, tidal elevations, and fresh water flows in the Sacramento-San Joaquin Delta Region.

(4934) WAVE DIFFRACTION AND REFRACTION.

(b) Corps of Engineers, U. S. Army, Coastal Englneerlng Research Center, Washington, D. C.

(c) Prof. R. L. Wlegel, Univ, of California, Berkeley, Callf.

(d) Experimental; baslc research.

(e) Determination by model tests the diffraction and refraction characteristics of wind waves. Also, model studies of the "Machstem" equivalent of water waves.

(g) IBM 7090 program developed for computing wave diffraction coefflcients at semiinfinite breakwater. Work being done on computing two dimensional wave spectra in model basin.

(4935) BEACH PROFILES AT VERTICAL WALLS.

(b) Laboratory project.

d Experimental; M.S. Thesis.

(e) This investigation was made to determine the characteristics of the equilibrium profile in front of and behind vertical sea walls of varlous helghts which were subjected to. waves of various steepness.

(f) Completed.

(h) "Beach Profiles as Affected by Vertical Walls" by A. A. Kadib, Beach Erosion Board Tech. Memo. No. 134, Washington, D. C., June 1963.

UNIVERSITY OF CALIFORNIA, Department of Naval Architecture.

(3026) SHIP RESISTANCE IN UNIFORM WAVES AS A FUNCTION WAVE STEEPNESS.

(b) David Taylor Model Basin, Dept. of the Navy.

(c) Mr. O. J. Sibul, Room 224, Bldg. T-3, Univ. of Calif. Berkeley, California.

(d) Experimental.

(e) A serles of experiments were performed to study the effect of width (beam) and the block coefflclent of the ship on the added resistance in uniform waves. The following 
block coefficlents were used for serles 60 -foot models: $0.60 ; 0.70 ; 0.80$ and a model of DE 1006 with a block coefficient of 0.49 . All of the models were towed in waves $3.75 ; 5.00 ; 6.25$ and 7.50 feet long at seven different wave steepnesses between 0.0146 and 0.0684

(g) All the experiments have been completed and the results evaluated. The final report is in preparation.

(3685) SHIP SLAMMING LOADS AND HULL RESPONSES.

(b) National Academy of Sclences - National Research Council, Committee on Ship Structural Design.

(c) Prof. H. A. Schade, Room 224, Bldg. T-3, Un1v, of California, Berkeley, Calif.

(d) Experimental and theoretical; basic and applied research.

(e) The project involves structural as well as hydrodynamic problems. Only the latter are described here. (1) It will be attempted to determine the virtual mass distribution along the length of a vibrating beam

in water (forced vibration as well as impact loading).

(f) Completed.

g) The beam was fitted into a number of sections( 8 ) of plastic bodies, semi-submerged in horizontal position in water, and forced to vibrate. Vibration frequencies and damping for the first six flectural modes were determined. An impact loading was applied also, to excite the vibrating response.

(h) "Dynamic Response of an Idealized Hull Girdle to Slam-Type Loading," by R. W. Clough and $W$. M. Maclean, University of California, Berkeley, Institute of EngineerIng Research, Report No. NA-63-6, July 1963.

(3686) NON-LINEAR COUPLED SHIP MOTIONS.

(b) David Taylor Model Basin, Department of the Navy.

(c) Prof. John R. Paulling, Jr., Room 224 Bldg. T-3, Univ. of California, Berkeley, California.

(d) Theoretical with some experimental verification.

(e) It has been shown that at certain frequencles of heave or pitch motion of ship, a rolling motion of large amplitude may arise. This is explained in terms of instabilities of solutions of the equations of motion which include certain non-linear coupling terms.

(f) Completed.

(h) "Effect of Nonlinear Static Coupling on the Motion Stability of a Ship Moving in oblique Waves, " by W. D. Kinney. University of California, Berkeley, Institute of Engineering Research, Report No. NA-63-3, June 1963.

(4083) DYNAMIC INTERACTION BETWEEN SHIPS.

(b) Office of Naval Research, Dept. of the Navy .

(c) Prof. J. R. Paulling, Room 224, Bldg. T-3, Univ, of Calif., Berkeley, California.

(d) Theoretical and experimental.

(e) The linearized equations of motion for two ships operating on parallel courses are formulated. Coefficients appearing in these equations are being evaluated by captive model techniques. Analog and digital means of solving the equations are being studied.

(g) Sinusoidal motion generator was used to evaluate velocity and acceleration derivatives for each of the individual models of the ship without the other model being present. Experiments are under way in which interaction forces and moments between two models are measured.

(4084) SHIPS OF MINIMUM RESISTANCE.

(b) Office of Naval Research, Dept. of the
Navy .

(c) Prof. J. V. Wehausen, Room 221, Bldg. T-3, Univ. of Calif., Berkeley, Califormia.

(d) Theoretical applied research. resistance fixed the profile and volume and minimizes Michell's Integral among some given class of functions describing the whole ship. Since the theory assumes irrotational flow of an inviscid fluid, it does not take account of the effects of viscosity, e.g., the possibility of a separated boundary layer for certain forms nor of the necessity of fitting a propeller asterm. Here one tries to take account of this by fixing the afterbody as one known to be satisfactory, and then allowing only the forebody to vary among a given class of functions.

(g) IBM 7090 was used to calculate ship lines for minimum resistances. The calculations were made for a number of ship speeds. The next step will be to bulld several models, test these models in towing tank and compare the results with theoretical calculations.

(h) "Ships of Minimum Total Resistance," by w. C. LIn, W. C. Webster, J. V. Wehausen, University of California, Berkeley, Inst. of Englneering Research, Report No.

NA-63-7, Aug. 1963.

"Schiffe Geringsten Wellenwiderstandes mit Vorgeschriebenem Hinterschiff," by w. C. Webster, and J. V. Wehausen, Schiff stechnik g (1962) 62-68,

(4570) PRESSURE DISTRIBUTION ON SEMI-SUBMERGED OSCILIATING BODIES.

(b) David Taylor Model Basin, Department of the Navy.

(c) Prof. J. R. Paulling, Room 224, Bldg. T-3, University of Califormia, Berkeley 4, Calif.

(d) Experimental and theoretical.

e) To determine the response of a floating body in a seaway, it is necessary to know the magnitudes and phases of hydrodynamic forces and moments acting on this body. In the inearized analysis the total pressure at any point takes the form of two terms: (a) exciting pressure dependent upon the waves only: (b) pressure dependent upon the geometry and motion of the body and independent of the waves. These two terms are being measured on: (1) A prolate spherold; (2) A ship-like form.

First the models are attached rigidly to the dynamometers, towed in waves and the pressure distribution, total forces and moments measured. Then the models are oscillated sinusoldally in still water and again the pressure distribution, total force and moment measured. The results will be compared with theoretical calculations.

(g) Both the models have been tested in still water as well as in waves. The results Indicate that the wave forces and moments follow the general trend as predicted by Krylow's Theory. For the oscillating models in still water, the longltudinal distribution of virtual mass and damping have been determined experimentally.

(h) Two reports are in preparation.

(4970) PRESSURES ACTING ON A HEMISPHERE OSCILIATING ON A FREE SURFACE.

(b) Office of Naval Research, Dept. of the iNavy.

c) Prof. J. V. Wehausen, Room 221. Rl.dg. T-3, Univ, of Calif., Berkeley, Calif.

(d) Experimental, theoretical, basic research. for a hemisphere undergoing forced harmonic oscillations on the free surface have been experimentally determined. The added mass and damping coefficients have been computed from both the integrated pressures and the direct force measurements.

(f) Completed. of the linearlzed hydrodynamic theory as 
computed by W. R. Porter. Qualitatively, it is belleved that the results are in agreement with the predictions.

(h) "The Experimental Determination of Forces and Pressures Acting on a Hemisphere Oscillating on a Free Surface," by R. A. Cumming, University of California, Berkeley, Institute of Engineering Research, Report No. NA-63-1, March 1963 .

(4971) SHIP RESISTANCE IN IRREGULAR WAVES.

(b) David Taylor Model Basin, Dept. of the Navy.

c) Mr. O. J.Sibul, Room 224, Bldg. T-3, Univ. of Calif., Berkeley, California.

(d) Experimental; applied research.

e) The previous resistance measurements of ship models in uniform waves will be used to predict the total added resistance in irregular waves of known spectral content. The predictions will be compared with experiments in irregular waves of various spectral contents and severity, combined with a number of model speeds.

(4972) STUDY OF A SPAR SHIP.

(b) Bureau of Ships, Dept. of the Navy.

c) Prof. John R. Paulling, Jr., Room 224 , Blg. T-3, Univ, of Calif., Berkeley, Calif.

(d) Experimental; theoretical, applied research.

(e) To study the hydrodynamic characteristics of a spar ship a cylindrical model with a cross section made up by two circular arcs was tested in still water as well as in waves. The length-draft ratio of the model was 0.25 and the beam-draft ratio 0.05 . The model was tested: (1) for resistance in still water as well as in waves: (2) wave forces and moments on restricted model;

(3) motions for the free model in uniform waves; (4) model was oscillated in still water and the virtual mass and damping calculated. An attempt was made to calculate the still-water resistance theoretically.

(h) A report is in preparation.

CARNEGIE INSTITUTE OF TECHNOLOGY, Department of Civil Engineering.

Inquiries conceming the following projects except when otherwise indicated should be addressed to Dr. T. E. Stelson, Dept. of Civil Engineering, Carnegie Institute of Technology, Pittsburgh, Pennsylvania 15213 .

\section{(2275) FLOW OF LIQUID-SOLID MIXTURES.}

(b) Laboratory project.

d) Analytical and experimental.

(e) Study of the movement of granular material carried in a fluid through closed conduits. Measurements of velocities, energy losses, concentrations and segregated conditions are made.

(3203) PRESSURE SURGES IN CLOSED CONDUITS.

(b) Laboratory project - National Science Foundation Fellowship.

(d) Analytical and experimental.

(e) Determination of pipe geometry on the reflection and transmission of pressure surges in closed conduits.

(f) Terminated.

(3390) MECHANICS OF NON-NEWTONIAN FLOWS.

(b) Laboratory project.

c) Dr. G. Bugliarello, Dept of Civil Engrg., Carnegie Inst. of Tech., P1ttsburgh, Pennsylvanta 15213 .

(d) Analytical and experimental.

(e) Study of energy relationships, velocities and flow structure in non-newtonian flows.

(h) "Flow of Clay-Water Suspensions" by G. Bugliarello. Discussion, Journal of the Hydraulics Division, ASCE (in the press).
(3689) PHASE SEPARATION EFFECTS IN THE FLOW OF BLOOD.

(b) National Institutes of Health.

(c) Dr. G. Bugliarello, Dept. of Civil Engrg., Carnegie Inst. of Tech., Pittsburgh, Pennsylvania 15213 .

(d) Analytical and experimental.

(e) Study of the magnitude of the phase separation effect in the flow of blood for vessels of different sizes and configurations, both under steady and pulsating flow conditions.

(h) "Detalled Characteristics of the Flow of Blood in Vitro," by $G$. Bugliarello and $\mathrm{J}$. W. Hayden, Transactions of the Soclety of Rheology, Vol. 7 (1963).

"The Profile Viscosity and other Characteristics of Blood Flow in a Non-Uniform Shear Fleld," Transactions, 4th International Rheology Congress (1963) (In the press).

(3692) SEPARATION FLOW OF SOLID-LIQUID MIXTURES.

(b) Allegheny County Sanitary Authority.

d Experimental and analytical.

(e) In the separation or divergence of flowing liquid-solid mixtures unbalanced concentrations frequently occur in the different channels. Methods are being developed to predict and control the unbalance.

(h) "Grit Unbalance in Sewage Flow Division," Y. Yoshimi and T. E. Stelson, J. of the Sanitary Engrg. Divisions, ASCE, Vol. 89, April 1963.

(4093) VIBRATORY MOTIONS OF FLOATING BODIES.

(b) Office of Naval Research, Dept. of the Navy.

d) Experimental and analytical.

(e) Development of theory for detemining wave pattern and virtual mass and damping in the three-dimensional flow field around a shallow ship.

(h) "Oscillation of a Shallow-Draft Ship--An Experimental Study," M. A. Anderson, M. S. Thesis, 1963.

(4094) MOLECULAR DIFFUSION STUDIES BY RANDOM WALK METHODS.

(b) Laboratory project.

c) Dr. G. Bugliarello, Civil Engineering Dept., Camegie Inst. of Tech., P1ttsburgh, Pa. 15213 .

(d) Analytical.

(e) Development of computer programs for the study of molecular diffusion in a laminar shear flow using random walk methods.

(h) "A Random Walk Study of Diffussion in Convective Flow Fields," E. D. Jackson III, Ph.D. Thesis, october 1963.

(4095) HIGH PRESSURE LIQUID FLOWS.

(b) Laboratory project.

c) Dr. G. Bugliarello, Dept. of Civir Engrg., Carnegie Inst. of Tech., Pittsburgh, Pa. 15213 .

(d) Experimental:

(e) Study of laminar and turbulent flow of various liquids between concentric cylinders, under pressures up to 15,000 psi.

(f) Inactive.

(4096) FLOW OF SOLID-LIQUID MIXTURES AT BIFURCATIONS.

(b) Laboratory project.

c) Dr. G. Bugliarello, Dept. of Civil Engrg., Carnegle Inst. of Tech., P1ttsburgh, $\mathrm{Pa}$. 15213 .

(d) Experimental.

(e) Study of the effect of bifurcations on the concentration of solid-liquid mixture in the laminar and turbulent flow range in closed condults.

(h) "Phase Separation in Suspensions Flowing through Blfurcations," by G. Bugliarello and G. C. C. Hsiao, Science (in the press). 
(4571) DESIGN OF A SYNTHETIC COMPUTER LANGUAGE FOR SANITARY ENGINEERING.

(b) U. S. Public Health Service.

(c) Dr. G. Bugliarello, Dept. of Civil Engrg., Carnegie Institute of Tech., P1ttsburgh, $\mathrm{Pa} .15213$.

(d) Analytical.

(e) Deslgn of a user-orlented computer language leading to a large degree of automation in the area of sanitary engineering and water resources. The first phase of the project is the development of a pilot language for hydrology.

(h) "An Informal Progress Report on HYDROL--A Content-oriented Computer Language for Hydrology and Hydraulic Engineering," G. Bugliarello, J. J. Gormley and W. McNally, Dept. of Civil Eng., Carnegle Institute of Technology.

(4572) WATER RESOURCES ENGINEERING.

(b) Laboratory projects.

(c) Dr. G. Bugliarello, Dept. of C1vil Engrg. Carnegie Institute of Technology, Pittsburg, Pennsylvania 15213.

(d) Analytical.

(e) Study of various aspects of water resources engineering, with particular emphasis on operational research methods.

(h) "The Role of flood Plains in the correlation between Flood Predictions and Dam Deslgn," G. Bugliarello and V. S. Bhavnagri, Proceedings of the International Assoc. for Hydraulic Research (IAHR).

(4573) VIBRATION OF A CIRCULAR CYLINDER IN A FLUID.

(b) Laboratory project.

(d) Theoretical and experimental; basic research for doctoral thesis.

(e) Ascertaining a representation for the functional dependence of the interaction force between vibrating body and the surrounding fluid.

(h) "On the Elastlc V1bration of a Clrcular Cantilever Tube in a Newtonian Fluid," J. Keane, Ph.D. Thes1s, 1963.

(5097) VIRTUAL MASS.

(b) Laboratory project.

d) Analytical and experimental. Determination of the inertial drag on bodies moving in fluids in rotational motion and under varying conditions of translational motion.

(h) "Virtual Moment of Inertia of Rectangular Bodies," G. G. Picher, M. S. Thesis, June 1963.

(5098) FLOW THROUGH COARSE GRANULAR MATERIAL.

(b) Laboratory project.

d) Analytical and experimental.

(e) Study of flow conditions in transitional range between laminar and turbulent.

(h) "Flow of Water Through Porous Media," J. F. Dolway, M. S. Thesis, June 1963.

(5099) FLOW CHARACTERISTICS OF FOAMS.

(b) Laboratory project; formerly U. S. Public Health Service.

(d) Experimental and analytical.

(e) Study of the flow characteristics of foams in closed conductors and open channels of varying geometry.

(h) "Foam Mechanics and Viscometry," R. J. Brungraber, Ph.D. Thes1s, June 1963.

(5100) JOINT LEADAGE IN VITRIFIED CLAY PIPE.

(b) Laboratory project.

(c) Dr. H. J. Day, Dept. of C1vil Engr., Carnegie Inst. of Tech., P1ttsburgh, Penna. 15213.

(d) Analytical and experimental.

(e) Effect of temperature and pressure on leakage from vitrified clay pipe with pre-formed joint materials will be studied.
(5101) OPEN-CHANNEL FLOW OF NON-NEWTONIAN FLUIDS.

(b) Laboratory project

(c) Dr. H. J. Day, Dept. of C1vil Engr., Carnegle Inst. of Tech., Pittsburgh, Pa. 15213.

(d) Analytical and experimental.

(e) The flow of a non-newtonian liquid in an open channel will be investigated. Energy losses, and velocity profiles will be measured.

(5102) SINGULAR PERTURBATION EXPANSION PROCEDURE FOR SOLUTION OF NAVIER-STOKES EQUATIONS.

(b) Laboratory project

(c) Dr.Y.Y. Sh1, Civil Eng. Dept., Carmegie Inst. of Tech., P1ttsburgh, $\mathrm{Pa}$. 15213.

(d) Theoretical.

(e) Search for uniformly valid asymptotic solutions of the Navier-Stokes equations by introducing two or more expansions.

(5103) SINGUTAR PERTURBATION EXPANSION PROCEDURE FOR SOLUTION OF MAGNETO-VISCOUS FLOW EQUATIONS.

(b) Laboratory project.

(c) Dr. Y. Y. Shi, Clvil Eng. Dept., Carnegie Inst. of Tech., P1ttsburgh, Pa. 15213.

(d) Theoretical.

(e) Search for uniformly valid asymptotic solutions of the Navier-Stokes equations in the presence of a magnetic field by introducing two or more expansions.

(5104) INTERACTION PROBLEMS OF OCEAN WAVES.

(b) Laboratory project.

(c) Dr.Y. Y. Sh1, Civil Eng. Dept., Carmegie Inst. of Tech., Pittsburgh, Pa. 15213.

(d) Theoretical.

(e) Study of the interaction of wave packets of small amplitude in an unbounded medium.

(5105) INTERACTION PROBLEMS OF FLUID PARTICLES IN VISCOUS FLUIDS.

(b) Laboratory project.

(c) Dr. Y. Y. Sh1, Civil Eng. Dept., Carnegie Inst. of Tech., Pittsburgh, Pa. 15213.

(d) Theoretical.

(e) Study of the interactions of two or more particles in a viscous fluid.

CATHOLIC UNIVERSITY OF AMERICA, Department of C1V1l Engineering.

(3030) TRANSIENT FLOW THROUGH POROUS INCOMPRESSIBLE MEDIA WITY VARIOUS BOUNDARY CONDITIONS.

(b) Experimental part was supported by the National Research Council of Canada.

(c) Dr. B. S. Browzin, Professor of Civil Engrg., The Catholic University of America, Wash., D. C. 20017

(d) Experimental and theoretical; basic research.

(e) The unsteady laminar flow was reproduced by a highly viscous liquid flowing between closely spaced translucid plates on a number of models with geometric boundaries representing various types of earth dams on impervious foundations and earth massives crossed by open channels.

Experimental part concerning earth dams and earth massives on impervious foundations completed. The theoretical part of the research completed for the case of rapid drawdown in homogeneous dams. The theoretical research of cases of gradual drawdown, of non-homogeneous dams, of tallwater condition, and the drawdown in canals is temporarily suspended.

(g) An approximate function, relating by dimensionless parameters, the shape and the position of free surface of flow through the earth dam, following rapid reservoir drawdown, to the geometry of the dam, was obtained theoretically and confirmed 
(h) "Nonsteady-State Flow in Homogeneous Earth Dams after Rapld Drawdown, "Proceedings of the Fifth International Conference on Soll Mechanlcs and Foundation Englneerling, Vol. II, p. 551, Parls 1961.

"Nichtstationare Sickerstromungen in

homogenen Erddammen und Erdkorpern," pp. 259, Doctoral dissertation at the RheinischWestfael1sche Technlsche Hochschule Aachen. The book is avallable at the library of the National Research Counc1l of Canada, Ottawa 2 , Ontario.

(3031) THE VARIATION OF HYDROLOGIC FACTORS AND THEIR INFLUENCE ON RIVER REGIMES IN THE GREAT LAKES-ST. LAWRENCE DRA INAGE AREA.

(b) Laboratory project.

(c) Dr. B. S. Browzin, Professor of Clvil Engrg. The Catholic Unlversity of America, Wash., D. C. 20017 .

(d) Basic research.

(e) Research $1 \mathrm{~s}$ based on long range flow and meteorologic record. Flow and preclpitation data on U.S. and Canada stations were stat1st1cally investigated in order to obtaln river regime characterlstics.

(f) Completed.

g) Classifled discharges for long range gauging stations are calculated. Characteristic parameters for river classification of the area are obtalned, water-balance in the basin is calculated; average, maximum and minimum mun-off for the perlod of avallable observations is analysed.

(h) "Runoff and 1 ts Seasonal Varlation in the Great Lakes-St. Lawrence Basin". Monograph in Brench completed.

COLORADO STATE UNIVERSITY, C1V1l Englneering Section.

(55) SNOW COURSE MEASUREMENTS AND FORECAST ANALYSIS.

(b) Soll Conservation Service, Colorado Agric. Experiment Station.

(c) Mr. Jack N. Wash1chek, Snow Survey supervisor, Agricultural Engineering section.

(d) Fleld Invest1gations; applied research.

(e) Systemat1c measurements of depth and water content of snow are being made at high elevations in Colorado and New Mexico mountain areas for the purpose of forecasting the munoff of the principal rivers in the interest of Irrigation, power, domestic supplies, and other uses. The use of electrical resistance soll molsture units is belng tested to determine a factor of soll molsture deficlency for water supply forecast purposes. Most of the major basins now have two or more soll molsture stations installed. Correlation of soll molsture and runoff is now belng developed with the hope that this information can be used as a factor in forecasting.

(g) Forecasts are now belng issued at forty-four gaging stations in Colorado and New Mexico. As forecast procedures 1mprove, additional streams w1ll be forecasted and other areas of potential power and irrigation development will be investigated on the Colorado, San Juan, Animas and Arkansas Rivers.

(h) Colorado Agricul tural Experiment Station General Serles Papers Nos. 780, 781, 782, and 783 covering monthly snow reports for all of Colorado and New Mexico.

Nine small basin reports and one two-state bulletin covering the South Platte River watershed; Arkansas River watershed; Rio Grande watershed in Colorado; Rio Grande watershed in New Mexico; Dolores River watershed; San Juan and An1mas R1ver watershed; Gunnison R1ver watershed; Colorado RIver watershed; Yampa, Wh1te and North Platte RIver watershed; Lower South Platte RIver watershed. Supplemental reports are 1 ssued January 1 , May 15 , and June 1.
A summary of all back data was issued this fall.

A bulletin entitled "Snow Surveys in Colorado" w1ll be ready for distribution in December. This is co-authored by Norman A. Evans, Homer J. Stockwell and Jack N. Wash1chek.

(821) GROUND WATER FLUCTJATIONS AND THEIR RELATION TO PUMPING.

(b) Colorado Agricultural Experiment Station. c) Mr. M. M. Skinner, Assistant C1vil Engineer. d Fleld investigation; applied research.

(e) Semi-annual measurements of the depth to the water table in approximately 610 observotion wells are presently being obtalned. The Ground Water Branch of the U. S. Geological Survey, Denver, Colorado are cooperating in furnishing measurements for about 130 wells. The observation wells are primarlly existing Irrigation wells in the south Platte and Arkansas River Basin's, the High Plains area of eastern Colorado and the San Luis Valley. Electrical Power and Natural Gas Consumption data are complled and estimates of groundwater pumpage made. The purpose of the project is to detect areas of ground-water depletion, to develop relationsh1ps between gross pumpage and respective ground-water reservolr storage volume changes, and acquire basic data for ground-water studies in the varlous areas of Colorado.

(g) Ground-water levels of the spring of 1963 are generally steady to down slightly as compared to the spring of 1962 in the South Platte and Arkansas River Basins and the San LuIs Valley. Conslderable groundwater pumpage is continuing in the High Plains area of eastern Colorado with some increase in purping lifts resulting. Reported electrical power consumption by electrical pumping during 1962 in Colorado amounted to approximately 104,000,000 k1lowatt hours for 8653 pumping units.

(h) "Art1flc1al Ground-Water Recharge operations in Prospect Valley," by M. M. Skinner. Progress Report No. 89, June 1963.

"Ground-Water Table Fluctuations in Colorado," by M. M. Skinner. Progress Report 90 , June 1963.

"Water Resource Management in the Prospect Valley Area, Colorado," by M. M. Skinner. CER63MMS40, September 1963.

(2760) METEOROLOGICAL OBSERVATIONS.

(b) Colorado Agricultural Experiment Station and U, S. Weather Bumpau.

(c) Mr. Lewls 0. Grant, Assoclate Research Engineer.

(d) Fleld Investigation; basic research.

e) Meteorological observations are being obtained to establish long-term records of climatological elements and to support current experiment station research which is weather dependent. The elements observed are: Maximum and minimum temperature and wet and dry bulb temperatures at 3,6 , $12,24,36$, and 72 1nches; wind direction and velocity at 15 inches and 65 feet above ground; barometric pressure; evaporation from a free water surface; surface water temperature; precipitation; cloud cover; dew and frost.

(g) Complete meteorological observations have been made throughout the year.

(h) "Meteorological Observation," by Lew1s 0 . Grant. Progress Report No. 107, Aug. 1963. "The Role of Dew and Frost in the water Balance of the Plains and Mountalns of Colorado," by L. O. Grant and W. E. Marlatt. Progress Report No. 109, August 1963.

(2770) TURBULENCE STUDIES IN LIQUID USING ELECTROKINETIC PHENOMENON.

(b) National Sclence Foundation.

(c) Dr. J. E. Cermak. 
(d) Experimental research; basic research doctoral thesis.

(e) The primary objective of the study is to determine the interaction between velocity fluctuations produced by turbulence in the liquid flow and electrokinetic potential fluctuations generated at a liquid-solid interface. Knowledge gained by this study will be applied to developing techniques for measuring turbulence characteristics in luquids.

(g) Probes constructed with electrode pairs have been used to measure the distribution of turbulence intensities (three components) and the turbulent shear stress across a diameter of a circular pipe. The distribution measured in water agree with those obtained by Laufer in air using a hot-wire anemometer.

(h) "Measurement of Turbulence in Water by Electrokinetic Transducers," by J. E. Cermak and L. V. Baldwin. December 2963.

"Physics of Fluids," by G. J. Binder and

J. E. Cermak. August 1963.

(2902) DEVELOPMENT IMPROVEMENT OF WATER MEASURING DEVICES.

(b) Colorado Agricultural Experiment Station and Northern Plains Branch, Soll and Water Conservation Research Division, ARS, USDA.

(c) Dr. D. B. Simons, Acting Chief, C1vil Engineering Section.

(d) Experimental, laboratory investigation; applied research, operation and development.

(e) New and improved devices and techniques for measurement of 1rrigation water are being developed. Specific objectives are (1) Design, evaluation and calibration of trapezoidal measuring flumes, (2) Evaluation of the constant head orifice farm turnout, and (3) Development of a probe using the drag on a suspended wire to indicate total flows, velocity distributions and forces on sediment particles.

(g) The development of trapezoldal measuring flumes is continuing. Flumes with crosssections corresponding to common slipform concrete ditches have been designed and calibrated.

Several forms of the constant head orifice farm turnout were evaluated during the year. Calibrations were verified and the rellability of measurement under different adverse operating conditions was determined. Alterations of the structure were developed to Improve the accuracy of measurement.

The suspension wire probe has undergone further refinement, and development. It is being used to take precise measurements of the vertical velocity distribution in open channels which are being used to improve existing velocity distribution theories.

(h) Discussion "Unification of Parshall Flume Data," by A. R. Robinson and Henry Liu. June 1962. "Conveyance, Control and Measurement of Irrigation Water on the Farm, "by A. R. Robinson, C. W. Lauritzen, D. C. Muckel, and Jack Phelan. 1962.

"Evaluation of the Vane-Type Flowmeter," by

A. R. Robinson, January 1963.

"A Flow Measuring Device Depending on the Drag Developed on a Wire Suspended in Water," by B. B. Sharp, December 7.962 .

"The Constant Head Orifice Farm Turnout," by $\Xi$. Gordon Kruse, November 1962.

"Control structures for Sand-Bed Channels," by F. C. Stepanich, D. B. Simons, and E. V. Richardson, May 1963

"Control Structures in Alluvial Channels," by Frederich C. Stepan1ch, August 1962.

"Flow Characteristics of Low Welr structures

in Alluvial Channels," by J. D. Lawson and D. B. Simons, April i 963 .

(3395) FUNDAMENTAL STUDY OF A SUBMERGED ITREEDI.ANSIONAI, JET IMPINGING U: OIN A NORW I IANE.

(b) National Science Foundation. (c) Mr. George L. Smith, Civil Engineering Sec., Colo. State Univ., Fort Collins, Colorado.

(d) Experimental and theoretical; basic research and graduate thesis.

(e) A study was made of an axtsymmetrical jet of air impinging normally on a flat smooth plate. The mean velocity, the turbulent intensities and the turbulent shear stress were measured by means of a hot-wire anemome ter in order to study the decay of the mean velocity, the growth of the boundary-layer thickness and the turbulent structure. A sensitive fioating-element type shearmeter was designed and used. Data on skin friction obtained by direct shear measurements may be used to predict the distribution of the skin friction in similar wall jets. The objective of the program was to investigate systematically the effects on jet flow of the interaction between the free boundary and the solid boundary of varying roughness and configuration.

(f) Completed.

(g) The characteristics of the whole boundarylayer is dominated by the effect of the free jet, and the wall influences the flow only in a very limited region close to the wall. This results in much higher turbulent intensities and turbulent shear stress which increases the wall shear stress for this flow case as compared to two-dimensional uniform flow over a flat plate and smooth pipe flow. The ratio of turbulent intensities

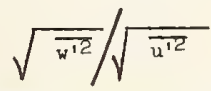

is in general not a constant across the boundary-layer which indicates non-applicability of PrandtI's assumption u' $w$ ' for this case.

(h) "Fundamental Study of a Submerged Three Dimensional Jet Impinging Upon a Normal Plane," compiled by G. L. Smith, June 1963.

(3398) TURBULENT DIFFUSION IN SHEAR FLOW.

(b) National Institute of Health, Public Health Service, U. S. Dept. of Health, Education and Welfare, Washington, D. C.

(c) Dr. J. E. Cermak.

(d) Experimental research; basic research, doctoral thesis.

(e) The objective of this project is to determine the influence of geometrical factors (land surface roughness, topography, structures), and thermal and aerodynamical factors (turbulence intensity and scale) upon atmospheric diffusion of heat and mass. "Laws of modeling" or "similitude parameters" are sougit by obtaining detailed data under various conditions in the wind tunnel and by comparing them with similar data now existing for the atmospheric prototype.

(g) Application of a hypothesis of Lagrangian similarity to particle motions in a turbulent shear flow near a solid boundary has ylelded similarity parameters and relationships between them which correlate the windtunnel diffusion data and avallable diffusion data obtained in the atmospheric surface layer.

(h) "Wind Tunnel Modelling of Atmospheric Diffusion," by R. C. Malhotra and J.E. Cermak, April $25,1963$.

(3400) HYDRAULICS OF SUB-CRITICAL FLOW IN SMALI, ROUGH CHANNELS.

(b) Colorado Agricultural Experiment Station and Agricultural Research Service, U. S. Department of Agriculture.

(c) Mr. Norman A. Evans.

d Theoretical, laboratory experiment.

e) Both laboratory and field studies have been conducted. A tilting flume was used in the laburatory, and a portable truss to carry a measuring carriage was used in the fleld. The purpose is to relate roughness in small channels to flow resistance. 
(g) Resistance to flow in small channels does not follow the same relationships established for large channels. The standard deviation of peak to valley heights was found to be a significant parameter, and a spectral density description of roughness 1 s beling tested.

(h) "Hydraulics of Surface Irrigation," by Norman A. Evans, 1962. See Project No. 4296, page 106, Agricultural Research Service.

(3696) STUDY OF CLOUDS AND SNOWFALL IN THE ROCKY MOUNTAINS, AND CHANGES RESULTING FROM THE ADDITION OF ARTIFICIAL ICE NUCLEI.

(b) National Sclence Foundation and the Climax Molybdenum Company

(c) Mr. Lew1s 0. Grant.

(d) Field Investigation; basic research, applied research.

(e) Varlous physical factors 1mportant in "Cold Cloud" orographic preclpitation processes are being investigated under winter-time conditions in the high mountains of Colorado. Th1s includes observations of alrflow over the mountalns, the characteristics of the "cold" orographic clouds rising over the nucle1, the characteristics of individual snow particles falling from these clouds, snow water freezing characteristics, snowfall amounts, and the changes in these cond1tions when artificial ice nuclei are supplied.

Large kites are being developed to serve as an instrumentation platform at elevations up to about $4000 \mathrm{ft}$. above mountain top levels. Observations will include temperature; humldity; horlzontal and vertical components of wind; cloud water droplet and $1 \mathrm{ce}$ crystal size, concentration and shape, and ice nuclel concentration.

(g) Field equipment and procedures for use at high elevetions in the Colorado Rockles have been developed. Observations of the dally accumulation of snowfall, atmospheric 1ce nuclel, and varlous other cloud and snow characterlstics have been made over a large area for seeded and unseeded days during two winter seasons. S1gniflcant increases in ice nuclel have occurred in the area of the observation network, on a number of the "seeded" days. The sample size is to be increased before attempting to determine the statistical significance of this apparent increase in snowfall.

(h) "Cloud Seeding for Increasing Mountain Snow Cover," by Lewis 0. Grant. Progress Report No. 108, August 1963 .

"Indications of Residual Effects from S1lver Iodide Released Into the Atmosphere," by Lew1s 0 . Grant.

(3697) MEASUREMENT OF ATMOSPHERIC OZONE WITY THE DOBSON SPECTROPHOTOMETER.

(b) A1r Force Cambridge Research Center, L. G. Hanscom Fleld, Bedford, Massachusetts.

(c) Mr. Lew1s O. Grant.

d) Basic research.

e) Measurements of the total amount and the vertical distribution of ozone with helght are being made with the Dobson Spectrophotometer. Direct measurements of the vertical distributions of ozone are being made to around $100,000 \mathrm{ft}$. ut1lizing an ozone sonde. Dally amounts of total ozone are being related to atmospheric clrculation patterns.

(g) Observations of total ozone and the vertical distribution with helght have been made on a regular basis for days when sky cond1tions have been clear.

(h) Obsevational data is belng supplied to the U. S. Weather Bureau for publication. Reports are submitted to Alr Force Cambridge Research Center.

(3704) DEVELOPMENT AND USE OF COLORADO BENTONITE IN SEALING IRRIGATION CANALS AND RESERVOIRS. (b) State of Colorado.

c) R. D. Dimeyer, Jr., Project Leader Field investigation; applied research and development.

(e) The work consists of three stages: (1) Inventory of clay deposits in Colorado with emphasis on those potentially usable in sealing canals and reservolrs. (2) Laboratory evaluation of clays from (1) above. (3) Fleld trials in canals and reservolrs with best clays found $\ln$ (1) and (2) and evaluation of sealing results (1nitial and with time.

(g) Inventory and Testing -- In excess of 310 samples of Colorado clays have been collected and tested in the laboratory.

Development of Deposits and Fleld Trials -Elght deposits have been developed commerclally. Clays from these deposits have been used in about 100 trials in canals and ponds during the past three years.

(h) A final report of the three-year project is beling prepared and 1 s scheduled for completion by $1-1-64$.

"Methods of Using Colorado Clays for Seal1ng Canals and Ponds," by R. D. DI meyer and M. M. Skinner. Progress Report No. 91, July 1963.

"Spec1f1cations for Colorado Clays for Seallng Canals and Ponds," by R. D. Dirmeyer, Progress Report No. 92, July 1963.

"Sampling and Testing of Colorado Clays for Sealing Purposes," by R. D. Dirmeyer, G. A. Lutz and L. G. White. Progress Report No. 93, July 1963.

(3708) INVESTIGATIONS TO DEVELOP WIND TUNNEL TECHNIQUES FOR MEASURING ATMOSPHERIC GASEOUS DIFFUSION IN MODEL VEGETATIVE SURFACES.

(b) Agricultural Research Service, U.S. Dept. of Agriculture.

(c) Dr. J.E. Cermak, Professor of Englneering Mechanics and Clvil Englneering; and $\mathrm{Mr}$. E. J. Plate, Assoclate Professor.

(d) Iaboratory research; baslc research, applied research for thesis (doctoral).

(e) Diffusion of a gas (ammonia) into and out of a model vegetated plane area of a wind tunnel test section floor 1 s to be studied. Using a test section $80 \mathrm{ft}$ long and $6 \times 6 \mathrm{ft}$ in cross-section the turbulent boundary layer in which diffusion occurs will be several times thlcker than the vegetation helght. Using the basic equations of fluid mechanics, an attempt w1ll be made to establish criterion for application of the model data to prototype conditions. The criterion developed will be checked using fleld data belng obtained at cornell University by the Agricultural Research Service.

(f) Completed.

(g) A study of diffusion from a line source into a boundary layer over a flat, smooth plate has been completed. Results show that the diffusion pattern can be separated into different zones, according to distances from the source in which different similarity laws are valld for the diffusion process. "Invest1gations to Develop WInd Tunnel Techniques for Measuring Atmospheric Gaseous Diffusion in Model Vegetat1ve Surfaces," by E. J. Plate and J. E. Cermak, July 1963 .

"Effects of Flextble Roughness Elements on Diffusion in a Turbulent Boundary Layer," by Al1 Akhtar Quralshi, December 1963.

(4098) HIGH LEVEL TURBULENCE.

(b) U. S. Navy Weather Research Facility, Bldg. R-48, Naval A1r Station, Norfolk, Va.

(c) Dr. Elmar Re1ter.

d Fleld investigation; basic research.

(e) By means of stereo-photography of highlevel clouds a study w1ll be made of wavelengths of disturbances in the jet-stream region, which might account for clear-air turbulence. Case studies and theoretical 
studies of clear-a1r turbulence will be made.

(f) Completed.

(g) Cameras have been callbrated and reduction procedures programmed for electronic computer.

(h) "Turbulenz im wolkenfrelen Raum (Clear-A1r Turbulence) - 1hre Beobachtung, ihre physikalische Beschaffenhe1t and inre Bedeutung fuer Ueberschal1 - und Raketenflug, by Elmar R. Re1ter, April 1963.

"A Case Study of Radioactive Fallout," by Elmar R. Relter, CER63ERR?.

"Die Feinstruktur der freien A tmosphaere und 1hre Messung," by Elmar R. Reiter, 1963. "A Case Study of Severe Clear-A1r Turbulence," by Elmar R. Re1ter, 1963.

"Nature and Observation of High-Level Turbulence, especially in Clear A1r," by Elmar R. Relter, Apri1 1963.

"Occurrence and Causes of High-Level Turbulence," by Elmar R. Relter, 1963 CER63ERR30.

(4099) WAKE CHARACIERISTICS FOR BODIES OF REVOLUTION.

(b) Dept. of Navy, David Taylor Model Basin, Washington, D. C. 20007.

(c) Dr. J.E. Cermak.

(d) Experimental research; basic research, doctoral thesis.

(e) A study will be made of the relations between axially symmetrical bodles and the wakes produced by them for varying mean velocities and turbulence levels of the mean flow, both with and without momentum addition by means of a jet directed downstream from the body. Basic data w11l be obtained for establishing similarity criterla for turbulent and mean flow characteristics at large distances downstream from the body.

(g) The general character of the axial-symmetric wake has been investigated. Detailed study of spectra-analysis and turbulence energy decay along the wake axis has been performed.

(4100) ANALYSIS OF RIVER FLOW SEQUENCE.

(b) National Science Foundation.

c) Dr. V. M. Yevdjevich, Professor of Civil Engineering.

(d) Theoret1cal; basic research.

(e) The study of fluctuations of river flow and precipltation on an annual basis is in final stage. Monthly flows and monthly preclpitation are belng gathered for the study of fluctuation on a monthly basis. The first approach to a stochastic analysis of continuous time series of flow and preclpitation has been initiated.

(E) Fluctuations of flow and preclpitation on an annual basis as stochastic process may be approximated by simple auto-regressive schemes.

(h) "Fluctuations of Wet and Dry Years," Part I, Research Data Assembly and Mathematical Models, by Vujlca M. Yevdjevich, 1963. "Patterns in Sequence of Annual River Flow and Annual Precipitation," by Vujica M. Yevd Jev1ch, 1963.

(4101) UNSTEADY FREE SURFACE FLOW IN A LARGE STORM DRAIN.

(b) U. S. Bureau of Public Roads and U. S. Public Health Service.

(c) Dr. V. M. Yevdjevich, Professor of Civil Engineering.

(d) Experimental and theoretical; basic research.

(e) A 825-ft long, 36-1n. diameter conduit movable on 43 supports on a hillside, $1 \mathrm{~s}$ used as the main experimental facility to simulate and record free surface waves in pipes. The same waves are computed by using a digital computer and then a comparison is made. The ultimate purpose is a development of a set of routing methods to sult the desired accuracy and the quality of the initial and boundary data. The experimental part of the hydraulic study $1 \mathrm{~s}$ underway and in 1963 the measurements of velocity distributions and resistance factors in a partiy full condult have been carried out.

(g) The analytical study for directing the research is being completed.

\section{(4102) WIND FORECASTING TECHNIQUES.}

(b) Federal Aviation Agency, Federal Aviation Facllities Center, Atlantic C1ty, New Jersey, Attn: $\mathrm{RD}-140$.

(c) Dr Elmar Relter, Associate Professor.

(d) Theoretical, experimental; basic and applied research.

(e) Automatic forecasting techniques for highlevel winds which can be used by an automatic alr traffic control system shall be devised and tested.

(f) Completed.

(h) "Note on the Eddy Kinetic Energy Distribution in Relation to the Jet Stream, "by Elmar R. Re1ter. CER62ERR68.

\section{(4106) GROUND-WATER RESERVOIR MANAGEMENT.}

(b) Colorado Agricultural Experiment Station and Colorado water Conservation Board with U. S. Geological Survey also participating under contract with Colorado Water Conservation Board.

(c) Mr. M. W. Bittinger, Associate C1vil Engineer: Feoretical and field Investigation; applied research

(e) It is the purpose to study the operating characteristics of ground water reservolrs in Colorado. Specific studies include (1) the inter-relationships of ground and surface water in alluvial valleys, (2) natural recharge from ephemeral streams, and (3) artificlal recharge possibilities in the H1gh Plains of Colorado.

(g) (1) Studies indicate a slgnificant change in phreatophyte growth affecting surfaceground water relationships in the Arkansas Valley of Colorado. Mathematical models have shown importance of priority of rights, aquifer characterlstics, ground water pumping and consumptive demand on management of an integrated surface-ground water system. (2) Data collection in Klowa Creek has continued--showing influence of stream losses on ground water levels. (3) Rainfall-munoff measurements in Playa-Lake watersheds has continued.

(h) "A Study of Phreatophyte Growth in the Lower Arkansas Rlver Valley of Colorado," by Morton W. Bittinger and Glen E. Stringham, April 1963.

"Water on the Hlgh Plalns of Eastern Colorado," by Robert A. Longenbaugh, Progress Report No. 72, June 1963.

"Phreatophyte Growth in the Arkansas River valley of Colorado," by Morton W. Bittinger, Progress Report No. 70, June 1963.

"Natural Ground-Water Recharge from K1owa Creek," by Robert A. Longenbaugh, Morton W. Bittinger and Edmund F. Schulz. Progress Report No. 88, June 1963.

"Interrelationsh1ps of Surface Water and Ground Water," by Morton W. Bittinger. Progress Report No. 104, August 1963. "Problems of Conjunctive Use of Surface Water and Ground Water Supplies," by Morton W. Bittinger, August 1963.

"The Problem of Integrating Ground Water and Surface Water Use," by Morton W. BIttinger, October 2, 1963.

"Ground and Surface Water Relationships Studied by Statistical Techniques," by Robert A. Longenbaugh and Morton W. Blttinges, December 1963.

"Natural Ground Water Recharge from KIowa Creek, 1962 Progress Report," by R. A. Longenbaugh, February 1963. 
(b) Colorado Agricultural Experiment Station. Dr. V. M. Yevdjevich, Research Hydraulic Engineer.

(d) Theoretical and experimental; basic research. The research is concerned with floods from small watersheds. It is being pursued in three phases: (1) Assembly of research data from actual floods on small watersheds, (2) physical experimental studies on a large rainfall-runoff simulation platform, and (3) theoretical studies of the relation between flood hydrographs and the rainfall and catchment factors that affect them.

(f) Phase one is active, data collection having been commenced, Phase Two 1s active in the planning stages, and Phase Three is active in the very initial stage.

(h) "Research Data Assembly for Small Watershed Floods," by E. M. Laurenson, E. F. Schulz, and V. M. Yevdjevich, September 1963. "Floods from Small Watersheds," by V. M. Yevdjevich and E. M. Laurenson. Progress Report No. 71, June 1963.

(4110) TURBULENT AIR MOTION IN THE HIGH ROCKIES IN RELATION TO THE WATER YIELD OF UPPER WA TERSHEDS.

(b) Colorado Agricultural Experiment Station.

(c) Dr. Herbert Riehl, Professor of Atmospheric Sclence.

(d) Fleld, basic and applied.

(e) The structure of the turbulent wind eddies, which produce the exchange of momentum between atmosphere and ground in the high mountains, $1 \mathrm{~s}$ unknown. Yet the se have sufficlent force for the most part to blow the snow away from the mountain slopes above timberline. This snow in part drifts into high-altitude basins where $1 \mathrm{t}$ accumulates in depth augmenting the summer water supply; in part it drifts on slopes where it readily evaporates. Much interest has been shown in the possibility of channeling the drift so that a substantially higher fraction goes into the basins. Technologically this appears to be feasible. But any constmuction is dependent on knowledge of the turbulence spectrum, especially on the first day following snowfall. In order to determine this spectrum, a first installation containing electronic wind and temperature measuring instruments have been established above timberline in the Central Colorado Rockies.

(f) Fleld experiments starting in winter of $1963-64$.

(4112) THE DISCHARGE OF MAJOR WESTERN RIVERS IN REIATION TO THE GENERAL CIRCULATION OF THE ATMOSPHERE.

(b) Office of Naval Research, Department of the Navy.

(c) Dr. Herbert Riehl, Professor of Atmospheric Science.

(d) Basic research.

(e) The discharge of major western rivers (Colorado, Columbia, Sacramento, R1o Grande) has fluctuations with the order of magnitude of the mean annual discharge 1tself. These fluctuations are brought about mainly by variations in precipitation yield and by varlable evaporation. Heavy precipitation may result from seasonal conditions favorable for the recurrence of cyclones over headwater areas. High evaporation, requiring weeks of abnormally dry and warm conditions, must be a manifestation of general circulation anomalies of longer duration. The objective of the study is (1) to separate the "systematic" and "random" components of the precipitation, and (2) to determine the controls for the systematic anomalies of precipitation and evaporation.

(h) "Precipitation Regimes Over the Upper Colorado River," by W1lliam Marlatt and Herbert Riehl, 1963.
"Precipitation Ep1sodes in the Upper Colorado River Basin," by Herbert Riehl and R. L. Elsberry, 1963.

"Some Aspects of the Monthly Atmospheric Circulation Affecting Monthly Precipitation Over the Colorado R1ver Bas1n," by James L. Rasmussen, 1963 .

(4113) WEATHER PATTERNS AND CIRCULATION OF THE TROPICS.

(b) U. S. Weather Bureau.

(c) Dr. Herbert Riehl, Professor of Atmospheric Science.

(d) Basic.

e) Part of the project deals with hurricanes, another part with general characteristics of weather in the troplcs. Hurricane invest1gation is concerned (1) with the energy cycle of the mature storm, especially the role played by air-sea interaction in maintaining the center; (2) with the balance of forces in these storms and the nature and importance of frictional forces in a fully turbulent vortex; and (3) w1th the formative stage of hurricanes. Other studies are concerned with the variability of radiative emission from the atmosphere and with the interaction between tropical disturbances of less than hurricane intensity w1th their environment at large.

(h) "Some Relations Between Wind and Thermal Stmucture of Steady State Hurricanes," by Herbert Rlehl. Febmuary 1963. "On the Origin and Possible Modification of Hurricanes," by Herbert R1ehl. Sept. 1963.

(4114) GRAVEL FILTER FOR TILE DRAINS.

(b) Colorado Agricultural Experiment Station.

c) Mr. Norman A. Evans, Agricultural Engineer.

d) Applied; experimental.

(e) Gravels classed as "pit-run" meeting the criteria for sand filters previously established were used in cylinders simulating mole drains to determine the flow capacity of such drains.

(g) Tortuosity is a significant geometric property of filter gravels as regards to their permeability.

(4115) INFLUENCE OF INORGANIC WATERSHED COVERS ON MOISTURE EXCHANGE IN A VERTICAL DIRECTION ACROSS THE SOIL-AIR INTERFACE.

(b) Colorado Agricultural Experiment Station, a contributing project of the Westerm Regional Research Project $\mathrm{W}-73$.

(c) Dr. A. T. Corey, Professor of Agricultural Engineering.

(d) Applied and basic research.

(d) Th1s project is a study of the effects of inorganic covers (especially gravel mulches) on the hydrolog1c processes of evaporation and infiltration of molsture across the soll-air interface and the relationship of these processes to water y1eld.

(f) Completed.

(g) It has been demonstrated by both laboratory and fleld experiments that gravel mulches substantially reduce the rate of evaporation from bare soils and promotes an increased accumulation of water in the soil.

(h) A final report on this project is in preparation and will be published in "Hydrology Papers," Colorado State University.

"Influence of Inorganic Watershed Covers on Molsture Exchange in a Vertical Direction Across the Soll. .1 r Interface, "Colorado Contributing Project, W-73, Progress Report No. 3, October 1963.

(4606) STRUCTURE OF TURBULENCE IN TURBULENT SHEAR FLOW.

(b) Department of the Army.

(c) Dr. J.E. Cermak, Prof. of Engineering Mechanics and Clvil Engineering, and Mr. E. J. Plate, Assoc. Professor. 
(d) Experimental research; bas1c research, doctoral theses.

(e) The effects of surface roughness and surface heating or cooling upon the structure of turbulence in boundary layer flow will be determined. The flows investigated will be those existing on the heated or cooled floor of a wind-tunnel test section $6 \times 6 \mathrm{ft}$ in cross section and $80 \mathrm{ft}$ long. Space-time correlations, joint probability densities, spectra and intensities of the turbulent velocities and temperatures will be obtained by hot-wire techniques and special analog computers employing magnetic tape

(g) A $2.5 \times 10^{-5}$ inch diameter, 90\% platinum-10\% rhodium wire was evaluated as a resistance thermometer. From steady state evaluation of the wire physical properties the transient response of the wire was predicted. The predictions agree well with measured time constants for the wire. The bare wire with a detection current of 0.1 milliamps will have a sensitivity of approximately .07 millivolts per ${ }^{\circ}$. The frequency response of the wire in still air is 3200 cycles per second and this increased to approximately 6000 cycles in a moving air stream of 100 feet per second.

(h) "A Resistance Thermometer for Transient Temperature Measurements," by J. L. Chao and V. A. Sandborn, 1963.

(4607) WIND-WAVE RESEARCH FACILITY.

(b) National Science Foundation and Colorado State University.

(c) Mr. E. J. Plate, Assoc. Professor.

(d) Laboratory development and basic research of experimental nature.

(e) The water surface conflguration of concurrent water and air flow, as well as the structure of the velocity fleld in both water and a1r are measured. The measurements serve to verify or extend recent theorles of wave generation by wind. At present, instrumentation is completed, and a data conversion system is being developed.

(g) The construction was successfully completed.

(4608) TURBULENCE DATA ANALYSIS SYSTEM.

(b) Department of the Army and National Center for Atmospheric Research.

(c) Dr. L. V. Baldwin, Assoc. Professor.

(d) Laboratory development.

e) The system employing magnetic tape input is designed to yield the following information: (1) spectra (10-3 to $10^{4}$ cycles/ second), (2) joint probability densities, (3) root-mean-squares, and (4) space-time correlation.

(4609) MODELING OF AIR-FLOW PATTERNS AT CANDLESTICK BALL PARK.

(b) Metronics Assoclates Inc., Menlo Park, Calif.

(c) Dr.J. E. Cermak, Prof of Engineering Mechanics and Clvil Englneering; and $\mathrm{Mr}$. E. J. Plate, Asst. Professor.

(d) Experimental; applied research.

(e) The applied study utilizes a 1:800 scale model of the local topography and the Candlestick Ball Park Stadium placed in a 6 by 6 foot wind tunnel. Veriflcation of the modeling technique is being accomplished as a first phase of the study by comparing model wind patterns with prototype wind patterns obtalned by field measurements. The second phase of the model study will consist of modifying both topography and stadium to obtain minimum wind disturbance in the ball park.

(f) Completed.

(g) The first phase of the study has been com. pleted with the result that model wind patterns have been found to be sufficiently representative of field behavior to permit proceeding to the second phase with confldence.

(h) "Candlestick Park Wind Study Model Invest1gation, Vol. I," by J.E. Cermak and R. C. Malhotra, July 1963.

(4610) PREPARATION AND ANALYSIS OF CLIMATOLOGICAL DATA OF IMPORTANCE, TO AGRICULTURE IN COLO.

(b) Colorado Agricultural Experiment station, a contributing project of the Western Regional Research Project $W=48$.

(c) Dr. A. T. Corey, Prof of Agricultural Engineering.

(d) Applied

(e) This project has as 1ts objectives: (1) To provide climatological data for a representative network of Colorado stations in a form suitable for weather analysis; (2) to obtain summaries of distributions of meteorological parameters pertiment to agriculture; (3) to devise and utilize statistical and computer methods for estimates of the probabilities of significant weather conditions; e.g., weekly rainfall totals and dates of critical spring and fall temperatures.

(f) Continuing.

(g) Work on objective 1 and objective 2 has been completed and work on objective 3 is in progress.

(h) "Colorado Contributing Project, W-48, Progress Report No. 2," Colorado Agricultural Exper1ment Station. October 1963.

(4611) PERMEABILITY AND CAPILLARY PRESSURE RELATED TO MEDIA PROPERTIES.

(b) National Sclence Foundation.

(c) Dr. A. T. Corey, Prof. of Agricultural Englneering.

(d) Experimental and theoretical basic research.

(e) The study involves an investigation of a tentative theory describing how the functional relationship between relative permeability and relative capillary pressure is related to measurable properties of porous media.

(f) Continuing, nearly complete.

(g) A theory describing the interrelation between capillary pressure, liquid and gas permeability, and liquid saturation has been developed and verified experimentally. The results have been used to develop criteria for similitude in models for studying flow in partially saturated solls.

(h) "Hydraulic Properties of Porous Media and Their Relation to Drainage Design," by R. H. Brooks and A. T. Corey, June 1963 . "Hydraul1c Properties of Porous Medla," by R. H. Brooks and A. T. Corey, December 1963. See Project 4296, page 106, Agricultural Research Service.

(4612) TRANSPORT OF PARTICLES THROUGH UNSATURATED SOILS.

(b) Department of Health, Education, and Welfare, Bureau of state Service.

(c) Dr. A. T. Corey, Prof. of Agricultural Englneering.

(d) Applied; experimental. termine to what extent the transport of solid particles by water flowing through soll may be affected by the degree of saturation of soll. The term "so1l" is interpreted broadly as including sands and gravels as well as agricultural solls. The solid particles to be considered in this study will be of sizes and shapes corresponding to that of vimises.

(f) Active, continuing.

(g) Work is still in a preliminary stage. Efforts to tag live vimus particles with radioactive lodine without killing the vimus has finally been successful. 
(4617) MECHANICS OF LOCAL SCOUR.

(b) Department of Commerce, Bureau of Public Roads, Hydraulic Research Division.

(c) Mr. S. S. Karaki, Assoclate C1vil Engineer.

d Theoretical and experimental; basic research.

(e) A theoretical study of the mechanics of local scour is under way to develop basic equations for determining local scour. Basic experiments will be undertaken simultaneously to assist theoretical development.

(5160) TRANSPORT PROCESSES IN THE ATMOSPHERE LEADING TO RADIOACTIVE FALLOUT.

(b) Atomic Energy Commission, Washington, D. C.

c) Dr. E. R. Reiter, Assoc. Prof., Colo. State Univ., Fort Collins, Colo.

(d) Theoretical; basic and applied.

(e) Computations and case studies of transport processes carrying radioactive debris from the stratosphere into the troposphere have been made. Attempts have been made to arrive at seasonal estimates of radioactive fallout at the ground.

(5161) CHANGE IN QUALITY OF DRAINAGE EFFLUENT FROM IRRIGATION PROJECTS USING A VISCOUS FLOW ANALOGY MODEL.

(b) U. S. Bureau of Reclamation.

c) Mr.M. W. B1ttinger, Assoc. Clvil Engineer, Colo. State Univ., Fort Collins, Colo.

(d) Experimental.

(e) The study 1 s designed to determine quality change (with time) of tile drainage effluent under various aquifer and geometry conditions.

(5162) CUMULUS CONVECTION AND OROGRAPHIC CONVECTION CELLS.

(b) U. S. A mmy Electronics Research and Development Laboratory.

(c) Dr. Herbert Riehl, Prof. of Atmospherlc Science and $\mathrm{Mr}$. Montie M. Orgill, Jr. Metorologist, Colo. State Univ., Fort Collins, Colo.

(d) Basic and applied research.

(e) The general goal of this research is to investigate various meteorological aspects of the monsoon circulations over southeast Asia. Satellite, radar, surface and upper level observations will be utilized to examine such features as (1) the time of onset and retreat of the monsoon and 1ts variability within the season; (2) macroand mesostructure of cloud systems; (3) synoptic time sequence of the winds during the monsoon season, location of princlpal bad weather areas, their frequency and succession and; (4) the course of diurnal variations, especially precipitation.

(h) "Cumulus Convection and Orographic Convection Cells," by Herbert Riehl, 1963.

"Stationary Aspects of the Tropical General Circulation," by Herbert R1ehl, June 1963.

(5163) RANGE AND RUN CHARACTERISTICS OF NORMAL VARIABLE OF RANDOM SEQUENCE.

(b) National Science Foundation (Subproject of Analysis of River Flow Sequence).

(c) Dr. V. M. Yevdjevich, Prof. of Civil Engineering, Colo. State Univ., Fort Collins, Colo.

(d) Experimental.

(e) A random sample of 100,000 numbers has been generated. The distribution of range and adjusted range, a joint distribution of the mean and adjusted range for periods of length $\mathrm{N}$ as well as two types of runs have been studied by using a digital computer. Distributions and characteristics on distributions have been analyzed as benchmarks for study of flow and precipitation fluctuations.

(5164) FLOW MEASUREMENT.

(b) Colorado Agricultural Experiment Station and Civil Engineering Section.

(c) Dr. D. B. Simons, Acting Chief, Civil Engineering Research Section, Colo. State Un1v. Fort Collins, Colo.

(d) Experimental laboratory and basic research wh1ch Involves staff and graduate student particlpation leading to M.S. and Ph.D. degrees.

(e) This project has the general objective of developing and improving devices and techniques for the measurement of $1 \mathrm{rrl}$ gation water. The present activity includes: (1) The further development of the sem1conductor strain gage method of measuring velocity in plpes and open channels and its utilization to measure the velocity distribution above and very close to both smooth and rough boundaries in open channels, and (2) continued studies of the trapezoldal measuring flumes, control structures for alluvial channels and other metering devices.

(g) A suspension wire probe involving use of semiconductor strain gages has been developed to measure average velocity in pipes and essentially point velocities in open channels. The probe is belng further modifled to measure velocity very close to boundartes.

(h) "Evaluation of the Vane-Type Flowmeter," by A. R. Robinson, January 1963.

"A Flow Measuring Device Depending on the Drag Developed on a Wire suspended in Water," by Bruce B. Sharp, December 1962. "Control Structures for Sand Bed Channels," by F. C. Stepanich, D. B. SImons and E. V." Richardson, May 1963.

(5165) HYDRAULICS.

(b) Colorado Agricultural Experiment Station and C1v1l Engineering section.

(c) Dr. D. B. Simons, Acting Chief, Civil Englneering Research Section, Colo. State Univ., Fort Collins, Colo.

(d) Bastc hydraulic re search.

(e) This research is in hydraulics oriented toward agriculture and irrigation. The principal areas under study include, fall velocity, sediment transport, resistance to flow in alluvial channels with limited research on rigid boundary hydraulics including hydraulic jump phenomena in pipes and the design of stable alluvial channels.

(g) A study has been completed on the fall velocity of porous media. Reports are in preparation on resistance to flow in open channels, bed material transport in open channels, and deslgn of stable channels.

(h) "Some Properties of Water-Clay DIspersions and Their Effects on Flow and Sediment Transport Phenomena," by W. L. Haushild, D. B. Simons, and E. V. Richardson.

"Some Properties of Water-Clay Dispersions and Their Effects on Flow," by D. B. Simons, E. V. R1chardson, and W. L. Haushild.

"A Study of Variables Affecting Flow

Characteristics and Sediment Transport in

Alluvial Channels," by D. B. Simons, January 1963.

"Closure to Depth-D1scharge Relations in Alluvial Channels," by D. B. Simons, E. V. Richardson, and W. L. Haushild.

"Fall Velocity of Artificial Porous Part1cles," by Komain Unhanand, 1963.

UNIVERSITY OF COLORADO, Department of C1V1l Eng1neering.

(4639) WAVE REFLECTION STUDIES.

(b) Laboratory project.

(c) Dr. Warren DeLapp, Department of Civil Engineerlng, University of Colorado, Boulder, Colorado.

(d) Experimental, basic research, for Master's thesis.

(e) Initial studies were made of artificially generated waves reflected from a beach of varlable slope and roughness, and included studies of the effects of the wave steepness 
ratios. Current studies are belng made of reflection and transmission of waves at a submerged barrier.

(g) The reflection coefficient is found to decrease with increasing beach roughness and wave steepness. An empirical equation was developed relating the variables for beach slopes of more than 30 degrees. An unstable transition condition was found for flatter slopes and results were considered inconclusive.

(h) "Effect of Roughness, Wave Steepness, and Beach Slope of the Reflection of Deep Water Waves," by D. K. Lysne, M. S. Thesis avallable on inter-library loan from University of Colorado Library.

(4640) STUDIES OF TURBULENT SWIRL FLOW IN A PIPE.

(b) National Science Foundation.

(c) Dr. Frank Kre1th, Department of Mechanical Englneering, UnIversity of Colorado, Boulder Colorado.

(d) Analytical and experimental; basic research.

(e) A swirling secondary flow is induced in a plastic plpe by a short section of twisted tape inserted in the pipe at the upstream end. The flow is studied downstream of the inducer to determine the rate of decay of the secondary flow and the effective resistance coefflclent. Reynold's Numbers of the main flow range from 15,000 to 150,000 . Other varlables include pipe diameters and the length and pitch of the swirl inducers.

(f) Completed

(g) Results of theoretical analysis and.exper1mental results have produced equations for the prediction of the rate of decay for swirl flow in a pipe and for the resistance coefflclent. For turbulent flow decay is virtually complete 100 diameters downstream of the turbulence inducer. The distance required for decay to a specific value in turbulent flow $1 \mathrm{~s}$ more than twice that for laminar flow.

(h) "A Theoretical Investigation of the Decay of Turbulent Swirl Flow in a P1pe," by otto Sonju, M. S. Thesis.

"An Experimental Invest1gation of the Decay of Turbulent Sw1rl Flow in a P1pe," by Arnold 0 . Musolf. Avallable on interlibrary loan from Unlversity of Colorado Library.

CORNELL UNIVERSITY, School of C1V1l Engineering.

(4121) TWO-DIMENSIONAL CHANNEL FLOW.

(b) Laboratory project.

c) Dr. J. A. Liggett, Holl1ster Hall, Cornell Univ., Ithaca, New York.

(d) Theoretical; baslc and applied research for Ph. D. thesis.

(e) The equations of two dimensional free surface flow have been solved numerlcally using hlgh speed computer.

(f) Completed.

(g) The feasibility of solving the hyperbolic differential equations of two-dimensional free surface flow on a computer has been demonstrated. The effects of slope and friction are included.

(h) Ph.D. Thesis.

(4531) SECONDARY CURRENTS IN NON-CIRCULAR CONDUITS.

(b) National Sclence Foundation.

c) Dr. J.A. Liggett, Hollister Hall, Comell Univ., Ithaca, New York.

(d) Theoretical and experimental.

(e) Those secondary currents caused by Reynold's stresses in stralght, non-circular conduits are being studied. A trlangular open channel is being used. Measurements are to be taken by the hot-film anemometer.

(g) A quantitative theory has been developed and is being tested.
(5037) RECESSION HYDROGRAPHS OF IDEALIZED UNCONFINED AQUIFERS.

(b) Laboratory project.

(c) Dr. W. H. Drut saert, Hollister Hall, Comell Univ., Ithaca, N. Y.

(d) Experimental; applied research for M.S. thesis.

(e) A Hele-Shaw model has been constructed to study the different parameters affecting drainage from large unconfined geological formations into stream channels. The obtalned ground water recession hydrographs are compared with those derived from previous theoretical, but approximate, solutions. The study could be equally applicable to dralnage of agricultural lands.

(h) M.S. thesis is being written.

(5038) NON-NEWTONIAN FLOW IN CLAYEY POROUS MEDIA.

(b) Laboratory project

(c) Dr. W. H. Brutsaert, Hollister Hall, Cornell Univ., Ithaca, N. Y.

(d) Experimental and theoretical.

(e) The non-Newtonian properties of water in clay-water systems become apparent under nonDarcy flow conditions at low hydraullc gradients. The most important parameters w1ll be determined by means of ordinary permeameters.

(5039) PRESSURES DUE TO SUDDEN DRAWDOWN IN EARTH ENBANKMENTS.

(b) Laboratory profect

c) Dr. J.A. LIggett, Hollister Hall, Comell Univ., Ithaca, N. Y.

(d) Theoretical; basic and applied research.

(e) The equations for unsteady flow in porous medila are being solved to find the pressures resulting from sudden drawdown in an earth embankment. Of particular interest is the effect of the variation of permeability on the flow. Both analytical and numerical techniques are being used.

(5040) FRICTIONAL EFFECTS IN RIVERS AND WATERWAYS.

(b) Laboratory project.

c) Dr.W.H. Graf, Hollister Hall, Cornell Univ., Ithaca, N. Y.

(d) Applied research.

(e) Under study are different Amerlcan, English, Indlan, Sw1ss and Austrian rivers and waterways. The data investigated are furnished by the different governmental offlces.

(5041) VARIATION OF KAFMAN'S K-VALUE IN PIPES CARRYING SUSPENSIONS.

(b) Laboratory-project

c) Dr.W.H.Graf, Hollister Hall, Cornell Univ., Ithaca, N. Y.

(d) Theoretical.

(e) A study of the Karman " $K$ " value, as $1 t$ appears in the logarithmic velocity distribution equation in an open channel shows considerable variation of 1 ts value dependent on the concentration. Under invest1gation in this research project is a closed plpe with varied concentration of sediment pumped through. Data are already obtained.

UNIVERSITY OF DEIAWARE, FluId Mechanics Laboratory Section, Dept. of CIvil Englneering.

(4123) WAVE REFIECTION STUDIES.

(b) Laboratory project.

(c) Department of Civil Englneering, Dr. K. P. H. Frey, Professor.

(d) Experimental; basic, applied research; educational a1d.

(e) To study the dominant vortices of fully detached flow in diffusers in confunction 
with varled rates of flow. The basic model was a two dimensional sudden enlargment (inlet 6 inch wide, expanded section $10 \mathrm{ft}$. long). The expansion ratios were $1: 3,1: 2$, and $1: 11$. The geometry was varled by inserts and change of depth from 7 inches to $1 / 8$ inch. Curved boundaries were inserted for (1) less abmupt increase of cross sectional area, (2) cusp arrangements, and (3) mod1flcations into three dimensional models, including cusp diffusers. A motor driven $35 \mathrm{~mm}$ camera was used for recording phenomena in sequence. A wind tunnel was used in parallel.

(g) Preliminary results indicate: At Reynolds numbers larger than about 3000 , (depth of flow greater than $1 / 4$ inch) starting vortices become predominant and affect the final characteristic of fully detached flow. starting vortices can be controlled. Physical aspects of control are based on the creation of effective interactions. Interactions affecting the symmetry of the vortex generation; the size of formed vortices; and the interchange of static pressure through the jet stream are signiflcant. Permanently trapped vortices in cusps of straight diffusers, have not been materlalized in these tests, except when interactions were provided. study of starting flow from rest was valuable in understanding the physical phenomena. Parallel results of flume tests were obtained in wind tunnel tests up to $100 \mathrm{ft} . / \mathrm{sec}$, also. The temporary trapping of starting vortices in the cusps of diffusers was achieved for cusp shapes calculated for permanent trapping of vortices, reported in literature. Permanently trapped vortices in cusps were generated by enforced local diversion of the jet boundary. Guide vanes of the slotted vane type were found appropriate to retain vortices in cusps of various shapes.

(h) Progress report by K. P. H. Frey and N. C. Vasuki is in preparation.

(5047) BREAKWATER DEVICES.

(b) Laboratory project.

(c) Dept. of Civil Engineering, Dr. K. P. H. Frey, Professor.

(d) Experimental; feasibility study.

(e) To extend the use of partially submerged flat plates for damping water waves. Rigid slotted vane-type breakwater designs were tested in 6-inch high waves, generated in an 18-by 12-inch flume, 20 feet long. Elementary vanes were arranged in a semi-circle, forming slots by overlapping each other. Stiffeners were provided between adjacent vanes. Four principal positions were tested: I. Set of slotted vanes with leading edge higher than trailing edge, facing (I) approaching waves, (2) backflow. II. Same device with reversed leading and trailing edge creating greater disturbances in (1) approaching waves, (2) backflow.

(i) Inactive.

(g) The vane set is much stronger than the known devices and appears to be more effective also. The physical function differs for each of the four positions. The configuration seemed to be promising in comparison to plate tests. The greater damping effect was achieved when the space between the set of vanes and the bottom was closed.

\section{(5048) FLOW CHARACTERISTICS OF VISCOELASTIC FLUIDS.}

(b) Laboratory project.

(c) Dept. of Civil Engineering, Dr. K. P. H. Frey, Professor.

(d) Experimental; feasibility studies of methods, in part section of $M$. S. thesis.

(e) A feasibility study of flow behavior of C.M.C. ( $0.7 \%$ by welght dissolved in water) was made. This was supplemental to known studies of physical properties. Three methods attempted were: (1) The dark field photomicrographic method for measuring velocity profiles (see 4557 ); rotating vessel, free surface (see $4123)$, stationary radial plate inserted normal to flow as an example of flow about a body; and (3) flume studies (4123) extended to the injection of a colored solution along boundaries and into flows of varied degrees of turbulence.

(i) Suspended.

(g) The three methods are fecsible and appear to be promising. More development is needed.

(h) Results on 1tem $\mathrm{e}(1)$ are included in "A Dark Field Photomicrographic Method For Measuring Velocity Profiles," by N. C. Vasuk1, C. E. Master Thesis, 1963, Library of the Univ. of Delaware, Newark, Delaware.

(5049) TURBULENT FLOW OF NON-NEWTONIAN SUSPENSIONS.

(b) Laboratory project.

(c) Dept. of Clvil Engineering, Dr. Iraf Zand1, Asst. Professor.

(d) Analytical and experimental, (M.S. thesis).

(e) Development of analytical technique for prediction of head loss in a closed conduit due to transport of suspension. The study is based on the boundary-layer theory in a turbulent flow with the consideration of the fact that the flow becomes non-Newtonian as the concentration of the solid in suspension increases. The equation will predict head losses in a plpe from only basic rheological properties of the field.

(g) A new intmision type viscometer proper for measuring non-Newtonian parameters of suspensions is designed and built; the experimental setup is completed and is ready to test. The differential equations of motion for laminar, turbulent and buffer zone of pipe flow of non-Newtonian suspension are developed and in laminar and turbulent zones are integrated.

\section{(5050) URBAN HYDROLOGIC STUDY.}

(b) Laboratory project and partly storm Drainage Project of The Johns Hopkins University.

(c) Dept. of Civil Engineering, Dr. Iraj Zand1, Asst. Professor.

(d) Applied research.

(e) Hydrologic study of the effect of urbanization upon relationship between rainfall and runoff. Two completely defined areas are gaged and precipitation and runoff is continuously recorded. These two areas consist of two adjacent sections of East Cleveland Avenue in Newark, Delaware. Rainfall measurements are obtained by the use of two tipping bucket rain gages, one being installed on each area. East Cleveland Avenue is a bituminous paved street 44 feet wide having concrete curb as gutter sections. The physical characteristics of areas are indicated below:

Area (1) 0.636 acres: $100 \%$ 1mpervious:

with average slope of $3.35 \%$

Area (2) .955 acres; $100 \%$ impervious; with average slope of $0.68 \%$.

The runoff is measured by a 9-and a 12-inch parshall flume.

(g) Data is collected since 1960 and partial analysis is made by the Johns Hopkins Drainage Research Project Staff members.

UNIVERSITY OF DELAWARE, Department of Mechanical Engrg

(4556) DRAG REDUCTION BY BOUNDARY LAYER GAS INJECTION.

(b) Laboratory project.

(c) Prof. B. Seldel, Prof. J. P. Harnett, Prof.K. Frey, (Civil Engineering) Univ. of Delaware, Newark, Delaware.

(d) Theoretical and experimental; master's thesis

(e) The possibility of reducing the skin-friction drag of a body moving through a liquid by ejecting air from the body is being investigated. Measurements of the drag on a flat plate are being obtained. 
UNIVERSITY OF FLORIDA, The Engineering and Industrial Experiment Station, Coastal Englneering Laboratory.

Inquiries concerning projects should be addressed to Dr. Per Bruun, Head, Coastal Englneering Laboratory, University of Florlda, Galnesville, Florlda.

(3413) INLET STUDIES.

(b) Laboratory project.

d) Fleld investigation; applied research.

(e) Study of the stability of coastal inlets.

(4127) FLUORESCENT TRACING OF SEDIMENT IN COASTAL AREAS.

(b) National Institute of Health, Department of Health, Education and Welfare.

(d) Field Investigation; basic and applied research.

(e) Tracing of sediment drift on beach and off shore bottoms by means of injected fluorescent materlal.

(g) Statistical sampling methods, rapld measurement fluorescent tracer concentration by electronic scanners, a new longshore current theory and a stat1stical approach to littoral transport mechan1sm are belng developed at the laboratory.

(h) "Longshore Currents \& Longshore Troughs," by Per Bruun, Journal, Am. Geophy. Union, Vol. 68 , No. 4, February 1963.

"Tracing of Sediments in Coastal waters by Fluorescent Materlal," Paper presented by Per Bruun at the 17 th Annual Industrial Waste Conference - Purdue Univ., May 1962.

"Quant1tative Tracing of L1ttoral Drift," by

Per Bruun, Proc. Federal Inter-Agency Sed1mentation Conference, Jackson, MIssissippi, February 1963.

"Summary of the Production and the Scanning of Fluorescent Tracers," by Paul Telek1, Append1x I of Reference 3, February 1963. "Statistical Analysis of Samples for Determination of Fluorescent Sand Concentration," by M. Manohar, under preparation. "Tidal Inlets \& L1ttoral Drifts," by Per Bruun and J.A. Battjes, presented at the International Association of Hydraulic Research, London, September 1963.

(4128) FLUX OF WAVE ENERGY PERPENDICULAR TO THE DIRECTION OF WAVE PROPAGATION.

(b) National Sclence Foundation.

d) Basic research.

(e) Experiments to determine flux of wave energy perpendicular to the direction of wave propagation.

(4129) INFLUENCE OF SEA LEVEL RISE ON EROSION.

(b) State Government.

d Basic fleld research.

(e) To determine the influence of short-term as well as long-term fluctuation of sea level on erosion and shoreline movements.

(4474) COASTAL ENGINEERING STUDY AT SOUTH LAKE WORTY INLET, FLORIDA.

(b) South Lake Worth Inlet District Commission.

(c) South Lake Worth Inlet District Commission, c/O K. C. Mock and Assoclates, 2930 Okeechobee Road, West Palm Beach, Florida.

(d) Experimental field and applied research.

(e) To study distribution of inlet currents, improvement of entrance jettles, and navigation channels and measures against beach erosion. Also study the effect of proposed landfills in the bay.

(4475) COASTAL ENGINEERING STUDY AT HILISBORO INLET, FLORIDA.

(b) Hillsboro Inlet Improvement and Maintenance District, C1ty of Pompano Beach and Trustees of the Internal Improvement Fund.

(c) Director, Trustees, Internal Improvement Fund, Capitol Bldg., Tallahassee, Florida. (d) Experimental, fleld and applied research.

(e) To study methods for inlet stabilization, navigation improvement, and sand bypassing across the inlet.

(4477) COOPERATIVE STUDY OF SHORE PROTECTION STRUC TURES IN FLORIDA (in cooperation w1th U. S. Army Corps of Englneers, Jacksonville District).

(b) State and Federal Government.

d Fleld Investigation; applied research

(e) To study effectiveness and structmal durability of various types of shore protection structures existing along florida coastline by making repetitive surveys of selected shore segments.

(f) Suspended.

(4479) REVIEW OF BEACH EROSION AND STORM TIDE SITUATION IN FLORIDA.

(b) Engineering and Industrial Experiment Sta., University of Florlda.

(d) Fleld investigation; applied research.

(e) Photograph1c review of the erosion situation in Florlda and preliminary suggestions for remedial measures.

(h) "Review of Beach Erosion and Storm Tide S1tuation in Florida," Tech. Progress Report No. 13, November 1962, Englneering and Industrial Experiment Station, University of Florida.

(4480) ENGINEERING STUDY OF COASTAL PROBLEMS IN FLA.

(b) Trustees of the Internal Improvement Fund, Florida.

(c) Trustees of the Internal Improvement Fund, Florida.

(d) Field Investigation; applied research.

(e) The Coastal Engineering Laboratory acts as consultant to the State Government and submits reports on the basis of fleld inspection and study of proposed structures, fills, dredging, etc.

(f) Suspended.

(h) "Emergency Measures to Lombat Beach Erosion," by Per Bruun and J. A. Purpura, Leaflet No. 158, Englneerling and Industrial Experiment Station, Un1versity of Florlda, June 1963 .

(4481) INVESTIGATION OF STABILITY AND MOVABLE BED MODEL IAWS OF INLETS.

(b) Laboratory project

d) Baslc and applied research.

(e) W1th a new basic approach to sim1litude laws in sediment transport by currents, invest1gations are underway in the stablitty analysis of inlets by means of model studies of sultable inlets. A theoretical study of model laws for movable bed models inftiated as introductory to inlet study.

(h) "Tidal Inlets \& Littoral Drifts," by per Bruun and J.A. Battjes, Presented at the International Assoclation of Hydraulic Research, London, September 1963. "Similarity of Bed Load Transport by currents," by J. A. Battjes, under preparation.

(4482) EXPERIMENTAL STUDY OF MECHANICS OF DUNE BUILDING AT CAPE HATTERAS NATIONAL SEASHORE AREA.

(b) Cape Hatteras National Seashore, National Park Service, Manteo, North Carolina.

(c) Cape Hatteras National Seashore, National Parks Service, Manteo, North Carolina.

(d) Experimental and fleld research.

(e) Study of mechanics of dune bullding by varlous types of sand fences and other sand catchment devices under controlled condition is underway in a laboratory wind tunnel to be later correlated with fleld tests.

(4895) SAND TRANSPORT BY WIND \& MECHANICS OF DUNE BUIIDING. 
(b) National Science Foundation, Washington, D. C.

d Experimental and theoretical; basic research.

(e) To study the baslc mechanics of sand transport by wind under dry and humid conditions, with and without vegetation, uniform and gusty winds and with and without solid and permeable vertical fences.

(4696) YYDRAULIC MODEL TESTS FOR SUCTION WELL DESIGN FOR MIAMI RIVER WELL TREATMENT PLANT, DAYTON, OH IO.

(b) F.M.C. Corporation, Hydrodynamic Division, Peerless Pump, Indlanapolis, Indlana.

(d) Experimental \& applied research.

(e) To determine the most optimum compatible location and deslgn of suction well baffling for the fleld treatment plant.

(4897) COASTAL ENGINEERING STUDY OF SEBASTIAN INIET, FLORTDA.

(b) Sebastian Inlet, D1strict, Melbourne, Florida.

d) Experimental and applied research.

(e) To conduct fleld survey and model study of the inlet for least shore erosion and best navigable inlet conditions.

(4898) BASIC RESEARCH ON LITTORAL DRIFT BY WAVE AND CURRENT ACTION.

(b) National Sclence Foundation, Wash, D. C.

(d) Experimental and basic research.

(e) A laboratory baslc research project on friction coefficlents and sediment transport by currents and waves running with or against each other and muning perpendicular to each other.

(4899) HYDRAULIC MODEL STUDY OF BURNS WATERWAY HARBOR, INDIANA.

(b) Indlana Port Commission, State of Indiana, Indlanapolis, Indlana.

(d) Experlmental and applied research.

(e) Laboratory model study of the effects of diffraction, siltation, and harbor surging on the proposed harbor.

(4900) COASTAL ENGINEERTNG STUDY OF THE PROPOSED CEDAR KEY HIGHWAY DOCK.

(b) Florida State Road Department, Lake C1ty, Florlda.

(d) Field and applied investigation.

(e) To determine the best method to ensure adequate circulation within the dock.

(i) Completed.

(h) "Coastal Engineering Study of the Proposed Highway Dock at Cedar Key, "by Coastal Engineering staff, University of Florlda.

(4901) COASTAL ENGINEERING STUDY OF BLIND PASS, FLORIDA .

(b) City of st. Petersburg and C1ty of Treasure Island.

(d) Field and applied investigation.

(e) To study the best method against siltation of the Pass and against erosion adjolning shores.

GEORGIA INSTITUTE OF TECHNOLOGY, Engineering

Experiment station.

(3725) SECONDARY MOTION IN ENCLOSED CONDUITS AND OPEN CHANNELS.

(b) Laboratory project.

(c) Dr. P. G. Mayer, School of C1vil Englneering, Georgia Institute of Technology, Atlanta 13 Georgia.

(d) Theoretical and experimental; research for Ph.D. thesis.

(e) A fundamental study of secondary motion in turbulent flows. Secondary motions are often superimposed upon flows in enclosed condults and open channels. The mode of origin, development and decay is being studied to delineate the influence on the general motion pattem in stralght, nonclrcular conduits and channels. The present phase concerns turbulent flow in a nonclrcular enclosed condult.

(4574) THE ROLE OF A PERMEABIE BED IN SEDIMENT TRANSPORT.

(b) Bureau of Sh1ps, Department of the Navy.

c) Dr. M. R. Carstens, School of C1v1l Eng1neering, Georgla Inst. of Tech., Atlanta 13, Georgia.

(d) Analytical and experimental; fundamental research for doctoral dissertation.

(e) To determine theoretically the effect of the vertical seepage force, which occurs in porous-medla flow, on the effective welght force in terms of an apparent speciflc welght of sediment. To study experimentally the Influence of the seepage force on inclpient sediment motion.

(f) Analytical part completed; experimental part in progress.

(g) For porous-media flow in a sand bed induced by progressive gravity waves, the seepage force is shown to render sediment particles lighter under the wave trough and, conversely, heavier beneath the wave crest. The apparent speciflc welght of sediment at the bed can be shown to vary from 0.85 to 1.40 times the real specific welght. The theoretical treat ment is effected for both Stoklan and cnoidal waves.

(4576) FLOW CHARACTERISTICS OF A TWO-DIMENSIONAL ORIFICE PLACED UNSYMMETRICALIY IN THE APPROACH CHANNEL.

(b) Laboratory project at Georgia Inst1tute of Technology and at SEATO Graduate School of Englneerlng, Bangkok, Tha1land.

(c) Dr. M. R. Carstens, School of C1vil Eng1neering, Ga. Inst. of Tech., Atlanta 13, Ga.

(d) Experimental and theoretical; research for M.S. theses.

(e) The flow characteristics, coefflclent of contraction and angle of jet deflection, were to be determined both analytically and theoretically.

(f) Continuing.

(g) Experimental results have been obtalned for opening width-approach channel width ratios of $0.2,0.4,0.6$, and 0.8 , for a range of opening eccentricities. Theoretical results have been evaluated for symmetrical jet and for maximum eccentricity. Numerical integration is belng done for intermediate eccentricities.

(4579) WHIRLPOOL FORMATION AND VORTEX STRETCHING.

(b) Iaboratory project; partly sponsored by the Georgla Power Company, Atlanic, Georgla.

(c) Dr. P. G. Mayer, School of C1vil Engineering, Georgia Institute of Technology, Atlanta, Ga.

(d) Experimental and theoretical.

(e) Asymmetric approach condition to the suction bells of centrifugal pumps led to severe whirlpool formation, prerotation, and air entrainment. A model study was conducted to alleviate existing conditions in a condenser-water circulating system. A rotating pot apparatus was bullt subsequently to study free vortex motion and vortex stretching under controlled conditions.

(g) Laboratory measurements and photographic analysis of vortices permitted a comparison with results predicted by hydrodynamic relationships.

\section{(4580) ISOTROPIC-TURBULENCE WATER TUNNEL.}

(b) Laboratory project; sponsored partly by U. S. Geological Survey.

(c) Dr. P. G. Mayer, School of Civil Englneering, Georgla Institute of Technology, Atlanta 13, Georgia.

(d) Experimental and theoret1cal. 
(e) In order to establish response characteristics of turbulence probes, a known field of turbulence is necessary. Isotropic turbulence can be created behind square-mesh grids and results of the decay of isotropic turbulence have been known from wind tunnel studies. The experimental flow system consists of a head tank, a contraction cone, an 8-inch diameter test section and a tallwater bay. The turbulence-generating grid was built into the throat of the contraction cone.

(f) Velocity callbration in progress.

(4581) INFLUENCE OF ROUGHNESSES ON FLOW ESTABLISHMENT AND VELOCITY DISTRIBUTION IN OPEN CHANNEL FLOW.

(b) Laboratory profect; partly sponsored by U. S Geological Survey.

(c) Dr. P.G. Mayer, School of C1v1l Engineering, Georgia Institute of Technology, Atlanta 13, Georgia.

(d) Experimental; research for M. S. thesis.

(e) Vorticity and secondary motions are created at channel transitions. The longevity of these vortices is to be investigated in a 80-foot-long variable-slope channel. The velocity profiles of the developing flows are to be compared with one another for various channel conditions. The deformation and recovery of velocity proflles downstream from disturbances are to be investigated.

(4582) INVESTIGATION OF THE SPECTRUM OF TURBULENCE IN A RECTANGULAR CLOSED CONDUIT.

(b) Laboratory profect.

(c) Dr. P. G. Mayer, School of Civil Engineering, Georgia Institute of Technology, Atlanta 13, Georgia.

(d) Experimental; basic research for doctoral dissertation.

(e) Energy spectra are being Invest1gated in a wind tunnel study. A hot wire anemometer and a wave analyzer are being used to measure spectral components in the streamwise direction. Various physical changes at the entrance to the wind tunnel create different turbulence conditions in order to shed light on the mechanism of turbulenceenergy transfer and the structure of turbulence.

(4584) VISCOUS FLUID FLOW UNDER THE INFLUENCE OF A RESONANT ACOUSTIC FIELD.

(b) Aeronautical Research Laboratories, office of Aerospace Research, United States Air Force.

(c) Prof. T. W. Jackson, School of Mechanical Englneering, Georgla Institute of Technology, Atlanta 13, Georgia.

(d) Experimental and theoretical; research for master's and doctor's theses.

(e) An experimental and theoretical study of the effects of resonant acoustic vibrations on the fluid flow and heat transfer in a 4-inch horizontal tube heated by steam. A1r was used as the flu1d, resonant frequencles were 220 and $356 \mathrm{cps}$, and sound pressure levels up to 164 decibels were obtained.

(B) The existence of standing vortices in the tube were confirmed experimentally by a visualization study of the flow. Periodic variations in the heat transfer coefficient were obtalned and the period of the varlation is a half wave-length of the resonant frequency. The resonant vibrations tended to Increase the overall heat transfer for laminar flow and decrease it for turbulent flow conditions. Analytical solutions for the channel and tube configurations have been obtained for the momentum and continulty equations.

(4585) THE VISCOSITY OF HIGH PRESSURE STEAM.

(b) National Sclence Foundation.

(c) Prof. T. W. Jackson, School of Mechanical
Engineering, Gecrgia Institute of Technology, Atlanta 13, Georgla.

(d) Experimental and theoretical; research for master's and doctor's theses.

(e) An experimental and theoretical study of the viscosity of steam to 10,000 psi and 1200 degrees $F$.

(g) Experimental data have been obtained for the viscosity of steam using an annulus type transpiration viscosimeter. A unique method of measuring small pressure drops at very high static pressures was developed. Experimental and theoretical work are continuing on the project.

(4586) EXPERIMENTAL AND THEORETICAL STUDIES OF SECONDARY FLOW PHENOMENA INDUCED BY CURVATURE AND VISCOUS SHEAR LAYERS.

(b) National Science Foundation.

(c) Prof. A. W. Marris, School of Mechanical Engineering, Georgia Inst1tute of Tech., Atlanta, Georgia 30332.

(d) Experimental and theoretical

(e) Theoretical work on secondary flows in curved channels.

(h) "The Generation of secondary Vort1c1ty in an Incompressible Fluid," Journal of Applied Mechan1cs, scheduled December 1963.

(4588) MASS TRANSFER IN THE ENTRANCE LENGTH OF A PIPE - IAMINAR FLOW.

(b) Departmental research.

c) Frof. H. C. Ward, School of Chemical Engrg., Georgla Institute of Technology, Atlanta, Georgla 30332.

(d) Experimental and theoretical; basic research for doctor's thesis.

(e) Flow conditions are belng extended and unusual natural convection effects are being 1nvestigated.

(4589) VARIABLE PROPERTY HEAT TRANSFER IN THE ENTRANCE OF A TUBE.

(b) Departmental research

(c) Prof. H. C. Ward, School of Chemical Engrg., Georgia Inst. of Tech., Atlanta, Georgia 30332 .

(d) Theoretical; basic research for doctor's thesis.

(e) Numerical solutions for the momentum, energy, and continuity equations are being developed for a variable property fluid flowing laminarly in the entrance of a vertical tube.

(5027) CHEMICAL ASPECTS OF SAND FILTRATION.

(b) U. S. Public Health Service.

(c) Dr. C. R, O'Melia, School of Civil Engrg. Georgla Inst. of Tech, , Atlanta, Ga. 30332

(d) Experimental and theoretical; applied research for master's thesis.

(e) A study designed to demonstrate chemical effects in the removal of flocculent materials from aqueous suspension and filtration and to investigate the causes of these effects.

(5028) EFFICACY OF A FRESH -WATER CANAL FOR THE ALIEVIATION OF THE EFFECTS OF SALT-WATER INTRUSION AT A DELTA.

(b) Laboratory profect

(c) Dr. M. R. Carstens, School of C1vil Engrg. Georgla Inst. of Tech., Atlanta, Ga. 30332 .

(d) Theoretical; research for doctoral thesis.

e) Solutions are being obtalned for seepage flow out of a fresh-water canal located at the function of delta and the sea. Particular interest is centered upon the lowering of the salt-water, fresh-water interface in the delta. Numerical solutions are belng obtalned for various canal locations, water levels in the canal, and drain locations.

(5029) UNSTEADY FLOW IN A PIPE. 
(b) National Science Foundation.

c) Dr. M. R. Carstens, School of C1vil Engrg. Georgia Inst. of Tech., Atlanta, Ga. 30332.

(d) Experimental; design and development of equipment and basic research for master's thesis.

(e) A device for the study of unsteady flow in a pipe has been designed, fabricated, and tested. Ilquid is moved hamnonically in the test p1pe. Velocity and acceleration are independent variables with the measured pressure gradient being dependent. The basic research is primarily directed to the determination of boundary-shear stress for turbulent flow in a smooth plpe.

(5054) A STUDY OF NONLINEAR CONTINUUM PHENOMENA IN THIN FILMS OF SIMPIE LIOUIDS.

(b) Laboratory project.

(c) Prof. A. W. Marris, School of Engrg. Mechanics, Georgia Inst. of Tech., Atlanta, Ga. 30332

(e) Initiation of research program in continuum mechanics of fluids.

(h) "The Reduction of the Simply Hygrosteric Fluid to Stokesian Fluid," Journal of Applied Mechanics forthcoming. "Dependence of Stress upon Temperature Gradient for an Ideally Elastic Solid Isotropic and Homogeneous in Reference state." To be published in Journal of Applied Mechanics.

(5149) MEASUREMENT OF VOID FRACTION IN TWO-PHASE FLOW BY X-RAY ATTENUATION.

(b) Departmental research.

(c) Prof. H. C. Ward, School of Chemical Engrg. Georgla Inst. of Tech., Atlanta, Ga. 30332.

(d) Experimental and theoretical; basic research for doctor's thesis.

(e) The objective of this work was to develop a method for measuring vold fraction in twophase gas-liquid flows using $X-r a y$ attenuation.

(g) A rapid, accurate technique has been developed for measuring vold fractions in two-phase gas-liquid flows using $X$-ray attenuation. In this method, a well columinated X-ray beam traverser, the channel containing the flowing materlal and the transmitted beam is detected by a Gelger-Mueller tube and recorded on a strip chart recorcir. Equations which relate the $\mathrm{X}$-ray attenuation to the vold fraction have been developed and an analysis has been made to determine optimum operating condition and evaluate errors. This technique has been applied to lucite mock-ups and to two-phase flows of steam and water with success.

(h) A paper is in preparation.

(5150) LAMINAR FLOW IN THE ENTRANCE OF A TUBE.

(b) Departmental research

(c) Prof. H. C. Ward, School of Chemical Engrg. Georgia Inst. of Tech., Atlanta, Ga. 30332.

(d) Theoretical; basic research for doctor's thesis.

(e) The objective of this study is to develop numerical solutions of the equations which describe the laminar flow of a Newtonian fluid in the entrance of a tube with suction and injection at the wall as well as for the case of no flow through the wall.

(5151) MULTICOMPONENT CONDENSATION IN THE ENTRANCE LENGTH OF A VERTICAL TUBE.

(b) Departmental research.

c) Prof. H. C. Ward, School of Chemlcal Engrg., Georgla Inst. of Tech., Atlanta, Ga. 30332.

(d) Theoretical and experimental; basic research for doctor's thesis.

(e) The boundary layer equations are being used to describe the liquid and gas phases in the entrance length of a vertical tube to determine possible effects of the entrance length on condensation. Fractionation is being considered.
UNIVERSITY OF HOUSTON, Dept. of Chemical Engineering.

(4936) MECHANISMS OF ENTRAINMENT IN TWO-PHASE, GASLIQUID FLOW.

(b) National Science Foundation.

(c) Prof. A. E. Dukler, University of Houston, Houston, Texas.

(d) Experimental, theoretical, basic research, for Ph.D. thesis.

(e) Analytical study of conditions for unstable waves at the interface of a thin liquid film. Experimental measurements of wave profile, interfacial shear and size distribution of drops generated from the interrace.

(8) Experimental measurements now under way. Methods and equipment for measuring interfacial profile and drop distribution in the flowing field are completed.

(4937) EFFECT OF A MOVING INTERFACE ON TURBULENCE FOR FLOW IN CONDUITS.

(b) Laboratory project.

c) Prof. A. E. Dukler, University of Houston, Houston, Texas.

(d) Theoretical, experimental, Master's thesis, basic research.

(e) For laminar flow, equations of motion have been solved which show that the presence of an oscillating interface causes increased flow resistance. Experimental measurements have been made to measure the Influence of similar oscillations for a flowing turbulent fluid.

(g) "An Effect of Rough and Wavy Moving Boundaries on Flow in Closed Conduits," paper to be presented at the A.I.Ch.E. Meeting in Memph1s, 1964.

(4938) FRICTIONAL ENERGY LOSS IN TWO-PHASE, GASLIQUID FLOW.

(b) American Gas Association - American Petroleum Inst1tute.

(c) Prof. A. E. Dukler, University of Houston, Houston, Texas.

(d) Theoretical, study of mechanisms, for Masters

(e) Systematic collection of source data on pressure drop measurement in two phase flow and preparation of "Data Bank" on cards and tape for use in correlation studies. Definitive tests of existing correlations and development of new correlation approaches.

(h) Two papers have been published. The first gives definitive tests of certain existing correlations w1th data. The second presents a new correlation based on similarity principles.

"Frictional Pressure Drop in Two Phase Flow, A: Comparison of Existing Correlations for Pressure Drop and Holdup," by A. E. Dukler, M. Wicks, R. G. Cleveland.

"Frictional Pressure Drop in Two Phase Flow, B: An Approach through Similarity Analysis," by A. E. Dukler, M. WIcks, R. G. Cleveland. To be published in A.I.Ch.E. J., Nov. 1963.

(4939) MECHANISMS FOR ENERGY LOSS IN SLUG FLOW.

(b) Laboratory project.

(c) Prof. A. E. Dukler, University of Houston, Houston, Texas.

(d) Experimental, theoretical, basic research, Ph.D. thesis.

(e) Experimental studies are being made of pressure distribution and circulation in and around slugs moving in horlzontal flow. Models for slug behavior are being set up analytically with the attempt to predict slug size, frequency and frictional characteristics.

(g) Equipment constructed and preliminary tests to test analytical results under way.

(4940) EFFECT OF TRANSVERSE ROUGHNESS ON TURBULENCE FOR CHANNEL FLOW OF MR. 
(b) Laboratory project.

Prof. A. E. Dukler, University of Houston, Houston, Texas.

(d) Theoretical, experimental, Ph.D. thes1s.

(e) Studies of turbulence and velocity distribution using a hot wire anemometer and pitot tube in or flowing over transverse roughnesses. objectlve is to relate roughness geometry to the Reynolds stresses.

(g) Equipment nearing completion.

(4941) TURBULENT FILM BOILING.

(b) Laboratory project.

c) Prof.A. E. Dukler, Un1versity of Houston, Houston, Texas.

(d) Theoretical, Master's thesis.

(e) Use of integral methods and electronic computer to predict flow patterns and heat transfer coefficlents during turbulent fllm bolling.

(4942) BOUNDARY LAYER APPROACH TO FILM BOILING.

(b) Laboratory project.

c) Prof. A. E. Dukler, University of Houston, Houston, Texas.

(d) Theoretical, basic research, Master's thesis.

(e) Use of simllarity transformation methods and electronic computer to provide exact solutions for film bolling in horizontal flow flelds without pressure gradients.

(g) Laminar flow case solution completed, showing earlier published work was only a special case of the general solution. Turbulent case now under study.

(4943) FRICTIONAL ENERGY LOSS FOR DILUTE PHASE FLOW OF SOLIDS IN GASES.

(b) Laboratory project.

c) Prof.A.E. Dukler, University of Houston, Houston, Texas.

(d) Theoretical, basic research, for Master's thesis.

(e) Use of modifled eddy viscosity distribution functions to predict the velocity distribution and momentum loss for turbulent flow of dilute solid-gas systems.

(g) Correlations have been developed. Thes1s now being prepared.

(3057) CONSERVATION OF WATER FOR RANGE STOCK.

Bureau of Land Management and ranchers. areas w1ll be lined and evaporation control

(b) Laboratory project; in cooperation w1th U. S. Bureau of Reclamation.

(d) Experimental and field investigation; basic and operational with master's thesis.

(e) Different types of canal linings are being studied and varlous ways of evaluating performance are being considered, especlally ideas for measuring canal seepage from both lined and unlined canals.

(g) New sealants are belng investigated in experimental sections of irrigation canals. Techniques for measuring seepage are being compared in simultaneous testing in by-pass sections of canal.

(h) "A Study and Development of a Fleld Method for Measuring Unsaturated Flow Pressures," A. A. Friedman, M.S. Thesis, Univ. of Idaho, 1963 .

(1862) DETERMINATION OF ANNUAL RUNOFF FROM WATERSHED CHARACTERISTICS.

(b) Laboratory profect; being carried on under Agricultural Experiment Station. (b) Laboratory project; in cooveration with

(d) Field invest1gation; applied operational research.

(e) Experimental stock watering ponds in desert measures supplied to see if extension of such water supply can be developed economically.

(g) Several ponds lined and unlined are being studied and enonomolecular films are being experimented with to find net water savings. The hydrology of small ponds is also being investigated.

(h) Progress report to be 1ssued early in 1964.

(d) Experimental; applied research. to the total water use in the area.

(2786) FARM IRRIGATION EFFICIENCIES.

(d) Fleld Investigation; basic and applied research.

Tactual farms to ald in planning of a water efflciency from aspect of farm operations and not just consumptive use of crops.

(3056) TELEMETERING HYDROLOGIC DATA FROM MOUNTAIN

(b) Laboratory project; in cooperation with

(d) Laboratory and fleld investigation; bas1c and applied operational research. more hydrologic data is being studied and basic parameters of snow melt are bein c1rcults for transmission by radio.

(g) Prototype unit is being tested on Moscow ducers are being studied both in the fleld and in the laboratory. License for station has been approved.

"Instrumentation for Hydrologic Measurements at the University of Idaho," D. L. Duncan and C. C. Warnick, Proceedings Western Snow Conference, 31 st Annual Meeting, Yosemite Park Cal1forn1a, April 1963.

3416) STUDY OF METHODS FOR AUTOMATIC MEASUREMENT OF SNOW WATER CONTENT.

(b) Laboratory project; cooperative with Agricultural Research Service, U. S. Dept. of Agriculture.

(d) Field Investigation; applied research.

(e) A study is being made of basic methods of measuring snow water content for use in telemetering data from remote mountain locations.

(g) Three methods appear to of fer good possib1lities.

(h) Contract Report completed "Methods of Automatic Measurement of Snow Water Content to Predict Water Supply". Final Report, October 1963.

"Radiation and Detection Applications in the Visible and Infrared Spectrum," J.E. Thomas, M.S. Thesis, University of Idaho, 1963.

"An Investigation of the Snow Capac1tor and Dlaphram-Deflection Methods of Measuring the A study of the hydrological factors affectire 
Water Equivalent of a Snow Pack," C. L. Hanson, M.S. Thesis, Univ, of Idaho, 1963.

(3417) INFILTRATION AS AFFECTED BY FURROW PARAMETERS AND SOIL VARIABIIITY.

(b) Laboratory profect; under investigation in Agricultural Experiment Station.

(c) Assistant Prof. D. W. Fitzsimmons, Dept. of Agricultural Engineering, Univ. of Idaho, Moscow, Idaho 83843 .

(d) Theoretical; basic research.

e) To determine the effect of various furrow geometric parameters and soil conditions on infiltration patterns by analogy methods.

(g) Dimenstonal analysis along with electrical analog techniques was used to group the variables affecting furrow discharge into a given soil for given soil-moisture conditions into dimensionless terms. Curves were obtained showing that the hydraulic depth of a furrow can be used as a parameter for describing the effect of furrow geometry on furrow discharge. These curves also show the effects of two other geometry parameters, furrow spacing. and the top width of the water surface in furrows, on furrow discharge.

(4535) CROP COEFFICIENTS FOR CONSUMPTIVE USE IN IDAHO.

(b) Laboratory project.

(c) Department of Agricultural Engineering, Univ. of Idaho, Moscow, Idaho 83843.

(d) Field investigation; applied research for master's thesis.

(e) To determine crop coefficients, using the Blaney-Criddle formula, for such crops as potatoes, beans, and corm for southern Idaho areas. The variation of the crop coefficients for (i) light, medium and heavy applications of water, (2) each month of growing or irrigation season, and (3) the stage of growth of each crop. These coefficlents will be compared with the coefficients developed by $\mathrm{Blaney-Criddle} \mathrm{and} \mathrm{other} \mathrm{investigators} \mathrm{for}$ other areas.

(f) Completed.

(g) Data were obtained on consumptive use for various crops in Idaho.

(h) "Crop Consumptive-Use Coefficients," D. R. Kohntopp, M.S. Thesis, Univ. of Idaho, 1963.

(5167) TOTAL HYDROELECTRIC RESOURCES IN IDAHO AND DEVELOPMENT PROBLEMS ON IDAHO STREAMS.

(b) Laboratory project.

d) Experimental, applied research for master's thesis.

(e) A study of streamflow data is being made to determine full water resource capability. The study is designed to develop estimating constants which may give a 90 percent accuracy. New Ideas for stream-to-stream diversion will be investigated.

(5168) INVESTIGATION OF RADIOISOTOPE SNOW GAGE COMPONENTS AND TECHNIQUES.

(b) Laboratory project: Cooperative with Walla Walla District, Corps of Engineers.

(d) Experimental and fleld investigation; applied research.

(e) Problems of monitoring water equivalent of a snow pack using a scintillation detection system to measure attenuation of snow and water of gamma radiation are being studied. Calibration methods and variation of electronic components both under controlled laboratory conditions and remote mountain winter conditions are being considered.

(g) An Improved syst $-m$ has been developed for use in a telemetering system of the corps of Engineers in the clearwater River drainage. Differences of attenuation by water and snow appear to be a problem the magnitude of which is yet to be determined.

(h) Progress reports are available on a limited basis.
(5169) EFFECTS OF CONTROLIED TURBULENCE ON MASS TRANSFER.

(b) Under NSF Grant G-17908

c) Dr. Godfrey Martin, Chem. Engr. Dept. University of Idaho, Moscow, Idaho 83843

(d) Experimental, basic research for masters thesis.

(e) The purpose of this work is to measure the effects of the relative intensity and integral scale of turbulence (measured previously using hot film anemometer techniques) on local mass transfer coefficients from solid cylinders involving water.

(g) Experimental equipment has been constructed and 8 preliminary runs have been made.

(5170) CORRELATION FOR THE DISPERSION OF LIQUIDS FLOWING THROUGH PACKED BEDS USING MODIFIED RANDOM WALK MODELS.

(b) Laboratory project.

(c) Dr. Godfrey Martin, Chem. Engr. Dept., Univ. of Moscow, Moscow, Idaho 83843.

(d) Theoretical and experimental, basic research for doctor thesis.

(e) Using an analogy to the diffusion of material fluids in turbulent flow, the relative intensity and integral scale will be obtained from experimental observation of the flow of fluids through packed beds. These parameters, normalized by dividing by the superficial velocity and packing size respectively, will be reported for different packing. The data should enable field engineers to predict the dispersion of liquids through packed beds. An attempt will be made to explain deviations from a strict random walk distribution by using other modified random walk models.

\section{ILIINOIS STATE WATER SURVEY DIVISION.}

A list of publications is available upon request; write to Illinois State Water Survey, Box 232, Urbana, Illinois.

\section{(552) SEDIMENTATION OF ILIINOIS RESERVOIRS.}

(b) Laboratory project; cooperative with Agricultural Research Service, Soll Conservation Service, and University of Illinois Agricultural Experiment Station.

(c) Mr. R. L. Corinth, Illinols State water Survey, Box 232, Urbana, Illinois.

(d) Field investigation; applied research. measurements of sediment accumulation in lakes in Illinois. Sediment samples are analyzed and complete surveys of watershed soll type, slopes, land use, and conservation practices are made.

(g) Results show correlation between rate of sedimentation and land use on watershed; results show six factors in explaining sediment deposition: age of lake, capacityinflow ratio, watershed gross erosion, a watershed shape factor, the density of non-incised channels, and a watershed slope factor.

(555) EVAPORATION IN ILIINOIS.

(b) Laboratory project

c) Mr. W. J. Roberts, Illinois State Water Survey, Box 232, Urbana, Illinois.

(d) Field investigation; applied research.

(e) A 16-year record of pan evaporation data for five Illinols stations closely correlates with evaporation data computed on basis of four meteorological parameters used in Kohler's equation. Maps of

lake evaporation based on 52-year records of computed evaporation are being prepared for a report on Illinois evaporation.

(f) Continuing. 
(b) Laboratory project.

c) Mr. Robert H. Harmeson, Peoria Laboratory, Ilinols state water Survey, Box 717, Peoria, Illinois.

(d) Experimental; basic research.

(e) Model studies of different pit types and variations in relationship between groundwater gradients and artificlal recharge.

(f) Inactive.

g) Pilot plant p1t operation by Water survey relinquished; laboratory analysis in progress.

(560) GROUND WATER INVESTIGATION IN PEORIA, ILLINOIS, DISTRICT.

(b) Laboratory project.

(c) Mr. Robert H. Harmeson, Peoria Laboratory, Ilinois state Water Survey, Box 717, Peoria, Illinois.

(d) Fleld investigation; applied research.

(e) Continuing evaluation of ground water resources of the district. Ground water levels and temperatures are monitored in wells in key locations. Effects of artificlal recharge are evaluated. Analyses for changes in composition of ground water used to trace movement of ground water and to observe for possible introduction and movement of contaminants as a result of artiflclal recharge.

(g) Ground-water conditions substantially Improved in past ten years and consistentlj since the use of four recharge pits was inltiated in 1956. One pit in North Field is operated the year-round with nearly complete recovery of the recharged water. Second pit in North Field Inoperative in 1962. Recharge in Central Field arbitrarily limited to cool surface water seasons. Central Field recharge has been reduced because of improved ground water conditions.

(561) GROUND-WATER INVESTIGATION IN EAST ST. LOUIS AREA.

(b) Laboratory project.

c) Mr. R. J. Schicht, Illinols state water Survey, Box 232, Urbana, Illinois.

(d) Field investigation; applied research. Evaluation of potential yield of the
sand and gravel deposits beneath the American Bottoms (East St. Louls area). Ground water levels are measured in more than 200 observation wells, 9 of which are equipped with recording gages. Ground water pumpage, Mississipp1 River stages, rainfall, and quality of ground water data are continuously collected. Maps have been prepared showing the distribution and areal extent of the hydraulic properties, the thickness of the aquifer, and watertable contours. The amount of recharge from precipltation and from induced infiltration of river water, and the amount of subsurface flow from valley walls into the American Bottoms were computed by flow-net analysis of water-table maps. An electric analog model consisting of a regular array of 2800 resistors and 1350 capacitors was constructed to simulate the complex aquifer system. The accuracy and rellability of the analog model were assessed by comparing past records of water-level change and values of water-level change computed with the analog model. Exc1tation-response equipment, 1.e., wave form generator, pulse generator and oscilloscope, was used to force electrical energy in the proper time phase into the analog model and to measure energy levels within the resistor-capacitor network. The analog model was used to estimate the practical sustained yields of existing pumping centers and to predict the potential yield of the aquifer with a selected scheme of development.

(h) "Ground-Water Development in East St. Louis area, Illinols," R. J. Schicht, State Water Survey Report of Investigation, in review.
AREA .

(b) Laboratory project, in cooperation with Illinois State Geological Survey.

(c) Mr.H. F. Smith, Illinols state water Survey, Box 232, Urbana, Illinols.

(d) Field investigation; applied research.

(e) Study of variations of natural resources. Investigation of artesian well field with wells 1200 to 2200 feet deep, locally heavily pumped. Study of ground water level recession, interferences, transmissibilities, effect of additional demands.

(g) Results show the ground water resources in Chicago region are developed from four water-yielding units: glacial drift aquifers, shallow dolomite aquifers, Cambrian-Ordovician Aquifer, and Mt. Simon Aquifer. The CambrianOrdovician has been the most highly developed source of large ground-water supplies. Future ground-water supplies should be taken from the shallow aquifers wherever possible.

(h) "Ground-water Resources of Dupage County, Illinols," A. J. Ze1zel, W. C. Walton, R. T. Sasman and T. A. Prickett, Cooperative Ground-Water Report 2, State Water Supvey and State Geological Survey, 1962. "Ground-Water Levels in Illinois through 1961," R. R. Russel1, State Water Survey Report of Investigation 45, 1963.

"Future Water-Level Declines in Deep Sandstone Wells in Chicago Region, Illinois," W. C. Walton, Ground Water, Vol. 2, No. 1, 1964 .

(1865) HYDRAULIC DESIGN OF DROP-INLET SPILLWAY STRUCTURES FOR SMALL RESERVOIRS.

(b) Laboratory project, in cooperation with Agricultural Research Service, Soll Conservation Service, and Illinols Agricultural Experiment Station.

(c) Mr. H.W. Humphreys, Illinols state Water Survey, Box 232, Urbana, Ill.

(d) Experimental; generalized applied research for development and design.

(e) To determine the most desirable proportions and shapes of drop-inlet spillway structures that have unique flow characteristics and to develop ant1-vortex devices. To provide the necessary information on flow relations and discharge coefflcients so that these structures may be economically designed. Initial phases of study concerned with hydraulics of square risers with free discharge. Effect of lip or crest shape and ant1-vortex devices being studied. Second phase to include the complete splilway. Experimental apparatus constructed and tests are belng conducted on the complete splilway. Information is being obtained on discharges, vortex effect on discharge, pressures, a flat plate ant1-vortex device, and flow conditions.

(g) Hydraulics of various types of flow possible in square risers are well defined as well as some of the effect of non-square crest shape. Model tests were performed on a drop-inlet spillway to determine whether or not a metal grating deck placed above the inlet can control vortices. The results of the tests show that gratings do not prevent or control strong vortices.

(2532) EVAPORATION RETARDATION.

(b) Laboratory project.

(c) Mr.W. J. Roberts, Illinols state Water Survey, Box 232, Ürbana, Ill.

(d) Field investigation; applied research, design.

(e) Monomolecular chemical films to retard evaporation from water supply lakes and ponds in Illinols.

(f) Additional tests planned.

(g) 1963 results w1th soluble packets were favorable. Cooperation with lake owners to be continued in 1964.

(2534) DENSE RAIN GAGE NETWORK PROJECTS. 
(b) Laboratory project.

Mr. G. E. Stout, Illinols state Water Survey, Box 232, Urbana, Illinois.

(d) Field investigation; applied research. Data from three rain gage networks, consisting of 50 gages in 400 square miles, 54 gages in 550 square miles, and 20 gages in 10 square miles. Studies include: (1) Rainfall varlability, (2) frequency of point and areal mean rainfall, (3) area-depth relations, (4) variation of point rainfall with distance, (5) areal representativeness of point rainfall, and (6) reliability of areal mean rainfall estimates.

(2535) FILTERING THROUGH COARSE MATERIALS.

(b) Laboratory project.

(c) Mr. Robert H. Hameson, Peorla Laboratory, Illinols state Water Survey, Box 717 Peoria, Illinois.

(d) Experimental; basic research.

e) Small, coarse media ( $1 / 4$ - to $3 / 4-1$ nch) filters are operated at rates comparable to those achieved in field practice. Purpose is to study the effects of coarse media on physical, chemical, and bacteriological properties of recharged water and to evaluate the function of coarse media in protecting aquifer materials.

(g) Results of former fleld tests of various sizes of materials are reported in state Water Survey Bulletin 48. Program of specially controlled laboratory test muns initiated in 1962 under grant from U. S. Public Health Service.

(2788) METEOROLOGY OF FLOOD-PRODUCING STORMS.

(b) Laboratory project.

c) Mr. F. A. Huff, Ilinols state water survey, Box 232, Urbana, Ill.

(d) Applied research.

(e) Investigation of meteorological conditions associated with flood-producing storms in Illinois to obtain basic data for reliable definition of time and space distribution of such storms and for calculation of probable maximum rainfall.

(g) Continuing project; analysis of storm areadepth relations, orientation of storms, seasonal and geographic distribution, synoptic weather types, topographic influences. Development of area-depth frequency relations underway.

(3058) HYDROMETEOROLOGICAL ANALYSIS OF SEVERE RAINSTORMS.

(b) Laboratory project.

(c) Mr. F. A. Huff, Illinols state Water Survey, Box 232, Urbana, Ill.

(d) Fleld investigation; applied research.

(e) Field surveys and detalled analyses of severe rainstorms in Illinols. Analyses based upon radar, synoptic weather, and field survey data and include area-depth-duration relations, antecedent rainfall evaluation, isohyetal maps for peak periods of storm.

(g) Analyses completed on 16 storms since 1951.

(h) State Water Survey Reports of Investigation Nos. $14,24,27,35$, and 42 .

(3059) THERMAL LOADINGS AND CHARACTERISTICS OF SURFACE WATERS.

(b) Laboratory project.

c) Mr. Robert H. Harmeson, Peoria Laboratory, Ilinols state Water survey, Box 717, Peoria, Illinois.

(d) Fleld investigation; applied research.

(e) A study of heat loads applied to fresh water bodies in Illinols to determine relationships between temperature and/or heat loadings, water usage, stream assets, and stream recovery capabilities.

(3419) PRECIPITATION DROUGHT CHARACTERISTICS.

(b) Laboratory project. (c) Mr. F. A. Huff, Illinois state Water survey, Box 232, Urbana, Illinois.

(d) Applied research. cy in Illinols, distribution in space and time of dry periods, relative severity of these periods, meteorological conditions favorable for drought in Illinols, correlation of precipitation drought with other meteorological factors such as thunderstorm frequency and atmospheric moisture distribution, and assodation of precipitation drought with low stream flow.

(f) Completed.

(h) "Drought Climatology of Illinois," F. A. Huff and S. A. Changnon, Jr., State Water Survey Bulletin 50, 1963.

(3420) FREQUENCY AND DURATION OF LOW FLOWS.

(b) Iaboratory project.

c) Mr. John B. Stall, Illinols state water Survey, Box 232, Urbana, Illinois.

(d) Theoretical; applied research.

(e) Analysis of the severity, frequency, and duration of low flows in Illinols streams as they affect impounding reservolr yields.

(g) Methodology devised to determine gross and nt yield of an impounding reservoir during various recurrence-interval droughts. A norsequential mass curve analysis gives gross yleld. Net lake evaporation is processed on a frequency basis; applied to the reservolr; and net yield is determined. Risks associated with an impounding reservoir have been determined and clarified to allow better under standing of reservoir design and recurrence of events.

(h) "A Partial Duration series for Low Flow Analyses," John B. Stall and James G. Ne1ll, Jour. Geophys. Res., December 1961.

"Reservolr Mass Analysis By A Low Flow Series," ASCE Sanitary Engineering Div., September 1962

"Calculated Risks of Impounding Reservoir Yield," ASCE Hydraulic Division, Jan. 1963.

"Low Flows of Illinois Streams for Impounding Reservoir Design," John B. Stall, State water Survey Bulletin 51 , in review.

(3421) PILOT DRAINAGE BASIN STUDIES IN NAPERVILLE AREA.

(b) Laboratory project.

(c) Mr. W. C. Walton, Illinois state Water survey, Box 232, Urbana, Illinols.

(d) Fleld investigation; applied research.

(e) All factors of the hydrologic cycle (especialy precipitation, temperature, stream flow, soll molsture, changes in surface and subsurface storage, and evaporation) to be measured and examined to obtain quantitative knowledge of the movement and storage of ground water under natural conditions in the 22 -square mile basin The annual rate of recharge to, and evapotranspiration from, the ground-water reservalr to be determined. Stream discharge hydrograph to be separated into its two components, surface munoff and ground-water munoff. Gravity yields of glacial deposits and under lying dolomite aquifer to be estimated.

(3731) HYDROLOGY OF DOLOMITE AQUIFERS.

(b) Laboratory project, in cooperation with III. State Geological Survey.

(c) Mr. W. C. Walton, Illinois state water Survey, Box 232, Urbana, Illinois.

(d) Field investigation; applied research.

(e) Evaluation of water yielding potential of dolomite aquifer in Illinols from pumping test and specific capacity data is in progress. Statistical analysis of well production data is being made to determine geological controls on aquifer productivity.

(g) Frequency graphs were used to determine the role of individual units of dolomite aquifers in northern Illinols, as contributors of ground water. Statistical analysis of specific-capacity data provided 
a basis for determining whether or not significant relationships exist between the yields of wells and geohydrologic controls. Probable ranges in yields of shallow dolomite wells in undeveloped areas in northern Illinols were estimated from specific-capacity frequency graphs, aquifer th1ckness and areal geology maps, and waterlevel data. The practical sustained yield of the dolomite aquifer in DuPage County was estimated based largely on case histories of heavy ground-water development.

(h) "Ground-Water Resources of DuPage County, Illinols," A. J. Ze1zel, W. C. Walton, R. T. Sasman and T. A. Prickett, Illinols State Water Survey and Geological Survey Cooperative Ground-Water Report 2, 1962. "Yields of Shallow Dolomite Wells in Northern Illinols," Sandor Csallany and W. C. Walton, State Water Survey Report of Investigation 46,1963 , in press.

"Statistical Analysis of Specific-Capacity Data for a Dolomite Aquifer," W. C. Walton and J. C. Ne1l, Jour. Geophys. Research, v. 68 , No. 8 , 1963

(3732) TRANSPIRATION RETARDATION.

(b) Laboratory project

c) Mr.W.J. Roberts, Illinols state water Survey, Box 232, Urbana, Illinols.

(d) Laboratory and field investigation.

(e) Monomolecular film-forming fatty alcohols are introduced to so1ls and roots of plants causing a reduction in evapotranspiration.

(g) Field tests being analyzed.

(h) "The Effect of Chemicals on the Reduction of Water Losses from Solls," J. P. Vavra and $W$. J. Roberts. Paper read at annual meeting of American Society of Agronomy, Denver, Colorado, November 20, 1963.

(3733) EVALUATING WELLS AND AQUIFERS WITH ANALYTICAL METHODS.

(b) Laboratory project.

(c) Mr.W. C. Walton, Illinols state water survey, Box 232, Urbana, Illinols.

(d) Field investigation; applied research.

(e) Case histories of ground-water development are being studied to determine if $1 \mathrm{t}$ is possible to evaluate wells and aquifers with analytical expressions by devising approximate methods of analysis based on 1dealized models of aquifer situations. Geohydrologic boundaries are assumed to be stralght-line demarcations and are given mathematical expression by means of the Image-well theory. The hydraulic properties of the aquifer and overlying confining beds are considered mathematically by using ground-water formulas. Records of past pumpage and water levels and a digital computer are used to establish the validity of this mechanism to describe the response of aquifers to pumping.

(g) Case historles of ground-water development have been used to evaluate the practical sustained yields of aquifers in the Chicago region and in the areas of Arcola, Taylorville, Tallula, Assumption, Pekin, Jollet, woodstock, L1bertyville, Chicago Helghts and LaGrange.

(h) "Ground-water Development in Several Areas of Northeastern Illinols," T. A. Prickett, L. R. Hoover, W. H. Baker, R. T. Sasman, State Water Survey Report of Investigation, 1964, in review.

(3734) INDUSTRIAL WATER USE IN ILIINOIS.

(b) Laboratory project.

(c) Mr.W. J. Roberts, Illinols state water Survey, Box 232, Urbana, Illino1s.

(d) Fleld investigation; applied research.

(e) Determine withdrawal of water by industries in Illinols, with delineation according to kinds of industry, location by area, and sources of supply.

(f) Project terminated.
(4135) CORROSION PREVENTION BY $\mathrm{CaCO}_{3}$.

(b) Laboratory project.

c) Mr.T. E. Larson or H. W. Humphreys, Illinots State Water Survey, Box 232, Urbana, Illinols.

(d) Experimental.

(e) To determine chemical requirements and veloo 1 ty requirements to provide protective coating in water pipes.

(4137) DIURNAL DISTRIBUTION OF PRECIPITATION AND RELATED WEATHER ELEMENTS.

(b) Laboratory project.

c) Mr.S. A. Changnon, Jr., Illinols state Water Survey, Box 232, Urbana, Illino1s.

(d) Applied research.

(e) Investigation of the diurnal distribution of various weather elements on a monthly, seasonal, annual, and geographic basis. Elements under study include ralnfall, sleet, hall, tornadoes, thunderstorms, freezing rain, and fog.

(f) Suspended.

(4138) EVAPOTRANSPIRATION IN ILLINOIS.

(b) Laboratory project.

(c) Mr. D. M. A. Jones, Illinols State Water Survey, Box 232, Urbana, Illinols.

(d) Applied research.

(e) Evaluation of methods for calculating evapotranspiration and assessment of evapotranspiration in Illinols.

(h) "Variability of Evapotranspiration in Illino1s," D. M. A. Jones, State Water Survey Circular 89, 1963.

(4139) PRECIPITATION PATTERNS OVER AND AROUND LOWER LAKE MICH IGAN.

(b) Laboratory project.

c) Mr.G. E. Stout, Ililnols state water Survey, Box 232, Urbana, Illino1s.

(d) Applied research.

(e) Radar film records are being studied to determine the influence of Lake Michigan on precipitation processes.

(f) Continuing project.

(4536) GEOHYDROLOGIC SYSTEM ANALYSIS WITH AN ELECTRE ANALOG COMPUTER.

(b) Laboratory project.

(c) Mr. William C. Walton, Illinols state water Survey, Box 232, Urbana, Ill.

(d) Experimental; applied research.

(e) Purpose of project is to apply electric analog computers to ground-water resource evaluation problems in Illinols. Ground-water development schemes are being tested and the relative merits of alternate cholces of development are being appraised. The consequences of the utilization of aquifers are being forecast. The electric analog computer in use consists of an analog model and excitation-response apparatus, 1.e., waveform generator, pulse generator, and oscilloscope. The analog model is a regular array of resistors and capacitors and is a scaled-down version of an aquifer.

(g) Analog models have been constructed for thre 1dealized aquifer situations to study the accuracy and reliability of the analog computer. close agreement between analog computer and exact analytical solutions for the three selected aquifer situations has been obtained. A comparison of the analog computer and simplified analytical solutions for a selected complex aquifer situation indicates that resource evaluations based on incomplete data and analog or 1dealized mathematical models can be meaningful and useful. Analog models for sand and gravel aquifers in the East St. Louls and Champalgn-Urbana areas have been constmucted. Past records of pumpage and water levels have been used to establish the validity of the analog model for the East st. Louls area. 
(h) "Electric Analog Computers for Analyzing Ground-Water Problems," W. C. Walton and T. A. Prickett, Journal of the Hydraulics Division, ASCE, in press.

\section{(4537) HYDROMETEOROLOGY OF SPECIFIC ILLINOIS BASINS.}

(b) Laboratory project.

c) Mr. F. A. Huff, Illinols state water Survey, Box 232, Urbana, IIl.

(d) Applied research.

(e) Development of relations defining the distribution of precipitation extremes in major basins. Included are studies of the frequency distribution of excessive point and areal mean rainfall in various regions of basins, the frequency distribution of drought, average slope of area-depth curves, actual depthduration-area relations in the heaviest storms on record, area-depth frequency relations based upon all major storms of record, seasonal distribution of heavy storms, and the shape characteristics of major storms. Research presently confined to the Kaskaskia basin.

(5051) GROUND-WATER RECHARGE AND RUNOFF IN ILLINOIS.

(b) Laboratory project.

c) Mr. William C. Walton, Illinols state Water Survey, Box 232, Urbana, Ill.

(d) Fleld investigation; applied research.

(e) Purpose of project is to describe recharge conditions throughout the state and to determine the relation between ground-water contribution to streams and basin characteristics.

(g) Recharge rates for several aquifers in Illinols have been estimated based on flownet analyses of plezometric surface maps. Recharge rates vary with vertical hydraulic gradlents and are not constant but vary in space and time. Annual ground-water runoff from 109 dralnage basins scattered throughout Illinols was estimated with streamflow hydrograph separation methods and flowduration curves. The relations between ground-water runoffs during years of near, below, and above normal precipitation and basin characteristics such as geologic environment, topography, and land use were determined by statistical methods. Studies indicate that no simple relation exists between ground-water runoff and the potential or practical sustained yields of aquifers.

(h) "Ground-water Recharge and Runoff in Illinols," W. C. Walton, State Water Survey Report of Investigation, 1964 , in review.

(5052) COMPARATIVE RAINGAGE STUDY.

(b) Laboratory project.

(c) Mr. D. M. A. Jones, Illinols state Water Survey, Box 232, Urbana, Ill.

(d) Applied research.

(e) Field comparision of shielded and unshielded recording and nonrecording precipitation gages including the WMO International Reference Precipitation Gage.

(h) Report on three years of data prior to installation of WMO gage in preparation.

(5053) CLIMATOLOGICAL ANALYSIS OF SEVERE WINTER STORMS.

(b) Laboratory project.

(c) Mr. Stanley A. Changnon, Jr., Illinols State Water Survey, Box 232, Urbana, Ill.

(d) Applied research.

(e) Detalled analyses of severe winter season snowstorms, sleet and 1ce storms. Analyses based primarily on U. S. Weather Bureau original station records for Illinois during the 1900-1962 period. Temporal and areal frequencies, storm movement, shapes, orientations, duration, and individual maps for each storm.

(f) Continuing project.

(8) Analysis partially completed on all storms in 1900-1957 period.
ILLINOIS STATE WATERWAYS DIVISION, Springfield.

(1863) EROSION CONTROL, ILLINOIS SHORE OF LAKE MICHIGAN

(b) State of Illinois.

(c) Mr. John C. Guillou, Chlef Waterway Engr. Div. of Waterways, Dept. of Public Works and Buildings, 201 West Monroe street, Springfleld, Illinois 62706 .

(d) Field investigation; applied research.

(e) To obtain and correlate basic data on the several forces and factors involved in erosion processes along the Illinols Shore of Lake Michigan to the end that future efforts toward the prevention of erosion might be founded upon a more definite and factual basis with a consequent greater degree of assurance that the works will serve the intended purposes.

UNIVERSITY OF ILLINOIS, Soll and Water Conservation Engineering Lab., Department of Agricultural Engrg.

Inquiries concerning the following projects should be addressed to Prof. B. A. Jones, 100 Agricultural Engineering, University of Illinois, Urbana, Ill.

(2316) RUNOFF FROM SMALL AGRICULTURAL AREAS IN ILLINOIS.

(b) Laboratory project cooperative with ARS, U. S. Department of Agriculture.

(d) Experimental and fleld investigation; basic research.

(e) To determine frequencles of peak rates and total amounts of munoff from agricultural watersheds of 25 to 1,500 acres; to determine maximum rates of munoff from agricultural watersheds in different soll association areas in Illinols; to compare munoff from agricultural watersheds under accepted soll conservation practices with watersheds cultivated without soll conservation practices. Watersheds of $45.5,63$, 82 , and 390 acres near Monticello, Ilinois are covered with a rain gage network, and runoff is measured at welrs and spillway stmuctures by water level recorders. Maximum stage recorders are installed at fleld structures on 8 watersheds in Champaign, Platt, Vermilison, and Ford counties on watersheds rangling in size from 45 to 1,400 acres. Model studies and field calibrations are made on the field stmuctures.

(2789) LABORATORY MODEL STUDIES OF CONSERVATION AND DRA INAGE STRUCTURES.

(b) Laboratory project.

(d) Experimental investigation in the laboratory; applied and basic research.

(e) To investigate the performance of soil and water conservation structures by means of hydraulic model studies, to study water flow patterns into surface drains and to determire the cause of fallures and remedial measures of certain conservation structures under flood conditions.

(h) "Side Wall Effects on Laminar Flow in Open Rectangular Channels," J. L. Woemer M.S. Thesis, Univ. of Illinols Library, Uroana, $104 \mathrm{p}$ (1963)

"Pitot-Tube Measurements in Debris Filled Flows," J. A. Replogle, L. F. Huggins, and R. D. Black, Agricultural Engineering Vol. 44 (in press).

"Gully Control Without Structures - Part II," B. A. Jones, Jr., Trans. of ASAE: 6:39, 40 , 47 (1963).

(3424) A STUDY OF RAINFALL ENERGY AND SOIL EROSION.

(b) Laboratory project cooperative with ARS, U. S. Dept. of Agriculture.

(d) Experimental; basic research.

(e) Natural rainstorms are photographed with a raindrop camera so that the number of raindrops, their size and size distribution, and 
the kinetic energy of a rainstorm may be calculated. Physical measurements w1ll be made of the soll to determine the effect of the kinet1c energy of the rainstorm on soll loss. The nature and properties of rainstorms that occur in this area of Illinols w1ll also be studied.

(h) "Improvement of Measuring and Sampling Equipment for Sediment-Laden Runoff," J. A. Replogle and L. C. Johnson, Trans. Of ASAE: $6: 3$ (in press 1963 ).

(4986) WATER INFILTRATION RATE METHODS AND DETERMINATIONS ON SOILS.

(b) Laboratory project.

d) Field investigation, basic research. To fleld test practical methods for determining and predicting relative infiltration rates of solls during irrigation and during rains. To determine infiltration rates for spec1fic soll types under various management practices.

(4987) THE EFFECT OF GYPSUM AND DRAINAGE ON SOLONETZIC SOILS (SLICK-SPOTS) IN ILLINOIS.

(b) Laboratory project in cooperation w1th Dept. of Agronomy

(d) Experimental field investigation.

(e) To test the feasibility of replacing and removing excess sodium from solonetzic solls under field conditions with (a) differert methods and rates of applying gypsum (calc1um sulphate), (b) different degrees of disturbing the subsoll, and (c) different spacings of tile drains

Twenty plots were established in a random pattern to compare 3 positions for the application of gypsum and 3 spacings of tile drains with check plots. The tile effluent is measured by recording equipment to determine the rate and volume of flow. Also samples w1ll be taken to determine the amount of sodium in the leachate.

UNIVERSITY OF ILLINOIS, Hydraul1cs and Water Resources Laboratory, Department of C1v1l Engrg.

Inquirles concerning all projects should be addressed to Dr. V. T. Chow, Prof. of Hydraullc Engineering, University of Illinols, Urbana, Ill., unless otherwise indicated.

(1591) DETERMINATION OF WATERWAY AREAS.

(b) Laboratory project, cooperative with Ill1nols Division of Highways and Bureau of Public Roads.

(d) Analytical and fleld 1nvestigation; applied research and design.

(e) To determine the discharge of water which will reach openings of highway drainage stmetures, such as bridges and culverts and to provide a simple but sclentiflc procedure for use of englneers in establishing the economical and adequate size of opening.

(i) Completed.

(g) A scientiflc, simple, and practical method is developed for the determination of peak discharges from small drainage basins. For practical applications, a deslgn chart for climatic and physiographic conditions in Illinols is prepared.

(h) "Closing Discussion on Hydrolog1c Design of Culverts," by Ven Te Chow, Proceedings, Amerlcan Soclety of C1vil Englneers, Paper 3071 , Journal of Hydraulic DIv., vol. 89, No. HY2, March, 1963, pp. 161-í62.

(3060) OPERATIONAL CHARACTERISTICS OF FIITER DRAINS.

(b) Assoclation of Amerlcan Rallroads.

(c) Prof. J. C. Guillou, Dept. of C1vil Engrg. Un1v, of Illinols, Urbana, Illinols.

(d) Experlmental; applied research.

(e) Investigation of characterlstics of flow through granular fliters and several types of drain pipe. Investigations have included tests of coated and uncoated corrugated metal plpe, drain tile, and plastic pipe. Compaction studies have been completed.

Laboratory activity during the past year has been directed toward evaluation of compaction in concrete sand fllter when used in conjunction w1th corrugated metal drain p1pe. The drain plpe has been located with perforations at both the top and bottom of the p1pe. Tests have also been conducted using perforated 2 -1nch plast1c pipe and farm tile to permit comparison with the corrugated metal plpe.

$\left(\begin{array}{l}f \\ g\end{array}\right)$ Completed. plpe perforations. optimum compaction of concrete sand filters appears to be about 15 percent greater than loose f1ll. F1lter stability is caused by binding of fines in the intergranular openings near the plpe openings. The several materials were found to perform equally well when they were properly installed.

(h) "Third Progress Report on Performance of F1lter Materlals," by J. C. Gulliou, Report ER-29, AAR Research Center, Chicago, Illino1s, February, 1963.

\section{(3425) LOCKPORT SLUICEGATE STUDY.}

(b) Metropolitan San1tary District of Greater Ch1cago.

(c) Prof. J. C. Guillou, Dept. of C1vil Engrg., Univ. of Illinols, Urbana, Illinols.

(d) Experimental, appiled research.

(e) A l:20 scale model has been constructed and tested. The subject slulcegates will be used for supplemental control of storm water releases from the Chicago Drainage Canal. Three turbine pits in the existing powerhous at Lockport have been modifled to recelve triple slulcegates. The model data have been used to develop operational rating data for the gates under varlous headwater and ta1lwater conditions.

(f) Completed.

(g) Offlcial calibration curves for the prototype stmucture have been completed and accepted by the sponsor.

\section{(4537) BOX CULVERT ENERGY DISSIPATORS.}

(b) Laboratory project.

(c) Prof. M. B. McPherson, Dept. of Civil Eng. Un1v. of Ill., Urbana, Illinols.

(d) Experimental; applied research; NSF undergraduate research grant problem, and M. S. Thesis.

(e) Applicability of U.S.B.R. Basin VI (ASCE Proc., Vol. 83, No. HY5, Paper 1406, Oct., 1957 ) for highway box culverts has been 1nvest1gated. Current phase: box culvert scour studies to evaluate erosion susceptibility of various solls.

(h) "Factors in Design of Culvert Energy Dissipator'," by M. B. McPherson and D. D. Meredith, a paper presented before the Annual Hyd. DIv. Conf., ASCE, at Penna. State Un1v., Aug. 8, 1963. (Univ. of Illino1s Englneerlng Library).

(4538) WATER DISTRIBUTION SYSTEMS-ANALYSIS CRITERIA.

(b) N. I. H. Research Grant.

(c) Prof. M. B. McPherson, Dept. of C1v11 Eng., Un1v. of Ill., Urbana, Illinols.

(d) Numerical; development.

(e) General criterla are belng sought for determination of minimum initial cost and optimum operating cost of systems comprising pumped input, network and equalizing storage. Consideration w11? be given to hourly and yearly demand variations.

(g) General network head-loss parameters and pump-network-storage balancing criterla have been developed. System balances are belng performed via digital computer.

(h) "A study of Storage and Power Requirement Criteria for Water D1stribution Systems 
Analysis," by Gary Wood, undergraduate special problem report, Feb., 1963. (UnIv. of Ill. Engrg. Library\}.

\section{(4539) NON-UNIFORM SUPPLY OVERLAND FLOW.}

(b) Laboratory project; support from University of Illinols Research Board.

(c) Prof. M. B. McPherson, Dept. of Clvil Eng., University of Illinols, Urbana, Illinols.

(d) Experimental and theoretical; applied research.

e) Uniform and linearly varying rainfall supply have been simulated with a sprinkling system on a sheet of variable slope and roughness.

(h) Discussion of "Spatially varied Flow from Controlled Rainfall," by R. L. Kuhlemeyer and D. B. Warner, Proc. ASCE, Vol. 89, No. HY4, Paper 3580, July, 1963, pp. 233-240.

(4540) CIRCULAR HYDRAULIC JUMP.

(b) Laboratory profect; cooperative with Illinols State Water Survey.

(c) Prof. M. B. McPherson, Dept. of Civil Eng. University of Illinols, Urbana, Illinois.

(d) Experimental; development; graduate special problem.

(e) A 60 degree sector of a circular hydraulic jump is being studied to determine feasibility of using energy dissipation. Later transitions will be modified to include a vertical curve to a sector stilling basin.

(g) A preliminary sequence of tests has been completed for a horizontal floor.

(4541) VARIATION OF TRACTIVE FORCE IN SEWERS AND DRA INS.

(b) Laboratory project for J. A. Replogle's doctoral thesis directed by $\mathrm{V}$. T. Chow.

(d) To study the distribution of boundary shearing stress, or tractive force in a circular conduit flowing partially full and to determine the relationship between the shearingstress distribution and the velocity distribution.

(e) A 4 in. smooth copper tube with fully developed open-channel flow is used for a variety of flow depths. The velocity distribution is measured by using a small pitot tube and the "law of the wall" method.

(h) Thesis is being prepared.

(4542) CRITICAL-FLOW CHANNEL.

(b) Laboratory project for graduate studies.

(e) To construct a critical-flow channel which will be used to verify the theory of critical flow and to examine the behavior of flow in such a channel.

(g) A critical-flow channel was constructed of Plexiglass plates which were shaped to the form of the theoretically computed cross section.

\section{(4543) WATER RESOURCES SYSTEM.}

(b) Laboratory profect supported by the University's Center for Advanced Study.

(d) Theoretical; basic research.

e) To study the methods of synthetic hydrology and the use of mathematical models in the planning and development of water resources systems. The approach is analytical and mathematical, including various methods of probability, programming techniques, and operations research.

(h) A progress report entitled "Water-Resources System Design by Operations Research" has been prepared by V. T. Chow.

(4544) ELECTRONIC ANALOG MODEL FOR GROUND WATER.

(b) Laboratory profect for graduate studies by P. A. Carr and S. H. Whitaker; cooperative with Illinois state water Survey.

(d) To construct an electronic analog model to simulate aquifer characteristics.

(e) Part of the electronic analog model to simulate the aquifers in the area of Champaign-Urbana, Illinols, has been completed.
(4905) WATER WAVE AND STRUCTURE INTERACTION.

(b) Laboratory project supported by the NSF undergraduate research grant and University of Illinols Research Board.

(c) Prof. J. P. Murtha, Dept. of Civil Engineering, Univ. of Illinols, Urbana, Illinois.

(d) Experimental; basic research.

(e) To study the time varlations of forces produced by gravity waves on structures and to evaluate subsequent structural motion. The principal effort during the first phase of the research is the design of the laboratory equipment for experimental studies at wave-structure interaction and preliminary studies of added mass effects in still water.

(4906) BASIC INVESTIGATION ON NATERSHED HYDRAULICS.

(b) National Science Foundation research project. (d) Experimental and theoretical; basic research. To investigate the basic laws governing the flow of surface water over drainage basins by controlled experiments on geometric basins. The approach used is to control artifically the various factors involved in the mechanics of flow, and the experimental data so obtained can be subjected to exact theoretical analyses for the determination of the basic laws. The first year work will be on the design of equipment for experimental uses.

(4907) A BASIC STUDY OF THE LINEARTTY OF THE RAINFALL-RUNOFF PROCESS IN WATERSHEDS.

(b) Laboratory project for M. H. Diskin's doctoral thesis directed by Prof. V. T. Chow.

(d) Theoretical; basic research.

(e) This is an analytical study of the rainfallrunoff relationship by means of Laplace transforms. The characteristic parameters for various mathematical solutions are evaluated and the results are applied to elght actual watersheds.

(4908) THE FORCES CAUSED BY WAVES BREAKING AGAINST VERTICAL IMPERVIOUS RIGID WALLS.

(b) Laboratory project for a doctoral thesis by W. J. Garcla, Jr., under the direction of Prof. V. T. Chow cooperative with U.S. A rmy Engineers Waterways Experiment station.

(d) Experimental and analytical; basic research.

(e) To formulate relations which w1ll enable one to determine pressures on impervious rigld walls due to breaking waves with sufficient accuracy to afford an economical and safe design for sea walls and breakwaters; also to investigate the varlation of pressure on the wall with respect to time and spacial distribution.

(4909) A STUDY OF THE EFFECT OF BASIN STORAGE ON SURFACE RUNOFF HYDROGRAPHS.

(b) Laboratory project for V. C. Kulandaiswamy's doctoral thesis under the direction of Prof. V. T. Chow.

(d) Theoret1cal; basic research.

(e) To analyze the storage-flow relationship as a dynamical system from which a generalized differential equation is derived to represent the storage loop curve generally obtalned from actual measurements.

(4910) PROBABIIITY AND SYNTHETIC HYDROLOGY APPROACH TO THE ANALYSIS OF RAINFALL-RUNOFF FREQUENCY REIATIONSHIP 。

(b) Laboratory project for S. Ramaseshan's doctoral thesis directed by Prof. V. T. Chow.

(d) Theoretical; basic research.

(e) To treat the rainfall-munoff phenomenon in a drainage basin as a stochastic linear process and thus to predict the outflow characteristics from those of the inflow and the system. Synthetic hydrology and 
simulation techniques are used in the analysis. The frequency of the historical peak discharges observed on actual watersheds is analyzed by the extreme-value probability distribution and results are to be compared with those obtained from synthetic hydrology models.

(4911) MECHANICS OF RAISING AND LOWERING HEAVY OBJECTS IN THE DEEP OCEAN.

(b) Laboratory project for B. J. Muga's doctoral thesis directed by Prof. V. T. Chow, cooperative with U. S. Navy Civil Engineering Laboratory.

(d) Analytical and experimental; applied research. by wind generated waves on a barge supported crane especially constmucted for a classifled project, as spread moored by $2.5-1$ nch die lock chain in approximately $160-\mathrm{ft}$. of water in the open Pacific Ocean.

(4912) SURGES IN OPEN CHANNELS.

(b) Laboratory profect for W. H. Huang's doctoral thesis directed by Prof. V. T. Chow.

(d) Theoretical and experimental; basic research.

e) To analyze the surges in power canals produced by sudden closure of the gate at the down stream. An improved Johnson method will be used and the results obtained will be compared with the actual or laboratory experimental data.

-

UNIVERSITY OF ILLINOIS, Fluid Mechanics and Hydraulics Laboratory.

Inquiries concerming Project No, 2083 should be addressed to W. M. Lansford, 219 Talbot Laboratory, University of Iilinois, Urbana, Illinois, and for Projects Nos. 2536, 3427, 4142, 4558 to Professor J. M. Robertson, 125 Talbot Laboratory, Univ. of Illinois, Urbana, Illinois.

(2083) VELOCITY DISTRIBUTION IN AN OPEN CHANNEL HAVING A TRIANGULAR CROSS-SECTION.

(b) Laboratory project.

d) Basic research.

e) Data being obtained from a channel artificially roughened.

(f) Investigation reactivated, additional data being taken with new improved instruments, one of which is a hot wire probe.

(2536) STUDY OF HOMOLOGOUS TURBULENCE.

(b) Laboratory profect, formerly National science Foundation.

(d) Basic research.

e) The nature of turbulence (its production and dissipation) is being studied in the simplest possible shear flow-plane couette flowwhere the shear is constant and the turbulence homogeneous but not isotropic. Mean-flow studies essentially complete. Transformation of turbulent stresses to different orientation of axes currently being studied.

(f) Reactivated.

(3427) STRUCTURE OF TURBULENCE NEAR ROUGH SURFACES.

(b) Bureau of Ships Fundamental Hydromechanics Research Program.

(d) Basic research; experimental.

e) Information on mean-flow and turbulence structure near roughnesses being studied in an 8-Inch "natural roughness" pipe and in 3 -inch sand-roughened pipe. Basic question is how roughness produces turbulence. Current emphasis is on spectrum.

(f) Investigation terminated.

(4142) TURBULENT BOUNDARY-LAYER FLOW TOWARDS A NORMAL STEP.

(b) Laboratory project.

(d) Basic research. (e) An analytical and experimental study is being made of upstream separation, 1.e., the real fluid behavior (separation, mixing, reattachment) in front of a normal step projecting inward from a plate along which fluid is flowing with a turbulent boundary layer. Air is fluid medium being used.

$\left(\begin{array}{l}f \\ \text { g }\end{array}\right)$ First phase of study completed; in one case rather good agreement was found between theoretical solution and experimental observation of separation streamline.

(4143) HEMODYNAMICS SIMILITUDE STUDY OF AN ARTERIAL DISTRIBUTION SYSTEM.

(b) Public Health Service, National Institutes of Health, Research Grant No. HEO8330-01.

(c) Prof. M. E. Clark, 123 Talbot Laboratory, University of Illinois, Urbana, Illinois.

(a) Basic research; experimental.

e) The flow of blood in the circle of Willis-the arterial distribution system for the brain-1s to be studied utilizing largesized models. Present goal is to fabricate a model which will simulate in as many ways as possible the prototype and its flow.

(f) Investigation in process.

(g) Fabrication and model-prototype verification of first-stage model essentially complete. Studies being initiated in the pulsatile flow aspects.

(4558) EFFECT OF TURBULENT NORMAL STRESS ON DRAG EVALUATION BY WAKE MOMENTUM METHOD.

(b) Laboratory project.

d) Basic research.

(e) Conventionally the evaluation of drag of bodies from wake transverses ignores normal stresses in wake. Estimates from scanty data indicate this factor to account for 2 to 10 percent of drag. Experiments are being conducted to obtain a more precise indication of the size of the error and how it varies.

(f) Investigation in initial stages.

(4559) FLOW STABILITY AND HEAD LOSS IN BRANCHED TUBES.

(b) Public Health Service, National Institute of Health, Research Grant No. HE08330-01.

(c) Prof. M. E. Clark, 123 Talbot Laboratory, Univ. of Illinois, Urbana, Illinois.

(d) Basic research; experimental.

(e) In confunction with a model study of the circle of Willis--the arterial distribution system for the brain--a need was felt for a better understanding of the stability of viscous flows through certain types of Junctions as well as the amount of head loss which occurs. A series of bifurcations and fusions of rigid, circular tubes are being studied to gain this understanding.

(f) Investigation in process.

IOWA STATE UNIVERSITY, Department of Agricultural Engineering.

Inquiries concerning the following projects should be addressed to Dr. H. P. Johnson, Department of Agricultural Engineering, Iowa State University, Ames, Iowa.

(2330) DEPTH, SPACING AND HYDRAULICS OF TILE DRAINS.

(b) Laboratory project.

(d) Theoretical and field investigation; basic and applied research; master's and doctor's thesis.

(e) Analytical and experimental approach is beirg studied to determine depth and spacing of tiled drains by analyzing soil characteristics and geometry of systems. Work is cooperative with Dr. Kirkham, Soll Physics Department of Agronomy. Studies of the relationship of hydrologic and applied hydraulic problems of field tile systems 
belng made.

(8) Studies of models and mathematical theory of unsteady flow through porous media are beling conducted in the Department of Agronomy under the direction of Dr. Kirkham. Field studies of flow through the spacing between individual tile for saturated conditions are being conducted by the Agricultural Engineering Department.

(h) "Unsteady-state Drainage of Fluld from a Vertical Column of Porous Material," by J. T. Ligon, H. P. Johnson, and Don Kirkham. Journal of Geophysical Research, 67:51995204. 1962 .

"Glass Bead Glycerol Model for Study1ng the Falling Water Table Between open D1tch Drains," by J. T. L1gon, H. P. Johnson and Don K1rkham. Transactions of ASAE, 6:61-63, 64. 1963.

"The Falling Water Table Between Open D1tch Drains," by J. T. L1gon, Don Kirkham and H. P. Johnson. Submitted for publication to Soll science.

(2331) SURFACE RUNOFF FROM AGRICULTURAL WATERSHEDS.

(b) Laboratory project.

d) Theoretical; applied research; doctoral thesis.

(e) A study designed to obtain frequencles of munoff for different solls, molsture condltions and cover has been completed. The elements of point rainfall intensity, infiltration rates, and the unit hydrograph are being integrated in such a fom that most of the work involved in finding the frequencles of flow can be completed with a computer. (B) Completed.

(h) "Runoff Prediction from Point Rainfall Data by Application of the Digital Computer, "by D. B. Palmer and H. P. Johnson. Submitted for publication to Transactions of ASAE.

(2333) IMPROVEMENT OF SURFACE DRAINS WITH TIIE BLIND INIETS.

(b) Laboratory project.

d Fleld investigation; design.

(e) Field study is being continued to determine the effect of different tile backfill materlal on the flow of water into the tile drains.

(2334) RUNOFF FROM SMALL WATERSHEDS.

(b) Laboratory project.

(d) Field investigation; applied research; deslgn.

(e) Measurements of rainfall, surface runoff, soll molsture, water table levels, and evaporation being made on six small agricultural watersheds under a single cover crop. Five additional agricultural watersheds are being gaged for ralnfall and surface runoff.

(4150) COMPARISON OF SYNTHETIC UNIT GRAPH METHODS.

(b) Laboratory project

d) Experimental, applied research.

(e) Three synthetic unit graph methods developed for application to small watersheds are being compared with actual unit graphs from given watersheds. The effect of duration of storm, and distribution of rainfall with time on the stom hydrograph is being studied.

\section{(4913) QUANTITATIVE EVALUATION OF GULLY EROSION.}

(b) Laboratory project

d) Fleld investigation; applied research.

e) A study where multiple regression has been used to relate gully growth to a series of independent variables. In1tial equation developed from 20 year history on one watershed. Study has expanded to include two watersheds with continuing measurement of gully growth, surface runoff, and sediment production. (h) "Factors Related to Gully Growth in the Deep Loess Area of Western Iowa," by C. E. Beer and $\mathrm{H}$. P. Johnson. Accepted for publication in Transactions of ASAE. 1963.

IOWA STATE UNIVERSITY, Department of Agronomy.

(3079) MOVEMENT OF WATER IN SOILS.

(b) Laboratory project.

c) Dr. Don Kirkham, Department of Agronomy Iowa State University.

(d) Theoret1cal and applied research; Doctor's thesis.

(e) Theoretical work done on the movement of ground water in soll, particularly in the saturated phase continues. Mr. John C. Corey is continuing isotope work on water movement in the unsaturated state (miscible displacement) in cooperation with the Iowa state University Institute for Atomic Research.

(4592) MOVEMENT OF WATER FROM WASTE RECHARGE INSTALLATIONS.

(b) U. S. Department of Health, Education, and Welfare, Public Health Service, National Institute of Health.

(c) Dr. Don K1rkham, Department of Agronomy, Iowa State Univ., Ames, Iowa.

(d) Theoretical and fleld investigation; basic and applied research; master's and doctor's thesis.

(e) The purpose of this project is to discover laws which predict, from the geometry of the waste recharge installation, and from the physical properties of the soll about 1t, how fast, and how far at certain times, water will move from the installation. This will be accomplished by (I) obtaining empirical laws governing seepage of water from an 1deallzed scaled model (2) testing by fullscale fleld experiments to see if the empirical laws found in (1) above need to be modifled when applied to fleld conditions, and (3) formulating rational relations between the water movement, the geometry of the system and the soll conditions, by setting up and solving the appropriate seepage differential equations and checking the result against the experimental data from (1) and (2) above.

(h) "Two-Dimensional Infiltration and the wetting Fronts in Some Iowa Solls, " by Sadik Toksoz. Thesls for the degree of Master of Sclence, Iowa State University LIbrary, Ames, Iowa. "Horlzontal and Vertical Hydraulic Conductivity Measurements of Some Iowa Soll Types," by Glen 0. Klock. Thesis for the degree of Master of Science, Iowa State University L1brary, Ames, Iowa.
IOWA INSTITUTE OF HYDRAULIC RESEARCH, Un1vers1ty of Iowa.

(66) HYDROLOGIC STUDIES, RALSTON CREEK WATERSHED.

(b) Cooperative with the Agricultural Research Service and the U.S. Geological Survey.

(c) Prof. J.W. Howe, Department of Mechanles and Hydraulics, University of Iowa, Iowa City, Iowa.

(d) Fleld investigation; applied research, and M. S. theses.

(e) Study being made of relation between rainrall and runoff over a small area. D1scharge from a 3-square-mile area measured by U. S. G. S.; ralnfall records at flve automatic recording stations collected by Agricultural Research Service. Continuous records since 1924 of precipltation, runoff, groundwater levels, and vegetal cover.

(g) Yearly records available for examination at Iowa Institute of Hydraulic Research. 
(h) Reports prepared annually since 1924 available in files at the Iowa Institute of Hydraul1c Research. Summary of 33-year record published as Bulletin 16 of the Iowa HIghway Research Board in 1961; avallable upon request from Iowa HIghway Commission, Ames, Iowa.

(67) COOPERATIVE SURFACE-WATER INVESTIGATIONS IN IOWA .

(b) Cooperative with U. S. Geological Survey.

(c) Mr. V. R. Bennion, Iowa Institute of Hydraulic Research, Iowa City, Iowa.

(d) Field Investigation; collection of basic stream-flow data.

(e) Stream-flow and sediment measuring stations maintained throughout the State of Iowa cooperatively on a continuous basis. Records collected by standard methods of U. S. G. S.

(g) Records of stream-flow and sediment discharge computed yearly.

(h) Records contained in Water-Supply Papers available through offices of the Geological Survey.

(68) HYDROLOGIC STUDIES, RAPID CREEK WATERSHED.

(b) Cooperative with U. S. Geological Survey.

(c) Mr. V. R. Bennion, Iowa Institute of Hydraulic Research, Iowa City, Iowa.

(d) Fleld investigation; applied research.

(e) Study being made of relation between rainfall and runoff over a small area. D1scharge from a 25-square-mile area measured and flood runoff on main subbasins determined by U. S. Geological Survey; rainfall records at four automatic recording stations collected by U. S. Weather Bureau. Cont1 nuous records since 1941 of precipitation, runoff, and ground-water levels.

(g) Rainfall records published in weather Bureau Climatological Bulletins and surface runoff and ground-water levels published in Geological Survey Water-Supply Papers.

(73) MEASUREMENT OF TURBULENCE IN FLOWING WATER.

(b) Cooperative with office of Naval Research, Department of the Navy.

(c) Dr. Philip G. Hubbard, Iowa Institute of Hydraulic Research, Iowa city, Iowa.

(d) Experimental and theoretical; basic and applied research.

(e) Instruments, primarily electrical in operation, are being developed to measure the characteristics of turbulent flow over a wide range of laboratory and fleld conditions. Both sensing and computing elements are involved.

(g) Factors which influence the convection of heat from fine wires in various liquids are being studied in detail.

(79) CAVITATION.

(b) Cooperative with office of Naval Research, Department of the Navy.

(c) Dr. Hunter Rouse, Iowa Institute of Hydraulic Research, Iowa C1ty, Iowa.

(d) Experimental and theoretical; basic research and graduate theses.

(e) Basic information is sought on cavitation for systematically varied boundary conditions. Studies of cavitation in jets and behind disks and plates are being continued.

(1875) CHARACTERISTIC: OF STABLE EDDIES.

(b) Laboratory project, partially supported by Office of Naval Research, Department of the Navy and U. S. Army Research office (Durham).

(c) Dr. Hunter Rouse, Iowa Institute of Hydraul1c Research, Iowa C1ty, Iowa.

(d) Experimental and analytical; basic research.

(e) Distributions of velocity, pressure, and turbulence are being investigated throughout the vicinity of separation zones produced by abrupt changes in flow section, to the end of establishing the primary eddy characteristics as functions of the boundary geometry. (g) Studies are being conducted on flow in the wakes of conical after-bodies. Analytical studies are also being conducted for an abrupt boundary expansion.

(h) "Flow Characteristics at Abrupt Axisymmetric Expansions," by Mahesh C. Chaturvedi, Journal of the Hydraulics Division, ASCE, May 1963; see also discussion by T. J. Carmody, T. T. Huang, and R. Chevray. "On the Pole of Eddies in Fiuld Motion," by Hunter Rouse, American Sclentist, Vol. 51 , No. 3, 1963.

\section{(2091) RESEARCH ON SHIP THEORY.}

(b) Cooperative with office of Naval Research and David Taylor Model Basin, Department of the Navy.

(c) Dr. Louis Landweber, Iowa Institute of $\mathrm{Hy}-$ draulic Research, Iowa clty, Iowa.

(d) Experimental and theoretical; basic research

(e) To determine the laws governing the forces, moments, and motions of ships. Work is under way on the following problems: (1) Development of procedure for computing potential flow about ship forms. (2) Determination of hydrodynamic images, forces, and moments for a spheroid in an arbitrary potentlal flow. (3) Effect of tank size on ship-model resistance. (4) Resolution of viscous and wave drag by means of wake and surface-profile measurements. (5) Effect of a free surface on separation. (6) Vibration of ships.

(h) "Force on a Prolate spheroid in an Axisymmetric Potent1al Flow," by L. Landweber and Matilde Macagno, IIHR Report, Feb. 1963. "Lagally's Theorem for Multipoles," by I. Landweber, IIHR Report, Feb. 1963. "An Evaluation of the Method of Direct Determination of Wavemaking Resistance from Surface-Profile Measurements, "by I. Landweber, Proc. of the International Seminar on Theoretical Wave Resistance, Ann Ârbor, August 1963.

"Technique of Determining the Viscous Drag of a Ship Model by Means of a Wake Survey," by Jin Wu, IJHR Report, August 1963. "Varlation of Viscous Drag with Froude Number," by Jin Wu and L. Landweber, IIHR Report, June 1963.

"Vibration in an Incompressible Fluid," by L. Landweber, IHHR Report, May 1963. "Vibration Frequencies of a Circular cylinder of Finite length in an Inviscid Fluid," by R. G. Warnock, IIHR Report, May 1963.

"Added-Mass Distribution of a Spheroid Vibrating at a Free Surface," by E. 0 . Macagno, IIHR Report, May 1963.

(2328) INVESTIGATION OF SURFACE ROUGHNESS.

(b) Cooperative with U. S. Geological Survey, Dept. of the Interior.

(c) Dr. Hunter Rouse, Iowa Institute of Hydraulte Research, Iowa City, Iowa.

(d) Experimental; basic research for doctoral dissertation.

(e) Apparatus is now being constructed for measuring drag on individual roughness elements and element groups.

(2541) DEVELOPMENT OF INSTRUMENTS FOR USE IN ANALYZING APERIODIC SIGNALS.

(b) Cooperative with office of Naval Research, Department of the Navy.

(c) Dr. Philip G. Hubbard, Iowa Inst1tute of Hydraulic Research, Iowa C1ty, Iowa.

(d) Experimental; applied research.

(e) The purpose is to improve the analysis of turbulent velocity and pressure fluctuations, especially where long-period fluctuations are significant.

(g) Analyzing systems specially designed to accommodate the long-perlodic fluctuations typical of turbulence in hydraulic models have been constructed and are in use. These are comblnations of special-purpose analog 
computers and digital integrators.

(2792) THE DECAY OF TURBULENCE IN A ZERO-MOMENTUM WAKE.

(b) Cooperative with the office of Naval Research, Department of the Navy.

(c) Dr. Philip G. Hubbard, Iowa Institute of Hydraulic Research, Iowa City, Iowa.

(d) Primarily experimental; basic research.

(e) Powered models of a strut-mounted propeller and a merchant vessel are driven in a towing basin, and the wake is investigated with a Pitot rake and a hot-wire anemometer.

(g) Measurements of the turbulence up to one and one-half lengths astern indicate that the decay is considerably more rapid for the self - propelled condition. The intensity $\mathrm{u}^{2} \alpha \mathrm{x}^{-4 / 5}$ for the powered model, as compared with $x^{-0.47}$ for a hull without a propeller.

(h) "Turbulence Studies in the Wake Behind a Powered Surface Vessel," by Charng-Ning Chen, M.S. thesis, Univ. of Iowa, Feb. 1964.

(3068) DETERMINATION OF DYNAMIC FORCES ON FLASHBOARDS.

(b) Laboratory project.

(c) Prof. J. W. Howe, Department of Mechanics and Hydraulics, UnIversity of Iowa, Iowa City, Iowa.

(d) Experimental; for M. S. thesis.

(e) Measurement of dynamic moment exerted by water flowing over flashboard.

(f) Completed.

(g) A parameter 1nvolving tuming moment on flashboard related to head- and tail-water levels for typical $O G$ spillway crest.

(h) "Overturning Moments on a Flashboard," by Hsing-hua Shih, M.S. thesis, Univ. of Iowa, February 1964. (Available on loan.)

(3074) WAKE OF ZERO MOMENTUM FLUX.

(b) Cooperative with office of Naval Research, Department of the Navy.

(c) Dr. Eduard Naudascher, Iowa Institute of Hydraulic Research, Iowa City, Iowa.

(d) Experimental; basic research.

(e) Mean flow and turbulence characteristics are being measured and the energy transformation is being analyzed in the fleld of flow past a bluff, axisymmetric body with a centrally located jet for the particular condition of zero momentum flux.

(g) The mean-velocity defect and the axial turbulence intensity along the centerline vary in inverse proportion to the 2nd and lst power of the longitudinal distance $x$, respectively. The wake spreads proportionally to the $1 / 4$ th power of $x$.

(h) "Wake with Zero Change of Momentum Flux," by Muhamed Ridjanovic, Ph.D. dissertation, Univ. of Iowa, August 1963. (Avallable on loan.)

(3428) MECHANICS OF BANK SEEPAGE IN NATURAL STREAMS DURING FLOOD FLOWS.

(b) Laboratory project.

c) Prof. J. W. Howe, Dept. of Mechanics and Hydraulics, University of Iowa, Iowa Clty, Iowa.

(d) Field investigation; basic research for Ph. D. thesis.

(e) observations taken on transverse profile of ground-water levels during rise and recession of hydrographs. Sections on MIssouri, Des Molnes, Boone, Iowa, and English Rivers, Clear Creek and Rapid Creek. Permeability tests made by pumping wells.

(f) Continuing.

(g) Early results indicate substantial flow into banks during period of rise, thus showing a negative groundwater contribution to the flow in this period.

(3432) ACCELERATED MOTION OF A SPHERE FALLING IN AN OSCILIATING FLUID.

(b) Laboratory project. (c) Mr. E. M. O'Loughlin, Iowa Institute of Hydraulic Research, Iowa C1ty, Iowa.

(d) Experimental and analytical; basic research and $\mathrm{Ph}$. D. dissertation.

(e) To determine accelerated motion of a sphere falling in an oscillating fluid.

(f) Completed. oscillating Fluid," by Hau-wong Ho, Ph.D. dissertation, Univ. of Iowa, Feb. 1964. (Avallable on loan.)

(3738) SEDIMENT DIFFUSION.

(b) Laboratory project partially supported by a grant from Gulf Research and Development Co.

(c) Mr. E. M. O'Loughlin, Iowa Institute of Hydraulic Research, Iowa City, Iowa.

(d) Experimental; Ph. D. dissertation.

(e) To determine the sediment-diffusion characteristics for small concentrations of particles in a submerged jet of water.

(3739) EDUCATIONAL FILMS ON THE MECHANICS OF FLUIDS,

(b) National Science Foundation.

(c) Dr. Hunter Rouse, Iowa Institute of Hydraulic Research, Iowa City Iowa.

(e) Six 20-minute sound films in color are planned to cover following material: (1) An introduction to the subject, stressing its great breadth of coverage, the necessarily close tie between theory and experiment, the role of the scale model in engineering analysis and design, and methods of flow measurement in laboratory and field. (2) The source and significance of the fundamental principles of continuity, momentum, and energy, and their application to typical problems in many professional fields. (3) Gravitational phenomena, including jets, nappes, channel transitions, waves, surges, and effects of density stratification. (4) Effects of viscosity, examples of laminar flow, characteristics of fluid turbulence, and problems of surface resistance. (5) Form drag and lift, and their application to propulsion and fluid machinery. (6) Compressibility effects - water hammer, submarine signaling, gravity-wave and sound-wave analogles, and supersonic drag.

(g) First three films of series, "Introduction to the Study of Fluld Motion," "Fundamental Princlples of Flow," and "Flow in a Gravitational Field," now avallable from Bureau of Audio-Visual Instruction, Extension Div., University of Iowa, Iowa City, Iowa. Fourth f:lm, "Characterlstics of Laminar and Turbulent Flow," in preparation.

(3740) HYDRODYNAMICS OF FLUIDS UNDER CONDITIONS OF RAPID ACCELERATION.

(b) Rock Island Arsenal, U. S. Arrmy .

(c) Dr. Philip G. Hubbard, Iowa Institute of Hydraulic Research, Iowa City, Iowa.

(d) Theoretical and experimental; basic research.

(e) Analytical techniques which are applicable to systems involving rapid acceleration of fluids through constructions or of solids through fluids. Results will be expressed as lumped-constant parameters similar to those used for steady-flow phenomena.

(g) Fleld and laboratory tests are planned to supplement the preliminary tests and analyses included in the report mentioned below. Volume changes due to compressibility were found to be quite 1mportant.

(h) "Research Study of the Hydrodynamics of Recoll Mechanisms," by Enzo O. Macagno and Philip G. Hubbard, Final Report to Rock Island Arsenal, July 1963.

(4145) INTERFACIAL EFFECTS IN FLUID FLOW WITH DENSITY STR TIFICATION.

(b) Cooperative th U. S. Army Research office (Durham).

(c) Dr. Enzo O. Macagno, Iowa Institute of $\mathrm{Hy}-$ draulic Research, Iowa City, Iowa.

(d) Experimental; basic research and graduate 
theses.

(e) Instability and mixing of two fluid layers of different densities flowing in the same direction. Effect of stratification on turbulent mixing of two fluid layers.

(g) Experimental data on the interfacial instability modes have been obtained and correlated with mean Reynolds number of the flow and the ratio of densities. The subsequent mixing is being measured and the results are under study.

(4146) EFFECT OF GATE LIP SHAPE UPON DOWNPULL.

(b) Laboratory project.

(c) Dr. Eduard Naudascher, Iowa Institute of Hydraul1c Research, Iowa C1ty, Iowa.

(d) Experimental; applied, for M. S. thesis.

e) From pressure measurements under high-head gates, a parameter is evaluated, with the ald of which the vertical hydrodymamic force on the gate can be analyzed as a function of $11 \mathrm{p}$ shape.

(f) Completed.

(h) "Effect of L1p Shape upon Hydraulic Forces on High-Head Gates," by H. . . Kobus, M. S. thesis, Univ. of Iowa, Feb. 1963.

"Effect of Gate and Conduit Geometry upon the Hydrodymamic Forces Acting on High-Head Gates," by R. P. R. Rao, M.S. thesis, Univ. of Iowa, August 1963.

"Hydrodynamic Analysis for High-Head Leaf Gates," by E. Naudascher, H. E. Kobus, and R. P. R. Rao, published in Proc., Amer. Soc. Civ. Eng., Vol. 89, Hy 6, Nov. 1963.

(4147) RESISTANCE OF CYLINDRICAL PIERS IN SUPERCRITICAL FLOW.

(b) Laboratory project.

(c) Dr. Hunter Rouse, Iowa Inst1tute of Hydraul1c Research, Iowa City, Iowa.

(d) Experimental, M. S. thesis.

(e) Drag is studied as function of Froude number, relative depth, and relative spacing of piers.

(h) "The Resistance of Cylindrical Plers in open-Channel Flow," by Tsu-ying Hsieh, Journal of the Hydraulics Division, ASCE, November 1963 or January 1964.

(4148) MEAN-FLOW AND TURBULENCE CHARACTERISTICS OF RIVER BENDS.

(b) Supported by the National Science Foundation.

(c) Mr.E.M. O'Loughlin, Iowa Inst1tute of Hydraulic Research, Iowa City, Iowa.

(d) Experimental; basic research; Ph.D. dissertation and M.S. thesis.

(e) To determine the mean-flow and turbulence characteristics of flow in a model river bend. Pressure, velocity, shear stress, and turbulence measurements are to be made in the curved channel for smooth, rough, and movable beds. The same quantities are to be measured in an a1r-flow model to investigate similarity criteria.

(4149) DRAG OF SUPERCAVITATING BODIES OF REVOLUTION.

(b) Bureau of Ships, offlce of Naval Research.

(c) Dr. Louls Landweber, Iowa Institute of Hydraul1c Research, Iowa C1ty, Iowa.

(d) Theoretical; applied research.

(e) An approximate method of computing pressure distributions on supercavitating bodies of revolution has been developed. Equipment for measuring drag of nose forms with airsimulated supercavitating flow in a towing tank has been constructed and experiments are under way.

(h) "Drag Coefficients of Supercavitating Bodies of Revolution at Various Angles of Yaw," by M. Macagno and T.-Y. Hsieh, IIHR Report, March 1963.

(4560) HEAD LOSS IN TRAPEZOIDAL CHANNEL AT 90 DEGREE BEND AS FUNCTION OF BEND WIDTH.

(b) Laboratory project. (c) Prof. J. W. Howe, Dept. of Mechanics and Hydraulics, University of Iowa, Iowa c1ty, Iowa.

(d) Experimental; for M.S. thesis.

e) Determination of degree of widening required at bend to produce minimum head loss.

(f) Completed.

g. Equiradial bend (approximately $40 \%$ wider at mid point) has least loss. Loss coefficient $(0.14)$ half of that for bend having constant width $(0.28)$.

(h) "Optimum Shape of a 90 Degree Bend in a Trapezoldal Channel," by Annamala1 Shanmugan, M.S. thesis, Univ. of Iowa, Aug. 1963. (Coples reproduced at cost.)

(4973) EFFECT OF RADIUS OF CURVATURE ON LOSS IN 90DEGREE TRAPEZOIDAL BEND.

(b) Laboratory project.

(c) Prof. J. W. Howe, Dept. of Mech. \& Hydr. Univ. of Iowa, Iowa City, Iowa.

(d) Experimental; for M.S. thesis.

(e) Observation of series of bends with varying: ratios of radius to width.

(4974) TURBULENCE CHARACTERISTICS OF THE WAKE OF A BODY OF REVOLUTION.

(b) Cooperative with David Taylor Model Basin, Dept. of the Navy.

(c) Dr. Phil1p G. Hubbard, Iowa Inst1tute of Hydraulic Research, Iowa C1ty, Iowa.

(d) Experimental basic research.

e) Measurements are being made of the turbuleno near the stern of an ellipsold mounted in an air tunnel. Specially designed instruments are used to respond correctly to the lowfrequency, high-intensity components.

(4975) EFFECT OF GATE SLOTS UPON DOWNPULL.

(b) Cooperative with Tennessee Valley Authority.

c) Dr. Eduard Naudascher, Iowa Institute of Hydraul1c Research, Iowa C1ty, Iowa.

(d) Experimental; applied research.

e The pressure distribution on the lip of a high-head gate is belng measured for various gate-slot geometries. A parameter is to be evaluated for the effect of the gate slot on the hydraulic downpull.

(4976) EFFECT OF LIFTING BEAMS ON GATE VIBRATION.

(b) Cooperative with Tennessee Valley Authority.

c) Dr. Eduard Naudascher, Iowa Institute of Hydraul1c Research, Iowa C1ty, Iowa.

(d) Experimental; applied research.

(e) The effect of the lifting-beam geometry upon the fluctuating hydrodynamic force acting on a multiple-leaf gate during overflow and underflow is being investigated.

(4977) PRESSURE FLUCTUATIONS BEHIND A NORMAL WALL OF FINITE VARIABIE THICKNESS.

(b) Cooperative with Tennessee Valley Authority.

c) Dr. Eduard Naudascher, Iowa Institute of Hydraulic Research, Iowa C1ty, Iowa.

(d) Experimental; basic research.

e) In the separation region of a normal wall in contact with a plane boundary, the spectrum of the pressure fluctuation, as affected by the upstream boundary layer and the wall thickness, is being measured.

THE JOHNS HOPKINS UNIVERSITY, Applied Phys1es Lab.

(2335) APPLICATION OF SWITCHING TECHNIQUES TO HYDRAULIC CONTROL SYSTEMS.

(b) Bureau of Weapons, Department of the Navy. (d) Theoretical and experimental; applied development and design.

(e) Study the dynamic qualities of an acceleration switching hydraulic servomechanism while operating in a closed loop under the presence of various loads and environmental conditions on the transfer valve, actuator 
and feedback transducer.

(g) The operation of a broad bandpass servomechanism driving a low resonant frequency linkage has resulted in radial design compromises to prevent instability. Extension of acceleration switching techniques without any mechanical modifications has pernitted closed loop operation with bandpasses equal to or exceeding the linkage characteristics.

(h) "Design of a Hydraulic Servo with Improved Bandpass Characteristics When Driving a Resonant Mechanical Load, "APL/JHU CM-962, by $W$. Seamone.

(3436) ADAPTIVE ELECTRO HYDRAULIC SERVOMECHANISMS.

(b) Bureau of Weapons, Department of the Navy.

d) Theoretical and experimental.

(e) Techniques have been developed for designing linear servomechanisms with a limit cycle instability about a relay type non-linearity. The closed loop characteristics of this servomechan $1 \mathrm{sm}$ becomes invariant to any pure gain changes occurring in the linear elements. Th1s servomechanism, categorlzed as a selfoscillating control servomechanism, appeared to be an evolutionary 1 mprovement over the acceleration switching hydraulic servomechanism.

(g) A self-oscillating rate servomechanism has been operated with the loop closed around the valve spool position. Predictable selfoscillation frequency was achleved and dynamic performance bandpass was independent of hydraul1c supply pressure between 500 and 2000 ps1. The bandpass of both servomechanisms exceeded 60 cycles per second with the latter operating a complex mechanical load system.

THE JOHNS HOPKINS UNIVERSITY, Department of Sanitary Englneering and Water Resources, School of Engrg.

Inquiries concerning the following profects should be addressed to Dr. John C. Geyer, Cha1rman, Dept. of Sanitary Englneering and Water Resources, The Johns Hopkins Unlversity, Baltimore 18, Maryland.

\section{(856) HYDROLOGY OF STORM DRA INAGE SYSTEMS IN URBAN} AREAS.

(b) Baltimore City, Baltimore County, Maryland State Roads Commission, and the U. S. Bureau of Public Roads.

(d) Fleld investigation; basic research and deslgn.

(e) Study of rainfall and monof relationships as affected by various drainage area parameters. At present, munoff from 6 urban areas ranging in size from 10 to 150 acres are gaged, 5 by stage Instruments and 3 by Parshall flumes. Three recording systems which simultaneously record rainfall and munoff from 12 inlet areas provide good opportunity for detalled study. About 10 years of ralnfall records now exist for a network of 12 recording gages covering an area of 50 square miles.

(g) The Rational Method of stom dralnage design has been studled to see if the method could be verifled or improvements in 1 ts use suggested. An attempt was made to study the assumption, implicit in the method, that the frequency of occurrence of the computed design peak munoff rate is the same as the frequency of occurrence of the selected rainfall intensity. The results suggest that constant values of the "C-Factor" and "tlme of concentration" can be selected for small urban areas such that this assumption is approximately correct for the range of rainfall intensities commonly considered in design practice in the Baltimore area.

(h) "Progress Report of the Stom Drainage Research Project, September 1963", by John C. Schaake, Jr., Department of Sanitary Englneerling and Water Resources, The Johns Hopkins University, Baltimore 18, Maryland.
(3437) RESIDENTIAL WATER USE RESEARCH PROJECT.

(b) Federal Housing Administration and 16 participating Water Utilities.

(d) Fleld Investigation; applied research and design.

(e) This project is directed toward obtaining data on maximum hourly demands and water use patterns in residential areas having varying populations and located in various climatic regions throughout the country. It also is directed toward obtaining information on the effect of lawn sprinkling and other large water uses on maximum demands. The purpose of the project is to obtain a rational design criterla for water distribution systems, to provide a basis for evaluating water rate structures and a basis for 1mproving system operation.

(g) Peak demands in residential areas can be described mathematically based upon statistical evaluation of field data. Based on data collected in four areas in Baltimore, Maryland, residential water use can be segregated into (1) domestic or short duration uses and (2) lawn sprinkling or long duration uses. Family size appears to be the dominant ractor in the domestic portion of residential water use. An inverse relationship shows up between the number of persons in a dwelling and the average dally per capita use, varying from 84 gpcd (two persons per dwelling), to 47 gped (five persons per dwelling.) Th1s relation remains fairly constant for different strata and for different seasons. The overall average annual domest1c use for all areas was $56 \mathrm{gpcd}$. No great difference in average annual domestic use among various housing densities appears, but a larger varlation shows up in the higher value areas. Lawn sprinkling affected peak demands enormously. Typlcal winter days varled greatly with maximum summer days. Residential sprinkling demands stem from deficiencies in rainfall and differ sharply from domestic demands. Lot size is the predominant factor, and peak demands are independent of family size.

Commerclal water users, with few exceptions, do not contribute signiflcantly to peak demands. Commercial peaks tend to occur in the morning, whereas the critical residential peaks take place after $6 \mathrm{p.m}$. when most commerclal establishments are dark. Except for shopping centers, service stations and apartments, the top commerclal demands colnclde with the weak, secondary residential peaks in the forenoon. A comparison of domestic or Indoor water use and sanitary sewer flows shows that designers can justifiably assume that the se are equal. After allowances for sprinkling and infiltration, 1t was found that about $5 \%$ of the water supplied for indoor use did not retum to the sanitary sewer. For most purposes, however, this figure is negligible and sewer flow can be assumed equal to domestic water usage exclusive of sprinkling.

(h) "Report on Phase one of the Residential water Use Research Project," by John C. Geyer, Jerome B. Wolff, and F. P. LInaweaver, Jr., 137 pages (October, 1963). A l1mited number of coples are avallable upon request.

(3438) RESIDENTIAL SEWERAGE RESEARCH PROJECT.

(b) Federal Housing Administration.

d) Field investigation; operation and design.

(e) Examination of adequacy and utility of residential sewerage system design criteria. Determination of the effects of parameters of design, construction, loading, and natural phenomena on operation of sewerage systems. Research includes analysis and study of representative sewerage systems throughout the country.

(g) General problems racing sewer deslgners have been studied using fleld data collected in four U. S. communities. Analysis of 
these data Indicates that basic causes of maintenance difficulties are tree roots, accumulations of debris in the absence of roots, other causes, and in areas having cohesionless sub-soll, sewer cave-ins. proportionately fewer blockages occur when grades are moderate, and proportionately more occur at the upper terminals of the sewers. In eight-1nch pipe, manhole spacing has little effect on the labor costs of stoppage rellef. Emphasis is placed on statistical techniques for estimating domestic sewage flow. Flow of ralnwater and groundwater was at times found to be excessive in all systems studied. Limited data on costs of operating and maintaining sewage pumping stations are reported and evaluated.

(h) "An Evaluation of the Problems of Sanitary Sewer System Design," by John C. Geyer and John J. Lentz, Final Report of the Residentlal Sewerage Research Project to the Federal Housing Administration.

(5171) GROUND WATER STORAGE PROJECT.

(b) National Institutes of Health Research Grant.

(d) Field investigation, applied research.

(e) Application of gravity meter to study of change of storage of ground water in water budget of 38 acre drainage basin.

(g) Commencing collection of data.

UNIVERSITY OF KANSAS, Dept. of Mechanics and Aerospace Englneering.

Inquiries concerning the following projects should be addressed to Dr. Y. S. Yu, Dept of Mechanics and Aerospace Engineering, Univ. of Kansas, Lawrence, Kansas.

(3743) STUDY OF THE MECHANICS OF DIVIDED FLOW.

(b) National Science Foundation.

d) Theoretical and experimental; basic research.

(e) A study of the instablilty of flow at branches of a manifold and of flow into a slot in a plane wall of a semi-infinite flow.

(g) The characteristics of flow at the division from a main condult into two symmetrical, clrcular laterals has been studied experimentally. Visual observations and motion plctures of the smoke patterns in the vicinity of the division show that the flow at the division is unstable. The instability is caused by the fluctuating motion of the vortex pair at the division.

(h) "An Experimental Study of Flow at Division into Symmetrical Laterals with circular Section," by Dan B. McVickar, M.S. Thesis, The University of Kansas, September 1963. A loan copy is avallable at the Engineering Library, The University of Kansas.

(3745) BASIC CHARACTERISTICS OF AN OVERIAND FLOW.

(b) Waterways Experiment Station, corps of Engineers, U. S. Dept. of the Army.

(d) Theoret1cal; basic research.

(e) Data from experiments made by the Los Angeles District, Corps of Englneers, on the controlled surface munoff due to ralnfall on an impervious plane slope are analyzed. The objective is to provide an improved method for estimating overland flow in the drainage of alrfield and expressways.

(g) The analysis was extended to munoff on an impervious surface due to rainfall of step function. The anomalour increase in discharge which often followed the cessation of rain is shown as a consequence of turbulent flow becoming laminar when the battering of the rain ceases.

(h) "Runoff from Impervious Surfaces," by Y.S. Yu and John S. McNown, FInal Report, Feb., 1963.

(4151) SEPARATION OF FLOW AT INTERIOR CORNERS.

(b) Kimberly-Clark Corporation, Neenah, Wis. (d) Theoretical and experimental; basic research.

(e) The instability of flow past interior corners was studied both theoretically and experimentally to determine the cause of ridges which skate on the free surface downstream from the slice on paper machine.

(g) Experiments were made for three types of flows, namely, (1) full head-box flow, (2) head-box not full, 1.e. with a free surface, and (3) free-surface flow over a weir to determine the onset of instability in these flows. At the lowest flows, no vortices were observed in some tests, but the results obtained are not conclusive. Further study will be carried out. A method of solution of the instability of laminar flow past interior corners is being developed.

(4641) HYDRODYNAMIC STABILITY OF FLOW BETWEEN TWO CONCENTRIC ROTATING CYLINDERS.

(b) Laboratory project.

d) Theoretical; basic research for M. S. thesis, Mathematical solution of Taylor's problem for finite radil of the concentric cylinders is sought.

(f) Completed.

g) The characteristic value problem of the stability of a viscous flow between two rotating, coaxial cylinders with large ratio of gap-width to cylinder-radius has been solved formally. Numerical calculations for the radius-ratio equal to 1.71 are carried out to determine the critical Taylor number at the onset of instability for different values of the ratio of the rotational speed of the outer cylinder to that of the inner cylinder. The calculated results are compared with Lew1s' experiments.

(h) "Stability of A V1scous Flow Between Two Rotating Coaxlal Cylinders," by Y. S. Yu and Dah-Chen Sun, to appear in Journal of the Franklin Institute.

(4642) ON POTENTIAL FLOW PROBLEMS WITH FREE STREAMLINES.

(b) Laboratory project.

d) Theoretical; basic research for M. S. thesis.

e) A synthetic study on methods of solution of potential flow problems with free streamines.

(f) Discontinued.

(h) "On Methods of Solution of Helmholtz Flows," by Richard Cary Coddington, II, M.S. Thesis, The University of Kansas, June, 1963. (Avallable on loan.)

(4643) MECHANICS OF BLOOD FLOW.

(b) Laboratory project financed by the NASA grant to the University of Kansas.

(d) Theoretical and experimental; basic research.

(e) A study of flow problems pertaining to blood circulating in a vascular system.

(g) The laminar, oscillatory flow in a circular rigid tube under a pressure gradient varying sinusoidally with time was studied both theoretically and experimentally. Numerical solution of the velocity distributions was obtained. Experiments were made in glass tube using water as the fluld medium. The measured velocity distributions agree qualitatively with the theory.

(h) "Mechanics of Blood Flow," by Hau-Wong Ho, Philiip R. Smith, and Svein Vigander, Progress Report to the Kansas Committee on Space Sclence and Technology, June 10, 1963. (Avallable on loan.)

(4944) SOLUTION OF POTENTIAL FLOW WITH FREE STREAMLINES BY INTEGRAL EQUATION METHOD.

(b) University research grant.

d Theoretical; M.S. thesis.

(e) To develop a method to solve free-streamline problems with curved walls and without gravity and flows with straight walls with gravity.

(g) A method of solution for flow past curved walls has been obtained. Numerical computations 
are being carried out for flow past a curved bucket of spillway.

(4945) SECONDARY MOTIONS IN A "DRAIN-HOLE" VORTEX.

(b) Laboratory project.

(d) Theoretical and experimental basic research for doctoral thesis.

(e) The secondary motions in a steady "drain-hole" vortex flow are being studied to determine the mechanics of its formation and the effects of rotational speed of the tank and the water depth on the secondary motions.

(g) Experiments were made in a circular tank with a drain-hole at the center of 1 ts bottom. Water was used as the fluid medium. For steady flow at different water depths with tank rotating or stationary, a series of torous shaped vortices along the axis were observed. These vortices appear to be similar in pattern to the Taylor vortices. A mathematical solution of laminar boundary layer on a fixed plane wall normal to the axis of a free vortex has been obtained.

\section{LEHIGH UNIVERSITY, Department of Civil Engineering.}

Inquiries concerning the following projects and requests for reprints and technical reports should be addressed to Dr. J. B. Herbich, Associate Professor, Chairman, Hydraulics Div., Fritz Engineering Laboratory, Leh1gh University, Bethlehem, Pennsylvania.

\section{(2543) STUDY OF CONDUIT EXIT PORTALS.}

(b) Laboratory Project.

(d) Experimental: M. S. Thesis.

f) General pressure-distribution study completed.

(g) Tests of square and circular conduit with free-jet, horizontal apron, and three different wall flares, have been completed.

(3084) STUDY ON IMPROVING DESIGN OF A HOPPER DREDGE PUMP.

(b) District Engineer, U.S. Army Engineer D1st., Marine Division, Philadelphia, Corps of Engineers.

(d) Applied and Baslc Research.

(e) The immediate purpose of the study is to improve design of a hopper dredge centrigugal pump for pumping silt-clay water mixtures. The long-term objective is to determine the effect of Bingham Body-type of f'luid on pumping characteristics. The project has been divided into four phases: (1) Model test of existing dredge pump; (2) recommendations for design changes of the dredge pump; (3) model investigation of the modifled design of the dredge pump; and (4) analysis of the investigation and final recommendations. Phase 1 involved installation in the hydraulic laboratory of a $1: 8$ scale model of the dredge pump now used on the U.S. Corps of Englneers dredge ESSAYONS. Water as well as silt-clay-water mixtures (Bingham Body-type of fluld) were pumped and complete characteristics of the pump obtained for capacity of 0 to 1200 gallons per minute, speed of 1150 to 1900 revolutions per minute, and liquid concentrations of 1000 and 1380 grams per l1ter. Phases 2 and 3 involve modifications in the shape of vane and changes in the exit vane angle of the 1mpeller. Experimental tests indicate considerable improvement in pump efficiency. Analysis of the experimental data resulted in recommendations for changes in pump design.

(f) $1,2,3$ and 4 completed.

(g) Considerable improvement in pump efficlency has been achieved.

(h) "Modifications in Design Improve Dredge Pump Efficlency," by J. B. Herbich, Fritz Engineering Laboratory Project Report No. 277.35, September 1962.

"Effect of Impeller Changes on Characteristics of a Model Dredge Pump," by J. B. Herbich,
American Society of Mechanical Engineers, Paper No. 63-AHGT-33, March 1963.

(3085) STUDY OF SCALE EFFECT BETWEEN MODEL AND PROTOTYPE SPILLWAYS.

(b) Laboratory project.

d) Graduate students' project.

e) A $1: 100$ scale two-dimensional model built of Chlef Joseph Dam. Prototype crest pressures compared with the data obtained on the model.

(f) Completed.

(g) Very good correlation obtained between the model and prototype.

(3086) INVESTIGATION OF DESIGN CRITERIA OF SPUR DIKES.

(b) Modjesk1 and Masters, Consulting Engineers, Harrisburg, Pa., Lehigh University Inst. of Research.

(d) Analytical and experimental.

(e) The project has been divided into four phase (a) Literature survey; (b) analytical study; c) experimental study in a fixed-bed model to determine the desired lengths and shapes of spur dikes to provide uniform velocity distribution in the waterway between bridge abutments; (d) experimental study in a movable-bed model to verify findings in part c. A spur dike has been defined as a projection extending upstream from the bridge abutments.

(f) Phases (a), (b) and (c) completed; phase (d) active.

(g) Preliminary investigation indicates that a properly designed spur dike can produce a fairly uniform velocity distribution between the abutments.

(3441) STUDY OF SCALE EFFECT BETWEEN MODEL AND PROTOTYPE 270 DEGREE BENDS FOR FLOW OF SILT-CIAY-WATER MIXTURES.

(b) Laboratory project.

d) M. S. Thesis.

e) Four-, six-, and eight-inch diameter 90 degree elbows assembled to form 270 degree bends. Head loss measurements obtained for various flows and concentrations of siltclay-water mixtures. Prediction equations have been investigated.

(f) Completed.

(g) No evidence of appreciable scale effect observed.

(3442) SUGGESTED DESIGN CHANGES FOR A CENTRIFUGAL PUMP IMPELIER HANDLING DREDGED MUD.

(b) Research report requirement of master's degree.

(d) Theoretical.

(e) Design changes in centrifugal pump impeller for handlirg mud are suggested on basis of past research and theoretical considerations.

(f) Completed.

(3746) ANALYSIS OF FLOW PATTERN IN VOLUTE OF A CENTRIFUGAL PUMP.

(b) Research report requirement of master's degree. District Engineer, U. S. Army Engineer District, Marine Division, Phila. Corps of Engineers.

(d) Experimental

(e) High-speed movies of flow taken through a transparent plexiglas volute casing were analyzed. Velocity distribution as well as distribution of the exit angle between the impeller vanes as flutd leaves the impeller were determined.

(i) Completed

(h) "Use of High Speed Photography to Analyze Particle Motion in a Model Dredge Pump," by J. B. Herbich and R. J. Christopher, Proceedings loth Congress, International Association for Hydraulics Research, Sept. 1963.

(3747) FRICTION HEAD LOSSES IN CIRCULAR PIPES FOR A BINGHAM-BODY FLUID. 
(b) Laboratory project.

(d) Experimental and theoretical. of the plpe flow characteristics of slurries of various concentrations. The slurries do not behave as fluids of constant viscosity so that $1 \mathrm{t}$ is not possible to use conventiona methods for prediction of head losses in plpes conveying them. Tests are being conducted in 6-1nch, 3-1nch, and 2-inch pipelin w1th velocities from less than 1 fps to over 30 fps.

(f) Suspended.

(4154) DREDGE PUMP DESIGN.

(b) National Bulk Carriers, Inc.

d) Experimental.

(e) The objective of the investigation is to obtain the efficiency and head-capacity curves, to check the effect of the reduced vane exit angle, and to determine the ef ficlency of a model dredge purp while pumping sllt-clay-water mixture of speciflc gravity equal to 1.17 . The experimental tests were carrled out on a $1 / 8$ model pump of the National Bulk Carriers Hopper Dredge, S. S. Zulla.

(f) Completed.

(h) Report in preparation.

(4155) WAVE RUN-UP ON COMPOSITE BEACHES

(d) Graduate students' project. Experimental, applied research for design.

(e) The main object of the study is to verify existing equations for determining the helght of wave mun-up and obtain the limits of application of the equation for long beach berms.

The study is conducted in a $67 \mathrm{ft}$. long, $2 \mathrm{ft}$. w1de and $2 \mathrm{ft}$. deep wave channel equlpped w1th pendulum-type wave generator and efficient absorbers.

(h) "Effect of Berm on Wave Run-Up on Composite Beaches," by J. B. Herb1ch, R. M. Sorensen, and $\mathrm{J} . \mathrm{H}$. Willenbrock, Jourmal of Waterways and Harbors DIvision, Proceedings of the American Soclety of Civil Engineers, Paper 3526, May 1963.

(4156) MULTIPLE DREDGE PUMP SYSTEMS.

(b) National Bulk Carrlers, Inc.

d) Experimental and theoretical.

(e) The study is conducted to determine the effect on total production of dredge pumps with separate discharges and a combined discharge. The Investigation $1 \mathrm{~s}$ divided Into two parts: (a) one pair of pumps is handling a mixture of water and solids, the other is pumping only water. It is required to determine what percentage of 1 ts normal output will the dredge pump passing the mixture attain. (b) If one of a pair of dredge pumps, both handling water-solids mixtures, is revolving slower than the other one, how does the total discharge compare to the total if the discharges were not combined?

(f) Completed.

(4644) STUDY OF THE GRAVITY WAVE REFLECTIONS FROM FLOATING RECTANGULAR BODIES.

(b) Research report requirement of master's degree.

(d) Experimental.

(e) The object of the study is to determine the magnitude of wave reflections from rectangular floating bodies. Tests are being conducted in a 67-ft. long, 2 ft.-wide and 2 ft.-deep wave channel equipped with pendulum-type wave generator and efficient absorbers.

(h) Report in preparation.

(4645) EFFECT OF LENGTH AND SPACING OF SPUR DIKES.

(b) Laboratory report. (d) Experimental and theoretical; M.S. Thesis.

e) The object of the study is to determine the effect of length and spacing of spur dikes on the magnitude of scour in uniform flow. The experiments are conducted in a $10-f t$. wide, 35-ft. long open channel w1th movable sand bed. Scour patterns are observed and analyzed.

(h) "Effect of Length and Spacing of Spur D1kes on Scour," by D. R. Joshi, M. S. thesis, Clvil Englneering Department, Lehigh Univ., 1963.

(5172) MEASUREMENT OF SLURRY FLOW BY USE OF $90^{\circ}$ ELBOW METER.

(b) National Bulk Carrier Inc., New York, New York.

(d) Applied and Basic Research.

(e) A four-1nch $90^{\circ}$ elbow meter was calibrated against a magnet1c flow meter. A flow range of from $0-1100 \mathrm{gpm}$ was effected in the calibration. Water and fine concentrations of silt-clay-water mixtures are included in the calibration tests. The basic theory of the "elbow meter" is discussed and an emperical mathematical relation between liquid concentration, differential head, and plpe veloc1ty is presented and discussed. The feaslbility of use of the elbow meter for flow measurement of slurry type flow 1 highly possible, but callbration of meter in place is recommended. Also, the viscous properties of the material metered are belleved to play an Important role in the meter's performance.

(h) "Measurement of Slurry Flow by Use of $90^{\circ}$ Elbow Meter," by W. P. Isaacs, Fritz Laboratory Report No. 299.1.

\section{(5173) SUCTION DREDGING LITERATURE SURVEY.}

(b) Ellicott Machine Corp., Baltimore, Maryland.

d) Applied and basic research.

(e) This report is a brief review and summary of selected literature pertaining to equipment and methods associated w1th dredging practice and laboratory studies of dredge pumps. It consists of four parts: (1) Summary and discussion section. (2) Selected abstracts. (3) Annotated b1bliography. (4) B1bllography. The discussion section consists of two parts. Part 1 discusses dredging equipment and dredging in general. Part 2 discusses dredge pumps.

(h) "Suction Dredging L1terature Survey," by Hugh D. Murphy \& John B. Herbich, Fritz Engineering Laboratory Report No. 301.1.

(5174) PERFORMANCE STUDY OF A 1:6 MODEL DREDGE PUMP.

(b) Ellicott Machine Corporation, Baltimore, Md.

d) Applied and basic research.

(e) Performance tests were made on five 1:6 scale model impellers. Each impeller was tested at four constant speeds over a wide range of heads and discharges. Water and two concentrations of a typical dredging mud were tested with each impeller at all four speeds. Varlous graphs and design application curves were developed for making similarity studies and designs in the homologous serles of pumps.

(h) "Performance Study of A $1: 6$ Model Dredge Pump," by W. P. I saacs, V. R. Marian1, H. D. Murphy, S. F. Talian. Fritz Engineering Laboratory Report No. 301.2 .

LOUISIANA STATE UNIVERSITY AND A AND M COLLEGE, Agricultural Engineering Department.

\section{(4489) SUBIRRIGATION WITH PERFORATED TUBES.}

(b) Laboratory project.

(c) Dr. Harry J. Braud, Jr., La. State University Agricultural Engineering Dept., Baton Rouge, Loul siana. 
(d) Experimental and field investigation; design and development.

(e) The hydraulic behavior of small plastic perforated tubes embedded in a soll medium for subirrigation is being investigated. Flow at low Reynolds number is utilized. Observations are made of combined tube friction loss, orifice head loss and hydrostatic pressures resisting discharge from the perforations. Discharge rates from drilled holes and slits are being studied.

(5030) A GROUND-WATER PRESSURE TRANSDUCER.

(b) Laboratory project.

(c) Prof. Jackie W. D. Robbins, L.S.U. Agricultural Engineering Department, Baton Rouge, La.

(d) Experimental; design and development.

(e) A study is being made to determine the applicability of an electrical gaging instmunt for measuring ground-water pressure. Essent1ally, the instrument consists of a strain gage attached to a diaphragm. Hydrostatic pressure of groundwater acting against the diaphragm will cause the transducer to produce a measurable electrical signal and thus indirectly measure the magnitude of the ground-water pressure.

MASSACHUSETTS INSTITUTE OF TECHNOLOGY, Department of Civil Engineering, Hydrodynamics Laboratory.

Requests for reprints and Technical Reports should be addressed to Dr. Arthur T. Ippen, Professor of Civil Engineering, Hydrodynamics Laboratory, Mass. Inst. of Technology, Cambridge 39, Mass.

(307) MECHANICS OF STRATIFIED FLOW.

(b) Laboratory project.

(c) Prof. D. R. F. Harleman, Mass. Inst. of Tech., Cambridge 39 , Mass.

(d) Theoretical and experimental; basic and applied research.

(e) General studies on the characteristics of two-layer, stratifled flows. Present studies are concermed with the problems of selective withdrawal of fluids of slightly different density. Small density differences may be due to changes in temperature, sediment in suspension or changes in concentration of dissolved solids.

(g) Experimental studies have been made on vertical intakes of various geometries placed beneath the interface of the lower layer fluld. The maximum discharge which can be obtained without drawdown of the lighter, upper layer fluid is determined. Similar studies on stratifled fluids in porous media are underway.

(h) "Characteristics of Inverted Inlets near a Density Interface," S. B. Thesis. M. R. Damghany and Q. N. Fattah, August 1962. "Comer Eddies in Rotation Flows," J. A. Tlapa. S. B. Thesis, June 1962.

(1609) STUDY OF BEACH PROCESSES IN THE INSHORE AND FORESHORE ZONES.

(b) Coastal Engineering Research Center, U.S. Army Corps of Engineers.

(c) Professor P. S. Eagleson, Mass. Inst. of Tech., Cambridge 39 , Mass.

(d) Experimental and theoretical; basic research (S.M. Thesis).

(e) Study of the surface profile and internal kinematics of a shoaling oscillatory wave up to and beyond the breaker.

(g) The theoretical phase is seeking an analytical description of the shoaling of finite amplitude waves which ylelds mass transport and is valid up to breaking. Preliminary results indicate that an exact irrotational solution may not exist. The experimental phase involves measurement of orbital velocities, static pressures and wave profile. Appropriate instrumentation is being developed. (h) "A Thermistor Probe for Measuring Particle Orbital speed in Water Waves," by P. S. Eagleson and W. P. M. van de Watering, Hydrodynamics Laboratory Technical Report No. 61, September 1963.

\section{(2548) TURBULENT DIFFUSION IN STRATIFIED FLUIDS.}

(b) Public Health Service.

(c) Prof. D. R. F. Harleman, Mass. Inst. of Tech., Cambridge 39, Mass.

(d) Theoretical and experimental; basic research.

(e) An investigation of various turbulent diffusion processes for application to salinity intrusion and waste disposal in tidal estuaries.

(g) The experimental equipment is a 32-foot channel in which turbulence is generated mechanically by means of a stack of expanded aluminum sheets oscillating vertically. Concentrations are measured and recorded at various stations by means of probes sensitive to the changes in condua tivity. The turbulence level is specified in terms of the measured rate of energy dissipation within the liquid. The effects of gravity convection due to density differences between the diffusant and recelving fluids are separated from turbulent diffusion effects by a series of control tests with zero density difference. Experiments were made to determine the longitudinal distribution of salinity in a uniform estuary with fresh water inflow at one end and a constant ocean salinity maintained at the other end.

Salinity distributions are determined for various fresh water inflow rates and turbulence levels in the flume.

The one-dimensional salinity distribution is found to be correlated with a stratiflcation parameter expressing the ratio of energy dissipation to the gain in potential energy of the flow in the estuary. Present studies are concerned with the two-dimensional salinity distributions and the relationship of the vertical salinity gradients to the vertical velocity distributions. The reversal of the bottom velocities which is characteristic of estuaries is also shown to be related to the stratification parameter described above.

(h) "An Analysis of one-dimensional Convective Diffusion Phenomena in an Idealized Estuary," D. R. F. Harleman, D. W. McDougall, C. J. Galvin, and J.A. Hoopes. Hydrodynamics Laboratory Technical Report No. 42, Jan. 1961.

"Density Effects on Vertical Turbulent Diffusion," R. B. Halaby and I. Taher. S. B. Thesis, June 1962 .

"Salinity Effects on Velocity Distributions in an Idealized Estuary," D. R. F. Harleman, J. A. Hoopes, D. McDougall, C. J. Galvin, and D. Goulis. Hydrodynamics Laboratory Technical Report No. 50, January 1962. "The Prediction of Salinity Intrusion Changes in Partially Mixed Estuaries," D. R. F. Harleman and J.A. Hoopes. Proceedings of the loth Congress, International Assoclation for Hydraulic Research, London, Sept. 1963.

(2801) INTERACTION OF WAVES WITH SUBMERGED AND FLOATING BODIES.

(b) Offlce of Naval Research, Dept. of the Navy. (c) Prof. A. T. Ippen, Mass. Inst. of Tech., Cambridge 39 , Mass.

(d) Theoretical and experimental; basic research.

(e) The purpose of the study is to determine the wave reflecting and transmitting characteristics of different types of structures suitable for application to floating or moored breakwaters.

(g) Two problems are currently under investigation: (1) Tubular Breakwater. Experiments on a tubular breakwater covered a series of tests on various lengths and number of tubes for a wide range of wave lengths and wave steepness.

The effects of these variables on the 
transmission and reflection coelilicients and on the wave power loss and on the forces on the breakwater are thus defined. (2) Effect of a Gradual Change of Depth and Width on Wave Transformation. A theory has been developed which $1 \mathrm{~s}$ applicable to long. waves encountering a gradual change in depth. These invest1gations are made in connection with a more general study on the transformation of long waves in the presence of submarine obstructions. A systematic investigation is now conducted to extend this work analytically and experimentally to the following phases:

(a) Reflection and transmission characteristics for gradual changes in depth. (b) Reflection and transmission characteristics for gradual changes in width. (c) Combinations of a and $\mathrm{b}$.

(2802) EXPERIMENTAL STUDY OF WAKE MECHANICS.

(b) Laboratory project.

(c) Prof. P. S. Eagleson, Mass. Inst. of Tech., Cambridge 39 , Mass.

(d) Experimental and theoretical; basic research (S. M. Thesis).

(e) A study of the effect of tralling edge geometry and flow-induced body vibration on span-wise correlations of instantaneous wake structure for flat plates.

(g) Flat plates are spring mounted in a water tunnel. Instantaneous total head is measured at one fixed and one variable (spanwise) location in the early wake. The spanwise spatial correlation is obtalned from the cross power spectrum as an indication of the effect of transverse motion and tralling edge geometry on two-dimensionality of the wake.

(h) "The Effect of Boundary Layer Thickness and Vibrational Amplitude on the Strouhal Numbers for Flat Plates," P. S. Eagleson and J.W. Da1ly. Proc. IAHR London Congress, 1963, pp. 73-80.

"The Nature of Self-Excltation in the FlowInduced Vibration of Flat Plates," P. S. Eagleson, G. K. Noutsopoulos and'J. W. Da1ly. Trans. ASME Paper No. 63-WA-95, Nov. 1963.

(3443) COMPUTER SIMULATION OF THE COMPIETE TRANSIENT PROBLEM IN A HYDRO-POWER PLANT.

(b) U. S. Army Corps of Engineers Division, Missouri River.

(c) Professor A. T. Ippen, Professor P. S. Eagleson.

(d) Theoretical, fleld tests; applied research. Development of a digital computer program of general utility and proven validity for performing design analyses involving the response of hydro-power plant systems to load fluctuation.

(g) Digital computer programs have been written which for a wide range of hydraullc geometries will yield the time varlation of the important hydraulic and mechanical variables for an arbitrary time variation in electrical laod under the assumption of an isolated system. The results of these programs compare well with field test measurements. Final reports and a user's manual are being prepared.

(3444) EFFECTS OF BASIN GEOMETRY AND VISCOUS DAMPING ON THE AMPLITUDE OF RESONANT OSCILLATIONS IN HARBORS.

(b) Office of Naval Research, Dept. of the Navy. Prof. A. T. Ippen, Mass. Inst. of Tech., Cambridge 39 , Mass.

(d) Theoretical and experimental; basic research. Investigation of the response of a harbor to waves incident on the harbor opening, with open ocean conditions simulated in a basin of finite size.

(g) The response of a rectangular harbor connected to the open sea was studied both analytically and experimentally. Solutions were obtained for the harbor response to wave incident from the ocean. Experiments were conducted on fully-open as well as partially-open harbors of different geometrical properties.
Wave fllters and absorbers were used to simulate the conditions of an open sea in a finite basin. It was found that the theoretical solutions accurately predict the resonant periods of the harbor. Good understanding was also reached regarding the "harbor paradox." Investigations revealed its relation to viscous damping and to the response of a harbor to waves of a continuous power spectrum.

(h) "Wave Induced Oscillations in Harbors: The Solution for a Rectangular Harbor Connected to the Open-Sea," A. T. Ippen and Y. Goda. Hydrodynamics Laboratory Technical Report No. 59, July 1963 .

"Theoretical and Experimental Investigation of Wave Energy Dissipators Composed of Wire Mesh Screens," Y. Goda and A. T. Ippen. Hydrodynamics Laboratory Technical Report No. 60 , August 1963.

(3748) DISPERSION IN POROUS MEDIAN AND WASTE WATER RECHARGE.

(b) National Institutes of Health, U. S. Public Health Service.

(c) Professor D. R. F. Harleman, Mass. Inst. of Tech., Cambridge 39, Mass.

(d) Theoretical and experimental; basic research (doctoral thesis).

(e) A numerical analysis to determine the amount of dispersion between miscible fluids of differing quality in radial, confined flow through a porous medium has been completed. An investigation of dispersion arising from the injection of a contaminant through a recharge well and the withdrawal of fresh water through a pumping well, both pumping at the same rate, in an infinite, confined aquifer is being carried out currently. Results will be important to engineering projects in the recharging of aquifers with reclaimed waste water.

(g) In the initial phase of this study a general correlation of known measurements of the longltudinal and lateral dispersion coefficients, using the correct dimensionless representation, is being undertaken. In addition, measurements of both these coefflclents are being carried out f'or several fine gravels with the Reynolds Number (based upon mean particle diameter and seepage velocity) varying from 0.1 to 1000 . The seciond phase is concerned w1th the prediction of the amount of dispersion (mixing) that occurs when a single well, pumping at a steady rate, discharges reclaimed waste water into an infinite, homogeneous, isotroplc aquifer. A numerical solution of the governing differential equation has been obtained. This solution is compared with several approximate methods of solution to the differential equation and to some known field and experimental results.

In the final phase, the problem of twodimensional dispersion, arising from the steady injection of a contaminant through a recharge well and the steady withdrawal of fresh water by a pumping well (both pumping at the same rate), is being investigated numerlcally with the help of a high speed computer. A sand model of this two well flow problem is also under construction.

(h) "Dispersion in Porous Media," P. F. Mehinorn. S. M. Thesis, June 1962 .

"Lor.gitudinal Dispersion in Steady and Unsteady Flow," R. R. Rumer, Jr. Proc. ASCE Vol. 88, HY4, July 1962.

"Aquifer Recharge from Intermittent Streams," J. M. Ochoa-P1le. S. M. Thesis, Aug. 1962. "Dispersion-Permeability Correlation in Porous Media," D. R. F. Harleman, P. F. Mehlhorn, and R. R. Rumer, Jr. Proc. ASCE, Vol. 89, No. HY2, March 1963.

"Dynamics of Salt Water Intrusion in Porous Media," R. R. Rumer, Jr. Sc. D. Thesis, August 1962 .

"Longitudinal and Lateral Dispersion in an Isotropic Porous Medium," D. R. F. Harleman and R. R. Rumer, Jr. Journal of Fluid 
Mechanics, Vol. 16, Part 3, July 1963.

(3749) RESISTANCE OF ENCLOSED ROTATING DISKS.

(b) Offlce of Ordnance Research, U. S. Dept. of the Army.

(c) Prof. J.W. Dally, M.I.T., Cambridge 39, Mass.

d) Experimental and analytical; basic research.

e) Effect of superposed throughflows on boundary layers, secondary motions and surface resistance of enclosed rotating disks.

(f) Experimental project completed. Final report in preparation.

(g) Quantitative measurements of torque, fluid velocity and pressure distributions and unsteady periodicities were made using smooth disks in an enclosure with variable axial clearance. The case of separate boundary layers with a rotating core between disk and stationary walls was modelled mathematically and checked against experiment using digital computations.

(h) "A Solution for the Flow Field Produced by an Enclosed Rotating Disk with Net Radial Flow," W. D. Ernst. S. M. Thesis, June 1963. "Unsteadiness and Close Clearance Torque for an Enclosed Rotating Disk with Superposed Throughflow," Val V. A sbedian. S. M. Thesis, August 1963.

(3750) WAVE FORCES ON STRUCTURES.

(b) Laboratory project.

(c) Pror. D. R. F. Harleman, Mass. Inst. of Tech., Cambridge 39, Mass.

(d) Theoretical and experimental; applied research (S. M. Thesis).

(e) The objective is the development of design information for wave forces on immersed objects.

(g) Analytical procedures have been developed to determine the variation with time of the lateral forces developed on a vertical cylinder due to eddy shedding. Experiments are being mun to determine the magnitude of the lateral forces as a function of cylinder diameter and wave characteristics. The phasing of the vortex shedding forces is being correlated with the wave motion.

(4158) EXPERIMENTAL AND ANALYTICAL STUDY OF THE FORMATION OF IONGSHORE CURRENTS.

(b) M. I. T. Inter-American Program in C1vil Engineering.

(c) Prof. P. S. Eagleson, Mass. Inst. of Tech., Cambridge 39 , Mass.

(d) Experimental and theoretical; basic research.

(e) Quantitative study of the mechanics of the formation of longshore currents.

(g) Earlier experiments are belng repeated at a larger scale to ascertain the general validity of results obtained. The formation of rip-currents is being investigated.

(h) "Experimental and Theoret1cal Study of Longshore currents on a Plane Beach," C. J. Galvin. Ph.D. Thesis, June 1963.

(4159) INSTRUMENTATION SYSTEM FOR THE ANALYSIS OF COMPLEX WAVE FORMS.

(b) National Science Foundation.

(c) Prof. A. T. Ippen, Prof. J. W. Dally, Prof. P. S. Eagleson.

(d) Basic research facility.

(e) Selection and assembly of an analoz computer for the calculation and plotting of correlation and spectrum functions. Design and construction of a mechanical time delay mechanism.

(g) Data are acquired on a portable, multichannel FN tape transport. A second transport permits frequency multiplication through rerecording and provides a 120-foot tape 10op capability for the repetitive analysis of short records. Matched filters allow the determination of cross power spectral

densities as well as the power spectral density of a single signal. The tape loop transport has been fitted with a mechanical time delay mechanism for the determination of correlation functions. Output of all operational modes is through an $x-y$ plotter.

(4160) MOTION OF SUBMERGED BODIES BELOW A FREE SURFACE.

(b) Office of Naval Research, Dept. of the Navy.

(c) Professor A. T. Ippen, Professor J. F. Kennedy, Mass. Inst. of Tech., Cambridge 39 , Mass.

(d) Experimental and theoretical; basic research

(e) An investigation of the turbulent wake generated by a moving two-dimensional body beneath a free surface, including the effects of density stratification.

(g) Velocity distributions have been measured at various distances behind a two-dimensional body moving at different depths of submergence in a homogeneous fluld, and similar measurements are now being made for a twclayered density-stratifled fluld with the body moving at the interface. The turbulent mixing between the two layers has been measured by measuring concentration profiles of the tracer, initially present in only the lower, heavier layer, at varlous distances behind the plate. An image method has been developed for predicting the velocity distribution. In the wake of a body moving near a rigid boundary or free surface. The vertical diffusion coefficient has been found to decrease significantly with increasing density difference between the two layers. In the presence of density stratification the wake width first increases due to mixing, then decreases as the heavier fluid that is initially diffused upward settles and the lighter fluld rises. The drag on the plate increases with decreasing depth of submergence, but is not measurably affected by the density stratification.

(h) "Mixing of a Stratified Fluid in a TwoDimensional Wake," E. A. Prych. S. M. Thesis, June 1963.

(4648) MECHANICS OF AERATION AND DISPERSION IN RIVER POLLUTION.

(b) National Institutes of Health, Public Health Service.

(c) Prof. D. R. F. Harleman, Mass. Inst. of Tech, Cambridge 39 , Mass.

(d) Experimental and theoretical; basic research (doctoral thes1s).

(e) A study of the basic mechanism of oxygen transfer from the atmosphere into turbulent water and investigations into the vertical diffusive transport and the longitudinal dispersive transport of the dissolved oxygen in a flowing stream.

(g) In one set of experiments turbulence is produced with oscillating screens in a shallow tank of initially deaerated water, and the dissolved oxygen is measured as a function of time and depth by means of an electro-chemical probe. One of the objectives is to separate the effects of turbulence on oxygen transfer across the surface from the effects of turbulent diffusion within the body of the fluid. In another set of experiments, longitudinal dispersion in an oscillating flow will be studied. The results will be applied to the oxygen balanœ of estuaries.

(4649) TURBULENT TRANSFER MECHANICS OF FLUID SUSPENSIONS OF SOLID PARTICLES.

(b) Ploneering Research Program, Institute of Paper Chemistry.

(c) Professor J.W. Dally, Mass. Inst. of Tech. Cambridge 39 , Mass.

(d) Experimental; basic research.

(e) Basic study of turbulent transfer mechanics of liquid flows with particles in suspension

(g) Experiments were continued using spherical plastic particles in water suspensions with emphasis on the distinct differences

observed in behaviour of very fine and coarse 
particles. Fully developed shear flows in circular tubes were used in a special flow facility.

(h) "Measurement of Particle Effects in Flowing Suspensions," Cheng-chung Shen. S.M. Thesis, october 1963 .

(4650) HURRICANE BARRIER STUDIES.

(b) U. S. Army Engineer Division, New England, Corps of Engineers.

(c) Professor R. T. McLaughlin, Mass. Inst. of Tech., Cambridge 39, Mass.

(d) Analytical; applied research.

(e) Determination by digital computation of waves produced by storms in the vicinity of Narragansett Bay, Rhode Island, and selection of design wave for hurricane barriers at the entrance to the bay. Determination of optimum geometry for the barriers.

(f) Completed.

g) Preparation of final report is in process.

(4651) REFRACTION OF TSUNAMI WAVES IN THE PRESENCE OF OCEANIC ISLANDS.

(b) U. S. Coast and Geodetic Survey.

c) Prof. A. T. Ippen, Prof. D. R. F. Harleman, Mass. Inst. of Tech., Cambridge 39 , Mass.

(d) Theoretical and experimental; basic research (doctoral thesis).

(e) Analytical and experimental study of tsunami refraction using non-linear shallow water wave theory.

(g) Tsunami refraction problems are characterized by the fact that the wave lengths of the wave train and the base diameter of a typical island are of the same order of magnitude. Hence usual methods of analysis assuming small wave lengths relative to the refracting body are inadequate. A piston type wave generator has been constructed in a wide shallow channel capable of generating a finite wave train simulating an open ocean tsunami. Expressions for various amplification factors, and reflection and transmission coefficients were derived. Exper1ments were performed on both two- and threedimensional island geometries for comparison with the theory.

(h) "Interaction of Tsunamis with oceanic Islands and Submarine Topographies," K. K. Wong, A. T. Ippen, and D. R. F. Harleman. Hydrodynamics Laboratory Technical Report No. 62, August 1963 .

(4654) A NEW METHOD FOR THE SYSTEMATIC INVESTIGATION OF SEDIMENT TRANSPORT.

(b) National Science Foundation.

(c) Prof. A. T. Ippen, Prof. P. A. Drinker, Mass. Inst. of Tech., Cambridge 39, Mass.

(d) Theoretical and experimental; basic research.

(e) A research program to develop the general characteristics of the flow of fluidsediment mixtures and of the interaction of fluid flow with movable boundaries.

(g) A study of sediment transport by shear flow in the annulus between two rotating drums rather than by flow in a channel has been initiated. A new experimental apparatus which replaces the commonly employed longitudinal channel by an annular channel between two rotating drums has been designed and built. The normal gravitational field is replaced by a centrifugal force field. With the cylindrical drums rotating at different relative speeds a large variety of flow conditions can be established in the "endless" annular channel, covering a wide range of tractive forces on the sediment deposited on the wall of the outer drum under various modes of relative motion. The difficult racirculation of sediment and liquid necessary in conventional flumes is thus avolded and uniform flow conditions seem assured.

(4655) ENTRAINMENT OF COHESIVE SEDIMENTS.

(b) Offlce of Naval Research, Department of the
Navy.

(c) Prof. P. A. Drinker, Prof. C. C. Ladd, Mass. Inst. of Tech., Cambridge 39, Mass.

(d) Experimental; basic research.

(e) A laboratory study of the relationship between shear strength and erosion resistance of cohesive soils in water.

(g) Equipment has been developed for measuring shear strength of normally consolidated. and overconsolidated clays, at conditions approaching zero effective stress. A flume is being prepared for direct examination by high speed motion pictures of clay erosion. The experiments are designed to study, under carefully controlled conditions, true cohesion of clays subjected to shearing at zero effective stress (1.e. at the claywater interface). Initial erosion of soll samples will be correlated with local velocity and boundary shear stress.

(h) "Erosion of Cohesive Solls," Report to ONR, Solls Division, Department of Civil Engrg., December 1963.

(5114) ROUTING UNSTEADY FLOWS FROM HYDROELECTRIC PLANTS FOR OPTIMIZATION OF NAVIGATION AND PEAK POWER PRODUCTION.

(b) Tennessee Valley Authority.

(c) Prof. R. T. Mclaughlin, Mass. Inst. of Tech., Cambridge 39 , Mass.

(d) Analytical; applied research. discharge in open-channels and the use of mathematical models of such flows in digital and analog computers.

(g) A method of characteristics especially suitable for large and rapid changes of discharge is being applied to a channel. having simple variations in geometry.

(5115) SYSTEMS METHODOLOGY FOR WATER-RESOURCE PLANNING IN A REGIONAL DEVELOPMENT CONTEXT.

(b) M.I.T. Inter-American Program in C1vil. Engineering.

(c) Prof. R. T. Mclaughlin, Mass. Inst. of Tech., Cambridge 39, Mass.

(d) Theoretical and analytical; basic research

(e) Research on the use of mathematical models and systems analysis in planning for comprehensive development of water resources in river basins or other hydrologic units. The relationship of such developments to the social and economic activity of the region in which the unit is located is also being considered.

(g) An existing mathematical model for simulating a single multi-purpose reservolr is being modified for more sophisticated handling of operating decisions during the simulation.

(5116) DEFINITION OF WATER-RESOURCE PROBLEMS IN LATIN AMERICA.

(b) M.I.T. Inter-American Program in Civil Engineering.

(c) Prof. R. T. Mclaughlin, Mass. Inst. of Tech., Cambridge 39 , Mass.

(d) Area survey; for problem identification.

(e) General study of water-resource problems of Latin America to define specific and significant problems that seem to be areas of fruitful research.

(5117) ANALYSIS AND SYNTHESIS OF HYDROLOGIC SYSTEMS

(b) M.I.T. Inter-American Program in C1vil Engrg. (c) Prof. P. S. Eagleson, Mass. Inst. of Tech., Cambridge 39, Mass.

(d) Experimental and theoretical; basic research (doctoral and S.M. Thesis).

(e) Development of improved analytical techniques for the prediction of the time variation in stream flow at some point in a drainage basin due to a given temporal and areal distribution of precipitation. Development of the means for synthesizing these predictors in the absence of long term hydrologic records.

(5118) MECHANICS OF SEDIMENT RIPPIES AND DUNES. 
(b) Laboratory project.

Prof. J. F. Kennedy, Mass. Inst. of Tech., Cambridge 39 , Mass.

(d) Theoretical; basic research.

(e) The formation of sediment ripples and dunes are being investigated as a stability problem by using a poiential flow solution for flow over a small-amplitude wavy bed and a sediment transport law in which the transport rate at any point is proportional to a power of the velocity near the bed a fixed distance upstream. The kinematics of the resulting sediment motion are used to determine the conditions for which the bed waves will grow, and the behaviour of the resulting bed features.

(g) Formulas for the wave lengths and velocity of movement of ripples, dunes, and antidunes in open channel have been developed, and the condition for formation of the different types of bed features have been delineated. Expressions for the length and velocity of ripples and dunes in closed rectangular conduits and in the desert have al so been developed. Insofar as comparison is possible, good agreement has been found between the theoretical results and experimental data. "The Mechanics of Dumes and Antidunes in Erodible-Bed Channels," J. F. Kennedy. Journal of Fluid Mechanics, Vol. i6, pp. 521-544, August 1963.

"The Mechanics of Wave-Generated Sediment Ripples," M. Falcon. S.M. Thesis, June 1963.

(5119) TIDAL, SALINITY AND SEDIMENTATION PROBLEMS IN LAKE MARACA IBO CHANNEL, VENEZUELA.

(b) M.I.T. Inter-American Program in Civil Engrg. Prof. A. T. Ippen, Prof. E. Parthoniades, and Prof. J. F. Kennedy, Mass. Inst. of Tech., Cambridge 39 , Mass.

(d) Theoretical and experimental; basic research. The primary purpose of this project is to investigate the laws governing tide propagation and salt water intrusion in estuarlal channels, and erosion, transport, and deposition of fine material in estuaries. The long range goals of these studies are: (a) To make possible a theoretical or an experimental prediction of salinity and current velocity changes caused by certain engineering operations in estuarial areas; (b) to provide enough information for a reasonable theoretical or experimental evaluation of fine sediment transport and deposition particularly in estuarial navigation channels; (c) to establish rational criteria for the stability of channels with cohesive bed and banks and their protection against objectionable erosion.

(g) Research work has Just started, an experimental setup is under study for an investigation to determine what factors are important in the erosion and deposition of cohesive solls.

(h) "A Study of Erosion and Deposition of Cohesive Soils in Salt Water," Emmanuel Partheniades. Tech. Report No. HE-1-63, Dept. Of Civil Engineering and Applied Mechanics, San Jose State College, San Jose, Calif.

(5I20) THE FEASIBILITY OF ROTATING MODELS IN THE STUDY OF CIRCULATION PATTERNS IN IARGE LAKES.

(b) Laboratory project.

(c) Prof. D. R. F. Harleman, Mass. Inst. of Tech., Cambridge 39 , Mass.

(d) Theoretical and experimental; basic research. A study of the feasibility of small scale models in which similitude with respect to gravity and coriolis forces is obtalned. Velocity and time scales are obtalned from Frondian conditions for a distorted model. Model is rotated to obtain effect of Coriolis acceleration.

(g) Surface current patterns on a small model of Lake Michigan have been obtained for a constant wind ifield both with and without rotation of the model. The effect of a vertical density stratification on current patterns has been studied. The production of a thermocline by infrared heating of the model surface has also been investigated.

(h) "An Investigation of the Establishment of a Thermocline in a Model Lake," T. D. Chappell. S.M. Thesis, June 1963.

"The Feasibility of a Dynamic Model of Lake Michigan," D. R. F. Harleman, E. R. Holley, $\mathrm{Jr}$., J. A. Hooper, and R. R. Rumer, Jr., Pubi. No. 9, Great lakes Research Division, Institute of Sclence and Technology, Univ. of Michigan, 1962.

MASSACHUSETTS INSTITUTE OF TECHNOLOGY, Department of Mechanical Engineering.

\section{(3758) FILM BOILING INSIDE OF TUBES.}

(b) National Science Foundation.

(c) Prof. W. M. Rohsenow, Mass. Inst. of Tech., Cambridge 39 , Mass.

(d) The project is both an analytical and an experimental investigation of film boiling heat transfer.

(e) The objective of the film bolling research is to derive relationships which will predict tube wall temperatures and heat transfer coefficients as a function of heat flux, tube diameter, flow rate, fluid properties distance from the tube inlet and temperature of the liquid entering the tube. Visual tests are made to obtain the flow reglme characteristics needed to set up a mathematical model of the film bolling process and quantitative tests are used to check the validity of the analytically derived relationships.

(f) The current study is an investigation of film boiling of liquid flowing upward through a uniformly heated vertical tube for the case of saturated liquid entering the tube and sufflcient tube length to vaporize most of the liquid.

(g) To date, three studies have been completed which were confined to the case in which the mass of generated vapor is small relative to the total mass of liquid flowing through the tube. The first two of these dealt with flim boiling of a liquid flowing through a horizontal tube, one covering the case of saturated liquid entering the tube and the other extending the work to include the effect of subcooled liquid entering the tube. The third dealt with film bolling of liquid flowing upward through a vertical tube when the flow entering the tube is saturated liquid.

(h) "Film Boiling on the Insids of Horizontal Tubes in Forced Convection," by R. A. Kruger, Ph.D. Thesis, June 1961.

"Effect of Subcooling on Film Boiling in a Horizontal Tube," by E. F. Doyle, S.M. Thesis, June 1962 .

"Film Boiling on the Inside of Vertical Tubes with Upward flow of the Fluid at Low Qualities," R. S. Dougall, Sc.D. Thesis, September 1963.

(4490) COOLING OF HIGH-PERFORMANCE ELECTROMAGNETS.

(b) National Magnet Laboratory.

(c) Prof. Arthur Bergles, M.I.T., Cambridge 39, Mass.

(d) Experimental and theoretical; basic and applied research; bachelor's, master's and doctor's theses.

(e) Th1s project has been concerned with the prediction of heat transfer and pressure drop under conditions simulating those encountered in high-performance electromagnets. Forced convection and forcedconvection boiling, including burnout, are being studied. Techniques of augmenting heat transfer are also being considered.

(g) A design procedure has been proposed for the prediction of forced-convection, surface bolling heat transfer from a minimum of experimental information. Subcooled burnout heat fluxes have been found to increase 
considerably as tube diameter is reduced below 0.25 in. Vibrations applied to the fluid cause substantial increases in heat transfer under certain flow conditions.

(h) "The Influence of Temperature Difference on the Turbulent Forced-Convection Heating of Water," A. E. Bergles and W. M. Rohsenow, Trans. ASME., J. Heat Transfer, Vol. 84 , No. 3, pp. 268-270, August, 1963. "The Determination of Forced-Convection Surface-Boiling Heat Transfer," A. E. Bergles and W. M. Rohsenow, ASME Paper No. 63-HT-22, 1963.

"Subcooled Burnout in Tubes of Small Diameter," A. E. Bergles, ASME Paper No. 63-WA-182, 1963.

(4494) THE TRANSITION BETWEEN TWO PHASE SLUG AND ANNULAR FLOW.

(b) Office of Naval Research, Dept. of the Navy. (c) Mr. P. Griffith, Mech. Engineering Dept.,

(d) To find the slug-annular flow regime transition.

(e) An electrical probe in the pipe with air and water flowing in it is used to determine the transition.

(f) Continuing.

(4498) ELECTROCHEMILUMINESCENCE STUDIES.

(b) Laboratory project.

(c) Mr. George S. Springer, Room 3-264, Mass. Inst. of Tech., Cambridge 39, Mass.

(d) Applied research.

(e) A water tunnel is being constructed for use in ecl flow visualization studies, with particular emphasis to be placed on the behavior of three dimensional boundary layers.

(4978) FLUID JET MODULATORS.

(b) U. S. Air Force, Aeronautical Systems Div., U. S. Army, AMC, Redstone Arsenal.

(c) Prof. Forbes T. Brown, Asst. Prof. of Mech. Engineering, Mass. Inst. of Tech., Room 3-461, Cambridge 39, Mass.

(d) Experimental and theoretical applied research. several master's and doctoral theses involved.

(e) Fluid jet modulators are a class of devices in which a jet of fluid is modulated, usually without the use of moving mechanical parts, to perform useful control or computational functions. Work is directed toward a more thorough understanding and optimization of amplifiers, relays, diodes, oscillators, and logic elements. Special application to control of turbomachinery. Current emphasis on dynamic interactions and stability, including especially the effects of fiuld lines.

(g) Analysis of dispersion of transients in fluid lines extended, including finding the complete step responses in cylindrical lines with laminar flow. Techniques and optimizing analysis for pressure-controlled amplifiers and relays have been proposed. Generalized stability criteria found. Dynamic controlled deflection of jet and interaction with receive ports are partially understood. Several proportional and bistable amplifiers built, and a constant-frequency oscillator is partly developed.

(h) "Theoretical and Experimental Analysis of optimum Geometry of Continuous Fluid Jet Amplifiers," W. B. Bails, S.B. Thesis, M.I.T., June 1962, Available: Engineering Projects Laboratory, M.I.T.

"Fluid Diode Sensor," W. B. Balls, S.M. Thesis, Engineering Projects Laboratory, Mechanical Engineering Department, M.I.T., August 1963. "Pneumatic Pulse Transmission with Bistable Jet Relay Reception and Amplification," F. T. Brown, Sc.D. Thesis, M.I.T., June 1962. Avallable: Engineering Projects laboratory, M.I.T.

"A Comblned Analytical and Experimental Approach to the Development of Fluid-Jet Amplifiers," F. T. Brown, ASME Paper No. 62-WA-154, accepted for publication in
Journal of Basic Engineering, ASME Transactions, with discussion by A. R. Van Koevering, included in booklet "Fluid-Jet Control Devices," ASME Winter Annual Meeting, November 26, 1962.

"The Transient Response of Fluid Lines," F. T. Brown, Journal of Basic Engineering, ASME Transactions, Volume 84 , No. 4, Dec. 1962.

"On the Inherent Limitations in Fluid Jet Modulators," F. T. Brown, available from Diamond Ordnance Fuse Laboratories, Wash. 25, D. C.

"An Experimental Investigation of Pneumatic Jet-Type Amplifiers and Relays," R. W. Crossley, S. M. Thesis, M.I.T. September 1961. Available: Engineering Projects Laboratory, M.I.T.

"An Experimental Study of the Characteristics of a Pneumatic Valve with No Moving Mechanical Parts," W. J. Hastings, S. B. Thesis, M.I.T., June 1962. Available: Engineering Projects Iaboratory, M.I.T.

"The Effect of Geometric Parameters on the Static Performance of an Axt-Symmetric Jet Modulator," H. A. Leibowitz, S. B. Thesis, Engineering Projects Laboratory, Mechanical Engineering Department, M.I.T., June 1963. "A Theoretical study of the Design Parameters of Subsonic Pressure-Controlled Fluid Jet Amplifiers," A. K. Simson, Ph.D. Thesis, July 1963. Available: Engineering Projects Laboratory, M.I.T.

"Experimental Load Characteristics of Fluld Jet Amplifiers," A. R. Van Koevering, S.M. Thesis M.I.T., August 1962. Available: Engineering Projects Laboratory, M.I.T.

(4979) FLUID FLOW AND HEAT TRANSFER IN MULTIPIECHANNEL NATURAL CIRCULATION SYSTEMS.

(b) National Sclence Foundation.

c) Prof. John C. Chato, Mass. Inst. of Tech. Cambridge 39 , Mass.

(d) Theoretical and experimental applied researo program done primarily for a doctoral thesis.

(e) Investigation of the flow phenomena pertaining to multiple-channel natural circulation systems, such as stable and metastable flow conflgurations, inverse flows, "premature" transitions to turbulence, and entrance effects with varying heat inputs.

(g) When there are more than two heat input levels in a multiple channel system, a metastable heat input regime exists within whlch more than one flow pattern can occur, depending on the history of the flow or the disturbances in the system. The magnitude of the metastable regime is affected by channel geometry, header temperatures, heat flux rates, and the occurrence of boiling. Transition to turbulence can oocur at a much lower Reynolds number in flows with heat transfer than in adiabatic flows.

(h) "Natural Convection Flows in Parallel-Channel Systems," J. C. Chato, Trans. ASME, J. Heat Transfer, Nov., 1963.

\section{(4980) FLOW OF CONDUCTING FLUIDS IN A MAGNETIC FIELD.}

(b) Mass. Inst. of Technology.

c) Mr. William H. Heiser, Mass. Inst. of Tech., Cambridge 39, Mass.

(d) Applied research; analysis, design and development.

(e) The flow pattern from a vertical, cylindrical tank which is emptying through a hole in the bottom can be severely altered by a vertical magnetic field if the fluid conducts electricity. This experiment is proposed to demonstrate and indicate the magnitude of this effect.

(f) Planning phase.

(4981) DEVELOPMENT OF A FLUID PULSE ACTUATION SERVOMOTOR.

(b) U. S. AIr Force, Wright Field.

(c) Prof. S.-Y. Lee, Mass. Inst. of Tech. Cambridge 39 , Mass. 
d) Applied research; design and development. An oscillating fluid jet is used to control the oscillation of a diaphragm actuator, the output motion of which is mechanically rectified. This system will have the inherent advantage of having a very small volume of fluid under compression. The dynamic response is expected to be high.

(4982) FUNDAMENTAL INVESTIGATION OF HEAT TRANSFER AND FLUID FLOW INSIDE A HORIZONTAL TUBE EVAPORATOR.

(b) American Society of Heating, Refrigerating and Air Conditioning Engineers, Inc.

(c) Prof. S. William Gouse, Jr. Asst. Prof. of Mechanical Engineering, Mass. Inst. of Tech., Cambridge 39 , Mass.

(d) Basic research; experimental and theoretical. To conduct a visual and quantitative study of the fluid mechanics of a horizontal tube evaporator in order to clarify the confusion which presently exists in the interpretation of experimental results.

(4983) DETERMINATION OF THE STATE OF THE ART IN TWOPHASE GAS-LIQUID FLOW PHENOMENA.

(b) Office of Naval Research (Nonr-184l(73).

(c) Prof. S. William Gouse, Jr., Asst. Prof. of Mechanical EngIneering, Mass. Inst. of Tech., Cambridge 39 , Mass.

(d) Literature search and review.

(e) Conduct a world wide search of the literature on various aspects of two-phase gas-liquid flow, index the literature and review the state of the art in various problem areas.

(h) "An Index to the Two-Phase Gas-Liquid Flow Literature---Part I," S. W. Gouse, Jr., EPL Report 8734-1, Dept. of Mechanical Engineering, May 1963.

(4984) VISUAL STUDY OF TWO-PHASE, ONE-COMPONENT FLOW WITH HEAT ADDITION.

(b) National Science Foundation, NSF Grant Gl1355 and G19771.

(c) Prof. S. William Gouse, Jr., Asst. Prof. of Mechanical Englneering, Mass. Inst. of Tech., Cambridge 39 , Mass.

(d) Basic research; experimental and theoretical investigation.

(e) Investigate two-phase one-component flow in transparent electric resistance film heated single and parallel vertical channels. Make measurements of pressure drop, temperature distribution, flow pattern, and flow stability.

(h) "Visual Study of Two-Phase one-Component Flow in a Vertical Tube with Heat Transfer," S. W. Gouse, Jr., Cheng-Chieh Hwang, EPL Report 8973-1, Dept. of Mechanical Engineering, June 1963.

"Flow Oscillations in a Closed Loop With Transparent, Parallel, Vertical, Heated Channels, "S. W. Gouse, Jr., Carl D. Andrysiak, EPL Report 8973-2, Dept. of Mechanical Engineering, June 1963.

(4985) THE FLOW PROPERTIES OF BUBBLY MIXTURES.

(b) Office of Naval Research.

(c) Mr. Peter Griffith, Mass. Inst. of Technology, Cambridge 39, Mass.

(d) To determine the flow properties of bubbly mixtures.

(e) A vertical tube is suspended so that shear forces can be measured directly. These are then used to compute a two phase friction factor.

(f) Continuing.

UNIVERSITY OF MASSACHUSETTS, School of Engineering.

\section{(2561) HYDROLOGY STUDIES IN WESTERN MASSACHUSETTS.}

(b) Cooperative with the U. S. Soll Conservation Service, U. S. Geological Survey, and Mass. Water Resources Commission. (c) Prof. George R. Higgins, Engineering Research Institute, Univ, of Mass., Amherst, Mass.

(d) Experimental-field and laboratory; for design of watershed yield, flood peak reduction and general information.

(e) Mass curve and Duration curve studies for reservolr and watershed yleld have been done for nearly all the gaged streams in Massachu setts. The purpose of the study is to determine general information for optimum use of water resources or the state. Particular emphasis on recreational aspects and low flow characteristics is presently being considered.

(h) Progress reports were submitted to the University Research Council in 1959 and 1960 A report for the Massachusetts Water Resources Commission was submitted in 1963.

(3766) AN EXPERIMENTAL STUDY OF THE STABILITY OF STANDING (TRAPPED RING) VORTICES IN TWODIMENSIONAL INCOMPRESSIBIE FLOW.

(b) Laboratory project.

c) Dr. Charles E. Carver, Jr., Professor of Civil Engineering, Dept. of Civil Engrg., Univ. Of Mass., Amherst, Mass.

(d) Experimental; basic research.

e) Using a Hele-Shaw table, a vortex is formed in a cusp and the tendency of the vortex to remain in the cusp is studied for various free stream velocities past the cusp as well as for various suction rates applied within the cusp in accordance with a theory of Ringleb.

(f) Inactive.

(g) Using dye, experimental streamlines and stagnation points agreed quite well with theory with and without suction. A small propeller was required to maintain the vortex within the cusp due to the overpowering viscous effect; hence vortex stability could not be studied.

(h) Master's thesis by $H$. Wang completed.

(4165) EXPERIMENTAL INVESTIGATION OF TWO-PHASE FLOW.

(b) Laboratory project.

(c) Senior student honors project, Dr. E. E. Lindsey supervisor, Associate Dean of Engrg., University of Massachusetts, Amherst, Mass.

(d) Experimental, basic research

(e) Effect of surface tension of pressure drop and slip for two-phase flow; variation in phase ratios along a pipe.

(4166) AGITATION CHARACTERISTICS IN LIQUID-LIQUID SYSTEMS.

(b) National Sclence Foundation; University of Massachusetts Research Council.

(c) Associate Dean E. E. Lindsey, Engineering Research Institute, University of Mass., Amherst, Massachusetts.

(d) Experimental; basic research for master's thesis.

(e) Two immiscible or partly miscible liquids are used. Dispersions are produced in a dynamometer agitator and particle sizes of the sampled dispersion are measured by a light scattering technique. One thesis was concerned with developing the technique and study in geometrically similar, baffled tanks, another thesis with transient change in drop sizes at the start of agitation. Current project is to study variations in geometry. Work is starting on development of light-scattering probe to measure particle size directly in the mixing tank.

(g) Primary peaks in the drop size distribution occurred at 1 to 3 microns, secondary peaks at about 30 microns. Drop size distribution is essentially identical in geometrically similar vessels of different size of equal power/volume. There is a slight decrease in size with increased agitator speed. Comparison of two liquid systems indicates drop size decreases with increasing viscosity. Steady state drop size distribution 
occurred in 30 to w minutes.

(h) "An Approach to Characterizing Agltation by Dispersion Particle Size," by D. M.

Sullivan and E. E. Lindsey, Industrial and Engineering Chemistry, Fundamentals Edition, 1. 87-93 (May 1962).

(4167) PRESSURE DROP ACROSS FITTINGS.

(b) Laboratory project.

c) Dr. Kenneth D. Cashin, Assoc. Prof. of Chemical Engineering, Dept. of Chemical Engineering, Univ, of Mass., Amherst, Mass.

(d) Experimentai; senior student honors project.

(e) Pressure drop is measured for a number of different pipe fittings placed in series and at different spacings; effect of approaching and leaving conditions investigated.

(g) Experiments underway.

(4656) THE EFFECT OF NON-NEWTONIAN FLUID INJECTION ON THE TURBULENT BOUNDARY IAYER OF A FLAT PLATE.

(b) Laboratory project.

c) Dr. Charles E. Carver, Jr., Prof. of C1vil Engrg., Univ. of Mass., Amherst, Mass.

(d) Experimental; basic research.

e) A non-Newtonian fluid, obtained by mixing guar gum with water, is injected through transverse slots cut in a flat plate into the turbulent boundary layer. The flat plate is immersed in clear water with a free stream velocity $U_{0}$. A barium titanate crystal is installed flush with the surface of the plate a few inches downstream of the slot and is used to measure the intensity of turbulence with and without injection of the non-Newtonian fluid.

(4657) THE RESPONSE OF A DENSITY CURRENT TO A SINUSOIDAL PRESSURE PULSE.

(b) Laboratory project.

(c) Dr. Charles E. Carver, Jr., Professor of Civil Engineering, Univ. of Massachusetts, Amherst, Mass.

(d) Experimental; basic research.

(e) A system of oscillatory waves is imposed on the upper layer of a two-layered system consisting of clear and saline water. The response of the interface is observed in terms of the frequency and amplitude of the imposed waves at the free surface. The amplitude of the interfacial wave is seen to increase in accordance with an inviscid theory of Stokes. Conditions under which mixing at the interface occurs are recorded and are to be compared with existing viscous theory for instability at the interface.

(h) Master's thesis by Chao-ho sung in preparation.

(4658) THE EFFECT OF HEADER GEOMETRY UPON FLUID FLOW CHARACTERISTICS IN NUCLEAR REACTORS AND HEAT EXCHANGERS.

(b) Laboratory project.

(c) Prof. Joseph M. O'Byrne, Engineering Research Institute, University of Massachusetts, Amherst, Mass.

(d) Experimental; applied research.

e) To determine the relationships between such varlables as core and tube diameter, tube lattice and spacing, header height, etc. upon the individual flow per tube for a pressure vessel in which fluid is introduced through a single radial line placed at the base of the header.

(f) Inactive.

(h) "The Effects of Geometry on Fluid Flow Characteristics in Nuclear Reactors," by David Creamer, Master's thesis, 1960.

(4914) BOILING OF WATER ON A HORIZONTAL SURFACE WITH A VARIABLE POWER INPUT.

(b) Laboratory project supported by Research Council, Univ. of Mass. (c) Prof. Joseph M. O'Byrne, Assoc. Prof. of Mechanical Engineering, Dept. of Mechanical Engineering, Univ. of Mass., Amherst, Mass.

(d) Experimental; basic research.

(e) The purpose is to determine if, by appropriate intermittent power pulses applied to a resistance ribbon, boliling heat fluxes in excess of those for steady state can be maintained. Previous tests have shown that this "overshoot" can be induced momentarily with a single step of continuous power, and this project will extend the results to account for the effect of pulses.

(4915) BASE FLOW STUDIES FOR MASSACHUSETTS STREAMS.

(b) Faculty Research Grant for Research Counc1l.

(c) Assoc. Prof. G. R. Higgins, Univ. of Mass., Engineering Building, Amherst, Mass.

(d) Experimental; field and laboratory.

(e) This project is intended to correlate and apply data concerning minimum stream flow in Massachusetts streams to provide indices whereby base flow may be more easily predicted at sites where water resource facilities may be of public or private benefit. Runoff records of the U. S. Geologlcal Survey, soll maps of the U. S. Soll Conservation Service, University Forestry Department cover maps, topographic maps, and any other data deemed pertinent wili be used. Statistical and probability methods will be applied to these data with computer application where possible.

(g) Studies to date indicate very ilttle, if any, correlation between any single factor and base flow.

(h) Results to date are included in a report to the Massachusetts Water Resources Commission in September, 1963.

UNIVERSITY OF MICHIGAN, Department of Civil Engrg.

(4858) WATER HAMMER: RESONANCE IN TRIPLEX PUMP SUCTION AND DISCHARGE LINES.

(b) Union Pump Company.

(c) Prof. V. L. Streeter, Prof. of Hydraulics, Dept. of Civil Engrg., Coliege of Engrg. Univ, of Mich., Ann Arbor, Mich.

(d) Theoretical and experimental; basic research

e) Theoretical determination of resonance-free suction lines and experimental study of actual transients.

(4859) PULSATILE FLOW THROUGH ARTERIES.

(b) National Institutes of Health

(c) Prof. V. L. Streeter, Prof. of Hydraulics, Dept. of Civil Engrg., College of Engrg., Univ, of Mich., Ann Arbor, Mich.

(d) Theoretical and experimental; basic research. Computer simulation of portions of the arterial tree; experimental studies of energy dissipation in pulsatile flow through distensible tubes.

(h) "Pulsatile Pressure and Fiow through Distensible Vessels," Circulation Research, Vol. XIII No. 1, Juiy 1963, pp 3-20.

( 860 ) WATER HAMMER: FAILURE OF PUMPS.

(b) National Science Foundation.

(c) Prof. V. L. Streeter, Prof. of Hydraulics, Dept. of Civil Engrg., Coliege of Engrg. University of Mich., Ann Arbor, Mich.

(d) Theoretical.

(e) Study of water hammer in suction and discharge lines of large pumping stations with multiple pumps when one or more lose their power. Dimensionless, homologous complete characteristics used with computer program for water hammer based on methods of characteristics.

(4861) WATER HAMMER, ITS EFFECT ON MINOR LOSSES.

(b) National Science Foundation. 
(c) Prof. V. L. Streeter, Prof. of Hydraulics, Dept. of Civil Engrg., College of Engrg., Univ. of Mich., Ann Arbor, Mich.

(d) Theoretical and experimental; basic research for doctoral thesis.

(e) Investigation of effect of minor losses on water hammer pulses, the losses belng developed from a sertes of closely-spaced oriflces. Transmission and reflection coefficlents obtained by theory; then programmed into a water hammer solution for the experimental set-up.

(f) Experimental work completed.

g) Transmission and reflection due to minor loss of $\mathrm{K} \mathrm{V} / 2 \mathrm{~g}$ each equal to $\mathrm{K} / 2 \mathrm{~V}^{2} / 2 \mathrm{~g}$.

(4862) WATER HAMIER, LIQUID COLUMN SEPARATION.

(b) National Science Foundation.

(c) Prof. V. L. Streeter, Prof. of Hydraulics, Dept. of C1vil Engrg., College of Engrg., Univ. of Mich., Ann Arbor, Mich.

(d) Theoretical and experimental; basic research for doctoral thesis.

(e) Study of shape of separated liquid free surface in a horizontal pipe.

(4946) RESONANCE IN PIPELINES.

(b) Horace H. Rackham School of Graduate studies, The University of Michigan, Ford Foundation, National Science Foundation.

(c) Prof. V. L, Streeter, Prof. of Hydraulics, Dept. of Civil Engrg., College of Engrg., Univ. of Mich., Ann Arbor, Mich.

(d) Theoretical.

(e) Study of geometry of plpelines and the frequencies for which resonance could occur. Effect of friction in damping resonance.

UNIVERSITY OF MINNESOTA, Agricultural Experiment Station.

\section{(1929) DRAIN TIIE JUNCTION LOSSES.}

Cooperative with St. Anthony Falls HydrauI1c Laboratory. See page 70 .

(2350) DRAINAGE OF AGRICULTURAL LAND BY PUMPING.

(b) Fleld and laboratory project.

c) Prof. Curtis L. Larson, Dept. of Agricultural Englneering, Un1v. of Minnesota, St. Paul 1, Minnesota.

(d) Theoretical and field investigations; applied research.

(e) The project has three phases: (1) The development of baslc relations for planning pump drainage systems, (2) the study of rates of dralnage, and (3) the study of factors affecting the efflciency.

(B) Continuous measurements of farm tile flow from mineral or organic soll are made, as well as precipitation amounts.

(h) "Loss of Energy at Sharp-Edged P1pe Junctions in Water Conveyance Systems," now ava1lable.

(2576) CONSTRUCTION, DEVELOPMENT, AND PUMPING OF SHALLOW WELLS FOR IRRIGATION.

(b) Fleld project.

(c) Prof. Evan R. Allred, Dept. of Agricultural Englneering, Univ, of Minn., St. Paul 1 , Minn.

(d) Field investigation; applied research and development.

(e) The objectives of the project are: (1) To study and develop inexpensive methods for construction of shallow Irrigation wells, (2) determine hydraulic permeab1lity and characteristics of varlous aquifers, and (3) to survey and determine extent and avallabllity of shallow ground water sources for 1 rrigation in Minnesota.

(3470) HYDRAULIC PERFORMANCE OF IRRIGATION BOOMSPRINKIERS.

(b) Fleld and laboratory project. (c) Prof. Evan R. Allred, Dept. of Agricultural Engineering, Univ. of Minn., St. Paul 1, Minn.

(d) Primarily field 1nvestigation; applied research.

(e) The objective of the project is to determine the effect of wind velocity, nozzle arrangement, rotation speed and operating pressure on the distribution from irrigation boom-sprinklers.

(f) Completed.

MONTANA STATE COLIEGE, Agricultural Experiment Station.

(4664) EFFICIENT APPLICATION OF IRRIGATION WATER BY SURFACE FLOODING METHODS.

(b) Laboratory project.

c) Prof. C. C. Bowman, Head, Agricultural Engineering Dept. Montana state College, Bozeman, Montana.

(d) This is a study to develop design criteria for more efficient applicatior. of irrigation water by flooding method. This $1 \mathrm{~s}$ basic research at the present time, but will be applied research immediately upon completion of the first phase.

(h) "Progress Report of Montana Project M.S. 973", Montana Agricultural Experiment Station, Annual Report of Contributing Project. Western Regional Research Project W-65, october 1963.

UNIVERSITY OF NEBRASKA, Hydrodynamics Laboratory, Dept. of Engineering Mechanics.

(3776) VORTEX FORMATION AND DRAG IN UNSTEADY FLOW PAST BLUFF BODIES.

(b) National Science Foundation.

c) Prof. T. Sarpkaya, Dept. of Engineering Mechanics, Bancroft Hali 219, University of Nebraska; Lincoln 8, Nebraska.

(d) Experimental and theoretical study of drag and inertia in unsteady flow. Basic research for master's and Ph.D. thesls.

(e) Primary objects of the research are: To determine the growth and motion of vortices behind two dimensional bluff bodies subjected to unidirectional unsteady flow; to determine the various components of corresponding resistance; and to correlate a particular vortex configuration with the instantaneous resistance.

(g) The forces predicted on the basis of the moving and growing vortices are comparable in magnitude to forces which are observed. Resistance to unsteady flow is not to be thought of as a mere juxtaposition of resistances to steady flow augmented by an inertial force.

(h) "LIft, Drag, and Added Mass Coefflcients for a Circular Cylinder Immersed in a Time Dependent Fluid Flow, "by T. Sarpkaya, Transactions of the ASME, J. Appl. Mechs., Vol. 30, Series E, No. 1, March 1963, pp $13,14,15$.

"Vortex Formation and Resistance In Unsteady Flow," by T. Sarpkaya and C. J. Garrison, Transactions of the ASME, J.Appl. Mechs., Vol. 30, Sertes E, No. 1, March 1963, pp $16-24$.

"Unsteady Flow over an Inclined Plate," by T. Sarpkaya, J. Appl. Mechs., ASME Paper No. 63-WA-47, i963.

Winter Annual Meeting of ASME.

(3780) MECHANISM OF TURBULENCE GENERATION IN PULSATING VISCOUS. FLOW.

(b) Offlce of ordnance Research, U. S. Dept of the Arny, (Durham).

(c) Dr. T. Sarpkaya, Bancroft Hall 219, Univ. of Nebraska, Lincoln 8, Nebr.

(d) Experimental and theoretical basic research for master's and Ph.D. thesis. 
(e) To understand the mechanism of turbulence generation in pulsating viscous fllow superposed on a steady and inftially laminar flow and to evaluate the resistance to fluld motion.

(B) Transition to turbulence takes place at much lower Reynolds numbers. When the amplitude ratio of the pulsating pressure gradient to steady one is not large, the maximum dissipation occurs at the wall. However, with the increase of the amplitude ratio the position of the maximum dissipation moves into the flowing fluld and 1 ts distance varies with time.

(3782) INDUCED MASS OF CONFINED FLUIDS.

(b) Laboratory project.

c) Prof. T. Sarpkaya, Bancroft Hall 219 , Un1versity of Nebraska, Lincoln 8 , Nebr.

(d) Theoretical basic research; for master's thesis.

(e) When a confined fluid is suddenly accelerated through an opening, initial average acceleration is determined by the induced mass of the fluid system. Since the equation of the elastic wave propagagion cannot be solved for the boundary conditions imposed, solution of Laplace's equation is joined to that obtalned from the wave equation through the application of the Schwartz-Christoffel transformation and electrical analogy.

(g) The effect of induced mass is most pronounced particularly for short conduits. Average times necessary for the reflection of an elastic wave from a given reservolr is determined.

(h) "Unsteady Flow of Flulds in Closed Systems," T. Sarpkaya, ASCE, J. of EM Div., Vol. 88, No. EM3, June 1962, pp 1-15.

(4I70) VIRTUAL MASS OF PARTLY SUBMERGED BODIES.

(b) Laboratory project.

(c) Prof. T. Sarpkaya, Bancroft Hall 219, Univ. of Nebraska, LIncoln 8 , Nebr.

(d) Experimental and theoretical basic research

(e) Study of the added mass of various objects partly submerged in a liquid.

(44.86) ANNULAR TWO-PHASE FLOW.

(b) Laboratory project.

(c) Dr. T. Sarpkaya, University of Nebraska, Lincoln 8, Nebr.

(d) Experimental and theoretical for Ph.D.Thesis.

(e) Amplitude and frequencies of interfacial waves are studied. The interfaclal structure influences the flow of gas in a manner similar to that of a rough wall pipe.

(g) The mean liquid film thickness increases with increase in flow rate at constant gas veloc1t1es; 1t decreases with an increase in gas velocity at constant liquid rate. Pressure gradient in the gas stream exceeds that for a smooth pipe at the same Reynolds number (gas) for gas velocities greater than some minimum value.

(4487) POTENTIAL FLOWS WITH UNISOTROPIC SINGULARITIES.

(b) Laboratory project.

c) Dr. T. Sarpkaya, University of Nebraska, Lincoln 8 , Nebr.

(d) Theoret1cal and for master's thesis.

(e) Mathematical singularities used have unisotrop1c characteristics. Potential flows resulting from the combinations of such singularities are studied.

(4893) COUNTER VORTEX OSCILLATOR.

(b) Diamond Ordnance Fuze Laboratorles, Wash., D. C.

(c) Dr. T. Sarpkaya, Bancroft Hall 219, Univ, of Nebraska, Lincoln 8 , Nebraska.

(d) Theoretical and experimental and for master's thesis.

(e) To determine the intensity of pressure fluctuations and frequency of the instability created by two vortices rotating in opposite directions in two vortex chambers connected by a circular tube. (g) Frequency and intensity of pressure fluctuations are determined as a function of fluid properties and the geometry of the system. The counter vortex oscillator unit proved to be usable together with a pneumatio amplifier in controlling the momentum of the power jet.

(h) Internal Report No. I to Diamond ordnance Fuze Laboratories, August 1963.

(4894) BISTABLE VORTEX OSCILLATOR.

(b) Laboratory project partly supported by DOFL. c) Dr. T. Sarpkaya, Bancroft Hall 219, Un1v. of Nebraska, Lincoln 8, Nebraska.

(d) Theoretical and experimental for master's thesis.

(e) To use the vortex shedding behind a clrcular cylinder placed between two parallel walls to activate a high frequency oscillator. The units built have varlable frequency and push-pull characteristics.

(g) Vortex shedding behind circular cylinders appears to be a powerfull means of switching "on" or "off" the load of a pneumatic amplifler.

(h) "A Bistable Vortex Oscillator," by T. Sarpkaya, J. Appl. Mechs., ASNE, November 1963.

NEW YORK UNIVERSITY, Department of Chemical Engrg.

(2583) EFFECT OF PARTICLE CONCENTRATION ON PRESSURE DROP AND SEDIMENTATION VELOCITY IN DILUTE BEDS OF PARTICLES.

(b) Grants from Texas Company and American Chemlcal Soclety; laboratory project.

(c) Professor J.Happel, Dept. of Chem1cal Engineering, New York University, Univ. Heights, New York, 53, New York.

(d) Theoretical; basic research for doctoral thesis.

(e) The slow translational motion of dilute beds of particles settling through viscous fluids subjected to the influence of cylindrical boundarles is belng studied. This will ultimately enable a theoretical prediction of the effect of particle concentration on pressure drop and sedimentation velocity in beds of particles.

(f) Completed. of reflections technique for solving boundary value problems is applied to a dilute suspension of spherical particles. Particle interaction and wall effect are evaluated on a digital computer for various particle orlentations ylelding expressions for settling rate vs. particle concentration in agreement with other theoretical treatments.

(h) "Theoretical study of Sedimentation of Dilute Suspensions in Creeping Motion," Jack Famularo, Eng. Sc.D. D1ssertation, New York University, July 1962. Write to Library of School of Englneering and Science, Bronx 53, New York.

(3474) HEAT TRANSFER AND CHEMICAL REACTION RELATIVE TO BEDS OF SPHERICAL PARTICLES.

(b) Laboratory project. ing, New York University, University Helghts, New York, 53, New York.

(d) Theoreticai; basic research for doctoral thesis.

(e) Analytical solution is developed by assuming a model where fluid is flowlng between two concentric spheres which are maintalned at different temperatures. The partial differential equations applicable are solved by assuming power series solutions in temperature and in spherical co-ordinate $\theta$. The results will be compared to existing data on heat and mass transfer in packed and fluldized beds.

(f) Completed.

(g) Particle to fluid heat and mass transfer rates for multiparticle systems are obtained 
analytically by solving an energy equation derived from a "free surface model". Solutions are obtained for Peclet Numbers between .1 and 100 , and fractional vold volumes between .4 and 1.0 . They show that the average Nusselt or sherwood number in a bed of particles is a function of both the fractional vold volume and Peclet number; the effect of Peclet number decreasing as the bed becomes more concentrated in the low Peclet number range.

(h) "An Analytic Study of Heat and Mass Transfer in Multiparticle Systems at Low Reynolds Numbers," Robert Pfeffer, and John Happel. Accepted for publication in A.I.CH.E. Journal.

(3788) BOUNDARY LAYER MASS TRANSFER WITH HETEROGENEOUS CATALYSIS.

(b) Grants from American Chemical Society and National Science Foundation; Laboratory profect.

(c) Prof. J. Happel, Dept. of Chemical Engrg., New York University, University Heights, New York 53, New York.

(d) Theoretical; basic research for doctoral thesis.

(e) This work includes a study of the rate of gas-solid catalytic reactions in multiparticle systems. Using boundary layer theory in confunction with a model consisting of a solid sphere inside a free-surface spherical cell, the relationship between rates of diffusion and rates of surfacecatalyzed reactions is developed.

(f) Completed.

(g) Theoretical results for chemically dilute systems correlate existing mass transfer data reasonably well. It was found that molar convective transport to or from the surface affects the mass transfer rate and may give appreclabiy different results than those obtained from film theory or the dilute solution equation. A simple criterion is set up to determine when the dilute solution correlations can be used.

(h) "Boundary Layer Mass Transport with Heterogeneous Catalysis," by C. L. Kusik and John Happel, I \& EC Fundamentals, Vol. 1, No. 3, p. 163-172, August, 1962 .

(4172) PRESSURE LOSS IN ORIFICE BAFFLED HEAT EXCHANGERS

(b) Laboratory project.

(c) Prof. Robert 0. Parker, Department of Chemical Engineering, New York University, New York 53 , New York.

(d) Experimental; basic research for master's degree.

(e) Project to determine pressure loss on the shell side of oriflc= baffled, shell and tube heat exchangers. Three exchangers are used in this experiment. All are exactly alike except for the fact that one has no clearance between the tube and tube hole, one has no clearance between the baffle and the ID of shell, and one has clearances at both points. This study will determine the effect of each flow stream, and the effect of their interaction.

(f) Completed.

(g) Pressure loss was measured in three orifice baffled heat exchangers. Friction factors were obtalned separately for flow through the clearance between baffle and shell, and flow through the clearance between tube and tube holes. The friction factor for the third exchanger in which both flows occurred simultaneously was found to be predictable from the separately derived friction factors indicating no interaction between flow paths. "Pressure Loss in Oriflce Baffled Heat Exchangers," Marvin Bressler, M.Ch.E. Dissertation, New York University, August 1962. Write to Library of School of Engineering and Sclence, Bronx 53, New York.

(4173) A THEORETICAL STUDY OF END EFFECTS IN THE FALIING BALL VISCOMETER. (b) Laboratory project

c) Prof. H. Brenner, Dept. of Chemical Engrg. New York University, New York 53, New York.

(d) Theoretical; basic research for doctoral thesis.

(e) The objective of this work is to obtain the increase in the stokes resistance to a particle in a container with top and bottom. This will be accomplished by solving the creeping motion equations subfect to boundary conditions of zero velocity on solid surfaces.

(4174) THE PRESSURE DIFFERENTIAL DUE TO A PARTICLE SETTLING IN A VISCOUS FLUID.

(b) Laboratory project.

(c) Prof. H. Brenner, Dept. of Chemical Engrg., New York University, New York 53, New York.'

(d) Experimental; basic research for master's degree.

(e) Experiments are designed to verify certain theoretical relationships pertaining to the dynamics of a particle in a viscous fluid. Pressure differentials due to spheres settling at low Reynolds numbers in a cylinder containing a viscous fluid will be measured and correlated with particle drag.

(f) Completed.

(g) Experimental measurements were made of the difference in pressure at large distances on either side of a spherical particle settling slowly along the axis of a long circular tube filled with viscous liquid. At low particle Reynolds numbers and for small sphere - cylinder diameter ratios, it was found that the product of the pressure difference and the cross - sectional area of the tube is equal to twice the drag on the particle, in accord with the theory.

(h) "Experiments on the Pressure Drop Created by a sphere settling in a Viscous Liquid," Irwin Pliskin and Howard Brenner, J. Fluid Mechanics, V. 17, part 1, pp. 89-96, 1963.

NEW YORK UNIVERSITY, Department of Meteorology and Oceanography.

(3120) OFFICE OF NAVAL RESEARCH ATMOSPHERE INTERACTION AND WAVE PROJECT.

(b) Geophysics Branch, Offlce of Naval Research, Department of the Navy.

(c) Frof. Gerhard Neumann, Prof. of Oceanography and Prof. Willard J. Plerson, Prof. of oceanography, New York University, New York 53, New York.

(d) Experimental and theoretical; basic and applied research.

(e) Study of wave generation and propagation in deep water; nonlinear properties of capillary and gravity waves in both Eulerian and Lagrangian form. Observations of temperature, humidity, and wind over the sea surface. Albedo measurements. Wind stress over the water surface. The prediction of large scale oceanic clrculations. Theoretical and observational studies of turbulence in water. Diffusion studies.

(g) Models of random seas in Lagrangian form have been developed that look promising. Fleld work has been expanded by the acquisition of a T-boat and additional scientific equipment. Dye studies in Long Island Sound and adjacent waters.

(h) "A Linear Lagrangian Model of Turbulent Heat Conduction and convection I," by W. J. Plerson. "Data for High Wave Conditions Observed by the OWS "Weather Reporter" in December 1959," by C. L. Bretschneider, H. L. Crutcher, J. Darbyshire, G. Neumann, W. J. Pierson, H. Walden, and B. W. Wilson, Deutsch. Hydrogr. Zeit, Band 15, Heft 6. "Gravity Waves," by W. J. Plerson, Trans. Amer. Geophys. Un., Vol 44, No. 2 . "Observations of Long-Crested Random-Breaking Waves in Both Lagrangian and Eulerian Form for Comparison with Avallable Theories," by W. J. Plerson, Time Series Analysis, John 
Wiley.

"Known and Unknown Properties of the Frequency Spectrum of a Wind Generated Sea," by G. Neumann and $W$. J. P1erson, Ocean Wave Spectra, Prentice-Hall.

"Various Discussions and Contributions," by W. J. Pierson. Ocean Wave Spectra, Prentice$\mathrm{Hall}$.

NEW YORK UNIVERSITY, School of Engineering and Science.

(4988) MECHANISM OF GAS ABSORPSION BY TURBULENT LIQUIDS

(b) Laboratory project.

c) Dr. William E. Dobbins, Prof. of Civil Engineering, New York University, School of Englneering and Sclence, University Helghts, Bronx 53, New York.

(d) Theoretical and experimental; basic research (doctoral thesis).

(e) A study of the mechanism by which gases are transferred across a turbulent gas-liquid interface, with particular emphasis on the process as it occurs in natural streams.

(g) A mathematical model for the transfer process has been developed. Experimental work using several gases of varying diffusivities indicates an acceptability of the mathematical model. The present phase is concerned with the effect of impurities in the liquid.

NORTH CAROLINA STATE OF THE UNIVERSITY OF NORTH CAROLINA, Department of Englneerling Research.

(4667) UNSTEADY FREE SURFACE FLOWS.

(b) Laboratory project.

c) Dr. M. Amein, Department of Civil Engrg., North Carolina State of the UnIv. of No. Carolina, Rale1gh, N. C .

(d) Experimental and theoretical; basic research.

(e) An experimental investigation on translatory motions with irregular profiles, on bore formations and on the propagation of unsteady motions through non-uniform flows is made in a glass-walled channel. The channel is $14 \mathrm{ft}$. long, $2 \mathrm{ft}$. Wide with adjustable varlable slope. The experimental results are analyzed by the nonlinear shallow water theory. The objective of the project is to seek improvements to the prevalent techniques for the computation of unsteady flows and to provide experimental data for further theoretical investigations.

(4668) STUDY OF VORTEX MOTION IN WAKE FLOWS.

(b) Laboratory project.

(c) Prof. Paul Harrawood, Department of Civil Engineering, North Carolina state of the Univ. of No. Carolina, Ralelgh, North Carolina.

(d) Experimental and theoretical; doctoral thesis.

(e) An investigation of the eddy motions present in the wakes of bluff bodies in a streaming fluid, with particular attention given to the periodicity of eddy motions and to vortex strength.

(4669) AN INVESTIGATION OF THE STABILITY OF FLOW IN CIRCULAR SEDIMENTATION BASINS.

(b) Laboratory project.

(c) Professor Charles Smallwood, Jr., Dept. of Civil Engrg., North Carolina State of the Univ. of No. Carolina, Raleigh, North Carolina.

(d) Experimental; master's thesis.

(e) A semi-circular center-fed model basin was built with a transparent back for visual examination of the flow pattern. A uranine dye tracer was used to determine flow through waves for the basin. Stability was measured by the reproducibility of the timeeffluent dye concentration waves. In an attempt to stabilize the flow radial baffles were placed in the basin to reduce the angle of divergence and to provide solid boundaries in the divergent flow.

(f) Completed.

(g) The baffles had no detectable effect. The flow pattern was characterized by a shortcircuit along the tank bottom and a backflow in the upper portion of the tank.

NORTH DAKOTA STATE UNIVERSITY, Agricultural Engrg Dept.

\section{(3121) PREFABRICATED DITCH LININGS.}

(b) Laboratory project.

c) Prof. Harold Holmen, Assistant Agricultural Engineer, Agricultural Engineering Dept. North Dakota State University, Fargo, N. Dak

(d) Experimental; applied research.

(e) A seepage test was made on $6 \mathrm{mil}$ and $10 \mathrm{mil}$, burled, black polyethylene ditch linings whlch have been in place for 3 years.

(g) These buried linings appear to be in excellent condition. Surface linings installed in 1960 have deteriorated so that they are no longer satisfactory for controlling seepage.

(3475) SURFACE DRAINAGE.

(b) Laboratory project.

c) Prof. Harold Holmen, Assistant Agricultural Engineer, Agricultural Engineering Dept., North Dakota State University, Fargo, N. Dak

(d) Field investigation; applied research.

(e) A study was made of accumulation of fill in field ditches that were constmucted 5 years ago.

(g) About $1 / 3$ of the orlginal volume of the ditches was filled after a period of 5 years.

(4175) WATER INTAKE RATES AND PHYSIOCHEMICAL PROPERTIES OF IRRIGABLE SOILS

(b) Jolnt laboratory project between Department of Agricultural Engineering and Department of Solls.

(c) Prof. Harold Holmen, Assistant Agricultural Engineer, Agricultural Engineering Dept. North Dakota State University, Fargo, N.'Dak.

(d) Experimental, basic research, and Master's thesis.

(e) Infiltration rings up to 38 inches in dlameter were made and tests were performed to compare these rings with smaller rings measuring up to 22 inches in diameter. Work was also continued on comparing the double ring infiltrometer, purdue sprinkler infiltrometer, and the inflow-outflow method for determining infiltration rates on irrigated soils.

(g) Highest intake rates have been obtained with the sprinkling infiltrometer. A wide variation in rates under various conditions has been obtained with the rings and inflowoutflow methods.

NORTHWESTERN UNIVERSITY, The Technological Institute,

(3476) FLOOD WAVE ROUTING.

(b) Northwestern Technological Institute.

(c) Prof. W. S. Hamilton, Dept. of Civil Engrg., Northwestem University, Evanston, Ill.

(d) Theoretical and analytical for doctoral and masters theses.

(e) The purpose is to calculate the movement of flood waves in prismat1c and natural channels. Finite difference equations based on (a) method of characteristics and (b) basic equations of momentum and continuity are to be programmed separately for solution on a digital computer.

(g) A backward difference method using the 
equations of momentum and continuity and a rectangular grld gave unstable, unreallstic profiles for a non-prismatic channel. The reasons for this are being investigated. A new finite difference method using characteristics is under study.

(3799) FORCES ON SUBMERGED BODIES IN UNSTEADY MOTION.

(b) Northwestem Technological Institute and U. S. Cold Regions Re search Laboratory.

(c) Professor W. S. Hamilton, Dept. of Civil Engineering, Northwestern University, Evanston, Illinois.

(d) Theoretical and experimental; for Ph.D. and M. S. theses.

(e) The purpose is to evaluate forces acting on accelerating bodies submerged in a fluld. Experiments have been mun for a sphere performing simple harmonic and other oscillations in a tank of oll.

(f) Flrst phase completed.

(g) Data were correlated in terms of velocity (drag), acceleration (added mass) and history coefficients, but the coefficlents seem to depend on the type of motion.

(h) "Forces on a Sphere Accelerating in a Viscous Fluid," F. Odar and W. S. Hamilton, Journal of Fluid Mechanics (accepted).

(4670) THE EFFECT OF SURFACE ACTIVE AGENTS ON THE STABILITY OF FALLING LIQUID FILMS.

(b) Northwestem University.

(c) Mr. Stephen Whitaker, Chemical Engrg. Dept., Northwestem Tech. Inst., Northwestern Univ. Evanston, Illinois.

(d) Experimental.

(e) Small amounts of surface active agents are often used to suppress the ripples or waves that tend to form on falling liquid films. The presence of a surface active agent at a gas-liquid surface gives rise to three phenomena: (a) lowered surface tension, (b) Increased surface viscosity, (c) the possibility of surface tension gradients. An experimental study 1 s being undertaken in order to determine the role of these phenomena in stabilizing falling liquid films.

\section{(4671) THE FLOW OF VISCOEIECTRIC FLUIDS.}

(b) Laboratory project.

(c) Mr. Thomas P. Anderson, Assist, Prof, Dept. of Mech. Englneering and Astronautical Sclences, Northwestern University, Evanston, Illinols.

(d) Experimental and theoretical thesis research relating to viscoelectric flows.

(e) The flow of fluids exhibiting the winslow effect (the varlation of viscosity under the influence of an applied electric field) is belng investigated, both theoretically and experimentally. In particular, those conflgurations in which the Winslow forces may be considered equivalent to the Lorentz forces of magnetohydrodynamic flows are being considered in order to investigate the analogies between these two flows.

(5031) THE EFFECT OF SHEAR ON THE STABILITY OF LIQUID FILMS.

(b) Northwestern University.

c) Mr. Stephen Whitaker, Chemical Engrg. Dept., The Technological Inst., Northwestern UnIv., Evanston, Ill.

(d) Mathematical.

(e) The effect of shear on the stability of falling liquid films, and on Taylor instabllity is belng studled by means of a numerlcal solution of the orr-Sommerfeld equation.

(i) Completed.

(g) The effect of shear is stabilizing for Reynolds numbers less than forty.

(h) Thesis in preparation.
(5032) WAVE ENERGY DISSIPATION.

(b) Northwestem Technological Institute

(c) Prof. W. S. Hamilton, Dept. of Clvil Engrg., Northwestern Unlv., Evanston, Illinols.

(d) Theoretical and hopefully experimental for Ph.D. thesis.

(e) The purpose is to obtain useful expressions for the velocity profiles and shear profiles in the boundary layer next to a wall along which deep-water oscillatory waves are progressing.

(g) The work involving laminar boundary layers has been reviewed and expanded.

UNIVERSITY OF NOTRE DAME, Department of Civil Engrg.

(5175) CORIOLIS AND BOUSSINESQ CORRECTION FACTORS FOR AVERAGE VELOCITY.

(b) Laboratory project.

(c) Dr. S. Kolupalla, 1136 E. Corby Blvd., South Bend, Ind., 46617 .

(d) Applied research, partly used for master's theses.

(e) Correction factors, essential in the energy and impulse-momentum equations, depend on the velocity distribution across a current. The values of these factors are determined by mechanical integration of areas enclosed by 1sotachs. The investigation is carried out for natural channels, both open and unde lce cover, and for artificlal channels, open and closed.

(g) Some 300 proflles have been examined. The Corlolis factor in open channels varled between 1.07 and 1.96 , with an average close to 1.30 , under 1ce cover between 1.23 and 4.28 , with an average about 1.50 , in artiflclal channels and condults between 1.04 and 2.65, with an average of 1.15. These preliminary results are in good agreement with the previously suggested values.

(h) Publication is planned.

OHIO AGRICULTURAL EXPERIMENT STATION, Department of Agricultural Englneering

(5033) DRAINAGE INVESTIGATIONS FOR AGRICULTURAL LANDS.

(b) Ohio Agricultural Experiment Station in cooperation with the Agricultural Research Service.

(c) Mr. G. O. Schwab, 2073 Neil Ave., The Ohio State University, Columbus, Oh10 43210.

(d) Fleld investigation; applied research.

(e) Tile flow, surface munoff, water table levels, and crop yields are measured to evaluate varlous types of drainage systems and to develop improved engineering design criteria.

(g) Thirteen years of tile flow data, partial analyses completed; procedure developed for applying a theoretical equation to predict tile spacing from tile flow and water table helghts.

(h) "Tile Spacing Prediction Based on Drain outflow," by G. J. Hoffman and G. O. Schwab. Paper No. 63-707 presented at American Soclety of Agricultural Engineers meeting, Chicago, Dec. 1963.

"Tile and Surface Drainage of Clay Solls, 1. Hydrologic Performance with Grass Cover," by G. O. Schwab, et al., Ohio Agricultural Experiment Station Bulletin 935, Apr11 1963. "Hydrologic Characteristics of Tile and Surface Drainage Systems with Grass Cover," by G. O. Schwab and T. J. Thiel, American Soclety of Agricultural Engineers Transactions 6 (No. 2): 89-92, 1963.

"Rate, Duration, and Frequency of Tile Flow," by G. O. Schwab, J. L. Fouss, and A. P. Leed Agricultural Engineering 42:546-549,555, 1961 
OHIO AGRICULTURAL EXPERIMENT STATION, Department of A gronomy .

(5176) SOIL CHARACTERISTICS. AND SUBSURFACE DRAINAGE.

(b) Oh1o Agrlcultural Experiment Station.

c) Prof. George S. Taylor, Dept. of Agronomy, Oh10 State Un1v., Columbus 10, Ohio.

(d) Experimental investigation, applied research.

e) Numerical analysis solutions of soll moisture flow problems in subsurface drainage are made with digital computers. Steady-state and transient analyses are studied for various parameters of size, depth, and spacing of tile and ditch drains and of soll hydraulic conductivity. Hillside seepage problems are also evaluated. The principal objective is to interrelate the above factors in rational design of subsurface drainage systems.

(g) Characteristics of water flow into tile drains have been studied for layered soils. An analysis of hillside seepage into open ditches was made. Agreement between analytical and numerical analysis techniques was establ1shed.

(h) "The Use of Electron1c Computers to Solve Subsurface Drainage Problems," by George S. Taylor and J. N. Luthin. Hilgardia 34 (12): $534-558$, 1963 .

M.S. Thesis by Wm. Burke in 1961 on ponded flow into drains in layered soll. Ohio State Un1versity Library.

OKLAHOMA STATE UNIVERSITY, Agricultural Eng1neering Department.

(2365) HYDROLOGIC STUDIES ON SMALL GRASS-COVERED WATERSHEDS.

(b) Agricultural Experiment Station cooperative with Agricultural Research Service.

(c) Prof. F. R. Crow, Okla. State Univ., Dept. of Agricultural Engrg., St1llwater, Okla.

(d) Field investigation; applied research. hydrolog1c data on total watershed runoff and peak rates of runoff from three small grass-covered watersheds (17 to 206 acres) in north central Oklahoma. H1ghway culverts, modified by the addition of weir sills, are being used as runoff measuring devices.

(g) Intensive model tests of culverts equipped with weir sills completed. Ten year data on precipitation and runoff completed.

(2828) THE EFFECTIVENESS OF MONOMOLECULAR FILMS FOR REDUCING EVAPORATION FROM RESERVOIRS.

(b) Oklahoma Agricultural Experiment Station, cooperative w1th U. S. Bureau of Reclamation.

(c) Prof. F. R. Crow, Oklahoma State Univ., Dept. of Agricultural Engineering, St1llwater, Oklahoma.

(d) Experimental; applied research.

(e) Two paired plastic lined ponds, designed for evaporation research, are being used to study various aspects of evaporation reduction by monomolecular films. Apparatus has been developed for automatic application of hexaoctadecanol slurry. Present research is on the effects of wind on monolayers and development and testing of methods of alleviating adverse effects of wind.

(g) Evaporation reductions of 25 to $40 \%$ have been obtained in long duration tests using slurry method of applying films. Curves have been developed relating wind speed and required film application rate. In current research a system of floating barriers is used to confine the monolayer to reduce frequency of application. Various helght/ spacing ratios have been tested. The effect of the barriers, with and without monolayer, on evaporation is being studied.

(h) "The Effect of Wind on Evaporation Suppressing Films and Methods of Modification, "by F. R. Crow, Proceedings, XIII General Assembly, International Union of Geodesy and Geophysics, Publication No. 62, pp. 26-37, August 1963.
(3804) THE HYDRAULICS OF CONSERVATION CHANNELS.

(b) Agricultural Research Service, U.S. Dept. of Agriculture in cooperation w1th the Oklahoma Agricultural Experiment Station.

(c) Mr. W. O. Ree, Agr. Research Service, Soil and water Conservation Research Div. Southern Pla1ns Branch, St1llwater, Okla.

(d) Experimental; applied research.

(e) Vegetation lined waterways of the kind used to convey short duration flood flows from small watersheds are constructed full size on the grounds of an outdoor hydraulic laboratory. Flow tests are made on these experimental channels to determine the protective ability of various grasses and to evaluate the flow friction factors under different conditions of growth. Perennial and annual grasses for the temporary protection of newly constructed earth waterways are both considered in these studies. Temporary liners of various fibers including Jute, paper and glass are also tested.

(g) Manning's $n$ values have been determined for various grass species. The physical characteristics of the vegetation and the flow character both influence the flow retardance factor so special deslgn diagrams have been prepared to ald in solving flow problems under these conditions.

\section{(4676) THE HYDRAULICS OF OVERLAND FLOW.}

(b) Oklahoma Agricultural Experiment Station cooperative with Agricultural Research Service, U. S. Dept. of Agriculture.

(c) Dr. J. E. Garton, Oklahoma State Univ., Dept. of Agricultural Engineering, Stillwater, Okla. 74075 .

(d) Experimental; applied research.

(e) A study of the basic relationships involved in the hydraulics of overland flow. Now in its intial phase, the research is being done at the stillwater outdoor hydraulic lab. Test channels, $96 \mathrm{ft}$ long w1ll be subjected to simulated rainfall of various intensities and droplet sizes. The water surface profile will be studied for transient and equilibrium states for channels surfaced with cement mortar and also for earth channels vegetated with wheat.

(5177) AUTOMATION OF CUT-BACK FURROW IRRIGATION.

(b) Oklahoma Agricultural Experiment Station. Dr. James E. Garton, Oklahoma State Univ. Dept. of Agricultural Engineering, stillwaten Okla.

(d) Experimental and field investigation; applied research and design for thesis.

(e) The development of a system of cut-back furrow irrigation using level furrow outlet tubes with hooded inlets. The system will irrigate through the furrows at a design initial flow, cut-back to a design cut-back flow, and shut of $f$ by the simple removal of sheet-metal check dams. The purpose of the method is to improve the uniformity of furro irrigation and to drastically reduce the $h 1$ gh labor requirement.

(g) Discharge characteristics of various lengths, and diameters of short, level, galvanized p1pe w1th hooded inlets have been determined. Design procedures for applying the system to a particular design situation have been developed. Operating characteristics of a designed system have been calculated. A prototype system has been constructed. The automation of check dams is being initiated.

(h) "Automation of Cut-back Furrow Irrigation," by James E. Garton, E. P. Beasley, and A. D. Barefoot. Paper No. 63-719, presented to the 1963 Winter Meeting of the ASAE, Ch1cago, IIl.

OREGON STATE COLIEGE, Hydraulics Laboratory.

(3805) INVESTIGATION OF SUPERCRITICAL FLOW CHANNEL JUNCTIONS. 
(b) U. S. Dept. of Commerce, Bureau of Public Roads.

(c) Prof. C. E. Behlke, Dept. of Civ1l Engrg., oregon State University, Corvallis, oregon.

(d) Theoretical and experimental; applied research.

(e) Wave effects resulting from the function of two supercritical, open channel flows are being studied to determine the magnitude and the location of the wave plle up on the channel walls. only rectangular channels are presently being considered. Trapezoldal channels w1ll be considered later.

(g) The prediction of wall pile-up.

THE PENNSYLVANIA STATE UNIVERSITY, Hydraulics Laboratory, Department of Civil Englneering.

Inquiries concerning the following profects, should be addressed to Prof. Sam Shulits, Head, Hydraulics Laboratory, 212 Sackett Building, The Pennsylvania State University, University Park, Penna. 16802.

\section{(5178) MOOSIC FLOOD CONTROL PROJECT.}

(b) Pennsylvania Dept. of Forests and Waters.

d Experimental; design.

(e) Investigation of design of debris basin, paved channel, and channel outlet for the control of 1 in a 100 year design flood of $15,000 \mathrm{cfs}$, in a $1: 50$ model of 3400-foot supercritical-flow channel, with a transition between an upstream trapezoldal cross-section and a downstream rectangular cross-section. There are five bends in the channel.

(f) Completed.

(g) Modification of channel entrance shape; provision of adequate clearance under 3 existing bridges as safeguard against standing waves; design of warped transition.

(h) "H1gh-Veloc1ty Channel Model Studies," Engineering Research Bulletin B-83, May 1962; sllent f1lm, "Moosic Model Study".

(5179) SMALL SCALE STUDY OF BAR MIGRATION IN A STRAIGHT ALLUVIAL CHANNEL.

(b) Laboratory project.

(d) Experimental; applied research; for master's thesis.

(e) Fel1x Exner reported in 1925 small rivermodel studies of changes in channel width and talweg location and found that quasi-stable conditions are to be expected in curved rather than stralght channel, and that the smaller the degree of curvature the less stable $1 \mathrm{~s}$ the talweg. Since Exner's real1stic, but qualitative results had apparently never been verified, a duplicative study seemed warranted, particularly to determine an experimental technique.

The experimental flume, 7 feet by 2 feet, was fed sand thru a vibrating trough. A channel, 2 Inches wide and $7 / 8$ inch deep was molded into the sand bed. The water discharge was about 0.006 cis for sand discharges from 1.2 to 2.4 lbs. per hour. Only one sand was used, with a geometric mean diameter of 0.0145 inches and a standard deviation from the geometric mean equal to 1.45 .

(f) Suspended.

(g) Exner's findings regarding bar migration in a stralght channel were substantiated but some improvements in the experimental technique are indicated. The results were consistent enough to foster hope for a quantitative application.

(h) "Small Scale Study of Bar Migration in a Straight Alluvial Channel," by D. E. Westfall, Master's thesis, March 1962, Pattee I1brary, The Pennsylvania State University.

(5180) DESIGN OF SMALI WATER TUNNEL AND ITS USE IN EVALUATING SURFACE ROUGHNESS EFFECTS ON CAVITATION

(b) Mob1l Petroleum Company, and ordnance Research Laboratory, The Pennsylvania State University. (c) Dr. G. F. Wislicenus, Director, Garfield Water Tunnel, ordnance Research Laboratory, The Pennsylvania State University.

(d) Experimental; applied research; doctoral research.

(e) Purpose: To design and erect a water-tunnel with 6-inch diameter test section and to study the effect of surface roughness or cavitation with $3 / 4-1$ nch diameter stainless steel noses having 1.5 caliber ogive, hemispherical and blunt profiles. The first roughness was finished smooth by polishing the second type was produced by sand blasting and two other roughness were made by blasting with steel shot.

(f) Suspended.

g) The incipient and desinent cavitation numbers increase as surface roughness increases. There is a difference between these two numbers for all roughnesses, the difference becoming greater as the surface become rougher. Higher air contents produce higher cavitation numbers, with the effect of air content belng less pronounced as the surface became rougher.

(h) "The Design of a Small Water Tunnel and Its Use in Evaluating Surface Roughness Effects on Cavitation," by Ken Kaku, September 1962. Limited number of coples available from Garfield Water Tunnel or Hydraulics Laboratory.

(5181) ROUGHNESS COEFFICIENTS OF COBBLE-STREWN STREAMS.

(b) Laboratory project.

(d) Experimental; applied research; doctoral thesis.

(e) Purpose: To provide a quantitative means of determining Manning's " $n$ " or the coefflc1ent $\mathrm{K}$ in $\mathrm{V}=\mathrm{KR} 273 \mathrm{~S} / \mathrm{2}$ in cobble-strewn streams, particularly for use in the slope-area method of computing flood discharge. In a t1lting flume, $5.5 \mathrm{ft}$. wide, $1 \mathrm{ft}$. deep and 53 feet long, 11 roughness patterns were created w1th 6-1nch and 3.75-1nch concrete cubes. Maximum discharge was $5 \mathrm{cfs}$, corresponding to a small stream.

(g) Systematic relationships exist among the roughness coefficlent, Reynolds and Froude numbers, and a special quantitative parameter of the roughness pattern. The measurements with the two sizes of cubes could be related through the Froude similitude law. Since the roughness shape did not seem so far to be 1mportant, the findings should be applicable to larger blocks or boulders.

(h) "Roughness Coefficients of Cobble-Strewn Streams--Part A--Cubical Roughness Elements 1n Transverse Rows--Symmetr1 $\mathrm{c}$ and Random Patterns for Low Flows," by John B. Herblch and Sam Shul1ts; Hydraulics Laboratory Bulletin, December 1963.

(5182) TRANSITIONS IN SUPERCRITICAL FLOW.

(b) Pennsylvania Department of Forests and Waters.

(d) Experimental; applied research, design.

(e) Purpose: To investigate supercritical flow phenomena in open-channel transitions between an upstream trapezoldal crosssection and a downstream rectangular section. Three types of transition, one warped and two composed of plane walls, are being tested, each in at least 3 different lengths. The experimental channel rests on a tilting platform, $54 \mathrm{ft}$. long. Froude numbers up to 3 have been tested so far. Design criterla will be determined first and then a theoretical approach w1ll be sought.

(g) Analysis in progress.

(5183) STUDY OF EXNER EROSION EQUATIONS BY MEANS OF THE IBM 7074 ELECTRONIC DIGITAL COMPUTER.

(b) Laboratory project.

d Theoret1cal; bas1c research.

(e) In the 1920's Felix Exner postulated equations 
for the shape and movement of sand dunes in channels of constant and changing width, and for bank erosion. The dune and bank forms are so similar to real rivers that their usefulness in predicting bed forms is being studied with the IBM 7074 electronic digital computer. Currently Exner's charts are being checked.

THE PENNSYLVANIA STATE UNIVERSITY, Institute for Sclence and Engineering, Ordnance Research Laboratory, Dr. John C. Johnson, Director. Work done under Dr. G. F. Wislicenus, Director of the Garfield Thomas Water Tunnel.

(2832) MEASUREMENT OF FORCES ON A MODEL IN A WATER TUNNEL.

(b) Laboratory project sponsored by the Bureau of Naval Weapons.

(c) Mr. George B. Gurney, ordnance Research Laboratory, University Park, Penna.

(d) Experimental; developmental.

(e) The problem concerns the measurement of forces on models in a water tunnel over a velocity range up to 80 feet per second, pressure ranges of 3 to 60 pounds per square inch absolute.

(g) Two four component (lift, axial force, pitching and rolling moment) balances for use in water tunnels utilizing strain gaged pre-tensioned flexure beams as the force sensing devices have been in successful operation for four years. A Planar Motion Mechanism capable of imparting pitching and heaving motions to models is now under construction and should be in operation in March of 1963. The balance assolcated with this mechanism will measure all the hydrodynamic stability coefficlents required in the equations of motion for a submerged body with four (4) degrees of freedom. These equations include the static, damping and acceleration derivatives. A balance which will measure unsteady forces on propulsors has been developed and successfully tested.

(3143) REDUCTION OF SKIN FRICTION DRAG.

(b) Jolnt program of investigation with the General Electric Company, the United States Rubber Company and the Northrop Corporation sponsored by the Bureau of Naval Weapons.

(c) Dr. John Lumley and Mr. John McMahon, Ordnance Research Laboratory, Un1versity Park, Pennsylvania.

(d) Experimental, basic research; theoretical and applied research.

(e) Investigations into the application of boundary layer control through suction and compliant surfaces for underwater bodies.

(g) A theoretical analysis of the mechanism by which an admissive boundary may reduce the skin friction has been completed.

Experimental measurements of boundary layer transition and thickness aft of the transition have been made for a number of flat plates which were covered with a compliant surface.

(3486) TURBULENCE MEASUREMENTS IN WATER.

(b) Laboratory project sponsored by the Bureau of Naval Weapons.

(c) Dr. John Lumley, ordnance Research Lab., University Park, Pennsylvania.

(d) Experimental.

(e) Using a constant temperature probe, some turbulent flows at high Reynolds numbers will be investigated with particular attention to homogeneous grid-produced turbulence and

(g) turbulent dispersion in a shear flow. Measurements have been taken in a small water tunnel settling section determining the effect of various screens and honeycombs
(3487) FLOW DISTORTION FEEDING INTO A PROPELLER.

(b) Laboratory project sponsored by the Bureau of Naval Weapons.

(c) Mr. J. J. Eisenhuth, Ordnance Research Lab., University Park, Pennsylvania.

(d) Theoretical and experimental.

(e) This is a study of the interaction effects between control surfaces and a propeller when the surfaces are located in front of the propeller and feed a distorted flow into 1t. The primary goal is to determine how effectively the propeller cancels the forces produced by the control surfaces.

(f) Completed.

(g) In solution of the problem actuator disc theory is used and reduced to a boundary value problem by linearizing the equations of motion and continuity. The theory is shown to be useable and it is supported by experimental results.

(h) "Propellers with Distorted Inflow," by J. J. E1senhuth, Ph.D. Thesis, Dept. of Aeronautical Engineering, The Pennsylvania State University, June 1963.

(3488) FLOW OVER A BODY OF REVOLUTION WITH STABILIZING SURFACES.

(b) Laboratory project sponsored by the Bureau of Naval Weapons.

(c) Mr. E. J. Rodgers, ordnance Research Lab. University Park, Pennsylvania.

(d) Theoretical and experimental.

(e) This study is directed toward the understanding of the flow conditions around a body of revolution with stabilizing fins under conditions of pitch and/or yaw. The eventual goal is to be able to predict more precisely the hydrodynamic coefficients of such a body by virtue of a better understanding of the flow conditions.

(g) Velocity components have been obtained for a slender body of revolution and a comparison has been made with potential theory.

(h) "Real Flow Over a Body of Revolution at Angle of Attack," by E. J. Rodgers, Ph.D. Thesis, Dept. of Engineering Mechanics, The Pennsylvania State University, March 1963.

(3807) INVESTIGATION OF THE CAVITATION CHARACTERISTICS OF A FEW SIMPIE LIQUIDS.

(b) Laboratory project sponsored by NASA.

(c) Dr. J. William Holl, ordnance Research Lab., University Park, Pennsylvania.

(d) Experimental, analytical; basic research.

e) To investigate experimentally the cavitation characteristics of a few simple (as regards to vapor pressure and handling) liquids under conditions occurring in space and alrcraft pumping machinery, and analyze the results so that a rellable basis for theory applicable to these conditions can be formulated.

A small high speed water tunnel having test section velocities of 370 feet per second, pressures to 1000 pounds per square inch, temperatures to 300 degrees Fahrenhe1t, has been constructed and has been in operation since April of 1962.

(g) Investigations of desinent cavitation at very high velocities on $1 / 4$ inch diameter ogive noses indicates that the desinent cavitation number approaches the minimum pressure coefficient. Studies of cavitation hysteresis on ogive noses show that the cavitation delay time is a random function and is of significant duration e.g. 3 to 4 minutes.

(4180) UNSTEADY FLOW INVESTIGATIONS AROUND AN ELIIPSOID OF REVOLUTION.

(b) Laboratory project sponsored by Bureau of Naval Weapons.

(c) Mr. Maurice Sevik, Ordnance Research Lab., University Park, Pennsylvania.

(d) Experimental and theoretical. 
(e) A study of unsteady forces acting on an ellipsoid of revolution over a range of Reynolds numbers and body attack angles.

(i) Completed.

(g) A theoretical and experimental investigation of the lift and moment on an 8/1 ellipsoid of revolution performing small oscillations in a direction normal to the free stream has been carried out. The maximum circulatory lift coefficient is about half that obtained in steady flow. A phase $l a g$ of 20 degrees in bulld-up of lift was observed. The maximum pitching moment is reduced by 16 percent from that predicted by potential theory.

(h) "The lift on an Oscillating Body of Revolution," by Mr. M. S. Sevik, Ph.D. Thesis, Department of Engineering Mechanics, The Pennsylvania State UnIversity, May 1963.

(4181) DETERMINATION OF EFFECT OF TUNNEL BOUNDARIES ON THE FORCES ACTING ON A MODEL.

(b) Laboratory project sponsored by Bureau of Naval Weapons.

(c) Mr. Thomas Pelrce, Ordnance Research Lab. University Park, Pennsylvania

(d) Theoretical and experimental.

(e) Investigation of the errors introduced by the physical boundaries of tunnel walls on the measured forces on large models. The investigation covers both the axially symmetric case and when the models are at low angles of attack. Establishing the means for correcting these errors is also a part of this investigation.

(g) A method has been developed for the prediction of errors in drag caused by watertunnel wall deviations. It 1 s shown that small deviations in contour can cause a significant error in model drag measurements. Tunnel wall interference effects on model pitching moment have been investigated and a correction procedure established for models of low attack angle and dlameters up to $1 / 3$ tunnel diameter.

(h) "Tunnel Wall Interference Effects on the Drag and P1tching Moment of an Axisymmetric Body, by Mr. Thomas E. Peirce, Ph.D. Thesis, Dept. of Engineering Mechanics, December 1963.

(4677) THE TNVESTIGATION OF TWO-DIMENSIONAL UNSTEADY CAVITY FLOWS ABOUT FIXED SYMMETRIC BLUFF BODIES.

(b) Laboratory project sponsored by Bureau of Ships, David Taylor Model Basin.

(c) Dr. J. William Holl, Ordnance Research Laboratory, University Park, Penna.

(d) Experimental and theoretical

(e) An investigation of the wake region behind supercavitating, two-dimensional wedges at zero degrees angle of attack is in progress with the purpose of determining the wake characteristics, in particular the Strouhal number as a function of Reynolds number, cavitation number and wedge apex angle.

(4678) HYDRAULIC SERVOMECHANISM FOR AN UNDERWATER MISSILE.

(b) Laboratory project sponsored by the Bureau of Naval Weapons and conducted under Dr. C. L. Key, Asst. Director, Ordnance Research Laboratory.

(c) Messrs. H. M. Jensen and R. E. Kershaw, ordnance Research Laboratory, University Park, Pennsylvania.

(d) Experimental, applied development and design.

(e) A high-performance hydraulic servomechanism for control of rudders and elevators in an underwater missile system. Speciflc design problems were instability caused by a resonant linkage and high-frequency oscillation of the servovalve.

(g) Stability was achieved by increasing the resonant frequency of the linkage, providing hydraulic damping with a bypass orifice, and lag-lead phase compensation in the servo amplifier. The high-frequency oscillation was eliminated by increasing the diameter of activator ports.

\section{(5106) MEASUREMENT OF LIQUID TENSIONS.}

(b) Laboratory project sponsored by NASA.

c) Dr. J.W1lliam Holl, Ordnance Research Laboratory, University Park, Penna.

(d) Experimental, analytical; basic research.

(e) To investigate experimentally tensions in liquids in the static state and compare these measurements with liquid tensions encountered in a flowing system.

(5107) INVESTIGATION OF THE KUTTA CONDITION IN UNSTEADY FLOW.

(b) Laboratory project sponsored by Bureau of Naval Weapons.

(c) Dr. Maurlce Sevik, Ordnance Research Laboratory, University Park, Penna.

(d) Experimental, theoret1cal; basic research.

(e) The validity of the Kutta-Joukowski criterion is being investigated for the prediction of control surface hinge moments in steady flow, or instantaneous forces on rapidly oscillating air and hydrofolls.

(5108) JET INSTABILITY IN MERCURY.

(b) Laboratory project sponsored by Bureau of Naval Weapons.

(c) Dr. David P. Hoult, Ordnance Research Laboratory, University Park, Penna.

(d) Experimental and theoretical; basic research. mercury into mercury in the presence of a magnetic field. The magnetic field acts to stabilize the jet and thus control the rate of amplification of unstable oscillation. The experimental findings are then to be compared with appropriate small disturbance theory in an effort to further understand the instability of jets.

(5109) INSTABILITY REYNOLDS NUMBERS FOR FLOW OVER A FLAT PIATE WITH RANDOM ROUGHNESS.

(b) Laboratory project sponsored by the Bureau of Naval Weapons.

(c) Dr. John L. Lumley, Ordnance Research Laboratory, University Park, Penna.

(d) Theoretical.

(e) The purpose is to determine why a rough surface affects the Reynolds number at which a laminar boundary layer becomes unstable. of particular interest is the dependence upon the nature of the roughness. The work has direct application to maintenance of laminar flow on moving submerged bodies.

PRINCETON UNIVERSITY, School of Engineering and Applied Science.

(5184) FALI OF A SPHERE IN A HORIZONTALLY OSCILLATING FLUID.

(b) Laboratory project.

(c) Prof. Lucien M. Brush, Jr., Dept. of Civil Engineering, Princeton University, Princeton, N. J.

(d) Analytical and experimental, basic research, master's thesis.

(e) The purpose of this research is to predict the temporal mean fall velocity of a spherical particle falling in a horizontally oscillating fluid. An analytical solution was derived for particles with a small (0.1) Reynolds number. A numerical solution is possible for large Reynolds numbers. Expertmental verification of the appropriate equations is the purpose of the study. The results will be applicable to problems involving turbulent diffusion of sediment.

(5185) DYNAMIC STORAGE OF GROUNDWATER.

(b) Laboratory project. 
(c) Dr. R. J. DeWtest, Assoc. Prof. of Civil and Geological Engineering, Princeton University, Princeton, New Jersey.

(d) Analytical and experimental, basic research, master's thesis.

(e) Purpose of the research is to investigate the dynamic behavior of a groundwater basin intersected by streams and from which water is withdrawn at a time dependent rate. An electric analog model (R-C) will be constructed.

(h) Preliminary steady state study was published In the Journal of the Hydraulics Division, American Society of C1v1l Engineers, Nov. 1963 "Replenishment of Aquifers Intersected by streams," pp. 165-191, avaliable from the American Society of Civil Engineers.

(5186) MEASUREMENT OF UNSTEADY PRESSURES.

(b) Laboratory project.

(c) Prof. C. P. KIttredge, Dept. of Aerospace and Mechanical Sciences, Princeton University; Princeton, N.J.

(d) Theoretical and experimental.

(e) The differential equations of motion for a simple manometer system with non-linear damping have been programmed for an IBM 7094 data processing system. An experimental program to check the computation is planned.

PURDUE UNIVERSITY, Department of Agricultural Engineering.

(2596) THE USE OF A RAINFALL SIMUIATOR FOR SOIL AND WATER MANAGEMENT STUDIES.

(b) Soll and Water Conservation Research Div. Agricultural Research Service, USDA and Purdue University. (See Agricultural Research Service, Corn Belt Branch, Project No. 4276).

(c) Mr. L. Donald Meyer, ARS-SWC, Agricultural Engineering Department, Purdue University, Lafayette, Indiana.

(d) Field investigation; applied research.

(e) The rainfall simulator is used on munoff plots for comparison of treatments which effect erosion and infiltration. Research includes studies of tillage methods, crop residue management, slope, sol1 type, crop rotations, and intensity histograms.

(h) "The Effects of Various Rates of Surface Mulch on Infiltration and Erosion," by J. V. Mannering and I. D. Meyer, Soll Sci. Amer. Proc. 27: 84-86, 1963.

"Philosophy and History of Simulated Rainfall for Erosion Control Research," by L. D. Meyer, ASAE Paper No. 63-724, 1963.

"Construction and Operation of a 16-Unit Ra1nulator," by L. F. Hermsmeier, I. D. Meyer, A. P. Barnett, and R. A. Young, ARS 4l-62, USDA, March 1963.

(2837) TREATMENT OF SURFACE WATERS FOR DOMESTIC USE ON THE FARM.

(b) Laboratory project.

(c) Dr. E. J. Monke, Agricultural Engineering Department, Purdue University, Lafayette, Indiana.

(d) Field investigation; applied and basic research.

(e) The treatment of pond water by use of slow sand and diatomaceous earth filters is being evaluated. Improved designs are under investigation. The effects of algae growth and coagulation-sedimentation methods on filtration processes are belng studied.

(3490) INVESTIGATION OF FLOW CHARACTERISTICS IN DRAIN TILE AND THE RELATIONSHIP OF THESE FLOW CHARACTERISTICS TO SEDIMENTATION.

(b) Laboratory project.

(c) Mr. L. F. Huggins, Agricultural Engineering

(d) Experimental; basic research. (e) An investigation into the hydraulic behavior of flow in a steep drain has been completed. Equipment is being built for studylng the effects of introducing sediment into the flow.

(h) "Model Study of Flow in Steep Tile Drains," by $W . D$. Lembke, J. W. Delleur, and $E . J$. Monke, Trans. ASAE, Vol. 6, No. 2, 1963.

(3808) DEVELOPMENT AND REFINEMENT OF METHODS FOR ESTIMATING FTELD RUNOFF AND SOIL LOSS.

(b) Soll and Water Conservation Research Div. USDA, and Purdue University. (See Agri. Research Service, Corn Belt Branch, Project No. 4274).

(c) Mr. Walter H. Wischmeier, ARS-SWC, Agric. Engineering Dept., Purdue Univ., Lafayette, Indiana.

(d) Experimental; development.

(e) The relationships of numerous rainstorm characteristics, topographic features, soll characteristics and surface conditions to fleld runoff and soil erosion are being evaluated from plot data obtained under natural and/or simulated rainfall. Basic plot and small watershed data on an individual storm basts have been assembled in an ARS central munoff and soll-loss data lab. at Purdue Univ., from 24 states. The data represent results of cooperative research studies over the past 32 years at 47 locations.

(g) Physical and management factor relationships that influence soil erosion, as empirically evaluated from the assembled data and combined in a soll-loss prediction equation, were sumarlzed for publication as a USDA. Handbook, "Estimating Water-Erosion Losses from Farm Land to Guide the Planning of Farms for soll and Water conservation". Information needed to derive locational values of the pertinent factors for use of the equation was included in the pending publication in ready-reference form. This compilation will facilitate use of the results of 30 years of erosion research anywhere in the agricultural regions of the United states.

(h) "Soll-Erodibility Evaluations for solls on the Runoff and Erosion Stations," by T. C. Olson and W. H. Wischmeler, Soll Scl. Soc. Amer. Proc. 27:590-592, 1963.

(4182) THE MECHANICS OF EROSION BY RAINFALL AND RUNOFF.

(b) Soll and Water Conservation Research Div., Agricultural Research Service, USDA and Purdue University, (See Agricultural Research Service, Corn Belt Branch, Project No. 4275.)

(c) Mr. L. Donald Meyer, ARS-SWC, Agricultural Englneering Department, Purdue University, Lafayette, Indlana.

(d) Experimental; basic research.

(e) The influence of slope inclination, slope length, particle size, particle shape, and wind velocity on the resulting splash and munoff erosion are being investigated in the laboratory. Methods for simulating rainfall, slope length, soll and wind have been developed. This study is providing an understanding of the mechanics of the process Involved in erosion and the basic relationships of the above variables.

(h) "Simulation of Rainfall and Soils for Laboratory Research," by G. D. Bubenzer and L. D. Meyer, ASAE Paper No. 63-729, 1963.

(4183) SUBSURFACE DRAINAGE OF BLOUNT SIIT LOAM.

(b) Laboratory project.

(c) Dr.E.J. Monke, Agricultural Engineering Department, Purdue University, Lafayette, Indiana.

(d) Field investigation; applied research

(e) Various spacings between parallel subsurface drains are under investigation to determine their effectiveness in water removal and 
crop response. Continuous records of tile discharge are being made and crop yields are determined at harvest time.

(4681) EVALUATION OF PLASTIC-LINED MOLE DRAINS AND INSTALIATION EQUIPMENT IN MUCK SOILS.

(b) Soll and Water Conservation Research Div. USDA, and Purdue University. (See Agri. Research Service, Corn Belt Branch, Project No. 4271).

(c) Dr. E. J. Monke, Agricultural Engineering Department, Purdue University, Lafayette, Indlana.

(d) Field investigation; applied research.

(e) The primary purpose of this investigation is to determine the stability with time of various cross-sectional types of plasticlined mole drains in muck soll. Secondary objectives are concerned with the improvement of the installation equipment.

(g) Faliures were noted with all of the crosssectional types of plastic-lined mole drains. The drain with interlocking edges stood up best. The causes of fallure were due to a shallow installation depth, vertical misalignment, and the fluidity of the soil in the upper profile.

PURDUE UNIVERSITY, Department of Agronomy.

(4186) MECHANISMS OF HYDRAULIC CONDUCTIVITY DECREASE IN WATER-SATURATED SOILS.

(b) Laboratory project and Purdue Research Foundation.

(c) Dr. Dale Swartzendmuber, Department of Agronomy, Purdue University, Lafayette, Ind.

(d) Experimental; basic research for Ph.D. thesis.

e) The effect of gases on the hydraulic conductivity of porous media was studied for air and methane. The presence of entrapped air was determined with a compression technique.

(f) Completed.

(g) A sensitive compression technique, utilizing the travel of a mercury droplet in a capillary tube, was used to study the entrapped air content of near-saturated quartz sand through which water and phenol solution were flowing. The compression technique was found to be an extremely sensitive qualitative indicator of entrapped a1r, but attempts to make the technique quantitative with respect to the actual volume of entrapped air were not successful. Nevertheless, the compression technique demonstrated that entrapped air was continually removed from the sand during prolonged flow, if bolled delonized water was used elther as the flow liquid or to make the phenol solution used as a flow liquid. This conflrms earlier conclusions reached in this laboratory -- that orders-of-magnitude decreases in hydraulic conductivity during prolonged water flow through quartz sand were caused by bacterial growth, and not by an accumulation of entrapped a1r.

Flow studies involving quartz sand and a flow solution consisting of methane dissolved in bolled delonized water showed that the dissolved methane did not reduce the hydraulic conductivity of the sand.

(h) "Entrapped Air Content and Hydraulic Conductivity of Quartz Sand During Prolonged Llquid Flow," by R. P. Gupta and D. Swartzendruber, in press Soll Sc1. Soc. Am. Proc. 28 , Mar.-Apr., 1964.

"Possible" Role of Methane in Affecting the Hydraulic Conductivity of Quartz Sand, "by D. Swartzendmuber and R. P. Gupta, in press Soil Sc1. 98, Sept., 1964.

(4679) FLOW IAWS FOR THE MOVEMENT OF WATER IN SOIL.

(b) Laboratory project.

(c) Dr. Dale Swartzendmuber, Department of Agronomy, Purdue Univ., Lafayette, Indiana.

(d) Experimental and theoretical; basic for Ph.D. thesis. (e) The validity of basic equations for water relationships in soll, such as Darcy's proportionality and Buckingham's capillary potential function, is being tested under various circumstances. Revised equations and mathematical solutions for deviating behavior are also being sought.

(g) The pressure-plate outflow method of measurth capillary conductivity and diffusivity of soll water has been used on two types of nonswelling porous materials. Determinations have been made for applied pressure steps ranging from 25 to $400 \mathrm{mb}$. Preliminary analyses of the data indicate that certain basic assumptions in the mathematical outflow solution are not met in the actual physical systems when the pressure step becomes small. Yet, 1 t $1 \mathrm{~s}$ only for small steps that the mathematical solution itself is applicable to actual physical systems. Also, the capillary conductivity and diffusivity, as measured by the pressureplate method, show erratic behavior when considered as functions of molsture content, depending on the size of pressure step. These anomalies will be studied further, to ascertain their causes.

(h) "Non-Darcy Behavior and the Flow of water in Unsaturated Solls," by D. Swartzendmuber, Soll Sc1. Soc. Am. Proc. 27:491-495, 1963.

PURDUE UNIVERSITY, Chemical Engineering Department.

(4188) SAMPLING OF HETEROGENEOUS FLUIDS IN FLOW.

(b) American Petroleum Institute

(c) Mr.J.H. Rushton, School of Chemical Engineering, Purdue University, Iafayette, Indiana.

(d) Both an experimental and theoretical project. Essentially an experimental project to which basic fluid mechanics is applied. Proposals are now being formulated to specify accurate sampling methods in commercial type operations.

(e) The work is for the purpose of developing methods whereby the accuracy of sampling can be maximized for heterogeneous materials flowing through pipe lines. The flowing fluids handled contain immiscible solids and liquids. Work is done in several sizes of pipes so that scale-up information w1ll be available.

(f) Experimental work is completed and final reports and a paper for publication are being prepared.

(g) Isokinetic sampling is to be recommended and the point at which a sample is to be withdrawn from a flowing stream will be specified. The relation between the composition of a sample drawn from one point and the average composition of the flowing stream has been determined for a wide range of flow velocities. Both solid and liquid particles have been used experimentally. A natural occurring cmude oll has also been used. A relation has been developed between a simple technique for determining setting velocity and the distribution of particles over the cross section of the flowing stream in a horizontal pipe.

(h) Six Master Degree theses have been written but as yet none of the work has been published. The published work will first be presented for the entire project by the American Petroleum Institute.

PURDUE UNIVERSITY, School of C1Vil Engineering.

(2839) HYDRAULICS OF RIVER FLOW UNDER ARCH BRIDGES.

(b) State Highway Department of Indiana and Bureau of Public Roads.

(c) Dr. J. W. Delleur, Hydromechanics laboratory, School of Civil Engineering, Purdue Univ., Lafayette, Indiana. 
(d) Experimental; for master theses and design manual.

(e) The purpose of the research is to study systematically the hydraulic efficiency of waterways under arch bridges, to provide a criterion for determining the proper clear span of arch bridges so as to compensate for the loss of efficiency at high flows, to pro. v1de a method for computing the backwater upstream of arch bridges and to provide a method of indirect flood discharge measurement from high water marks observations.

(g) A method for the determination of backwater has been obtained for single span arch bridge constrictions. The effects of various constriction geometries have been considered. The following factors were investigated: The amount of contraction, the length of the contraction, the effeot of wingwalls, skew and eccentricity. Dual bridges, two span bridges, and arch segment bridges were also investigated. The effect of bridge submergence was studied. A program of fleld verification is in progriss.

(h) "Hydraulics of Submerged Arch Bridges," by o. E1ker1, M.S. Thesi's, January 1964.

(2840) MECHANISM OF TURBULENCE IN FREE SURFACE FLOW.

(b) Purdue Research Foundation and National Sclence Foundation.

(c) Dr. J. W. Delleur and Dr.: G. H. Toebes, Hydromechanics Laboratory, Civil Engineering, Purdue University, Lafayette, Ind.

(d) Theoretical and experimental for Ph.D. thesis. Experimental and theoretical studies of: (a) Boundary layer development in free surface flow with applications to channel conveyance, alr-entrainment and flow measuring stmuctures; (b) Secondary flow development in free surface flow with applications to channel conveyance, polutant dispersion and sedimentation problems. Studies based on mean velocity and turbulert velocity component data.

(g) Improvements and evaluation of hot-w1re anemometer equipment for liquids. Original turbulence data and their analysis for the flow establishment reach in an open channel of moderate aspect ratio.

(h) "Boundary Layer and Secondary Current Development in Free surface Flow," by $S$. Sumawiganda, Ph.D. thes1s, August, 1963.

(2841) HYDROLOGY OF SMALI WATERSHEDS IN INDIANA.

(b) State H1ghway Department of Indiana and Indiana State Flood Control and Water Resources Commission.

(c) Dr. J. W. Delleur, Hydromechanics Laboratory, School of C1vil Engineering, Purdue Univ. Lafayette, Ind.

(d) Analysis and field investigation for Ph.D. thesis.

(e) The purpose of the research is to study the hydrology of watersheds less than 200 square miles throughout the State of Indlana to improve the existing methods for estimating the munoff from these watersheds and to 1mprove the existing methods of design of highway drainage structures servicing small watersheds.

(g) Peak discharges were analyzed stat1st1cally and a correlation was obtalned between the 25 year peak discharge and geomorphological character1 stics of the watersheds. Peak discharges for other frequencles may also be obtained. A synthetic design hydrograph was developed on the basis of the instantaneous hydrograph theory. The hydrograph is determined by two parameters which have been related statistically to geomorphological characteristics of the watershed. The theory of overland flow has been investigated from a hydrodynamics standpoint.

(h) "Design Hydrographs for Small Watersheds in Indiana," by I. P. Wu, ASCE, Journal of the Hydraulics Division, Vol. 89, No. HY6. "Hydrology of Small watersheds in Indiana and Hydrodynamics of Overland Flow," by I. P. Wu, Jolnt H1ghway Research Project, Rept. No. 15, July 1963 .

\section{(4191) MEANDER FLOOD PLAIN MODEL.}

(b) Engineering Experiment Station; Purdue Research Foundation; Agricultural Research Service.

(c) Dr. G. H. Toebes, Hydromechanics Laboratory, School of Clvil Engineering, Purdue Univ.

(d) Analytical and experimental research for Ph.D. thesis.

(e) A 5- x 30-foot styrofoam meander-flood plain model is bullt with adjustable slope, side walls and channel dimensions. Flow visualization equipment and a directional prandtl tube are in use. Both stage-discharge relations as well as internal flow fleld characteristics are being investigated.

(g) The literature concerning meander mechanisms has been reviewed. Several experimental stage-discharge relations are ava1lable. Internal characteristics of flow field have been determined for a number of cases. Implications of findings to basic facets of the meander problem, to flood routing and to river 1mprovements studies have been formulated.

(h) "The Flow in a Meander-Flood Plain Geometry," by A. A. Sooky, Ph.D. thesis. "The Hydraulics of Meandering Rivers with Flood Plains," by G. H. Toebes and A. A. Sooky, Hydromechanics Laboratory, Purdue UnIversity, Technical Report No. 9.

(4685) DEVELOPMENT OF THE FREE SURFACE FOR FLOW AROUND PILING.

(b) School of C1vil Englneering, Purdue Univ.

(c) Dr. M. E. Harr, School of Civil Engrg., Purdue Un1v., Lafayette, Indiana.

(d) Experimental and theoretical for M.S. Thesis,

(e) The study is almed at the development of a rational method of determining the locus of the free surface for flow around piling and thus permit more reliable estimates of factors of safety with respect to piping.

(f) Completed.

(E) Approximate methods of solution were developed whereby one can predict with some degree of rellability, the location of the free surface and the quant1ty of seepage for homogeneous earth structures founded on Impervious bases with vertical cutoff walls. The accuracy of the methods depend upon the positioning of the cutoff.

(h) Submitted to RIIEM at Paris meeting April, 1964 .

\section{(5110) HOT-WIRE PHYSICS IN LIQUIDS.}

(b) Purdue Research Foundation.

c) Dr.J. W. Delleur, Hydromechanics Laboratory, School of Clvil Engineering, Purdue Univ., Lafayette, Ind.

(d) Theoretical and experimental for Ph.D. thesis

(e) The purpose of this research is to invest1gate the heat transfer characterlstics of hot wires in liquids, to determine their sensitivity to fluctuations of velocity, temperature and flow direction, and to arrive at an understanding of the physical causes of their limitations.

(g) System response equations have been formulated and determination of necessary empirical constants is 1ts purpose. Equipment for the necessary experimental work for checking theory is operat1ve.

(5111) HYDROELASTIC STRUCTURING OF SEPARATED FLOW AND WAKE TURBULENCE.

(b) Purdue Research Foundation.

(c) Dr. G. H. Toebes, Hydromechanics Laboratory, School of C1vil Engineering, Purdue Univ., Lafayette, Ind.

(d) Analytical and experimental for Ph.D. thesis.

(e) Analytic and experimental study aimed at correlating the hydroelastic loading of structural components and the turbulent structure of the generated wake and separating boundary layers.

(g) Force, displacement and wake turbulence measurements are being made for varlety of 
cylindrical components and plate-like structures. Reduction of data by means of spectrum analysis equipment.

\section{(5112) TURBULENCE MEASUREMENTS IN LIQUIDS.}

(b) David Taylor Model Basin, Dept. of the Navy.

c) Dr. G. H. Toebes, Hydromechanics Lab., School of Civil Engrg., Purdue Univ., Lafayette, Ind.

(d) Theoretical and experimental; for Ph.D. theses. Analytic and experimental investigations aimed at optimization of turbulence measurements in liquids using hot-wire anemometer equipment and to compare performance characteristics of hot-wire equipment with hot-film thermistor, electro-magnetic and pressure transducers.

(g) System response characteristics are being studied. Special calibration and test eqipment has been designed. Collecting of liquid anemometry data is in progress.

PURDUE UNIVERSITY, School of Electrical Engineering.

(4499) AN INVESTIGATION OF PULSE WIDTH MODULATED HYDRAULIC CONTROL SYSTEMS.

(b) Laboratory project.

c) Dr.J.E. Gibson, School of Elec. Engrg., Purdue Univ., Lafayette, Ind. 47907.

(d) Experimental and analytical investigation; basic research.

(e) Experimental work is being conducted to investigate the feasibility of a new type of pulse width modulating valve. In addition, some analytical work has been done to study the use of a pulse width modulated valve in a dual mode hydraulic servo.

(g) Some analytical results have been obtained in which mathematical models for the pulse width valve system have been derived. A method for estimating transient responses of a system with coulomb friction has been developed.

PURDUE UNIVERSITY, Jet Propulsion Center.

(2374) MASS TRANSFER IN TWO-PHASE ANNULAR FLOW OF IIQUIDS IN A VERTICAL TUBE.

(b) National Science Foundation.

c) Dr. M. J. Zucrow, Jet Propul sion Center, Purdue University, Lafayette, Indiana.

(d) Experimental and theoretical; basic research for $\mathrm{Ph} . \mathrm{D}$. degree.

(e) This problem is concerned with the analytical and experimental study of the mass transfer from an annular liquid film on the inside wall of a vertical circular tube to a co-current gas flow in the core of the tube. Systematic experiments will be conducted for determining the effect of the rates of flow of air and liquid, and the temperature difference between air and liquid upon the rate of mass transfer from the liquid film.

PURDUE UNIVERSITY, Automatic Control Laboratory, School of Mechanical Engineering.

\section{(4197) FLUID LINE DYNAMICS.}

(b) National Aeronautics and space Administration. Prof. Rufus oldenburger, School of Mech. Engrg., Purdue Univ., Lafayette, Ind. 47907.

(d) Theoretical and experimental project; Master's and Doctor's Thesis Research.

(e) Mathematical models in use for systems with signiflcant f'luid lines are generally so complicated as to make design with such models impractical. In this investigation models are sought which are as simple as possible but which still adequately describe the response of the system to the class of disturbances of interest. Using infinite product expansions of transcendental functions satisfactory results have been obtained for single conduits terminating in lumped elements. Viscosity, boundary effects and line vibration are being considered in the analytical work. Frequency response runs to verify the theory are being made to determine the range for which solutions obtained are applicable. The theoretical and experimental approaches are being extended to systems with two or more lines. Rational approximations to the transfer functions of such systems are sought where the accuracy of the approximation can be seen directly from the approximation, as is the case where infinite products have been applied. Studies so far have been restricted to medium and large diameter lines. They are being extended to very small lines in the capillary class. The rate of dispersion of a pressure wave in a single line of constant cross section is also under study and the reinforcement of such a wave traveling back and forth in a conduit closed at both ends.

(g) Theory and tests show that for a wide range of operation encountered in practice flow through bends may be treated as flow through straight conduits. Mathematical models developed for straight fluid lines describe their response to high frequency. However, if resonance effects are to be included a certain complication of the model is necessary, beyond which further simplificaticn

(h) "Hydraulic LIne Dynamics," by R. Oldenburger and R. E. Goodson, presented at the Congress of the International Federation of Automatic Control in Basle, Switzerland, 1963. "Dynamic Response of Fluid Lines," by R. oldenburger and A. F. D'Souza, American Society of Mechanical Engineers Paper No. 63-WA-73, 1963.

FURDUE UNIVERSITY, School of Mechanical Engineering.

(4686) FULLY-DEVELOPED TURBULENT FLOW IN TUBES OF ANNUIAR CROSS-SECTION.

(b) Laboratory project.

c) Dr. J. B. Jones, Prof. of Mechanical Engrg., Purdue University, Lafayette, Indiana 47907 .

(d) Experimental basic research for doctoral thesis.

(e) The purpose of this project was to obtain data on mean velocity and turbulence intensity distributions for steady fullydeveloped flow in annuli similar to the data obtained by J. Laufer, V. A. Sandborn, and G. Comte-Beliot on flow in circular pipes and between parallel planes.

(f) Completed.

g) For annular pipes with diameter ratios from 0.0625 to 0.562 and w1th Reynolds numbers from 46,000 to 327,000 , accurate mean veloc1ty distributions were determined. The point of maximum mean velocity in turbulent flow occurs at a smaller radius than in laminar flow. Velocity profiles deviate from the usual law of the wall and velocity defect law correlations whenever the radial distribution of Reynolds stress is far from linear. This occurs in the inner profiles for small diameter ratios. Turbulence intensity distributions were determined, and these in confunction with already published distributions for flow in circular pipes and for flow between parallel planes provide knowledge of turbulence intensity distributions for all cases of fully-developed one dimensional flow.

(h) "The Structure of Fuily-Developed Turbulent Flow in Annul1," by J. A. Brighton, Ph.D. Thesis, Purdue University, August 1963.

(4687) FULLY-DEVELOPED TURBULENT FLOW IN RECTANGUIAR CHANNELS.

(b) Laboratory project. 
(c) Dr. J. B. Jones, Prof of Mechanical Engrg., Purdue University, Lafayette, Indiana 47907 .

(d) Experimental basic research for doctoral thesis.

(e) The purpose of this investigation was to obtain knowledge of the relationships among velocity distributions, secondary flows, and turbulence characteristics in fully-developed incompressible flow in channels of rectangular cross-section.

(f) Completed.

g) For fully-developed incompressible flow in a square channel at Reynolds numbers of 150,000 and 300,000 and in a $2 \times 1$ rectangular channel at Reynolds numbers of 50,000, 150,000, and 300,000 , complete measurements of mean flow velocity distributions, wall shear stress distributions, and Reynolds stress distributions were made. The results indicate that the motion of fluid along secondary flow streamlines is related to Reynolds stress interactions and not to transverse pressure gradients.

(h) "Turbulence and Mean Flow Characteristics of Fully-Developed Flow in Rectangular Channels," by F. B. Gessner, Ph.D. Thesis, Purdue Univ., January 1964.

(4690) EXPERIMENTAL DETERMINATION OF THE INLET LENGTH AND CRITICAL REYNOLDS NUMBER FOR PULSATING FLOW IN RIGID TUBES.

(b) Laboratory project.

(c) Dr. R. W. Fox, Assoclate Prof. of Mech. Engineering, Purdue University, Lafayette, Indlana. 47907 .

(d) Experimental basic researeh for doctoral thesis.

(e) The calculation of volume flow rates from pressure gradient measurements in the cardiovascular system are based on the assumptions of fully-developed laminar flow. The purpose of this investigation is to determine experimentally the entrance length and critical Reynolds number for pulsating flow. Conflicting data are avallable as to the effect of pulsations on the critical Reynolds number in tube flow. It is hoped that visualization techniques employed will shed some light on the mechanism of transition in tube flow. It is anticipated that this work will also provide a point of departure and reference point for additional work on pulsating flow in elastic tubes.

(f) Temporarily inactive.

(5015) THE INTERSECTION OF TWO IMCOMPRESSIBLE JETS BETWEEN PARALIEL PLANES.

(b) Harry Diamond Laboratories, U. S. Army Materiel Command.

(c) Dr. J. B. Jones, Prof. of Mechanical Engrg., Purdue University, Lafayette, Indiana 47907.

(d) Analytical and experimental applied research in part for doctoral thesis.

(e) The deflection of a fluid jet between parallel planes by a smaller jet, with 1 ts axis approxi mately normal to that of the initial jet, and the nature of the resulting jet are important in the design and operation of some fluid jet amplifiers. The purpose of this research is to determine means for predicting the resulting jet flow as a function of the characteristics of the incident jets and the boundary geometry.

(5016) EXPERIMENTAL INVESTIGATION OF PULSATING IAMINAR FLOW IN A RIGID TUBE.

(b) Laboratory project.

c) Dr. R. W. Fox, Assoc. Prof of Mechanical Engineering, Purdue Univ., Lafayette, Indiana 47907 .

(d) Experimental basic research for doctoral thesis.

(e) Several analytical methods which permit the calculation of volume flow rates from pressure gradient measurements in the cardiovascular system are currently avallable. There are polnts of definite conflict in reported results using different methods. The purpose of this investigation is to obtain an experimental evaluation of the available analyses.

(5017) EXPERIMENTAL INVESTIGATION OF TURBULENT FUUID FLOW IN CONICAL DIFFUSERS.

(b) Army Research office, Duke Station, Durham,

(c) $\mathrm{Dr} \cdot \mathrm{R}$. W. Fox, Assoc. Prof of Mechanical Engrg., Purdue Univ., Lafayette, Ind. 47907.

(d) Experimental applied research for doctoral thesis.

(e) The primary objective of this work is to obtain systematic flow regime and performance data for conical diffuser flows over a wide range of diffuser geometries. While the initial investigation will be restricted to incompressible flows, it is anticipated that the work will be later extended to include subsonic compressible flows. Existing semi-empirical methods for predicting the behavior of turbulent boundary layers in adverse pressure gradients will be investigated in light of the experimental results.

(5018) ANNULAR DIFFUSER FLOWS.

(b) Laboratory project.

c) Dr. R. W. Fox, Assoc. Prof. of Mechanical Engrg., Purdue University, Lafayette, Indiana 47907.

(d) Experimental applied research for master's thesis.

(e) This work is a preliminary investigation aimed at providing information as to the most promising means of correlating annular diffuser behavior with existing diffuser data. Specifically, diffuser performance and flow regime data will be obtained for several diffuser geometries; different geometries will be obtalned by varying inner body shape in confunction with a fixed outer conical section. Initial work will be restricted to incompressible, non-swirling inlet flows.

ST. ANTHONY FALLS HYDRAULIC LABORATORY, UNIVERSITY OF MINNESOTA.

Inquiries concerning Projects 2144, 2603, 3153, $3502,3824,4199,4200,4201,4202,4209,4691$, $4692,4693,4694,4695,4696,4697,4699.4700$, 5187 , and 5188 should be addressed to Director, St. Anthony Falls Hydraulic Laboratory, Mississippi River at Third Avenue S. E., Minneapolis, Minnesota, 55414 .

Inquiries concerning Projects $111,1168,1929$, and 2386 , which are conducted in cooperation with the Agricultural Research Service, should be addressed to Mr. Fred W. Blaisdell, Hydraulic Engineer, Soll and Water Conservation Research Division, Agricultural Research Service, St. Anthony Falls Hydraulic Lab.,
Mississippi River at Third Avenue S. E., MInneapolis, Minnesota, 55414 .

Inquiries concerning Project No. 194, which is conducted in cooperation with the Corps of Engineers and the U. S. Geological survey, should be addressed to Engineer in Charge, Mr. Byrnon Colby, Federal Inter-Agency Sedimentation project, St. Anthony Falls Hydraulic Laboratory, Mississippi River at Third Avenue, Minneapolis, Minnesota, 55414.

\section{(1II) CLOSED CONDUIT SPIILWAY.}

(b) Agricultural Research Service, U. S. Dept. of Agriculture, in cooperation with the Minnesota Agricultural Expt. Station and the St. Anthony Falls Hydraulic Laboratory.

(d) Experimental; generalized applied research for development and design.

(e) A two-sided drop inlet having a width equal to the pipe diameter and a variable length is currently being tested to determine the effect of orifices in a drop inlet on the 
splliway performance. The tests on the drop inlet without orifice and having a flat bottom have been completed; tests of a drop inlet having a sem1-circular bottom are planned. The ant1-vortex device consists of a horlzontal plate supported above the crest of the drop inlet by end plers. The character1stics, performance, losses, and pressures $1 \mathrm{n}$ the drop 1nlet and on the ant1-vortex plate are being determined for various combinations of drop inlet length, and helght and overhang of the ant1-vortex plate. Water $1 \mathrm{~s}$ used as the model fluld to determine the performance character1stics, and head-d1scharge relationships during flows of water-a1r m1xtures. For full flow, a1r 1 s used as the model fluid to determine the various energy loss coefflcients and the pressure coefflelents.

A square drop inlet having a hood barrel

entrance is being tested to determine entrance loss coefficlents for various drop inlet sizes and helghts and varlous barrel slopes. Previous tests have evaluated the performance of this type of inlet.

(g) The theory of closed condult splllways has been developed, verifled, and published. Results of tests on many forms of the closed condult splilway entrance have been published. P1pe culverts la1d on steep slopes may flow completely full even though the outlet discharges freely. Generalized methods for analysis and reporting of the results have been developed. The use of air as the model fluld has been verifled by comparing test results with those obtalned using water as the model rluid. The drop inlet with the horlzontal ant1-vortex device causes the sp1llway to act as a selfregulating siphon when the headpool level approximates the ant1-vortex plate eleyation. The helght of the ant1-vortex plate above the drop inlet crest and the overhang of the ant1-vortex plate determine the effectiveness of the plate as an ant1-vortex device. For one form of the inlet, tests have been made to determine the crest loss coefflclent, the barrel entrance loss coefflclent, the pressures on the plate and the drop 1nlet, the general performance of the inlet, minimum and maximum permissible plate heights, and the head-d1scharge relationsh1p for plate control. Variables have been the length of the drop inlet, the barrel slope, the helght and overhang of the ant1-vortex plate, and the sldewall thlckness.

Tests on the hood drop inlet have shown that the hood barrel entrance can be used to reduce the minimum required helght of the drop inlet. Minimum sizes of drop inlet and ant1vortex devices have been determined.

\section{(1168) A STUDY OF CANTILEVERED OUTLETS.}

(b) Agricultural Research Service, U. S. Dept. of Agriculture, in cooperation with the Minnesota Agricultural Expt. Station and the St. Anthony Falls Hydraullc Laboratory.

(d) Experimental; generallzed applied research for design.

(e) P1pe outlet condu1ts for small splliways are frequently cantilevered beyond the toe of the earth dam. Attempts w1ll be made to determine quantitatively for the size of the scour hole to be expected under various fleld conditions.

(f) Preliminazy planning and study.

(1929) DRAIN TILE JUNCTION LOSSES.

(b) Minnesota Agricultural Expt. Station in cooperation with the Agricultural Research Service, U. S. Dept. of Agriculture and the St. Anthony Falls Hydraulic Laboratory.

(c) Prof. Phil1p W. Manson, University of Minnesota, St. Paul Campus, St. Paul, Minn.

(d) Exper1mental; generalized applied research for design.

(e) The function losses in drain tile flowing full are determined for laterals of different s1zes enterling mains of different sizes at varlous angles. The laterals enter the main at the centerline. Add1tional tests have been made with the crowns (or inverts) of both maln and lateral in the same plane.

(f) Completed.

(G) Tests have been completed on sharp edge functions entering the ma1n at angles varying in 15 degree increments from 15 degrees to 165 degrees. Both the lateral and the main are completely full. The tests cover all possible combinations of discharge in the lateral and in the ma1n. Laterals having areas $1 / 1,1 / 2,1 / 4,1 / 7$, and $1 / 16$ that of the main have been tested. A color motion plcture f1lm entitled "Energy Losses at Converging P1pe Junctions" has been completed and $1 \mathrm{~s}$ ava1lable. The $16 \mathrm{~mm} f 11 \mathrm{~m}$ is 800 feet long.

(h) "Loss of Energy at Sharp-Edged P1pe Junctions" by Fred W. Bla1sdell and Ph1l1p W. Manson. U. S. Department of Agriculture Technical Bulletin No. 1283, Aug. 1963.

(2386) GENERALIZED DESIGN OF TRANSITIONS FOR SUPERCRITICAL VELOCITIES.

(b) Agricultural Research Service, U. S. Dept. of Agriculture, in cooperation with the Minnesota Agricultural Experiment Station and the St. Anthony Falls Hydraul1c Lab.

(d) Experimental; general1zed applied research for development and design.

(e) Studies will be made to develop a transition and to determine the rules for 1 ts design. The transition w11l be used to change the flow cross section from circular to rectangular when the veloc1ties are supercritical.

(f) Suspended.

(2144) EXPERIMENTAL AND ANALYTICAL STUDIES OF HYDROFOILS.

(b) Offlce of Naval Research, Department of the Navy.

(d) Experimental and analyt1cal; bas1c research.

e) Investigation of the air entrainment phenomenon of an artificially ventilated hydrofoll of finite span in the vicinity of a free surface.

(g) A method has been developed to predict a1r requirements of ventilated bodies w1th reentrant-jet type cavities. The accuracy of predicting air requirements by this method 1 s on the order of 15 per cent. Experimental data for tralling vortex type cavities (high a1r entrainment rates) were found to be a function of the froude number based on the vertical projection of the foll chord, cav1tation number, aspect rat1o, and submergence of the foll in chords. An empirical expression relating these parameters has been derlved to predict the occurrence of tralling vortex cavities and their assoclated $\mathrm{h} 1 \mathrm{gh}$ alr entrainment rates.

(2603) WATER TUNNEL AIR CONTENT STUDIES.

(b) Dav1d Taylor Model Basin, Dept. of the Navy. d) Analytical and experimental applied research e) Establishment of procedures for accoust1cally measuring the size and number of small gas bubbles existing in water.

(g) Studies have validated the use of acoust1c attenuation as a measure of the presence of gas bubbles in water. Continuing work w11l develop an instrument for a spec1f1c water tunnel application.

(3153) FLOW ABOUT BODIES AT SMALL CAVITATION NUMBERS.

(b) Office of Naval Research, Department of the Navy.

(d) Experimental and analyt1cal; basic research.

(e) The experimental study of an oscillating flat plate in a free-jet tunnel has just been concluded. A new experimental program is to oscillate a tralling flap. The ma1n 
purpose is to achieve a higher reduced frequency.

(h) "A Quasi-Linear and Linear Theory for NonSeparated and Separated Two-Dimensional, Incompressible, Irrotational Flow about Lifting Bodies," by C. S. Song, St. Anthony Falls Hydraul1c Laboratory, Technical Paper No. 43, Series B, 36 pages, May 1963.

(3502) MANGLA SPILIWAY STUDIES.

(b) Harza Engineering Company, Chicago; Binnie and Partners, London; Government of Pakistan.

(d) Experimental; design and operation.

(e) A 1:300 scale section model consisting of half the control stmucture and basin and a 1: 150 scale comprehensive model for study of all important hydraulic features. A 1:216 scale section model consisting of two control structure gates for study of pressures and gate calibration. A $1: 300$ scale comprehensive approach model for study of flow conditions in approach. Two 1:150 scale section models, one a detalled study of pressures and forces on baffle blocks, one a detalled study of waves on the basin side walls. Typical dimensions of earth fill dam spillway include a drop in water level of $330 \mathrm{ft}$, and a design discharge of 900,000 cfs through a two-stage stilling basin energy dissipator.

(3824) SURFACE CHARACTERISTICS OF AIR ENTRAINED FLOW IN STEEP CHANNELS.

(b) Laboratory project.

(d) Analytical and experimental investigation of the alr concentration, velocity distribution, and surface roughness of water flow in steep open channels, Ph.D. thesis.

(e) Experimental investigation was carried out on the SAF high velocity channel for slopes up to 53 degrees. Velocities were measured by means of a pitot tube and high speed photography. AIr concentration was measured by the SAF concentration meter. The surface elevation was measured by a device which measures the average time the surface is above a given elevation.

(f) Experimental work completed.

(4199) GEOMETRY OF AIR CAVITIES IN A BOUNDARY LAYER.

(b) David Taylor Model Basin, Dept. of the Navy.

d) Experimental; basic research.

(e) Experiments performed to observe the geometry of the air cavity formed downstream of wedges mounted on channel wall when alr is introduced through parts on downstream face of the wedge. Geometry of cavity and alr demand will be observed in relation to wedge length and thickness for case of single wedge and for a serles of wedges at various longltudinal spacings. The ultimate objective is to study drag reduction due to presence of air in boundary layer.

(g) Cavity geometry and air demand obtained for single wedges from $2.5^{\circ}$ to $90^{\circ}$ seml-angle. Influence of blockage ratio and free surface on cavity formation has been studied.

(4200) INVESTIGATION OF THE FORCES AND INTERFERENCE EFFECT OF TANDEM FIAT HYDROFOILS.

(b) Offlce of Naval Research, Dept. of the Navy.

d) Experimental basic research.

Investigation of the lift and drag forces on the aft foll of a tandem hydrofoll configuration employing ventilated hydrofolls.

(g) Surface waves generated by a ventilated hydrofoll of finite span near the free water surface were measured for a number of foll submergences, velocities, and cavitation numbers. Experimental data have been obtained on the interference effect of two forced ventilated folls in tandem. The cavitation number and the force characteristics of the aft foll were found to be a function of the longltudinal spacing of the foils. In general, rather severe changes were noted. (h) "Interference Effects for Tandem Fully Submerged Flat Noncavitating Hydrofolls," W. H. C. Maxwell, St. Anthony Falls Hydraulle Laboratory Memorandum No. M-92, March 1963. "Surface Waves Generated by a Supercavitatirg Hydrofoll of Finite Span," J. M. Wetzel, and L. T. Boyer, St. Anthony Falls Hydraulic Laboratory Memorandum No. M-94, June 1963.

(4२O1) GURI HYDROELECTRIC PROJECT MODEL STUDIES.

(b) Harza Engineering Company, Chicago, Corp. Venezolano de Guayana.

(d) Experimental, design and operation.

e) Preliminary study for the design of the Gurl Hydroelectric development on the Caront RIver, Venezuela using a 1:394 comprehensive splllway model, 1:197 spillway section model, and a 1:197 comprehensive model. Studies include spillway design, channel closure, and cofferdam studies.

\section{(4.202) MICRO BUBBLE STUDIES.}

(b) David Taylor Model Basin, Dept. of the Navy.

d) Analytical and experimental applied research

(e) Measurement of micro bubble structure of laboratory and natural waters before and after exposure to dynamic disturbances characteristic of common forms of hydraulic machinery with the ultimate objective of correlating micro bubble structure with critical cavitation performance.

(f) Completed.

$(\mathrm{g})$ Acoustic attenuation measurements served to indicate that micro gas bubbles are evolved from dissolved gases by the shear dymamics of a boundary layer.

(h) "An Acoustic Study of Gaseous Micro-Bubbles in Boundary Layers and Propeller Wakes," by John F. RIpken and John M. Killen, St. Anthony Falls Hydraulic Laboratory, Project Report No. 67,28 pages, December 1962.

(4.209) THE INFLUENCE OF ELECTROKINETIC PHENOMENA ON THE HYDRAULIC AND ELECTROOSMOTIC PERMEABILITY OF UNIFORM VERY FINE SANDS.

(b) Laboratory project.

d) Experimental and theoretical; Ph.D. thesis.

(e) Accurately sized, narrow range, angular quartz particles and spherical glass beads were tightly placed in a permeameter with reversible silver-silver chloride electrodes at the ends of the test section. Streaming potential, streaming current, electrical resistivity of low conductivity liquid, and filter velocity were precisely measured. Studies Include: (1) Flow retardation from return electroosmosis: (2) analysis of electroosmotic permeability factors with respect to particle characteristics and hydraulic permeability, and (3) comparisons of streaming current and filter velocity at varying Reymolds numbers.

(g) It has been found that the streaming currentpotential varies linearly with hydraulic gradient to a slightly higher Reynolds number than the filter velocity. Lack of complete deaeration causes a larger reduction in the filter velocity than the streaming. When "bolling" action takes place anomalous relations between the filter velocity and streaming current occur.

(4691) A STUDY OF DRAG REDUCTION BY THE USE OF NON-NEWTONIAN BOUNDARY LAYER ADDITIVES.

(b) David Taylor Model Basin, Department of the Navy .

(d) Analytical and experimental applied research. A study of boundary layer mechanics and resulting shear forces for high velocity pipe flow of dilute water solutions possessing non-Newtonian characteristics.

(g) Tests with the additive CMC have shown that as compared to water, this fluid shows a substantial resistance to flow in the laminar regime and greatly decreased resistance to flow in the fully turbulent regime. 
(h) "Studies of the Reduction of Pipe Friction with the Non-Newtonian Additive CMC," by John F. Ripken and Meir Pilch, St. Anthony Falls Hydraulic Laboratory Technical Paper No. 42, Series B, 54 pages, April 1963.

(4692) INTERFERENCE EFFECTS BETWEEN TRANSVERSE CYLINDRICAL CONFIGURATIONS IN OPEN-CHANNEL FLOW.

(b) Project conducted for master's thesis.

d) Experimental.

e) The problem of backwater arises in natural and artificial waterways when a pipe crosses a river beneath the surface. From preliminary tests, the backwater from support bents, built from pairs of cylindrical vertical pipes with wooden caps, and the backwater from cylindrical pipes transverse to the flow, cannot be added to give the backwater effect of the bents and transverse pipe in combination. It is my purpose to determine some means of estimating this interference effect.

(f) Completed.

g) Very generally, interference effects are the result of two primary effects: (1) The velocities to which a given body is exposed are increased when a second body is introduced into the flow at the same section, thus increasing the drag, (2) the backwater to which a given body is exposed is increased when a second body is introduced into the flow at the same section, again causing an increased drag.

(h) "Interference Effects between Transverse Cylindrical Configuration in open-Channel Flow," by Harold W. Coleman, M. S. Thesis, Univ. of Minnesota, Dec. 1963. (Ava1lable at University of Minnesota Library.)

(4693) JET FLAPS ON SUPERCAVITATING HYDROFOILS FOR LIFT CONTROL.

(b) Bureau of Ships, Department of the Navy

d) Experimental; basic research.

(e) Experimental research has been conducted in the free-jet water tunnel on supercavitating flat plate hydrofolls for the purpose of finding the effect of jet flaps on such foils.

(g) As in the non-supercavitating case, lift increment appears to be proportional to the sine of the jet-flap angle and to the square root of the jet momentum coefficient; however, the proportionality constant is materially less. There is no utility in jet flaps for ventilated supercavitated folls.

(h) "Experiments on a Jet Flap in Supercavitating Flow," by E. Silberman, Technical Paper No. 46, Series B, St. Anthony Falls Hydraulic Laboratory. In preparation.

(4694) ANGAT PROJECT.

(b) Harza Engineering Co., Chicago; Englneering and Development Corp. of the Philippines, Manila; National Power Corporation, Manila.

(d) Experimental; applied.

e) Experimental studies are being carried out on a $1: 118$ scale comprehensive model to verify proposed designs for the for the spillway structure and achieve optimum dimensions for the various components.

(f) Completed.

(g) Data were obtained on head-discharge relationships for the spillway crest, flow conditions in the spillway approach channel, velocities and pressures in the chute, and flow conditions in the vicinity of the ski-jump type terminal structure. The studies indicated that the elevation of the bottom of the approach channel could be raised, resulting in a saving in excavation cost. It was also found that the preliminary design of deflection at the end of the spillway produced good dispersion of the jet but tended to create a backwater effect with objectionable effects at the powerhouse further upstream. A new deflector was developed which tumed the flow and directed it downstream, greatly reducing backwater effects. (h) No publications available.

(4695) A STUDY OF THE HYDRAULIC EXIT GRADIENT FOR FLOW THROUGH A GRANUIAR MEDIA.

(b) Laboratory project.

(d) The project is for a master's thesis, classified as basic research, with theoretical and experimental aspects.

(e) The project deals with upwards flow through a granular media. Materials used were basalt and concrete sand with sizes ranging from 0.5 to $5 \mathrm{~mm}$. The hydraulic conditions present when the flow through the granular bed transfers the bed from a dense to a fluidized state are studied.

(f) Completed.

g) The experimentally determined exit gradient agreed reasonably well with calculated exit gradients based upon a simplifled analysis.

(h) "A Study of the Critical Hydraulic Exit Gradient for Flow through Granular Media," by Havard Aas, M. S. Thesis, Univ. of Minnesota, August 1963. (Available at Univ. of Minnescto Library.)

(4696) THEORETICAL INVESTIGATION OF TWO-DIMENSIONAL UNSTEADY, SUPERCAVITATED HYDROFOIL FLOWS WITH FREE-SURFACE BOUNDARY CONDITIONS.

(b) David Taylor Model Basin, Dept. of the Navy.

d) Theoretical, basic research.

(e) The purpose of this research is to find the effect of free-surface on the unsteady force acting on an oscillating flat plate with a trailing cavity. Both the finite cavity case and the infinite cavity case are considered. The effect of the gravitation is also to be estimated.

(g) The force coefficient is found to consist of steady term, added mass term, and the circulatory force term. The effect of cavitation number appears linearly, but the effect of submergence appears non-linearly. The result agrees with the existing theory when the submergence is infinitely large. The force coefficient for the zero submergence case is found to be exactly one-half of that of fully wetted infinite fluid case.

(h) Under preparation.

(4697) KARNAFULI PROJECT.

(b) Agency for International Development, Dept. of State.

(d) Experimental; applied research.

e) Experimental review of flow conditions leading to partial fallure of Karnafuli spillway.

(g) Two models of the spillway have been constructed, one a 1:132 scale comprehensive model and the other a 1:60 scale section model. Measurements have been obtained of both steady and transient pressures acting on the chute surfaces. In addition, data are being obtained on impact forces on model logs and the optimum gate operation to pass debris through the spillway.

(4699) FORCE CHARACTERISTICS OF A CAVITATING BODY IN A COMPRESSIBLE LIQUID MIXTURE.

(b) David Taylor Model Basin, Bureau of Ships, Department of the Navy.

(d) Experimental, basic research.

(e) Investigation of the force characteristics of a cavitating body in a flowing air-water mixture.

(g) No results yet avallable.

(4700) OSCILIATORY LIFT AND DRAG FORCES ON VENTIIATED HYDROFOILS IN REGULAR WAVES.

(b) Office of Naval Research, Department of the Navy.

(d) Experimental; basic research.

e) Investigation of the force characteristics of a restrained, naturally ventilated hydrofoil moving through regular waves.

(g) The oscillatory lift and drag forces on a foil of finite span ventilated to the 
atmosphere were measured for a number of wave conditions. Satisfactory agreement with quasi-steady theory was obtained for all the conditions considered.

(h) "Force Characteristics of Flapped, Ventilated Folls in Smooth and Rough Water," J. M. Wetzel, and W. H. C. Maxwell, St. Anthony Falls Hydraulic Laboratory Project Report No. 66, January 1963.

(5187) VORTEX MOTION IN AN EMPTYING CONTAINER.

(b) Laboratory project.

(d) The project is for a master's thesis, classified as basic research, with theoretical and experimental aspects.

(e) The project deals with the relationship between vortex formation at the outlet of an emptying container in relation to the vorticlty in the container. The pirpose is to study the formation of vortices at outlet works.

(5188) SEDIMENT RIPPLE CHARACTERISTICS IN LOW FROUDE NUMBER FLOW.

(b) Laboratory project.

d) Analytical, Ph.D. thesis.

(e) An analytical attempt to predict the length helght and shape of sediment ripples under a flow of fluid as a function of the mean parameters of the flow and of the sediment particles.

(g) A first approximation to wave shape has been determined as well as a relationship between wave helght, length, and celerity for given flow and particle parameter.

INTER-AGENCY SEDIMENTATION PROJECT IN COOPERATION WITH ST. ANTHONY FALLS HYDRAULIC LABORATORY.

(194) A STUDY OF METHODS USED IN MEASUREMENT AND ANALYSIS OF SEDIMENT LOADS IN STREAMS.

(b) Subcommittee on Sedimentation, Inter-Agency Committee on Water Resources, Personnel of the U. S. Army Corps of Engineers and the U. S. Geologlcal Survey are actively engaged on the project.

(c) Englneer in Charge, Mr. Byrnon C. Colby, Federal Inter-Agency Sedimentation Project, St. Anthony Falls Hydraulic Laboratory, Hennepin Island and Third Avenue S. E., Minneapolis, Minnesota. 55414.

(d) Experimental; applied research and development.

(e) Drawings and specifications are avallable to facilitate the manufacture of suspendedsediment and bed-material samplers, particlesize analyzers, and assoclated laboratory equipment. Approved designs of suspended sediment samplers include a single-stage sampler, 4-, 22- and 62-pound samplers, and electrically operated samplers welghing 100,200 , and 300 pounds. Instruments for sampling bed material include a piston-type hand-operated sampler, a 30-pound hand-line sampler, and a 100-pound sampler for cable suspension. Also avallable are a sediment sample splitter, a bottom-withdrawal sedimentation tube with recording equipment for particle size analyses of sands. The primary objective of the current program is the development of an instrument to automatically record suspended-sediment concentrations in flowing streams.

(g) Fleld and/or laboratory tests have been continued on intermittent pumping-type samplers, turbidimeters, and on electronic, ultrasonic and nuclear sensing devices. Field tests on pumping-type samplers and on an improved nuclear density probe will be continued in 1964. An improved sedimentation chamber for the ultrasonic device has been fabricated and installed for future testing. Development of a turbidity meter using transmitted light for measuring the concentration of particles suspended in a fluid is progressing. A progress report on electronic sensing of sediment is in preparation. Report No. 14, titled "Determination of Fluvial Sediment Discharge," Is being prepared for publication in 1964.

(h) "A Summary of the Work of the Federal InterAgency Sedimentation Project," Report S, 29 pages, 28 January - 1 February 1963. "Ultrasonic Measurement of Suspended Sediment, "by Gordon $\mathrm{H}$. Flammer, Geologlcal Survey Bulletin 1141-A, 48 pages, 1962 .

SCRIPPS INSTITUTION OF OCEANOGRAPHY, UnIversity of California, San Diego.

\section{(4500) A STUDY OF INTERNAL WAVES IN THE OCEAN.}

(b) Laboratory project.

c) Dr. Charles S. Cox, The Scripps Institution of Oceanography, La Jolla, California 92038.

(d) The project is theoretical, including field investigation and is basic research.

(h) "Coupling of Internal and Surface Waves in Water of Variable Depth," Charles Cox and Helmuth Sandstrom, Jour. Ocean. Soc. Japan, 20th Ann. Vol., pp. 499-513, 1962.

(4501) STUDY OF OCEANIC AND ATMOSPHERIC TIDES.

(b) NSF laboratory project.

(c) Prof. Walter H. Munk and Mr. Frank Snodgrass, Institute of Geophysics and Planetary Physics, Univ. of Calif., San Diego, La Jolla, Calif. 92038.

(d) Baslc research; both theoretical and field investigation.

(e) This is a continuation of work from the last two years. The new results are that we have successfully traced the continuous spectrum through the tidal frequencies; furthermore, we have discovered sharp peaks or "cusps" of the continuum adjoining each strong tidal IIne. These cusps are undoubtedly due to non-linear interaction between the tidal line spectrum and the low frequency continuum.

(h) "Patching the Long-Wave Spectrum Across the Tides," W. H. Munk and E. C. Bullard. J. Geophys. Research, 68, No. 12, pp. 36273634, June 1963.

"Statistical Relationships Between Time Serles of Sea Level and Weather," Bernard Zetler (paper presented at UGGI meeting, Berkeley, August 1963).

\section{(4502) SWELL ATTENUATION STUDIES.}

(b) Office of Naval Research laboratory project

c) Prof. Walter H. Munk, Assoc. Director, Institute of Geophysics and Planetary Physics, University of California, San Diego, La Jolla, California. 92038 .

(d) Basic research; both theoretical and field investigation.

(e) During the summer of 1963 we occupled six wave stations along a great circle route stretching from New Zealand to Yakutat, Alaska. Twice daily at each of the stations records were taken for three hours, and these have been spectrum analyzed and plotted. We expect to determine the attenuation of ocean waves as a function of frequency.

(h) "Comparative Spectra of Microseisms and Swell," R. A. Haubrich, W. H. Munk and F. E. Snodgrass. Bull. Se1smol. Soc. Am., 53, No. 1, pp. 27-37, Jan. 1963. "Bispectra of Ocean Waves," K. Hasselmann, W. Munk, and G. J. F. MacDonald. Time Series Analysis, pp. 125-139, w1ley, 1963.

"Directional Recording of Swell From Distant Storms," W. H. Munk, G. R. Miller, F. E. Snodgrass, and N. F. Barber. Phil. Trans. Roy. Soc. London, Series A, No. 1062 , Vol. 255, pp. 505-584, April 1963 .

(5010) LABORATORY STUDY OF THE RUNUP AND REFIECTION OF LOW-STEEPNESS WAVES.

(b) Offlce of Naval Research, Code 418 Field 
Project office.

(c) Dr. Wm. G. Van Dorn, Scripps Institution of oceanography, Univ. of Calif., San Diego, La Jolla, Calif. 92038.

(d) Experimental investigation; basic research. Th1s experiment is designed to test current one-dimensional theories of the enhancement and reflection of waterwaves against shoaling boundaries, as well as in the hope of understanding - at least empirically - the mechanisms whereby high-frequency incoming oscillatory waves can be transformed into low-frequency oscillations of the shelf water as a whole. In these experiments a dispersive wave train is formed by the singlestroke by vertical insertion of a parabolic generator at one end of the tank having the dimensions 16-inches wide by one foot deep by 90 -feet long. The dispersive wave train then propagates up the tank and reflects from an impermeable shoreline whose slope can be adjusted from infinite to about one on one hundred. Wave amplitudes at all parts of the tank are measured by pressure transducers coupled to probes set very slightly beneath the free water surface. Wave amplitudes in all cases are kept substantially below. 01 ft.

UNIVERSITY OF SOUTH CAROLINA, COllege of Engineering, Department of Civil Engineering.

Inquiries concerning the following projects should be addressed to Dr. Harold Flinsch, Civil Engrg. Department, University of South Carolina, Columbia, South Carolina.

(4) THE DEVELOPMENT OF SURFACE WAVES BY WIND.

(b) Laboratory project.

(d) General theoretical, experimental, and field research.

(e) Research on the theories of surface wave origin and growth, on measurements in the laboratory and in nature, and on the comparative results of theory and measurement. Equipment has been assembled for telemetering and recording wave helght, period, and direction.

(g) A lake shore receiving and recording station is under construction.

(1631) THE EFFECT OF WAVES ON BEACHES.

(b) Laboratory project.

(d) General theoretical, experimental, and field research.

(e) Research on beach slopes and contours, in the laboratory and in nature.

(g) Eight-directional wave tank has been completed.

(1907) SHIP STABILITY AND ROLLING PERIOD.

(b) Laboratory project.

(d) General theoretical, experimental, and field research.

(e) Rolling and pitching period and metacentric height relationships are studied for stationary and moving ships, in still water and under wave action.

(g) Model experiments have been assembled in a brief report.

(4701) THE EFFECT OF TIDES ON HARBORS, BAYS, AND ESTUARIES.

(b) Laboratory project.

(d) General theoretical, experimental, and fleld research.

(e) A study of the scouring or shoaling effect of tidal currents in south Carolina harbors and estuaries.

SOUTHWEST RESEARCH INSTITUTE, Department of Mechanical Sciences.
(3826) HYDRODYNAMICS OF SHIP SLAMMING.

(b) Bureau of Ships, Department of the Navy (DTMB technical supervision).

(c) Dr. H. N. Abramson, Director, Department of Mechanical Sciences, Soutliwest Research Inst., 8500 Culebra Road, San Antonio, Texas 78206 .

(d) Theoretical; applied research

(e) Study of pressure distribution on bodies of arbitrary cross-section entering a plane water surface.

(f) Completed.

(3828) STUDIES IN HYDROEIASTICITY.

(b) Bureau of Ships, Department of the Navy (DTMB technical supervision).

(c) Dr. H.N. Abramson, Director, Dept. of Mechanical Sclences, Southwest Research Inst., 8500 Culebra Road, San Antonio, Texas 78206 .

(d) Experimental, theoretical; applied research.

(e) Present work includes the design, construction, and testing of flexible hydrofoll models to obtain data on unsteady hydrodynamic lift and moment for a variety of operating conditions.

(h) "Experimental Unsteady Airfoll Lift and Moment Coefficients for Low Values of Reduced Velocity," by H. N. Abramson and G. E. Ransleben, Jr., AIAA Journal, 1, 6, pp. 1441-1443, June 1963 .

"Experimental Determination of Oscillatory Lift and Moment Distributions on Fully submerged Flexible Hydrofolls," by G. E. Ransleben, Jr., and H. N. Abramson, Journal of Ship Research, October 1963.

Other published papers and Southwest Research Institute technical reports.

(4216) STUDIES OF FUEL SLOSHING.

(b) National Aeronautics and Space Admin., Marshall Space Flight Center.

(c) Dr.H.N. Abramson, Director, Department of Mechanical Sciences, Southwest Research Institute, 8500 Culebra Road, San Antonio, Texas 78206 .

(d) Theoretical and experimental; applied research.

(e) Studies of forces and moments in missile fuel tanks resulting from sloshing motions of fuel.

(h) "Liquid sloshing in spherical Tanks," by H. N. Abramson, W. H. Chu, and L. R. Garza, AIAA Journal, 1, pp. 384-389, Feb. 1963. Several other Southwest Research Institute technical reports.

(4217) LIQUID DYNAMIC BEHAVIOR IN ROCKET TANKS.

(b) National Aeronautics and Space Administration, Washington, D. C.

(c) Dr. H. N. Abramson, Director, Department of Mechanical Sciences, Southwest Research Inst., 8500 Culebra Road, San Antonio, Texas 78206 .

(d) Theoretical and experimental; applied research.

(e) Studies of liquid dynamic behavior in elastic tanks.

(h) "Bending Vibrations of a Circular Cylindrical shell Containing an Internal Liquid with a Free Surface," by U. S. Lindholm, W. H. Chu, D. D. Kana, and H. N. Abramson, AIAA Journal, 1, 9, pp. 2092-2099, Sept. 1963. "Liquid Dynamic Behavior in Moving Containers," by H. N. Abramson, Applied Mechanics Reviews, 16, 7, pp. 501-506, July 1963. Several additional Southwest Research Institute technical reports.

(4702) HYDRODYNAMICS OF SHIP ANTI-ROLL TANKS.

(b) Bureau of Ships, Department of the Navy (DTMB technical supervision).

(c) Mr. John F. Dalzell, Senior Research Engineer, Department of Mechanical Sciences, Southwest Research Institute, 8500 Culebra 
Road, San Antonio, Texas 78206.

(d) Theoretical and experimental; applied research.

(e) Studies of forces and damping effects in passive anti-roll stabilization tanks for ships.

(4703) VIBRATION OF SUBMERGED ELASTIC PLATES.

(b) Bureau of Ships, Department of the Navy (DTMB technical supervision).

(c) Dr.H. N. Abramson, Director, Department of Mechanical Sclences, Southwest Research Institute, 8500 Culebra Road, San Antonio, Texas 78206 .

(d) Theoretical and experimental; applied research.

(e) Study of the vibration characteristics of elastic cantilever plates submerged in water.

(f) Completed.

(4704) VIBRATION OF HYDROFOIL STRUCTURES.

(b) Bureau of Ships, Department of the Navy (DTMB technical supervision).

(c) Mr. Guido E. Ransleben, Jr., Senior Research Engineer, Department of Mechanical Sclences, Southwest Research Institute, 8500 Culebra

Road, San Antonio, Texas 78206.

(d) Theoretical and experimental; applied research.

(e) Study of the vibration characteristics of hydrofoll-type structures.

(f) Completed.

(h) "Vibration Characteristics of Three Representative Hydrofoll Configurations," by $K$. D. Doshi and G. E. Ransleben, Jr., Final Report, Contract Nobs-88114(X), September 1963.

(4926) LIQUID FREE SURFACE NEAR ZERO G.

(b) National Aeronautics and Space Administration, Marshall space Flight Center.

(c) Dr. H. N. Abramson, Director, Dept. of Mechanical Sciences, Southwest Research Institute, 8500 Culebra Road, San Antonio, Texas 78206.

(d) Theoretical; applied research.

(e) Analysis of liquid free surface shape for very small values of gravity.

(4927) LIQUID DYNAMIC BEHAVIOR IN TANKS UNDER AXIAL OSCILLATION.

(b) National Aeronautics and space Administration, Marshall Space Flight Center.

(c) Dr. H.N. Abramson, Director, Dept. of Mechanical Sclences, Southwest Research Institute, 8500 Culebra Road, San Antonio, Texas 78206 .

(d) Theoretical and experimental; applied research.

(e) Studies of nonlinear liquid motions in rigid and elastic tanks undergoing axial oscillations.

(4928) FLUTTER ANALYSIS OF HYDROFOILS.

(b) U. S. Navy, Bureau of Ships.

c) Dr. H. N. Abramson, Director, Dept. of Mechanlcal Sciences, Southwest Research Institute, 8500 Culebra Road, San Antonio, Texas 78206 .

(d) Theoretical; applied research.

(e) Calculations of flutter speed for a hydrofoll flutter model by several different techniques.

STANFORD UNIVERSITY, Department of Civil Engineering.

(1946) SYNTHESIS OF HYDROGRAPHS FOR SMALL AREAS.

(b) National Sclence Foundation.

c) Prof. Ray K. Linsley and N. H. Crawford, Dept. of Civil Engineering, Stanford UnIv., Stanford, Calif.

(d) Theoretical and field research. (e) A study of the munoff process with a v1ew to estimating the streamflow hydrograph from rainfall and eventually by statistical means.

(g) A simplified mathematical treatment of nonequilibrium overland flow has been developed. Studies on the computation of the hydrograph from rainfall excess by use of fluld mechanics and a statistical analysis of soll-molsture frequency are underway. A conceptual model has been programmed for the digital computer to permit synthesis of continuous streamflow from hourly rainfall. Testing and refinement of the model is underway. Analysis of results to develop procedures applicable to ungaged basins will follow.

(h) "Hydraulic Behavior of Small Drainage Basins," by J. R. Morgal1, Tech. Rept. No. 30, Dept. of Civil Engrg., Stanford Univ., oct., 1963.

(2151) MODEL STUDY OF PETERS DAM CHUTE SPILLWAY.

(b) Laboratory project.

c) Prof. John K. Vennard, Dept. of Civil Engrg., Stanford University.

(d) Experimental; engineer thesis.

(e) Comparison of splilway performance and design predictions.

(g) Experimental work completed; thesis being written.

(2614) PIPE FRICTION IN UNSTEADY FLOW.

(b) Laboratory project.

(c) Prof. John K. Vennard, Dept. of C1vil Engineering, Stanford University.

(d) Experimental and analytical; Ph.D. thesis.

e) Comparison of friction processes for steady and unsteady states.

(g) Experimental work completed and analyzed; thesis being written.

(3507) STUDY OF INFILTRATION.

(b) U. S. Public Health Service.

(c) Prof. Joseph B. Franzini, Dept. of Civil Engrg., Stanford Univ., Stanford, Calif.

(d) Theoretical investigation; laboratory and flield studies; basic research; Ph.D. theses.

(e) An attempt is being made to develop relations between soil parameters and infiltration capacities. Investigation is being extended to unsteady unsaturated flow through solls as experienced in capillary rise, drainage, and infiltration situations.

(g) An analytic approach to the solution of unsteady unsaturated flow in solls has been developed. If the initial molsture condition and the hydraulic and capillary characteristics of the soll are known, the method permits prediction of the future disposition of soll molsture. Experimental equipment using a gamma source for moisture content determination is under construction.

(h) "An Approach to the Solution of Unsteady Unsaturated Flow Problems in solls," by Flora Chu Wang, Tech. Rept. No. 19, Dept. of Civil Engineering, Stanford Univ., 1963.

(3508) EVAPORATION SUPPRESSION.

(b) U. S. Public Health Service.

(c) Prof. Joseph B. Franzini, Dept. of Civil Engineering, Stanford University, Stanford, California.

(d) Laboratory and fleld investigations.

(e) Field studies with Class A evaporation pans have been employed to evaluate the evaporation reduction capabilities and biological attrition resistances of various monomolecular films. In a full scale program at a 40 acre lake methods of application of the film were investigated together with the effect of the film on biota.

(f) The research is being extended to a study of evaporation from solls. The effect of adding long-chain fatty alcohols to the soll to reduce evaporation is being investigated.

(g) Full scale field tests using hexadecanol on a 40 acre lake during the summer of 1960 
gave an evaporation reduction of 18 percent.

(4219) SUPERCAVITATING HYDROFOIL THEORY.

(b) David Taylor Model Basin, Bureau of Ships, Navy Department.

(c) Prof. R. L. Street, Dept. of Civil Engrg., Stanford Univ., Stanford, Calif.

(d) Theoretical, basic research for Ph.D. thesis. The forces on supercavitating hydrofoils having large curvature are being studied. In addition studies are being conducted on the effects of gravity and rotation on the forces acting on supercavitating hydrofolls and wedges. Additional research being carried on on nonlinear effects and freesurface phenomenon.

(g) Rotation and gravity have been shown to have significant effects on forces acting in supercavitating flows.

(h) "A Nonlinear Theory for Supercavitating Flow Past a Wedge in a Longitudinal Gravity Field," by Charles Lenau, Tech. Rept. No. 28, Dept. of Civil Engrg., Stanford Univ., 1963. "Supercavitating Flow About a siender wedge in a Transverse Gravity Fleld," R. L. Street, J. Ship Research, Vol. 7, No. 1, June 1963. "Symmetric, Rotational, Supercavitating Flow About a Slender Wedge," R. I. Street, ASME Annual Mtg. Paper No. 63-WA-106, 1963.

(4705) HYDRAULICS OF OPEN CHANNELS.

(b) Laboratory Project.

c) Prof. Joseph B. Franzini.

(d) Theoretical investigation and experimental program; Ph.D. theses.

(e) Several aspects of open-channel flow are under investigation including (1) velocity and shear distribution in open channels having different cross-sectional shapes, (2) characteristics of flow in a channel that simulates the cross-section of a river. In particular, the case where supercritical flow in the main channel section changes to subcritical flow in the overbank-stage section is being investigated.

(f) Analytic approach to (I) above is underway. A $50 \mathrm{ft}$. flume for (2) above has been built and experimental work has commenced.

(4706) INVESTIGATION OF THIN-FILM LIQUID FLOW OVER SOLID BODIES OF DIFFERENT SHAPE.

(b) Laboratory project.

c) Prof. Joseph B. Franzini.

(d) Theoretical and experimental investigation; Ph.D. thesis.

(e) The characteristics of thin-film liquid flow over solid bodies (spheres, ellipsoids, cones, cylinders, and composites) are being investigated. In later stages of the research it is anticipated that the results from flow over single bodies will be applied to packings so that the research can be extended to the hydraulics of trickling filters.

(f) Preliminary analysis for thin-film liquid flow over spheres and ellipsoids has been completed. Experimental rig is under construction.

(h) "Laminar flow of Thin Liquid Films Around Solid Bodies of Various Shapes," by Nabil A. Hassan, Techn. Rept. No. 24, Dept. of C1vil Engineering, Stanford Univ., 1963.

(4707) FREE SURFACE FLOW OVER SPILLWAYS.

(b) Laboratory project.

c) Prof. R. L. Street, Dept. of civil Engr., Stanford Univ. Stanford, Calif.

(d) Experimental and theoretical, basic research for doctoral thesis and laboratory course work.

(e) Analytic methods are being developed to determine the shape of the free surface on and up-stream of spillway. Small experimental program to be carried on to verify analytic results.

(g) Complex variable analysis has produced method for predicting free surface shape, flow velocities and pressures for varying bottom configurations.

(h) "A Theory for Two-dimensional Flow in open Channels with Varying Bottom Configurations," by Gary $z$. Watters, Tech. Rept. No. 27, Dept. of Civil Engrg., Stanford University, 1963.

(4708) SEEPAGE FROM CHANNELSIAND RESERVOIRS.

(b) Laboratory project.

(c) Prof. B. Perry, Dept. of C1vil Engr., Stanford, Calif.

(d) Theoretical basic research for doctoral thesis.

(e) To determine effects of variable permeability and three dimensional flow in seepage problems.

(f) Completed.

(g) First and second order perturbation theories are given for seepage from ditches and ponds through different types of solls.

(h) "Hydrodynamics of Seepage from Channels and Reservoirs," by Ahmed El-Amin El-Nimr, Doctoral Dissertation, Dept. of Civil Engr. Stanford University June 1962. Report No. 18 by same title issued Jan. 1963.

(4916) DISPERSION OF POLLUTANTS IN FLOW THROUGH POROUS MEDIA.

(b) Laboratory project.

(c) Prof.E.Y. H su and R. L. Street, Dept. of Civil Engrg, Stanford Univ., Stanford, Calif.

(d) Basic experimental and theoretical research for Ph.D. thesis.

(e) Study of hydrodynamic dispersion in porous media. Complex variable analysis of flow fields is combined with a connective dispersion equation to define time-space history of pollutant concentrations. Effects of channel boundary shapes and free streamlines on dispersion are to be studied also.

(g) Theoretical examination underway.

(4917) MECHANISMS INVOLVED IN WIND-GENERATED WAVES.

(b) Fluid Mechanics Branch, Math. Sci. Div., Office of Naval Research.

(c) Prof. E. Y. H su and R. I. Street, Dept. of Civil Engrg., Stanford Univ., Stanford, Calis

(d) Experimental' and theoretical basic research for doctoral theses.

(e) Examination, experimental verification, and extension of available theory are the purpose of this project. A steady flow model of the wind-wave problem is being constructed in the laboratory.

STEVENS INSTITUTE OF TECHNOLOGY, Davidson Laboratory.

(2154) INVESTIGATION OF HIGH SPEED SHIP FORMS.

(b) ONR and Buships, Dept. of the Navy, Stevens Institute of Technology, 711 Hudson Street, Hoboken, N. J.

(d) Theoretical and experimental; basic research e) Investigation of hydrodynamic and motion characteristics of high speed ship forms for supercritical operation in search of considerable improvement of seakeeping qualities and powering requirements.

(g) Parametric studies utilizing analog and digital computers of the stability, powering, and design characteristics of a semisubmerged craft similar in nature to a shallow-running submarine incorporating a surface piercing hydrofoil system to provide inherent heave, pitch and roll stability. Towing tank tests of a model of the craft have also been completed.

(2155) SEAKEEPING QUALITIES OF SHIPS AT ALI HEADINGS TO WAVES.

(b) David Taylor Model Basin, Bureau of Ships, Department of the Navy. 
(c) Mr. P. A. Lalangas, Davidson Laboratory, Stevens Institute of Technology, 711 Hudson Street, Hoboken, N. J.

(d) Theoretical and experimental; basic research.

(e) To Investigate the coupled responses of $\operatorname{sh} 1 p$ models at all headings to waves in order to assist in the prediction of sea-keeping qualities and to evaluate means of reducing or controlling ship motions so as to increase sea speeds. Three specific objectives are: (1) Extension of theoret1cal work on the lateral forces acting on spherolds at a free surface to cover the case of a thin ship. (2) Measurements of sway force and yaw moment exerted by waves on a completely restrained surface ship model (Series $60,0.60$ block coefficient). (3) Experimental investigation of the applicability of linear systems analysis techniques to rolling and swaying motions of a ship model in irregular long-crested beam seas.

(g) Good agreement is shown between strip theory calculations and measured forces and moments exerted by waves on a completely restralned surface ship model.

It is concluded that the principle of linear superposition can be used with reasonable engineering confldence for studying the roll response of fast cargo ships when under way in moderate to severe beam seas.

(h) "Stripwise Calculation of Hydrodynamic Forces Due to Beam Seas," by S. Motora, Davidson Laboratory Note 656 .

"Application of Linear Superposition Techniques to the Roll Response of a Ship Model in Bearn Irregular Seas," P. A. Langas, Davidson Laboratory Report 983.

(2616) THE BLADE-FREQUENCY FORCE GENERATED BY A PROPELLER ON A BODY OF REVOLUTION.

(b) David Taylor Model Basin, Bureau of Ships, Department of the Navy.

(c) Dr. J. P. Breslin, Director, and Dr. S. Tsakonas, Head of Fluid Dynamic Division, Davidson Laboratory, Stevens Institute of Tech., 711 Hudson Street, Hoboken, N. J.

(d) Theoretical; applied research.

(e) The purpose is to evaluate the importance of the pulsating near field of the propeller in generating vibratory forces on ships and to determine the attenuation of these forces with tip clearance and number of blades. Case of axial propeller in water has been evaluated. Case of offset propeller near an infinitely long cylinder has also been analyzed.

(f) Completed.

(g) Results indicate that small amplitude vibratory force can be attributed to the oscillating pressure field generated by an operating marine propeller.

(h) Davidson Laboratory Report 855, March 1963.

(3516) INVESTIGATION OF HULL BENDING MOMENTS IN WAVES OF EXTREME STEEPNESS.

(b) Ship Structure Committee.

(c) Mr. Edward Numata, Dav1dson Laboratory, Stevens Institute of Tech., 711 Hudson St., Hoboken, N. J.

(d) Experimental; applied research.

(e) Model tests were carried out to determine midship bending moments in very steep waves. objective is to determine if an upper limit of wave bending moments exists. Six models were tested over a moderate range of speeds in waves of various lengths and several helghts. Program has been extended to investigate variation of bending moments within the midship half length of a Mariner cargo sh1p model cut into six segments.

(g) For the six models tested, wave bending moment is found to be roughly linear with wave height. No significant limit on wave bending moment in head or following waves is to be expected as wave helght/length ratio is increased to a value of about $1 / 9$. For the Mariner model, sagging moment tends to reach a maximum within 10\% of ship length forward of amidships; hogging moments peaked at about 12\% of ship length off amidships.

(h) "An Investigation of Midship Bending Moments Experienced in Extreme Regular Waves by Models of the Mariner Type Sh1p and Three Variants," J. F. Dalzell, OTS Report PB 181,508 .

"An Investigation of Midship Bending Moments Experienced in Extreme Regular Waves by Models of a Tanker and a Destroyer," J. F. Dalzell, OTS Report PB 181,509.

"Investigation of Bending Moments Within the Midship Half Length of a Mariner Model in Extreme Waves," N. M. Maniar (in preparation)

(3830) ACOUSTIC RADIATION OF A CYLINDRICAL BAR AND AN INFINITE PLATE EXCITED BY THE FIELD OF A SHIP PROPELLER.

(b) David Taylor Model Basin, Bureau of Ships, Navy Department.

(c) Dr. S. Tsakonas, Head of Fluid Dynamics Div. C. Y. Chen, Research Engineer, and Winnifred R. Jacobs, Senior Research Engineer, Davidson Laboratory, Stevens Institute of Tech., 711 Hudson St., Hoboken, N. J.

(d) Theoretical; applied research. pressure field radiated from the pulsating boundary of an elastic plate and cylinder when these are subjected to vibratory pressures generated by a marine propeller, and to determine the extent of the contribution of the elastic boundary in amplifying the sound level generated by a propeller.

(f) Completed

g) Formal solutions for the cases of an elastic cylinder and an infinite plate have been obtained in the transform plane. Expressions for the velocity potentials of the scattered and radiated waves have been developed with the corresponding pressure signals. The limiting case for the far-acoustic fleld has been considered. Furthermore, closed form expressions of extreme simplicity were developed for the propeller-induced vibratory force on the cylinder and on the plate. Numerical results were obtained on the assumption of constant loading for a 2- 3- and 4-bladed propeller at various distances and different propeller clearances. The calculated sound pressures for realistic values of the parameters indicated that an appreclable sound level is obtained through the mechanism of the elastic boundary reaction to the propelier motion. The calculations also indicated that the pressure signal obtained from the rigid body scattering mechanism is the most important contribution in the case of the cylindrical beam whereas the radiated component of the pressure is the main contribution in the case of the infinitely long elastic plate.

(h) Report 888 issued July 1963.

(3832) FORMULATION OF EQUATIONS FOR SUBMARINE TRAJECTORIES WITH SIX DEGREES OF FREEDOM.

(b) David Taylor Model Basin, Dept. of the Navy.

(c) Mr. James White, Davidson Laboratory, Stevens Inst. of Tech., 711 Hudson St., Hoboken, N.J.

(d) Theoretical; applied research.

(e) Equations of a very general nature are being formulated to study the transient and steady state turning motion of deeply submerged submarines.

(f) Completed.

g) Partial differential equations for the motion of a deeply submerged submarine with six degrees of freedom are being written in accordance with the SNAME, "Nomenclature for Treating the Motion of a Submerged Body Through a Fluid". The hydrodynamic forces and moments will be expressed in terms of third order Taylor series expansions which contain all of the cross-coupling terms. Particular emphasis is being placed on the 
terms expressing roll instability due to yaw and pitch. The thrust exerted on the submarine is to be expressed as a function of speed of advance and propeller R.P.M. The effects of the interaction of bow planes on stern planes, the effect of propeller R.P.M. on stem plane effectiveness, and the effect or changes in ballast are are also included.

(h) Final report in preparation.

(4220) ANALYTICAL INVESTIGATION OF COURSE STABILITY AND STEERING QUALITIES OF SHIPS.

(b) David Taylor Model Basin.

c) Miss Winnifred R. Jacobs, Senior Research Engineer, Davidson Lab., Stevens Inst. of Tech., 711 Hudson St., Hoboken, N. J.

(d) Theoretical; applied research.

(e) Data ava1lable on 8 Taylor Serles models have been reanalyzed in order to develop a rational method for estimating the course stability and steering qualities of ships.

(f) Completed.

g) An analytical method combining simplified potential flow theory and low aspect-ratio wing theory with empirical modifications for a real viscous fluid is used to predict the first order hydrodynamic force and moment derivatives of a Taylor standard Series of hull forms. Comparison with experimental measurements shows good agreement. The method can predict the relative effects of the geometrical characteristics.

(h) Published as Report 945, March 1963, at Davidson Laboratory, Stevens Institute of Technology. Accepted for publication in International Shipbuilding Progress.

(4221) UNSTEADY FORCES AND MOTIONS ON A HYDROFOIL MOVING UNDER AN IRREGULAR SEA .

(b) Office of Naval Research, Fluid Mechanics Branch, Dept. of the Navy.

(c) Mr. Charles J. Henry and Mr. M. Al1, Research Engineers, Davidson Laboratory, Stevens Institute of Technology, 711 Hudson Street, Hoboken, New Jersey.

(d) Theoretical and experimental; applied research.

(e) To determine by model tests and basic analytical studies the unsteady forces acting on a fixed, non-cavitating, finiteaspect-ratio hydrofoil and the motions of a single hydrofoil (elastically supported) when submerged and moving under an irregular seaway .

(f) Completed.

(8) The lift response was found to be linearly related to the wave height, thus validating the use of spectral superposition theory. Computed and measured irregular sea $11 \mathrm{ft}$ spectra were in good agreement. Measured and predicted magnitudes of the gust response operator were in falrly good agreement but a discrepancy was found in phase. It was shown that two dimensional theory is not adequate to predict the unsteady lift on typical hydrofolls.

(h) "Hydrofoil Lift in Head Seas," C. J. Henry and M. R. All, Davidson Laboratory Report 982 , october 1963.

(4222) THREE-DIMENSIONAL APPROACH TO THE GUST PROBLEM FOR A SCREW PROPELLER.

(b) David Taylor Model Basin, Bureau of Ships, Navy Dept.

(c) Dr. J. Shiolri, visiting scientist from Tokyo University, and Dr. S. Tsakonas, Head of Fluid Dynamics Division, Davidson Lab., Stevens Inst. of Tech., 711 Hudson St., Hoboken, N. J.

(d) Theoretical; applied research.

e) To adapt the existing lifting-surface theory of aerodynamics to the marine propeller case and to study the resulting surface integral equation for various chordwise and spanwise loading distributions. The purpose of this study is to evaluate the blade loading more realistically in terms of the geometric characteristics of the propeller and the inflow conditions, since the loading is immediately related to vibratory thrust and torque, to ship vibration and to underwater sound generators.

(f) Completed

g) The surface integral equation has been derived and the case of a propeller represented by the Weissinger three-dimensional model has been considered. Calculations for the evaluation of the kernel have been made at various order of harmonics for sector type blade at different blade ratios and pitch of advance of a four-bladed propelier. Results indicate that the overall correction from the two-dimensional to three-dimensional is much more pronounced in the stationary case than in the unsteady flow case. Further more, as the blade area ratio increases, the three-dimensional effect is more pronounced.

(h) Report 940 1ssued March 1963, and accepted for publication in Journal of Ship Research.

(4224) INFLUENCE OF AFTERBODY SHAPE ON ANGULAR HARMONIC CONTENT OF THE WAKE OF SINGLE SCREW SHIPS.

(b) David Taylor Model Basin, Bureau of Ships, Department of the Navy.

(c) Dr. J. P. Breslin, Director, Davidson Lab., Stevens Inst. of Tech., 711 Hudson St., Hoboken, N. J.

(d) Theoretical; applied research.

(e) Theoretical analysis of potential wake of thin ship forms having $U$ - and $V$-shaped stern sections.

(f) Completed.

(g) The approximate three-dimensional closed form solution for the axial velocity ratios in the wake at the propeller plane was determined and applied to the specific case of $\mathrm{U}$ - and $\mathrm{V}$-shaped body profiles. Using thin ship theory, the approach consisted of determination of the potential function for a distribution of three-dimensional sources. The strength of the source system was assumed to be proportional to the slope at the ship surface. The forebody contribution was found by inspection to be negligibly small. Free surface effects were neglected.

An exact and an approximate two-dimensional closed form solution, obtained from the approximate three-dimensional treatment, was obtained and the axial velocity ratios computed in the wake at the plane of the propeller.

Harmonic analyses of both the approximate three-dimensional and approximate and exact two-dimensional results at the plane of the propeller were conducted, by means of an IBM 1620 computer, to determine the amplitude content of the second through fifth harmonics.

(h) Davidson Laboratory Report 956, Apr11 1963.

(4226) INVESTIGATION OF SURFACE-PIERCING FULLY VENTILATED DTHEDRAL HYDROFOILS.

(b) Office of Naval Research, Department of the Navy.

(c) Mr. P. Ward Brown, Chief of High speed Craft Division, Davidson Laboratory, Stevens Inst. of Tech., 711 Hudson Street, Hoboken, New Jersey.

(d) Experimental and theoretical; applied research.

(e) A continuing investigation aimed at providing basic design information on three-dimensional hydrofolls operating near a water surface, under conditions of either fully wetted or fully ventilated flow. To date the forces and moments on a series of surface piercing dihedral hydrofolls have been measured and the dymamics of systems employing such folls has been studied, including the problem 
of a hydrofoil impacting on the water surface and the stability of hydrofoll craft, and their response in waves.

(g) Analytical expressions for the forces and moments on surface piercing fully ventilated dihedral hydrofolls have been obtained and conflrmed experimentally. A theory covering the impact phenomena of hydrofolls, and particularly applicable to seaplanes, has also been evolved and confimed by experiment. A parametric study of the effect of system geometry on hydrofoll system dynamic stability has been completed and confirmed experimentally.

The response of a superventilated hydrofoll craft in waves has been measured and analyzed by IInear superposition technique. Conventional linearlzed supercavitating theory has been reexamined and it has been shown that the lift force is given accurately over the whole angle of attack range by

$$
\mathrm{C}_{\mathrm{L}_{2}}=\mathrm{C}_{\mathrm{L}_{1}} /\left(1+\frac{1}{2} \mathrm{c}_{\mathrm{L}_{1}}\right)
$$

where $C_{L_{1}}$ is the lift found by the conventional linearization.

(h) "Heaving and PItching Motions of Supervent1lated Hydrofoll Craft in Irregular Seas," Richard P. Bernicker, Davidson Laboratory Report 958, June 1963.

"Improved First Order Supercavitating Theory," P. Ward Brown, Davidson Laboratory Report 971, August 1963.

"Ventilation Inception on a Surface-Piercing Dihedral Hydrofoll with Plane-Face Wedge Section," Gerard Fridsma, Davidson Laboratory Report 952, October 1963.

(4227) SMOOTH WATER BEHAVIOR OF SURFACE-PIERCING HYDROFOIL VESSEL.

(b) Office of Naval Research, Fluid Dynamics Branch, Navy Dept.

(c) Mr. A. Strumpf, Head Underwater Weapons Div., Davidson Lab., Stevens Inst. of Tech., 711 Hudson St., Hoboken, N. J.

(d) Theoretical and experimental; applied research.

(e) An experimental and theoretical study is being made of the smooth water operation of a 110-ton craft supported by a tandem set of surface-piercing hydrofolls. The aim of the study is to develop equations of motion and obtain the hydrodynamic data necessary to permit the behavior of the boat to be predicted in the case of coupled six degrees of freedom motions. Previous work has been restricted mainly to the study of the pure pitching and heaving motions. Approximately 46 different hydrodynamic rate coefficlents have been evaluated from the test data obtalned during the experimental phase of this profect. Many of these derivatives have been obtalned experimentally for the first time and a comparison of results with avallable theory 1 s being made wherever this is possible. In addition, the hydrodynamic derivatives not obtained from the experiments also are being predicted theoretically for use in the motion equations. The non-linear equations of motion for six degrees of freedom which had been developed previously in this project were linearized about the straight course equilibrium conditions. These equations will be used to detemine the numerical values of the equilibrium conditions and the stability of the conflguration. An attempt will be made to predict the steady-turning performance of the vessel from both the linear and non-linear equations of motion. This will permit an evaluation of the importance of non-linear effects in the estimation of steady-turning performance of a surface piercing hydrofoll boat.

(g) The experimental results show that the $11 \mathrm{ft}$ developed by the rear foil is reduced apprec1ably by the presence of the forward foil.
The rear foll also ventilates under design conditions. For the first time a number of hydrodynamic derivatives with respect to turning angular veloc1ty were obtained from the experimental test results.

(h) Progress Reports may be obtained through Corré spondent.

\section{(4228) FLUTTER OF HYDROFOILS ON FLEXIBLE STRUCTURES.}

(b) David Taylor Model Bas1n, Bureau of Ships, Dept. of the Navy.

(c) Mr. Charles J. Henry, Research Engineer, Davidson Laboratory, Stevens Inst. of Tech., Hoboken, N. J.

(d) Theoretical; basic research.

(e) The variation of flutter speed and frequency w11l be found for a hydrofoll connected to a free-free beam. The effects of including varying numbers of modes for beam and foil will be investigated. In addition, the effect of beam parameters will be studied. The beam-foll system will, in the final analysis, represent as close as possible a ship-rudder system.

THE BOUNDARY IAYER UNDER PROGRESSIVE AND STANDING WAVES.

(b) Offlce of Naval Research, Dept. of the Navy. c) Dr. S. J. Lukasik, Chief, Fluid Physics Division, Davidson Laboratory, Stevens Inst. of Tech., 711 Hudson St., Hoboken, N. J.

(d) Experimental, theoretical, and field investigations; basic research.

(e) The purpose of this work is to study energy loss processes in shallow water waves. Theoretically, this is of interest because unsteady viscous flows have recelved relatively little attention, particularly the case of an osclilatory flow with no mean flow. Analytical and numerical solutions of the non-linear Navier-Stokes equations are under investigation. Laboratory measurements in the stevens shallow water wave channel have been made of the wave attenuation coefficlent of a progressive wave, the bottom shear stress under a progressive wave, and the time decay of standing waves. Field measurements of the bottom pressure and bottom velocity in 40 foot depths have been made off Block Island, R.I. These fleld measurements provide the possibility of determining the applicability of the laboratory measurements and the theoretical studies to the geophysical problem of the energy loss by ocean waves in shallow coastal waters.

(g) Direct measurement of the wave attenuation coefficlent both at Stevens and MIT indicated that the energy dissipation in a shallow water gravity wave exceeded that which would be expected from a linearized laminar solution of the Navier-Stokes equation valid in the bottom boundary layer. Several hypotheses have been examined in order to reconcile the discrepancy. It appears that the cause of the excess attenuation lies in the fact that the finite amplitude nature of the wave potential flow must be considered when formulating the boundary layer problem. For small deviations from infinitesimal amplitude theory, the stokes approximation is valid. The attenuation theory, when revised to include the effect of the first two harmonics as well as the fundamental frequency, is then in much better agreement with the laboratory measurements of the attenuation. Oceanographic studies to relate the theory and laboratory work on the attenuation of gravity waves to the case of ocean swell are continuing.

(h) "Pressure-Velocity Correlations in Ocean Swell," S. J. Lukasik and C. E. Grosch, J. Geophys. Res. 68 5689-99 (1963). "Laminar Damping of Oscillatory Waves," Discussion by S. J. Lukasik and C. E. Grosch, J. Hydraulics Div. Am. Soc. Civil Engr. 89 231 (1963). 
(4231) PREDICTION OF TRAJECTORIES FOR AN UNDERWATER MISSILE.

(b) Bureau of Naval Weapons, Dept. of the Navy. Mr. Howard Dugoff, Research Engineer, Davidson Iaboratory, Stevens Inst. of Tech., 711 Hudson St., Hoboken, N. J.

(d) Theoretical investigation; applied research. The main purpose of the study is to determine whether the observed underwater flight of the Basic Finner Missile can be predicted using equations of motion and hydrodynamic coefficients obtalned from experiment or theory. The project is part of a larger program, sponsored by the Bureau of Naval Weapons, to verify present-day trajectory prediction methods.

(f) Completed.

(B) Trajectories could not be predicted sucessfully using hydrodynamic coefficients obtained from the experimental data alone. However, theoretical coefficlents ylelded predictions which agreed well with the observed (planar) motions. The computed trajectories were particularly sensitive to changes in individual hydrodynamic static and damping rate coefficlents. However, when the values of these coefficients were kept consistent with relations expressing their physical interdependence, they could be varied over fairly wide ranges without appreclably affecting the predictions.

(h) "Prediction of Trajectories for an Underwater Mlssile," by Howard Dugoff, DL Report No. 898 , February 1963.

(4709) SURFACE PIERCING HYDROFOII FLUTTER.

(b) David Taylor Model Basin, Office of Naval Research, Dept. of the Navy.

(c) Mr. Charles J. Henry and M. Ali, Research Engineers, Davidson Laboratory, Stevens Inst. of Tech., 711 Hudson Street, Hoboken, N. J.

(d) Theoretical and experimental; applied research.

(e) Measured response characteristics and flutter speeds of an aspect-ratio-four, surfaceplercing strut supported with two degrees of freedom were compared with values predicted for two-dimensional, infinite-fluid flow.

(r) Completed.

(B) It was found that the two-dimensional infinitefluid representation of the unsteady hydrodynamic loads was not adequate to predict surface-plercing hydrofoll response. Reasons to doubt the accuracy of surface-piercing hydrofoil flutter speed predictions using Infinite fluid theory were discussed.

(h) "Surface-Piercing Hydrofoll Flutter," C. J. Henry and M. R. Ali, Davidson Laboratory Report 992, Nov. 1963.

(4711) STUDY OF THE PROPELIER SINGING PHENOMENON.

(b) David Taylor Model Basin, Office of Naval Research, Dept. of the Navy.

(c) Dr. S. Tsakonas, Head of Fluid Dynamics Division, Davidson Laboratory, Stevens Inst1tute of Technology, 711 Hudson St., Hoboken, New Jersey.

(d) Theoretical; applied research,

(e) To study the propeller singing phenomenon as a self-exclted vibration system composed of the Karman vortex-sheddIng mechanism and the propeller blade.

(4712) INTERFERENCE EFFECTS OF A SUBMERGED HYDROFOIL ON A SURFACE-PIERCING STRUT.

(b) Offlce of Naval Research, Department of the Navy.

(c) Mr. Y. Chey, Davidson Laboratory, Stevens Institute of Technology, 711 Hudson Street, Hoboken, New Jersey.

(d) Experimental and theoretical; applied research.

(e) To conduct experimental and theoretical studies on the mutual interference effects between a submerged hydrofoll and a vertical surface-plercing strut with respect to total Iift, total drag, hydrofoil drag, side force, roll moment, and inception of ventilation.

(f) Completed.

(B) A model of a single strut to which the hydrofolls of several aspect ratios were attached perpendlcularly was used in the experiment. The presence of the submerged hydrofoll with zero attack angle increased the side force on the strut by approximately 15\%. The submerged hydrofoil al so increased the drag of the strut and the roll moment of the strut-foll system. As the hydrofoll angle increased, the increments of side force, drag and roll moment decreased. The lifting line theory and the Welssinger Lmethod were applied to the side force producing strut and its image. The side force coefficlent of the strut estimated by the former method was slightly greater than the experimental value while that estimated by the latter method was slightly smaller than the experimental value. The effects of a submerged hydrofoll on the strut were theoretically analyzed by a conformal mapping. The theoretical result agreed well with the experimental result.

(h) "Interference Effects of a Submerged Hydrofoll on a surface-Plercing strut," by $Y$. Chey and T. Kowalski, Davidson Laboratory Report 936, June 1963.

(4713) EXPERIMENTAL STUDY OF PROPELIER-INDUCED VIBRATORY PRESSURES ON SIMPLE SHIP SURFACES.

(b) David Taylor Model Basin, Bureau of Sh1ps, Department of the Navy.

(c) Dr.J.P. Breslin, Director, Davidson Laboratory, Stevens Institute of Technology, 711 Hudson Street, Hoboken, New Jersey.

(d) Experimental; applied research.

(e) To measure the vibratory pressure signatures of a marine propeller model in free space and on horizontal circular cylinder and flat plate boundaries, and to compare these results with theoretical predictions.

(f) Completed.

(g) Pressures were found to become vanishingly small within about one propeller diameter fore and aft of the center of the propeller. The comparison with theoretically calculated pressures and forces gives very close agreement for free space pressures and reasonable agreement for forces on a cylindrical surface.

(h) "Experimental Study of Propeller-Induced Pressures on Simple Surfaces and Correlation with Theoretical Predictions," by T. Kowalski and J. P. Breslin, Davidson Laboratory Report 973, July 1963.

(5055) THE WAVE RESISTANCE OF A SHIP REPRESENTED BY SOURCES DISTRIBUTED OVER THE HULL SURFACE.

(b) Soclety of Naval Architects and Marine

(c) Dr.J.P. Bresiln, Director, Davidson Laboratory, Stevens Institute of Tech., 711 Hudson St., Hoboken, N. J.

(d) Theoretical; applied research.

(e) Hess and Smith of Douglas Aircraft co. had obtained the strengths of sources distributed over the surface of the hull for a Series $60\left(c_{B}=0.60\right)$ ship. This ensemble provides a velocity potential which accurately represents the flow about the hull in an ideal fluid at the condition of vanishing Froude number. The wave resistance associated with the source distribution was computed and compared with the usual thin sh1p approximation.

(f) Completed.

$(\mathrm{g})$ Wave resistance computed this way agreed $\mathrm{w} I$ th data only at extremely low Froude numbers and was larger than all other Froude numbers than that given by the thin ship approximations. Both theorles grossly overestimate the residuary resistance in the range of interest to naval architects.

(h) Davidson Laboratory Report 972, July 1963, presented at the International Seminar on 
Theoretical Wave Reslstance held at the Univ. of Mich1gan, August 1963.

(5056) CALCUIATION OF THE WAVE-RESISTANCE OF A SHIP REPRESENTED BY SOURCES DISTRIBUTED OVER THE HULL SURFACE.

(b) Soclety of Naval Architects and Marine Engineers.

(c) Dr. John P. Bresl1n, DIrector, and Mr. K1ng Eng, Research Engineer, Davidson Laboratory, Stevens Inst1tute of Tech., 711 Hudson St., Hoboken, N. J.

(d) Theoretical; applied research.

(e) To calculate the wave resistance of a ship represented by surface distribution of sourses and sinks of known strength and location and compare the results w1th those obtained by thin ship approach and correspondIng experiments.

(f) Completed.

(g) The calculation of wave-resistance from a mathematical model made up of sources distributed over the surface shows that a larger resistance is secured than from the corresponding Michell theory (thin ship approach) for all Froude numbers of practical interest. However, this 1mproved representation of the hull does not yleld better agreement with residuary resistance derlved from model tests except at exceedingly low Froude numbers.

(h) Report 972 1ssued July 1963.

(5057) UNSTEADY LIFTING SURFACE THEORY FOR A MARINE PROPELLER OF LOW PITCH ANGLE WITH CHORDWISE LOADING DISTRIBUTION .

(b) Dav1d Taylor Model Bas1n, Bureau of Sh1ps, Dept. of the Navy.

(c) Dr. S. Tsakonas, Head of Fluld Dynamics Div., and W. R. Jacobs, Senior Research Englneer, Davidson Laboratory, Stevens Institute of Tech., 711 Hudson St., Hoboken, N. J.

(d) Theoretical; applied research.

(e) The purpose is to solve the surface integral equation for a mathematical model with chordw1se loading based on the first term of B1rnbaum's distribution and to apply the results to the problems of vibratory thrust and torque of a marlne propeller and farfleld pressure slgnal from the propeller when 1 t is moving in non-uniform 1nflow.

(h) Report in preparation.

(5058) UNSTEADY LOADS ON TEED HYDROFOILS IN OBLIQUE SEAS.

(b) Bureau of Sh1ps, Dept. of the Navy.

(c) Dr. S. Tsakonas, Head of Fluld Dynamics Div., and $\mathrm{Mr}$. Charles J. Henry, Research Englneer, Davidson Laboratory, Stevens Inst1tute of Tech., 711 Hudson St., Hoboken, N. J.

(d) Experimental and theoret1cal; basic research.

e) To Investigate the forces and moments acting on hydrofoll struts and folls while operating in oblique regular waves.

(5059) THREE DIMENSIONAL GUST PROBLEM IN THE PRESENCE OF A FREE SURFACE.

(b) Laboratory project.

(c) Dr. S. Tsakonas, Head Fluld Dynamics D1v., and $\mathrm{Mr}$. Charles J. Henry, Research Englneer, Davidson Laboratory, Stevens Inst1tute of Tech., 711 Hudson Street, Hoboken, N. J.

(d) Theoretical, basic research.

(e) The kernel function $1 \mathrm{~s}$ derlved which relates the normal velocity to the load distribution on a thin osc1llating wing of arbitrary conflguration moving near a free surface in three dimensional flow. This kernel function is developed in such a way that the resulting integral equation is amenable to numerical solution.

(g) Limiting forms of the kernel function at high and low Froude numbers, in two dimensional flow and for Infinite submergence have been shown to agree with results previously obtained by other investigators. (h) "Three Dimensional Gust Problems in the Presence of the Free Surface for Arb1trary Foll Orlentation and Froude Number," S. Tsakonas and C. J. Henry, Davidson Laboratory Note No. 705, Dec. 1963.

(5060) UNSTEADY LIFTING SURFACE THEORY FOR A MARINE PROPELLER OF AN ARBITRARY PITCH ANGLE WITH CHORDWISE LOADING DISTRIBUTION.

(b) David Taylor Model Basin, Bureau of ShIps, Dept of the Navy.

(c) Dr. S. Tsakonas, Head of Flu1d Dynamics DIv., and C. Y. Chen, Re search Eng1neer, Davidson Laboratory, Stevens Institute of Tech., 711 Hudson St., Hoboken, N. J.

(d) Theoretical; applied research.

(e) To solve the surface integral equation relating the unknown loading distribution on the propeller blade lylng on a hellcoldal surface of an arbitrary p1tch with the known velocity distribution induced by the presence of a hull, w1 thout resorting to any mathematical simplification.

(5061) APPLICATIONS OF UNSTEADY LIFTING SURFACE THEORY USING WEISSINGER MODEL.

(b) Dav1d Taylor Model Basin, Bureau of Sh1ps, Dept. of the Navy.

(c) Dr. S. Tsakonas, Head of Fluld Dynamics D1v., Mr. King Eng, Research Engineer, and W. R. Jacobs, Research Engineer, Dav1dson Laboratory, Stevens Inst. of Tech., 711 Hudson St., Hoboken, N. J .

(d) Theoretical; applied research.

(e) The purpose is to solve the surface integral equation for the Weissinger model by expressing the kermel in a form which can be assimilated by a digital computer and to apply the results to the problems of vibratory thrust and torque of a propeller and the far-field pressure slgnal from the propeller when it is moving in non-uniform inflow.

(f) Completed.

(g) The surface integral equation in the marine propeller case is solved for the Welssinger mathematical model in confunction w1th Glauert's lift operator. The nature of the singularity is studied and its finite

"Hadamard" type evaluated without resorting to approximations. The results are applied to the problems of propeller vibratory thrust and torque and the far field pressure signal due to the effect of hull wake on propeller loading. Comparison of theoretical values with experimental results indicates a considerable improvement in prediction by utilizing the unsteady lifting surface theory rather than unsteady two-dimensional theory applied in stripwise manner in conjunction with Burrill's correction factors for threedimensional effects.

(h) Preliminary Report 987 prepared.

(5062) EFFECT OF PLANFORM VARTATIONS ON HYDROFOIL FLUTTER.

(b) Bureau of ShIps, Dept. of the Navy.

(c) Mr. Charles J. Henry, Research Engineer, Davidson Laboratory, Stevens Institute of Tech., 711 Hudson St., Hoboken, N. J.

(d) Experimental and theoretical; basic research. Measurements of flutter speed w1ll be obtalned for a two degree of freedom system Including the effects of sweep, taper and aspect rat1o. The results w1ll be compared with predictions using stripwise theory. approximate three dimensional alrfoll theory and lifting surface theory.

(5063) WAVE-RESISTANCE REDUCTION OF NEAR-SURFACE BOLIES.

(b) Offlce of Naval Research, Dept. of the Navy.

c) Mr. King S. Eng, Research Englneer, and Dr. Pung N. Hu, Staff Sc1ent1st, Davidson Laboratory, Stevens Inst. of Tech., 711 Hudson St., Hoboken, N. J. 
(d) Theoret1cal; applied research.

(e) An analytical study of wave-resistance characteristics of near-surface bodies was conducted to determine (1) for a given length and displacement, what changes in body-surface geometry are necessary to cause wave-resistance reduction; and (2) how geometrical change affects the waveresistance behavior with Froude number and submergence depth.

(f) Completed.

(g) Generally, the favorable wave-resistance geometries are: (1) for froude numbers $>0.3$, the huli form neck in at the midsection and bilge out at the ends, (2) for froude numbers $<0.3$, the hull form bilge out at the midsection and narrow at the ends. The amount of bilging out or necking in at the midsection depends upon design speed.

(h) Report 933 1ssued March 1963.

(5064) INVESTIGATION OF SHIP MOTIONS.

(b) U. S. Naval Training Devices Center, Dept. of the Navy.

(c) Prof. Earl M. Uram, Staff Scientist, Davidson Laboratory, Stevens Inst. of Tech., 711 Hudson St., Hoboken, N. J.

(d) Theoretical and experimental; basic research. Development of equations of motion of ships in very low speed maneuvering condition to be applied to a simulator for training.

(g) Analysis of general linearized motion equations including terms of importance at very low speeds. Experimental model and full scale program to determine static and dymamic derivatives of importance for inclusion in computer programs for calculating responses to bridge commands.

(5065) A STUDY OF SHIP FORMS AT HIGH FROUDE NUMBERS.

(b) Office of Naval Research, Dept. of the Navy.

(c) Dr. Hajime Maruo, visiting scientist from Univ. of Yokohama, and Mr. King Eng, Research Engineer, Davidson Laboratory, Stevens Inst. of Tech., 711 Hudson St., Hoboken, N. J.

(d) Theoretical; applied research.

(e) To evolve, develop and evaluate new concepts and modifications for surface and near surface ship forms for the attainment of high speeds and good seakeeping qualities in calm and rough water.

(5066) DEFORMATION OF REGULAR WAVES BY A SHIP MODEL.

(b) David Taylor Model Basin, Bureau of Ships, Dept. of the Navy.

(c) Mr. E. Numata, Davidson Laboratory, Stevens Inst. of Tech., 711 Hudson Street, Hoboken, N. J.

(d) Experimental; applied research.

(e) To measure the changes in amplitude of regular head and following waves as they pass along the length of a ship model running at several speeds and to compare these results with theoretical predictions. (f) Completed.

(g) In head seas the height of the incident wave diminished by some $20 \%$ to $40 \%$ as 1 t passed along the length of the fully restrained, double-ended model from bow to stern. In following seas the wave diminished by some $50 \%$ from stern to bow when the model speed was less than the wave group velocity, and from bow to stern when the model speed was greater than the wave group velocity. These experimental results are in fair agreement with theoretical predictions by Grim.

(h) "Experimental Measurements of the Deformation of Regular Head and Following Seas by a Ship Model," P. G. Spens, Davidson Laboratory Report 966, June i963.

\section{(5067) PROPULSION OF WHEELED VEHICLES OVER WATER.}

(b) U. S. Army Tank Automotive Center.

(c) Mr. Howard Dugoff, Research Engineer, Davidson Laboratory, Stevens Inst. of Tech., Castle Point Station, Hoboken, N.J. (d) Theoretical investigation; applied research.

(e) The purpose of the study is to develop an analyt1c representation for the basic fluid dynamic mechanism which enables a floatable land vehicle to propel itself through water by spinning 1ts fully submerged wheels. To restrict the problem to only its most basic elements, a conceptually equivalent but mathematically simpler system of a flat disk rotating about an'axis parallel to a plane boundary is considered, rather than a typical vehicle undercarriage configuration.

(g) The simplified configuration has been analyzed by applying classical hydrodynamic theory to a hypothetical potential flow field constructed so as to simulate the actual viscous flow. Solutions for the thrust coefficlent as a function of Reynolds number and distance from the boundary have been obtained for both laminar and turbulent flows. Physically, it is indicated that the thrust is developed as a result of the influence of the boundary on the flow induced by the pumping action of the disk. A simple experimental program to verify the theoretical results is currently being prepared.

(h) "On the Propulsion of Wheeled Vehicles over Water, " Howard Dugoff, DL Note No. 704, presented at the Second Regional Meeting of the U. S. Canadian Eastern Section of the International Society for Terrain Vehicle Systems, Stevens Institute of Tech., sept. 19-20, 1963.

\section{ROBERT TAGGART INCORPORATED.}

(4863) DIMENSIONAL EFFECTS ON HYDROPHONE OUTPUT IN THE NEAR FIELD.

(b) David Taylor Model Basin, Department of the Navy.

(c) Mr. Robert Taggart, Robert Taggart Inc., 400 Arlington Boulevard, Falls Church, Va.

(d) Experimental; applied research.

(d) Measurements were made of the outputs of two cylindrically shaped hydrophones, 5/8" and $2^{11}$ diameter, whose bases formed the active area. The hydrophones were mounted in a closed trunk over a flat flexible plate forming part of the wall of a rectangular water tunnel. The distances between the active face and the plate were $1 / 8^{\prime \prime}, 1 / 4^{\prime \prime}$, $1 / 2^{\prime \prime}, 1^{\prime \prime}, 2^{\prime \prime}$ and $4 "$, while the flow velocities through the main pipe ranged from 6 to $13 \mathrm{kts}$. These tests were conducted to determine whether a "distance" effect. previously noted, could be reproduced in a laboratory facility.

(f) Completed.

(g) It was found that a relation did exist between output levels and distance, the higher level occurring at the closest position. During the process of reducing the data, there was some evidence of an "area" effect also, at least for the two closest positions of the hydrophones.

(h) "Dimensional Effects on Hydrophone Output in the Near Field," Report RT-5703 to David Taylor Model Basin (Contract Nobs 86122) February 1963.

\section{(4864) SEA-CHEST STRAINER PLATE SUCTION.}

(b) Bureau of Ships, Department of the Navy. (c) Mr. Robert Taggart, Robert Taggart Inc., 400 Arlington Boulevard, Falls Church, Va.

(d) Experimental; applied research.

(e) An experiment was performed in a $2^{\prime \prime} \times 8^{\prime \prime}$ plastic water tunnel, to determine the acoustic effects of a fully developed turbulent boundary layer sucked through a model strainer plate. The plate is flush-mounted in the lower tunnel wall and contains 1100 holes 1/16" dlameter. Flow through the plate is by gravity and ali throttling and flow control is by pinch-type Flex valves. Flushmounted hydrophones and accelerometers provide a measure of the boundary layer 
pressure fluctuations and the acoustic radiation at several locations near the strainer plate. The ratio of suction velocity through the plate to the maximum velocity across the plate is varied.

(f) Completed.

(g) The model experiments show that the source of noise in such a configuration is definitely related to the suction through the strainer plate holes. This source is seen to be broadband in nature resulting from the combination of a large series of discrete frequencies comprising jet-tones originating in each of the openings.

(h) Final Report RT-6701 to Bureau of Ships, Navy Dept., under Contract NObs 86386 (FBM) Serial Number SF-013-11-O1, Task 1356, dated July 1963.

(5189) ACOUSTIC EXCITATION OF FLAT PLATES BY TURBULENT FLOW.

(b) David Taylor Model Basin, Dept. of the Navy

(c) Mr. Robert Taggart, Robert Taggart Inc. 400 Arlington Blvd., Falls Church, Va.

(d) Experimental; applied research.

e) Tests were carried out in a rectangular water tunnel in which various thin flat plates were mounted flush with the tunnel wall. (1) Using a 1/16" thick stainless steel plate, the investigation was directed toward correlation of the boundary layer characteristics with the pressure spectra of a flush-mounted pencil-end hydrophone and an accelerometer located on the quarter diagonal point of the plate surface.

(2) Experiments were conducted to determine the dimensional effects of cylindrical hydrophones located in a water-filled trunk above the plate. The helght above the plate was varied for two hydrophones of different sensitive areas. (3) The effect of damping on the acoustic pressure was examined for two aluminum and two fiberglass plates. Comparison is made between the four plates (damped and undamped) at a maximum flow velocity of $20 \mathrm{ft} . / \mathrm{sec}$. Acceleration levels were measured.

(f) Completed

(g) (1) It is demonstrated that unsteady flow excitation from a turbulent boundary layer on a thin flat surface, causes vibration of the plate at many natural modes. Chladni figures are shown for a frequency range $170<f<200$ cps. (2) Both the area of a hydrophone and its distance above a vibrating plate have considerable effect on the dimensionless pressure spectra. (3) Measurements on the four damped plates show that the acoustic response of aluminum plates is lowered more than that of fiberglass plates. The ratio of the thickness of the damping material to the plate thickness 1 s 2 .

(h) "An Experimental Study of Acoustic Excitation of Flat Plates in a Turbulent Boundary Layer. Final Report RT-1101 to the David Taylor Model Basin (Bureau of Ships Fundamental. Hydromechanics Research Program SROO9 Ol ol, Office of Naval Research Contract Nonr $3030(00)$ ) dated January 1964.

TEXAS A AND M COLLEGE, Department of Oceanography and Meteorology.

Inquiries concerning the following projects should be addressed to Prof. R. O. Re1d, Texas $A$ and $M$ college, College station, Texas.

THE EXCHANGE CHARACTERISTICS AND SALTNITY REGIME OF SHALLOW WATER BAY SYSTEMS

(b) National Science Foundation, Grant NSF-F 19780 .

(d) Analysis methodology; applied research

(e) The object is to develop a numerical model which can reproduce the temporal changes in the gross features of the salinity distribution in a shallow bay in response to changes in control factors and to determine changes in the variance spectrum of the detailed features as related to the spectral statistics of the control factors.

(f) Completed, September 1963

(g) Studies being undertaken include evaluation of the spectra and cross-spectra of salinity and river discharge data for Lake Pontchartrain, La., over a period of eleven years. Also multiple regression techniques have been employed to evaluate the effective exchange coefficient between the bay and the adjoining Gulf associated with tidal exchange.

(h) The Salinity Regime and Exchange Characteristics of a Shallow Coastal Bay System, Toshitsugu Sakou, Texas A\&M University, Project 299 Technical Report, Reference 63-21T, August 1963.

(4866) MODIFICATION OF TWO-DIMENSIONAL LONG WAVES OVER VARIABLE BOTTOM TOPOGRAPHY .

(b) Beach Erosion Board, DA-49-055-CIV-ENG63-9.

(d) Theoretical.

(e) The objective is to investigate the modiflcation of free gravity waves in variable depth, including reflection and transmission aspects, especially considering those long wave phenomena where simple refraction theory is inadequate.

(f) Initiated, March 1963

(g) of particular concern is the propagational aspects of a tsunami wave packet in the vicinity of a continental shelf. Methods are being developed to take into account vertical acceleration which is usually ignored when treating long waves.

(h) Paper in preparation on "Variational Formulation for Long Waves in Variable Depth"; by R. O. Reid and A. C. Vastano.

UNIVERSITY OF TEXAS, Department of Civil Engineering.

Inquiries concerning Projects Nos. 2162, 2397, 3524, 4234,4235 and 4715 should be addressed to Dr. walter L. Moore, Department of Civil Engineering, Univ, of Texas, Austin 12, Texas.

(2161) CHARACTERISTICS OF A HYDRAULIC JUMP AT AN ABRUPT CHANGE IN BOTTOM ELEVATION.

(b) University of Texas Research Institute and Bureau of Engineering Research.

(c) Dr. Carl W. Morgan, Assoc. Prof. of Civil Engineering, Univ. of Texas, Austin, Texas.

(d) Experimental.

(e) Experimental determinations are made of the flow characteristics at two-dimensional channel drops and rises. The velocity distribution and surface profile will be determined throughout the lerigth of the jump for various relative changes in bottom elevation. The longitudinal location of the jump in relation to the change in bottom elevation will be varied over a broad range in distinction to previous related investigations in which relative location of the jump was held constant.

(B) Results for the abrupt drop are complete and have been published. For a given entering Froude number lying between 2 and 8 three types of fump may form, the type and its longitudinal location depending only on the relative downstream depth. The velocities near the bottom below the drop are always less than the mean velocity in the downstream channel for the jump type of maximum height. Experimental measurements have been made on the related investigation for an abrupt rise and report is being prepared.

(2162) HYDROIOGIC STUDIES, WALIER CREEK WATERSHED.

(b) Cooperative with U. S. Geological Survey.

d Field investigation; applied research. Measurements of rainfall and munoff for a 4 square mile and a 2 square mile portion of the Waller creek watershed are being made to provide basic information for estimating 
munoff from small urban watersheds in the Southwest area. Two stream flow stations and a rain gage net are in operation. studies of the correlation between runof $f$, rainfall, and the characteristics of the drainage basin are being made by various proposed methods to serve as a base for comparison with the data as it is collected from the stream.

(g) The records are now long enough to begin comparing with peak discharge estimates previously given at least for short recurrence intervals. A start 1 s being made on this analysis.

(2397) EFFECT OF UPSTREAM DEVELOPMENT ON THE RUNOFF FROM SMALL WATERSHEDS IN THE SOUTHWEST.

(b) Laboratory project.

d Field investigation (thesis).

(e) For selected watersheds rainfall munoff relations are being developed on a storm by storm basis. Multiple correlation diagrams, based on data before changes in the watershed, have been developed and used to compute munoff for later periods. Comparison of these computed munof $f$ values with measured values is taken as an index of the effect of watershed development.

(g) The first results were not conclusive because of random error in the computed values. Further studies are being made on another watershed with an improved method which better accounts for the spacial variation of rainfall.

(h) "Multiple Correlation Estimates of Runof $f$ as Affected by Areal Distribution of Rainfall," Stanley P. Sauer, Hydraulic Engineering Laboratory, Dept. of C1vil Engrg., The University of Texas, Tech. Rep. HYD 03-6301 June 1963.

(2874) AN INVESTIGATION OF THE SCOUR RESISTANCE OF COHESIVE SEDIMENTS.

(b) The University of Texas Research Institute. Dr. Frank D. Masch, Department of C1V1l Engineering, The University of Texas, Austin 12, Texas.

(d) Analytical and experimental (laboratory). Exploratory tests have been made with two different schemes, one with radially outward flow between a clrcular disc and the soll sample, and one with a submerged vertical circular jet impinging on a horizontal soll surface. With the first scheme 1t was not possible to obtain the necessary precision of measurement at low scour rates, but with the second scheme satisfactory measurements were obtained. A correlation based on dimensional analysis gave consistent results in evaluating the relative scour resistance of several materials. Apparatus has been fabricated for a new test which permits direct evaluation of the shear stress at the soll surface. In this test a cylindrical soll sample is submerged in a transparent concentric cylinder which can be rotated at a controlled speed to generate a shear stress on the soll surface. Attempts are being made to relate the scour resistance to other measurable soll properties, and finally to interpret the results in relation to fleld observations.

(g) The apparatus to determine shear stress at the soll surface has been constructed and calibrated, a test procedure has been developed, and tests have been conducted on soil samples.

(h) "Measurements of the Shear Resistance of COHESIVE SEDIMENTS," by F. D. Masch, W. H. Espey, Jr., W. L. Moore, Paper presented at Interagency Conference, Jackson, M1ss., January 1963.

"A New Test to Measure the Scour of Cohesive Solls, "Hydraulic Engineering Laboratory, Dept. of Clvil Engrg., The University of Texas, Tech. Rep. HYD Ol-6301, April 1963.
(3522) LONG TIME FLUCTUATIONS IN STREAM RUNOFF.

(b) Laboratory project.

(c) Dr. Carl W. Morgan, Dept, of C1vil Engrg., Univ. of Texas, Austin 12, Texas.

(d) Analytical and field study.

(e) Values of munoff from selected drainage areas in the lower Mississippi River Basin and in basins of the rivers emptying directly into the Gulf of Mexico were studied. Variations in the runoff values for each stream were considered and these trends compared with solar variations. The relative sunspot numbers were used as the measure of solar variations and were correlated with the mean annual munoff. Further correlations are being made with different "lag" periods between solar activity and surface runoff.

(g) The gradual shifting of the centers of runoff excess and deficiency is consistent rather than random and appears to represent a gradual cyclic change in the runoff pattem. It appears that the locations of the centers of runoff deflclency are following roughly the same path that they did some 22 to 24 years previously. Correlation coefficients of plus 0.2 to plus 0.5 are obtained for selected rivers in Mississippi, Alabama, Georgla, and Arkansas when sunspot numbers in the il-year sunspot cycle are correlated with runoff. Texas streams do not give significant correlation with the 11-year sunspot cycle but give better correlation if runoff is compared with the double sunspot cycle in which sunspot numbers are assumed as negative in alternate cycles.

(3524) GROUND WATER FLOW AND SEEPAGE IN NONHOMOGENEOUS, NON-ISOTROPIC SEDIMENTS.

(b) Laboratory project.

(d) Theoretical, basic.

(e) A relaxation solution for the Laplace equation has been developed which is applicable across a boundary between two regions of different permeabilities. It is believed that the method can be expanded to apply to any specified non-homogeneous and non-1sotropic condition. It is intended that the solution be set up for computation on an electronic computer and that selected numerical solutions be checked against those from an electrolytic tank.

(4234) EVAPORATION REDUCTION BY CONTROL OF ADVECTED ENERGY.

(b) Partial sponsorship by the Lower Colorado River Authority of Texas.

(d) A Master's thesis involving theoretical and field investigation.

(e) Measurements have been made to determine the temperature field in Lake Travis for the 1962-63 season. A method was developed to estimate the effect of withdrawing water from near the lake surface. Monthly est1mates of the resulting temperature field and reduction in evaporation were made.

(h) "Selective Withdrawal as a Means of Reducing Evaporation from Reservoirs," by C. S. Vaughn, Hydraulic Englneering Laboratory, Dept. of Clvil Englneering, The Univ, of Texas, Tech. Rep. HYD 02-6301 June 1963.

\section{(4235) TWO-PHASE FLOW IN CONDUITS.}

(b) Laboratory project.

d) Experimental master's thesis.

(e) It is apparent that for a two-phase flow system with a liquid and gas, many different types of flow are possible. This investigation explored the use of sound measurements to detect the type of flow present, in a metal pipe. Various types of flow were established in a thin-walled aluminum pipe, 1.66 I.D., with a transparent plastic section at each end. Records of the sound pattern were made with different pick-ups and correlated with the visual 
observation of the flow type. Magnetic tape records of the sound were also made.

(g) Study of the recorded sound patterns revealed some identifiable characteristics related to the type of two-phase flow in the line. Additional work is needed to refine techniques and try other sound pick-up and recording methods.

(h) "Sonic Signatures of Multi-Phase Flow," by R. G. Hindman, Masters Thesis, The Univ. of Texas, Austin, Texas, June 1962.

(4715) CONTROL OF CROSS WAVES IN AN OPEN CHANNEL DOWNSTREAM FROM A CURVE WITH SUPER-CRITICAL FLOW .

(b) Laboratory.

(e) Various methods have been investigated for controlling cross-waves in an open channel downstream from a curve with super-critical flow. A simple method that has not been previously investigated is the design of radius and deflection angle so that the disturbance caused at the entrance to the curve will be cancelled by the one caused at the end of the curve. Laboratory studies were made to explore this method.

(g) Preliminary results indicate that the curve can be so proportional as to effectively eliminate cross waves in the downstream channel. The disturbance within the curve remains large as predicted by the work of Ippen.

(h) "Design of Simple Curves for Supercritical Channel Flow, "by K. E. Burch, Masters Thesis, The Univ. of Texas, Austin, Texas, Aug. 1963.

\section{(4716) DRAG FORCES IN VELOCITY GRADIENT FIELDS.}

(b) David Taylor Model Basin, Dept. of the Navy.

(c) Dr. Frank D. Masch and Dr. Walter L. Moore, Department of Civil Engineering, The Univ. of Texas, Austin 12, Texas.

(d) Theoretical and experimental; basic research. The investigation $1 \mathrm{~s}$ being conducted to determine the effect of a velocity gradient on the local and conventional drag coefficients for cylinders of varying $L / D$ ratio and at different Reynolds Numbers. The study will be extended to other shapes.

(g) Preliminary studies have demonstrated that the velocity gradient along a cylinder af fects the drag coefficient. The local drag coefficient decreases along the cylinder in the direction toward the end of the cylinder where the velocity is high. The reduction in drag coefficient is related to a dimensionless measure of the velocity gradient along the cylinder.

(4717) TWO-FLUID FLOW IN A POROUS MEDIUM.

(b) Laboratory project.

(c) Dr. L. R. Mack, Department of C1vil Engineering, Univ. of Texas, Austin 12, Texas.

(d) Theoretical; basic research.

(e) The velocity distribution within and the shape of the interface between two 1mmiscible fluids of different densities flowing through a uniform isotropic porous medium toward a well is sought. This problem is of interest in both petroleum engineering and ground-water hydrology.

(8) A method has been devised for satisfying the governing equations, including the nonlinear boundary conditions at the interface. This method is applicable to both twodimensional and axisymmetric systems.

(4989) INVESTIGATION OF DAMAGE TO GALVESTON SEA WALL PROJECT DURING HURRICANE CARLA.

(b) Cage Brothers General Contractors, San Antonio, Texas.

(c) Dr. Walter L. Moore, Dr. Frank Masch, Jr. Dept. of Civil Engineering, The Univ. of Texas, Austin 12, Texas.

(d) Experimental, theoretical, field; applied research. (e) Study of causes of damage to Galveston Sea Wall Project during Hurricane Carla. A study was made of waves, overtopping and erosion of the toe protection in relation to the erosion damage to the embankment behind the seawall.

(4990) WAVE CHARACTERISTICS IN SHOAIING WATER.

(b) Beach Erosion Board, Corps of Engineers.

(c) Dr. Frank D. Masch, Dept. of Civil Engrg., The Univ. of Texas, Austin 12, Texas.

(d) Theoretical; basic and applied research.

(e) This study is to develop a workable method for computing water wave characteristics in shoaling water using cnoldal wave theory. The method involves evaluating the power transmission for a wave train in shallow water from cnoldal theory and using the concept of constant power between orthogonals on a refraction diagram.

(g) Integrals of the cnoidal functions have been evaluated in terms of elliptic integrals and computer programs have been developed to solve the resulting equations.

(4991) LOCAL SCOUR IN CHANNELS.

(b) Laboratory project.

c) Dr. Frank D. Masch and Dr. Walter L. Moore, Dept. of Clvil Engrg., The Univ. of Texas, Austin 12, Texas.

(d) Theoretical and experimental; basic and applied research.

(e) This project is designed to investigate the characteristics of the three dimensional flow patterns at channel obstructions and to study the extent to which these flows affect local scour. It is belleved that a more thorough understanding of the fundamentals of the flow at an obstruction would provide the basis to devise methods for controlling scour. The nature of scour at culverts is also under consideration with efforts being devoted to develop methods for dissipating energy and reducing local scours.

(h) "The Influence of Secondary Flows on Local scour at obstructions in a Channel," by W. L Moore and F. D. Masch, Proceedings, Federal Inter-Agency Sedimentation Conference, Jackson, Miss1ss1pp1, February 1963.

(Preprints of paper available from authors.)

UTAH STATE UNIVERSITY, Engineering Experiment Sta.

(3183) DYNAMICS OF FLOW IN STEEP, ROUGH, OPEN CHANNELS.

(b) Laboratory and fleld project; Rocky Mt. Exp. Sta.; U. S. Forest Service; Nat'l Sc1. Found.

(c) Dr. Dean F. Peterson, Dean of Engineering, Utah State University, Logan, Utah.

(d) Experimental, theoretical, field investigation; basic research for doctoral theses.

(e) A basic study of relationships involved in flow in steep, rough channels where the roughness is relatively an appreciable part of the depth, and where channels are sufficlently steep or steeper than a slope such that supercritical flow can occur in connection with contractions caused by the roughness. The work is basic, however, it will have application to steep mountain streams and to hydraulic structures. The objective of the work is to relate descriptive parameters describing the size and configuration of the bed roughness to slope, depth and discharge of channels of this class. Studies began using simple bar and cube elements and have progressed through the use of beds formed by gluing natural gravel elements of various size, gradation and intensity to the bed. Fleld sites were installed in $1961-62$ at 13 locations on streams in the Wasatch Mountains in Northerm Utah. Detalled studies of bed geometry were made at all sites. Three plezometric type 
stilling wells to measure slope and depth were installed at each of 6 sites for which discharges were determined. Slope, effective depth, bed element size and roughness intensity were characterized and related to discharge using parameters suggested by the previous studies in the laboratory flume using natural gravel bed elements. Seven additional field sites have been selected and surveys of bed configuration made. To provide information under varying geological conditions sites have been located also in Colorado and New Mexlco, as well as at new locations in Utah. DIscharge measurements are being continued at the old sites as well as the new ones in order to obtain larger ranges than occurred in 1962 and 1963. A laboratory model study was made of the scourlng and paving of high gradlent streams by discharging a constant stream over a graded bed of sand and gravel placed in a sloping flume. Hydraulic geometry, bed element conflguration and stream hydraulics were also studied and related to other observations, analysis and interpretation of this study is not yet complete.

Further study is being planned using natural gravel beds in sloping flumes. One study will attempt to delineate Reynolds number effects by varying viscosity. The other study will involve detalled investigation of velocity distribution.

(g) Bed element size and conflguration of the natural sites was characterized by taking measurements of vertical distance from a plane grid system installed above the streams. These were reduced to a mean bed plane datum for each site. It was found that the number of bed elements $N$ larger than a certain size in any arbitrarily chosen bed area $A$ were related by the equation

$$
\mathrm{A}^{\frac{1}{2}} / K_{\mathrm{n}}=\mathrm{IN}^{\mathrm{u}}
$$

In which $K_{n}$ is the minimum element height whose percentage of occurrence is $n$ and $u$ is a uniformity coefficient of sampling, theoretically $1 / 2$. A general velocity equation of the Chezy form giving good results for all sites studied was developed. The equation for the Chezy coefficient C included relative bed element height to depth, depth-width ratio of the stream and intensity $I$.

At the steeper sites combination bed elements formed in the form of transverse bars which controlled the flow in a manner similar to overflow weirs. The spacing of these bars varled directly with bed element size and inversely with slope. The range of slope was from 1.0 to 4.0 percent with average Froude number varying from 0.2 to 0.7 . Discharges varled from about 16 to nearly 700 cfs. Field results were also applied to the equations proposed by Leopold and Maddock, $\mathrm{v} 1 \mathrm{z}, \mathrm{W}=\mathrm{a} \mathrm{Q}^{\mathrm{b}}, \mathrm{d}=\mathrm{CQ}^{\mathrm{f}}$ and $\mathrm{V}=\mathrm{PQ} \mathrm{Q}^{\mathrm{W}}$ where $\mathrm{W}, \mathrm{d}$, and $V$ are width, depth and velocity; $Q 1 \mathrm{~s}$ discharge and $a, c, p, b, f$ and $m$ are numerlcal coefficlents. Average values obtained were almost 1dentical to those found by wolman for Brandywine creek.

(3185) HYDRAULICS OF SURFACE IRRIGATION.

(b) Public Health Service.

c) Dr. Vaughn E. Hansen, Director, Englneering Experiment Station, Utah State University, Logan, Utah.

(d) Experimental, theoretical; bas1c research; Doctoral dissertation.

(e) Hydrodynamic and fleld study of movement of water over a porous surface when intake varies with time. The free surface and the rates of advance are defined.

(g) Differential equations have been developed which define the free surface and rates of advance. High speed computers have been used to obtain typical solutions which have been compared with fleld measurement of the rete of advance. The results are within ten percent of field observations. A dimensionless plot has been constructed which will predict the advance for any given set of known soll conditions. A companion study is based upon utilizing empirical relationships as a foundation for subsequent development of rate of advance functions. The results compare well with measured values.

(h) "Hydraulics of Unsteady Open Channel Flow Over a Porous Bed," by Hon-Hsleh Su. MS thesis, 1962.

"The Theory and Characterist1cs of Overland Flow," by Cheng-lung Chen and Vaughn $E$. Hansen. Publication pending ASAE 1964.

(3525) MEASUREMENT OF FLOW FROM HORIZONTAL PIPE BY THE COORDINATE METHOD.

(b) Laboratory project.

(c) Dr. Vaughn E. Hansen, Director, Englneering Experiment Station, Utah State University, Logan, Utah.

(d) Experimental; theoretical; applied research. The error involved in the conventional method of measurement is shown to be large. The coefflclent has been defined and parameters developed so that more accurate measurements can be obtained in a quick, easy method of water measurement.

(f) Completed.

(h) "The Discharge coefficient in the coordinate Equation for Measuring Water Flow from Horizontal P1pes," by Day L. Bassett and Vaughn E. Hansen. Publication pending by ASAE 1963.

(3528) THE EFFECT OF SEDIMENT PROPERTIES ON THE ATTENUATION OF AN ULTRASONIC PIANE WAVE.

(b) National Science Foundation. Englneering Department, Utah State UnIv., Logan, Utah.

(d) Theoretical and experimental; basic research Some theoretical and experimental work has been performed on the attenuation of an ultrasonic plane wave passing through a sediment suspension. However, experimental work is still very limited in scope, particularly over certain loss regions. Th1s study uses a standard pulse technique to Investigate a wide range of natural and manufactured sediments over the varlous loss ranges. Of primary concern is the effect of the varlous sediment properties on the attenuation.

(g) Natural sediments have been completed and an MS thesis has been prepared giving the results. Manufactured sediments of known properties have been tested and a PhD dissertation is belng prepared.

(h) A publication is now avallable on work done previous to this project entitled, "Ultrasonic Measurement of Suspended Sediment," by Gordon H. Flammer, Geological Survey Bulletin 1140A, December 1962.

"The Effect of the Properties of Natural Sediments on the Attenuation of an Ultrasonfc Plane Wave," by Yung-Huang Kuo. MS thes1s, Utah State Un1v., Logan, Utah, 1961.

(3530) WATER REQUIREMENTS OF MARSHLANDS.

(b) Utah State F1sh and Game Dept.

(c) Prof. Jerald E. Christiansen, Professor C1vil and Irrigation Englneering, Utah State Univ., Logan, Utah.

(d) Field Investigations; applied research, Master's theses.

(e) Large areas of marshy lands adjacent to Great Salt Lake have been developed and Improved by the State F1sh and Game Dept., and the Federal Wildlife Service, as Migratory Bird Refuges. Available stream rlow from several of the major streams flowing into these areas where the water is Impounded behind dikes to create habltat sultable for nesting, feeding and resting of water fowl. Millions of ducks and geese ut1lize this area each year during their 
migratory flights.

(g) The basic purpose of the study is to determine the quantities of water necessary for marshlands in order to maintain them in a productive state.

(h) Several progress reports have been written.

(3845) WATERSHED MODEL STUDIES.

(b) Agricultural Research Service, U. S. Dept. of Agriculture.

(c) Prof. Jay M. Bagley, Civil and Irrigation Engineering, Utah State University, Logan, Utah.

(d) Experimental; basic research for master's thesis.

(e) The purpose is to establish techniques and model-prototype laws so that watersheds can be intensively studied in a laboratory. A small watershed has been modeled. A rainfall simulator has been constructed for which design or actual rainfall events can be programmed to occur automatically over the model. The dominant factors influencing the characteristic shape of the run-off hydrography are being studied. Initial efforts nave been aimed at determining effect on modeling relationships resulting from changes in the physical properties of water-chemical mixtures used in the rainfall simulator. Test muns are being made using a physical model with an 1mpervious surface. Subsequent tests will incorporate the relationship between infiltration and run-off by providing for permeability changes in the model.

(g) Model and simulator constructed. Exper1mental tests underway.

(3846) CONSTRUCTION OF AN INTERSTATE HICHWAY ACROSS THE SALT F'LATS NEAR WENDOVER, UTAH.

(b) Utah State Road Commission.

(c) Prof. Jerry E. Christiansen, Civil and Irrigation Engineering, Utah State Univ., Logan, Utah.

(d) Field investigation for design and development of Interstate highway.

(e) The design and constmuction of an interstate highway across the salt flats near wendover, Utah, poses a number of problems that require solutions. This 1s one of the few places in the world where a highway must be built over a salt bed. The maintenance of the present highway and railway that traverses these salt flats has been difficult. It is hoped that a better understanding of the problem, based on extensive field and laboratory investigations of materials on which the highway will be built, will result in a design that will be relatively free of maintenance problems. The objective, therefore, is to fully determine the characteristics of the salt bed and the underlying soil materials to considerable depth. The work completed to date has been concerned primarily with the permeability of the sub-soll materials to the flow of water. Surprisingly, it has been found there are very permeable strata underlying the salt. These are of considerable concern because of the movement of partially saturated solutions through these permeable zones which tends to dissolve and remove salt, resulting in uneven settlement of the roadway.

(f) Completed.

g) A sound and economic design depends upon a complete knowledge of the materials involved. Investigations should be of definite practica value in determining the basic requirements for the design and construction of the multimilion dollar highway, which will be built within the next few years. Economies in design should result from the studies being undertaken.

(h) Several progress reports have been written.

(4236) METHODS FOR PREDICTING MEAN ANNUAL WATER YIELDS IN UTAH.

(b) Utah Water and Power Board. (c) Prof. Jay M. Bagley, Civil and Irrigation Engineering Dept., Utah State University, Logan, Utah.

(d) Experimental; applied research.

(e) This work was undertaken to develop methods of obtaining economical and reasonably accurate determinations of watershed yield where stream gaging records are not avallable. Certain relatively easily obtained parameters characterizing the physical and climatic factors have been correlated with water yield for a number of watersheds having good records of stream fllow.

(f) Completed.

(g) Regression equations have been developed for estimating water yield from physical characteristics of basins in various regions of Utah. Based on the developments of this study, a water yield map for the entire state of Utah is being prepared. The map, equations and graphs should aid materially in broadening the coverage of hydrologic information needed for first stage planning of a long range state-wide nature.

\section{(4239) MECHANICS OF EVAPOTRANSPIRATION.}

(b) Laboratory.

(c) Dr. Vaughn E. Hansen, Director, Engineering Experiment Station, Utah State University, Logan, Utah.

(d) Theoretical; basic research

(e) An analysis of water movement from the soll, through the plant and into the atmosphere is made using basic hydraulic properties of flow. The mechanism of water transmission within the plant is given particular attention.

(h) "Mechanics of Evapotranspiration," by David W. Hendricks and Vaughn E. Hansen. Journal of the Irrigation and Drainage Division. Proceedings of American Soclety of Civil Engineers, June 1962.

(4719) FREE SURFACE FLOW AROUND A HEMISPHERICAL ROUGHNESS ELEMENT.

(b) Laboratory project.

(c) Dr. Gordon H. Flammer, Associate Professor, Civil and Irrigation Engineering Dept., Utah State University, Logan, Utah.

(d) Experimental and theoretical research toward a Master's thesis.

(e) Th1s study was made to gain further information on flow characteristics (primarily drag) around a hemispherical roughness element where the element size is of the order of the depth of the free surface flow. To accomplish this, water surface data, velocity profile data and primarily drag data was taken for a range of Froude numbers. The thesis attempts to answer certain questions concerning the effects on a single large hemispherical roughness element in open channel flow. Of particular interest is the flow condition where the element has an effect on the fluid surface conf'iguration.

An M.S. thesis has been prepared on this project. This work, however, is considered to be only preliminary to a continued study of much wider proportions.

(B) The results of this investigation may be summarlzed as follows: (1) The drag force on the hemisphere is due primarily to wave drag in the Froude number range 0.35 to 2.50 and for submergence intervals $\mathrm{y} / \mathrm{k}$ up to 1.2. (2) At a given submergence interval the coefficient of drag decreases as the Froude number of 1.5 for all submergence intervals. This constant value is approximately 0.2. (3) The drag coefficient increases with an increase in submergence in the Froude number range up to 1.5 . (4) The relationship between the coefficient of drag and the Froude number tends to become linear as the submergence increases.

(h) An M.S. thesis has been prepared under the 
following title, "Free surface Flow Around Hemispherical Roughness Element," by Dirk Van Woerden. M.S. Thesis, Utah State University, Logan, Utah, 1962.

(5129) CALIBRATION OF IRRIGATION HEADGATES BY MODEL ANALYSIS.

(b) D.M.A.D. Irrigation Companies, Delta, Utah.

(c) Mr. Gaylord V. Skogerboe, Asst. Research Engineer, Engineering Experiment Station, Utah State Univ., Logan Utah.

(d) Experimental; applied research.

(e) The D.M.A.D. Irrigation Companies have approximately 600 of these headgates in their distribution system and would like to use the headgate as a measuring device. Standards for the installation of such a headgate will. be developed along with flow rate curves and tables.

(h) Publication will be 1ssued during the early part of 1964 .

(5130) FARM IRRIGATION STRUCTURES.

(b) Laboratory project.

c) Mr. Gaylord V. Skogerboe, Asst. Research Engineer, Engineering Experiment Station, Utah State Univ,, Logan, Utah.

(d) Library research.

(e) A compilation of the material pertaining to the design of small irrigation structures that would be found on a farm. Will also determine gaps in information which will require additional research.

(5131) THE STRUCTURE OF TURBULENT BOUNDARY FLOWS IN ROUGH OPEN CHANNELS.

(b) Laboratory project.

c) Dr. Calvin G. Clyde, Civil Engineering Dept., Utah State Univ,, Logan, Utah.

(d) Experimental and theoretical; basic research for $\mathrm{Ph} . \mathrm{D}$. Thesis.

(e) To describe the structure of the turbulence and the boundary layer growth in rough open channels. Necessary instrumentation is to be developed.

(5132) TECHNIQUES OF AERIAI APPLICATION OF EVAPORATION-FORMING MATERIALS TO IARGE IAKES AND RESERVOIRS.

(b) U. S. Bureau of Reclamation.

(c) Dr. Vaughn E. Hansen, Director, Engineering Experiment Station, Utah State Univ., Logan, Utah.

(d) Experimental; applied research and development.

(e) Development of equipment and techniques for the aerial application of monolayer-forming materials.

(g) The performance of the equipment has been very satisfactory. Techniques have been developed for the use of alcohols in molten form and the use of powdered alcohols. Further research and development will be concermed only with powdered alcohols.

(h) "Aerial Spraying Equipment - Feasibility Study Applying Hexadecanol Monolayer Films on Storage Reservolrs," by Vaughn E. Hansen and Glen E. Stringham, Engineering Experiment Station, Utah State Univ., Logan, Utah, 1961. "Aerial Application of Evaporation-Reducing Chemicals," by Vaughn E. Hansen and C. Earl Israelsen, Engineering Experiment Station, Utah State University, Logan, Utah, 1963.

(5133) UTAH STATE UNIVERSITY STILIING BASIN FOR PIPE TO OPEN CHANNEL FLOW.

(b) Laboratory project.

(c) Dr. Gordon H. Flammer, Assoc. Prof. Civil and Irrigation Engr. Dept., Utah State University, Logan, Utah.

(d) Experimental research toward a master's thesis.

(e) The objective of this study is to find an economical and effective means of energy dissipation at the transition of plpe flow to open channel flow. (g) An effective design has been found involving a short dissipator pipe placed on the opposite wall of the stilling basin from the inflow pipe. The best ratios have been found for: the dissipator pipe diameter to inflow pipe diameter, length of dissipator pipe to inflow pipe diameter, slit width to inflow pipe diameter, and center line offset to the inflow pipe diameter.

(h) An M.S. thesis is currently being prepared. Further, a paper is being prepared for publication in a professional fournal.

(5134) CHARACTERISTICS OF THE SURFACE WAVE CAUSED BY VARIOUS SUBNERGED OBJECTS IN OPEN CHANNEL FLOW AND THEIR RELATIONSHIP TO THE DRAG ON THE OBJECT.

(b) Laboratory Project (An NSF grant has been applied for).

(c) Dr. Gordon H. Flammer, Assoc. Prof. of Civil and Irrigation Engineering Dept., Utah State University, Logan, Utah.

(d) Theoretical and experimental work leading toward a doctoral dissertation.

(e) The characteristics of the surface waves caused by various shapes of submerged objects in open channel flow will be studied. The relative submergence, Froude number, the approach velocity profile, etc. Wili be varied. A surface wave characteristic will be studied and related to the drag on the respective objects.

(5135) LIFT FORCES ON ISOIATED REGULAR OBJECTS ATTACHED TO A BOUNDARY.

(b) Laboratory project (NSF grant has been applied for).

(c) Dr. Gordon H. Flammer, Assoc. Prof., Civil and Irrigation Engr. Dept., Utah State Univ. Logan, Utah.

(d) Experimental and theoretical research leading to a doctoral dissertation.

(e) Ifft forces on isolated regular objects attached to a boundary will be studied for the following conditions: (1) A threedimensional, semi-infinite, flow field where viscous forces and approach velocity proflle are important. (2) A three-dimensional, finite, flow fleld where viscous forces, velocity profile, and relative submergence are important. (3) A three-dimensional, finite, flow fleld, with free surface effects, where viscous forces, velocity profile, relative submergence and gravity forces are important.

(5136) VEIOCITY AND PRESSURE DISTRIBUTION IN ACCELERATED CURVILINEAR FLOW.

(b) Laboratory profect.

(c) Dr. Gordon H. Flammer, Assoc. Prof., Civil and Irrigation Engrg. Dept., Utah State Un1v., Logan, Utah.

(d) This project is primarily theoretical in nature, however, for verification it uses experimental results by others along with theoretical results obtained from classical hydrodynamics. The research is of a basic nature and is the result of a Doctoral research program.

(e) The basic objectives of this study may be summarized as: (1) To derive the basic dynamic equations governing laminar flow for a curvilinear coordinate system. (2) To obtain new equations giving the direction and magnitude of the local velocity vector for curvilinear flow of an ideal fluid. Convergence of the streamlines will be considered in contrast to existing relations. (3) To find a more precise relation between velocity proflle and streamine curvature or potential line curvature for potential theory. (4) To find a direct solution for the new relation. This solution will give the magnitude and direction of a velocity vector anywhere in the flow field. (5) To verify this relation analytically and experimentaliy and to compare 1ts accuracy with previous techniques. (6) To apply the 
new technique in the determination of the velocity function in any curvilinear flow field with symmetrical boundaries such as convergent, divergent, passages. (7) To find a solution for the problem of laminar flow between two concentric boundarles with no temperature gradient effect.

(f) This project will be completed by Jan. I, 1964

(g) The objectives stated in Item (e) have been realized.

(h) A doctoral dissertation is presently being prepared and should be completed by Jan. I, 1964. It should be published and ava1lable sometime during the year 1964 .

(5137) DRAG ON A HEMISPHERE IN A THREE DIMENSIONAI FINITE FLOW FIELD WITH FREE SURFACE EFFECTS.

(b) Laboratory project (NSF grant has been applied for).

(c) Dr. Gordon H. Flammer, Assoc. Prof. of Civil and Irrigation Engr. Dept., Utah State Univ., Logan, Utah.

(d) Experimental and theoretical research toward a PhD dissertation. This study is basic in nature.

(e) The objectives are to study and compare drag on a hemisphere attached to a boundary for: (1) A three-dimensional, semi-infinite, flow fleld where viscous forces and approach velocity profile are important. (2) A threedimensional, fintte, flow fleld where viscous forces, velocity profile, and relative submergence are 1mportant. (3) A threedimensional, finite, flow field with free surface effects where viscous forces, velocity profile, relative submergence, and gravity forces are important.

(g) Since this program has just begun no results are available at present.

(5138) STATE WATER PIAN INVESTIGATIONS.

(b) Utah Water and Power Board.

(c) Mr. Jay M. Bagley, Civil Engrg. Dept., Utah State University, Logan, Utah.

(d) Field investigation.

(e) Water supply and use determinations and projections. Frequency analyses of various kinds of hydrologic data.

(g) Hydrologic inventories of major study area of state completed.

(h) "Developing a State water Plan---Summary and Recommendations," Utah Water and Power Board and Utah State University, Nov. 1962.

"Utah's Water Resources--Problems and Needs-A Challenge," Utah Water and Power Board and Utah State UnIversity, Engineering Experiment station, PR-EC48g-2, March 1963. "Summary of Surface Water Records of Utah," Utah Water and Power Board and Utah State Un1versity, Engineering Experiment Station, P.R. -EC-48g-3, Sept. 1963 .

(5139) HYDROLOGY OF THE GREAT SALT IAKE.

(b) Engineering Experiment station project.

(c) Prof. Jay M. Bagley, Civil and Irrigation Engineering Dept., Utah State Univ., Logan, Utah.

(d) Fleld investigation, applied research.

(e) Attempting to develop an adequate description of the sources, amounts and regimen of water inflow into the lake from precipitation, surface flows, and subsurface flows. This will provide the basis on which to predict the effect of future development so that altemative resource use patterns for the lake and its tributary system can be evaluated.

(g) Approximately 3,000,000 acre feet of water enter the Great Salt lake from all sources and are evaporated.

(5140) EIECTRONIC ANALOG MODEL STUDIES OF RIVER BASINS.

(b) Soil Conservation Service, U.S.D.A.

(c) Prof. Jay M. Bagley, Assoc. Prof., Civil and Irrigation Engineering Dept, Utah' State Univ., Logan, Utah. (d) Experimental. approach to the Sevier River Basin Investigations for water resources development and conservation planning is being explored. Characteristics and costs of various simulator systems are being investigated.

(g) Circuitry for an exploratory model for Circle valley has been designed. Analog model has not been constructed.

(h) "Report on Feasibility of an Electronic Analog Approach to Sevier River Basin Investigations," Jay M. Bagley, Duane G. Chadwick, Robert B. Hickok, Marvin J. Rosa. U.S.U. Engineering Experiment Station, Report EC-51g-1, 47 pages, August 1963.

(5141) THE EFFECT OF LOCAL VARIATIONS IN TOPOGRAPHY ON RAINFALL MEASUREMENT.

(b) Agricultural Research Service and Laboratory.

(c) Prof. Joel E. Fletcher, Engineering Expt. Sta. Utah State University, Logan, Utah.

(d) Field investigation, applied research, master's thesis.

(e) From a study of the perfomance of existing raingages on Reymold's Creek Experimental Watershed and by installing different types of gages at selected sites, the objective is to determine what differences in rainfall at the ground level are actual and what are due to measurement differences. From the study it is planned to develop guides for the positioning and selection of future gages.

WASH INGTON STATE UNIVERSITY, The R. I. AIbrook Hydraulic Laboratory.

Inquiries concerning the following projects should be addressed to Dr. E. Roy Tinney, Head, The R. I. Albrook Hydraulic Laboratory, Division of Industrial Research, Washington State University, Pullman, Washington.

\section{(1689) STUDY OF FLUID FLOW IN PIPE NETWORKS.}

(b) Personnel responsible for the design and/or operation of water and gas distribution systems.

(d) Analyses by analogue and digital computers.

(e) Flow distributions have been made with the McIlroy Analyzer for over 50 clties, several gas systems, an air system, a generator cooling system, and several other unique systems. Losses throughout the system are obtained. Englneers use the analogue to design system pumps, tanks, and plping additions or revisions.

\section{(2631) ROCKY REACH HYDROELECTRIC DEVELOPMENT.}

(b) Chelan County Public Utility District No. 1. (d) Experimental; design.

(e) Hydraulic model studies on several problems of design and operation have been completed. Three final reports are now in preparation. Construction sequences, flshway design and operation, spillway energy dissipators, splliway capacity, downstream erosion and waves, and splllway operation all underwent detalied investigation on six hydraulic models over a period of more than six years. sound motion picture films are now being prepared on the use of the models.

(g) The energy dissipator, consisting of a 14-ft. high solid baffle a high slotted endsill and spillway nappe deflectors, adequately dissipated the energy in the spillway flow. Vortices rangingffrom 2 to 30 feet in diameter will not adversely affect the spillway gates.

(h) "River Diversion," by Howard D. Copp, Part I, Technical Report No. 9 , Washington state Institute of Technology, June 1963, 49 pages.

(3534) WELLS HYDRO-COMBINE FLUME MODEL.

(b) Bechtel Corporation. 
(d) Experimental; design.

e) A $1: 23.3$ scale model of a section of the splilway-power unit was tested to evaluate hydraulic characteristics of an unusual design for hydroelectric developments.

(f) Suspended.

(g) These tests indicated that the power units or the splilway, when operated as separate units, perform the same as conventional designs. When operated simultaneously, the spillway discharge coefflclent is about the same as conventional ogee spillways, and the spill increased the operating head on the power units through a local tallwater depression.

(h) "Hydraulic Model Studies, Wells Hydroelectric Project, Volume II. Sectional Model Studies," edited by $E$. Roy Tinney, Washington state Institute of Technology, Bulletin 271, July 1963,62 pages.

(3848) CALIBRATION OF FLOW METERTNG FLUMES.

(b) Agricultural Research Service, Bolse, Idaho.

d Experimental; design.

(e) Metering flumes are belng placed on several streams within an experimental watershed in southern Idaho. Desirable shapes, location of head measuring taps, orlentation and elevation of invert of these flumes are being investigated by hydraulic model. The effect of flow rate, upstream and downstream topography, and sediment deposition are considered. Calibration of three metering devices have been completed by use of the models and one prototype flume is now constructed.

(4244) SULTAN DAM NO. 1.

(b) R. W. Beck and Assoclates.

(d) Experimental; design.

(e) Final tests were conducted in the 1:50 scale model of the sultan Dam to determine the best arrangement for the tunnel spillway and morning-glory intake. Data were recorded to determine the spillway rating curve pressure patterms and aeration conditions. A total of 681 tests were conducted in this model before a suitable solution was found. The second stage tunnel will have a capacity of $80,000 \mathrm{cfs}$. Additional tests are being conducted to obtain best method of releasing the water from the tunnel to the natural channel.

(g) A two-stage tunnel splliway was found to be satisfactory with the second stage formed by adding a 38-ft. diameter shaft with a new morning-glory intake.

(4245) HYDRODYNAMIC INVESTIGATION.

(b) Laboratory project.

(d) Theoretical and experimental; applied research.

(e) Tests are belng made on nappe deflectors adjacent to splilway plers to obtaln design data and permit selection of this type of energy dissipator prior to experimental testing in connection with a specific application. Th1s type of energy dissipator has been used on Rocky Reach and Noxon Raplds dams and is belng considered for use at chungju dam, in Korea.

(f) Suspended.

(g) Stiling basins can be considerably shortened and ralsed with the use of nappe deflectors.

(4246) ROUND BUTTE TRIFURCATION MODEL.

(b) Portland General Electric Company.

(d) Experimental; design.

(e) A $1: 23.7$ scale model of a power penstock trifurcation was constructed and invest1gated for head loss and undue structural vibrations.

(i) Completed

(g) Head losses were minimal, information regarding stmuctural vibration was used in the structural design. (h) "The Round Butte Penstock Trifurcation T1eBar," by John S. Gladwell, E. Roy Tinney and Harald Kreuzer Research Report No. 63/9-80, Washington State University, Inst1tute of Technology, August 1963. 14 pages.

(4721) MODEL CALIBRATION OF ROCK ISLAND SPILIWAY.

(b) Public Ut1lity District of Grant Co., Washington.

(d) Experimental; analytical.

(e) A 1:50 scale model of the west section of the Rock Island Dam splliway was constructed. Tests were made to determine the discharge coefflclents for each bay as they may be influenced by adjacent and nearby bays, tallwater and apron elevations, and distribution of flow approaching the spillway discharges. Accurate discharge ratings were required in connection with power losses due to tailwater encroachment at Rock Island by the Wanapum pool. A final report is being prepared.

(g) Correlation of model and river discharge data indlcate that the model can be used to predict spillway discharge with an accuracy of $\pm 2 \%$.

(4722) BOUNDARY COMPREHENSIVE MODEL.

(b) Bechtel - Leedshill.

d Experimental; design.

(e) A 1:65 scale model of approximately 0.6 miles of the Pend oreilie River, the arch dam, forebay, and spillways have been constructed. Investigations were concerned primarily with the slulce ring orientation, power house, diversion dam, and ogee spillways. The slulce ring is particularly of concern because it must pass flows of approximately $280,000 \mathrm{cf}$ 's at a depth which results in velocities of about $100 \mathrm{f} . \mathrm{p} . \mathrm{s}$.

(f) Completed.

(n) "Hydraulic Model Studies of the Boundary Hydroelectric Project," by John S. Gladwell, Howard D. Copp and E. Roy Tinney, June 1963, 67 pages. Washington State University Inst1tute of Technology Bulletin 270.

(4723) BOUNDARY PROJECT SLUICEWAY MODEL.

(b) Bechtel Corporation.

d) Experimental; design.

(e) A 1:25 scale model of low level slulceways has permitted experimental investigation of sluiceway design and the determination of a sultable intake shape that w1ll operate, cavitation free, under heads up to 190 feet. Slulceway gate vibration tests have been conducted.

(f) Completed.

g) The original intake shape, designed according to conventional procedures was not cavitation free. A converging section formed by a rising invert was found necessary.

(h) "Hydraul1c Model Studies of the Boundary Hydroelectric Project," by John S. Gladwell, Howard D. Copp, and E. Roy Tinney, June 1963,67 pages. Washington State Univ., Institute of Technology Bulletin 270 .

(4724) WELLS COMPRFHENSIVE MODEL.

(b) Bechtel Corporation.

d Experimental; design.

(e) A 1:78 model of the Wells Hydrocombine has been constructed to study potential erosion, wave action, passage of migratory flsh. splilway capacity, and construction sequences. Since the power house and spillway are comblned into one structure, several unique problems in design and operation must be investigated. The model is 44 feet wide and 66 feet long and w1ll pass the equivalent of $1,300,000 \mathrm{cfs}$.

(5042) A STUDY OF MECHANISMS OF FLASHING AND CAVITATION DURING FLOW THROUGH APPERTURES.

(b) Laboratory project. 
(d) Primarily experimental study; relatively basic in character; one M.S. thesis is being developed.

(e) Hot water flows are expanded through a variety of free and submerged orifices and nozzles in an attempt to determine general conditions on incipient cavitation and flashing.

(h) "A Study of the Dynamics and Thermodynamics of Liquid-Gas-Vapor Bubbles," by John $\mathrm{H}$. Lienhard, Washington State Institute of Technology Bulletin 266, 64 pages. Discussion by John H. Lienhard of ASME Paper 63 AH GT4 "Expansion of a Very Low Quality Two Phase Fluid Through a Convergent Divergent Nozzle," by E. S. Stakman, V. E. Schrock, K. F. Neusen, and D. J. Nanely, Journal of Basic Engineering.

(5043) THE PLACE OF PUMPED STORAGE IN THE POWER ECONOMY

(b) Laboratory project.

d Theoretical; design.

(e) Examination with examples of pumped storage in a predominantly thermal and a predominantly hydro system: sizing of water conduits; suitability of equipment and methods of operation.

(g) Daily pumped storage will be used to an increasing extent in USA to supplement thermal base load. Seasonal pumped storage may be used to a minor extent to supplement a hydro base in favorable conditions. Economic factors differ considerably from those of conventional hydro. Strong economic pressure exists for development of higher head pump-turbine.

(h) "Pumped Storage in the Power Economy," by Robert A. Sutherland, Proceedings of 4 th Biennial Hydraulics Conference, Washington State University, 1964, 10 pages.

(5044) INTERFACIAL WAVES - STRATIFIED RESERVOIR.

(b) Laboratory project.

d) Experimental; theoretical; basic research. Two liquids of nearly equal densities are placed in a glass sided flume. Waves are generated and withdrawals are made at different levels. The fluid behaviors are studied under either of these conditions.

(5045) WELLS FISHWAY MODELS.

(b) Bechtel Corporation.

d) Experimental; design.

(e) Models of the fish ladder and fish entrances with attraction jets are constructed at a $1: 12$ scale and being tested to determine best arrangement of orifices, and best method of operation. Tests are still in progress.

(5046) MODEL STUDIES OF ROCK TRAPS IN TUNNELS.

(b) Bechtel Corporation; Sacramento Municipal Utility District.

(d) Experimental; design.

(e) Rock and sand traps were modelled. These included the existing Jaybird tunnel and the proposed revision, the proposed Camino tunnel and the theoretical design. Graded rock particles were introduced upstream of the traps. Rock passing over the traps was collected on screens at the downstream exit and weighed and sieved.

(g) Effective removal of rock from the flow can be accomplished by gratings over a pit which is baffled and protected from large scale turbulent eddies. Expansion of flow into a larger cross-section is ineffective due to turbulence which reintroduces rock into moving stream.

(h) "Rock Trap Experience in Unlined Tunnels," by J. J. Mattimoe, E. Roy Tinney, and W. W. Wolcott, ASCE Annual Meeting, October 1963, 14 pages.

"Hydraulic Model Studies of Rock Traps," by James W. Crosby III and E. Roy Tinney, Research Report No. 63/8-73, Washington State Inst. of Tech., Sept. 1963, 53 pages.
UNIVERSITY OF WASHINGTON, Charles $w$. Harris Hydraulics Laboratory.

(3853) FLOW THROUGH AN ARRAY OF CYLINDERS.

(b) Laboratory project.

(c) Prof. Ronald E. Nece, Dept. of Civil Engrg., Univ. of Washington, Seattle, Wash. 98105.

(d) Experimental; basic research.

(e) Hydrodynamic forces are to be determined on one of a row of circular cylinders. Cylinder spacing and orientation of the single row with respect to a uniform approach flow are to be varied.

(f) Suspended.

(g) Proximity effects upon drag coefficlents have been determined for two cylinder row orientations for the case of laminar boundary layers on the cylinders.

(h) one M.S. Thesis completed (available on loan).

(4725) SALT WATER ENTRAINMENT FOR DILUTION IN SEWER OUTFALLS.

(b) U. S. Department of Health, Education, and Welfare-Public Health Service.

(c) Prof.R. E. Nece, Dept. of Civil Engineering, University of Washington, Seattle, Wash., 98105 .

(d) Experimental; basic and applied research.

(e) The mechanism of the entrainment of a fluid from an infinite still reservoir through discrete ports into a conduit flowing full is to be studied experimentally and analytically.

(g) Data have been obtained for the case of zero density differential for single and double circular ports of different sizes and various edge configurations.

(h) Two M. S. Thesis completed (available on loan).

(4726) A STUDY OF VELOCITY BARRIER DEVICE FOR DOWNSTREAM MIGRANT BYPASS .

(b) Columbia Fisheries Program office, U. S. Bureau of Commercial Fisheries, Portiand, Oregon.

(c) Prof. H. S. Strausser, 317 Hydraulics Lab., University of Washington, Seattle, Wash., 98105.

(d) Experimental investigation; developmental research.

(e) The problem requires a structure which will guide downstream migrant fish into a collection facility with a minimum obstruction to flow. The methods under study utilize velocity changes which would attract or repel the fish, thereby steering them into a desired location.

(g) No satisfactory results as yet.

(4728) THE INTERACTION EFFECTS OF FIXED SEMIIMMERSED CIRCULAR CYLINDER WITH A TRAIN OF PROGRESSIVE OSCILIATORY WAVES IN A CHANNEL OF FINITE DEPTH.

(b) Laboratory project.

(c) Prof. E. P. Richey, Department of Civil Engineering University of Washington, Seattle, Washington 98105 .

(d) Basic theoretical research with experimental verification for a doctoral thesis.

(e) The objective of the work is to obtain an analysis of the problem which can be used to determine force components and coefficlents of reflection and transmission.

(f) Completed.

(g) An analysis of the force, reflection and transmission coefficients was obtained by superposition principles and a computer program written for a limited range of variables, which were then compared with experimental results.

(5113) MODEL STUDY OF THE MOSSYROCK DAM AND SPILI WAY.

(b) Harza Engineering Company and the City of Tacoma, Major Projects Division. 
(c) Professors E. P. Richey and H. S. Strausser, Un1v. of Washington, seattle, wash. 98105.

(d) Experimental and applied research.

(e) The study will be concermed especially with erosion resulting from splilway flows as well as the usual problems of a dam and spillway model.

UNIVERSITY OF WASHINGTON, F1 sheries Research Inst.

(3535) EFFECTS OF LOGGING ON PRODUCTIVITY OF PINK SALMON STREAMS IN ALASKA.

(b) Bureau of Commerclal Fisherles, U. S. Fish and Wildlife Service, Juneau, Alaska, is contracting agency. Co-operating agency is Northern Forest Experiment Station, U. S. Forest Service, Juneau, Alaska, and Alaska Department of Fish and Game, Juneau, Alaska.

(c) Prof. Donald E. Bevan, Research Assoclate Professor, Fisheries Research Institute, University of washington, Seattle 5, wash.

(d) Experimental, theoretical, and fleld investigation; basic and applied research, including master's and doctoral thesis research.

(e) To identify environmental factors causing mortality of pink salmon embryos; (2) to gain a more complete understanding of interrelationships among spawning behavior, physical and biological attributes of the stream and spawning bed, and mortality of embryos; (3) to determine how the quality of the spawning bed environment as it pertains to growth, development, and mortality of embryos is affected by logging; and $(4)$ to determine criteria for the Improvement of natural spawning areas to increase production of juvenile salmon. Included among active routine studies are hydrological conditions, intragravel water quality, spawning bed quality, and channel debris evaluation. Included among active basic studies are composition and source of suspended sediment and bed load, relationsh1p between surface and intragravel water, and sources of intragravel water.

(g) Methods have been developed for routine fleld measurement of dissolved oxygen content of intragravel water, gravel composition, and mortality of salmon embryos. Gravel shift has been 1dentified as an important natural cause of embryonic mortality. A theoretical model of factors controlling interchange between stream and intragravel water has been proposed and tested qualitatively.

(4247) IMPROVEMENT OF SALMON SPAWNING AREAS IN INDIAN CREEK, ALASKA.

(b) U.S. Forest Service, Juneau, Alaska, Bureau of Commercial F1sheries, Alaska, Department of Fish and Game, Juneau, Alaska.

(c) Prof. Donald E. Bevan, Research Associate Professor, Fisheries Research Institute, Unlversity of Washington, Seattle 5, wash.

(d) Experimental, theoretical, and field investigation basic and applied research, including thesis research.

(e) Artiflcial spawning areas have been constructed on Indian creek on Prince of Wales Island within the Tongass National Forest, Alaska. The project is to test the general hydraulic considerations assoclated with the design of improved pink salmon spawning areas in natural streams. Objectives of the research program are to test the design of artificial improvements to salmon spawning grounds. The problem is to determine if we can provide, at reasonable cost, small areas of stable permeable gravel in which low water flow of stream wIll be concentrated. The evaluation of artificlally constructed channels will provide information of the detailed requirements of spawning fish as well as the requirements of eggs and larvae. Further information will be obtalned on movement of bed materlal as no stream flow regulation is provided.

(g) Data currently belng analyzed.

(4730) DETERMINING CHANGES IN SIZE COMPOSITION IN STREAMBED MATERIAL IN LOGGED WATERSHEDS.

(b) Institute of Forest Products, Un1v. of Washington.

(c) Prof. Donald E. Bevan, Flsherles Hall \#2, University of washington, Seattle 5, Wash.

(d) Experimental, theoretical and field investigation; applied research for M.S. thesis.

(e) The research is to evaluate ecological changes in salmon streams caused by deforestation. Soll erosion, subsequent logging operations in a watershed, may cause large quantities of fine particles to be deposited in the beds of the streams adfacent to logging areas. The presence of fine materials reduces the permeability of the stream and gravel thereby reducing the rates of waterflow in the streambed and the rate of exchange of inter-gravel water. The rate of exchange between the intergravel and stream water limits the quality of the inter-gravel environment of the habltat for salmon eges and larvae. The results of the proposed investigation will assist in determining if logging will affect salmon production. The objectives of the study are: (1) To evaluate the present gravel sampling procedures and index of streambed quality for salmon; (2) to determine the physical factors controlling the size of the particles within the stream bed; (3) determine if streambed composition can be used to measure effects of logging on salmon.

\section{(5019) THE ECOLOGY OF BOISE CREEK.}

(b) The Weyerhaeuser Company.

(c) Prof. Donald E. Bevan, Research Assoc. Prof., Fisheries Research Institute, Univ, of Washington, Seattle 5 , Wash.

(d) Experimental, theoretical, and field investigation; basic and applied research including masters thesis research.

(e) Sewage effluence from industrial, agricultur al and domestic sources have been regularly discharged Into Bolse Creek for many years. It is the purpose of the study to gather ecological, hydrographic, and chemical data in several strata of stream use to determine the suitability of Boise Creek as a spawning and rearing stream for salmonid fishes.

(g) Project begun September 1963.

(5034) EVALUATION OF STREAM CARRYING CAPACITY OF FINE MATERIALS AS RELATED TO GRAVEL PERMEABILITY.

(b) Inst1tute of Forest Products.

(c) Prof. Donald E. Bevan, Fisheries Hall \#2 Unlversity of Washington, Seattle 5 , wash.

(d) Experimental, theoretical, and fleld Investigation; applied research for M.S. thesis.

(e) This research is to ald in evaluating the changes in salmon streams caused by logging. Soll erosion caused by logging at times increases the amount of fine particles within the flowing stream. Depending upon the hydraulic conditions within the stream and the water turbidity, the streambed permeablilty will be lowered. Reduced permeability lowers the water interchange between the gravel and bed. The amount of Intragravel flow is vital to the survival of salmon eggs and larvae. The 1nvestigation w1ll attempt to define the hydraulic conditions and define concentration for a particular permeability. The objectives of the study are: (1) Determine experimentally the amount of deposition of fines in gravel; (2) for given hydraulic conditions, streambed composition and turbidity a theoretical prediction of the streambed permeability; (3) measurement of stream hydraulic 
conditions, turbidity, bottom composition and permeability; and (4) analysis of data and previous permeability data avallable to determine limitations of turbidity on salmon stream.

UNIVERSITY OF WISCONSIN, Hydraulics and Sanitary Engineering Laboratories.

(149) THE EFFECT OF SUBMERGENCE ON FLOW CHARACTERISTICS OF HYDRAULIC STRUCTURES.

(b) Laboratory project.

c) Prof. J.R. Villemonte, Hydraulics and Sanitary Engineering Laboratories, Univ, of Wisconsin, Madison, Wisconsin 53706.

(d) Theoretical and experimental; basic and applied research for M.S. degree.

(e) The effects of submergence on discharge of large circular thin-plate weirs and orifices and broad-crested weirs are being studied.

(g) General correlation equations have been developed for all thin-plate weirs, Parshall Flumes, and one type of Ogee spillway.

(956) ENERGY LOSS IN LIQUID FLOW IN PIPES AND FITTINGS UNDER HIGH PRESSURE.

(b) Laboratory project in cooperation with the Ladish Company, Cudahy, Wisconsin, and the Wisconsin Alumn1 Research Foundation.

(c) Prof. J.R. Villemonte, Hydraulics and Sanitary Engineering Laboratories, Univ, of Wisconsin, Madison, Wisconsin 53706.

(d) Theoretical and experimental; applied research and design for B.S., M.S. and Ph.D theses.

(e) Energy loss measurements in straight pipes and fittings have been completed on sizes $1 / 4$ inch to 2 inches. Pressure range $0-2500 \mathrm{ps} 1$, temperature range 60 to 120 degrees F. Reynolds number range 50 to 150,000 .

(f) Suspended.

g) If viscosity, density, and temperature relations are known, the standard plpe friction theory applies at high pressures. The fitting loss constants for laminar flow are about 3 times those for turbulent flow when $\mathrm{N}_{\mathrm{R}}=2000$. The loss gradually reduces to zero at $\mathrm{N}_{\mathrm{R}}=150$.

(1181) VORTEX FLOW FROM HORIZONTAL THIN-PLATE ORIFICES.

(b) Laboratory project.

c) Prof. J. R. Villemonte, Hydraulics and Sanitary Engineering Laboratories, Univ. of Wisconsin, Madison, Wisconsin 53706 .

(d) Theoretical and experimental; basic research for M.S. and Ph.D. theses.

(e) The effects of vorticity on orifice discharge are being studied over a wide range of vorticity, head, orlfice size, and fluid viscosity.

(g) A new parameter, the vortex number, was developed as the ratio of inertial and centrifugal forces. A general correlation procedure was also developed for estimating discharge rates through orifices with varying degrees of vorticity.

(3539) DISTURBED LAMINAR AND TURBULENT FLOW.

(b) W1sconsin Alumni Research Foundation.

c) Prof. J. R. Villemonte, Hydraulics and Sanitary Engineering Laboratories, Univ. of Wisconsin, Madison, Wisconsin 53706 .

(d) Theoretical and experimental; basic research for M.S. and Ph.D. theses.

(e) The equation of motion has been applied to several situations of disturbed laminar and turbulent flow and compared with experimental results. Flows are disturbed using oriflces and screens. Turbulence is measured by a newly developed magnetohydrodynamic probe in conjunction with analog and digital computers to give the turbulence energy spectra. (g) New equations have been developed for estimating losses due to combined and divided flow as well as losses due to other disturbances. Turbulence energy spectra have been developed for a wide variety of boundary configurations. The new probe permits the observation of the distribution of turbulent energy across the section of flow.

(3540) MODEL STUDIES OF PUMP INLET STRUCTURES.

(b) Wisconsin Alumni Research Foundation in cooperation with the Government of West Bengal, India.

(c) Prof. J. R. Villemonte, Hydraulics and Sanitary Engineering Laboratorles, University of Wisconsin, Madison, Wis. 53706.

(d) Experimental; design for M.S. thesis.

e) A 1/16-scale model of the inlet structure for one of four axial flow pumps at the Uttarbhag Pumping Station (Sonarpur, India) has been made. Studies of inlet flow patterns and pressure coefficients for a wide variety of flow situations are being made for the purpose of reducing the cavitation threshold.

(f) Completed.

g) Pressure coefficients were computed at 37 polnts on the model over a wide range of flows.

(354.1) HYDRAULIC CHARACTERISTICS OF CIRCULAR SEDIMENTATION BASINS.

(b) National Institutes of Health, Washington, D. C.

(c) Prof. J. R. V1llemonte and Prof. G. A. Rohlich, Hydraulics and Sanitary Laboratories, Madison, Wisconsin 53706.

(d) Experimental; basic research and design for M.S. and $\mathrm{Ph} . \mathrm{D}$. theses.

(e) Hydraulic characteristics of two model clrcular basins and one model rectangular basin are being studied using a wide range of flow and types of inlet and outlet design, using the flourescent tracer technlque and the automatic recording of dimensionless dispersion curves.

Field tests on actual basins are also being undertaken where dispersion curves and removal efficiencies are being observed simultaneously, so that correlations can be studied.

The principles of similitude which apply to gravitation separation basins are also being studied in the laboratory and in the field.

(g) Hydraulic characteristics have been determined for a wide range of flows and inlet and outlet situations. New criteria have been developed.

\section{(3854) REACTION JET INLET FOR OIL-WATER SEPARATORS.}

(b) The American Petroleum Inst.

(c) Prof. G. A. Rohlich and Prof. J.R. Villemonte, Hydraulics and Sanitary Engineering Laboratories, Univ. of Wisconsin, Madison, Wisc. 53706.

(d) Experimental; basic research and design for master's and doctoral theses.

(e) A transparent basin 5 feet wide, 10 feet 10 rg and 3 feet deep has been constructed. Investigations will be made using various slzes and spacings of the stengel reaction jets at the entrance to the basin to determine the effects of jet inflow on the hydraulic characteristics.

(f) Completed.

g) Hydraulic characteristics for rectangular basins with Reaction Jet inlet devices were observed using a wide range of flows.

(h) "Reaction Jet Inlets in Settling Basins," J. R. Villemonte and G. A. Rohlich, Presented at National Water Resources Engineering Conference of ASCE, Milwaukee, Wisc., May 1963.

(4251) CHANNEL DYNAMICS ABOVE GULLY CONTROL STRUCTURES. 
(b) U.S. Department of Agriculture, Agricultural Research Service.

(c) Dr. Arno T. Lenz, Cha1rman, Dept. of Civil Engineering, Un1versity of W1sconsin, 1513 University Aveue, Madison 5, Wisconsin.

(d) Theoretical study and field investigation of basic research in channel dynamics for $\mathrm{Ph} . \mathrm{D}$. thesis.

(e) Data from field surveys of 44 gully control structures in Southwestern W1sconsin have been analyzed to develop procedures for estimating quantitatively the dynamic changes in channel profiles which occur when a gully control or sediment detention stmacture is built.

(f) Completed.

(g) An equation has been developed for the ratio of the average deposition slope to the original channel slope as a function of past and present hydraulic and sediment parameters.

(h) "Channel Dynamics Above Gulley Control Structures," D. A. Woolh1ser and A. T. Lenz, Presented at National water Resources Engineering Conference of ASCE, Milwaukee, Wisconsin, May, 1963.

(4252) FLOW OF A DENSITY STRATIFIED FLUID.

(b) Laboratory Project.

(c) Prof. P. L. Monkmeyer, Hydraulics and Sanitary Engineering Laboratories, University of Wisconsin, Madison, W1sc. 53706.

(d) Theoretical; basic research.

(e) Dynamic characteristics of compressible and incompressible density - stratified fluids, are being investigated. Both steady and unsteady flow problems relating to internal gravity waves are included in the study.

(g) Linearized equations for steady, inviscid, compressible flow in atmospheres with various density distribution have been developed and solved for simple boundary configurations.

(4732) UNIT HYDROGRAPH VARIATION WITH STORM HYDROGRAPH SHAPE.

(b) Laboratory project.

c) Dr. Amo T. Lenz, Chalrman, Dept. of Civil Engineering, 1513 University Avenue, Madison 5, Wisconsin.

(d) Theoretical study and field investigation of the unit hydrograph. Basic research for $\mathrm{Ph} . \mathrm{D}$. thesis.

(e) A general one-hour dimensionless unit hydrograph derived from 16 Illinols basins was used successfully to derive 92 one-hour unit hydrographs for four midwestern basins of 22 to 77 square miles in area for storms of 1 to 13 hours duration. Computations were made using IBM 1620 and CDC 1604 computers.

(f) Ph.D. thesis by Dr. Donald L. Bender completed

(g) Unit hydrographs needed to reproduce singlepeak storm hydrographs varied with peak discharge, shape, and volume of the storm hydrographs. Shapes can be described by a dimensionless parameter $\phi$, the ratio of the hydrograph peak to the flow in a rectangular hydrograph of equal runoff volume and unit time base.

(h) Paper for A.G.U. in preparation.

(4733) THE TRANSFORMATION OF RAINFALI ON THREE BASINS IN NORTH CENTRAL WISCONSIN.

(b) Laboratory project.

(c) Dr. A. T. Lenz, Chalrman, Dept. of Civ1l Englneering, University of Wisconsin, 1513 University Avenue, Madison 5, Wisconsin.

(d) Experimental and theoretical with field investigation; basic research for Ph.D. thesis.

(e) This study is to determine the relationships existing between rainfall, stream runoff, infiltration, groundwater, and evapo-

transpiration with respect to three drainage basins in North Central Wisconsin which have both similar and dissimilar soil types and aquifers, based on published data.
(4734) FLOW BETWEEN CONCENTRIC ROTATING CYLINDERS.

(b) Wisconsin Alumn1 Research Foundation and Falrbanks Morse Co.

(c) Prof. P. L. Monkmeyer, Hydraulics and Sanitary Engineering Laboratories, Univ. of W1sc., Madison, Wisc. 53706.

(d) Theoretical and experimental; basic research for $\mathrm{Ph} . \mathrm{D}$. thesis.

(e) This study is concerned with the characteristics of turbulent flow in an annulus, with rotating inner cylinder. Theoretical prediction and experimental confirmation of shearing stresses, torque, pressure grad1ents, and frictional resistance are being sought.

(g) A theory has been developed to predict the frictional resistance to turbulent flow in a rotating annulus.

(4735) MODEL STUDY OF A PROPOSED BARRAGE AT MUSCODA, ON THE WISCONSIN RIVER.

(b) Muscoda Development Corporation, Muscoda, W1sconsin.

(c) Prof. J.R. Villemonte and Prof. P. L. Monkmeyer, Hydraulics and Sanitary Engineering Laboratorles, Univ. of Wisc., Madison, Wisc. 53706.

(d) Experimental; applied research and design for M.S. thesis.

(e) A comprehensive study is under way to determine the possible effects of constructing a barrage, at Muscoda, on the Wisconsin River. The study includes construction of two models to determine scour patterns downstream of the dam, as well as stability of the dam itself. Backwater effects are also being studied.

(g) Scour patterns for the proposed barrage have been obtained from two models and recommendations made for 1mprovement of the design. Stability has been confirmed.

(h) Two unpublished M.S. theses are avallable.

(4736) UNSTEADY FLOW IN POROUS MEDIA.

(b) Laboratory project.

(c) Prof. P. L. Monkmeyer, Hydraulics and Sanitary Engineering Laboratories, Univ. of Wisconsin, Madison, Wisconsin 53706.

(d) Theoretical; basic research for Ph.D. theses.

(e) The following aspects of unsteady flow through a porous medium are under investigation: pressure waves passing through the liquid in a confined porous medium, the characteristics of unsteady ground water flowing toward a stream with clogged streambanks, and the behavior of unsteady, unconfined flow toward a well.

(50II) HYDRAULIC CHARACTERISTICS OF CYLINDRICAL SLOI ORIFICES.

(b) W. A. Kates Company.

(c) Prof. J. R. Villemonte, Hydraulies and Sanitary Engineering Laboratorles, Univ. of Wisconsin, Madison, Wisconsin 53706 .

(d) Experimental; design.

(e) The effects of viscosity, head, and slot type and shape on the coefficlent of discharge are being studied.

\section{WOODS HOLE OCEANOGRAPHIC INSTITUTION.}

\section{(4737) EXPERIMENTAL HYDRODYNAMICS OF ROTATINO} SYSTEM.

(b) Office of Naval Research, Dept. of the Navy.

c) Mr. Alan Ibbetson, WHOI, Woods Hole, Mass.

d Experimental and theoretical; basic research. Hydrodynamics a rotating liquid systems, with application to blocking action by topographic features in oceanic and atmospheric flows.

(f) Beginning approximately February 1964.

(g) Previous results on occurence of blocking action. 
(4738) SYNOPTIC OCEANOGRAPHY - SURFACE EFFECTS.

(b) Office of Naval Research, Dept. of the Navy.

(c) Mr. Raymond G. Stevens, Woods Hole Oceanographic Inst1tution, Woods Hole, Mass.

(d) Experimental, fleld Investigation, basic research, doctoral dissertation.

(e) Measurement of the directional spectrum of wind generated gravity waves in the generating area.

(g) Directional spectra have been measured in Buzzards Bay, Massachusetts, and Panama City, Florida.

(h) "On the Estimation of the Directional Spectrum of ocean Waves from Time Series Observations of Surface Elevations," by Raymond G. Stevens, WHOI Reference No. 63-22. Technical Report. June 1963. Copies avallable from the author.

WORCESTER POLYTECHNIC INSTITUTE, Alden Hydraulic Laboratory.

Inquiries concerning the following projects should be addressed to Professor Leslie J. Hooper, Director, Alden Hydraulic Laboratory, Worcester Polytechnic Institute, Worcester, Mass. 06109.

\section{(1963) METER CALIBRATION.}

(b) Foxboro, Company, Foxboro, Mass.

d) Experimental, for design.

(e) Calibration of various sizes of magnetic flow tubes ( 1 " to 36 " diameter).

(f) Test in progress.

(3859) METER CALIBRATIONS.

(b) B-I-F Industries, Providence, R. I.

d) Experimental, for design.

(e) Calibration of open flow nozzles and venturi meters up to $48^{\prime \prime}$ in dlameter.

(f) Tests in progress.

(4255) METER CALIBRATIONS.

(b) Penn Meter Company, Philadelphia, Pa.

d) Experimental; for design.

(e) Calibration of open flow nozzles and flow tubes from 2" to $48^{\prime \prime}$ in diameter in standard plping test loop. In addition, tests have been performed to determine operating characteristics for installations in pipes with different finishes and in set-ups just downstream of a variety of fittings.

(f) Tests in progress.

(4739) CHONG PYONG HYDROELECTRIC PROJECT.

(b) Stone and Webster Engineering corp., Boston, Mass.

(d) Experimental; for design.

(e) A $1 / 50$ scale model of a section of the spillway was installed in the 3 foot glass sided flume of the laboratory. Calibration of the splilway and flood gates was performed. Tests were also conducted on a variety of apron designs for different sections of the splllway.

(f) Completed.

(h) Report in preparation.

(4740) CHONG PYONG HYDROELECTRIC PROJECT.

(b) Stone and Webster Engineering Corp.,

(d) Experimental, for design.

(e) A $1 / 75$ scale model of a reach of the North Han RIver in the Republic of Korea is under construction for the Korea Electric co. The model will include the spillway and powerhouse as well as river topography up and downstream of the development. Studies will be made of the flow characteristics for various operating conditions.

(g) Model under construction.

(4741) CORNWALL PUMPED STORAGE DEVELOPMENT. (b) Uhl, Hall and Rich, Boston, Mass.

d) Experimental, for design.

(e) A $1 / 80$ scale model of the intake at the upper reservolr was constructed including local topography near the intake. The studies will involve the flow patterns and possible surface disturbances in the reservolr as well as the flow in the first few diameters of the vertical shaft of the intake.

(f) Test completed.

(h) Report in preparation.

(4743) HYDRAULIC CYCLONE.

(b) Bird Machine Co., South Walpole, Mass.

d) Experimental, for design.

(e) Evaluation of the percentage breakup of the flow between the two discharge paths (accepts and rejects) in a cyclone type separator was made. The flow pattern in varlous sections of the machine was measured in the course of the studies.

(g) Tests in progress.

(4746) METER CALIBRATIONS.

(b) Hagan Chemicals and controls, Inc., P1ttsburgh, Penn.

(d) Experimental, for design.

(e) Calibration of a variety of sizes and designs of flow nozzles.

(g) Tests in progress.

(5020) AEP 200.

(b) Amerlcan Electric Power Co., New York, N. Y.

d) Experimental, for design.

e) $\mathrm{A} 1 / 120$ by $1 / 40$ distorted scale model of a section of the Oh1o River has been reproduced in the area above and below the power plant. The plant intakes and outlets for condenser cooling water have been installed at the required locations. Studies will be performed on the hot water flow patterns in order to insure minimum recirculation of hot water to the condenser intakes. In addition bed load movement of the river and barge handling techniques will be studied over a range of river stages.

(f) Model under construction.

(5021) MUDDY RUN PUMPED STORAGE DEVELOPNENT.

(b) Philadelphia Electric Co., Philadelphia, Penn.

(d) Experimental, for design.

(e) A $1 / 35.3$ scale model of the intake structure, a section of the tunnel below the intake and the immediate topography were modeled to study the flow patterns and evaluate the losses in both the pumping and generating cycles.

(f) Tests in progress.

(5022) DYNAMIC EFFECTS IN FLOW METER COEFFICIENT PREDICTION.

(b) Laboratory project.

d) Experimental, for thesis.

e) A number of differential producer type flow meters are being studied under different Reynolds Number levels with the same volume flow rate. It is planned to evaluate the dynamic effects on the discharge coefflclent for the different instruments.

(f) Tests in progress.

(5023) VELOCITY DISTRIBUTION INFLUENCE ON BEND LOSSES.

(b) Laboratory project.

d) Experimental for thesis.

(e) An experimental and parallel theoretical study of variation in energy loss in a $90^{\circ}$ bend is being developed. A $90^{\circ}$ bend has been set up so the upstream velocity profile can be varied.

(f) Tests in progress. 
(5024) CORNWALL PUNPED STORAGE DEVELOPMENT.

(b) Unl, Hall and RIch, Boston, Mass.

d) Experimental, for design.

(e) A $1 / 56$ scale model of the manifold and penstock sections was constmucted in plexiglass and PVC pipe. The sections varied in diameter (full scale) from 40 ' at the manifold to 101 at the lower penstocks. Measurements of pressure head at each change in section were made to evaluate the loss coefflcients in both the generating and pumping situations.

(f) Tests in progress.

(5025) PALO SECO STEAM PLANT, SAN JUAN, P. R.

(b) Jackson and Moreland International.

(d) Experimental, for design.

e A $1 / 40$ scale model of the cooling water intake for the Palo seco plant was constructed along with a section of the beach and ocean in the adjacent area near San Juan Harbor in Puerto Rico. A wave generator was installed in the deep water off shore to produce a range of ocean waves. Studies of variation in breakwater design are underway to reduce the wave effects within the intake canal and structure.

(5026) BIG SANDY POWER PIANT.

(b) Kentucky Power Co., Louisa, Ky.

d) Experimental, for design.

(e) A $1 / 30$ scale model for a section of the $\mathrm{BIg}$ Sandy River was constructed including the intake structure for make-up cooling water for the steam plant. Studies were conducted of river bed load transport in order to reduce the amount of material taken into the intake with the water. Various structure and various locations were tested during the studies.

(f) Completed.

(h) Report in preparation.

BOLT BERANEK AND NEWMAN INC.

(5190) SOUND RADIATED FROM A TURBULENT BOUNDARY LAYER.

(b) Bureau of Ships Fundamental Hydromechanics Research Program Administered by the Dav1 Taylor Model Basin.

(c) Dr.J. E. Ffowcs Williams, Bolt Beranek and Newman Inc., 50 Moulton st., Cambridge, Mass. 02138 .

(d) Basic theoretical research.

(e) The research is almed at clarifying the exact role of a solid surface in determining the mechanism by which sound generated in a turbulent boundary layer is radiated. It is known that if the surface is very large, it merely acts like a passive reflector, and if it is small, it constitutes an additional dipole field. The intermediate size situation remains obscure and it is on this problem that the work is concentrated.

(g) The role of a responsive surface of infinite extent has been studied and under certain conditions the response can be shown to reduce the radiated sound.

(h) First Quarterly Progress Report. Obtainable from David Taylor Model Basin.

(5191) INTERACTION OF DISTRIBUTED SURFACE VIBRATIONS WITH AN ADJACENT BOUNDARY LAYER FLOW.

(b) Bureau of Ships Fundamental Hydromechanics Research Program Administered by the David Taylor Model Basin.

(c) Dr. Francis J. Jackson, Bolt Beranek and Newman Inc., 50 Moulton St., Cambridge, Mass. 02138 .

(d) Basic theoretical research.

(e) The program is aimed at studying the stability of a flow in contact with a flexible wall. Particular reference is being paid to the possibility of actuating the wall motion by external means. (g) An analysis of the Reynolds stress very close to the wall has revealed how it is determined, to a large extent, by the wall response.

(h) Quarterly Progress Reports. Obtainable from David Taylor Model Basin.

CORNELL AERONAUTICAL LABORATORY, INC.

(5192) FORCES AND MONENTS ON AN OSCILLATING HYDROFOIL.

(b) David Taylor Model Basin, Office of Naval Research, Dept. of the Navy.

(c) Dr. Irving C. Statler, Head, Applied Mechanics Dept., Cornell Aeronautical Laboratory, Inc., P. O. Box 235, Buffalo, New York 14221.

(d) Applied research (theoretical).

(e) This study was undertaken to determine the forces and moments on a hydrofoil oscillating near the free surface. Specifically, the case of a fully-wetted hydrofoll in two-dimensional, linearized potential flow was considered, taking rigorous account of free-surface effects with Froude number.

(f) Completed.

(g) It was found that at reduced frequencles below about 3.0 for practical values of Froude number and submergence depth, the behavior of the unsteady lift and moment is dictated by the considerable influence of surface waves.

(h) "Forces and Moments on an Oscillating Hydrofoll," by P. Crimi and I. Statler, CAL Report No. BB-1629-S-1, Aug. 1962.

(5193) THEORETICAL STUDY OF HYDROFOIL FLUTTER CHARACTERISTICS.

(b) David Taylor Model Basin, Office of Naval Research, Dept. of the Navy.

(c) Dr. Irving C. Statler, Head, Applied Mechanics Dept., Cornell Aeronautical Laboratory, Inc., P. O. Box 235, Buffalo, New York 14221

(d) Applied research (theoretical)

e) The purpose of this investigation is to formulate the two-degree-of-freedom flutter determinant of a two-dimensional hydrofoil near the free surface and, then, to compute flutter boundaries for various values of system parameters.

(5194) THEORETICAL INVESTIGATION OF FORCES AND MONENTS ON AN OSCILIATING HYDROFOIL WITH AN OSCILLATING FIAP.

(b) Bureau of Ships, Dept. of the Navy.

c) Dr. Irving C. Statler, Head, Applied Mechanics Dept., Cornell Aeronautical Laboratory, Inc., P. O. Box 235, Buffalo, New York 14221.

(d) Applied research (theoretical)

e) The objective of this study is to compute the lift, total moment and hinge moment for a fully-wetted oscillating hydrofoll with an oscillating flap from the exact, linearized, two-dimensional potential solution. The solution to be used takes full account of the surface waves caused by the hydrofoll.

GRUMMAN AIRCRAFT ENGINEERING CORP.

(5195) THE EFFECTS OF GAS BUBBLES IN LIQUID SHEAR FLOWS.

(b) Laboratory project.

c) Dr. Richard A. Oman, Head of Gas Dynamics Group, Research Dept., Plt. 25, Bethpage, New York.

(d) Experimental and theoretical; basic research.

e) This program is aimed at determining how a suspension of gaseous bubbles perturbs a liquid flow field. Bubbles can change the effective viscosity, introduce compressibility 
effects, and by convection through the liquid can transport momentum. Any or all of these may influence the development of cavitating flows. We have rewritten the Navier-Stokes equations for two-phase flow, with modified viscosity law accounting for non-Newtonian shear stresses. Unsteady bubble growth and collapse are initially neglected. We intend to solve several boundary layer problems numerically and survey the effects of varying bubble density, size, and distribution. Experiments in a small laminar water tunnel will provide data on viscosity coefficients, bubble cloud distributions, and flow patterns.

IIT RESEARCH INSTITUTE.

(5196) TURBULENT FLOW TRANSITION NEAR SOLID AND FLEXIBLE BOUNDARIES.

(b) BuShips Fundamental Hydromechanics Research Program administered by David Taylor Model Basin.

(c) Mr.H. B. Karplus, Research Physicist, 10 West 35th St., Chicago 16, Ill.

(d) Experimental basic research.

e) Transition to turbulence is investigated in a water channel having walls with adjustable rigidity. It is intended to obtain a better understanding of the effect of resilfence and damping of the walls on the bulld up of turbulence in boundary layers. The ultimate objective is the reduction of drag of vessels and the reduction of boundary layer nolse in hydrophone domes.

(g) Transition to turbulence is affected by wall resilfence. Flexible walls may delay turbulence onset over limited flow rate regions.

(h) Interim Technical Report No. IITRI 1205-4.

THERM ADVANCED RESEARCH, INC.

(5197) SPECIAL PROBLEMS IN FLUID DYNAMICS.

(b) Office of Naval Research, Dept. of the Navy.

(c) Dr.A. Ritter, President, Therm Advanced Research, Inc., 100 Hudson Circle, Ithaca, N. Y.

(d) Theoretical basic research.

(e) This is a continuing project of analytical studies which to date have consisted of: (1) The Hydrodynamics of Free-Surface Crossings, concerned with predicting the hydrodynamic forces acting on bodies in vertical motion crosing an a1r-water interface, and includes examination of the accuracy of the standard assumptions of Infinite Froude number and small disturbances; and (2) The Jet-Flap Hydrofoll Near a Free Surface, a study which will provide expressions for the forces and moments acting on a twodimensional jet-flap hydrofoll in close proximity to a free surface as well as determining the depth of submergence at which free-surface effects may be neglected.

(f) Completed.

(g) A second-order, small-perturbation theory for the water-exit and -entry of slender symmetric bodies, including Froude number and afrdensity effects, has been developed.

(h) "Image Solution for Vertical Motion of a point Source Towards a Free Surface," by John P. Moran, To be published in the Journal of Fluid Mechanics.

"IIne Source Distributions and Slender-Body Theory, " by John P. Moran, Journal of Fluid Mechanics, Vol. 17, Part 2, pp. 285-304, 1963. "On the Small-Perturbation Theory of WaterExit and Entry," by John P. Moran and Keith P. Kerney, Presented at the Eighth Midwestern Mechanics Conference, Cleveland, Ohio, April 1-3, 1963. To be published in the Conference proceedings.

(5198) THE LOW-ASPECT-RATIO JET-FLAP HYDROFOIL. (b) David Taylor Model Basin, Dept. of the Navy.

(c) Mr. Gary R. Hough, Staff Scientist, Therm Advanced Research, Inc., 100 Hudson C1rcle, Ithaca, N. Y.

(d) Theoretical basic research. a theory which will predict satisfactorlly the forces and moments acting on a fully wetted, low-aspect-ratio jet-flap hydrofoll. The influence of aspect ratio and jet momentum coefficlent upon these forces and moments will be determined.

VIDYA DIVISION, Itek Corp.

(5199) THE EFFECT OF FLOW SEPARATION FROM THE HULI ON THE STABILITY OF A HIGH SPEED SUBMARINE.

(b) Office of Naval Research, David Taylor Model Basin (jointly) under the Buships Fundamental Hydromechanics Program.

(c) Mr. S. B. Spangler, Vidya Division, 1450 Page Mili Road, Palo Alto, Calif. 94304 .

(d) Theoretical; applied research.

(e) The separated flow over a body of revolution at angle of attack is characterized by a potential vortex system in order to determine the forces and moments induced on the body and tall by the separated flow. The purpose of the work is to predict static stability characteristics of modern submarines.

(g) Forces and moments have been computed at angles of attack up to 20 degrees for hull alone and hull with stern control surfaces, using a separation line location based on experimental data taken in wind tunnels on bodies of revolution. The results indicate separation - induced effects becoming apparent at about 10 degrees angle of attack and appreclable at 20 degrees angle of attack. It is noted that very little data on separation on inclined bodies of revolution is avallable in the typical submarlne Reynolds number range.

(h) "The Effect of Flow Separation from the Hull on the Stability of a High Speed Submarine," S. B. Spangler, A. H. Sacks, J. N. N1elsen. $\mathrm{Vi}$ dya Report 107, August 1963.

(5200) INTERFERENCE BETWEEN A HULL AND A STERNMOUNTED DUCTED PROPELIER.

(b) Dept. of the Navy, Bureau of Ships Fundamental Hydrodynamics Research Program.

(c) Dr. A. R. Kriebel, Vidya, 1450 Page Mill Road Palo Alto, Calif. 94304.

(d) Theoretical investigation; applied research.

(e) The purpose of this analysis is to predict the effect of interference on the net forces on the hull, duct, and propeller for various assumed configurations. The results will indicate the variation of propeller thrust coefficient with ducted propeller configuration for a specified hull shape. The analysis is restricted to axially symmetric flow and the method of concentrated singularities is employed.

(g) Preliminary results indicate that the interaction between a hull and duct can cause a relatively large increase in drag force on the hull and an equal increase in thrust force on the duct. The increased duct thrust significantly affects the design of the duct to avold flow separation.

(h) "Interference Between a Hull and a sternMounted Propeller," First Quarterly Status Report, Vidya Project 9066.

(5201) THEORETICAL INVESTIGATION OF DYNAMIC STABILITY DERIVATIVES OF DUCTED PROPELLERS.

(b) Bureau of Naval Weapons, Dept. of the Navy. (c) Dr. A. R. Kriebel, Staff Englneer, Vidya, 1450 Page Mill Road, Palo Alto, Callf. 94304.

(d) Theoretical investigation; applied research.

(e) The force and moment coefficlents at angle 
of attack and their dynamic pitching derivatives are predicted by potential flow analysis for an isolated ducted propeller. A firstorder analysis is made of the interference between a pair of ducted propellers in a freestream at angle of attack.

(f) Completed.

(8) The analysis is based upon Fourler expansions of the vorticity distribution and offers a valid technique for combining the previous theoretical results for ring wings at angle of attack and ducted propellers in axial flow. The theoretical results compare favorably with data for an isolated ducted propeller in, hovering, axial, and non-axial flow. The theory is applied to estimate the static stability and damping in pitch for VTOL alrcraft and torpedo conflgurations which employ ducted propellers.

(h) "Theoretical Investigation of Dymamic Stability Derivatives of Ducted Propellers," Vidya Technical Report No. 63-95, Jan. 9, 1963. "Theoretical Stability Derivatives for a Ducted Propeller," Vidya Interim Report Project 9063, october 18, 1963. "Theoretical Investigation of Dynamic Stability Derivatives of Ducted Propellers," Final Report Vidya Project 9063 . (in preparation)

\section{$----$}

WEBB INSTITUTE OF NAVAL ARCHITECTURE.

(5202) DETERMINATION OF SHIP WAVE RESISTANCE.

(b) David Taylor Model Basin, Bureau of Ships, Dept. of the Navy.

(c) Dr. Lawrence W. Ward, Prof. of Engineering, Webb Institute of Naval Architecture, Glen Cove, Long Island, New York 11542.

(d) Experimental and theoretical; basic research. Investigation of means for direct experimental determination of ship wave resistance from measurements of the wave pattern during a model test. Purpose includes improvement in scaling model test results to full size as well as basic understanding of nature of ship resistance.

(g) New method utilizing forces exerted by the wave pattern on a long vertical cylinder has been developed and tests run. Results encouraging and in agreement with other investigators. Experimental wave resistance when added to estimated skin friction is

less than measured total resistance.

(h) "The XY Method of Determination of Ship Wave Resistance from the Wave Pattern," by L. W. Ward, International Seminar on Theoretical Wave Resistance, sponsored by Office of Naval Research and Univ. of Michigan, Ann Arbor, Michigan, August 1963.

(5203) ASSESSMENT OF SEAKEEPING CHARACTERISTICS OF SHIPS.

(b) Society of Naval Architects \& Marine Engineers, Panel $\mathrm{H}-7$ of Hydrodynamic Committee.

(c) Prof. Edward V. Lewis, Research Prof. of Naval Architecture, Webb Institute of Naval Architecture, Glen Cove, Long Island, New York 11542 .

(d) Theoretical application of available experimental results; applied research.

(e) Application of available knowledge of ship model behavior in regular waves to the prediction of trends of ship performance in realistic irregular wave patterns. Purpose is to provide the ship designer with guidance in the selection of hull characteristics.

(g) The tendency for shipping water forward and for bow emergence have been evaluated as a function of speed for one hull form in one particular irregular sea. Work is continuirg on other hull characteristics and different sea conditions.

(h) Progress report on "Assessment of Seakeepability," by R. B. Zubaly and E. V. Lewis, April 1963, issued to Panel H-7, SNAME. 
U. S. DEFARTMENT OF AGRICULTURE, AGRICULTURAL RESEARCH SERVICE, So1l and water Conservation Research Division.

CORN BELT BRANCH, University of Minnesota, St. Paul, Minn., Dr. C. A. Van Doren, Branch Chlef.

(66) HYDROLOGIC STUDIES, RALSTON CREEK WATERSHED.

See Iowa Institute of Hydraulic Research, page 40.

(1723) THE HYDRAULICS OF CONSERVATION STRUCTURES.

See St. Anthony Falls Hydraulic Laboratory Projects Nos. 111, 1168, 1929, and 2386. See also U. S. Department of Agriculture, Agricultural Research Service, Soll and Water Conservation Research Div., Southern Plains Branch, Project No. 4335, and Illinols State water survey D1vision Project No. 1865.

(b) Cooperative with the Minnesota Agricultural Experiment Station, the St. Anthony Falls Hydraulic Laboratory, and the Illinols State Water Survey.

(c) Mr. Fred W. Blaisdell, Hydraulic Englneer, St. Anthony Falls Hydraulic Laboratory, 3rd Ave. S. E., at Mississippi River, Minneapolis, Minnesota 55414.

(d) Experimental; applied research for development and design.

(e) Research dealing with the design, construction, and testing of structures for conserving and controlling soll and water are carrled out. Studies during the past year have been concerned with the two-way drop inlet for closed conduit spillways. The width of this drop inlet is equal to the barrel diameter. Its length varies. water flows only over the two sides. The end walls support a horlzontal plate over the drop inlet which acts as an ant1-vortex device. The overhang of the plate supports a trash guard. Tests are conducted using both water and air as the model fluid to determine the performance, loss coefficients, and pressure coefficients for the drop inlet. Cooperation with and co-ordination of the tests at the Stillwater, Oklahoma, Outdoor Hydraul1c Laboratory and the Illinols State Water Survey is maintained.

(g) If the anti-vortex plate is too low, undesirable orifice flow will control the discharge. If the anti-vortex plate is too high, harmful vortices will form under the plate. Rules for determining acceptable plate helghts have been determined. The overhang of the plate must be greater than a certain minimum to insure satisfactory performance. The action of the two-way drop inlet is that of a self-regulating siphon. The tests using air agree with the results obtained from the water tests and are much easier to perform. A1r is used as the model fluid only for the condition of full conduit flow.

Tests on the hood drop inlet have shown that the hood barrel entrance can be used to reduce the minimum required helght of the drop inlet. Minimum sizes of drop inlet and ant1-vortex devices have been determined.

(2316) RUNOFF FROM SMALL AGRICULTURAL AREAS IN ILLINOIS.

See University of Illinols, Department of Agricultural Englneering, page 36.

(4264) HYDROLOGIC STUDIES ON AGRICULTURAL WATERSHEDS IN WISCONSIN.

(b) Laboratory project, cooperative with the Wisconsin Agricultural Experiment Station and the Wisconsin Valley Improvement $\mathrm{Co}$.

(c) Mr. N. E. Minshall, Hydraulic Engineer, 3230 University Avenue, Madison, W1sconsin.

(d) Field investigation and office analysis.

(e) Varlous records of runoff, ground water, precipltation and climatic factors, soli molsture, land use, and agricultural conditions and practices are malntained for 22 agricultural watersheds ranging in size from 2.7 to 11,000 acres in the vicinity of Lacrosse, Pennimore, Colby and at other locations in Wisconsin. Analyses are made to evaluate the factors affecting flood flows, hydrograph characteristics, and the yleld of stream flow.

(4265) PRECIPITATION CHARACTERISTICS INFLUENCING RUNOFF FROM AGRICULTURAL WATERSHEDS ON THE UNGLACIATED ALIEGHENY PLATEAU.

(b) Laboratory project, cooperative with onio Agricultural Experiment Station.

(c) Mr. L. L. Harrold, Supervisory Hydraulic Engineer, ARS, Coshocton, Ohio.

(d) F1eld investigation and office analysis.

(e) To develop methods of characterizing watershed precipitation related to runoff rates and volumes and to evaluate "normalcy" of sample periods.

(g) Records of dense network of rain gages are being analyzed to determine network specifications for characterizing rainfall for munoff rates and volumes. Shielded and tilted catchment surfaces of rain gages have been installed in the field along with wind recording apparatus for studying the effect of wind on the rain gage catch and how the latter evaluates the rainfall on sloping land surfaces of a single aspect.

(h) "Accuracy of Estimating Watershed Mean RaInfall," by Mr. J. L. McGuinness, Jour Geophys. Res. 68(16): 4763-4767, 1963 1lius.

(4266) SURFACE RUNOFF AND INTERFLOW STUDIES IN THE UNGLACIATED ALLEGHENY PLATEAU.

(b) Laboratory project, cooperative with the Oh1o Agricultural Experiment Station.

(c) Mr. L. L. Harrold, Superv1 sory Hydraulic Engineer, ARS, Coshocton, Ohio.

(d) Fleld Investigation and office analysis.

(e) To evaluate the factors affecting the volume of storm surface munoff and interflow from various combinations of upland watershed soll, cover, and treatment, and to study the basic factors affecting the hydrograph of these flows under various soll-cover combinations.

(g) Work is continuing on these studies. Storm flow totals from all unit source watersheds along with specific watershed and climatic parameters have been assembled for all the major storm munoff periods of record. Computer analysis of these data is being made to test for parameter significance.

(4267) STUDIES OF RUNOFF FROM COMPLEX WATERSHEDS IN THE UNGLACIATED ALIEGHENY PLATEAU.

(b) Laboratory project, cooperative with the Ohio Agricultural Experiment Station.

(c) Mr. L. L. Harrold, Supervisory Hydraulic Engineer, ARS, Coshocton, Ohio.

(d) Fleld Investigation and off1ce analysis.

(e) To determine how flows from incremental areas combine to produce hydrographs of stream flow on larger complex watersheds; determine the effects of climate and watershed characteristics on rates and amounts of munoff; and develop methods for predicting the magnitude and frequency of flows from ungaged watersheds.

(g) Work is continuing on these studies. Preliminary analysis showed that the summation of flow from incremental areas accounted for, at the best, only 70 percent of the storm flow measured for the larger complex watershed. Base flow was at a minimum. Interflow studies are being made to evaluate the magnitude and timing of this quick return flow as a factor in flood stream flow. Geologic investigations of aquifers contributing to stream flow are included in the study of the effects of watershed characteristics and management of stream flow. Their effect is an important factor, 
as runoff volumes increase rapidly with watershed size up to areas of 1,000 acres. A small watershed has been thoroughly instmumented to identify and evaluate shallow-depth interflow.

(h) "Field Manual for Research Agricultural Hydrology," by H. N. Holtan, N. E. Minshall, L. L. Harrold, U.S. Dept. Agr. Agriculture Handbook 224: $215 \mathrm{pp}$. (1962) lilus.

"Water Conservation Research in Ohio," L. I. Harrold, R. B. Marston, G. O. Schwab. Ohio Jour. Sc1. 63(2): 49-55 (1963) 11lus. "Water Intake by So11," Experiments for High School Students, I. L. Harrold, U.S. Dept. Agr. Misc. Pub. 925: 10 pp. (1963) 1lius. Aug. 1963.

\section{(4268) STUDIES IN SUBSURFACE HYDROLOGY IN THE} UNGLACIATED ALLEGHENY PLATEAU.

(b) Laboratory project, cooperative with the Ohio Agricultural Experiment Station.

(c) Mr. L. L. Harrold, Supervisory Hydraulic Engineer, ARS, Coshocton, Ohio.

(d) Field investigation and of 1 ce analysis.

e) To evaluate ground-water and interflow contributions to stream discharge of agriculture watersheds and the recharge to aquifers under various watershed and climatic conditions.

(g) Work is continuing on geologic mapping for identifying and evaluating aquifer flow to stream discharge. Catchment areas of these contributing aquifers is being mapped. Studies of interflow have been started on the upland watersheds to help account for that storm flow at the complex watershed runoff gages not measured as upland surface munoff.

(4269) MOISTURE REGIMES OF SOILS IN THE UNGLACIATED ALLEGHENY PLATEAU.

(b) Laboratory project, cooperative with the Ohio Agricultural Experiment Station.

(c) Mr. L. L. Harrold, Supervisory Hydraulic Engineer, ARS, Coshocton, Ohio.

(d) Field investigation and office analysis.

(e) To maintain the soli molsture inventory of agricultural watersheds; to evaluate the effect thereon of soil, land use, and climate; to develop methods of estimating soil moisture quantities under various land use and climatic conditions; and to determine the Influence of frozen soll and frost structure on water movement.

(g) Nuclear soll-molsture equipment is now providing good data on soll moisture down to 90-inch depths. They show material variations in molsture within a small watershed. Presently, methods of evaluating watershed soil moisture are being studied. Effect of vegetation of different rooting depths on soll moisture is being evaluated. Deep-rooted crops extract moisture to depths unaffected by shallow-rooted crops. In dry seasons, the former consumes more water than the latter, resulting in less percolation to ground water reservolrs. Lysimeters, 8 feet deep and $1 / 500$ acre area of undisturbed soli record welght changes and percolation.

(h) "Soll Molsture Measurements w1th the Neutron Method Supplement Weighing Lysimeters," J. L. McGuinness, F. R. Dreibelbis, L. L. Harrold. Soll Sc1. Soc. Amer. Proc. 25: 339-342 (1961) 11lus.

(4270) CHARACTERISTICS OF FLOW IN IRRIGATION EURROWS.

(b) Laboratory project in cooperation with the Missouri Agricultural Experiment Station.

(c) Dr. C. A. Van Doren, Chief, Corn Belt Branch, Univ. of Minnesota, St. Paul, Minnesota.

(d) Experimental and field investigations, both basic and applied.

(e) The purpose of the study is to investigate the hydraulics of flow in irrigation furrows, as influenced by furrow shape, slope, roughness, and rate of flow. Develop engineering techniques that w1Il provide maximum effective control and management of $1 \mathrm{rr}$ gation water.

(g) The work is continuing on the basic hydraulic aspects of flow in irrigation furrows to contribute to better understanding of furrow irrigation and the ultimate achievement of more efflcient use of water.

(4271) PLASTIC-LINED MOLE DRAIN STUDIES.

(b) Laboratory project in cooperation with the Ohio Agricultural Experiment Station.

(c) Mr. James L. Fouss, Research Agricultural Englneer, Agricultural Engineering Dept. Ohio State University, Columbus, Ohio.

(d) Experimental and fleld investigations, both basic and applied.

(e) The purpose of these investigations is to improve plastic mole drainage techniques and test the effectiveness of other subsurface and surface drainage systems. Tile, mole and other subsurface drainage systems are developed and their effectiveness determined.

(g) The work is continuing on improving plastic mole drainage techniques and the effectiveness of other subsurface and surface drainage systems.

(h) "New Machine Lays Plastic Drains," by James L. Fouss, Civil Engineering, Vol. 33, No. 4, pp. 58-59, 1963 .

"Material and Equipment for Installing Z1ppered Plastic-Lined Mole Drains," by James L. Fouss, M.S. Thesis, Ohio State University, 1962.

"Plastic Tubes for Subsurface Drainage," by James L. Fouss, 4 th Nat'l. Agr. Plastics Conf. Proc. 4:137-142 (1963) illus. Oct. 1963.

(4273) SURFACE AND SUBSURFACE DRAINAGE.

(b) Laboratory project in cooperation with the Minnesota Agricultural Experiment Station.

(c) Mr. Lee Hermsmeler, Agricultural Engineer, North Central Soll Conservation Field Station, Morris, Minnesota.

(d) Experimental and fleld investigations, both basic and applied.

(e) The purpose of these investigations is to develop engineering techniques that will provide maximum effective control and management of water. Techniques are developed for managing surface water flow through land forming and surface drainage systems. Tile, mole and other subsurface drainage systems are developed and their effectiveness determined.

(g) Work is continuing on land forming and the development of Improved surface drainage systems, the effectiveness of field diversions, improved plastic mole drainage techniques and effectiveness of other subsurface drainage systems.

(4274) NATIONAL SUMMARIZATION AND ANALYSIS OF RUNOFF AND SOIL-LOSS DATA.

See Purdue University, Agricultural Engrg. Dept., Project No. 3808 .

(b) Laboratory project, cooperative with the Purdue Agricultural Experiment Station.

(c) Mr. W. H. Wischmeler, Research Statistician, ARS, Agricultural Engineering Department, Purdue University, Lafayette, Indiana.

(d) Data analyses, applied research.

(e) Objectives of the national data summarization and analysis profect are (1) to consolidate all available past, current, and future runoff, soll loss and related data in standardized form to make them available for application of current methods of hydrologic and statistical analyses; (2) to analyze the data on an over-all basis, with speclal emphasis on 1dentification and evaluation of signiflcant factor interactions; and (3) to develop bases for prediction of runoff and soll losses from different landscapes under various land use and management conditions. In analyses of the assembled data, speclal emphasis is directoward identification and evaluation of factors and 
interaction effects responsible for the frequent wide differences in results of localized studies at various locations. over-all results are reduced to charts and tables readily usable by application techniclans.

(g) The recently developed procedure for computing expected soll losses from fleld areas on the basis of rainfall characteristics, physical features, and management practices was supplemented in 1963 by: (1) expanding the 1960 cropping-management factor table to include evaluations for additional combinations of cropping systems and management practices; (2) investigating interaction effects of slope, cover, and contour farming; and (3) further investigation of the soll-erodibility factor. Results of the past 6 years' investigations were consolidated in a report submitted for publication as a USDA Handbook.

(h) "Soil-Erodibility Evaluations for Solls on the Runoff and Erosion Stations," by T. C. Olson and W. H. Wischmeler, Soll Scl. Soc. Amer. Proc. 27:590-592. 1963.

(4275) THE MECHANICS OF EROSION BY RAINFALL AND RUNOFF.

See Purdue University, Agricultural Expt. Station, Project No. (4182).

(b) Laboratory project, cooperative with the Minnesota and Purdue Agricultural Experiment Stations.

(c) Mr. L. D. Meyer, Agricultural Engineer, ARS, Agricultural Engineering Dept., Purdue Univ., Lafayette, Indiana.

(d) Experimental; laboratory investigations, basic research

(e) Fundamental investigations of the mechanics of rainfall and runoff erosion are conducted at two Corn Belt Branch locations. At Morris, Minnesota, C. K. Mutchler and R. A. Young are using a 40-foot drop tower for studies of raindrop splash patterns as affected by drop size, surface irregularity, water depth, target sortness, and target inclination. The pressure distribution at impact is also being investigated. At Lafayette, Indiana, the effect of slope steepness, munoff rate and particle size on erosion by rainfall and/or munoff is being investigated. Non-cohesive glass spheres ( $50-500 \mathrm{micr}$ on) were used initially, with sands, silts, and soils to follow.

(g) Hlgh-speed movies of drops at impact showed that splash begins as a film of water that rises around the center of impact. The form was initially a truncated cone which soon broke into splash droplets. Helght and distance of splash increased with dropsize. Splash angles from vertical increased as water depths decreased.

Runoff erosion of the non-cohesive particles increased with flow rate and slope steepness. The rate of increase was greater for the smaller particle sizes than for the larger sizes. The addition of rainfall increased erosion for the smaller particle sizes and decreased erosion for the larger sizes. Splash erosion was insignificant relative to munoff erosion.

(4276) IMPROVED PRACTICES FOR CONTROL OF RUNOFF AND EROSION.

(b) Laboratory project in cooperation with the Purdue Agricultural Experiment Station.

(c) Mr. J. V. Mannering, Soll Scientist, ARS Department of Agronomy, Purdue University, Lafayette, Indiana.

(d) Experimental; field investigations, applied research.

(e) The purpose of these studies is to determine the effects of soll properties, slope characteristics, type and extent of canopy cover, quantity and management of crop residues, seedbed and tillage practices, and various factor interactions on infiltration and erosion. Replicated tests are conducted on selected plots on Purdue-owned and privately-owned farms in Indiana and adjoining states under simulated rainfall applied with the ARS-Purdue "Rainulator". Investigations in 1963 included: (1) measurement of residual erosion-control effectiveness of meadows on erodibility of fallow solls, (2) effects of minimumtillage practices on infiltration and soll erosion on corn land, and (3) influence of row direction on erosion-reducing effectiveness of minimum tillage for com.

\section{(4277) SOIL ERODIBILITY DETERMINATIONS.}

(b) Laboratory project, cooperative with the Purdue and Iowa Agricultural Experiment Stations.

(c) Mr.W.H.Wischmeier, Research Statistician, ARS, Agricultural Englneering Dept., Purdue University, Lafayette, Indiana.

(d) Experimental; laboratory and field investigations, basic and applied.

(e) The purpose is to investigate differences in the erodibility of soils; Identify and evaluate the soll properties and profile characteristics that influence erodibility; and, if possible, derive an equation that expresses the functional relationship of soll erodibility to these variables. The equation would serve as a means of computing locational values of the sollerodibility factor in the universal erosion equation. Both "in situ" measurements on fleld plots and laboratory measurements on small, disturbed soll samples are made under simulated rainfall and related to laboratory analyses of the solls.

(g) Results to date indicate that the desired soll-erodibility estimating equation should be possible but will require more fleld-plot data. In preliminary regression analysis of two years' data, on 32 soils, more than $90 \%$ of the variation in values of the soll-erodibility factor could be explained by elght primary variables and their interaction effects. Laboratory measurements on the small, disturbed soll samples show promise of providing some of the needed information more quickly and more economically than it could be obtained in fleld-plot studies. The erodibility measurements and related investigations are continuing.

(4278) RAINFALL ENERGY AND SOIL EROSION RELATIONSHIPS.

(b) Laboratory project, cooperative with the Illinois Agricultural Experiment Station.

(c) Mr. L. C. Johnson, Soll Scientist, ARS, 276 Davenport Hall, University of Illinols, Urbana, Illinois.

(d) Experimental; fleld investigation.

(e) The purpose of this study is (1) to obtain an experimental check on the computed rainfall intensity-kinetic energy relationship, and (2) to study the physical phenomere and changes associated with the infiltration of natural rain into solls. Three replications of fallow and continuous com are under both hydrological and meteorological measurements.

(g) Equipment for the study has been perfected, and collection of data is underway.

(4279) RUNOFF AND EROSION STUDIES IN IOWA.

(b) Laboratory project, cooperative with the Iowa Agricultural Experiment Station.

(c) Dr. W. C. Moldenhauer, Soll Sc1entist, ARS, 225 Agronomy Bldg., Iowa State University, Ames, Iowa.

(d) Experimental; field investigations, applied research.

(e) Purpose is to evaluate soll and crop management practices in relation to water management and erosion control on the major Iowa solls. Runoff, soll loss and related data, 
under natural rainfall, are taken on fract1onal-acre plots on Marshall, Grundy, Ida and Carrington silt loam solls.

(g) Consistent good management of abundant crop residues has continued to prove very effective in reducing runoff and erosion both from rotation corm and from continuous corm. Even with the high productivity level and good residue management, however, the erosionreducing effectiveness of good sod turned under before corn is st1ll apparent.

(4280) RUNOFF AND EROSION STUDIES ON THE SLOPING LANDS OF WISCONSIN.

(b) Laboratory project, cooperative with the Wisconsin Agricultural Experiment Station.

(c) Mr. R. E. Taylor, Soll Sclentist, ARS, P. 0. Box 6, Lancaster, Wis.

(d) Experimental; fleld Investigations, applied research.

(e) More than 30 years of runoff and soll-loss measurements on field plots under natural ralnfall on steeply sloping Fayette soll near Lacrosse, Wisconsin, were terminated at the close of the 1963 crop season. Investigations will be continued on a state-owned farm near Lancaster, W1sconsin. These studies will emphasize analysis and evaluation of erosioncontrol effectiveness of contouring, row grade, strip cropping, terracing, and tillage practices.

(g) On com after hay, wheeltrack planting and seedbed preparation with a fleld cultivator each reduced munof f by 50 percent and soll loss about 75 percent. Corm stover mulch in corm following corn gave excellent control of runoff and erosion on 16 percent slope, Fayette soll. Interseeding legumes in wide-row corm established meadows which produced ylelds comparable to those established in small grain and greatly reduced total rotation soll loss.

(h) A 30-year summary report of erosion studies in Wisconsin is being prepared for publication in bulletin form.

(4281) RUNOFF AND EROSION STUDIES IN THE MIDWEST CLAYPANS.

(b) Laboratory project, cooperative with the Missouri Agricultural Experiment Station.

(c) Mr. Fred D. Whitaker, ARS, Agricultural Engineerling Dept., Univ. of Missour1, Columbia, Missour1.

(d) Experimental; fleld Investigation, applied research.

(e) To evaluate effects of soll treatments, tillage practices and supplemental irrigation on runof $f$ and erosion from Midwest Claypan solls. Measurements of munof $f$, soll loss and concomitant variables on a series of fractional-acre plots and small watersheds under natural ralnfall are continuing.

(g) Fertilization adequate to produce high crop ylelds and large quantities of plant residues has greatly reduced the formerly serious soll and water losses from this gently sloping, claypan soll. Preparing seedbeds so that shredded cornstalks remained at the surface resulted in further significant reduction in soll loss from the high-intensity rains. corn receiving full fertility treatment has been a more efficlent user of water than has corn with only starter fertilizer.

(4282) RUNOFF AND EROSION STUDIES IN MINNESOTA.

(b) Laboratory project, cooperative with the Minnesota Agricultural Experiment Station.

(c) Mr. R. A Young, Agricultural Engineer, ARS North Central Soll Conservation Fleld Station, Morris, Minnesota.

(d) Experimental; field Investigations, applied research.

(e) Water and soll loss measurements under natural rainfall are obtained from fallow, continuous corm and rotation corm to characterize munoff and erosion on Barnes silty clay loam in the North Central Region. Simulated rainstorms applied with the Ralnulator in each of three cropstage periods are used to evaluate the relationships of runoff and erosion to percent land slope, shape of slope, row direction, intensive cropping, residue management, t1llage practices and other factors. Soll and water losses resulting from thaw and snow melt will also be measured and associated with cover and management.

(g) Results have shown that the Barmes soil is highly erosive under intense rainfall when the surface is unprotected, and that it is very responsive to soll and crop management practices as erosion-control measures. Inter relationships of effects of slope, row direction and type of vegetal cover were investigated under simulated rainfall. Ef'fects of slope shape and of varlous tillage methods for corn and soybeans on infiltration and soil erosion are being measured in other plot studies.

(4307) RESERVOIR FORMULAS AND THE VOLUME-WEIGHT OF RESERVOIR SEDIMENT.

(b) Laboratory project, cooperative with the Soll Conservation Service and State Agricultural Experiment Stations.

(c) Mr. H. G. Heinemann, Hydraulic Engineer, Bldg. T-12, P. 0. Box 208, Columbia, Missouri.

(d) Field and theoretical investigations, and office analyses.

(e) This project provides criteria for more accurate determination of the sediment yield of watersheds from reservolr survey data. The investigations include: (1) Refinement of survey procedures and methods for determining reservolr capacities and sediment volume from reservolr sedimentation survey data: (2) explanation of varlations in the volume welght of reservoir sediment; (3) recommendations on determination of the total welght of reservolr sediment; and (4) development of procedures for predicting the volume-weight of sediment in a proposed conservation structure.

(4817) RUNOFF AND EROSION STUDIES IN EASTERN SOUTH DAKOTA.

(b) Laboratory project, cooperative with the South Dakota Agricultural Experiment Station.

(c) Mr. C. R. Umback, Agricultural EngIneer, ARS, South Dakota State College, Brookings, South Dakota.

(d) Experimental; field investigations, applied research.

(e) Water and soll loss measurements under natural ralnfall are obtained from fallow, continuous corn, and continuous oats plots to characterize runoff and erosion on the Poinsett soils of Eastern South Dakota. Simulated rainstorms applied with the Rainulator in each of three cropstage periods are used to evaluate the croppingmanagement factor in the erosion equation for flax, sorghum, corn and oats grown in various sequences in this general climatic region. These studies are conducted on an experimental farm near Madison, which is operated as a substation of the Morris, Minnesota, fleld station.

(4825) RESERVOIR SEDIMENTATION STUDIES.

(b) Laboratory profect, cooperative with the Soll Conservation Service and State Agricultural Experiment Stations.

(c) Mr. H. G. Helnemann, Hydraulic Engineer, Bldg. T-12, P. 0. Box 208, Columbia, Missouri.

(d) Field and theoretical investigations, and office analyses.

(e) Numerous small reservolrs form the basis for this study. The objectives of this project are: (1) Determine the amounts, 
rates, and character of sediment yields from agricultural watersheds; and (2) relate sediment accumulation in the reservoirs with sediment yleld, precipitation, runoff, watershed characteristics, and cultural practices. Sediment yield and related information are 1mportant factors in the planning and design of small reservolrs and other conservation installations.

(5033) DRAINAGE INVESTIGATIONS FOR AGRICULTURAL LANDS.

See Oh1o Agricultural Experiment Station, Dept. of Agricultural Engineering, page 60.

(5204) HYDROLOGIC STUDIES ON WATERSHEDS IN MISSOURI VALLEY DEEP LOESS.

(b) Laboratory project, cooperative with the Iowa Agricultural Experiment Station.

(c) Mr. H. G. Helnemann, Research Supervisor, P. O. Box 208, Columb1a, Missour1.

(d) Field investigation and office analysis.

(e) To evaluate the effect of level terraces and other land practices on surface munoff, molsture retention, groundwater recharge, and base flow in severely-eroded areas of deep loess.

(g) Installation of fleld equipment is belng completed. Data collection has started.

(5205) ANALOG STUDIES OF SUBSURPACE DRAINAGE.

(b) Laboratory project in cooperation with the Ohio Agricultural Experiment Station, Dept. of Agronomy.

(c) Dr. George S. Taylor, Dept. of Agronomy, Oh1o State Un1v., 1885 Neil Ave., Columbus 10, on10.

(d) Theoretical and experimental; basic and applied.

(e) An electrical resistance network analog is used to study the placement of subsurface drain tubes to provide optimum water table control for plant growth.

(g) Use of electrical transmission theory in calculating network resistance values has resulted in improved accuracy of the electrical resistance network. Network analysis of interceptor drainage of a sloping fragipan soll has shown that drain efflclency is much more dependent upon the hydraulic conductivity of the backfill material than on drain depth.

(h) "Improvements in Construction and Use of Resistance Networks for Studying Drainage Problems," B. S. Vimoke, T. D. Tyra, T. J . Thiel, and G. S. Taylor. Soll Sic. Soc. Amer. Proc. 26:203-207, 1962.

"Instmumentation and Fabrication of an Electrical Resistance Network for Studying Molsture Flow Problems," T. J. Th1el, B.S. V1moke, and G. S. Taylor. British Journal of Agricultural Engineering Research 7(4):323$327,1962$.

"Simulating Water Flow in Soll with an Electrical Resistance Network," B. S. Vimoke and G. S. Taylor. U. S. Dept. Agr. ARS 4l-65: 51 p. (1962) 1llus.

U. S. DEPARTNENT OF AGRICULTURE, AGRICULTURAL RESEARCH SERVICE, Soll and Water Conservation Research Division.

NORTHEAST BRANCH, Plant Industry Station, Beltsville, Maryland, Mr. W. W. Pate, Branch Chlef.

(3867) IRRIGATION FACILITIES.

(b) Cooperative project with the Virginia Agricultural Experiment Station.

(c) Mr.J.N. Jones, Agricultural Engineer Agricultural Engineering Dept., Virginia Polytechnic Inst., Blacksburg, Virginia.

(d) Field investigations.

(e) Irrigation studies are designed to determine the effect of 1rrigation practices on the yield and quality of tobacco. Plant response, as measured by Leaf Area Index, is related to consumptive use of water and evapotranspiration.

(f) This study was initiated in 1961. Only preliminary data are avallable. Current study includes evaluation to the solar radiation utilization.

(4283) A STUDY OF FLOOD FLOWS AND THEIR EFFECTS ON STREAM CHANNELS.

(b) Cooperative project with Soll Conservation Service and comell University.

(c) Mr. R. P. Apmann, Hydraulic Engineer, 21 South Grove Street, East Aurora, N. Y.

(d) Experimental field investigations. qualities which materially affect the intensity of attack upon the stream channel periphery material and the variation throughout the flow boundary of forces destructive to the channel periphery material. Investigations are conducted on selected natural reaches of Buffalo Creek and tributarles in the vicinity of East Aurora, New York and on the Pequest River in Warren County, New Jersey.

(g) The geometric and hydraulic characteristics of a 5-mile reach of Buffalo Creek are being studied intensively by analyzing 500 cross-sections within this reach. A special analysis is being made of the March 30 , 1960, flood on th1s reach in order to determine the magnitude and distribution of mean boundary shear stresses, energy losses, and retardance coefficlents. An approximate method for estimating channel discharge is being developed from high water marks and topographic survey, and from an analysis of the superelevation of the water surface at an open channel bend. It is assumed that the differential transverse head is a function of the channel geometry and velocity head and that the phenomenon is reasonably reproducible under many conditions of flow.

(4284) DEVELOPMENT AND EVALUATION OF METHODS FOR CHANNEL STABILIZATION.

(b) Cooperative profect with Soll Conservation Service and Cormell University.

(c) Mr. R. P. Apmann, Hydraulic Englneer, 21 South Grove Street, East Aurora, New York.

(d) Experimental field investigations.

(e) To develop economical methods for streambank stabilization through observation and measurement of the effectiveness of various vegetal and structural measures in relation to streamflow over a range of streamflow conditions and channel geometry. Principal investigations are conducted on Buffalo creek and tributaries in the vicinity of East Aurora, New York.

(g) Valuable information is being gained by observing continuously the past stabili. zation works in Buffalo Creek and noting the conditions which made repair works necessary.

(4285) CHANNEL HYDRAULICS AND FLOOD ROUTING IN STEEP MOUNTAIN STREAMS.

(b) Cooperative project with the Vermont Agricultural Experiment Station and College of Technology of the University of Vermont, Vermont Water Conservation Board, and So1l Conservation Service.

(c) Mr. M. L. Johnson, Hydraulic Engineer, Route 2, Danville, Vermont.

(d) Experimental fleld investigations. River channel involving determination of: travel speed of controlled waves of different volumes; profiles of natural and controlled waves of different volumes; practical field methods of measuring the friction slope of mountain channels; comparlsons between results obtained with flood routing formulas and observed flood wave 
data; and the relationship between channel efficlency, flow duration curves, and watershed morphology.

(4286) INFLUENCE OF SNOW AND FROZEN SOIL ON RUNOFF.

(b) Cooperative project with the Vermont Agricultural Experiment Station, Vermont Water Conservation Board, and Soll Conservation Service and College of Technology of the University of Vermont.

(c) Mr. M. L. Johnson, Hydraulic Engineer, Route 2, Danville, Vermont.

(d) Experimental field investigations.

(e) Th1s study on the 43-square mile sleepers RIver watershed is concerned with the factors influencling the accumulation and melting of snow; the relationship of frozen soll to munoff; and the development of methods for predlcting runoff assoclated with snow melt. Data are collected and analyzed from snow courses, preclpltation gages, temperature records, heat budgets, soli molsture, frost measurements and snow melt in conjunction with streamflow records at nine stations in the subdivided watershed.

(g) It was found from an analysis of three types of snow runoff events (1) runoff from rain falling on snow with alr temperature near $32^{\circ}$ F., (2) munoff from snow melting on clear, warm days, and (3) runoff from a combination of rain and snowmelt, that timing and shape of runoff hydrographs are much more dependent on channel characteristics, such as the stagedischarge relationship and drainage density, for runoff events during the snowmelt season than for those occurring during other seasons. The following conclusions were reached from the above study: (1) When snow is present but not melting, the time lag from the end of intense rain to the inflection of the hydrograph is apparently dependent on some exponential function of the permeablilty and depth of snow in the vicinity of the gaging station; (2) Watersheds w1th most snow responded slowest, regardless of watershed size or other characterlst1cs; (3) The hydrograph of an 1solated snowmelt event differs from that of an isolated summer rain becuuse the contributing area of a snow-covered watershed 1 initlally small and because channel velocities, due to higher stages, are much greater during the snowmelt season; and (4) Highest instantaneous rates of spring runoff occur at the end of the snowmelt season when conditions favor a rapld discharge to the channels.

(h) "A Comparison of Snowmelt Hydrographs," by M. L. Johnson, Eastern Snow Conf. Proc., Quebec, Can. pp. 149-168, 1963.

\section{(4287) PRECIPITATION PATTERNS AND CHARACTERISTICS.}

(b) Cooperative project w1th the vermont Agricultural Experiment Station and college of Technology of the University of Vermont, Vermont Water Conservation Board, and Soll Conservation Service.

(c) Mr. E. T. Engman, Hydraul1c Englneer, Route 2, Danvilie, Vermont.

(d) Experimental field Investigations.

(e) The purpose of this study is to develop a method for calculating average precipitation on the 43-square mile Sleepers River watershed and 1ts subdivisions in relation to elevation, storm source and direction to study the behavior of summer convectlve storms in the northeast; and to provide information on rainfall depth-area-duration in relation to polnt rainfall in this part of the northeast.

(4288) INFLUENCE OF SOIL AND LAND USE ON STREAMFLOW FROM AGRICULTURAL WATERSHEDS.

(b) Cooperative project with the vermont Agricultural Experiment Station and College of Technology of the University of Vermont, Vermont. Water Conservation Board, and Soll Conservation Service.

(c) Mr. G. H. Comer, Hydraul1c Englneer, Route
2, Danville, Vermont.

(d) Experimental field investigations.

(e) Investigations of the influence of land use, climatic factors, and physical characteristics such as solls, geology, and topography upon munoff rates and water ylelds from the 43-square mile Sleepers River watershed and 1ts important subdivisions to derive relationships for predicting the hydrologic performance of ungaged watersheds in the other parts of the physlographic area.

(4289) SUBSURFACE CONTRIBUTIONS TO STREAMFLOW IN SLEEPERS RIVER WATERSHED.

(b) Cooperative project with the Vermont Agricultural Experlment Station and college of Technology of the University of Vermont, Vermont Water Conservation Board, and Soll Conservation Service.

(c) Mr. G. H. Comer, Hydraul1c Englneer, Route 2, Danville, Vermont.

(d) Experimental fleld investigations.

(e) To invest1gate procedures for separating streamflow into components of surface runoff, return flow, and base flow for storm and annual flows; to investigate the rates, amounts, and seasonal time distribution of subsurface contributions to streamflow; and to invest1gate the relationship of the physical characterlstics of watersheds to baseflow recession equations and to groundwater hydrograph shapes.

(4290) GROUNDWATER ACCRETION AND MOVEMENT IN RELATION TO WATERSHED CHARACTERISTICS.

(b) Cooperative project w1th the Vermont Agrlcultural Experiment Station and College of Technology of the University of Vermont, Vermont Water Conservation Board, and Soll Conservation Service.

(c) Mr. E. T. Engman, Hydraulic Engineer, Route 2, Danville, Vermont.

(d) Experimental field Investigations.

(e) To develop information on ground water accretion and movement as affected by 1 and use, solls, geology, and topography; and to develop methods for predicting ground water accretion and movement in relation to the physical, hydraulic, and meteorological characteristics of the 43-square mile Sleepers RIver Watershed.

(4291) INFLUENCE OF LAND USE ON THE HYDROLOGY OF AGRICULTURAL WATERSHEDS IN VIRGINIA.

(b) Cooperative project with the Virginia Agricultural Expt. Sta., Virginia Polytechnic Inst, and the soll Conservation service.

(c) Mr.J. B. Burford, Hydraulic Engineer Agricultural Englneering Department, Virglnia Polytechnic Inst., Blacksburg, Va.

(d) Experimental field Investigations.

(e) To provide additional knowledge concerning the disposition of precipitation in agricultural watersheds, and to develop procedures based upon watershed characterlstics, climat1c factors, and various land use practices for the prediction of flood peaks and seasonal and annual water ylelds in three physlograph1c areas. Hydrologic, geologic, solls, plant cover and cultural data are being obtalned on 4 unit source watersheds varying in size from 3.5 to 19.3 acres in the Appalachlan Valleys and Ridges and on 10 complex watersheds from 182 to 3,054 acres in the Appalachian Valleys and Rldges, Blue Rldge Mountalns, and the Pledmont Plateau.

(4292) HYDROLOGIC EFFECTS OF CHISELING SHALLOW SHAIE SOIL IN WEST VIRGINIA APPALACHIAN VAIIEYS AND RIDGES.

(b) Cooperative with West Virginia Agricultural Experiment Station and the Soll Conservation Service.

(c) Mr. V. O. Shanholtz, Hydraul1c Englneer, 409 Grant Avenue, Morgantown, West Virginia. 
(d) Experimental field investigations.

(e) The purpose of this study is to determine the effect of chiseling shallow shale subsoil upon rainfall-runoff relationships on small watersheds. Measurements for calibration of four 10-acre watersheds have been underway since the spring of 1958. Two of the watersheds will be treated following the calibration period.

(h) "Influence of Selected RaInfall CharacterIstics on Runoff," by V. O. Shanholtz and W. H. Dickerson. Thesis for M.S. at West Virginia University, 1963.

(4293) MECHANICS OF EROSION.

(b) Laboratory project, cooperative with New Hampshire Agricultural Experiment station.

(c) Mr. R. S. Palmer, Agricultural Engineer, University of New Hampshire, Agricultural Englneering Dept., Durham, New Hampshire.

(d) Field and laboratory studies, both basic and applied, for development and design.

(e) The purpose of these investigations is: (1) To Investigate basic soll and water problems and their relation to the mechanics of erosion; (2) to determine the impact forces of varlous size water drops in relation to the depth of water layer on the soll surface and particle detachment from that surface.

(g) A laboratory apparatus has been designed for producing raindrops of various sizes. Other equipment has been devised for measuring waterdrop impact as affected by varying depths of water films.

(4294) ERODIBILITY OF SOILS IN THE NORTHEAST.

(b) Laboratory project, cooperative with Maine Agricultural Experiment Station.

(c) Mr. Eliot Epstein, Soll scientist, Univ. of Malne, Orono, Malne.

(d) Laboratory and fleld investigations both basic and applied for development and design.

(e) The purpose of these investigations is to obtain fundamental information on the erodibility of Northeast solls and to determine the interrelations of climate, cover (including rock fragments), munoff, and soll loss.

(g) Removal of rocks that interfere with sorting of potatoes by mechanical harvesters resulted in increased munoff and soll erosion and decreased crop yields during the first year of the study. Installations were completed on a laboratory rainfall simulator where basic studies on soll erodibility are being initiated.

(4295) TILLAGE PRACTICES AND DIVERSION TERRACES FOR WATER AND EROSION CONTROL.

(b) Laboratory project, cooperative with the New York Agricultural Experiment Station, and the Soll Conservation Service.

(c) Mr. George R. Free, soll scientist, Balley Hall, Cornell University, I thaca, New York.

(d) Field investigations.

(e) The purpose of these investigations is to determine the inter-relation of tillage, topography, climate, munof $f$ and soll loss, and to evaluate the effectiveness of diversion terraces for controlling surface and subsurface flow.

(g) Work is continuing on the effectiveness of conventional, mulch and minimum tillage for corn on munoff and erosion from slopes of different steepness and length and on the effect of diversion terraces on surface soll molsture during critical crop growth stages for several sloping solls having seepage problems.

(4819) DEVELOPMENT AND EVALUATION OF DRAINAGE PRACTICES IN THE NORTHEAST.

(b) Laboratory project cooperative with the Vermont Agricultural Experiment Station and the Soll Conservation Service.

(c) Mr. Joseph Bornstein, Agricultural Englneer, University of Vermont, Burlington, Vermont.

(d) Field investigation both basic and applied research.

(e) The purpose of this study is to develop and evaluate drainage practices for sloping lands of the Northeast. This involves development of techniques for determining directional components of subsurface water flow before and after installation of drainage treatments. Surface drainage practices are instrumented to measure munoff from rainfall and snowmelt.

(f) Instrumentation of this project has just been completed. Preliminary piezometric data are avallable.

\section{(4820) HYDROGRAPH LABORATORY.}

(b) Laboratory project. Cooperative efforts on occasion.

(c) Mr.H.N. Holtan, Director, Hydrograph Laboratory, ARS, Beltsville, Md.

(d) Basic and applied research.

(e) The purposes of this project are to evolve and test new concepts, theorles and principles for understanding the hydrologic processes on agricultural watersheds; to test and adapt information from various sources for application to water control and related problems encountered in watershed engineering; to conduct special analyses involving ARS data from more than one station or more than one Branch that can be more adequately carried out at a central location which has avallable a full-time staff of scientists with speciallzed training in hydraulics, hydrology, meteorology, and mathematics; and to provide case assistance to field personnel detailed to the Laboratory for specific analys s as requested by the field.

(g) The Hydrograph Laboratory is currently performing hydrologic computations with digital computers to simulate watershed performance as affected by varlous protective measures. A method of analyses was developed for expressing the runoff hydrograph in terms of rainfall and constants derived from the recession curve. Numerical studies are conducted in the hydraulics of flood flows. Both kinematic and kinetic formulations are considered. Frequencies of small amounts of dally rainfali in eastem United States are under study for use in classification of climates, in the design of irrigation systems, and for economic evaluations of small flood events. A procedure was developed for estimating the maximum probable 24-hour snowfall in the United states and is in process of publication. A multivarlate analyses is in progress to determine the effect of raingage density on the apparent rainfall-runoff relationship on the Sleepers RIver Watershed in Vermont.

(h) "Analyses and Application of Simple Hydrographs," by H. N. Holtan and D. E. overton, North-Holland Int. J. of Hydrology, Vol. (3): 250-264 (1963) 1ilus. March 1963. "Precipitation," by D. M. Hershfield. Trans. Amer. Geophysical Union, Vol. 44(2): 553-555, June 1963.

"Arid Zone Precipitation Research in the United States," by D. M. Hershfield. Contribution to chapter on Climatology and Meteorology, Aridity and Man, published Dec. 1963 by the Amer. Assoc. for the Advancement of Sclence.

"Estimating Coefficients for storage Routing," by D. L. Brakenslek. J. of Geophys. Res., Vol. 68, No. 24: 6471-6474, Dec. 15, 1963 .

(4821) EFFECTIVENESS OF STREAMBANK STABILIZATION AND PROTECTION MEASURES IN REDUCING SUSPENDED SEDIMENT LOAD.

(b) Cooperative project with Soll Conservation Service and Cornell University. 
(c) Mr. R. P. Apmann, Hydraul1c Eng1neer, 21 South Grove Street, East Aurora, New York.

(d) Experimental field investigations.

(e) To develop procedures for estimating effectiveness of streambank stabilization and other measures in reducing the sediment discharge of a stream. It is postulated that the total sediment load of a stream is directly related to the mean concentration of the suspended sediment for a flood series, and that changes in time of the mean concentration resulting from installation of streambank stabilization measures are 1nd1cative of changes in total sediment load. The streambank stabilization measures are being installed by Soll Conservation service as part of the authorized flood prevention program in the Buffalo River watershed. Measurements of suspended sediment load concentration and of stream discharges are made for all floods above a certain magnitude.

(g) Analysis indicates that stream stabilization works Installed between 1953 and 1961 have reduced the suspended sediment load of Buffalo Creek by about forty percent. During the same period the suspended sediment load of adjacent tributaries to Buffalo R1ver with similar but untreated streambank problems have increased ten percent.

(4822) A STUDY OF THE MOVEMENT OF COARSE-TEXTURED BED MATERIAL OF A NEW YORK MOUNTAIN STREAM.

(b) Cooperative project with Soll Conservation Service and Cormell University.

(c) Mr. R. P. Apmann, Hydraul1c Engineer, 21 South Grove Street, East Aurora, New York.

(d) Experimental field 1nvestigations.

(e) To relate the quantities of transported bed materials to flood discharge rates and durations, to determine applicability of bed load equations in coarse material transport problems and, if appropriate, devise new or revised relationships. A stream reach has been instrumented and debris basin made larger for the initiation of this study In 1963 on the Little Hoosic River near Berlin, New York.

(4823) COMPILATION AND PUBLICATION OF SELECTED HYDROLOGIC DATA.

(b) Cooperative project with various state Experiment Stations and Land Grant Colleges and with the Soll Conservation Service.

(c) Mr. H. W. Hobbs, Hydraulic Englneer, Plant Industry station, Beltsville, Ma.

(d) Office assembling and processing of current hydrologic data.

(e) To provide information on monthly precipitation and runoff, annual maximum discharges and volumes of munoff, and selected munoff events with assoclated data on rainfall, land use, and antecedent conditions for all current ARS research watersheds in the U. $S$. Hydrologic Data for 1960 and 1961 w1ll be published in early 1964. Hydrologic Data for years 1962, 1963 and 1964 w1ll be published separately at six-month intervals. Hydrolog1c Data for 1965 and subsequent years will be published by August of the following year.

(h) "1956-1959 Hydrolog1c Data for Experimental Agricultural Watersheds in the United States," by $\mathrm{H}$. W. Hobbs, USDA M1scellaneous Publication 945,1963 1llus.

(5206) DRAINAGE PRACTICES FOR LEVEL AND SLOPING LANDS.

(b) Cooperative project w1th the V1rginia Truck Experiment station and the Virginia Agricultural Experiment Station.

(c) Mr. Truman Goins, Agricultural Engineer, P. 0. Box 2160, Norfolk, Virginia.

(d) Laboratory and field investigations including both theoretical and applied phases.

(e) Drainage studies for level land 1nclude study of drainage requirements of various vegetable crops with emphasis on the various factors related to high soll water contents and their effect on plant growth. Landforming will be studied as a means of minimizing the need for surface drains in flat Coastal plains areas, and for more eff1clent soll and water management practices on sloping lands of the Fledmont.

(f) This project has just been initiated.

U. S. DEPARTMENT OF AGRICULTURE, AGRICULTURAL RESEARCH SERVICE, So1l and Water Conservation D1V.

NORTHERN PLAINS BRANCH, P. O. Box 758, Fort Collins, Colo., Dr. C. E. Evans, Branch Chief.

(2902)

DEVELOPMENT AND IMPROVEMENT OF WATER MEASURING DEVICES.

Cooperative w1th Colorado Agricultural Experiment Station. See Colorado State University, C1vil Engineering Section, Fort Collins, Colo., page 19.

(3217) HYDROLOGIC STUDIES OF GROUND WATER IN THE RED RIVER VALIEY OF NORTH DAKOTA.

(b) Laboratory project.

(c) Mr. L. C. Benz, Agricultural Englneer, P. 0. Box 806, Grand Forks, North Dakota.

(d) Field investigation. Applied research.

(e) A fleld investigation covering more than 200 square miles to determine possible causes for a saline condition on a large area of land. Measurements consist of water tables, artesian conditions, soll and water physical and chemical data.

(g) Salt-affected solls are caused by h1gh water tables, poor drainage conditions and saline artesian waters. High water tables are caused by precipitation. The salt source is the Dakota sandstone artesian aquifer. "Small and Large-Dlameter Water Table Observation Wells Compared," by L. C. Benz, R. H. M1ckelson, M. E. Jensen, and F. M. Sandoval. Trans. ASAE 6(2): 93-97, 1963. (Reprints ava1lable from authors.)

(4296) HYDRAULICS OF SUB-CRITICAL FLOWS IN SMALL, ROUGH CHANNELS.

See Colorado State University, C1vil Engrg. Section, Project No. 3400 .

(b) Laboratory project, cooperative with the Colorado Agricultural Experiment Station.

(c) Mr. E. Gordon Kruse, Agricultural Engineer, Hydraulic Laboratory, Colorado State Un1v., Fort Collins, Colorado.

(d) Experimental Investigations; basic and applied, portions used for masters and doctoral theses.

(e) Th1s study is an experimental investigation utilizing a tilting flume in which a small channel 60-feet long is formed by natural soll which is fixed in position agalnst movement by chemical spray. A variety of roughness forms can be created on the bed. The relation of roughness dimensions and channel shape to flow resistance is determined for a range of channel slopes and flow depths.

(f) Inactive.

g) Relationships between resistance coefficlents and measured roughness dimensions were developed for both laminar and turbulent flows. The transition between these flows was found to occur at a Reynolds number $(\mathrm{RV} / \mathrm{v})$ of 500 for these channels. For low Reynolds number flows (Re less than 500) over rough boundaries, normal flow depth was proportional to discharge, viscosity and roughness helght and inversely proportional to roughness spacing and channel slope. For turbulent flows, resistance was a logarithmic function of roughness helght and flow depth. The standard deviation of bed elevation measurements 
was used in both cases to represent the effective helght of the nonuniform roughness elements. Effects of roughness spacing and channel shape on flow resistance could not be detected for turbulent flows.

(4297) COOPERATIVE WATER YIELD PROCEDURES STUDY.

(b) Laboratory project, cooperative with Soll Conservation Service, USDA, and the Bureau of Reclamation, USDI.

(c) Mr. A. L. Sharp, (Coilaborator), 1697 S. W. 19th, West Linn, Portland, Oregon.

(d) Office analyses, applied research.

(e) To develop and test methods for use by field engineers to evaluate the downstream effects of upstream conservation use and treatment of land on water ylelds of creeks and rivers. The project is one purely of analytic hydrology. The project uses avallable hydrologic and other data wherever it is available. It secures no new hydrologic data such as streamflow data, climatic data, or land-treatment data. The project is nearing completion.

(g) Studies have demonstrated that it cannot be proved statistically significant that there are downstream effects on stream flow of upstream conservation treatment and use of land, although it is ariomatic that in subhumid to arid areas such effects must exist. A rational method of evaluating such effects has been developed and tested. A summary of the studies performed and presentation of the rational method will be published through Department of Agriculture media during 1964.

(4298) COMPARTSONS OF RATES AND AMOUNTS OF RUNOFF FROM SMALL SINGIE-COVER WATERSHEDS.

(b) Laboratory project, cooperative with the Nebraska Agricultural Experiment Station.

(c) Mr. Frank J. Dragoun, Hydraulic Eng1neer, ARS-SWC, Hastings, Nebraska.

(d) Field Investigations -- applied research.

(e) To evaluate the effect of (1) different land use treatment and (2) different crops on the runoff from single crop watersheds in the Central Great Plains, as one of the significant factors influencing runoff from complex watersheds. Replicate 4 -acre single crop watersheds in meadow, pasture, cult1vated and eroded cultivated land seeded to grass are instrumented with recording rain gages, flumes and waterstage recorders. S1x cultivated watersheds are in a wheat-sorghumfallow rotation. Mulch (subsurface) tillage, on the contour, is practiced. Effects of different crops and land uses on storm runoff rates and amounts are determined by analyzing hydrographs and histograms.

Seasonal, annual, and long time effects are determined by analyzing precipitation and munoff data.

(g) Twenty-four years of record show that runoff from a single crop 4-acre watershed averaged 3.3 inches. Durlng the same perlod a 4 -acre native-pasture yielded 2.0 inches and $a$ native-meadow yielded only 0.25 inches. Rainfall during the perlod averaged 22.4 inches. These results indicate the relative differences that can be expected in runof under different land-use practices.

(h) "A Comparison of Performance of Flve RainGage Installations," by J. A. Allis, B. Harris, and A. L. Sharp, Journal of Geophysical Research, Vol. 68, No. 16, pp. 4723-4729, August 15, 1963.

(4299) RUNOFF AND HYDROGRAPH CHARACTERISTICS OF LARGE MIXED-USE WATERSHEDS.

(b) Laboratory project, cooperative with the Nebraska Agricultural Experiment Station.

(c) Mr. Frank J. Dragoun, Hydraulic Engineer, ARS-SWC, Hastings, Nebraska.

(d) Field investigations -- applied research.

(e) To determine characteristics of runoff from large mixed-use watersheds as related to, or affected by, precipitation, channel storage, transmission losses to valiey alluvium, time of concentration, stream gradient, and watershed size. Three watersheds, in mixed use, 481, 2086 and 3490 acres in size, are instrumented with rain gages, welrs, and stage recorders for observing precipitation and runoff. Transmission losses to valley alluviums are estimated by use of gaged outflow and estimates of inflow from unit source areas of tributary land. These latter estimates are based on gaged rainfall on and runioff from small 4-acre single-use source area watersheds. Hydrographs and histograms are analyzed to obtain watershed retention (infiltration) rates and hydrograph characteristics.

(8) Twenty-four years of record indicate that average yeariy runoff from a conventionaliy farmed area of 481 acres was 3.3 inches. on a single crop 4-acre area the average was 3.6 inches. Rainfall for the perlod averaged 22.4 inches. A comprehensive analysis of the 24 years of continuous records is underway.

(4300) COMPARISON OF RUNOFF AND SEDIMENT YIELDS FROM CONSERVATION AND CONVENTIONALIY FARMED WATERSHEDS.

(b) Laboratory project, cooperative with the Nebraska Agricultural Experiment Station.

(c) Mr. Frank J. Dragoun, Hydraulic Englneer, ARS-SWC, Hastings, Nebraska.

(d) Fleld investigations -- applied research.

(e) To determine the effects of conservation farming, land use, climate, and physlography on rates and amounts of munoff and sediment yields. Two 400-odd-acre watersheds, one conventionally farmed and the other conservation farmed, are equipped with recording rain gages, welrs and stage recorders, and sediment samplers, to measure precip1tation, munoff, and sediment yields. The two watersheds were operated the same during a calibration period from 1939 to 1947 . one was then treated by terracing, contour tillage and seeding eroded cultivated land to grass.

(g) Current data substantiate previous analyses indleating conservation measures are effective in controlling soil erosion from average rainfall events. Six years of continuous measurement show that annual sediment yield from the area under conservation was 5.4 tons/acre compared with 8.7 tons/acre from the conventionally farmed area or a difference of 38 percent. In 1957 , a year of above normal rainfall with intense storms, no significant reduction in sediment yleld was realized under conservation practices whereas in 1963, a year of above normal rainfall but no intense storms, the sediment yleld from the area under conservation was only 14 percent of that from the conventionally farmed area. The significance of kinetic energy of rainfall in sediment yield determinations is indicated.

(4301) RELATIONSHIP BETWEEN INTENSITY OF GRAZING AND RUNOFF AMOUNTS ON FINE-TEXTURED SOILS.

(b) Laboratory project, cooperative with South Dakota Agricultural Experiment Station.

(c) Mr. Clayton L. Hanson, Agricultural Engineer, Newell Irrigation and Dryland Field Station, Newell, South Dakota.

(d) Field investigations -- applied research.

(e) To determine the effects of light, moderate and heavy grazing and other factors such as precipltation, antecedent soll molsture, soll frost and snow accumulation, on rates and amounts of runoff from fine-textured range solls in southwestern South Dakota. Replicated plots of about 2 acres in each of the lightly, moderately and heavily grazed pastures are instrumented to observe runof amounts (stage recorders and H-flumes) rates and amounts of precipitation (recording 
rain gages), soil moisture, soll frost and vegetative conditions. The studies are being made on the South Dakota Range Exper1ment Station near cotton wood, South Dakota.

(g) RaInfall-runoff events during the first year of study indicate that grazing intensity materially influences range cover and that runoff is normally higher from heavily grazed areas although storm sequences and antecedent moisture conditions can signif1cantly influence the normal trend.

(4302) MEDICINE CREEK WATERSHED INVESTIGATIONS.

(b) Laboratory project, cooperative with the Soll Conservation Service, U. S. Geological Survey, Bureau of Reclamation, and Nebraska Agricultural Experiment station.

(c) Mr. V. I. Dvorak, Hydraulic Engineer, ARS-SWC, Hastings, Nebraska.

(d) Field investigations; compilation and analysis of data.

(e) Data from this southwestern Nebraska project are being analyzed for the following purposes: (1) To estimate the long-time munof and sediment yields from 8 years of observed hydrologic watershed data; (2) to determine if acquired munoff, sediment and channel data will adhere to the existing channel regime equations for six munoff stations; and (3) to compile and prepare a publication indicating what data have been collected as part of the cooperative Investigations, and where these data may be found.

(g) The long-time sediment yields for the six watersheds have been computed by three different approaches. In each of these methods, the observed mnoff and sediment data for 8 years were used for the projection.

(4303) SEDIMENT YIELD AS RELATED TO GULLY AND CHANNEL EROSION.

(b) Laboratory project, cooperative with the Soll Conservation Service, and Nebraska and Kansas Agricultural Experiment stations.

(c) Mr. V. I. Dvorak, Hydraulic Engineer, ARS-SWC, Hastings, Nebraska.

(d) Field investigations; compilation and analysis of data.

(e) The objectives of this project are: (1) To determine and relate rates of gully and channel erosion to causal factors; (2) to provide basic data on rates of land loss and land depreciation due to gully erosion; and (3) to develop criteria, based upon hydrologic and physical factors, for est1mating quantities of sediment derived from gully erosion.

(g) Results of studies covering an 11-year period indicate that channel slopes and shapes are related to erosion and munoff conditions. It was found that for a unit cross section area, depths of flow, in a gullied channel, increase in a downstream direction but the rate of increase declines with distance downstream from the head-cut. Head cutting erosion in one case was equivalent to 8 percent of the total sediment yield and the material removed from the channel was equivalent to 30 percent of the total sediment yield of the tributary drainage in the 11-year period.

(4304) SABETHA LAKE WATERSHED SEDIMENTATION STUDIES.

(b) Laboratory project, cooperative with the Soll Conservation Service and Kansas Agricultural Experiment Station.

(c) Mr. V. I. Dvorak, Hydraulic Engineer, ARS-SWC, Hastings, Nebraska.

(d) Fleld investigations and offlce analysis.

(e) The objectives of this study are: (1) To determine the amount, rate, and character of the sediment yields from this 10-square mile watershed In northeast Kansas; (2) to relate sediment accumulation in the reservoir with sediment yield, precipitation, munoff and other watershed characteristics.
(4306) SEDIMENT DISTRIBUTION IN FLOODWATER RETARDING-TYPE RESERVOIRS.

(b) Laboratory project, cooperative with the Soll Conservation Service and State Experiment Stations.

(c) Mr. Verne I. Dvorak, Hydraulic Engineer, ARS-SWC, Hastings, Nebraska.

(d) Theoretical and field investigations, and office analyses.

(e) Th1s study was undertaken to improve the design criteria for floodwater retarding-type reservoirs by: (1) determining those factors that influence sediment distribution and evaluating their importance, and (2) derivirg and testing methods for predicting the horizontal and/or vertical sediment distribution in floodwater retarding-type reservoirs. Th1s is important in determining the minimum elevation of the principal spiliway and the required original capacities of various storage pools.

(4309) ISOLATION AND RELATIVE EVALUATION OF RUNOFF PRODUCING POTENTIALS OF RANGE SITES OF WESTERN SOUTH DAKOTA.

(b) Laboratory project, cooperative with the South Dakota Agricultural Experiment Station.

(c) Mr. A. R. Kuhlman, Botan1st, Newell Irr1gation and Dryland Field Station, Newell, South Dakota.

(d) Fleld and laboratory investigations --

(e) To evaluate relative runoff producing potentials of principal range sites of Western South Dakota including sandy, silty, shallow, thin breaks, panspots, overflow, clayey, and dense clay range sites as characteristic of $\mathrm{D}-4, \mathrm{D}-10$, and $\mathrm{D}-11$ so11 conservation problem areas in the Dakotas, Montana and Wyoming. To evaluate relatively the same range sites by rainfall simulators. To 1solate vegetative factors such as standing vegetation, mulch, root systems and soll factors that cause differences in runoff from different range sites.

(4310) WATER YIELD AND SEDIMENT ACCUMULATION FROM RANGELAND WATERSHEDS.

(b) Laboratory project, cooperative with the South Dakota Agricultural Experfment Station.

(c) Mr. Clayton L. Hanson, Agricultural Engineer, Newell Irrigation and Dryland Fleld Station, Newell, South Dakota.

(d) Field investigations, applied research. of various amounts from rangeland watersheds ranging in size from a few acres to 13,000 acres, and gross sediment ylelds (volumetric) from the same watersheds, as representative of the D-4, D-10, and D-11 soll conservation problem areas in eastern Montana, Wyoming and the Western Dakotas. Purposes of these studies are to provide data on water ylelds and information on which to estimate the probable useful life of ponds and reservolrs in the problem areas. The work is being done by gaging precipitation, measuring water ylelds in stockwater reservolrs, making reservolr sedimentation surveys, and securirg data on watershed physical, topographic, ecologic and grazing use factors.

(g) Data continue to show that sediment yields from fine-textured soils are double those from the medium textured soils ( 7.5 tons) acre and 3.7 tons/acre respectively). Similar1ly, surface runoff from the finetextured solls has continued to average 4 times that from medium-textured solls. In $1962,6.1$ inches of munoff or 27 percent of the 22.6 inches of precipation occurred In a 90 acre fine-textured soil area which is the highest percentage measured since the studies were inltiated in 1957. The highest runoff during 1962 from the mediumtextured solls areas was 6 percent of the annual rainfall.

(h) "An Improved Staff Gage System for Reservolrs," 
by J. W. Newberger and A. L. Sharp, Journal of the American Society of Agricultural Engineering, Vol. 44, No. 2: 86-87 (1963) 1llus. Feb. 1963.

(4824) EVAPORATION AND SEEPAGE FROM RANGELAND STOCKPONDS.

(b) Laboratory project, cooperative with the South Dakota Agricultural Experiment Station.

(c) Mr. Clayton L. Hanson, Newell Irrlgation and Dryland Field Station, Newell, South Dakota.

(d) Fleld investigations -- applied research. To differentiate total stockpond water dissipation into evaporation and seepage and develop a basis for predicting expected stockpond water losses. The purpose of this study is to a1d in the development of practical methods to reduce losses of water from stockponds to provide dependable water supplied for livestock.

(g) Data show that the ratio of the total pond evaporation (floating pan) to that from the Class A land pan is 0.64 . Seepage and deep percolation in ponds in the medium-textured solls region amount to 55\% of the total pond dissipation. In one 12 ac. ft. capacity stockpond the volume of daily seepage loss over a 37-day perlod averaged 910 cu. ft. per day or an equivalent volume to water more than 600 cows each day. Stockponds on medium-textured solls are continuing to show water losses exceeding inflow up to 80 percent of the time resulting in dry ponds nearly 50 percent of the time.

(4826) HYDRAULIC. CHARACTERISTICS OF PARTIALLY SATURATED POROUS MEDIA.

See Colorado State University, C1vil Engrg. Section, Project No. 4611.

(b) Laboratory project, in cooperation with Colorado Agricultural Experiment Station.

(c) Mr. R. H. Brooks, Agricultural Engineer, Hydraulics Laboratory, Colorado State Univ., Fort Collins, Colorado.

(d) Basic research.

(e) Certain hydraulic characteristics of porous medla must be known for laboratory modeling of complicated field problems involving water movement in solls. Problems involving flow of fluids in partially saturated solls often cannot be solved except by inferences derlved from the performance of models. The purpose of the study is to be able to predict from equations how any porous medium will behave with respect to the functional relationship between permeability, degree of saturation (or fluid pressure) when certain media properties are known. A thorough understanding of the way permeability is effected by measurable properties of porous media might eliminate the necessity of selecting a porous medium by trial for use in model studies.

(g) A theory showing how the variables capillary pressure, water and air permeability are related to degree of saturation has been developed. Methods and equipment have been developed for measuring these variables using steady state experiments. Verification of the theory with experimental results has been good. It appears that hydraulic properties of partially saturated media can be described by three parameters: the bubbling pressure, $\mathrm{Pb}$; a measure of the uniformity of the pores in the medium, $\eta$; and the saturated permeability $\mathrm{K}$.

(4827) HYDRAULICS OF FLOW IN BORDER CHECK IRRIGATION SYSTEMS.

(b) Laboratory project, in cooperation with Nebraska Agricultural Experiment Station.

(c) Mr. 0.W. Howe, Scotts Bluff Experiment Station, Route 2, Mitchell, Nebraska.

(d) Fleld investigation; applied research, design.

(e) This is a study of the operational characteristics of low-gradient border checks on medium textured soll. It 1nvolves measurement of the efflciency of irrigation, uniformity of distribution, effect of uneven grade, kind of crop, stage of crop development, etc., upon irrigation efflciency. Soll molsture samples are taken before and after Irrigation at intervals in the length of the run. Continuous measurements are taken of depth of water at these stations throughout the set. The purpose is to obtain relationships regarding the effect of crop retardance, slope, surface conflguration, intake rate, on rate of advance of irrigation water. Such relationships will be useful in designing and operating lowgradient border check irrigation systems.

(i) Discontinued.

$(\mathrm{g})$ Slopes of 0 to 0.05 percent gave hlghest irrigation efflciencles, around 90 percent, when crop retardance to the flow of water was small. Slopes of 0.10 to 0.15 percent were needed to offset the high retardance caused by fully developed sugar beet follage.

(4828) DESIGN DATA FOR LEVEL OR NEARLY LEVEL BENCH IRRIGATION SYSTEMS ON HEAVY CLAY SOILS.

(b) Laboratory project, in cooperation with South Dakota Agricultural Experiment Station.

(c) Mr. Niel A. Dimick, Agricultural Engineer, Newell Irrigation and Dryland Fleld Station, Newell, South Dakota.

(d) Field investigations. Results will be used for design purposes.

(e) This is a study of the operational character 1st1cs of low-gradient border checks on a fine textured soll. It involves measurement of the efficiency of irrigation, uniformity of distribution, and effect of uneven grade, kind of crop, stage of crop development, etc, upon irrigation efficiency. Soll molsture samples are taken before and after irrigation at intervals in the length of the mun. Continuous measurements are taken of depth of water at these stations throughout the set. The purpose is to obtain relationships regarding the effect of crop retardance, slope, surface configuration, intake rate, on rate of advance of Irrigation water. Such relationships will be useful in designing and operating low-gradient border check irrigation systems.

(g) No signiflcant findings have been obtained as yet since this project was just initiated in 1962 .

(4829) THE INFLUENCE OF RELIEF UPON VEGETATION, SOI SALTS, AND WATER TABLES IN AN IMPERFECTLY DRAINED GIACIO-IACUSTRINE SALINE AREA OF INTERCONNECTING RIDGES AND DEPRESSIONS IN NORTH DAKOTA.

(b) Laboratory project.

c) Mr. F. M. Sandoval, Soll Sclentist, U. S. Fleld Stat1on, Mandan, North Dakota or Mr. L. C. Benz, Agricultural Engineer, P. O. Box 806, Grand Forks, North Dakota.

(d) Field investigation; applied research.

(e) A field experiment of dimensions $450 \times 800$ feet in a ridge-depression micro-relief area where depressions are non-saline but ridges highly saline. Purpose of study is to determine reasons for the differences in salinity. Evaluated by measurements of ground-water gradients and studies of water chemistry and soll physical and chemical data.

(f) Terminated. depressions owing to impounded precipitation. Artesian pressures are present but play a minor role.

(4830) THE EFFECTIVENESS AND FEASIBLITY OF LOWCOST SUBSURFACE, PLASTIC DRAINS IN A SALINE, POORLY DRA INED AREA.

(b) Laboratory project.

c) Mr. L. C. Benz, Agricultural Engineer, P. 0. Box 806, Grand Forks, North Dakota.

(d) Field experiment; applied research. 
(e) Experiment consists of nine lines, each 300 feet long, of elther plastic tile or mole drains installed in a high water table and saline area. Purpose of experiment is to evaluate effectiveness of shallow, closelyspaced, plastic tile in a saline area.

(f) Terminated.

(4831) LAND FORMING ON SALT-AFFECTED LACUSTRINE SOILS IN THE RED RIVER VALLEY HAVING AN INTERSECTING MINOR RIDGE-DEPRESSION TYPE OF MICRORELIEF .

(b) Laboratory project.

(c) Mr. L. C. Benz, Agricultural Engineer, P. 0. Box 806, Grand Forks, North Dakota.

(d) Fleld experiment; applied research.

(e) Consists of four 5-acre plots under cult1vation in a saline ridge-depression microrellef area. TWo plots are leveled -- one having surface dralnage, the other having only internal (tile) drainage (precipitation is impounded). One unleveled plot has internal drainage, the second one has none. Purpose of work is to determine effects of land forming and tile drainage on saltaffected land.

(4832) A STUDY OF THE FALLING WATER TABLE, SOIL MOISTURE, AND SOIL SALT TRANSLOCATION DURING WINTER MONTHS.

(b) Laboratory project.

(c) Mr. L. C. Benz, Agricultural Englneer, P. O. Box 806, Grand Forks, North Dakota.

(d) Field experiment; basic research.

(e) Experiment consists of two treatments (straw mulch and fallow) each replicated 3 times. Fleld plots are $60^{\prime} \times 60^{\prime}$. Measurements obtalned are; soll molsture (neutron method), water tables, soll temperatures, freezing depth, water and soll physical and chemical data. Purpose of the experiment is to determine translocation of water table waters which recede during the winter months.

(f) Field work terminated. Report not yet available.

(4833) RELATIONSHIP OF MEASURED EVAPOTRANSPIRATION TO SOLAR RADIATION IN WESTERN U.S.A.

(b) Laboratory project, (joint project with Mr. M. E. Jensen, Northwest Branch.)

(c) Dr. H. R. Haise, Agricultural Research Service, P. O. Box 758, Fort Collins, Colo.

(d) Analytical and theoretical; basic and applied.

(e) Measurements of evapotranspiration rates for one- to three-week perlods made by USDA personnel during the past 35 years have been re-evaluated and selected data for field and orchard crops are being related to solar radiation and air temperature using an energy balance approach. Solar radiation data for 20 locations in the Western U.S.A. have been summarlzed and procedures developed for estimating radiation for specific periods. The resulting relationships can be used for estimating evapotranspiration for various crops.

(f) Completed.

(h) "Estimating Evapotranspiration From Solar Radiation," by $M$. E. Jensen and $H$. R. Halse. Amer. Soc. Civ. Engin. Proc., Irrig. \& Drain. D1v. Jour. 89(IR-4): 15-41 (1963) 1llus. Dec. 1963.

(5207) VOLUMETRIC EROSION AND DEPOSITION ON A COMPLEX WATERSHED.

(b) Laboratory project, cooperative with the Soll Conservation Service and Nebraska Agricultural Experiment Station.

(c) Mr. Frank J. Dragoun, Hydraulic Engineer, ARS-SWC, Hastings, Nebraska.

(d) Field investigations and office analysis; master's thesis study.

(e) To develop a method of determining volumes of erosion and deposition within a watershed using topographic maps developed from aerial photographs, and to delineate the areas, determine the volumes and indicate the depths of erosion and deposition with time. It is expected that from this research a new method will evolve for use in conservation work.

(5208) DEVELOPMENT OR CHANGES OF VEGETATION ON PERMANENT GRASS WATERSHEDS AS AFFECTED BY USE AND AS RELATED TO WATER YIELDS.

(b) Laboratory project, cooperative with the Nebraska Agricultural Experiment Station.

(c) Mr. Warren L. Rice, Englneering Techniclan, ARS-SWC, Hastings, Nebraska.

(d) Field investigations--applied research; compllation and analysis of data.

(e) Objectives of the research are: (1) To follow deterioration of vegetation when converting from meadow to pasture; (2) to follow development of vegetation on cropland seeded to native grasses; and (3) to follow changes in vegetative cover of a permanent pasture watershed. In all cases the effect on water yields will be determined. It is the purpose of this research to provide needed information on the effect of changes in pasture and meadow land use on munoff and water yields.

U. S. DEPARTMENT OF AGRICULTURE, AGRICULTURAL RESEARCH SERVICE, So1l and Water Conservation Research Division.

NORTHWEST BRANCH, P. O. Box 1096, Bo1se, Idaho, Dr. J. S. Robins, Branch Chief.

(3550) THE EFFECT OF SPRINKLER PATTERN VARIATION ON IRRIGATION EFFICIENCY.

(b) Laboratory project.

(c) Mr. Claude H. Palr, Research Engineer (Im.), Agricultural Research Service, Snake River Conservation Fleld Station, P. O. Box 1239 , Twin Falls, Idaho.

(d) Experimental; applied research and design. To determine the effect of sprinkler patterm on fleld irrigation efficiency and develop a method for calculation of field water application efficiency for a sprinkler system from sprinkler pattern, wind velocity, humidity, temperature, Irrigation period, and related factors. Another phase of this project 1 s to test typical sprinkler heads for reproducibility of water distribution pattern.

(g) Tests conducted to date indicate that 90 percent of the water applied by the sprinklers to the plots could be accounted for in the catch cans and correction for evaporation using the Frost-Schwalen nomograph. Only 79 percent of the water could be accounted for by the soll sampling method when corrected for consumptive use of plants and evaporation from the sprinkler nozzle to the soll surface using the FrostSchwalen nomograph. The losses not accounted for above are being investigated.

(h) "Making Use of Sprinkler Pattern Data," Claude H. Pair, Irrigation Englneering and Maintenance, Vol. XIII, No. 7, pp. 10-11, 26. oct.-Dec. 1963.

(3552) HYDRAULICS OF SURFACE IRRIGATION.

(b) Laboratory project.

c) Mr. James A. Bondurant, Agricultural Enginees Agricultural Research Service, Snake River Conservation Field Station, P. O. Box 1239 , Twin Falls, Idaho.

(d) Experimental; field investigation, basic research

(e) To investigate the factors that influence the advance and recession of water in an irrigation border strip.

(3553) DEVELOPMENT OF AUTOMATIC SURFACE IRRIGATION EQUIPMENT. 
(b) Laboratory project.

(c) Mr. Allan S. Humpherys, Agricultural Eng1neer Agricultural Research Service, Snake R1ver Conservation F1eld Station, P. O. Box 1239, Twin Falls, Idaho

(d) Experimental; design and development.

(e) To develop automatic and sem1-automatic control structures for surface 1rrigation.

(g) Gates which will check the flow of water in a head ditch for a pre-determined period of time are being developed. These allow a field to be irrigated a portion at a time. When the flow of water into the head ditch ceases, these gates automatically reset themselves and are ready for the next irrigation. Automatic gates for pipeline systems are also being developed.

(h) "Surface Irrigation Through Automat1c Control," by James $A$. Bondurant and A. S. Humpherys. Agricultural Englneering, Vol. 43, No. 1, January 1962.

(4311) FLOOD HYDROGRAPHS BY ELECTRONIC ANALOG.

(b) Laboratory profect, cooperative with the University of Idaho.

(c) Mr. J. Marvin Rosa, Hydraul1c Englneer, P. O. Box 414, Moscow, Idaho.

(d) Analytical, basic and applied

(e) Further development and adaption of electronic analog methods in the solution of flood routing problems and the prediction of flood hydrographs from agricultural and Footh1ll range watersheds of the northwest.

(4312) WATER YIELD AS INFLUENCED BY CHARACTERISTICS OF NORTHWESTERN RANGE WATERSHEDS.

(b) Laboratory project, cooperative with the University of Idaho.

(c) Mr. J. Marvin Rosa, Hydraulic Englneer, P. O. Box 414, Moscow, Idaho.

(d) Analytical.

(e) Regional analysis of water yleld as affected by climat1c, topographic, geologic, soll, land use and other characteristics and conditions of rangeland watersheds in the northwest.

(4313) SNOWMELT HYDROGRAPHS AS INFLUENCED BY CLIMATIC FACTORS AND WATERSHED CHARACTERISTICS.

(b) Laboratory project, cooperative w1th the University of Idaho.

(c) Mr. J. Marvin Rosa, Hydraulic Englneer, P. O. Box 4l4, Moscow, Idaho.

(d) Analytical, basic and applied.

(e) To develop improved methods for estimating da1ly hydrographs of streamflow from mounta1nous watersheds where the supply is from snowmelt and occasional rain and the evolution of a regional map of snowmelt design coefficients reflecting cover, geology and so1ls, exposure, elevation, latitude, etc.

(4314) PRECIPITATION CHARACTERISTICS OF A NORTHERN SEMI-DESERT WATERSHED.

(b) Laboratory project.

(c) Mr. Charles F. Cooper, Research Botanist, P. O. Box 2724, Bo1se, Idaho.

(d) Experimental, basic and applied.

(e) The 93 square mile Reynolds Creek Experimental watershed, Owyhee county Idaho, has recording raingages to a density in excess of one per square mile. From this network, methods for evaluating rainfall amounts and intensities for different areas are belng developed. Seasonal distribution with respect to amounts, character, and areal extent of precipitation are being measured.

(g) It appears that such characteristics of the thunderstorms as 1ntensity, area, and duration are similar to those of the convective storms of Arizona and New Mexico.

(4315) THE DESIGN OF SELF-PROPELLED SPRINKLER SYSTEMS. (b) Laboratory project.

(c) Mr. Claude H. Pa1r, Research Eng1neer (Irr.), Agricultural Research Service, Snake River Conservation Field Station, P. O. Box 1239 , Twin Falls, Idaho.

(d) Experimental, applied research, design. Determine water application patterns of self-propelled sprinkler systems. Determine the effect of wind on application patterns of self-propelled sprinkler laterals, and develop method of designing self-propelled sprinkler laterals from theoretical formulas.

(g) Patterns of individual sprinklers making up the self-propelled moving lateral have been determined and are to be put together to see how the synthetic pattern compares with the fleld pattern of the moving lateral.

(4834) INFLUENCE OF PHOTO SCALE, VEGETATION, TOPOGRAPHY, AND SNOW CONDITIONS ON PHOTOGRAMMETRIC MEASUREMENT OF SNOW COVER.

(b) Laboratory project.

(c) Mr. Charles F. Cooper, Botan1st, P. O. Box 2724, Bo1se, Idaho.

(d) Experimental; basic and applied.

(e) Th1s project seeks to determine the feas1bility of determining the quantity of snow stored in a snowpack on a selected area by photogrammetric techniques and evaluate the influence of topography and vegetation on the accumulation and melting of snow. The study of different photoscales on the precision of estimate is included in the project.

(g) Preliminary results indicate that a photogrammetric technique is very promising as a means for determining snow volume on areas up to a few hundred acres.

(4835) LEAF AND CROWN AREA OF ARTEMESIA TRIDENTATA.

(b) Laboratory project.

(c) Mr. Freeman M. Sm1th, Botanist, P. O. Box 2724, Bo1se, Idaho.

(d) Experimental: basic and applied research.

(e) Develop methods of determining total leaf area for a given size-vigor classification of A. tridentata. Determine the capacity of these leaves to store precipitation, intercept precipitation and to transpire. Evaluate the effect of 1 mmediate vegetation structure on leaf area of 1ndividual plants. Since vegetation and solls on watersheds act as reservolrs which recelve, store and d1scharge water, an understanding of the1r individual performance in these capacities is tantamount to an understanding of watershed hydrology.

(4836) WATER BUDGET OF A UNIT SOURCE AREA.

(b) Laboratory project.

(c) Mr. Charles F. Cooper, Research Botanlst, P. 0. Box 2724 , Bolse, Idaho.

(d) Experimental; bas1c and applied research.

(e) Determine as fully as possible the fate of water falling on a small representative watershed throughout the year and estimate evaporation and transpiration from readily obtalned instrumental and climatological data. Such a general understanding of the disposition of precipitation on an area $1 \mathrm{~s}$ basic to an understanding of the effects of solls, geology, vegetation and climate.

(4837) FACTORS AFFECTING SNOW ACCUMULATION AND MELT ON UNIT SOURCE AREAS.

(b) Laboratory project.

(c) Mr. Charles F. Cooper, Botan1st, P. O. Box 2724 , Bo1se, Idaho.

(d) Experimental; basic and applied research.

(e) Determine physical and meteorological factors contributing to non-uniformity of snow accumulation and melt in a shmub covered unit source area in the sagebmush zone of owyhee County, Idaho.

Any improvement in the quantity or timing of 
flow from snow fed streams by manipulation of vegetation or other practices requires a thorough understanding of the behavior of snow under these conditions. Such information must be derived from research.

(g) Instmmentation Just partially installed.

(4838) A STUDY OF SURFACE WATER DIVERSIONS AND RETURN FLOW IN REYNOLDS VALLEY.

(b) Laboratory project

c) Mr. Clifton W. Johnson, Hydraulic Engineer, P. O. Box 2724, Bo1se, Idaho.

(d) Experimental; basic and applied research.

e) This investigation $1 \mathrm{~s}$ designed to find the consumptive use of water by an upstream irrigated area as it affects downstream water supplies. All of the inflow to Reynolds Valley is measured as is the outflow and general ground water levels.

(8) Preliminary data indicate about 50 percent of water diverted is retained on the land. Because of incomplete instrumentation, conclusive results are not yet avallable.

(4839) GEOLOGIC CONTROL OF SUBSURFACE STORAGE AND FLOW CHARACTERISTICS OF BASALT TERRANE.

(b) Laboratory project.

c) Mr. Gordon R. Stephenson, Geologist, P. O, Box 2724, Bolse, Idaho.

(d) Experimental; basic and applied research. the hydrologic effects of the basalts found on Reynolds Creek Experimental Watershed, owyhee County, Idaho. The objective is approached by studying the water balance on a closed basaltic basin.

(g) The basalts on Reynolds creek are much less permeable than those on the snake River plains.

(4840) THE DEVELOPMENT OF A PORTABIE IRRIGATION SPRINKLER EVALUATION DEVICE.

(b) Laboratory project. See project 4368 , page

(c) Mr. Claude H. Palr, Research Englneer (Irr.), Agricultural Research Service, Snake River Conservation Field Station, P. O. Box 1239, Twin Falls, Idaho.

(d) Experimental; applied research.

(e) To design a portable device that can be used in the design and evaluation of sprinkler irrigation systems. To determine procedures for the use of this device.

(g) This equipment has been used to measure the intake rate of soll for sprinkler design.

(h) "A Method for Measuring Water Intake Rate into Soll for Sprinkler Design," Rhys Tovey and Claude H. Palr. Proceedings 1963 open Technical Conference, Sprinkler Irrigation Association, pp 109-118, 1963.

(5209) DEVELOPMENT OF IRRIGATION WATER MEASURING DEVICES AND METHODS.

(b) Laboratory and field project.

c) Mr. A. R. Robinson, Agricultural Engineer, Agricultural Research Service, Snake R1ver Conservation Field Station, P. 0. Box 1239, Twin Falls, Idaho.

(d) Experimental; basic and applied research. The general objective of this project is developing and improving devices and techniques for the measurement of 1 rrigation water. Specialized laboratory equipment will be utilized for the initial development phases.

(h) "Distribution, Control and Measurement of Irrigation Water on the Farm," U.S.D.A. Miscellaneous Publication No. 926, July' 1963. "Evaluation of the Vane-Type Flow Meter," Agricultural Engineering, Vol. 44, No. 7 , $\mathrm{pp}$ 374-375, July 1963.

$$
----
$$

U. S. DEPARTMENT OF AGRICULTURE, AGRICULTURAL RESEARCH SERVICE, Soll and Water Conservation Research Division.
SOUTHERN BRANCH, University of Georgia, Athens, Georgla, Mr. Russell Woodburn, Branch Ch1ef.

(3869) FLUVIAL MORPHOLOGY.

(b) Laboratory project, cooperative with the Univ. of M1ss. and M1ssissippi State Univ.

(c) Dr. Ne1l L. Coleman, Geologist, and Mr Richard A. Stein, Hydraulic Engineer, Sedimentation Laboratory, P. O. Box 3o, oxford, Mississippi.

(d) A Joint fleld and laboratory project - basic and applied research.

(e) Detailed field measurements are made on selected natural water courses and flood plains in the Yazoo River Basin and other selected locations in Mississippi to delineate the variables of stream geometry, bend and bank roughness factors, dune migration, and stream hydraulics in terms of sediment transport characteristics. Laboratory studies in both 100-foot and 50-foot long flumes are carried out to define significance of varlous factors under controlled conditions. Acquired data are studied for adherence to existing regime equations, tractive force concepts, resistance coefficients, and bed material transport formulae, and to develop new or improved concepts and relationships.

(g) The existence of a discontinuity in the stage-discharge relation under certain conditions in sand-bed streams has been established. Changes in channel conveyance efficiency, occasioned by changes in bed configuration have resulted in variances in water discharge of over 100 percent for given water stages. Varlations in Manning's roughness coefficient from 0.015 to 0.035 during the course of a storm munoff event have occurred, and for a given water discharge on separate occastons the "n" value has been known to double. Similar variations in the Darcy-Welsbach coefficient have been noted. Froude numbers for floods over plane beds or antidunes in the fleld are less than Froude numbers computed from comparable flow conditions in the laboratory flumes; this difference in Froude numbers is believed to be partly a function of depth.

(3870) AGGRADATION AND DEGRADATION AS REIATED TO CHANNEL STRUCTURES.

(b) Laboratory project, cooperative with the Univ. of Miss. and Miss. State University.

(c) Mr. Joe C. Willis, Hydraulic Engineer, Sedimentation Laboratory, P. O. Box 30, oxford, Mississipp1, and Mr. Paul Yates, Hydraulic Engineer, $P$. O. Box 33, Watkinsville, Georgia.

(d) F1eld and laboratory investigations; basic and applied research.

(e) It is necessary for proper planning and design of agricultural watershed conservation work to have knowledge of the extent of aggradation or degradation that is likely to occur with placement of structures in alluvial channels. Studies of deposition and scour as related to actual stmuctures at various locations in Mississipp1, Georgia, Wisconsin and other selected locations to provide the needed field data are underway to develop proccdures and criteria useful in predicting channel adjustments with structural installations and accompanying changes in sediment transport and flow pattern.

(g) The degree of channel scour and channel erosion rates are being determined in connection with several structural installations in Mississipp1. Case histories of over 70 gully control structures in Wisconsin have been established. Laboratory studies of degradation have been started. LABORATORY STUDIES OF SEDIMENT TRANSPORT.

(b) Laboratory project, cooperative with the University of Mississippi and Mississippl State University. 
(c) Mr. Richard A. Stein, Hydraulic Englneer, and Dr. Neil L. Coleman, Geologist, Sedimentation. Laboratory, P. O. Box 30, Oxford, Mississippi.

(d) Experimental; basic and applied research.

(e) To better explain, by laboratory flume experiments, the relationships between stream hydraulics and sediment transport which generally occur in natural channels. Work includes the testing and development of sediment transport equations, means and methods of total transport determination in natural channels, and determination of the relationship between the measured transport by use of sediment samplers now in use and the total bed material discharge.

(g) Flume studies indicate significant errors in sand concentration are possible depending upon relative position of sampler nozzle to a dune front. Studies of various type structures installed in a sand bed channel that will permit total load measurements with minimum upstream and downstream influence suggest the use of a Parshall flume under certain conditions.

(4305) TRAP EFFICIENCY OF RETARDING-TYPE RESERVOIRS.

(b) Laboratory project, cooperative with the Soll Conservation Service and the U. S. Geological Survey.

(c) Mr. D. A. Parsons, Director, sedimentation Laboratory, P. O. Box 30, Oxford, Mississippi.

(d) Theoretical and field investigations, and office analyses.

(e) The trap efficiency of a reservoir is a measure of the effectiveness of the structure in retaining incoming sediment. Structures need to be designed and built with different degrees of trap efficiency, and information is needed so that the influencing parameters can be adjusted to provide the desired trap efficiency. In this study we are endeavoring to (1) collect and study data from retarding-type reservolrs in order to determine those factors that influence trap efficiency, and (2) derive and test methods for predicting the trap efficlency of retarding-type reservolrs.

(4316) HYDRAULICS OF CHANNELS RELATIVE TO CHANNEI STABILITY.

(b) Laboratory project, cooperative with the University of Mississippi and Mississippi State University.

(c) Mr. D. A. Parsons, Hydraulic Engineer, Sedimentation Laboratory, P. O. Box 30, Oxford, Mississippi.

(d) Experimental, field investigations, applied and basic research.

(e) The determination of flood flow qualities in selected reaches of Pigeon Roost Creek Mississippl, and other streams in studies of the resistance to erosion of streambank and bed materials, and streambank vegetation. Measurements of the boundary shear stresses in curved channels as affected by bend radius, bed angle, and Froude number.

(4317) PRINCIPLES OF STABIE CHANNELS IN COHESIVE MATERIALS.

(b) Laboratory project, cooperative with the University of Mississippi and Mississippi State University.

(c) Dr. Earl H. Grissinger, soil scientist, Sedimentation Laboratory, P. 0. Box 30, oxford, Mississippi.

(d) Experimental, applied and basic research.

(e) Determination of: (1) The reasons for the resisting ability of soil and streambank materials to erosion by flowing water; (2) the kinds of tests needed to measure the resistance; and (3) the quantitative values of the resistance for natural and synthetic materials.

(G) A sample of the Grenada silt loam soll was mixed with various types and amounts of clays and compacted to varying densities. The molded samples were eroded by a constant erosive force. The stability of cohesive materials was found to be dependent upon the type, amount, and orientation of the clay minerals; the bulk density, antecedent moisture, and wet aging time of the sample; and the temperature of the eroding water. In general stability increased with increasing clay mineral content and with increasing density. Stability was greater for the 2:1 type clay mixtures than for the 1:1 type. The influences of antecedent molsture, wet aging time, and orientation upon stability were dependent upon the type of clay mineral. Stability decreased with increasing temperature of the eroding water.

(h) "DISCUSSION - Channel Stability in Undisturbed Cohesive Soils," by Earl H. Grissinger and Loris E. A smussen, ASCE Proceedings, Journal of the Hydraulics Division, November, 1963.

\section{(4318) METHODS OF CHANNEL STABIIIZATION.}

(b) Laboratory project, cooperative with the University of Mississippi and Mississippi State University.

(c) Mr. D. A. Parsons, Hydraulic Engineer, Sedimentation Laboratory, P. 0. Box 30, oxford, Mississippi.

(d) Experimental, field investigations, applied and basic research.

(e) Includes: (1) Determination of the speeds of motion and the requisite conditions for beginning of motion of solid particles in fluld flow for various flow, particle quality, and boundary conditions in a laboratory study; (2) fleld investigations on Pigeon Roost Creek, Mississippi, and other streams of the resisting abilities of bank and bed materials and bank vegetation as determined by measured flood experiences (this study is assoclated with the one on channel hydraulics); and (3) laboratory and field study of the behavior of non-cohesive stands and silts in a stream channel bank for the conditions of lateral seepage flow to the stream.

(g) A sand of narrow size range and median diameter of $0.11 \mathrm{~mm}$ assumed angles of repose of 29 degrees and 9 degrees for the conditions of submergence and nonsub:mergence respectively, under the simulated condition of a high water table in a ditch bank. This sand was stable in the fleld when found with as little as 5 percent clay, even for near vertical banks.

Small submerged spheres, rolling in laminar sheet flow over a smooth bed, travelled at speeds equal to one-half the speeds of the water in their vicinity.

(4319) SEDIMENT YIELDS AND CORRELATION WITH WATERSHED CHARACTERISTICS.

(b) Laboratory project, cooperative with the University of Mississippi and Mississippi State University.

(c) Messrs. Farris E. Dendy and Andrew J. Bowie, Agricultural Engineers, Sedimentation Laboratory, P. 0. Box 30, Oxford, Mississipp.

(d) Field investigation project - applied research.

(e) Analyses of hydrologic, hydraulic, land use, solls, and physlographic characteristics of agricultural watersheds (varying in size from a fraction of an acre to $100 \mathrm{sq} . \mathrm{ml}$.) are made to establish relationships with sediment transport rates, amounts, and delivery ratios. Establishment of methodology for determining long-time average annual sediment yields from fragmental fleld data, correlation of characteristics of the basic munoff-sediment relation (sediment rating curve) with affecting hydraulic and hydrologic parameters, and evaluation of the role of large storms as sediment contributors are all basic objectives that will lead to better sediment yield prediction procedures.

(g) Data from Pigeon Roost Creek Basin, Miss. indicates that sediment yields are highly correlated with direct runoff. Variations 
in unit direct runoff (and therefore unit sediment) yields between watersheds of the basin are marked. They have to some extent been correlated with basin physiography and land use. There are significant channel transmission losses in streams of the basin.

\section{(4320) SEDIMENT ORIGIN AND ROUTING.}

(b) Laboratory project, cooperative with the University of Mississippi and Mississippi State University.

(c) Dr. L. L. McDowell, soil scientist, Sedimentation Lab., P. O. Box 30, Oxford, Mississippi.

(d) Experimental, basic research

(e) Runoff' and sediment production are measured from a small gully typical of the YazooTallahatchie watershed. Sediment produced from this gully will be related to gully area, thereby providing information on the rate of gully erosion. When applicable, comparisons will be made between the estimated sediment discharge utilizing radioactive tracer sand, and the measured sediment discharge.

(g) Runof'f and sediment measuring equipment have been installed. A detalled topographic survey has been made of the gully area. Surveys will be made periodically to observe changes in gully shape.

(4321) RESERVOIR SEDIMENTATION.

(b) Laboratory project, cooperative with the University of Mississippi and Mississippi State University.

(c) Dr. J. Roger McHenry, Soll Scientist, Sedimentation Laboratory, P. O. Box 30 , oxford, Mississippi.

(d) Experimental and field investigation for basic research and developmental work.

(e) To relate sediment accumulation in reservoirs to sediment yields, munoff, and physical parameters of the watersheds. The nature of the sediment, its origin, mineralogy, chemistry, and biology are studied in relation to distribution and deposition within the reservoir. Nuclear methods are used where applicable.

(g) A number of reservoirs have been perlodically surveyed for sediment accumulation. Nuclear means of determining in situ densities have been employed.

(4322) DEVELOPNENT OF METHODS FOR UTILIZING RADIOACTIVE ISOTOPES AND RADIOACTIVE MATERIALS FOR SEDIMENTATION AND HYDROLOGY RE SEARCH.

(b) Laboratory project, cooperative with the University of Mississippi and Mississippi State University.

(c) Dr. J. Roger McHenry, Soll Scientist and Dr. L. L. McDowell, Soll Scientist, Sedimentation Laboratory, P. O. Box 30, oxford, Mississippi.

(d) Experimental basic research

(e) To devise, develop, and utilize procedures for "tagging" sediment particles with radioisotopes and identifying same in the laboratory and in the fleld. Results are to be used in predicting sediment production, transport and deposition.

(g) A satisfactory method has been developed for "tagging" quartz particles with scandium-46, silver-110, cerium-144, and antimony-124.

(h) "Theory and Application of Neutron Scattering in the Measurement of Soll Molsture," by J. Roger McHenry, Soll Science, vol. 95, pp. 294-307, May, 1963.

(4323) SEDIMENT PRODUCTION AND CONTROL PRACTICES ON HIGHWAY CUTS AND FIILS.

(b) Laboratory project, in cooperation with Georgla state Highway Dept., Soll Conservation Service USDA, the University of Georgla College of Agriculture Experiment Stations, and Bartow County, Georgia.

(c) Mr. E. G. Diseker, Agricultural Engineer,
P. O. Box 124, Cartersville, Georgia.

(d) Experimental, field; applied.

(e) Runoff and soil losses are measured from three pairs of bare, roadbank plots (approximately $1: 1,2: 1$, and $3: 1$ ) on Cecil clay subsoll using six H-flumes and Coshocton vane samplers. Metal hub stakes are used as an adjunct in determining bank erosion, and for measuring deposition or scour from the flow channels. Over 30 different plants have been tested on 850 roadbank plots for erosion control.

(g) Bare bank losses have varied from 25 to 400 tons per year per acre for the past 5 years depending on the ralnfall, frost action, bank aspect and slope. Bank aspect and frost action have been major factors in the erosion process. Banks facing northwest have lost, on an average, 2.2 times as much soll as those facing southeast. Plants which have proved satisfactory for erosion control are fescue, common Bermudagrass, lovegrass, broomsedge, Pensacola and Wilmington

Bahlagrasses, crownvetch, sericea lespedeza, honeysuckle and kudzu. For the establishment of satisfactory cover on slopes $2: 1$ and steeper, mulches were necessary particularly for the slowly developing plants such as crownvetch and Bahlagrasses. For maintenance of most plants, especially the grasses, a timely application of fertilizer is necessary. Previously outlined procedures to determine fertility requirements for maintaining vegetation on roadside areas in the Pledmont Uplands of Georgia were put into practice in the fall of 1962 . Studies to determine rates and amounts of sediment delivery for selected storms at monthly intervals and annual production and delivery from bare road banks in relation to (1) rainfall intensity (2) antecedent molsture and temperature conditions and (3) face slope length with different aspects on Cecil type soils will begin in the spring of 1963. A study w1ll be initiated in the spring of 1963 to determine sediment productions and delivery rates from fully developed, mature stands of five different representative plant species.

(h) "Roadbank Erosion and Its Control in the Pledmont Uplands of Georgia," by E. G. Diseker, E. C. Richardson and B. H. Hendrickson. U.S. Dept. Agr. ARS 41-73: 40 pp (1963) 1llus. Aug. 1963.

"Crownvetch Stabilizes Pledmont Highway Banks," by E. C. Richardson, E. G. Diseker, and B. H. Hendrickson. Crops \& Solls 15(7): 25 (1963) 1llus. April-May 1963. "Crownvetch for Highway Bank Stabilization in the Pledmont Uplands of Georgia," by E. C. Richardson, E. G. Diseker, and B. H. Hendrickson. Agronomy Jour. Vol. 55: 213-215 (1963) 11lus.

(4324) UTILIZATION OF TRITIUM IN WATERSHED RESEARCH.

(b) Laboratory project, cooperative with the University of Mississippi and Mississippi State University.

(c) Dr. J. Roger McHenry, Soll Scientist, Sedimentation Laboratory, P. O. Box 30, Oxford, Mississippi.

(d) Experimental basic research and development.

(e) To devise, develop, test and apply tracer techniques using tritium and other radiolsotopes in support of studies of soil molsture and groundwater movement.

(g) Methods of high efficiency have been developed using a liquid scintillation counter. Laboratory studies have shown the precision and accuracy of the methods are adequate. Some fleld tests have been conducted. Results have not been conclusive. Tests designed to date water in limestone aquifers have not been completed.

(4325) RUNOFF FROM AGRICULTURAL WATERSHEDS.

(b) Laboratory project, cooperative with the University of Mississippi and Mississippi 
State Un1versity.

(c) Mr. W. R. Hamon, Research Agricultural Engineer, Sedimentation Laboratory, P. 0. Box 30, Oxford, Mississippi.

(d) Fleld investigations; basic and applied research.

(e) To develop procedures for predicting fllood munoff, water yield and hydrograph characteristics for ungaged upstream watesheds. Kunoff and precipitation are observed for the 117 square-mile P1geon Roost Creek Watershed in Northern M1ssissipp1 Including 11 sub-watersheds, and for four unit-source watersheds under 4 acres in size. These data, accumulated over the past four years, are being processed by computer and analyzed to develop synthetic unit hydrographs by incorporating antecedent soil mo1sture and watershed factors. The predicted hydrographs will be used to establish flow-duration curves.

(h) Hydrologic data releases are prepared yearly with summaries of monthly precipitation and runoff, tabulated annual maximum flows, and detailed data for selected munof events.

(4326) SUBSURFACE HYDROLOGY.

(b) Laboratory project, cooperative with the University of M1ssissippl and Mississipp1 State University.

(c) Mr. F. E. Dendy, Agricultural Englneer, Sedimentation Laboratory, P. O. Box 30, oxford, Mississippi.

(d) Experimental and field investigations; basic and applied research.

(e) To study the hydraulic characteristics of geologlc strata and develop methods of predlcting ground water accretion and movement; subsurface and ground water contribution to streamflow from a knowledge of geology, solls, topography, climate, land use and treatment of agricultural watersheds; and to evaluate hydrogeologic factors governing transmission gains and losses in stream channels. A portable drilling rig is utilized to obtain geologic samples, establish ground water observation welis, and conduct permeability fleld tests.

(g) Maps showing structural and stratigraphic characteristics and groundwater contours of the Pigeon Roost Creek watershed have been prepared. Estimates have been made of groundwater storage and outflow from the watershed.

(h) "A Report on Geological and Ground-Water Investigations in Pigeon Roost Creek Watershed, Marshall County, Mississipp1," by Lorls E. Asmussen and Farris E. Dendy, Southeastern Geology, Vol. 5, No. 1, Sept. 1963.

(4327) MOISTURE REGIMES OF AGRICULTURAL WATERSHEDS.

(b) Laboratory project, cooperative with the University of Mississippi and M1ssissippi State University.

(c) Mr. John Kozachyn, Soll Sclentist, Sedimentation Laboratory, P. O. Box 30, Oxford, M1ssissipp1.

(d) Fleld investigation; applied research. To provide soll molsture data for the development of prediction techniques for munoff and sediment production and to relate the molsture regimes of agricultural watersheds to soil, climate and vegetative parameters. Field observations of so11 moisture to depths of 10 and 20 feet are obtained by the neutron probe method for different cover, slope, and soll complexes.

(g) The superiorlty of the neutron probe procedure over other avallable methods was established from laboratory and field tests. A method of installing access tubes has been perfected.

(4328) RELATION OF CLIMATE AND SOIL MOISTURE LEVELS TO PLANT GROWTH AND WATER USE.

(b) Laboratory project, cooperating with the Central and Southern Florida Flood Control
District and the Florida Agricultural Experiment Station.

(c) Mr. E. H. Stewart, Soll Scientist, P. O. Box 9087 , Fort Lauderdale, Florida.

(d) Laboratory and field investigations, both basic and applied for evaluating measured environmental conditions.

(e) Laboratory and fleld procedures are employed to determine moisture intake, retention and transmission characteristics of mineral and organic solls. Controlled water table studies in non-welghing lysimeters are conducted to determine evapotranspiration, crop growth, and soll physical properties as influenced by various water table depths. Fleld and plot studies in organic solls are conducted to determine soil subsidence.

(g) Root content of the plow layer $\left(0-9^{\prime \prime}\right)$ of a St. Augustinegrass sod was much higher over a 12-inch water table than over a 24- or 36-1nch water table. Organic residues of this root material markedly improved early growth of the subsequent grain sorghum crop.

Average dally evapotranspiration of grain sorghum, from November 1960 to June 1961 , for 12-, 24-, and 36-1nch water tables was $0.15,0.10$, and 0.09 of an 1 nch respectively. Evapotranspiration during the spring months was about twice that of the winter months.

(4329) HYDROLOGIC RESEARCH ON SMALI AGRICULTURAL WATERSHEDS IN CENTRAL AND SOUTHERN FLORIDA.

(b) Laboratory project, cooperating with the Central and Southern Florida Flood control District and The Florida Agricultural Experiment Station.

(c) Mr. E. H. Stewart, Soll Scient1st, Attention: W. H. Speir, Engineering Technician, P. 0 . Box 9087 , Fort Lauderdale, Fla.

(d) Experimental, field investigations; basic and applied research.

(e) To collect, analyze, and correlate basic hydrologic data on agricultural watersheds ranging in size from 4,000 to 63,000 acres in the Coastal Plain of Florida. To determine the influence of climate, topography, solls, geology, and land use on the rate and volume of munoff and to evaluate the water balance. To devise methods of interpreting watershed characteristics as similitudes related to physlography of other areas.

(g) For an unimproved 98-sq. mile watershed the maximum dally discharge (Oct. 1956) was 2.28 inches-over-area with an instantaneous peak rate of $70 \mathrm{c.f.s./sq.} \mathrm{mile;} \mathrm{and} \mathrm{for} \mathrm{the}$ 16-sq. mile upper sub-basin the respective rates were 3.14 inches and $158 \mathrm{c.I.s./ \textrm {sq } .}$ mile. For an improved 78 square mile watershed the maximum dally discharge (sept. 1960) was 2.37 inches-over-area with an

instantaneous peak rate of $66 \mathrm{c.f} . \mathrm{s} . / \mathrm{sq}$. mile. The ratio of runoff to rainfall has averaged 0.46 for the artesian-irrigated 78 sq. mile watershed for the past 11 years; 0.33 for the $98 \mathrm{sq}$. mile unimproved watershed; and 0.28 for the 16 square mile sub-basin duning the past 7 years. Total water yield varled inversely with area on the unimproved watersheds. For the $98 \mathrm{sq}$. mile watershed base flow has averaged $71 \%$, interflow $22 \%$, and overland flow $7 \%$ of total streamflow. For the $78 \mathrm{sq}$. mile watershed these flow components have averaged $84 \%, 8 \%$, and $8 \%$ respectively. For the $16 \mathrm{sq.} \mathrm{mile} \mathrm{watershed}$ they averaged $36 \%, 32 \%$, and $32 \%$.

Low cost non-welghing evapotranspirometers were valuable for ascertalning plant-soll relations and evapotranspiration for solls with rapid internal drainage,- especially for high water tables. Comparison of correlaition coefficlents for measured versus computed monthly pan evaporation in South Florida over a 6-year perlod showed the Weather Bureau Method ranked highest and the Thornthwaite Method lowest of nine methods. In a similar comparison for 30 months of measured versus computed potential evapotranspiration from St. Augustinegrass, 
the Fractional Evaporation Equivalent Method ranked highest and the Thornthwalte Method again ranked lowest. Evapotranspiration was predicted with more accuracy than pan evaporation. Potential evapotranspiration losses for the watersheds were $78 \%$ of USWB pan rates, and annual ET losses were the most stable element in the hydrologic balance. In Florlda, water weeds raised Manning's $n$ values in proportion to density of growth as influenced by weed type, and channel geometry. Submersed and emersed weeds increased $n$ values exponentially as the VR product declined below a threshold value of 20 feet. Aquatic weeds were controlled by mechanical or chemical methods.

(h) "Installation and operation of Non-welghing Lysimeters," Willlam H. Speir. Proc. Soll and Crop Sclence Society of Florida, Vol. 22, pp. 167-176, 1962 .

"Flow Retardance by Channel Weeds and Their Control," J. C. Stephens Et al. Jour. of the Irr. and Dr. Div., Proc. of the Am. Soc. of Civil Engs. Vol. 89, No. IR2, pp 31-53, June, 1963.

"A Comparison of Procedures for Computing Evaporation and Evapotranspiration," John C. Stephens and Ernest H. Stewart. International Union Geodesy Geophys. 13th Gen. Assembly, Berkeley, Calif., Proc. 1962, 7: 123-133 (1963) 1lius. Aug. 1963.

(4330) RUNOFF AND EROSION CHARACTERIZATION OF BROWN LOAM SOILS.

(b) Laboratory project

(c) Mr. Coy W. Doty, North Mississippi Branch Experiment Station, Holly Springs, Miss.

(d) Experimental, fleld; basic and applied.

(e) Rates and amounts of runoff and soll losses from small plots are measured. The plots range in size from $1 / 45$ acre to 4 acres. The slopes of the smaller areas are $2-1 / 2$ percent, 5 percent, and 10 percent. Land use varies from fallow and cultivated to pasture, with good and poor management conditions for the cultivated and pastured areas.

(g) Both water and soll losses are excessive on bare land, and are reduced as the degree of ground cover is increased.

(4331) HYDRAULICS OF FARM WATER CONTROL IN THE SOUTHERN PIEDMONT.

(b) Laboratory project in cooperation with the University of Georgia, College of Agriculture Experiment Stations.

(c) Mr.W. Campbell Little, Agricultural Englneer, Southern Pledmont Soll Conservation Field Station, Box 33, Watkinsville, Georgia.

(d) Experimental laboratory; basic and applied.

(e) Baslc research on the mechanics of erosion and hydraulics of flow in individual crop rows and in terraced channels will be developed for both terrace systems and individual row systems for the different solls of the Piedmont.

(g) Initial studies are underway.

(4332) SURFACE DRAINAGE -- ROW LENGTHS AND GRADES FOR REMOVAL AND APPLICATION OF SURFACE WATER ON FORVED AGRICULTURAL IAND OF THE MISSISSIPPI DELTA.

(b) Laboratory project in cooperation with the Loulsiana Agricultural Experiment station.

(c) Mr. Irwin L. Saveson, Project Administrator, Agricultural Englneering Building, Louisiana, P. O. Drawer B817, University Station.

(d) Experimental; basic and applied research. Approximately 80 acres of land have been formed with four different slopes, in two replications, of $0.11,1.15^{\prime}, 0.2^{\prime}$, and $0.25^{\prime}$. For each slope class, row lengths of 500', 700', 900', and 1,100' will be used to determine the maximum row length for formed land as related to slope. Runoff, time-of-concentration, infiltration, soll temperature, and soll molsture data w11 be gathered and correlated with rainfall, wind humidity, and sunshine radiation.

Future studies are contemplated to evaluate flow characteristics of surface water in furrows on agricultural land. This information will be used to develop a furrow crosssection with the best hydraulic characteristics.

(g) Established in full operation in 1962.

(4333) RUNOFF AND EROSION STUDIES FOR THE SOUTHERN PIEDMONT.

(b) Laboratory project in cooperation with the University of Georgia, College of Agriculture Experiment Stations.

(c) Mr. A. P. Barnett or Mr. J. S. Rogers, Agricultural Englneers, Southern Piedmont Soil Conservation Fleld Station, Box 33, Watkinsville, Georgia.

(d) Experimental fleld Investigations, development and applied.

(e) The purpose of these studies is to determine the Interrelations of climate, soll, topography, cover, management, row direction, munoff, soll movement and loss from Southern pledmont solls. The work is conducted on fractional acre fleld plots under both natural and simulated rainfall.

The natural rainfall plot study includes six cover, two row direction and three slope steepness treatments on a total of 42 plots. rotal amounts of runoff and soll loss are measured for 1ndividual rainstorms. Meteorological data are also secured.

The rainfall simulator designed to apply rain at $4,2-1 / 2$ and $1-1 / 4$ inches per hour simultaneously to three adjacent plots is used to secure runoff and soll loss data from speciflc soll, slope, crop, and management complexes through the application of designed storms. These data w1ll be used to evaluate their runoff and erosion control effect 1 veness.

(g) Progress $1 \mathrm{~s}$ reported each year in Station annual reports.

(h) "Runoff and Erosion control Studies on cecll Soll in The Southern Piedmont," by B. H. Hendrickson, A. P. Bamett, J. R. Carreker, and W. E. Adams; ARS, USDA Tech. Bulletin No. 1281 , April 1963.

(4334) RUNOFF AND EROSION STUDIES FOR SOUTHERN COASTAL PLAINS SOILS.

(b) Laboratory project in cooperation with the Georgia Agricultural Experiment Stations.

(c) Mr. G. N. Sparrow, Agricultural Engineer, Georgia Coastal Plain Experiment Station, Tifton, Georgia.

(d) Fleld investigations; applied, for design.

(e) The purpose of these studies is to determine interrelations of climate, soll, land cover, munoff and soll loss for southern coastal Plain solls. The work is conducted on 18 field plots, $1 / 20$ acre in size, under natural rainfall. There are four cover treatments. Total amount of runoff and soll loss are measured for individual stoms. Meteorological data are also secured.

(g) Grass-based rotations and continuous corn have been evaluated, showing protective effects of perennial grass sods and of annual crop residues.

(4841) SURFACE WATER STORAGE AND SUPPLY ON FARMS IN THE COASTAL PLAINS.

(b) Laboratory project in cooperation with the Georgia Agricultural Experiment Stations and Soll Conservation Service, USDA, in Georgia.

(c) Mr. G. N. Sparrow, Agricultural Englneer, Georgia Coastal Plain Experiment Station, Tifton, Georgia.

(d) Fleld investigation; applied for design and development.

(e) Purpose of the studies is to determine pond storage efficiency under vartous soll and 
topographic conditions as affected by watershed yield, pond surface evaporation, seepage into and out of the impoundment, farm use of storage, and related factors. Inftial study to be on one rather typical farm pond in the coastal plain, with anticlpation of extending the work to other ponds.

(g) Study currently in progress.

(4842) SHALLOW WELLS AND IRRIGATION PITS FOR IRRIGATION AND OTHER FARM WATER SUPFLY IN THE COASTAL PLAINS.

(b) Laboratory project in cooperation with the Georgia Agricultural Experiment Stations and Soll Conservation Service, USDA, in Georgia.

(c) Mr. G. N. Sparrow, Agricultural Engineer, Ga. Coastal Plain Experiment Station, Tifton, Ga.

(d) Field Investigation; applied, for design and development.

(e) The purpose of the studies is to develop criteria by which engineers and soll scientists can classify sites for irrigation pits, shallow wells, or other access to shallow ground water aquifers in the coastal plains on the basis of topography and solls. Initial study is concerned with excavated irrigation pits, their adequacy of supply, the relation of recharge to rainfall and solls, and other related influences. Investigations now 1nvolve 3 pits, each under somewhat different soil and topographic situations.

(g) Study currently in progress.

(4843) AN EFFICIENT DRAINAGE SYSTEM FOR SUGARCANE LAND.

(b) Laboratory project in cooperation with the Loulsiana Agricultural Experiment Station.

(c) Mr. Irwin L. Saveson, Project Administrator, Agricultural Englneering Building, Loulsiana State University, Baton Rouge, Loulsiana, P. O. Drawer 8817, University Station.

(d) Experimental applied research.

(e) The present conventional system of sugarcane land requires considerable land occupled by ditches and is costly to maintain. Experimental work is underway to develop a more efficlent drainage system which will consume less land and be more economical to maintain. This is an adaptation of the cotton drainage system to sugarcane.

(g) This system reduces the amount of land in ditches from 4 to 7 percent with a $\$ 5.22$ per acre per annum savings in cost of maintenance.

(h) "An Efficlent Drainage System for Sugarcane Land" by I. L. Saveson, USDA, ARS 4l-72, (In Press):

(5210) RADIO-CARBON DATING OF SEDIMENTS.

(b) Laboratory profect, cooperative with the University of Mississippi and Mississippi State University.

(c) Dr. L. L. McDowell, Soll Scientist (Chemistry), Sedimentation Laboratory, P. O. Box 30, oxford, Mississippi.

(d) Laboratory and field investigations; basic research.

(e) To establish and maintain a radio-carbon dating laboratory meeting the requirements of sedimentation research. The program is used to supplement geomorphological investigations by providing information on (1) the age of sediments, e. g., buried soils and geologic horizons, and (2) the past rates of sediment aggradation and degradation.

(g) The carbon in samples to be dated is processed to benzene $\left(\mathrm{C}_{6}{ }^{1 \mathrm{H}_{6}}\right)$ and the number of beta disintegrations arising from the natural $\mathrm{c}^{14}$ is determined by liquid scintillation spectrometry. The necessary equipment for synthesis of benzene has been built and tested for operation. The liquid scintillation spectrometer has been modifled and stabilized for radio-carbon.
The overall program has been standardized and calibrated using contemporary carbon standards (NBS) and inter-laboratory "check" samples from other dating laboratories. A few unknown samples have been dated; additional samples are now being processed.

U. S. DEPARTMENT OF AGRICULTURE, AGRICULTURAL RESEARCH SERVICE, Soll and Water Conservation Research Division.

SOUTHERN PLAINS BRANCH, ARS-USDA, Bushland, Texas, Dr. J. R. Johnston, Branch ChIef.

(3879) CHARACTERIZATION OF THE "HOT SPOT" PROBLEM IN THE LOWER RIO GRANDE VALIEY OF TEXAS.

(b) Laboratory project.

(c) Mr. Ronald R. Allen, Agricultural Engineer, P. O. Box 267, Weslaco, Texas.

(d) Experimental and field investigation applied research.

(e) The purpose of the study is to determine the extent of salinity problems; characterize and correlate the water table, soll, topographic and related measurable factors associated with salinity problems in the area.

(f) Completed; data is being summarized for publication.

(g) Extensive water table observations show a fluctuating seasonally high saline water table beneath the area. The water table and ground surfaces slope approximately one foot per mile to the northeast in the general direction of the Gulf coast.

(3880) THE MICRODYNAMICS OF UNSATURATED MOISTURE FLOW.

(b) Laboratory project.

(c) Dr. Craig L. Wiegand, Soll Scientist, P. O. Box 267, Weslaco, Texas.

(d) Experimental, basic research.

e) The objectives are to obtain evidence on the generality of the parabolic moisture distribution with respect to the interface of extraction and to interpret unsaturated moisture flow in terms of molecular level mechanisms of flow. The experimental technique is that of inducing molsture flow by various techniques at a series of temperatures and measuring the flow rate. The Arrhentus equation is applied to the data and an activation energy calculated. The activation energy is then interpreted in terms of enerey barriers to molecular level flow mechanisms. The so1l columns are sampled at the end of the runs to determine the molsture distribution with respect to the interface of extraction.

(g) The results to date indicate that the resulting molsture distribution is a function of peculiarities of the microdynamic flow processes Involved and independent of the method of extraction.

(h) "Drying Patterns of a Sandy Clay Loam in Relation to Optimal Depths of Seeding," by Cra1g L. Wiegand, Agronomy Journal 54 : $473-476,1962$.

(3881) FACTORS AFFECTING THE EVAPORATION OF FREE WATER.

(b) Laboratory project.

c) Dr. Craig L. Wiegand, Soil Scientist, P. O. Box 267, Weslaco, Texas.

(d) Experimental, basic research.

(e) The evaporation of free water is being studied under controlled conditions to: (1) Obtain quantitative information on the rate of evaporation of free water under controlled atmospheric conditions; (2) measure the rate of evaporation of water as a function of water temperature; and (3) correlate the rate of evaporation with (a) the saturation deficit of the atmosphere, and (b) the fugacity of the water molecules. 
Evaporation $1 \mathrm{~s}$ belng measured under all combinations of $10,20,30$, and 40 degrees C water temperature; $10,20,30$, and 40 degrees $\mathrm{C}$ air temperature; and $30,50,70$, and $90 \%$ relative humidity. Water temperature is controlled to plus or minus. I degrees $C$, ambient temperature to plus or minus 1.0 degrees $C$, and relative humidity to plus or minus $3 \%$.

(g) Rates encountered range from condensation at the rate of $1.1 \mathrm{~cm}$. per day to evaporation at the rate of $4.4 \mathrm{~cm}$. per day. The evaporation and condensation rates correlate closely with the vapor pressure difference between the water surface and the bulk a1r. The data Indlcate that the rate of evaporation is more a function of the capacity of air to take on molsture than of the escaping tendency of the water molecules.

The evaporation rate increases faster with increasing water temperature than does the vapor pressure of water 1 tself. The implication $1 \mathrm{~s}$ that the latent heat of vaporization, the energy barrier to evaporation, does not limit the evaporation rates in this study.

(4335) THE HYDRAULICS OF STRUCTURES USED IN SOIL AND WATER CONSERVATION WORKS.

See U. S. Department of Agriculture, Agr1cultural Research Service, Soll and Water Conservation Research Division; Corn Belt Branch, Project 1723 , and Illinols state Water Survey Division Project No. 1865.

(b) Laboratory project, cooperative with the Oklahoma Agricultural Experiment Station.

(c) Mr.W. O. Ree, Hydraul1c Englneer, P. 0. Box 789, St1liwater, Oklahoma.

(d) Experimental and fleld Investigation; applied research for design.

(e) Experiments employ small scale models as well as full size structures tested under simulated natural conditions to develop designs for structures needed for soll and water conservation. Closed condult splilway entrances including drop inlets, hood inlets, and oriflce plates are tested. Debris guards are tested using full size structures to provide verification of the small models.

(g) Testing is underway on trash racks for pipe outlet spillways. Racks for a full scale, 24-1nch pipe outlet are being subjected to trash-laden flows. Rigid, or stick type trash is being used in the current tests.

(4336) DESIGN AND CALIBRATION OF DEVICES FOR THE MEASUREMENT OF RUNOFF.

(b) Laboratory profect, cooperative with the oklahoma Agricultural Experiment Station.

(c) Mr. W. O. Ree, Hydraullc Engineer, P. O. Box 789, Stiliwater, Oklahoma.

(d) Experimental, applied research.

(e) The measuring devices tested are used in the hydrology research program of the Agricultural Research service. Sites for munoff measuring stations are surveyed and then modeled in the laboratory. Proposed structures are placed in the model and tested to develop a satisfactory design. The final design is calibrated by model tests. All current work is on specific sites and no general experiments are done.

(g) Model calibrations were made during the past year on a super critical flow flume for measuring discharge rates up to 15,000 cublo feet per second. Also a callbration was made on a V-notch weIr and highway culvert combination employed for runoff measurement.

(4337) HYDRAULICS OF FLOW IN VEGETATION LINED CHANNELS.

(b) Laboratory project, cooperative with the Oklahoma Agricultural Experiment Station. (c) Mr. W. O. Ree, Hydraulic Engineer, P. O.
Box 789, St1llwater, Oklahoma.

(d) Experimental, applied research.

e) Channels or portions of channels are bullt full size on the outdoor hydraulic laboratory grounds. These are planted to the vegetation being investigated and then tested by flowing water at selected times. Friction factors and permissible velocities (or tractive force values) are determined. In recent years the establishment phase of vegetal channels has recelved the greater emphasis. This has included the evaluation of temporary, fabricated IIners of Jute, glass fliber, and asphalt.

(g) During the past year tests were made on a channel with a good grass cover and with some brush and trees. Tests were also made on a glass fiber mulch intended for temporary protection of channels.

(4338) HYDRAULICS OF UNSTEADY FLOW IN OPEN CHANNELS.

(b) Laboratory project, cooperative with the oklahoma Agricultural Experiment station.

(c) Mr. W. O. Ree, Hydraulic Engineer, P. O. Box 789, Stiliwater, Oklahoma.

(d) Experimental, applied research.

(e) Studies are made of unsteady flow phenomena occurring in the runof process. Included are Investigations of overland flow, spatially varied unsteady flow in channels, and flood wave movement in channels. The initial phase of the study $1 \mathrm{~s}$ an analytical one utilizing existing knowledge and theory. This phase will be followed by a large scale outdoor laboratory study to test hypotheses and evaluate coefficients.

(g) Steady state spatially varled flow tests have been run on a 400-foot long by 30-foot wlde V-shaped, grass-lined channel. Simulated rainfali tests have been run on flume type channels lined with wheat and with a coarse sand. Profile buildup and outflow hydrographs were determined for steady rainfall application.

(4339) RUNOFF CHARACTERISTICS OF AGRICULTURAI AREAS IN THE RED PRAIRIE OF OKIAHOMA.

(b) Laboratory project, cooperative with the Oklahoma Agricultural Experiment station.

(c) Mr. W. O. Ree, Hydraulic Engineer, P. O. Box 789, stlliwater, oklahoma.

(d) Field investigation, applied research for design.

(e) Three watersheds, 17 acres, 92 acres, and 206 acres in size and covered with native grass, are instrumented to measure rainfall and runoff. Annual water yield as well as peak flood flows are determined. Selected munoff events provide data for distribution graphs or unit hydrograph development.

(g) Data are on hand from continuous measurements since 1951 .

(4340) SEDIMENT PRODUCTION, MOVEMENT AND DEPOSITION IN THE WASHITA RIVER BASIN, OKLAHOMA.

(b) Laboratory project, cooperative with the Oklahoma Agricultural Experiment Station.

(c) Mr. M. A. Hartman, Hydraulic Engineer, P. O. Box 400, Chickasha, oklahoma.

(d) Field Investigation, applied research.

(e) Suspended sediment sampling and total sediment transport determinations are made at selected tributary and main stream locations in the Washita River Basin. These samples are analyzed for size distribution.

(4341) STREAM CHANNEL STABILIZATION AND SEDIMENT CONTROL WORKS IN CHANNELS OF THE WASHITA RIVER BASIN.

(b) Laboratory project, cooperat1ve with the oklahoma Agricultural Experiment station.

(c) Mr. M. A. Hartman, Hydraulic Engineer, P. 0. Box 400, Chickasha, Oklahoma.

(d) Field investigation, applied research.

(e) Selected reaches of channels representing different geologies, soils, and flow 
reglmes are being established for detalled studies of stream channel morphology. Information is being obtained on crosssections, slopes, thalweg lengths, allgnments, vegetation, and bed and bank materials. Any control works are completely identifled as to location, orlentation, shape, size, and materials. Flow history will be recorded, including both water and sediment. Changes in channel conditions, or lack of change, will be related to flow history and other controlling factors for the development of criteria for stable channel design.

(4342) PRECIPITATION CHARACTERISTICS INFLUENCING RUNOFF FROM AGRICULTURAL, WATERSHEDS IN THE WASHITA RIVER BASIN, OKLAHOMA.

(b) Laboratory project, cooperative with the Oklahoma Agricultural Experiment Station.

(c) Mr. M. A. Hartman, Hydraulic Engineer, P. 0. Box 400, Chickasha, Oklahoma.

(d) Field investigation, applied research.

(e) A network of 170 recording precipltation gages has been established on a 3-mile grid in an 1100-square mile area in the central portion of the Washita River Basin. The precipitation characteristics will be analyzed to determine and evaluate precip1tation parameters useful in estimating runoff.

(4343) RUNOFF PRODUCTION BY UNIT SOURCE AREAS IN THE WASHITA RIVER BASIN, OKLAHOMA.

(b) Laboratory project, cooperative with the Oklahoma Agricultural Experiment station.

(c) Mr. M. A. Hartman, Hydraullc Engineer, P. O. Box 400, Chickasha, Oklahoma.

(d) Field investigation, applied research.

(e) Small watersheds generally not exceeding 100 acres in size, each representing a single soll-cover combination are being instrumented to measure rainfall, munoff, and soll molsture. Information on the runoff producing characteristics of the unit source areas will be useful in the development of equations for predicting runoff from ungaged complex watersheds.

(4344) RELATION OF INTEGRATED CLIMATIC AND WATERSHED FACTORS TO STORM RUNOFF AND WATER YIELD OF THE WASHITA RIVER AND TRIBUTARIES, OKLA.

(b) Laboratory project, cooperative with the Oklahoma Agricultural Experiment station.

(c) Mr. M. A. Hartman, Hydraulic Engineer, P. O. Box 400, Chickasha, Oklahoma.

(d) Field investigation, applied research.

(e) A reach of the Washita River extending from Anadarko, Oklahoma, to Alex, Oklahoma, has been selected for study. This reach has a length of 78 river miles and a drainage area along this length of 1128 square miles. Gaging stations are being established near the mouth of 10 tributaries and at 6 sites along the main stem of the Washita River in this reach. Watershed characteristics are being measured and defined. The watershed land use and structures development will be inventorled periodically. Flood peaks, total flow and its rate-time distribution will be determined and related to climatic and land factors.

(4345) EXPLORATORY STUDY OF THE REGIMES OF WASHITA RIVER MAIN STEM FLOWS

(b) Laboratory project, cooperative with the Oklahoma Agricultural Experiment station.

(c) Mr. M. A. Hartman, Hydraulic Engineer, P. 0. Box 400, Chickasha, Oklahoma.

(d) Analysis of record, applied research.

(e) The flow history of the Washita River, Oklahoma, for the 10-year period 1941 to 1950 is being analyzed to: (1) Detemine parameters characterizing the regime flows prior to development of upstream flood abatement measures; and (2) establish a base for reference in defining any future changes in flow regimes assoclated with conservation and treatment programs in tributary watersheds.

(4346) AQUIFER-STREAMFLOW RELATIONS, GROUND WATER BUDGET, WASHITA RIVER BASIN, OKIAHOMA.

(b) Laboratory project, cooperative with the Oklahoma Agricultural Experiment Station.

(c) Mr. M. A. Hartman, Hydraulic Engineer, P. o. Box 400, Chickasha, Oklahoma.

(d) Field investigation, applied research.

(e) The alluvia and underground flow system of the Washita River Basin are being defined by use of drilling equipment and existing well logs. Permeability coefflclents will be determined and ground water observation wells established. This is one part of a comprehensive research study of the total water budget in a portion of the Washita River Basin.

(4348) PRECIPITATION CHARACTERISTICS INFLUENCING RUNOFF FROM SELECTED AREAS IN TEXAS.

(b) Laboratory project.

(c) Mr. Walter G. Knisel, Hydraulic Engineer, P. O. Box 1147, Riesel, Texas.

(d) Field investigation, applied research.

(e) Rain gage networks are established on the Blacklands Experimental Watershed near Riesel, Texas, and on the Edwards Plateau near Sonora, Texas. Information is being obtained on amounts, duration, seasonal distribution, and other characteristics of rainfall to the extent that the characteristics influence runoff from agricultural watersheds.

(f) The work at Sonora, Texas, was initiated in 1961 .

(4349) RELATION OF CLIMATIC AND WATERSHED FACTORS TO STORM RUNOFF AND TO WATER YIELD FROM AGRICULTURAL WATERSHEDS IN THE BLACKIANDS OF TEXAS.

(b) Laboratory project.

(c) Mr. Ralph W. Baird, Hydraulic Engineer, P. 0. Box 1147, Riesel, Texas.

(d) Field investigation, applied research.

(e) Thirty watersheds at the Blacklands Experimental Watershed near Riesel, Texas, varying in size from approximately 3 acres to 5860 acres, have been equipped with precalibrated flumes or with current meter rated welrs to measure runoff rates. Precipitation is measured by recording rain gages. The land factors are determined by periodic inventory of crops, covers, and crop systems on the land. Relationships between climatic and land factors and the runoff produced are analyzed to develop prediction methods for est1mating storm peaks and water yields.

(h) Monthly summaries of rainfall and runoff, maximum volumes of flow for selected periods of time, and detalled data for selected runoff events are reported annually. Several analytical and interpretive reports have been published.

(4350) RUNOFF PRODUCTION BY UNIT SOURCE AREAS IN THE BIACKIANDS OF TEXAS.

(b) Laboratory project.

(c) Mr. Ralph W. Balrd, Hydraulic Engineer, P. O. Box 1147, Riesel, Texas.

(d) Field investigation, applied research.

(e) Twelve watersheds, approximately 3 acres in size each, of single land use, crop or grass, are instmumented with $\mathrm{H}$-type flumes to measure the runoff. The relationships betwen the runoff and the associated precipitation as influenced by the land characteristics are investigated. These relationships will facilitate the prediction of runoff from ungaged watersheds composed of combination of these single soll-cover, sub-watersheds or unit source areas.

(h) Monthly summaries of rainfall and runoff, maximum volumes of flow for selected periods 
of time, and detalled data for selected runoff events are reported annually.

(4351) SEDIMENT YIELD IN RELATION TO CLIMATIC AND WATERSHED CHARACTERISTICS OF AGRICULTURAL AREAS IN THE TEXAS BLACKIANDS AND THE EDWARDS PIATEAU.

(b) Laboratory project.

(c) Mr. Ralph W. Baird, Hydraulic Engineer, P. 0. Box 1147, Riesel, Texas.

(d) Field investigation, applied research.

(e) At the Blacklands Experimental Watershed near Riesel, Texas, sediment yield measurements have been or are being made on twenty-four plots or watersheds varying in size from one-quarter to 5860 acres. These sediment yields are correlated with precipitation, runoff, topography, soils, land use, and conservation practices. The data are analyzed to develop techniques and procedures for estimating sediment yield and sources from ungaged watersheds. on Lowry Draw in the Edwards Plateau area near Sonora, Texas, sediment range lines have been established, in cooperation with Soll Conservation Service, at two detention reservolr sites with drainage areas of 4.38 and 16.85 square miles. In addition, arrangements have been made for sampling the flow from the reservolr spillways.

(4352) RELATION OF CLIMATIC AND WATERSHED CHARACTERISTICS TO STORM RUNOFF AND WATER YIELD IN THE EDWARDS PIATEAU AREA OF WEST CENTRAL TEXAS.

(b) Laboratory project.

c) Mr. Walter G. Knisel, Hydraulic Engineer, P. O. Box 1147, Riesel, Texas.

(d) Field investigation, applied research.

e) Five detention reservolrs in Lowrey Draw are equipped with water level recorders. Runoff volumes are measured by volume change in the reservolr. Rates of inflow can also be determined. The watersheds above the reservolrs range in size from 686 to 10787 acres. A current meter rated gaging station will be placed at the outlet of the Lowrey Draw watershed which has a drainage area of 48 square miles. A rain gage network will determine the precipitation over the area. In addition to the development of the rainfall-runoff relationship for this area, a study will be made of the disposition of the water temporarily stored in the reservoirs.

(4353) EVALUATION OF OPERATION AND DESIGN CRITERIA OF OLD TILE DRAIN SYSTEMS.

(b) Laboratory project

c) Mr. Victor I. Myers, Research Agricultural Engineer, P. O. Box 267, Weslaco, Texas.

(d) Field investigation - applied research.

e) A study to evaluate the effectiveness of some old existing tile systems in draining and leaching solls; to evaluate the functioning of tile drains with and without filter materials; and, to evaluate the adequacy of tile drain design criteria.

(g) Tile lines laid in certain solls, without filter or envelope materials provided, accumulate soll over a long period of time until they become plugged or only partially effective. Studies are shedding light on the occurrence of the salinity - clay mineral complex and interactions that influence movement of soll particles into drain lines.

(4354) INFILTRATION RATES AND PROFILE CHARACTERISTICS IN REIATION TO THE OCCURRENCE OF SALINITY.

(b) Laboratory project.

(c) Mr. Leon Lyles, Research Agricultural Englneer, or Dr. Craig Wiegand, Research Soll sclentist, P. 0. Box 267, Weslaco, Texas. (d) Field investigation; applied research. infiltration rates to the occurrence of salt-affected profiles. Infiltration rates are to be determined on about a dozen salt affected and adjacent non-affected profile pairs which have been chemically and physically characterized. The infiltration rates will be related statistically to the severity of salinization and to the chemical and physical properties of the profiles.

(g) The final intake rate (5 hours) in the nonsaline sites averaged about 3 times those of the adjacent saline sites. Analysis of varlance revealed that saline profiles were higher in percent clay and surface elevations were slightly higher than adjacent nonsaline sites. Multiple regression analyses relating infiltration rate and salt concentration to the physical and chemical properties of the profiles are currently being interpreted.

(4356) EFFECTS OF BENCHING AND TERRACING ON MOISTUE CONSERVATION ON SLOPING HARDLANDS OF THE SOUTHERN GREAT PIAINS.

(b) Laboratory project.

(c) Mr. Victor L. Hauser, Agricultural Engineer, Southwestern Great Plains Field Station, Bushland, Texas.

(d) Fleld investigation, applied and design research.

(e) 1. To test the feasibility of altering the configuration of the land to intercept, spread, and infiltrate surface runoff in contour basins. 2. To determine the extent to which such intercepted runoff will add to avallable soll moisture supplies and how such additional soll molsture may best be utilized for crop production. 3. To determine the relative value of the three types of terrace systems, conservation benching, graded, and level closed end for molsture conservation and crop production. 4. To measure munoff from well managed contour farmed hardland solls.

(g) It has been found that graded and level terraces are equally effective in conserving runoff water under semi-arid conditions where 10 or 11 months of fallow precade planting either wheat or grain sorghum. It has been found that the conservation bench terrace system is superior to either graded or level terraces in the conservation of runof $\mathrm{f}$ water.

(4357) EFFECT OF CROPPING SYSTEMS AND CLIMATE ON RUNOFF, EROSION, AND CROP YIELDS UNDER BLACKLAND CONDITIONS.

(b) Laboratory project.

(c) Mr. D. W. Fryrear, Agricultural Engineer, P. O. Box 748, Temple, Texas.

(d) Experimental - applied research.

(e) Runoff and soll loss are measured from 12 fleld scale ( $1 / 2$ acre) plots representing a typical cultivated slope of Blackland Prairle solls. The plots are in three cropping systems with row cropping every year, in alternate years, and every third year. By taking soil moisture and crop residue measurements, in the future the interactions of varying climatic influences with crops and management are determined as a basis for determining munoff and erosion on farms and watersheds.

(g) Statistical analysis of runoff results for 4-year period 1959-62 indicated no significant difference between plot replications or cropping systems but a significant difference in runoff for different years. Similar analysis of soil loss data for this period showed no significant difference between cropping systems, and a significant difference between plot replications and years.

(4844) TESTING OF MATERIALS FOR IMPROVED SUBSURFACE 
DRA INAGE.

(b) Laboratory project.

(c) Mr. Victor I. Myers, Research Agricultural Engineer, P. O. Box 267, Weslaco, Texas.

(d) Experimental; applied research.

(e) Laboratory tank studies $w 111$ be made to evaluate drainage materials with particular emphasis on filters and new drain tube materials. One or more field installations will be made in which drainage materials will be compared and evaluated. Electric analogue studies w1ll be made for predicting flow rates into tile lines.

(g) Laboratory studies have been made on several old and new drainage tubing materials, including concrete plpe, plastic tubing, flber plpe, flberglass wall tubing, and thinwalled steel tublng. Tank tests and measurements include deformation of tubing under pressure, rate of water movement into tubing, and effectiveness of filter materials.

(4845) SOIL-WATER-PLANT RELATIONS OF IRRIGATED COTTON AS INFLUENCED BY DEPTH TO WATER TABLE.

(b) Laboratory project.

(c) Mr. L. N. Namken, Research Soll Scientist, P. 0. Box 267, Weslaco, Texas.

(d) Field invest1gation; applied research.

(e) A set of thirty-six lysimeters, one meter square and ten feet deep, are being ut1lized to study the Influence of soll moisture level, water table depth and water table salt level treatments on evapotranspiration, vegetat1ve growth and yield of cotton. The object1ves of the project are: (1) To determine the contribution of a water table to the water requirement of cotton; (2) to study soll molsture use and extraction by cotton as Influenced by varlous water table depths; and $(3)$ to study the effect of water tabie salt concentration on salt movement and molsture uuuptake by the cotton plant.

(g) Molsture condition in the root zone and water table depth significantly influenced the proportion of total molsture use (evapotranspiration) attributable to use from the water table. The relationsh1p between water table depth and percent molsture use from the water table was nearly linear. During the period May 7 to August 1, 60 percent of the total water requirement of cotton was ut1lized from the water table under low soll molsture and high water table ( $3 \mathrm{feet}$ ) conditions. Lowering the water table to 9 feet under the same molsture conditions reduced molsture use from the water table to approximately 20 percent of the total water requirement. Under high soll molsture conditions, approximately 42 percent of the total water requirement of cotton was utilized from a water table 3 feet below the soll surface compared with 11 percent when the water table was at 9 feet.

(4846) TILIAGE PRACTICES AND CROPPING SYSTEMS WITH ALFALFA FOR SOIL AND WATER CONSERVATION AND WHEAT PRODUCTION.

(b) Laboratory project.

(c) Mr. M. B. Cox, Agricultural Engineer, P. O. Box 128, Cherokee, Oklahoma.

(d) Field Investigation; applied research.

(e) Comparison of clean tillage versus stubble mulch tillage on continuous wheat with and without nitrogen fertilizer, and rotations of three years wheat with three years alfalfa. Plowing to 12 inches was done in 1955 to disrupt the plow pan on half of all plots. The purpose of the project is to evaluate stubble mulch tillage and deep plowing with different cultural practices for increasing water infiltration, reducing runoff, controling erosion, and improving crop production.

(g) Deep plowing reduced munof the first year approximately $25 \%$, the second year about
15\% and the third year about 5\%, the following years there was no measurable difference. There was no measurable differencee in crop production. Spring application of nitrogen has materially reduced runoff and Increased wheat production. Runoff is reduced by stubble mulch during the fall season but not in the spring. Runoff is reduced and wheat production is increased the first and second years of wheat following three years of alfalfa.

(4847) EFFECT OF SURFACE CROP RESIDUE MANAGEMENT ON RUNOFF, EROSION, CROP YIELDS, AND SOIL PROPERTIES.

(b) Laboratory project.

(c) Mr. D. W. Fryrear, Agricultural Engineer, P. 0. Box 748 , Temple, Texas.

(d) Field invest1gation; applied research.

(e) Eight individual terrace fields on characterlzed Blackland Prairle solls are managed by 2 tillage systems in a 2 -year rotation of cotton-wheat w1th crop growth and yields and soll characterlstics determined, and with rainfall and runof $f$ gauging on 4 terraces.

(f) Terminated December 7, 1962.

(g) N1ne years of data show no consistent or significant difference between the runoff from trash-mulch t1llage versus clean, conventional tillage.

(h) "Surface Residues Reduce Erosion," R. M. Smith and R. C. Henderson, Soll and Water Mag. (Assoc. Tex. Soll Conserv. Dist.) $10(9): 8$, September 1960 .

(4848) GRADED FURROWS FOR RUNOFF AND EROSION CONTRA.

(b) Laboratory project.

(c) Mr. D. W. Fryrear, Agricultural Engineer, P. O. Box 748 , Temple, Texas.

(d) Field Investigation; applied research.

(e) Purpose of work is to determine relationships between furrow length and slope, runoff and soil loss, and to see if graded furrows will permit increased terrace spacing. Terrace spacing is doubled and a channel rather than a conventional ridged terrace is used to convey munoff water. Increased terrace spacing is accomplished by planting on 40-1nch lister furrows on a 1 percent grade. The amount of munoff and soll loss from the furrows is measured along with rainfall intensities, soll moisture, and surface residues.

(g) Physical system was established in summer of 1963. Methods used in designing munoff structures and instrumenting the system include model tests and electronic devices for recording water depths and wetted perlmeters.

(4849) EVALUATION OF DRAINAGE METHODS FOR THE NONIRRIGATED AREA OF THE LOWER RIO GRANDE VALLEY OF TEXAS.

(b) Laboratory project.

c) Mr. Ronald R. Allen, Agricultural Englneer, or Mr. Victor I. Myers, Research Agricultural Engineer, P. O. Box 267, Weslaco, Texas.

(d) Experimental and fleld investigation; applied research.

(e) The purpose of the study is to compare the effectiveness and cost of installation operation and malntenance of three drainage methods; open drain ditches, subsurface drain tile, and dralnage wells in reduction of soil salinity and control of a ground water table.

(5211) LIMITED IRRIGATION OF GRAIN SORGHUM IN THE SOUTHERN PLAINS.

(b) Laboratory project.

(c) Mr.J.T. Musick, Agricultural Engineer, Southwestern Great Plains Field Station, Bushland, Texas. 
(d) Fleld Investigation; applied research.

(e) To determine number and timing of 1 rrigations for most efficient use of limited 1rrigation and expected precipitation; plant spacing for most efflclent use of limited water; and some soll molsture-plant growth-yleld relationships under limited soll molsture conditions.

(g) Results in 1963 indicate that water application during plant fruiting resulted in very efficient use of limited water. Higher grain yields and more efficlent use of water were obtained from double rows on $40-1$ nch beds compared to single rows and also by a closer within row plant spacing.

(5212) SOIL LOSS FROM THE ENDS OF LEVEL TERRACES AND THE EROSION OCCURRING BETWEEN TERRACES.

(b) Laboratory project.

(c) Mr. M. B. Cox, Agricultural Engineer, P. O. Box 128, Cherokee, Oklahoma.

(d) Fleld investigation; applied research. from terraces and from different sections downslope within terrace intervals. Runoff and soll loss are measured from a system consisting of 8 terraces and 20 small plots. Half of the area is clean tilled and half stubble mulched. Terraces are arranged in palrs, one concrete and one soll channel. Concrete lined channels are used to provide a permanent base for measuring soll movement Into terrace channels. Plots, located at the ends of the palrs of terraces, permit determination of silt contribution from three sections of normal terrace intervals.

(g) Terrace installations are completed and 1963 spring and summer munoff and soll loss data have been obtained. Data showed some varlation between different pairs of terraces but marked similarity of both runoff and soll loss was obtalned within palrs, 1.e., between concrete and regular soll channel terraces. The small plot portion of the study w1ll be installed in early 1964.

(5213) WATER INTAKE AND DISTRIBUTION OF SOIL MOISTURE UNDER GRADED FURROWS ON PULLMAN SILTY CLAY LOAM.

(b) Laboratory project.

(c) Mr.W.H. Sletten, Agricultural Engineer, Southwestern Great Plains Field Station, Bushland, Texas.

(d) Field investigation; applied research.

(e) Determine water intake characteristics, storage, distribution, and 1rrigation efflclency of long furrows on Pullman silty clay loam soll.

(g) High inftial water intake rates which rapldiy declines to less than 0.1 1nch per hour permit rather uniform and efficient irrigation of long irrigation furrows. Soll shrinkage cracks contribute signiflcantly to intake and storage of irrigation water in the plant root zone.

(5214) DEVELOPMENT AND TEST OF A SIMPLE SYSTEM TO CLARIFY PLAYA WATER WITH FLOCCULENTS AND THE USE OF AN IRRIGATION DITCH AS A SETTLING BASIN.

(b) Laboratory project.

(c) Mr. Victor L. Hauser, Agricultural Englneer Southwestern Great Plains Fleld Station, Bushland, Texas.

(d) Fleld Investigation; applied and design research

(e) To develop a simple system for removing sediments from muddy playa lake water. Th1s research project will be an effort to assemble relatively simple equipment to clarify muddy lake water prior to injection into a shaft as a means of storing runoff water and thus prevent 1ts loss to the atmosphere by evaporation.

(f) Th1s experiment was terminated early in 1963. The system design specified in the research outline is not capable of removing enough sediment to be used in widespread recharge projects. The modified system including a sand filter did remove enough sediment to be used in recharge work but the capacity of the system is low.

(5215) STRATIGRAPHY AND HYDROLOGIC CHARACTERISTICS OF THE SEDIMENTARY FORMATIONS UNDERLYING A PLAYA AND ITS WATERSHED.

(b) Laboratory project.

(c) Dr. Frederick B. Lotspelch, Research Soll Scientist, Southwestern Great Plains Field Station, Bushland, Texas.

(d) Field and laboratory investigation to determine the stratigraphic relationships and hydrologic properties of the sedimentary formations underlying a playa and its watershed.

(e) Areal extent and thickness of each major lithologic unit w1ll be determined by drilling several bore holes in and on the perlphery of the playa and obtaining cores of the complete section where possible. Properties of the sedimentary formations to be determined in the laboratory will include particle size distribution, permeability, specific yield, bulk density, carbonate equivalent, cation exchange capac1ty, exchangeable cations, mineralogy, and $\mathrm{pH}$.

(f) Initiated in 1963, fleld and laboratory work is continuing.

(5216) GEOPHYSICAL EXPLORATION OF A PLAYA AND ITS WA TERSHED.

(b) Laboratory project. Southwestern Great Plains Field Station, Bushland, Texas.

(d) Determine the stratigraphy of a playa and its watershed using surface electrical resistivity and electric and gamma-ray well logging equipment.

(e) The playa w1ll be surveyed w1th the electrical resistivity equipment on a 500 foot grid. Data will be collected and analyzed according to standard practice. Each bore hole drilled on the playa watershed w1ll be logged electrically and these data correlated with the drillers $l o g$ and the stratigraphy and properties of each lithologic member.

(f) Initiated in 1963, fleld and laboratory work is continuing.

(5217) RUNOFF PRODUCTION BY UNIT SOURCE AREAS IN THE EDWARDS PLATEAU OF TEXAS.

(b) Laboratory project.

(c) Mr. Walter G. KnIsel, Jr., Research Hydraulic Englneer, P. O. Box 1147, Riesel, Texas.

(d) Field investigation, appiled research.

(e) S1x watersheds of 5 to 15 acres; s1x planned, three selected, one installation completed in 1963. These watersheds are all in range areas of different soll and geologic

formations, and runoff will be measured by pre-calibrated flumes. The relationsh1p between the runoff and the assoclated precipitation as influenced by range use, geology, and solls are investigated.

(5218) THE DURABILITY AND EFFECTIVENESS OF DRAINAGE MATERIALS UNDER FIELD CONDITIONS.

(b) Laboratory project.

(c) Mr. V1ctor I. Myers, Research Agricultural Englneer, P. O. Box 267, Weslaco, Texas.

(d) Field investigation; applied research.

(e) A field installation of old and new drainage tile, plpe and tubing is belng made to evaluate the durability, and effectiveness of the materials. In addition, the investigation includes a study of the effectiveness of providing envelope material to increase the flow of water and decrease movement of sediment into drain lines under stratifled soll conditions. 
U. S. DEPARTMENT OF AGRICULTURE, AGRICULTURAL RESEARCH SERVICE, So11 and Water Conservation Research Division.

SOUTHWEST BRANCH, P. O. BOX 2326, Riverside, Cal1f., Mr. W. W. Donnan, Branch Chief.

(151) LINING OF IRRIGATION CANALS AND RESERVOIRS.

(b) Laboratory project, in cooperation with the Utah State University and Bureau of Reclamation.

(c) Dr. C. W. Lauritzen, Soll Sclent1st, Utah State University, Mechanic Arts, 130, Logan Utah.

(d) Experimental; basic and applied research.

(e) Linings for irrigation canals and reservolrs are being tested to develop more effective and lower cost methods of reducing seepage losses in irrigation systems. The investigation included: Evaluation of physical properties of lining materials; (2) model testing of linings in an outdoor laboratory; and (3) fleld testing at selected sites to determine relative durability under varying subgrade and climatic conditions.

(g) After nearly 10 years both vinyl and polyethylene film employed as burled linings continue to provide effective seepage control. A bullt-up asphalt coated jute lining is highly effective after 7 years. After 9 years as an exposed canal lining the tensile and elongation of butyl sheeting remained unchanged. After 17 jears of exposure on a walking deck butyl sheeting retalned 80 percent of the original tensile and elongation.

(h) "Conveyance Losses in Irrigation Systems and Measures for Control," Seepage Symposium, Feb. 19-21, 1963.

"Irrigation Research in the Un1ted States," Arldity \& Man, Publication of American Assoclation for the Advancement of Sclence. "New Sl1pform Uses Free-Flow Hopper," Farm \& Home Sclence, Vol. 23, No. 3, September 1962.

"Distribution, Control, and Measurement of Irrigation water on the Farm," USDA M1scellaneous Fublication No. 926, July 1963.

(2117) WATER REQUIRENENTS IN IRRIGATED AREAS OF SOUTHWEST.

(b) Laboratory project in cooperation with state and Federal agencies.

(c) Mr. Dean C. Muckel, Agricultural Englneer, P. O. Box 8014, University Station, Reno, Nevada.

(d) Field experiments and office analysis. Applied research.

(e) To determine the consumptive use of water by crops, phreatophytes, and otier vegetation, and net irrigation supply requirements. To develop empirical formula from climatological and other data for determining rates of consumptive use.

(h) "Determining Consumptive Use and Irrigation Requirements," by Harry F. Blaney and Wayne D. Criddle, U.S.D.A. Tech. Bul. No. $1275: 59$ pp. (1962) 11ius.

(2180) EVAPORATION LOSSES FROM RESERVOIRS AND LAKES.

(b) Laboratory project in cooperation with state of California, counties and other agencles.

(c) Mr. Dean C. Muckel, Agricultural Englneer, P. O. Box 8014, University Station, Reno, Nevada.

(d) Experimental; compilation and analysis of data. Applied research.

(e) To determine evaporation losses from reservolrs and lakes and develop empirical formulas from climatological data for computing monthly evaporation. Cooperative fleld measurements are being made of pan evaporation at stations in California ranging from near sea level in Santa Barbara County to 9,194 feet elevation at Kaiser Pass in the S1erra-Nevada Mountains.
(2181) ARTIFICIAL RECHARGE OF GROUND WATER FOR IRRIGATION IN CALIFORNIA.

(b) Laboratory project in cooperation with the Californla Department of Water Resources.

(c) $\mathrm{Mr}$. Leonard Schiff, Hydraulic Engineer, 4816 East Shieıds Avenue, Fresno 3, Cal1f.

(d) Experimental; laboratory and field investigations, applied research.

(e) To efficiently store imported water underground in quantity and of a qualty needed in varlous locations. The objectives are: (1) To determine the physical and chemical characteristics of surface soll and substrata on selected recharge sites and to relate these characteristics to inflitration and percolation rates, and to lateral aquifer flow; (2) to determine the feasibility of recharge 1rrigation (deep percolation by heavy irrigation of crops) as a means of storling water underground; (3) to determine the effect on recharge of the quality of water reaching the groundwater table under selected site conditions, and on the quality of the groundwater; and (4) to prepare a recharge gulde which permits the evaluation of a site for recharge, suggests methods and systems of recharge to be used and indicates the quality of groundwater that may be expected as a result of recharge.

(h) "Proceedings 1963 Blennial Conf. on Ground Water Recharge and Ground Water Basin Management," edited by Leonard Schiff. Issued November 1963 by Ground Water Recharge Center, Fresno, California. "A Soll-Dralnage Study in Southwestern Fresno County," by W. C. Blanch1, et al. H1lgardla, vol. 33(5), pp 171-78, 1962. "Research in Ground Water Recharge - Southwestern Fresno County," by E. E. Haskell, Jr., W. C. Blanch1 and C. R. Pomeroy, Calif. Agr. vol. 17(9), 1963.

(2650) EFFECT OF WATER TABLE DEPTH ON IRRIGATION REQUIREMENTS AND YIELD OF LAHONTAN ALFALFA,

(b) Laboratory project, in cooperation with the Nevada Agricultural Experiment Station.

(c) Mr. Rhys Tovey, Agricultural Eng1neer, ARS, Box 8014, University Station, Reno, Nevada.

(d) Experimental; applied research.

(e) To determine surface-1rrigation requirements of Lahontan alfalfa grown on three soll textures with constant water tables at various depths, and on well-drained soll in the absence of a water table; to determine the effect of plant growth stage on the rate of water use by Lahontan alfalfa; to determine the relation between the use of wate by alfalfa under various water table conditions, evaporation from porous atmometer bulbs, and evaporation from a Weather Bureau evaporation pan; and to evaluate the effects of a fluctuating water table on the yield and growth rate of alfalfa.

(B) The seasonal values indicate that: (1) The consumptive use and yleld of alfalfa for the non-1rrigated treatments decreased as the depth to water table increased; (2) the non-1rrigated lysimeters show a lower consumptive use and yleld than the irrigated lysimeters in most instances; (3) the consumptive use and yleld of the drained irrigated treatments are comparable to the values measured for the elght-foot water table, non-irrlgated treatment; and (4) the differences due to water table depth are less for the non-1rrigated treatments. Alfalfa plants, grown on a sandy loan soll, can stand submergence for three days without a reduction in yleld.

(h) "Consumpt1ve Use and Y1eld of Alfalfa Grown in the Presence of Static Water Tables," by Rhys Tovey. University of Nevada Agr. Expt. Sta. Tech. Bul. 232, 65 pp. (1963) ilius.

(2651) DRAINAGE INVESTIGATIONS IN THE NORTH SHORE AREA OF CARSON LAKE, NEVADA. 
(b) Laboratory project, in cooperation with the Nevada Agricultural Experiment Station.

(c) Mr. Anthony S. Dylla, Agricultural Engineer, Box 8014, University station, Reno, Nevada.

(d) Field and applied research.

(e) To determine the causes for drainage problems in the study area, to develop equipment and techniques suited to conditions in the study area which will permit determining qualitative and, if possible, quantitative relationships between causes for drainage problems in the study area and in other similar areas; to develop physical$1 \mathrm{y}$ and economically feasible methods of correcting or alleviating problems in the study area and in other similar areas.

(f) Project completed and preparation of report underway.

(g) Canal seepage measurements are being analyzed for relationship to high water table build-up. Results of investigative borings are being compiled for determination of corrective drainage measures. Hydraulic conductivity and specific yield data are being compiled for design of corrective drainage measures. Plastic lined mole drains are being studied as a possible economical drainage problem. Well, plezometer, and irrigation efficiency data are being compiled for analyzing the cause for drainage problems.

(h) "Experimental Plastic Drains in Nevada," by A. S. Dylla, M. E. Rollins, and V. I. Myers. U. Nev. Agr. Expt. Sta. B. 228: 13 pp. (1963) illus.

(3556) FARM CONVEYANCE AND WATER APPLICATIONS.

(b) Laboratory project, in cooperation with the Utah State University.

(c) Dr. C. W. Lauritzen, Soil scientist, Utah State University, Mechanic Arts, 130, Logan Utah.

(d) Experimental; basic and applied research.

(e) New methods and equipment for conveying and applying irrigation water are being developed. The hydraulic properties of layrlat tubing are being studied and new materials are being evaluated to determine their use in conveyance structures.

(g) Two devices for regulating and measuring water deliveries în implgation canals and ditches have been developed. These devices are essentially leakproof and simple to regulate.

(3558) LABORATORY MODEL AND FIETAD STUDIES OF REDUCING SEEPAGE IN SANDS WITH BENTONITE.

(b) Laboratory and fleld project, in cooperation with the Nevada Agricultural Experiment Station.

(c) Mr. Myron B. Rollins, Research Soll Sclentist, Agriculturai Research Service, P. 0. Box 8014, University Station, Reno, Nevada.

(d) Experimental; applied research.

(e) To determine factors influencing blanket treatments and sediment penetration and retention involved with sealing irrigation canals or reservolrs with bentonite, and to develop procedures to obtain effective seals. Laboratory experimentation is being done with sands placed in lucite cylinders 3 inches in diameter and 2 feet long. Ponds $20 \times 40$ feet are used in field tests. Bentonite is applied by blanket treatment and by dispersing it in the water. Numerous aspects concerning the chemical, physical, and mineralogical properties of the bentonites, waters, and sands will be evaluated.

(g) Investigations, to date, suggest that offective seals can be obtained within certain unknown limitations for the dispersion or sediment treatment. Blanket treatments are very effective if kept moist.

(h) "Experimental Bentonite Sealing," by Myron B. Rollins, A. S. Dylla, and G. A. Myles. Nevada Expt. Sta. Bul. No. 228, il p. June 1963.

"Bentonite Can Reduce Seepage Iosses," by Myron B. Rollins and A. S. Dylla. Nevada
Ranch and Home Review, vol. 2 (5), 14-15, Spring-Summer, 1963.

(3560) EVAPOTRANSPIRATION OF HUMBOLDT MEADOW VEGETATION AS MEASURED WITH LYSIMETERS.

(b) Laboratory and fleld project, in cooperation with University of Nevada Agr. Expt. Sta. and Nevada State Department of Conservation and Natural Resources.

(c) Mr. Anthony S. Dylla, Agricultural Englneer, P. O. Box 8014, University Station, Reno, Nevada.

(e) To measure the evapo-transpiration of meadow vegetation in the Humboldt Basin area which subsists primarily under shallow water table conditions The data wil l be used to determine areal use of ground waters by native vegetation and phreatophytes and to develop methods of more efficient utilization of those water supplies.

(f) Progress report covering three years data underway.

(g) Evapo-transpirational rates are being obtaind by water use measurements of meadow grasses growing in plastic lysimeters. Vegetative growth, soll molsture, water table, and weather data are being collected to which evapo-transpiration rates from tanks can be related.

(h) "Plastic Membrane Tanks for Evapotranspiration Determinations," by A. S. Dylla and Rhys Tovey, Agricultural Engineering, vol. 43 (10), pp 584-585, 1962, 11lus.

(3872) DYNAMIC SIMILARITY IN PIPE ELBOW FLOW METERS.

(b) Laboratory project.

(c) Mr. Lloyd E. Myers, Director, Water Conservation Laboratory, Route 2, Box 816-A, Tempe, Arizona.

(d) Experimental; applied research.

(e) ASA, class 125, cast 1ron, 90-degree, flanged elbows from five different manufacturers have been calibrated under standard flow conditions. Magnitude of errors caused by flow disturbances fror various fittings and installations were determined for 3 -inch diameter elbows.

(r) Completed.

g) Comparison of calibration results from 3,6 , and 10-inch diameter elbows give standard deviations within \pm 3 percent.

(h) Report in preparation.

(3873) GROUND COVERS AND OTHER STRUCTURES FOR COLIECTING AND STORING PRECIPITATION.

(b) Laboratory project, in cooperation with the Utah State University.

(c) Dr. C. W. Iauritzen, Soil Scientist, Utah State University, Mechanics Art, 130, Logan, Utah.

(d) Experimental and applied research.

(e) There are areas in many regions where water for livestock and even culinary uses is scarce or nonexistent, yet considerable water in the form of precipitation falls each year. As an example, the precipitation on one acre of land in an 8-inch rainfall area amounts to 217,248 gallons. Th1s is enough to supply water to more than 200 head of cattle for 100 days. This study includes the development and testing of materials for ground covers and storage facilities to be used for the collection and storage of water in low rainfall areas together with the design and operation of these facilities.

(g) Ground covers and closed storage structures have been developed for intercepting and storing precipitation. To satisfy the need for a name this combination of structures has been termed a "Rain Trap." Butyl sheeting continues to be the most satisfactory material for both the interceptor and the storage reservolr. Other materials are being investigated, and there are indications that some of these will be less expensive and reasonably serviceable as ground covers. Modifications have been made 
In the design and fabrication of ground covers and storage bags made of butyl to improve their performance.

(h) "Graze More Range with This New Water-Saving Idea". Ford Farming, p. 22, summer 1962. "Capturing Precipitation". ICID Annual Bulletin, 1962, p. 52. "Trap Water as Well as Tap Solar Energy". Sclence, Vol. 140, No. 3571, pp. 1149-50, June 7, 1963.

"Rain Traps". Proceedings, National Agr1cultural Plastics Conference, 1963.

(3874) INFLUENCE OF COLORADO RIVER WATER UPON IRRIGATION AND DRAINAGE IN THE SAN JACINTO BASIN, CALIFORNIA.

(b) Laboratory project.

(c) Mr. Luther B. Grass, Soll Chemlst, P. 0 . Box 629, Pomona, California.

(d) Experimental.

(e) A study of the use of Colorado River water for Irrigation applicable to the intermediate valley and plains areas of southern callf. is being conducted in two ways. First, in 1954 a group of key soll sampling stations were selected and sampled annualiy. The soll analyses were compared with previous analyses, annual rainfall patterns and cropping practices. The second study, inftiated in 1960, encompasses a plot program in which potatoes and grain are grown in a three-year rotation. One-half of the plots were presalinized. Only sufficlent water to supply evapotranspiration is applied to one group of plots, while to the second an excess of 20 percent evapotranspitation demands is applied.

(f) Fleld work completed, report being prepared.

(g) Key salinity trend stations have revealed during the past ten years that soil salinity has increased gradually in areas irrigated with Colorado River water. Winter rainfall has a very marked influence upon this rate of accumulation. A winter of substantially above normal rainfall will do much to leach the accumulated salts from the soil.

However, on an average annual basis rainfall is not a dependable means of leaching. Consequently, the farm operation must Include a leaching program as part of the irrigation practice. The plot studies have, in the first season, indicated the influence of but moderate concentration of salts upon productivity.

(4358) FLOOD WAVE MOVEMENT AND ROUTING IN ALLUVIAL CHANNELS.

(b) Laboratory project, cooperative with the Arizona and New Mexico Agricultural Experiment Stations, and the U. S. Soll Conservation Service.

(c) Mr. R. V. Keppel, Agricultural Engineer P. O. Box 3926, Tucson, Arizona.

(d) Experimental, field Investigation.

e) Water level recorders are located at 2,000foot intervals in a 3 -mile reach of natural channel. The reach has a gaging flume at the Inlet and at the outlet, and major tributary inflow is gaged. Flood waves generated by cloudburst type thunderstorms are belng studied.

(g) Propagation of the peak of the flood wave for discharges between 1000 and $2000 \mathrm{cfs}$ took place at velocities of 10-15 feet per second, as compared with velocities of 5-7 feet per second for the front of the wave moving on a dry channel bed.

(4359) PRECIPITATION CHARACTERISTICS INFLUENCING RUNOFF FROM SEMIARID WATERSHEDS.

(b) Laboratory project, cooperative with the Arlzona and New Mexico Agricultural Experiment Stations, and the U. S. Soll Conservation Service.

(c) Mr. H. B. Osborn, Hydraulic Englneer, P. O. Box 3926, Tucson, Arlzona.

(d) Experimental, field and laboratory; basic research. (e) Raingage networks with densities of one recording gage per square mile are being operated on the 58-square-mile Walnut Gulch watershed in southeastern Arizona and the 67-square-mile Alamogordo Creek watershed in northeastern New Mexico. The walnut Gulch study is augmented by horlzontalsearch $3-\mathrm{cm}$. radar. Objectives of the study are to determine precipitation parameters of importance in predicting runoff and sediment yield, and to give particular attention to the small area, highly intense, convective summer thunderstorms typical of the region.

(g) Data from walnut Gulch watershed for a 7-year period of record indicate that summer convective thunderstorms are elliptical in shape with the major axis approximately 1.5 times the minor axis. Elghty percent of the storms are smaller than $41 / 2$ square mile: in area, and $96 \%$ are smaller than 10 square miles. Maximum runoff events are typlcally the result of multi-celled storms separated In space and time. On the Alamogordo Creek Watershed, convective thunderstorms are of greater intensity and larger areal extent than at Walnut Gulch. The difference is due to the greater amount of pricipitable water in the a1r mass in eastern New Mexico as compared with Southeastern Arizona, and to the fact that frontal action is more common thus giving an added IIft to convective storm cells.

(h) "A Record Storm Event on the Alamogordo Creek Watershed in Eastern New Mexico," by R. V. Keppel. J. Geophys. Research Vol. 68 , No. i6: $4877-4880$. Aug. 1963 .

"Convective Storm Patterns in the Southwestern United States", by H. B. Osborn and W. H. Reynolds. Bul. of International A ssoc. Scientific Hydrology $\mathrm{V}: 8$, No. 3 : 71-83. Sept. 1963.

(4360) RUNOFF FROM COMPIEX WATERSHEDS AS INFLUENCED BY CLIMATIC AND WATERSHED CHARACTERISTICS.

(b) Iaboratory project, cooperative with the Arizona and New Mexico Agricultural Experiment Stations, and the U. S. Soll Conservation Service.

(c) Mr. R. V. Keppel, Agricultural Engineer, P. O. Box 3926, Tucson, Arizona.

(d) Experimental; applied research.

(e) On semiarld rangeland watersheds up to 43,000 acres in size, runoff measurements are being malntained, and an attempt $1 \mathrm{~s}$ being made to relate water yield to

climatic and watershed characteristics, and to evaluate the effects of a range program on rates and amounts of flood runoff and on net water yields. A new design of critical depth flume with capacities up to 18,500 cfs is being used to gage the flashy, sediment-laden flows.

(g) On 5 walnut Gulch watersheds ranging from 560 to 36,900 acres, water yleld decreases exponentially w1th the 0.3 power of the watershed size. All of the water yields to date have occurred from June to september as a result of intense convective thunderstorms. On the Alamogordo Creek Watershed $(43,000$ acres), flow events originating on the central portion of the valley floor cause a flat-top hydrograph with a sustained peak lasting 2 to 3 hours. It is belleved that this is caused by unusually large valley storage located upstream from a channel discontinuity. On the other hand, runof events originating on the highly inclsed southeast or southwest branch of the main stem are sharp-peaked.

(h) "Field Performance of Large Critical Depth Flumes for Measuring Runoff from Semiarid Rangelands," by Osborn, H. B., Keppel, R. V., and Renard, K. G., ARS-41-69: 14 pp. March 1963. AND VEGETATION IN THE HYDROI,OGY OF SEMIARID WATERSHEDS. 
(b) Laboratory project, cooperative with the Arizona and New Mexico Agricultural Experiment Stations, and the U. S. Soll Conservation Service.

(c) Mr. K. G. Renard, Hydraulıc Engineer, P. 0. Box 3926, Tucson, Arizona.

(d) Experimental, field investigation.

(e) Measurements from tandem gaging stations are utilized to evaluate the losses that occur as munoff traverses ephemeral stream channels. Records from shallow wells show depletion patterns of the transmission loss water.

(8) Losses up to 25 acre-feet-per-mile of channel have been measured on one reach of channel in a single flash flood. Records from wells in both the local and regional water tables indicate that in one reach of the main channel, most of the water is dissipated by evaporation and transpiration, while in another reach there may be some movement from the channel alluvium down to the regional water table.

(4362) THE HYDROLOGY OF SEMI-ARID WATERSHEDS AS INFLUENCED BY CHARACTERISTICS OF SOIL AND NATIVE VEGETATION.

(b) Laboratory project; cooperative with Arlz. and New Mexico AGricultural Experiment Stations, and the U. S. Soll Conservation Service.

(c) Dr. J. L. Gardner, Botanist, P. O. Box 3926, Tucson, Artzona.

(d) Experimental, field and laboratory. Basic research.

(e) Interrelations of solls and native vegetation as they influence water and sediment yield are being evaluated on rangeland watersheds of 100 to 43,000 acres in Arlzona and New Mexico. Supplementary to studies on entire watersheds, infiltrometer studies on $6 \times 121$ plots are in progress. A primary objective of the infiltrometer studies is determination of parameters of rangeland vegetation most effective in evaluating its influences on runoff and sediment production on watersheds.

(g) On the infiltrometer plots, maximum runoff is reached in about half the time on areas supporting brush as compared to those supporting grass. On small watersheds above stock tanks, average anr.jal sediment production -. but not munoff -- is logarithmically correlated with basal area of grass cover.

(4363) HYDROLOGIC DATA REDUCTION WITH ANALOG-TODIGITAL CONVERTER.

(b) Laboratory projects, cooperative with the Arizona and New Mexico Agricultural Experiment stations.

(c) Mr. H. B. Osborn, Hydraulic Englneer, P. 0. Box 3926, Tucson, Artzona.

(d) Experimental; laboratory.

(e) Hydrologic records in analog form are being reduced to digital form by means of an automatic analog to digital converter. Information is transferred primarily from rainfall charts to punched cards for future computer rograms.

(h) "Use of Chart Readers for Analog to D1gltal Conversion of Hydrologic Data," by Herbert B. Osborm, ARS-4l-8l: 12 pp. June 1963.

(4364) RUNOFF AND SEDIMENT MOVEMENT ON UNIT SOURCE WATERSHEDS AS INFLUENCED BY MICROCLIMATE, WATER BALANCE, SOIL AND VEGETATION.

(b) Laboratory project, cooperailve with the A rizona and New Mexico Agricultural Experiment Stations, and the U. S. Soll Conservation Service.

(c) Mr. H. B. Osborn, Hydraulic Englneer, P. 0. Box 3926, Tucson, A.rizona.

(d) ङxperimental, fleld and laboratory. Basic research.

(e) Runoff and sediment ylelds are being measured from several small, single sollcover subwatersheds located within larger experimental watersheds having mixed sollcover situations. Objectives are to evaluate the effects of varlous, soll-vegetation complexes, microclimate and water balance ohases on local runoff and sediment production, and to 1dentify and characterize unit source-areas controlling the net storm runoff and sediment ylelds of larger, more complex watersheds.

(g) Average annual sediment yleld from small predominantly grass-covered watersheds $1 \mathrm{~s}$ about $1 \%$, by welght, of their water yleld. Sediment yleld measured from predominantly brush-covered watersheds ranges from aroun: $2 \%$, by welght, of water yleld upward.

(4365) SEDIMENT MOVEMENT ON COMPLEX WATERSHEDS AS INFLUENCED BY CLIMATE AND WATERSHED CHARACTERISTICS.

(b) Laboratory project, cooperative with the Arlzona and New Mexico Agricultural Experiment Stations, and the U.S. Soll Conservation Service.

(c) Mr. K. V. Keppel, Agricultural Engineer, P. O. Box 3926, Tucson, Artzona.

(d) Experimental, field and laboratory.

(e) The objectives of this study are: (1) to determine the relationship of sediment production on unit source areas to sediment ylelds of complex watersheds, (2) to develop methods for sediment yield prediction, and (3) to develop methods for reducing sediment yields from semiarid rangeland watersheds in the Southwest. Integrated depth samples of suspended sediment are belng collected, and single-stage samples by automatic samplers. Total load and particle slzes are being determined for correlation with storm and runoff measurements on several experimental watershed with varylng soll, vegetation characteristics, and drainage features. Studies will be carried out over a number of years during which effects of changing range cover and corresponding changes in flow regimes of the watersheds may be evaluated.

(4368) DEVELOPMENT OF A PORTABLE IRRIGATION SPRINKLER EVALUATION DEVICE.

(b) U. S. Dept. of Agriculture, Agricultural Research Service, Soll and Water Conservation Research Division.

(c) Mr. Rhys Tovey, Agricultural Engineer, ARS, Box 8014 , Un1versity Station, Reno, Nevada.

(d) Experimental; applied research.

(e) (1) To develop a portable device that can be used in the design and evaluation of sprinkler irrigation systems and (2) to determine procedures for the use of the portable irrigation sprinkler evaluation device in measuring soll intake rates, sprinkler application rates and other factors pertinent to the efficient design of sprinkler irrigation systems.

(g) A portable irrigation sprinkler evaluation device has been designed and constructed. Tests show that the device works satisfactorily. Procedures for measuring soll intake rates for sprinkler irrigation system design have been developed.

(h) "A Portable Irrigation Sprinkler Evaluation Device", Irrig. Engin. \& Maintenance 12(2): 8-9 (1962) 1llus.

"A Method of Measuring Water Intake Rate into the Soll for Sprinkler Design", by Rhys Tovey and Claude H. Palr, Proc. of the Sprinkler Irrigation Association Tech. Conf., March 1963.

(4850) WATERSHED REIATIONS TO RECHARGE OF DIRECTLY ASSOCIATED GROUND WATER BASINS.

(b) Laboratory project, cooperative with Calif. Dept. of Water Resources, California Agric. Experiment Station, and the U. S. Soll Conservation Service.

(c) Mr. Paul R. Nixon, Agricultural Engineer, P. O. Box E, Lompoc, California.

(d) Basic and applied research. 
(e) Soll molsture measurements (made with neutron scattering molsture meters to depths of ten to twenty-e1ght feet) together with measurements of precipitation and other climatological factors are being made on a watershed near Lompoc, California, to determine how much, if any, of the rainfall in certain areas penetrates beyond the root zone, to recharge groundwater. The thirteen sites now being studied represent various cover, soll, and topographic conditions. A study is made of movement of water in various solls to help determine net contribution to ground water recharge by deeply penetrating ralnwater. A technique for predicting ground water recharge by deep penetration of ralnwater is being developed which will provide probability estimates of seasonal recharge based site conditions and climatological records.

(g) Downward translocation of moisture has been observed to continue during the dry season following winter precipitation. The magnitude of this migration is predictable and amount of downward movement of molsture through the root zone can be estimated fairly accurately without the benefit of periodic molsture determinations; provided monthly precipitation data are avallable and the range of avallable molsture in the root zone is known.

(h) "Agricultural Utilization of the waters of the Santa Ynez River Basin in Southern Santa Barbara County, California". H. F. Blaney, P. R. N1xon, G. P. Lawless, and E. J. Wiedmann. Processed report. Oct. 1963. "So1l Mo1sture Measurement with the Neutron Method", C. H. M. van Bavel, P. R. Nixon, and V. L. Hauser. U. S. Dept. Ag., Agr. Res. Serv. ARS-41-70: 39 pp. 1963.

(4851) WATERSHED EVAPOTRANSPIRATION LOSSES IN CENTRAL AND SOUTHERN CALIFORNIA.

(b) Laboratory project, cooperative with Calif Dept. of water Resources, California Agric. Experiment Station, and the U. S. So1l Conservation Service.

(c) Mr. G. Paul Lawless, Soll Scient1st, P. 0. Box E, Lompoc, California.

(d) Experimental and field investigation, basic and applied research.

(e) Measurements of so1l mo1sture content are being made at 13 neutron scatter metering sites on a watershed near Lompoc, Calif. Soll suction is measured at one site by tensiometers. Precipitation is measured within a complex of four of the soll molsture sites. Outside of the watershed, in a plot (approx. one acre) of perennial ryegrass, soll molsture data are obtained by an electronically welghing lysimeter, neutron scatter meter, tensiometers and moisture blocks. Soll temperature, soll heat flux, drainage from the lysimeter, wind velocity and direction, solar, total hemispherical, and net radiation, albedo, a1r temperature and humidity are measured in or near the lysimeter. Most of this data is automatically recorded. Data is also obtained from an adjolning USWB class A type climate station, which contains extra instruments consisting of a hygrothermograph, spherical atmometers, and recording rain gage. Purpose of this work is to detemine the relationships between evapotranspiration and various climatic, soll, and plant influences as these relationships affect watershed performance with respect to net water yield.

(g) Much of the available water in the root zones of the native vegetation was quickly used after each dry season started. The lack of avallable water reduced evapotransplration rates. It was found that these rates of evapotranspiration correlated to considerable degree with the soll molsture content of the root zones.

(h) "Evapotranspiration - Climate Comparisons in Coastal Fogbelt, Coastal Valley, and Interior Valley Locations in California," P. R. N1xon,
N. A. MacGillivray, and G. P. Lawless. Gen. Assem. of Berkeley, IUGG, Internal. Assoc. of Sc1. Hydrology, Committee for Evap., Publ. No. 62, pp. 221-231. 1963. "Agricultural Utilization of the waters of the Santa Ynez River Basin in Southern Santa Barbara County, California", H. F. Blaney, P. R. Nixon, G. P. Lawless, and E. J. Wledmann. Processed report. Oct. 1963.

(4853) SALINITY BALANCE INVESTIGATION OF CITRUS IRRIGATION ON RESIDUAL SOILS, USING COLORADO RIVER WATER.

(b) Laboratory project, in cooperation with the U. S. Soll Conservation Service, and Riverside County (California) Flood Control D1st.

(c) Mr. Sterling Davis, Drainage Engineer, P. O. Box 629, Pomona, California.

(d) Experimental.

(e) The salinity of the soll and drainage water from this watershed is compared with total Colorado River water irrigation application plus rainfall to determine the salinity trends within a 1,000 acre watershed planted primarily to citrus orchards. Granodiorite rock underlying these solls minimizes loss of effluent to deep percolation. Bi-annual soll samplings are taken of selected sites within the watershed. Intensive investigations including flow recorders, flumes, and recording rain gages, were activated in May 1961. The program was expanded in 1962 to include sufficiently large flumes to measure winter storm runoff. The project was established as a five-year program.

(g) Preliminary observations have demonstrated the capabilities of this research technique in securing information on salinity trends on a watershed-wide basis.

(4854) EFFECT ON TILE DRATNS OF MANGANESE AND IRON SOLUBILITY IN SOILS.

(b) Laboratory project, in cooperation with the U. S. Soll Conservation Service.

(c) Mr. Luther Grass, Soll Chemist, P. O. Box 629, Pomona, Calif.

(d) Experimental.

(e) A study to determine the ability of various solls to yield ferrous or amanganous ions in drainage effluent under varying cond1tions of reduction and $\mathrm{pH}$ and to develop an index for classifying solls as to their reduction potential. Tile line deposits of manganese and ferric oxide now represent a serious threat to irrigated agriculture, particularly in the Coachella and Imperial Valleys of California. SCS and ARS technlclans have collected and forwarded soll samples from Il locations throughout the United States where this problem has been observed in agricultural drain lines. Apparatus has been set up in the laboratory to subject these reduced conditions.

(5219) WATER DISCHARGE MEASUREMENTS WITH CHEMICAL TRACERS.

(b) Laboratory project

(c) Mr. Lioyd E. Myers, Director, U. S.' Water Conservation Laboratory, Route 2 , Box 816-A, Tempe, Arizona.

(d) Experimental; applied research.

(e) Techniques and equipment for the integrated sample method of water discharge in open channels and in pipelines using fluorescent chemical tracers are belng developed.

(g) A sensitive laboratory fluorometer has been adapted for field use. Preliminary field measurements indicate that uniform mixing of tracer with water flowing in an open channel is difficult to obtain.

(5220) UNSATURATED FLOW CHARACTERISTICS OF AGRICULTURAL SOILS.

(b) Laboratory project.

c) Mr. E. J. Doering, U. S. Salinity Laboratory, 
P. 0. Box 672, Riverside, California.

(d) Experimental; basic research

(e) The objectives are (1) To develop improved techniques (in terms of effort, reliability, and time) for measuring the water transmitting properties of agricultural soils at varlous matric suction values; and (2) to determine the unsaturated flow properties of a varlety of agricultural soils. Diffusion theory and linear flow systems are beling utilized.

(g) The measurement of the unsaturated rlow properties of soll is by no means experimentally routine. However, the recent development of apparatus for accurately measuring and recording low rates of liquid flow simplifies the collection of the required outflow data.

(5221) THE ROLE OF SOIL MOISTURE IN SEMIARID RANGELAND HYDROLOGY AND SEDIMENT PRODUCTION.

(b) Laboratory project, cooperative with the Arizona and New Mexico Agricultural Experiment Stations, and the U. S. Soll Conservation Service.

(c) Dr. H.A. Schreiber, Soll scientist, P. 0. Box 3926, Tucson, Arizona.

(d) Experimental; field and laboratory.

(e) The objectives of this study are: (a) To determine the relation of soll molsture to vegetation and soll characteristics; (b) to determine and evaluate effects of soll molsture and related vegetation conditions on detention, retention, and deep penetration of rainfall; (c) to compare with the naturally occurring molsture regime the effects produced by two imposed molsture refimes on soil and vegetation characteristics relating to the hydrology and sediment production of semiarid rangelands; (d) to study the effects and interactions with soll molsture of maintaining a higher than natural level of fertility on soll and vegetation characteristics affecting the runoff net water yield, and sediment yields and forage production of semiarid rangeland watersheds.

(5222) PRECIPITATION CHARACTERISTICS AFFECTING HYDROLOGY AND SEDIMENT PRODUCTION OF SMALI AGRICULTURAL WATERSHEDS IN CENTRAL AND SOUTHERN CALIFORNIA.

(b) Laboratory project, cooperative with Tehachapi Soli Conservation District, and California Agricultural Experiment Statior.

(c) Mr. Paul R. Nixon, Agricultural Englneer P. O. Box E, Lompoc, Calif. 93438.

(d) Experimental and field investigations; basic and applied research.

(e) Objectives of this study are to develop storm time-depth-area relationships of rainfall in Central and Southern California to geographic location in the detail needed for design of flood munoff control works on agricultural watersheds of 400 square miles or less; and to characterize other precipitation parameters relating to the net water yields, flood munoff and sediment production of such watersheds.

(5223) DETERMINING THE EFFECTS ON PHYSICAL WATERSHED MODELING RELATIONSHIPS CAUSED BY MANIPULATING THE PHYSICAL PROPERTIES OF THE FLUID USED IN THE MODEL'S RAINSTORM SIMULATOR.

(b) Laboratory project, cooperative with the Engineering Experiment Station, Utah State University.

(c) Mr. D. L. Chery, Jr., Hydraulic Engineer, USU Box 229, Logan, Utah.

(d) Experimental laboratory. Applied research (also for both a master's and doctoral thesis).

(e) To determine the effect on model-prototype relationships resulting from changes in the physical properties of water-chemical mixture used in a model watershed's rainstorm simulator. Data from the model are compared with records of the prototype watershed (97-acre semiarid watershed near Albuquerque, New Mexico) to ascertain which water-chemical mixtures give the best correlation between the two. The watershed model consists of a $1: 175$ fiber glass topographical model and an automatically programmed rainstorm simulator. In the storm simulator the fluid is applied in several independent subunits by positive displacement pumps driven by variable speed D. C. electric motors. The fluid is distributed evenly over the subarea by equal length polyethylene tubing.

(h) "Description of a Watershed Model and Rainfall Simulator," D. L. Chery, Jr., Engenusu, January 1964, Utah State University, Logan, Utah.

(5224) GROUND WATER AS A FACTOR IN THE WATER BUDGET OF SEMIARID WATERSHEDS.

(b) Laboratory project, cooperative with the Arizona and New Mexico Agricultural Experiment stations, and the U. S. Soll Conservation Service.

(c) Mr. D. E. Wallace, Geologist, P. 0. Box 213, Tombstone, Arizona.

(d) Experimental, field; applied research.

(e) objective of the study is to provide information on ground water accretion and movement and aquifer-streamflow relationship as affected by surface and subsurface geologic conditions.

(g) Research will include: (1) Preparing maps and stratigraphic sections of the watershed and assoclated areas; (2) collecting cores and samples of the various materials for laboratory analysis; (3) utilizing drilling techniques and sensory methods to determine porosity, permeability, and transmissability of aquifers and valley material. Pumping tests and tracers will also be utilized in determining flow movement in subsurface strata.

(5225) HYDROLOGIC EFFECTS OF RESEEDING RANGELAND.

(b) Laboratory project, cooperative with Agricultural Experiment Stations of Arizona and New Mexico, U. S. Soll Conservation Service, local ranch owners.

(c) Mr. D. R. Klncald, Research Botanist, P. 0 . Box 3926, Tucson, Arizona.

(d) Experimental, field; applied research.

(e) Treatments comprise combinations of brush removal, soll pitting and reseeding to perennial range grasses. They are applied to replicated $6 \times 12$-foot plots, and to drainage areas up to 10 acres. Objective 1 s to investigate effects of a practical range con servation program on ylelds of water and sediment.

(g) Mean munoff from eleven storms in the summer of 1963 varied significantly among 24 untreated brush-covered $6 \times 12$-foot plots. Soll and vegetation characteristics to which the differences are due are being investigated. Indications are that microrelief, cover of erosion pavement, and cover of vegetation are the most important.

\section{(5226) DYNAMICS OF WATER AVAILABILITY TO PLANTS.}

(b) Laboratory project.

c) Dr. W. R. Gardner, U. S. Salinity Laboratory, P. O. Box 672 , Riverside, California.

(d) Experimental and theoretical; basic research. e) Principles involving uptake of water from soll by plants and subsequent loss to atmosphere are under study. A mathematical model for the soll-plant atmosphere system ha has been derived. Experiments are conducted in the greenhouse and growth chamber to test the validity of the model.

(g) The unsaturated conductivity of the soll as well as the soil suction has been shown to be important in governing water uptake by plants. The mathematical model has been extended to provide a quantitative relation between transpiration and soil molsture.

(h) "Some Observations on the Movement of Water to Plant Roots," W. R. Gardner and C. F. Ehlig. Agron. J. 54: 453-456, 1962 . 
Impedence to Water Movement in Soll and Plant," W. R. Gardner and C. F. Ehlig. Sclence 138: 522-523, 1962.

"Relation of Root Distribution to Water Uptake and Avallability", W. R. Gardner. Agron. J. 56:41-45 (1964) lilus.

"The Influence of Soll Water on Transpiration by Plants", W. R. Gardner and C. F. Ehlig. $\mathrm{J}$, of Geophys. Research $68(20): 5719-5724$, (i963) illus.

(5227) EVAPORATION OF WATER FROM FIELD SOILS IN THE PRESENCE OF A WATER TABLE.

(b) Fleld project conducted in cooperation with the Southwestem Irrigation Field station.

(c) Mr. E. J. Doering, U. S. Salinity Laboratory, P. 0. Box 672, RIverside, Calif.

(d) Experimental; basic research.

(e) The objectives are (1) To develop simplified but accurate techniques for evaluating evaporative losses from field solls, and (2) to determine the applicability of theory describing evaporation from solls in the presence of a water table to the solution of field problems.

(g) Both direct (evaporimeter) and indirect (salt accumulation and distribution) methods have been used at a fleld site in Imperial valley, California to estimate the actual evaporation rate under essentially steady flow conditions. The two methods produced comparable estimates of the evaporation rate, but greater precision of estimate was achieved by the evaporimeter methods.

(h) "A Direct Method for Measuring the Upward Flow of Water from the Water Table", E. J. Doerling. Soll Sc1. 96(3): 1.91-195 (1963) lilus. Sept. 1963 .

U. S. DEPARTMENT OF AGRICULTURE, FOREST SERVICE, Central states Forest Experiment station.

Inquiries concerning the following projects should be addressed to R. D. Lane, Director, 111 old Federal Bldg., Columbus 15, Ohio.

(3563) SUBSURFACE WATER MANAGEMENT ON NORTHERN HARDWOOD FOREST AREAS.

(b) Laboratory project.

(d) Experimental and field investigations; basic and applied research.

(e) Movement of subsoll water will be studied in various geologic and soll types to: (1) Develop techniques for quantitatively measuring subsurface water movement from small plots; (2) to learn the effect of artificial rainfall on quantity and timing of subsurface water movement; and (3) to develop a flow equation, including coefficients for the significant variables affecting that flow. This information will aid watershed technicians in making land management decisions on areas that have lots of subsurface stormflow.

(g) The upper 10 to 15 feet of a 50-foot long plot was wetted while the lower 30 to 35 feet was left dry. The subsurface movement of water down the plot lowered downslope tensiometer readings. In almost every case seepage occurred from the collection system several hours after the simulated storm started, indicating that water moved laterally beneath the surface parallel to the slope. In all storms seepage occurred only from the trough immediately overlying the water-impeding strata. Unsealed nuclear meter access tubes, installed near each group of tensiometers have served as plezometers during most of the simulated storms. The tubes terminate in heavy clay at 48 inches in the downslope tube. After pumping the water out of the tube it refilled to 1 ts former level in 30 to 40 minutes. Th1s confirms the hypothesis developed from tensiometer readings that a temporary ground water table builds up above the clay layer during heavy rainstorms. In most cases these levels have receded within 12 to 18 hours.

(4373) USE OF NUCLEAR RADIATION EQUIPMENT FOR MEASURING FOREST SOIL MOISTURE AND DENSITY.

(b) Laboratory project

d) Experimental and field investigations; basic and applied research.

(e) Some newly developed equipment, operating on the principle of nuclear radiation, facilitates the measurement of soll molsture and the soll's closely allied property--bulk density. We now have a five-plece set of this nuclear radiation equipment. We are investigating principles that will guide us in the use of this equipment.

(g) A local calibration curve developed for a surface molsture nuclear probe on forest and range land of the Central States predicts a higher soll molsture for a given impulse rate than does the curve furnished by the manufacturer. Results for the extreme conditions of water and dry soll show that the impulse rate became constant when the water depth was increased to 5 inches and the dry soll was thickened to 12 inches. If this meter is to be used on soll that is less than 12 inches thick, a separate field cal1bration should be made for that particular soll on its underlying material. The probe must be placed on a smooth, even surface when observations are being made because the impulse rate decreased rapidly as an air space or layer of unincorporated organic matter, between the probe and the surface to be measured, increased. Standardized placement procedures should be followed in order to give reproducible results. Since shallowly frozen soll gave a lower (drier) reading than the same soil when not frozen, special care should be taken to insure a good contact between the meter and the frozen soll surface, an applicable calibration curve must be developed for use when the soll is frozen. Changing the temperature of a 12-inch deep layer of water had no significant effect upon the impulse rate. However, the mean of a group of cold weather readings on the manufacturer's paraffin standard was significantly lower than that of a similar group made in the summertime. Therefore, the impulse rate computed from the direct meter readout, rather than the ratio method, should be used for converting from meter reading to a related molsture content. In October 1962, surface moisture and density nuclear meters were compared with gravimetric samples in an inventory at the ohio Power Company's stockpiled coal at a thermoelectricity generating plant. The results suggest that after careful calibration, the nuclear method could be easier and faster than the gravimetric sample method for estimating the moisture and density of the stockpiled coal. The California sand cone method and gravimetric samples secured with a post hole auger have been used for estimating the density and moisture, respectively, in previous inventories of this coal stockpile. Such measurements have been obtained from the bottom of 2 to 4 foot deep pits cut into the surface of $t$ the coal with a bulldozer.

Measurements and samples were taken from 15 such shallow pits on this coal pile on October 1962. Molsture and density nuclear meter readings were then made on a surface adjacent to that used for taking the sand cone measurement and the gravimetric sample.

The density, as determined from the 15 California sand cone measurements, ranged from 68.8 to 86.8 and averaged 79.8 pounds per cubic foot. The molsture content of the 15 gravimetric samples ranged from 5.1 to 10.2 and averaged 8.3 percent on an ovendry weight basis. The range in values for both density and molsture are relatively narrow and the nuclear probes are capable of measuring much wider ranges than these. The simple linear correlation between the surface density nuclear meter readings and 
the densities determined by the California sand cone gave a correlation coeffecient of 0.452 . This is statistically significant at about the 90 percent probability level. The correlation coeffecient between the surface moisture nuclear meter reading and the gravimetric molsture samples was only slightly higher, 0.456. This was also statistically significant at the 90 percent probability level.

Since sampling with the nuclear meters would not require that pits be opened with a bulldozer or that the samples be processed in the laboratory, it appears that this method would be a better way of sampling moisture and density of stockpiled coal. No doubt the accuracy of nuclear meter sampling can be greatly improved over that found in this study if additional calibration measurements were obtained.

(4752) THE CHARACTERISTICS OF A CONIFEROUS PLANTATION THAT ARE MOST CLOSELY RELATED TO TREE GROWTH AND TO WATER AVAILABLE FOR STREAMFLOW.

(b) Laboratory project.

(d) Experimental and field investigations; basic and applied research.

(e) This is an intensive soll-moisture study initiated to discover some basic tree stand characteristics that are closely related to tree frowth and to water available for stream flow and to develop guides for field use in managing forest plantations to obtain optimum production of wood and water.

(g) Analysis of the calibration readings on the plots of this study shows that the uniformity between plots is satisfactory. The differences between wet readings in the spring of 1962 and dry readings in the autumn of 1962 indicate that the larger treatment effects, ranging from zero to 0.6 inch of water per foot of soll, will be just detectable in the smaller difference range. These results suggest that the cutting treatments that will open the stand to different spacings may now be made and that the design will be successful in isolating treatment effects if: (1) Treatment effects are at least as large as those described above; and (2) Basic plot variability remains the same for subsequent years as it was in 1962. Trees on the plots were cut to different spacings in the auturn of 1963. Effects of the cutting on soll molsture should be apparent within the next one to two years.

(4753) FOREST RESTORATION AND WATERSHED MANAGEMENT ON STRIP MINED LANDS.

(b) Laboratory project.

(d) Experimental and field investigations; basic and applied research.

(e) Surface munoff on spoil banks, freshly formed during strip mining in the Appalachian coal fields, has a high soil erosion and sediment transport potential. This seriously affects water quality and has other deleterious effects on watersheds in which coal is harvested. It is highly desirable to establish a vegetative cover as quickly as possible after mining disturbance in order to minimize erosion and maintain water quality. The purpose of this project is to develop practical surface mining methods for the rugged, forested watersheds of the Appalachian coal field that will result in a minimum of damage to soil, water, and other resources and that will leave the mined areas in the best possible condition for restoration of these resources.

(g) Surveys of coal seams in the Harlan, Kentucky area gave an average swell factor of 1.55 for the number of observations taken but individual measurements varled over a wide range. The angle of repose was 37 degrees -- the same as for sand or gravel and clay mixtures. This varied within the limits of 34 to 40 degrees.

Using highwall height and original slope angle as independent variables, an equation was developed for predicting slope distance covered by spoll materlal.

$$
\hat{\mathrm{y}}=3.9145 \mathrm{x}_{1}+1.7342 \mathrm{x}_{2}-29.0095 \text {. }
$$

The mean disturbed width (horizontal) of the strip mines observed in this study was found to be 231 feet. On this basis, each mile of contour strip mining disturbs 28 acres: 2 acres of highwall, 16 acres of pit, and 10 acres of outslope per mile. This study has shown that the area of stripmine disturbance can be predicted if the proposed highwall height and the original slope angle are known. A useful corollary to this is that if some land use or feature downslope from a proposed strip mine limits the amount of disturbed area that can be tolerated, the allowable depth of cut or height of highwall can be computed during the planning stage. In this way, the outslope can berestricted to the desired length and the property below protected. A slight increase in the concentration of dissolved solids -- from $50 \mathrm{ppm}$ to $85 \mathrm{ppm}$-and specific conductance -- $78 \mathrm{epm}$ to 134 epm -- was observed in the non-flood stage of the stream during mining, but both decreased during the first half of 1963 after stripping ceased.

Theoreticaliy a quick temporary ground cover supported by a more permanent cover of trees should materially reduce sheet and rill erosion from the fresh spil banks. Accordingly, European alder (Alnus glutinosa) from 10 seed sources and 7 other species of alder were tried on some eastern Kentucky spoil banks.

Weeping love grass, crabgrass, and Kentucky 31 fescue seeded in the spring germinated and appeared to be well established after one growing season. Brown mustard germinated, but quickly died out. Crown vetch had low germination and grew slowly. Summer seeded species: German millet, sudan grass, Kentucky 31 fescue, grain sorglium, and crabgrass had low germination and developed slowly.

U. S. DEPARTMENT OF AGRICULTURE, FOREST SERVICE, Intermountain Forest and Range Experiment Station, Ogden, Utah.

Inquires concerning projects should be addressed to Mr. Joseph F. Pechanec, Director, Intermountain Forest and Range Experiment Station, Ogden, Utah.

\section{(4992) CONTROLLING EROSION FROM LOGGING SKIDTRAILS.}

(b) Laboratory project.

(d) Experimental and field investigations; applied reseárch.

(e) A 5-year field test of the efficlency of different types of mechanical structures in stabilizing and controlling erosion on skidtrails.

(f) Completed.

(g) Erosion measurements on 569 intervals of 105 logging skidtrails revealed the following: (1) Erosion is greater and rate of healing is slower on soil derived from granite than on soil derived from basalt; (2) More soll is eroded from skidtralls unavoldably located in ravine bottoms than from trails on sidehills; (3) Control structures that divert water off the skidtrail onto undisturbed forest floors are superior to those that only retard water movement and filter out sediment along the skidtrail; (4) Any increase in spacing between control structures is accompanied by increase in soil movement; and (5) optimum spacing between erosion control structures depends upon the percent of slope, whether location of the skidtrail is on a sidehill or in a ravine, and the soll parent material. "So1l Erosion Control Structures on Skidtrails," W. J. Kidd, Jr., Intermountain Forest and Range Expt. Sta., Ogden, Utah. 8 pp., 1llus. 1963. (U. S. Forest Service Res. Paper INT-1). Copies avallable upon 
request to station Director.

(4993) SOME SNOWMELT CHARACTERISTICS OF A WESTERN WHITE PINE FOREST.

(b) Laboratory project.

(d) Experimental and field investigations; basic and applied research.

(e) A study of 4 -year's data to determine effects of climatic and site factors on snowmelt characteristics in a western white pine forest.

(f) Completed.

g) Average daily snowmelt in the spring months was 0.42 inch. The increase in average snowmelt rate with the delay in the time at which melting began, reflects the effect of warmer temperatures as the spring season progressed. When other studied factors were held constant, average da1ly snowmelt rate increased with increasing elevation. A greater snow accumulation at high elevations left more snow subject to warm temperatures in late spring. Snowmelt rate 1 ncreased as the forest canopy density decreased. Maximum snowmelt rates occurred on southwest exposures; minimum snowmelt rates were on northerly exposures.

(4994) EFFECTS OF TOPOGRAPHIC AND CLIMATIC FACTORS ON FREE-WATER EVAPORATION IN MOUNTAINOUS TERRA IN.

(b) Laboratory project.

(d) Experimental and field investigations; basic and applied research

(e) An investigation of evaporation rates in mountainous terrain in northern Utah is being conducted with a speclaliy designed network of 13 weather Bureau Class A evaporation stations at elevations ranging from 4,400 to 9,000 feet. The investigation seeks to determine the effects of elevation, topography, and exposure on evaporation.

(g) Preliminary results indicate that meteorological and topographic parameters can be correlated with evaporation rates for different locations on a dally basis. Conclusions concerning the degree that evaporation can be explained by these parameters will have to awalt completion of the study.

Maximum daily rates of evaporation in 1962 from these 13 sites varied from 0.33 to 0.57 inch, and maximum hourly rates on selected days ranged from 0.018 to 0.040 inch. Of the several variables affecting evaporation, wind appears to be the dominant meteorologlcal factor.

(h) "Evaporation Rates in Mounta1nous Terrain," 1963, Eugene L. Peck and Dale J. Pfankuch. I.A.S.H. Com. for Evaporation, Pub. No. 62 , pp. 267-278. Coples avallable upon request to Station Director.

U. S. DEPARTNENT OF AGRICULTURE, FOREST SERVICE, Lake States Forest Experiment Station.

Inquirles concerning the following projects should be addressed to the Director, Lake states Forest Experiment Station, St. Paul Campus, University of Minnesota, St. Paul, Minn., 55101, unless Indicated otherwise for a specific project.

(3887) WATERSHED MANAGEMENT RESEARCH IN NORTHERN MINNESOTA.

(b) Laboratory project.

(d) Experimental and field investigations; basic and applied research.

(e) Tests the influence of forested bogs on streamflow and groundwater behavior. Bive major projects have been undertaken to date: 1) Studies of the effect of forest cover conditions on individual hydrologic processes. This has included the impact of soll-cover types on snow accumulation and melt, soll freezing, and moisture regime.
2) Studies of forest bog hydrology on flve small forested swamp watersheds. Present instrumentation includes a recording well and a serles of 9 to 12 nonrecording wells in each of 5 bogs, plus several upland wells in adjacent mineral soll. Involved are a total of 5 recording wells and 52 nonrecording wells. Four swamp watersheds have been equipped with stream-gaging stations, 1nvolving two 120 degree $\mathrm{V}$-notch weirs and three "H" flumes. (3) Laboratory and field studies to evaluate the hydrologic and physical characteristics of peat solls. Moisture characteristics of undisturbed peat cores have been determined with speclally bullt pressure cells. The hydraulic conductivity of several peat materials is being tested using fleld piezometer and laboratory techniques. (4) A study of four bottomless rleld lysimeters to evaluate evapotranspiration from peat lands under forest and nonforest wildland conditions. These are 10-foot-diameter, sheet metal cylinders, 3 feet in height, driven into the soll about 18 inches, or deep enough to reach rather impermeable peats. (5) A classification of peat lands from a watershed management viewpoint.

(g) Results to date on 22 in-situ tests of permeablilty of peats by the auger-hole method indicate that hydraulic conductivity of four classes of peats studied to date range from $1.58 \times 10^{-3}$ for moss peats to $8.52 \times 10^{-6}$ for aggregated peat, with woody and herbaceous peats being between these two values. The hydraulic conductivity found in the above fleld tests were somewhat lower than those observed in laboratory tests run on 36 cores of peat about 4 inches in diameter and 4 inches high. The rate of water loss in early August from a forested plot in terms of inches per day in bottomless lysimeters agrees closely with a similar situation in an entire bog where table fluctuations were observed by means of wells and also with potential evapotranspiration calculated by the Thornthwalte method. The rise in water table level in the denser, well-decomposed peat 1 s around 12 inches per inch of precipitation, while in low density sphagnum peat moss the water table rise was only about 2 inches per inch of prec1p1tation.

Stream flow records from four swampland watersheds during the first full year of record showed that 65 to 85 percent of the total annual runoff occurred in a 2 -month perlod in the spring.

(h) "Forest Soll Freezing and the Influence of Management Practices, Northern Minnesota," SIdney Weitzman and Roger R. Bay. U.S. Forest Serv. Res. Paper LS-2, 8 pp., tbls., 1963.

"Management Practices can Affect Freezing of Soll," S1dney Weltzman and Roger R. Bay. Forest World 2(4): 41-43, 1963

"A Review of Forest Swamp Drainage Methods in Northern Europe." J. H. Stoeckeler. Jour. For. 61: 99-104, 11lus. 1963.

(3889) WATERSHED MANAGEMENT RESEARCH IN THE DRIFTLESS AREA OF SOUTHWESTERN WISCONSIN .

(b) Laboratory project, with some aspects in cooperation with Wisconsin Conservation Dept.

(d) Field investigations; basic and applied research.

(e) Major emphasis is given to methods of controlling runoff and erosion, including gully stabilization through reforestation, and other land-use treatments. Studies of infiltration, soll freezing, soll-molsture movement, and storage on loessal solls under the impact of grazing and other uses are underway including coniferous versus broadleaf tree plantings. The effect of land use and land treatments on springflow continues to be investigated. A total of 35 water-measuring devices have been installed on watersheds rangling from about 2 to 55 
acres in area. The devices 1nclude 90-degree $V$-notch weirs, modifled 2-foot San Dimas flumes, and several sizes of $\mathrm{H}-f l u m e s$. All are equipped with recording instruments. Of the above devices, four are at springs with permanent flow. A total of about 35 wells up to 100 feet deep have been drilled above 4 springs in an attempt to locate the water table divide.

(g) Studies of soll molsture with the neutron meter revealed that water was released from the snowpack with only brief rises of temperature above the melting point and that this water infiltrated and percolated through 3 feet of frozen ground. Mo1sture content of the frozen proflles changed frequently as a result of water movement into and out of the profile.

Closely spaced wells were installed to determine the actual elevation of the water table to topographic surface of the land. Preliminary data indicate that the absolute elevation of the water table $1 \mathrm{~s}$ higher in the valleys than under ridges. Should this be generally true in the Driftless Area, it would raise considerable question as to aspects of determination of true watershed boundarles.

Runoff studies of dual-use watersheds (1.e., partly in farmland on gently sloping ridgetops and with timber cover on the steeper land below) Indicate that of 35 storms that produced munoff from farmed uplands on 3 gaged watersheds, only 3 storms produced runoff at the bottom of the wooded slopes. Apparently the higher infiltration rate of the solls in the steeper wooded part of the watershed accounts for absorption of much of the runoff.

(h) "Flow Characteristics of Two Types of Springs in Southwestern W1sconsin," Willie R. Curtis. U.S. For. Serv. Res. Note LS-1, 2 pp., 11lus., 1963.

"Tool for Editing Analog-to-Digital Tapes," Willie R. Curtis. Jour. Soll and Water Conserv. 17: 254, 11lus., 1962.

"Device for Automatically starting a

Recording Rain Gage when Rainfall Begins," Willie R. Curtis. U.S. For. Serv. Res. Note LS-3, 3 pp., 1lius., 1963.

(3890) WATERSHED MANAGEMENT RESEARCH IN LOWER MICH IGAN

(b) Laboratory project.

(d) Fleld Investigation; basic and applied research.

(e) Two major projects have been undertaken to date: 1) A major study is designed to determine the hydrology of ground-water recharge and consumption in deep sandy solls of the Udell Hills area in Michigan. Installations to date include a series of 114 ground-water wells in deep morainal areas and adjoining outwash plains; of these, 8 have automatic recorders. After the callbration period, the effect of cover manipulation -- especially plantation establishment and harvesting methods -- on ground-water recharge and use will be established. A second major study is concerned with streambank stabllization and the sediment problem in streams flowing through these sandy areas. Major objectives of this study are (a) to determine the influence of land use upon sediment production, and (b) to evaluate the effect of streambank stab1l1zation measures upon suspended sediment loads. A total of 20 sampling stations have been establ1shed on 11 streams. A new aspect of the study on streambank stab1l1zation 1ncludes tests of rock riprap at or near the waterline and planting brush species above it. Upperbank treatments also Include seeding and fertilizing plus various chemical mulch applications.

(g) Fieldwork was completed in summer 1963 using two geophysical exploration techniques to describe the water-table depths and aquifer thickness in the upper morainal portion of the Udell Experimental Forest near wellston, Mich. Major emphasis has been placed on the use of selsmic refraction methods. Electrical resistivity measurements were also taken along the same transects as the seismic profiles. The results, as yet in a preliminary stage of analysis, indicate that large portions of the Udell ground water basin have sand aquifer thickness of 100 feet or more, and that the selsmic velocity constants through unsaturated sands remalned rather constant at about 1200 fps. at depths below 10 feet. Studies of actual ground water elevations in relation to surface topography in this area show that there was a general conformity of slope between the water table and the ground surface, but the water-table gradient was much subdued.

Hydrograph records of water-table behavior show a total annual ground water recharge for 1962 of 8.9 Inches under red maple-aspen type and 6.4 inches under plne, indicating that alteration of the cover type has an effect hydrologlcally.

U. S. DEPARTMENT OF AGRICULTURE, FOREST SERVICE, Northeastern Forest Experiment Station.

Inquiries concerning the following projects should be addressed to Dr. Ralph W. Marquis, Director, Northeastern Forest Experiment Station, 102 Motors Avenue, Upper Darby, Pennsylvania.

(1188) WATERSHED MANAGEMENT RESEARCH, FERNOW EXPERIMENTAL FOREST, WEST VIRGINIA.

(b) Laboratory project

(d) Fleld investigation; basic and applied research.

(e) Studies were started In 1951 on the Fernow Experimental Forest, Tucker county, W. Va. to determine the effect of different levels of cutting practices, different logging methods, and different forest uses upon water quantity and quality. Nine watersheds have been equipped with streamgaging stations and rain-gages.

(g) Increases in streamflow from forest cutting disappear rapidly with regrowth of vegetation; growing season increases in a commerclal clearcut watershed dropped from 4.4 inches in 1958 to 0.2 inches in 1961. watersheds less heav1ly cut over showed similar trends. Suspended sediment from erosion was greatest during and Immediately after the logging operation. Average turbidity during the logging operation on the commerclal clearcut watershed was 490 p.p.m., the first year after logging, 38 , and the second year, 1 . The rapld decrease was due to formation of erosion pavement on the sediment-source areas, and regrowth of vegetation. Following clearcutting the average maximum water temperature was $8^{\circ} \mathrm{F}$ higher than on the uncut watershed. Temperature of $75-79^{\circ} \mathrm{F}$, observed several times, would probably eliminate brook trout.

Assuming that average annual increase in water yleld of 5.3 inches could be malntained by clearcutting and perlodic spraying to $\mathrm{klll}$ small trees and low vegetation, based on cost of spraying and loss in timber income, the cost for the increase in streamflow would be an estimated 4 cents per 1,000 gallons.

(h) "Effect on Streamflow of Four Forest Practices in the Mountalns of West V1rginia," K. G. Relnhart, A. R. Eschner, G. R. Trimble, Jr. Northeast. Forest Expt. Sta. $79 \mathrm{pp}$. , 1lius. (U.S. Forest Service Res. Paper NE-1). "Cutting the Forest to Increase Water Y1elds, G. R. Trimble, Jr., K. G. Relnhart, Henry H. webster. Jour. Forestry 61: 635-640, 1963. "Logging and Trout: Four Experimental Forest Practices and their Effect on water Qual1ty, "Arthur R. Eschner and Jack Larmoyeux. 1963. 
(2419) WATERSHED MANAGEMENT RESEARCH, HUBBARD BROOK EXPERIMENTAL FOREST, NEW HAMP SHIRE.

(b) Laboratory project.

(d) Field investigation; basic and applied rese arch.

(e) The objective is to determine the effect of forest type, condition, and treatment on quantity and quality of streamflow. Studies are conducted in plots and experimental watersheds on the 7500-acre experimental forest in the White Mountains at west Thornton, New Hampshire. Seven weirs have been built and climatic stations established.

(g) In the winter of 1959-60, the maximum snow depth in white pine and red pine plantations was about $2 l$ inches and in the open and in hardwood stands about 26 inches: Melt rate was $0.10,0.05$, and 0.04 inches per degreeday over $32^{\circ} \mathrm{F}$ for the hardwood, red pine, and white pine respectively. Concrete frost was extensive in the open field and under white pine. Temperature readings above a snowpack, in the snow, and in the soil beneath indicated that no soil freeze will occur under 18 inches of snow with a1r temperatures as $10 \mathrm{w}$ as $4^{\circ} \mathrm{F}$.

clearcutting experimental watersheds exposes precipitation gages to much greater wind movement and can reduce annual catch by 3 to 6 percent. Windshields should be employed when a heavy cutting treatment is planned. In the East tilted gages have not given the increased catches that have been reported in the West probably due to their exposure in relation to wind direction and to surrounding protective forest cover.

(h) "Snow and Frost Conditions in New Hampshire, Under Hardwoods and Pines and in the Open," George Hart. Jour. Forestry 61: 287-289. "Some Relationships Among Air, Snow, and Soll Temperatures and Soll Frost," George Hart and Howard W. Lull. Northeast. Forest Expt. Sta., 4 pp., 1llus. (U. S. Forest Serv. Res. Note NE-3) "Some Observations on Precipitation Measurements on Forested Experimental Watersheds," Raymond E. Leonard, Kenneth G. Reinhart. Northeast. Forest Expt. Sta., 4 pp. (U.S. Forest Service Res. Note NE-6).

(2910) WATERSHED MANAGEMENT RESEARCH, LEADING RIDGE WATERSHED, PENNSYLVANIA.

(b) Laboratory project, in cooperation with the School of Forestry, Pa. State Univ. and the Pennsylvania Dept. of Forests and Waters.

(d) Field investigation; basic and applied research.

(e) A cooperative study was started in 1957 to determine the effect of forest cover and treatment on quantity and quality of streamflow in the oak-nickory type in Pennsylvania, and to study associated and basic soll-water relationships.

(g) Six experimental watersheds have been selected weirs have been constmucted, and climatic stations established.

(3567) WATERSHED MANAGEMENT RESEARCH, BALTIMORE WATERSHEDS, BALTIMORE, MARYLAND.

(b) Laboratory project in cooperation with the Baltimore Bureau of Water Supply.

(d) Field investigation; basic and applied research.

(e) A cooperative study started in 1958 to determine effect of growth of loblolly and white pine in plantations on streamflow, and to compare streamflow from watersheds in conifer plantations with streamflow from a hardwood-forest watershed. Streamflow of three experimental watersheds is being measured and a climatic station has been established.

(g) An inexpensive weir to gage small streams was built of wood and lined with a sheet of vinyl film. The cost was about $\$ 850$ and the weir is expected to last 5 to 10 years without repair. (h) "A Vinyl-Line weir for Small watershed Studies," Irvin C. Reigner. Jour. Forestry 61: $297-8,1963$.

(3568) WATERSHED MANAGEMENT RESEARCH, NEWARK WATERSHEDS, NEWFOUNDLAND, N.J.

(b) Laboratory project in cooperation with the Division of Water Supply of the City of Newark, N. J..., New foundland, N. J .

(d) Field investigation; basic and applied research.

(e) A cooperative study to determine the influence of selected treatments of forested municipal watersheds on water supply.

(g) Weirs on 3 experimental watersheds were built in the fall of 1958 and stream gaging and climatic measurements were started in the spring of 1959.

(4756) WATERSHED MANAGEMENT RESEARCH, SYRACUSE UNIVERSITY, NEW YORK.

(b) Laboratory project, in cooperation with the State University College of Forestry at Syracuse University, Syracuse, New York.

(d) Field investigation; basic and applied research.

(e) This cooperative project was started in 1961 to determine quantitative relationships of forest types and stand conditions to the amount, timing, and quality of streamflow in the Adirondacks, the glaciated Appalachian Plateau, and the Catskills.

(g) A problem analysis has been completed and 2 studies initiated: a study of snow deposition and melt under different forest types and densities in the Appalachian Plateau, and a study of long-time trends in water yield from an Adirondack watershed to forest conditions.

(h) "Forest Watershed Management in New York," D. R. Satterlund, A. R. Eschner. State Univ. College of Forestry at Syracuse Univ., Bull. 46, 32 pp., illus. 1963.

U. S. DEPARTMENT OF AGRICULTURE, FOREST SERVICE, Northern Forest Experiment Station.

Inquiries concerning the following projects should be addressed to Mr. Richard M. Hurd, Director, Northern Forest Experiment Station, 210 Admiral Way, Juneau, Alaska 99801 .

(2654) EFFECT OF LOGGING ON PHYSICAL CHARACTERISTICS OF SALMON STREAMS IN SOUTHEAST ALASKA.

(b) Laboratory.

d) Field investigation, applied.

(e) This work is concerned with the relationships between salmon spawning streams and timber harvesting in Southeast Alaska. Work is concentrated on 3 streams lying 40 miles west of Ketchikan. Two of the watersheds have been logged. The third watershed will ramain unlogged.

Study is concentrated on factors which can exert a major influence on pink and chum salmon development and survival in a logged stream. During 1963 measurements or samples were taken of: 1) stream discharges; 2) stream temperatures; 3) stream channel shift; 4) stream debris occurrence and movement; 5) suspended sediment levels in streams.

(4995) EFFECT OF LOGS AND DEBRIS IN LIMITING SALMONPRODUCING STREAMBED AREA IN A SOUTHEAST ALASKA STREAM

(b) Laboratory.

d Field investigation, theoretical; applied.

(e) Work was undertaken to explore efrects of log-debris pools in limiting effective salmon spawning area in a southeast Alaska stream. Special emphasis was placed on the role of pools (log-debris caused or otherwise) in shaping a stream's profile. 
The effect of profile on stream velocities during salmon spawning conditions was examined by using Manning's velocity formula,

$$
v=\frac{1.486}{n}\left(s^{\frac{1}{2}}\right)\left(r^{2 / 3}\right) \text {. }
$$

Th1s involved measurement of roughness coefflclents $(n)$ for the study stream. Flow velocity conditions were then estimated for component lengths of streambed models incorporating pools. The ability of pink salmon to ut1lize the model proflle was rated.

(r) Completed.

(g) Pools, elther log-debris caused or otherwise, form a significant loss of product1ve streambed spawning area when the general gradient is sultable. This loss can be much enlarged when pool associations are viewed in profile. There 1 s an advantage in salmon streams which have relatively long 1ntervals between pool structures, provided the overall stream gradient does not closely approach or exceed usable gradlent. In cases where overall stream gradient exceeds usable gradient, pool structures in the streambed can only be benef1cial.

Low stream stages should favor spawning on steeper gradients, and conversely higher stages should favor spawning on milder gradients. Usable gradient limits should also increase with roughness of the stream bottom.

U. S. DEPARTMENT OF AGRICULTURE, FOREST SERVICE, Pac1f1c Northwest Forest and Range Expt. Station.

Inquiries concerning the following projects should be addressed to Mr. Ph1l1p A. Brlegleb, Director, Pac1f1c Northwest Forest and Range Expt. Sta., P. 0. Box 3141, Portland, Oregon, 97208.

\section{(4757) WATER YIELD AND EROSION, WENATCHEE, WASH.}

(b) Laboratory project.

(d) Field 1nvestigations; basic and applied research.

(e) Field studies in ponderosa pine and mixedconffer forests and forest-ranges on the east slopes of the Cascade Range in oregon and Washington: Erosion in forests and ranges: (1) Sediment production from Swauk sandstone-ponderosa pine; (2) sediment production from grazed p1ne-f $1 \mathrm{r}-\mathrm{larch}$ ranges, Blue Mountains; (3) stimulation of seeded and natural grass cover by fertilization Swauk sandstone solls; (4) relation of parent materlal and vegetative cover to organic matter, aggregation, pH, and bulk density of forest-range solis - eastem Washington; (5) effect of climate on development of solls from 1dentical parent rock. Evapotranspitation: Includes studies with the overall objective of measuring factors which affect distribution and use of water in forests and related ranges: (1) Measurement of solar energy in a pine forest; (2) seasonal changes in so1l molsture under a lodgepole plne forest; (3) measurements of molsture use by plants; (4) effect of removing bursh and tree growth in three experimental watersheds on water yleld (Ent1at watershed study, in callbration stage -- no treatment yet applied); (5) water-holding capacity and drying rates for humus types characteristic of ponderosa pine-Douglas-fir forests - east side of the Cascade Range.

(g) Solls formed from basalt, sandstone, and granodiorite have been sampled at three horizon depths in relatively undisturbed sites with elther grass or forest cover. Properties measured were aggregat1on, bulk density, organic matter, pH, total porosity, and percents of clay, silt, and sand. These properties were not significantly influenced by cover dif ferences in the samples measured. Mean size of water-stable aggregates was used as an Index of erodibility. Over 40 percent of 1ts varlability was accounted for by multiple variation in organic matter content, $\mathrm{pH}$, total porosity, and bulk density. A pattern of Increasing soll erosion hazard appears to be assoclated with increasing soll depth for solls developed from all three parent materials. Quant1ty of soll organic matter is apparently a very important factor in maintaining stable soll conditions.

Sandstone solls formed from very similar parent materials in eastern and western Washington show a significant influence of climate on several so1l properties. Molsture equivalent, permanent wilting mo1sture percent, and total porosity were all found signiflcantly different. Erodibility, as measured in grams of soil moved by artificial rainfall was also significantly different.

(h) "Vegetat1ve Manipulation for Controlled Water Supply," by Earl G. Dunford, Oregon State Un1versity-Soclety of Amer. Foresters Symposium Proc., pp. 77-87. March 1963.

\section{(4758) WATERSHED LOGGING METHODS AND STREAMFLOW.}

(b) Laboratory project with some phases in cooperation with C1ty of Portland, Bureau of Water Works and Oregon State University.

(d) Fleld investigations; basic and applied research.

(e) Research is conducted at three fleld locations in the Cascade Range of western oregon: Bull Run watershed (domest1c supply area for Portland), H. J. Andrews Exper1mental Forest, and South Umpqua Experimental Forest. Studies are confined to two forest types representing major segments of the remaining old-growth forests of the Pacific Northwest: (1) Douglas-f1r, western hemlock, western redcedar, and (2) Douglasf1r, sugar p1ne. Investigations represent an initial effort to study precipitation runoff, erosion, and soll molsture in undisturbed stands, and to follow changes caused by several methods of logging.

Included are studies in four categories: (1) So11 movement on logged land and an evaluation of effectiveness of grass seeding on roadbanks; (2) changes in water quality resulting from roadbullding, two methods of cable logging, two degrees of forest removal - 25 percent and 100 percent .- and slash burning; (3) changes in streamflow caused by clear cutting and partial cutting in groups of varying size on matched watersheds in old-growth Douglas-fir and sugar pine-fir. pretreatment measurements are st1ll being made to provide statistical basis for treatment evaluation; (4) soll molsture movement and disposition and the role of vegetation in evapotranspiration, including measure of seasonal changes in soil molsture under a Douglas-f1r stand, vertical movement of water in Douglas-fir so1ls, rainfall interception by crowns of old-growth Douglasfir solis, rainfall interception by crowns of old-growth Douglas-f1r, and changes in plant succession following logging and slash burning.

(g) Effect of timber cutting on soll mo1sture use was studied in the Bull Run watershed, source of municlpal water for Portland, Oregon. Samples show that removal of old-growth Douglas-fir results in lower soil molsture depletion during the growing season and accelerated recharge of the soll mantle w1th the beginning of fall rains. Accuracy of such soll molsture determinations is dependent on density of vegetation and depth of sampling. During the period of growth, soll molsture sampling variation was smaller in nonlogged areas than in clear-cut areas, where vegetative cover was drasticaliy reduced. Varlation tended to be lower in samples obtained from the deeper portions of the soll profile.

After constructing 1.65 miles of road in a 250-acre experimental watershed, mnoff from the first rainstorms carried 250 times the sediment concentrations measured in an 
adjacent undisturbed watershed. Two months later, sediment levels had diminished to levels slightly above those measured before construction. However, disturbance caused by the road construction appears at least partlally responsible for several slides that have taken place in the watershed. The largest of these resulted in a massive movement of debris which scoured a 3,000-ft. section of streambed and deposited over 5,000 cublc yards of sediment in debris jams downstream. Roads were not in use during the period of measurement; the experiment was designed to examine the effects of construction only. Statistical analysis of suspended sediment data indicate that sed1ment concentrations are significantly related to volume of stream discharge, rates of increase in discharge, and elapsed time since construction.

Another analysis shows that experimental watersheds can be calibrated in $1-3$ years by comparing their reaction to storms. Varlables used include: (1) rise-in-stage from beginning of storm to 1ts peak; (2) elapsed time for this occurrence. Regression of one watershed on another is determined separately for the two varlables. Existence of a treatment effect can be demonstrated by the proposed method. Quantitative evaluation of the treatment must be determined in the usual manner by summing discharge for the period of interest.

(h) "Mud, Rock, and Debrls Sl1de on an Exper1mental Watershed," by R. L. Fredriksen. Pac. NW. Forest \& Range Expt. Sta. Res. Note PNW-1, January 1963.

"So11. Molsture Sampling Varlation as Affected by Vegetation and Depth of Sampling, " by Nedavia Bethlahmy. So1l Sc1. Vol. 95(3): 211-213, March 1963.

"Effects of Burning on So11," by C. T. Dyrness. Forest-Watershed Sympos. Proc., Oregon State University, pp. 291-304, March 28, 1963.

"Rapid Calibration of Watersheds for Hydrologic Studies," by Nedavia Bethlahmy. Internatl. Assoc. Sc1. Hydrol. Bull. VIII(3): 38-42, Sept. 1963 .

U. S. DEPARTMENT OF AGRICULTURE, FOREST SERVICE, Pac1fic Southwest Forest and Range Experiment Station.

(4996) WATERSHED MANAGEMENT RESEARCH IN CALIFORNIA'S SNOW ZONE (SNOW MANAGEMENT RESEARCH).

(b) Laboratory and the following cooperators: State of California, Dept. of Water Resources, Atomic Energy Commission, and Pacific Gas \& Electric Company.

(c) Dr. James L. Smith, Project Leader, Snow Management Research, Paciflc Southwest Forest \& Range Experiment Station, 1960 Addison Street, Berkeley 1, California.

(d) Experimental; field investigations; basic and applied research.

(e) The objective of this project is to determine methodology for increasing water yield and changling of timing of water delivery by vegetation manipulation, by evaporation suppressants, etc. Its area of interest is confined to the snowpack zone of the sierra Nevada of Californla. Present studies emphasize development of methods for management of high elevation snowpacks for yleld and control of water; the effects of timber cutting upon soll molsture losses and snow accumulation and melt; and the evapotransp1ration from various sites -- species combinations.

Project sclentists are located in Berkeley with field personnel and studies located at the Central. Sierra Snow Laboratory, Soda Springs, Califormia, and the Teakettle Experimental Forest in the headwaters of the north fork of the Kings RIver above Fresno, California. Both sites lie at 6000 7000 feet elevation. At the Teakettle Experimental Forest four small watersheds
(0.27-0.86 square miles in area) are under study prior to installation of $10 \mathrm{~g}$ roads and a timber harvest to determine their effects upon water yleld and sediment. At the Central S1erra Snow Laboratory seven small watersheds are gaged for the study of logging effects and riparian treatment upon water yield. In the headwaters of the Feather RIver a practical sized logging is being tested for snow accumulation and melt effects. Gamma and neutron probes are belng tested for measuring hydrologic characteristics of snowpacks. Evaporation suppressants are belng tested for reduction of such losses from snowpacks.

(g) Rapld measurement of hydrologic characterIstics of snowpack which may permit more accurate appraisal and prediction of delivery of snowmelt water may be possible using gamma and neutron probes. Commercially available probes with gamma and neutron sources (Nuclear-Ch1cago, $\mathrm{P}-20$ and $\mathrm{P}-19$ probes) were tested for the ability to measure snow density, 1ce lenses, and the thermal quality (free water) of the individual layers in the snowpack. Usable regresslons of snow density (D) at each depth, measured gravimetrically and with neutron counts $(\mathrm{Cn})$ and gamma counts $(\mathrm{Cg})$ In CPM in the snowpack were obtalned. Ice lenses in the snow were readily detectable by shifts in the neutron probe counts; neutron counts would increase markedly at the occurrence of $1 \mathrm{ce}$; gamma counts were only slightly affected. In a study of changes in the thermal quality of snowpack throughout the day and from day to day, neutron counts were directly related to the percentage of 1 ce in the snow, as contrasted with free water.

Summer soll molsture losses and winter surface evaporation from snowpack at high elevation sites were reduced by the addition of the suppressant hexadecanol. Hexadecanol was applied to the soll surface of $1 / 15$ acre plots of bare soll, brush, and red $\mathrm{flr}$ forest. The hexadecanol was applied to 17 natural sites, the applications being at rates of 35,130 , and 680 pounds per acre. In fully vegetated sites of red fir and natural brush, indicated reductions in the loss were small, ranging from 0.2 to 0.3 Inches for the total summer. At sites where vegetation had been removed by bull. dozing or in which natural bare ground occurred, reduction in evaporation of treated sites was 0.3 to 1.0 inch. Application of hexadecanol to the snow surface decreased evaporation by as much as 50 percent. Without the hexadecanol, the evaporation rates ranged from 0.012 to 0.039 inch per day; with 20 to 30 pounds per acre of hexadecanol, the rates were 0.006 to 0.016 per day. Measurements of evaporation from snow under varlous topographic and forest conditions for the years 1958-1.960, were summarlzed and evaporation for the Castle Creek watershed, elevation 7,500 feet, was computed. Evaporation ranged from 0.5 inch under dense forest on the valley floor to 3.1 inches in large openings on exposed ridges. Average evaporation for the four square mile castle Creek Basin was computed as 2.0 inches depth. Average annual precipitation for Castle Creek is 74 inches per year, so snow evaporation is about 2.7 percent of total precipitation.

(h) "Evaporative Loss From Soll, Nat1ve Vegetation, and Snow as Affected by Hexadecanol," by Henry $W$. Anderson, Allan J. West, Robert R. Ziemer, and Frankiln R. Adams, Internat. Assoc. Sc1. Hydrol. Publ. No. 62, pp. 7-12, 1963.

"Use of Radioactive Sources in Measuring Characteristics of Snowpacks," by Henry $W$. Anderson, Philip M. McDonald, and Lloyd W. Gay, U.S. Forest Serv. Res. Note PSW-1l, 9 pp., 1963. 
(b) Laboratory project. Cooperators are: State of Callformia, Department of Water Resources; University of Califormia; State of Hawail, Division of Forestry.

(c) Mr. Henry W. Anderson, Project Leader, Pacific Southwest Forest and Range Experiment Station, P. O. Box 245, Berkeley 1, California.

(d) Experimental and theoretical; basic and applied research.

(e) The objective is through analytical modeling to advance the state of knowledge of watershed hydrology and sedimentation, and particularly, knowledge of the relationship of watershed management and other hydrologic processes at the water sources to water yleld, floods, sedimentation, and water quality delivered from w1ldland watersheds.

(g) The relation of some soll characteristics to soll-forming factors at high elevation wildland sites was determined from soil samples taken at 208 places in the teakettle Experimental Forest (elevation, 6,700 to 8,000 feet.) The relation of soll texture, organic matter, Middleton's dispersion ratio and Anderson's soll-aggregation ratio to rocktype, cover type, aspect, elevation and slope was determined by multiple regression analysis. First results showed that solis developed from olivine basalt were less erodible than solls developed from quartzite and granodiorite. F1r solls were less erodible than those under pine, brush, and grass cover types. Soils developed under grass on basalt at these high elevation sites, however, were the least erodible solls. Solls on the east aspects tended to be less erodible than on the north, south, and west aspects. Texture variations were significantly related to both elevation and slope-- in that particles larger than sand size and total clay decreased with elevation; correspondingly, sand increased with

elevation. Sand did not correlate with slope, but particles larger than sand and total clay decreased with an increase in slope. Erodibility tests showed that these higher solls were approximately 2.7 times more erodible than solls formed on similar rock types and similar sites at lower $(1,000$ to 4,000 foot) elevations.

Studies of 258 soll samples all collected on 20 percent west slopes, throughout northerm California showed marked relationship of soll characteristics to climate, as well as to rock type. Soll erodibility (the soll. aggregation ratio) was found to vary widely within the single group of acid igneous rocks as well as among major divisions of geologic rock types. Solls developed on granite and rhyolite had erodibilities more than twice that of solls developed on diorite. Solis on quartzdiorite and on granodiorite were intermediate. The dispersion ratio of solls was found to be related to the temperature at the site, expressed as the dissoclation constant of water at the mean monthly temperature at the site. The surfaceaggregation ratio of the soll was found to be related to a quadratic expression of the amount of precipitation, the dissociation constant of water for that precipitation at the temperature of the site, and their joint products.

Analytical studies of watershed channel, patterns and characteristics suggest that channel bifurcation ratios and channel length ratios are largely the result of the definition of stream order numbers; however, the slope ratio of watersheds appears to be a valid expression of slopes in the watersheds. Mean path length after Busby and Benson (International Association of Scientific Hydrology 20: $32-36,1960)$, together with the second, and perhaps third and fourth moment of the distribution of path lengths appear to be promising measures of watershed shape. Computer programs to simplify computation of soil texture, distributions and erodibility, watershed equivalent plane and orientation, and area-elevation distributions have been developed.
Soll sampling in a study of erodibility of Hawall wildland soils was completed during the summer of 1963. Seventy-five sampling sites ( 365 individual soil samples) were selected along 26 transects of the Walanae and Koolau Mountain Ranges on Oahu. The solls were sampled under tree, shrub, or grass cover under varying precipitation aspect, and slope conditions. The parent materlals of the watershed solls are mainly basaltic flows, pyroclastic deposits, or other detrital materials.

The solls aggregate stability was tested by the wet sieving technique using aggregates initially passed through a $7.93 \mathrm{~mm}$ sleve, and the results expressed as mean welghtdiameters or percent distribution of certain aggregate sizes.

An inspection of our limited preliminary data shows the following results: (1) on some transects mean welght-diameters appear to increase with increasing rainfall with a decrease in aggregates smaller than $0.50 \mathrm{~mm}$. on other transects there is no apparent change in mean we1ght-diameter but there is an increase in aggregates less than $0.50 \mathrm{~mm}$ in size; while on other transects we find a decrease in mean welght-diameter with increasing rainfall, with an increase in aggregates less than $0.50 \mathrm{~mm}$ in size. (2) Generally we found larger mean welghtdiameters on steep slopes (60\% or greater). (3) Unconsolidated ash solls, with low bulk density, have the smallest mean welghtdiameters with aggregates less than $0.50 \mathrm{~mm}$ exceeding 50\%. (4) Mean welght-diameters from solls developed from cinders are larger and the aggregates resist slaking as do solls from basalt flows.

(h) "A Rapld Method for Getting Area-Elevation Information," by James R. Wallis and Kenneth L. Bowden, U. S. Forest Service, Pacific Southwest Forest and Range Experiment Station Research Note 208, 10 pp., 1llus., 1962. "Logging for Water Quality in Northerm California," by James R. Wallis, U. S. Forest Service Research Note PSW-N23, 6 pp., 11lus., 1963.

Sediment Sources and Causes, Pacific coast Basins in Oregon and California," by Henry W. Anderson and James R. Wallis, Proceedings Second Inter-Agency Conference Sedimentation 1963. (In press.)

"Snowcover Relations in the Kings River Basin, California," by Arnold Court, Journal Geophysical Research 68(16):4751-4761, 1963. "Area Burned by Wildfire in Califormia Watersheds, 1940-1959," by James R. Wall1s, Kenneth $\mathrm{L}$. Bowden and $\mathrm{J}$. D. Lent. U. S. Forest Service Research Note PSW-30, 22 pp., 111us., 1963.

(4998) WATER YIELD IMPROVEMENT, AND FLOOD AND SEDIMENT REDUCTION IN THE LOWER CONTFER ZONE OF CAIIFORNIA.

(b) Laboratory project. Cooperators are: California Department of Water Resources, California Division of Forestry, East Bay Municipal Utilities District, California Department of $\mathrm{F} 1 \mathrm{sh}$ and Game.

(c) Mr. Robert P. Crouse, Project Leader, Lower Conifer Zone, Pacific Southwest Forest \& Range Experiment Station, 1960 Addison Street, Berkeley, Califomia.

(d) Experimental; field investigations; basic and applied research

(e) This project conducts basic studies of forest hydrology which will suggest methods of land management for improving water yield, preventing floods and controlling sediment in the commercial timber zones of California below the snowpack.

A study of soll moisture depletion in the Sierra zone of the Lower Conifer Zone concems the magnitude of soll molsture storage and depletion under different stand and timber cutting intensities.

Because soll creep and landslides are prevalent in the zone, a study of gravitational 
mass movement will form an effort to develop the means of estimating the consequences of mass movement in terms of sedimentation. The ultimate objective is to develop the means of predicting the role of land management practices, such as logging and road building in initiating or accelerating mass movement. "Forest Radiation Balance--Lower Contfer Forests" is a study measuring the components of the solar radiation balance of lower conifer stands. Measurements of shortwave transmission in pine stands will provide a basis for planning analytical methods. The Caspar Creek-Jackson State Forest study continues as reported last year.

(g) The soll molsture study has installed 20 plots on the Challenge Experimental Forest in the Yuba drainage area (an area representative of optimum precipitation, soll depth, and growing conditions within the zone) to study the effects of various intensities of logging upon soll molsture storage and depletion. Groundwater level is being recorded and changes in soll molsture are measured by the neutron scattering method. An IBM 1620 computer program has been developed which takes raw data in the form of neutron counts and plot graphs for each sampling point and each study site in terms of percent volume molsture content by depth of measurement. A plan of study and analysis has been developed and instrumentation chosen for the observation of soll creep rates and trajectaries. The first experimental site has been located in the coastal mountains near Berkeley.

Measurements of shortwave solar radiation transmission through tree crowns to the forest floor were initiated in a dense Monterey pine stand with nine Eppley pyranometers. Preliminary analysis indicated a range in mean transmission on clear days from about two percent at a solar altitude of $30^{\circ}$ to about 10 percent when the solar altitude was about $70^{\circ}$.

(4999) FLOOD AND SEDIMENT REDUCTION FROM STEEP UNSTABLE BRUSHIANDS OF THE SOUTHWEST.

(b) Laboratory project. Cooperators: California Division of Forestry, Los Angeles County Flood Control District, Los Angeles County Fire Department, University of California, Berkeley, Los Angeles, and Riverside, Angéles National Forest.

(c) Mr. Jay S. Krammes, Acting Project Leader, Pacific Southwest Forest and Range Exper1ment Station, 110 North Wabash Avenue, Glendora, California.

(d) Experimental; field investigations; basic and applied research.

(e) Purposes are (1) to determine how watersheds function: what happens to the precipitation, and how water and soll movement are influenced by conditions of vegetation, soll, geology, and topography; and (2) to develop methods of watershed management, including treatment of areas denuded by fire, to insure maximum yield of usable water and satisfactory flood munoff and soil erosion control.

Principal work center is the 17,000-acre San Dimas Experimental Forest situated in the San Gabriel Mountains. A fire started by lightning in July 1960 consumed the vegetat1on, mostly brush, on 90 percent of the area and destroyed or damaged many of the research instaliations. Immediately after the fire a major emergency research program was started to test the effectiveness of various measures used to reduce flood runoff and erosion on the denuded watersheds. These rehabilitation meas. ures include seeding grasses and mustard singly and in combination with physical treatments such as wa,tling, channel barriers and contour terraces. The tests are being made on 38 watersheds of 2 to 90 acres each, equipped to measure rainfall intensity, peak discharge and suspended sediment. Twenty-five have basins to measure bedload. Studies of the erosion. processes and tests of applied managemel.t methods to decrease the erosion potential are being continued.

(g) The lack of rapid infiltration over a burned watershed contributes to excessive surface runoff. Reducing debris movement from burned watersheds then appears to be partly a problem of getting water into the soil mantle.

Surface solls following a rire are usually "non-wettable" due to an ash dust layer. Some of the solls are naturally hydrophobic as a result of particle coatings with a chaparral leachate. In a recent burn, we tested a wetting agent treatment on six small plots. The objective of the treatment was to establish the suitability of a surficant for reducing debris movement. During the dry winter of 1962-1963, the plots treated with the wetting agent produced 95 percent less debris and 32 percent less surface munoff than the treated plots. There was additional evidence that the treat ment benefited grass establishment. The treated plots had four times the vegetative cover of the untreated controls. In cooperation with the Los Angeles County Flood Control District, we ran several hydraulic model tests on our flumes that were installed since the fire. All flumes are 30 feet long, 25 feet high, have 1.5:I side slopes, and are set on approximately a 5 percent slope. They are constructed of elther reinforced gunite or reinforced soll cement and can be installed at a reasonable cost. We have two types: those with an invert width of 0.5 feet installed in 25 watersheds and those with an invert width of 2 feet constructed in 11 watersheds. All flumes have soll cement transitions added to direct flow into the flume. The model tests on the large and small flume consisted of having a control section at the flume inlet and varying the approach flow conditions. The conditions tested were: (1) subcritical approach velocity considerably less than critical velocity, (2) a subcritical approach velocity near critical velocity, (3) a supercritical approach velocity near critical velocity, and (4) a supercritical approach velocity considerably greater than critical velocity. For each condition a rating curve was obtained. The curves seem to be in relativeiy close agreement with no consistent variation between supercritical and subcritical approaches. The rating curves appear to be valid when applied to fleld runoff data containing appreciable debris quantities.

(h) "The San Dimas Experimental Forest, " by L. W. Hill, U. S. Forest Service, Pacific SW Forest and Range Expt. Sta. (unnumbered publication), $25 \mathrm{pp} ., 1963$.

"Tests of Chemical Treatments to Reduce Erosion from Burned Watersheds," by J.S. Krammes and H. Hellmers, Jour. Geophys. Res. 68(12): 3667-3672, 1963.

"It's Not Over When the Fire's Out," by R. Mo Rice, U. S. Forest service, Paciflic SW Forest and Range Expt. Sta. (unnumbered publication), 4 pp., 1963.

"Aspirin Solves Ralngage Headache," by R. B. Thomas, Weatherwise, 1963.

(5000) WATER YIELD IMPROVEMENT FROM THE BRUSHLANDS OF THE SOUTHWEST.

(b) Laboratory project. Cooperators: California Division of Forestry, Los Angeles County Flood Control District, and University of California at Berkeley, Riverside, and Los Angeles.

(c) Mr. Leonard F. DeBano, Project Leader, Paclfic Southwest Forest and Range Experiment Station, 110 North Wabash Avenue, Glendora, Calif.

(d) Experimental; field investigations; basic and applied research.

(e) The work center is the 17,000-acre San Dimas Experimental Forest in the San Gabriel Mountains of southern California.

Field investigations include studies concernd 
with the hydrologic factors of chaparral watersheds, riparian zone hydrology, and evaluation of water yield improvements. Laboratory studies on the movement (saturated and unsaturated), loss and storage of water in brushland soils supplement field studies on chaparral and riparian zone hydrology. Purpose of the work is (1) to establish fundamental plant, soil, water relationships as they influence water losses and water yields; and (2) to develop and test cultural practices aimed at improving water yield.

(g) Applied watershed management studies on Monroe Canyon, a 875-acre watershed on the San Dimas Experimental Forest, have shown that the removal of deep-rooted woodlandriparian vegetation on select reaches of canyon bottom sites increases streamflow yleld appreclably. The average annual increase in streamflow during the 24-month perlod following removal of 38 acres of woody vegetation was 25.5 acre feet. The largest increases were during the summer months and streamflow, which had ceased by early July before treatment, became yearlong. Below normal precipitation occurred during the 2-year study period indicating that greater yields could be expected under average rainfall conditions.

The cost of increasing water yield (based on a 30-year period) by riparian treatment was estimated to be 68 dollars per acre treated. This cost is not considered competitive with the cost of water supplied locally in southern California, but may be competitive with the estimated cost of delivering water from northern Callfornia.

The conversion from chaparral vegetation to grass on side slopes with deep soils in Monroe Canyon showed less increase in water yield per acre treated than the riparian zone treatment. On the side slope sites an increase in water yield of 17-acre feet per 140 acres treated might be expected by converting brush to grass. The cost of this conversion may be prohibitive for water yield alone.

Studies of soll temperature and moisture regime under coulter pine and native chaparral species were carried out in the San Dimas lysimeters during the summer of 1963. Preliminary analysis of these data indlcates that the soll temperature regime under these species is amenable to a Fourier analysis. Data on molsture transfer in response to temperature gradients are being evaluated.

(h) "The Cost of Converting Brush Cover to Grass for Increased Water Yield," by L. W. Hill, U. S. Forest Service Research Note PSW-2, 7 pp., 1963.

"Converting from Brush to Grass Increases Water Yield in Southem Califomia," by L. W. Hill and R. M. Rice, Jour. Range Management. 16(6): 300-305, 1963.

"Streamflow Increases After Removing WoodlandRiparian Vegetation from a Southern California Watershed," by P. B. Rowe, Jour. Forestry. $61(5)$ : $365-370$, i 1963 .

\section{(5001) WATER YIELDS IN HAWAII.}

(b) Laboratory project. Cooperators: State of Hawail, Department of Forestry.

(c) Mr. Henry W. Anderson, Acting Project Leader, Pacific Southwest Forest and Range Experiment Station, P. O. Box 245, Berkeley 1, Calif.

(d) Experimental; field investigations; basic and applied research.

(e) The objective is to develop a hydrological and meteorological base in Hawail's wildland watersheds that will suggest methods of land management for maintaining or improving water yield and water quality and minimizing soll erosion and sedimentation; to obtain adequate understanding of the processes of recelving and discharging water and being able to predict the effects of a wide span of forest land management practices upon water yleld and water control; such studies are to suggest ways to manage watersheds that will (1) assure the continued protection of watersheds; (2) improve the distribution of the water yield by modifying the balance between the groundwater recharge and surface waterflow; (3) increase water yields by decreasing evapotranspiration losses; and (4) minimize flood runoff and sedimentation.

Major work center is in Honolulu, w1th the principal study being the determination of evapotranspiration from soll moisture measurements and meteorological determinations at the sites. Perlodic sampling of soil moisture under stands of various trees, brush, and grass species has been made at two sites near Honolulu and at one site in the Walanae Range, all on Oahu.

(g) Water loss measurements in the April to September 1963 period, together with soll moisture storage to the 10.5-foot depth are summarized below: Total water content to $10.5 \mathrm{ft}$. depth Early Early
May Sept.
In.

Decrease in water content for interval

Rainfall Cover type

$53.3 \quad 42.2$

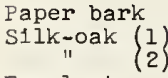

Eucalyptus

54.0

$59.5 \quad 46.4$

Grass

Brush

$\begin{array}{ll}56.0 & 49.3 \\ 58.9 & 48.6\end{array}$
11.1
11.6
13.2
13.1
6.7
10.3 for

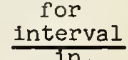

The spring of 1963 was unusually wet and soll molsture depletion did not start until about the last week in April. Rainfall during the depletion period was of low intensities and generally short duration. Iittle, if ary, of the rainfall was runoff. Consequently, most was lost through interception or evapotranspiration.

Plans now call for thorough analysis of the molsture losses as related to weather and soll factors.

(h) "Hydrology of the Alaka1 Swamp, Kaua1, Hawa11," by Bessel D. Van't Woudt and Robert E. Nelson, Hawail Agricultural Expt. Sta., University of Hawail, Bulletin No. $132,30 \mathrm{pp} ., 111$ us., 1963.

"Soil Moisture Constants and Physical Properties of Selected Solls in Hawai1," by Teruo Yamamoto, U. S. Forest Service Research Paper PSW-P2, 10 pp., 11lus., 1963. "Water Storage Capacities of Soll Under Four Different Land Uses in Hawa11," by Teruo Yamamoto and Paul R. Duffy, U. S. Forest Service Research Note PSW-5, 4 pp., 1963 .

U. S. DEPARTMENT OF AGRICULTURE, FOREST SERVICE, Rocky Mountain Forest and Range Experiment Station.

Inquiries concerning the following projects should be addressed to Mr. Raymond Price, Director, Rocky Mountain Forest and Range Experiment Station, Room 221 Forestcy Building, Fort Collins, Colorado.

WATERSHED MANAGEMENT RESEARCH, FRASER HYDROLOGIC IABORATORY.

(b) Laboratory project.

d Field investigations; applied research. To determine influence of lodgepole pine and spruce-fir forests and of the management of these forests for wood products on factors associated with the yield of water, largely from stored snow. The purpose is to solve problems in the management of forested watersheds of the high altitude zone of the Rocky Mountains for maximum yields of usable water.

(g) Detailed studies of snow physics at Fraser Experimental Forest in the Colorado Rockies are revealing how forest cover influences runoff from accumulated winter snow. Results show that water vapor loss takes place throughout the snowpack, not just the surface 
layers. The total loss from the snow was about 0.1 inch per day for clear days during March 1962.

(h) "An Improved Heat Pulse Velocity Meter as an Indicator of Sap Speed and Transpiration," C. M. Skau and R. H. Swanson, Jour. Geophys. Res. 68: 4743-4749, 11lus.

(657) WATERSHED MANAGEMENT RESEARCH, TEMPE,ARIZONA.

(b) Laboratory project.

d) Experimental; basic and applied research.

(e) To study the disposition of rainfall as influenced by waterhed vegetation; to determine the influence of varlous types of forest and grassland vegetation as well as vegetation modifled by cultural treatment such as grazing and timber harvest, on streamflow, water use, water loss, and erosion and sediment yield; and to determine for phreatophytic vegetation (water-loving plants) the amount of water used, methods for reducing water use by phreatophytes or for replacing them with more useful plants; and for mixed conifer and chaparral types of vegetation to determine the hydrologic characteristics of natural watersheds and the effect of cover modification upon water ylelds, soll stability and other resource values. At Sierra Ancha Experimental. Watersheds in central Arizona, rainfall, runoff, and erosion are measured on three watersheds in the pine-fir vegetation type at high elevation, on two watersheds in the ponderosa-chaparral type, and from four watersheds in the grassland-chaparral type at intermediate elevations, and on nine small watersheds in the semidesert-chaparral type at low elevations. Water use by different types of plants in various solls is studied on eleven large lysimeters. Three watersheds have been established on the ponderosa pine type, three in the mixed-conifer type, and two watersheds in the high (9300-foot elevation) grassland type (measuring weirs currently under construction). Effect of frost on water ylelds (surface munoff and soll molsture accretion) is studied on small grass, aspen and mixed conifer plots. Solls from grass, aspen and mixed conifer plots are belng laboratory tested for hydrologic characteristics. Soll molsture is followed with a neutron probe. Gaging stations for four watersheds in the pure chaparral type are also ava1lable to evaluate watershed-game interrelations. One cluster of two watersheds and and another cluster of three watersheds are avallable for testing the effect of mantpulating chaparral cover. Supplemental studies are determining the proper use of chemicals, fire, and mechanical treatment for manipulating shrub in the type.

Interception, molsture use, and factors affecting water yield are being tested in Utah and alligator juniper forests on the Beaver Creek Project, south of Flagstaff, Arizona. Ecology of Tamarix pentandra and other phreatophytes is under investigation. Germination, seedling survival, sprouting ability, and rate of spread studies were continued. A fileld apparatus employing plastic tents, a ventilating system, and a wet-dry bulb hygrometer has been developed and used for detalled measurements of evapotranspiration of phreatophytes.

(g) Some early findings from the study of salt secretion in tamarlsk show that salt appears first as a single strand (monofilament) from salt gland (not as a "whisker" as reported earlier). Monof'llament can reform later into whisker. Tlme lapse photomicrographs showing growth rate of fllament have been made.

Seventy-four percent of the tamarisk clipped at 2-week Intervals were dead by August 1962; by March 1963 the mortality had increased to 92 percent. The same relationship occurs for plants clipped 4 weeks apart; mortality in August 1962 was 56 percent, but by April
1963 1t had increased to 80 percent. It is possible the successive clipplng has lowered the stored carbohydrate content to account for the continued deaths during the winter. Apparently three species of tamarlsk had been Introduced Into the United States by the $1870^{\prime} \mathrm{s}$ and all three specles growing in Washington, D. C. Tamar $1 x$ tetrandra was a common ornamental shrub without spreading into wild areas. Tamarix gallica appeared about the same time in the Texas Gulf area where $1 t$ is now a common naturalized shrub. Very few plants of this species have been collected in the West and always as an ornamental. Tamarix pentandra had appeared as an ornamental in the East by the $1870 ' \mathrm{~s}$, but in the arid West no collections were made until 1900. Tamarisk occurring in the Salt and Verde Rlver drainages in Arizona does not show appreclable increases or marked decreases. Comparison of a U.S.G.S. survey of 1944, with aerlal photos taken by the Army Englneers in 1958, shows no appreclable spread of phreatophytes. observations made along the Pecos River in Texas indicate that tamarisk is definitely decreasing in importance in this area. With total annual precipitation during the past year, approximate average, both volume and duration of streamflow in the 3-Bar chaparral watersheds $\mathrm{C}$ and $\mathrm{D}$ continued to be greater than prior to destruction of plant cover by wildfire in June 1959. Differences In consumptive use of water on the two watersheds, expressed as total precipitation minus total measured yield at the weir dams, appears to be widening. This may be related to the increasing difference in total shrub canopy cover. Watershed $\mathrm{C}$ has been sprayed yearly by helicopter to keep the shrub canopy cover depressed to 10 percent or less. Shrub cover is now approximately 7 percent. This compares with 30 percent on Watershed $D$ where shrubs have been allowed to make natural regrowth. Artiflclal seedirg with Lehmann lovegrass and transplanting of native curlymesquite grass clumps during the summer of 1961 and 1962 has apparently produced the start toward a satisfactory cover on Base Rock lysimeters Nos. 2 and 3. They are producing much larger water ylelds both as percolation and surface flow, than lysimeter No. 1 where the original grass and half-shrub cover was left undisturbed. Comparison of evaporation from snow in three covers (grass, aspen, and mixed contfer), was studled at the Rudd Knoll soll molsture plots. The estimated total seasonal loss which averaged between 0.53 inch per month for the grass plots, and 0.60 inch per month for the aspen plots, did not vary signiflcartly between vegetative types, probably because even though the losses were higher in the open grassland plots, snow left these plots earlier and subsequent evaporation from the aspen and mixed conifer plots was enough to bring the seasonal totals approximately equal. Soll molsture use during the water year of 1961-1962 was $9.14,14.56$, and 8.79 inches, respectively, for grass, aspen, and mixed conifer. In addition, 10.19 inches of precipitation occurring during the growing season was utilized. However, a detalled analysis of the soll-water regime is necessary to eliminate drainage water from plant use.

Both concrete and granular types of soll freezing occur in the White Mountains of Arizona. Concrete type of soll freezing occurred to a depth of 6 inches or greater throughout the snow season in open grassland under 24 inches of snow. However, only granular type of freezing occurred under mixed conlfer and aspen types, but $1 \mathrm{ce}$ layers were formed in the litter. These lce layers were present only after thawing and freezing periods. Surface munoff was signiflcantly greater on plots where concrete freezing was present. Using the heat pulse velocity meter as an indicator of sap speed 
and transpiration, field experiments with juniper trees show that (1) on clear days the heat pulse velocity increases rapidly from sunrise to midmorning and remains high until sunset, low rates prevail at night, (2) leaf wetting produces an immediate decrease in heat pulse velocity; rates remain low while leaves are wet, then increase rapidly when leaves dry, (3) within 24 hours after dry soll is irrigated, heat pulse velocity increases $2-5$ times, and (4) natural soll drying, even with high air temperatures, causes a decrease in heat pulse velocity.

(h) "Root Distribution of Five-Stamen Tamarisk, Seepwillow, and Arrowweed," Howard L. Gary, Forest Sc1. 9: 311-314, 11lus.

(1969) WATERSHED MANAGEMENT RESEARCH, AIBUQUERQUE, NEW MEXICO.

(b) Laboratory project. Some work in cooperation with Bureau of Land Management and Geological Survey.

(d) Applied research.

(e) Evaluation of range-watershed conditions on small watersheds in the San Luis drainage of the Rio Puerco. Three contiguous watersheds, ranging from 338 to 555 acres located about 8 miles north of the San Luis community and west of the Rio Puerco main channel provide the study area. Water and sediment inflow are measured in small reservoirs formed by earthen dams. Precipitation rates and amounts of vegetation changes are periodically measured over the watersheds. Ten years of data have been collected under cattle grazing during a $51 / 2-6$ month overwinter period (November 1 to April 30).

Evaluation of soll ripping (Jayhawker) on surface munoff, erosion, and vegetation. Surface munoff plots $(64), 10^{\prime} \times 31^{\prime}$, are installed on a north and south aspect and upper and lower slopes representing different soll conditions in the Rlo Jemez drainage. Precipitation, munoff, and sediment are measured.

To obtain information on factors effecting rates of snowpack ablation and correlation to relative water ylelds from several vegetation zones in high altitude watersheds in New Mexico. Plastic membrane lysimeters 50 square feet in size and in batterles of three were installed in open areas and in spruce-fir forests on north and south slopes.

(g) Runoff, sediment, ground cover, and precipitation measurements have been taken on three watersheds of 338,471 , and 555 acres. From 1952 to 1958 the watersheds were grazed as open range and partly under fence yearlong and overwinter. Since 1958, grazing control consisted of overwinter (Nov. I to May 1) use only to 55 percent utilization of the principal forage species, alkali sacaton.

Average annual sediment production declined from 0.8 acre-foot for the period 1952-58 to 0.1 acre-foot for the period 1959-62 on Watershed I; comparable values on WS II are 0.9 and 0.2 acre-foot, and for WS III 0.4 and 0.2 acre-foot. Runoff and precipitation averages were about the same between periods. Ground cover decreased between 1952-58, but doubled on the three watersheds under grazing control.

(h) "An Inexpensive Runoff Plot," George Garcia, Wayne Hickey, Jr., and E. J. Dortignac, Res. Note RM-12, 8 pp., 11lus.

(2658) WATERSHED MANAGEMENT RESEARCH, RAPID CITY, SOUTH DAKOTA.

(b) Laboratory project.

(d) Experimental; basic and applied research.

(e) (1) Soll molsture effects of thinning dense ponderosa pine. (2) Control of runoff and soll erosion by seeded and native vegetation of the 1959 Deadwood Burn. (3) Development of a diversion type sampler for continuous measurement of sediment and munoff in small streams. (4) Runoff from grazed and protected Kentucky bluegrass range in relation to soll compaction. Water yield and sediment production in relation to standard forest management practices.

(f) Items $1,2,3$, and 5 active; 1tem 4 temporarily suspended.

(g) Sixteen plots designed to evaluate control of munoff and soil movement by seeded and native vegetation on the Deadwood Burn continue to reflect basic differences between 1 gneous derived solis of the City Creek site and limestone derived soll at the Pine Crest site. Following seeding, vegetation became established more rapidly on the city Creek plots, but after three years live plant cover is about the same on both plots. Total cover, including litter, is greatest on City Creek plots. Average runoff per inch of rain is about the same from both sites. Sediment production has dropped considerably as ground cover increases. Highest production per unit of runof 1 is fram the Plne Crest site. Results suggest good control of runoff and soil erosion by plant cover.

(3569) WATERSHED MANAGEMENT RESEARCH, LARAMIE, WYOMING.

(b) Laboratory project

d) Field investigation; applied research.

e) The objectives of the study are to determine the effects of big sagebmush on total munoff from snowmelt, snow accumulation and storage pattern. Three high elevation sagebrush watersheds, 60 to 106 acres, in western Wyoming provide the study area. V-notch weirs gage the runoff, and suspended sediment samples are taken periodically. Snowpack is sampled along permanent transects and at random points. Precipitation is sampled by a network of recording and non-recording gages.

The objective of this study is to determine the soll moisture withdrawal pattern under natural stands of big sagebrush, and the effect of sagebrush eradication on molsture withdrawal. Four 0.1 acre plots on an east and a west exposure have been established within high elevation sagebrush type in western Wyoming. Sagebrush on two of the plots on each exposure has been eradicated by spraying. Soll moisture samples are taken periodically to trace moisture withdrawal under each condition. Study to evaluate the comparative efficlencies, in terms of water stored in accumulated snow, of tandem 4-foot slatted snow fences erected at different spacing intervals on open windswept slopes in woutheast Wyoming. Study to evaluate the effects of inducing snow accumulation on a watershed through use of artificial barriers. Three experimental. grassland-type drainages, 88 to 144 acres, have been selected for the study area in southeastern Wyoming where snow transport by wind commonly occurs. V-notch weirs are installed to measure water yield. Snowpack is sampled in areas of natural accumulation along permanent transects. Sumner precipitation is sampled by a network of recording and nonrecording gages.

(g) The rate of incrase of snow-water content was greater in the sagebrush cover type than in the grassland from December 28 to January 29, 1963. During this period, the crowns of sagebrush plants were exposed. After January 29, the sagebrush plants became completely covered by snow and the rate of increase became similar in both cover types. Signiflcantly more water accumulated on the sagebrush plots than on comparable grass type plots. The metamorphism and subsequent melt of snow began earlier and proceeded at greater rates in and adjacent to sagebrush crowns. However, the average rate of decrease in water content was nearly the same in both cover types. 
Snowpack data from uncut lodgepole pine stands and from each clearcut block size, averaged over four aspects, indicate that there are only minor differences in snow accumulation and retention characteristics of clearcut blocks, 5, 10, and 20 acres in size. The peak snowpack water equivalent of the blocks was about 2.5 inches greater than that of the uncut forest. Snow persisted in the uncut stands approximately 10 days longer than in the cutover areas.

(3895) WATERSHED MANAGEMENT RESEARCH, ALPINE HYDROLOGIC IABORATORY.

(b) Laboratory project.

d) Field investigations; basic research.

(e) The purpose 1s: 1) To correlate snowdrift intensity with meteorological and terrain features; 2) to measure the amount and vertical distribution of snow carried by the wind in an area of moderately rough terrain; 3) To determine important features associated with the deposition of snow; 4) to determine the effect of slat and wire fencing on the accumulation of snow in selected natural catchments in the alpine portion of Loveland Basin, Colorado, and to test the relative effectiveness of this type of fence at two locations in the same general area; and 5) to test several types of wind barriers in alpine conditions.

(g) Vertical slot snow fencing increased snow depths and net snow volume at three of the six alpine test fields. Fences more than doubled the volume of snow in two of these fields. At a third field snow volume increased 50 percent. At the other three fields, snow depths were increased close behind the fences but were decreased in other places giving no net increase in the total amount of snow caught. Lee drifts usually hand lengths 8-12 times the height of the fence $(8-12 \mathrm{H})$. In steep terrain this length shortened to $7-8 \mathrm{H}$.

A study was made of the influence of the gap between the bottom of a snow fence and the ground on the position and size of the lee snowdrifts. After the first major storm, the average distance from a 6 -foot snow fence to the leading edge of the lee drift was 12.2 feet for a 1-foot gap, 31.7 feet for a 2-foot gap, and 45.5 feet for a 4 -foot gap. In midMarch, at the end of the accumulation season, these distances had reduced to zero for a lfoot gap, 16.5 feet for a 2-foot gap, and 25.6 feet for a 4-foot gap. The magnitude and location of the maximum snow depth in the lee drifts after the first storm was 65 inches 51 feet behind the fence with a l-foot gap. On the same date it was 42 inches 70 feet behind the fence with a 2 -foot gap, and 32 inches 86 feet behind the fence with a 4-foot gap. By mid-March these had changed to 83 inches of snow 28 feet behind the fence with a 1-foot gap, 65 inches of snow 62 feet behind the fence with a 2-foot gap, and 52 inches of snow 90 feet behind the fence with a 4-foot gap. The maximum snow depth moved closer to the fence with the smaller gap as this gap became plugged with snow. There was not enough snow to plug the larger gaps, therefore, the position of the maximum snow depth remained about the same all winter.

(3896) WATERSHED MANAGENENT RESEARCH, FORT COLLINS, COLORADO.

(b) Laboratory project.

d) Fleld investigations; applied research. Field plot to observe the adaptability and growth characteristics of twenty-three tree shmub and twenty-six grass and forb species for further testing on critical erosion sites.

Research to find the influences of mechanical watershed rehabilitation measures on the microclimate and other site factors in the southern Rocky Mountains. To determine the effect of range conditions and related factors on sediment production and runoff on three mountain grassland watersheds in western colorado. Range condition is being measured by means of 20 or more 3 -step transects on each watershed. Ninety degree v-notch weirs are used to gage the watersheds which vary in size from 86 to 272 acres. Water samples are taken several times dally during snowmelt and periods of storm runoff for determination of suspended sediment; bedload 1 s measured in the weir ponds.

(g) The challenge to improve past methods of gully control has led to the development of a new design and new installation methods for a check dam. Using prefabricated concrete the design is for a gravity type stmucture made up of three types of members. The piers rest on 1 -foot thick footing slabs which are 3 feet wide and 8 feet long. piers and footings are made of reinforced conventional concrete. The dam wall is 3 inches thick and made from prestressed lightweight concrete. Small steel plates and angle irons are used to help hold the wall members rigid. The wall is inclined 10 degrees downstream. This simplifies design and insures that the overflowing water will fall at a distance downstream from the wall. A backhoe is used to make the necessary excavation and the boom of the backhoe also is used to set the dam parts in place. The prototype is 45 feet long and 6 feet high. The footing was set 1.5 feet below grade and the sidewalls extended 4 feet into the bank. The energy dissipating apron was made from loose rock and is placed well above the bottom of the wall to prevent undercutting.

The prototype dam was placed in 3 hours, not including time for excavation and backfill. There is no "hole-to-hole" fitting needed. Steel loops are attached when parts are fabricated to facilitate handling in the field. The piers are aligned by eye and elevations determined by hand or engineer's level. The design is well suited for mass production and can be easily adapted to most locations.

U. S. DEPARTMENT OF AGRICULTURE, FOREST SERVICE, Southeastern Forest Experiment Station.

(380) WATER RESOURCE AND WATERSHED MANAGEMENT RESEARCH.

(b) Laboratory project. For general public use and information.

(c) Dr. Thomas F. McLintock, Director, Southeastern Forest Experiment Station, U. S. Forest Service, P. O. Box 2570, A sheville, North Carolina.

(d) General investigations of forest influences in the southeastern United States, with primary emphasis on fundamental hydrologic research on watershed processes and related application in watershed management.

(e) Basic research into forest hydrologic processes from the precipitation of water over an area until it leaves the watershed as streamflow or evapotranspiration. Demonstrations of several cover types and land management practices and their effect upon water yield, quality and flow characteristics Development of watershed management methods pertinent to the region and cooperative trials and demonstrations of these methods. Most of the experimental and hydrologic data are collected on the 5600-acre coweeta Hydrologic Laboratory, located in the zone of maximum precipitation for the eastern United States (Nantahala Range of the southern Applachians). The basic hydrologic gaging network at the Coweeta Hydrologic Laboratory, near Franklin, N. C., includes I multiple and 11 unit watersheds currently active and 19 standby watersheds on which up to 27 years of continuous streamflow 
records and a cumulative total of more than 680 years are available on drainages ranglng from 4 acres to 8 square miles, 11 recording and 12 standard rain gages, 1 recording hygrothermograph, 1 metering anemometer, 1 recording anemometer and wind vane, 1 evaporation pan, and 2 recording pyrheliometers. An additional 42 rain gages of various types are currently belng used for speclal studies. Occasional water samples are collected from selected watersheds for quality analysis on a storm period basis. Soll molsture 1 s measured in the fleld with 2 neutron scattering devices servicing a network of some 48 access tubes. A small laboratory equipped for soll and plant physical analysis and instrument repalr $1 \mathrm{~s}$ on the area. Most recording devices are of the chart-trace type with exception of one analog-to-digital streamflow recorder. Streamflow data are belng reduced from chart traces to punch cards by an Oscar-K chart reader with subsequent computation and analysis by computers at the National Weather Records Center in A shevilie, N. C. Supplementing the plant-so11-water studies at Coweeta 1 s a research unit located in the pledmont at Union, S. C. Past soll molsture studies include development of fleld measurement techniques for molsture investigations by the neutron method, comparative water use requirements of cover types, molsture recharge and depletion investigations, and depth of molsture withdrawal by representative cover types. Research facilities are largely inactive at the present time but Include 4 unit watersheds, and a standard Weather Bureau weather station. Research studies include: (1) a review of the relation of rain gage catch to actual precipltation on steep forested watersheds; (2) incident solar radiation on forested and cleared slopes; (3) effect of forest cover and mountain physiography on the radiant energy balance; (4) intermal water balance of forest trees as related to transpiration and drought; (5) distribution of roots of common forest trees in the southern Appalachlans; (6) movement and storage of soll water on steep slopes; (7) molsture storage and drainage of pledmont soll profiles; (8) predicting soll molsture in steep terrain for hydrologic purposes; (9) morphology of the soll mantle related to molsture storage and movement; (10) the effect of forest cutting on water yleld; (11) the hydrology of mountain unit watersheds under several cover types; (12) mechanizing streamf?ow data collection and computing; (13) a study of the high munoff-rainfall relations on Watersheds Numbers 36 and 37 ; (14) source, volume, and timing of streamflow from mountain watersheds, (15) a reglonal study of the small watershed hydrograph based on records from Coweeta. Bent Creek, Union, and Fernow, and (16) a pllot study testing multiple uses such as water, timber, recreation, and wildlife on a 360-acre watershed. Research by personnel of the Wetland Improvement Project at Charleston, South Carolina is developing effective water control practices to Improve productivity of wetland forest solls of the southeastern coastal plain and evaluating effects of these practices on wetland hydrology and solls. Accordingly, much of the program consists of dralnage studies in cooperation with National Forests, wood-using industries, and other wetland forest managers who have made or plan capital investments to drain their land. In addition, research is also belng conducted on the Santee Experimental Forest, located 32 miles north of Charleston, which has a small solls laboratory and two stream gaging stations on watersheds of 400 and 10,000 acres. Active studies include: (1) response of wet, slash pine flats to dra1nage; (2) relationsh1ps between soilwater conditions and tree survival and growth on dralned wetlands; (3) study of the waterbalance of selected wetland units; and (4) evaluation of the drainage state of representative wetland sites.

(f) All projects are to be carried to completion through analysis of data, preparation of reports, and publication of technical articles.

(E) Past cutting experiments at Coweeta have resulted in 6 to 16 inches of increased water yleld the first year following 100\% reduction in basal area of the hardwood forest cover. As the forest vegetation recovered after cutting, these increases in yleld dropped of $f$ at a rate approximately linear with the logarithm of time, ind1cating that as the copplce forest matured evapotranspiration returned to precutting levels. The 23-acre watershed conversion from hardwood to grass to compare evapotranspiration losses continues to show no difference attributable to conversion. The grass cover w11l be deadened in 1964 to compare yield increases from deadening grass with past watershed cutting experiments. Large, inclined soll columns are belng used to study storage and movement of water on steep slopes. A $3 \times 3 \times 45$-foot soll column inclined at 40 percent drained for 145 days after soaking, strongly supporting the theory that baseflow at Coweeta originates largely from unsaturated molsture flow through the sloping soll to the stream. A larger soll column, 4.5 feet wide, 7 feet deep, 200 feet long and inclined at 38 percent, was seeded to grass and allowed to recharge naturally. After a 33-day rainless period, water yield rate was only slightly lower than nearby watersheds. Indlcations are that this soll column will flow perennially under grass cover and exlsting climatic conditions. Appraisal of past precipitation measurements at Coweeta indicates that the sampling density of 1 gage per 10 acres plus a fortuitous original cholce of gage sites has provided good estimates of areal precipltation. Maximum errors are well under 5 percent of seasonal and annual totals. Gage openings in high forest were found to provide natural shielding against adverse wind effects. P1t gages were studied and found satisfactory for measuring precipitation on exposed, windswept sites. In the hotter, drier pledmont where rainfall averages 50 inches yearly, loblolly pine growing on plastic covered and noncovered plots used practically all avallable water in the surface 10 feet of soll by the end of the growing season. With plastlc removed and winter recharge allowed, cumulative recharge and precipltation were IInearly related from mid-November through mid-February. Thereafter, cumulative recharge practically ceased while cumulative ralnfall continued to increase. Recharge slowed when the $B$ horlzon became fully recharged and because of a textural discontinulty at the B-C horlzon, very little water entered the $C$ horizon. Recent study results at the Wetland Improvement Project demonstrate how widely water requirements of plants vary. Survival and growth of baldcypress and water tupelo planted and drained wetland sites Indlcate that these specles require flooded or near flooded conditions for best early development, while loblolly pine and sweetgun do best when water levels are at their lowest polnt. Sandy, flatwood sites that were once too wet to plant show an excellent, early response to drainage after one year. Survival of planted 1-year-old slash pine averages over 95 percent. Also the 4-footdeep drainage ditches in the area exert definite internal drainage effects 300 feet from the ditch during perlods when the water table is within a foot of the ground surface and 500 feet when the water table is 2 feet or deeper.

(h) "Rainfall Interception by Hardwood Forest Litter in the Southern Appalachians," by J. D. Helvey, to be submitted to Forest Sclence. 
"The Measurement of Water Deficits in Broadleaf Plants," by John D. Hewlett and Paul J. Kramer, Protoplasma 381-391, I962.

"A Pilot Test of Multiple Use on a Small Mountain Watershed," by John D. Hewlett and James H. Patric, Appalachian Section, Soc. Amer. Foresters, Proceedings 42nd Annual Meeting, 11-18; presented also to the Soll Conservation Section Meeting at Rock Eagle State Park, Ga., 1963.

"Instrumental and Soli Molsture Variance Using the Neutron Scattering Method," by John D. Hewlett, James E. Douglass and Jerome L. Clutter. Soll sclence (in press) 1964.

"Moisture and Energy Conditions Within a sloping Soil Mass During Drainage," by John D. Hewlett and Alden R. Hibbert. J. of Geophys. Research, 68: 1081-1087, 1963.

"Investigation of the Schardakow Method for the Measurement of Diffusion Pressure Deflc by Edward B. Knipling, Thesis, Duke Univ., $72 \mathrm{pp} ., 1963$.

"Forest Experiment Demonstration Area on Trail," by James H. Patric, Appalachian Trailways News, 24: 21-22, 1963.

"Seasonal Water Absorption by Deep Rooting Forest Trees on Plastic Covered Mountain and Pledmont Solls," by J. H. Patric and J. E. Douglass, to be published in the soll science Soc. Amer. Proceedings.

"Research in Hydrology of Forested Headwaters at the Coweeta Hydrologic Laboratory," by John D. Hewlett, presented at the North Amer. Wildlife and Nat. Res. Conf., March 1964. "What's New in Wetland Hydrology," by Roger R. Bay and Ralph A. Klawitter, to be published in Proceedings of Soclety of American Foresters, 1963.

"A Method of Sealing Neutron Access Tubes in Wet Areas," by C. E. Young, Jr. and James E. Henderson, to be published as a Station Research Note.

U. S. DEPARTMENT OF AGRICULTURE, FOREST SERVICE, Southern Forest Experiment Station.

Inquiries concerning the following projects should be addressed to Mr. W. M. Zillgitt, Director, Southern Forest Experiment Station, T-10210 Federal Bldg., 701 Loyola Avenue, New orleans, Louisiana 70113.

(2914) WATERSHED MANAGEMENT RESEARCH, OXFORD, MISSISSIPPI.

(b) Laboratory project, in cooperation with soll Conservation Service, Agricultural Research Service, and University of Mississippi.

(d) Field investigation of runoff and erosion from small experimental watersheds on forest and potential forest lands; basic and applied research.

(e) Twelve small natural headwater catchments, two to four acres each, were installed in batteries of three to determine runof $f$ and erosion from old fields, depleted upland hardwoods, pine plantations, and mature upland pine-hardwoods. Treatments are deferred until after a sultable calibration period. Five additional watersheds in pine plantations are being calibrated prior to testing effects of timber harvesting on munoff, erosion, and sediment flows. Related studies include restoration of depleted watersheds and plant-soil-water relationships.

(g) Data collection on all watersheds was continued. Watershed treatments have been initiated on six watersheds.

(h) "Sediment Yields from Small watersheds Under Various Land Uses and Forest Covers," S. J. Ursic and Farris E. Dendy, SFES, 9 pp., 11ius., 1963.

"Planting Loblolly Pine for Erosion Control in North Mississippi," Stanley J. Ursic, U. S. Forest Serv. Res. Paper SO-3, 20 pp., ilius., 1963.

(3225) WATERSHED MANAGEMENT RESEARCH, HARRISON, ARKANSAS. (b) Laboratory project.

d) Field investigations on effects of forest type and condition on timing of flows in streams of the Ozark-Ouachita uplands; basic and applied research.

(e) Runoff and sediment from three small mountain watersheds are measured currently. Cover conditions will be changed after an adequate calibration period. Related studies of soll molsture and erosion are continuing.

CORPS OF ENGINEERS, U. S. ARMY, Coastal Engineering Research Center.

Inquiries concerning the following projects should be addressed to the Director, Coastal Englneering Research Center, 5201 Little Falls Road, N. W., Washington, D. C. 20016.

(181) EQUILIBRIUM PROFILE OF BEACHES AND STUDY OF MODEL SCALE EFFECTS.

(b) Laboratory project.

d Experimental; basic research.

(e) Equilibrium beach profiles will be determined experimentally for waves up to 6 feet in height in a prototype tank; the waves will be modeled at a 1 to 10 scale in small laboratory tanks (to determine scale effects) for various median diameter and specific gravity sediments.

(g) Additional tests were made using crushed coal of average specific gravity 1.5 (modeled by the settling velocity relationship to give corresponding characteristics of material tested in the large tank). Observed material movement and profile changes corresponded basically to the large scale results in the prototype tank, although the coal slope deteriorated somewhat faster. A partial explanation for differences is the wide range of specific gravities of individual coal particles. Tests for a few selected storm waves were made in the large tank with waves from 2 to 5.5 feet in helght using a sand of 0.4-mm. median diameter. The profiles obtained in these tests are being compared with those obtained earlier with $0.2-\mathrm{mm}$. sand to indicate differences in rates of scour and degree of protection with different sized material. A single test was made simulating a tidal condition.

(660) OBSERVED WAVE CHARACTERISTICS.

(b) Laboratory and fleld prolect.

d Field investigation; basic research.

e) To secure a more thorough knowledge of the characteristics of ocean waves. Wave gages have been installed in a number of locations in coastal waters. These wave gages provide electrical recordings on pen and ink paper strip chart recorders and also magnetic tape recordings. The records from the paper chart recorders are analyzed for significant wave height and wave period. The records from the magnetic tape recorders are analyzed on a laboratory spectrum analyzer to provide a spectral analysis of wave frequency (or period) versus: (1) IInear average wave helght; (2) squared average wave height; and (3) peak wave height.

(g) Two additional wave recording stations were installed during 1963 at Virginia Beach, Virginia, and Manteo, North Carolina, the latter in cooperation with a study of beach phenomena by Louisiana State University. Installation of 3 pressure wave sensors at the Buzzards Bay Iight Tower (Coast Guard) is planned for 1964. These wave sensors will be used to establish pressure gradient at different water depths. This data will be compared to surface waves iresently being measured by the relay wave gage now operating at the tower. 
(b) Laboratory project.

d) Fleld investigation; applied research. To study methods and requirements for pump1ng sand past inlets and to determine the applicability of the methods in stabilization of beaches adjacent to inlets. Data are belng procured on the effect to the shoreline of sand by-passing operations at Port Hueneme, Califomia and Iake Worth Inlet, Fla. and on the effect to the shoreline of a new harbor constructed at Ventura,

California. This latter harbor involves an offshore detached breakwater along w1th entrance jetties to the new harbor. Data at the three locations include periodic hydrographic surveys south and north of the inlet, wave data, sand samples, detalled records of pumping operations, and detailed records of entrance channel maintenance. A general study is being made of the possibility of adapting commercial instmuments utilizing a radioactive source to the discharge Iine to measure quantity of material pumped in by-passing operations.

(976) ESTABLISHMENT OF CRITERIA FOR CONSTRUCTION OF ARTIFICIAI BEACHES.

(b) Laboratory project.

d Theoretical; applied research.

(e) To develop criteria for construction of beaches by artificlal means. The present continuing phase of this general study involves the measurement of a natural beach slope and attempts to determine its response to the forces normally incident upon the shore such as wave helght and period, angle of wave approach, tide, and direction and magnitude of littoral current. By statistical methods the relative importance of the forces or combinations of forces may be evaluated.

(g) Computing machine techniques have been applied to the statistical evaluation of the importance of the forces and of the parameters.

(977) DEVELOPMENT OF WAVE HEIGHT AND WAVE DIRECTION GAGES.

(b) Laboratory project.

d Experimental; development.

e) To develop wave height and wave direction gages for use in securing accurate records of wave characteristics. (See also project 660).

(g) Two staff and four pressure wave gages were furnished to the Detroit District (Lake Survey) for Installation in Lake Michlgan for a study of wave conditions at several points in the lake. Data from these gages are to be used in a wide study of the lake for pollution control by the Public Health service. One pressure wave gage was furnished the Portland, oregon, District for installation at Umpqua. This gage will be installed about one mile offshore with the sensing unit mounted on top of a plling at a depth below the draft depth of ships. All of these gages use magnetic tape recorders.

(2190) STUDY OF EPFECT OF A GROIN ON THE RATE OF LITTORAI MOVENENT.

(b) Laboratory project.

d) Experimental; basic research.

(e) To study the effect of groins on the rate of littoral drift passing a groin system. Initial tests consist of waves generated at a 30-degree angle to the sand beach with measurement of materlal movement being made at the downdrift end. The tests planned for the immediate future, as have the current season tests, will continue to emphasize the task of collecting and establishing reliable calibration data on the relationship between the littoral transport rate and the wave characterist1cs. These generalized (not to specific model scale) studies are being made in the Shore Processes Test Basin of the Beach Erosion Board. They will
Include tests of waves up to about 1 foot in height and wave perlods of 1.25 to 4.00 seconds.

(g) In tests of I1ttoral transport and wave characteristics, it 1 s important that waves impinging on a test beach remain constant for sustained periods of wave action. In such tests the beach is constantly undergoing deformation and change due to the wave action. A testing problem of wave helght variability has caused a temporary delay in the progress of littoral transport testing. The problem is illustrated by results from two types of wave helght measurements. In the first type, wave helghts are obtained by moving a wave gage from point to point along the toe of the test beach slope and analysis of these measurements shows a rather large variability of wave helght. In the second type of measurements, wave heights are obtained at a flxed gage and analysis of these also shows a fairly large variability of wave helght. In summary, the wave helghts vary with length along the test beach and with time. Only one value of average littoral transport rate is derlved from a given test, and correlation of the wave characteristics (heretofore, assumed falrly constant) is made to this average value. The fact that the waves are variable in helght leads to interpretation as to what wave characteristics (helght, energy, etc.) to correlate in a given test. The causes of the wave height variability are only partially understood. Its cause has been attributed to wave resonance in the basins, resulting from: interaction of waves generated and test set-up geometry; probable aperiodic effects in wave generation; irregular changes in the beach; or a combination of two or more of these sources. Wave height data have been collected in the Shore Processes Test Basin for several special setups, including; splitter walls, baffles on wave generating bulkheads, direct onshore wave approach instead of the usual 300 approach, and for a rubble beach in lieu of a sand beach. Additional observations were made in other CERC laboratory facilities. Results of these measurements and observations are negative in that they do not point sharply to the cause of wave height variability in the test setups. Certain leads have been suggested from observations and from analysis of the measurements, but definite conclusions or causes have not been found. Further speclal tests are planned.

(2192) REGIONAL STUDIES OF THE ATIANTIC COAST OF NEW JERSEY; AND THE DELAWARE-MARYLANDVIRGINIA SHORE LINE FROM CAPE HENLOPEN TO CAPE CHARLES.

(b) Laboratory project.

d) Fleld Investigations; basic research.

(e) To compile all existing data pertinent to shore processes on a reglonal scale. Reports to consist of three chapters: geomorphology and shoreline historles, littoral forces, and littoral materials. Subject matter to include physiography, geological development of the shore region, sources of littoral materlal, waves, tides or water level fluctuations, current physical characteristics of the littoral materials, interrelation of sedimentary properties, relation of properties of littoral materlals to position in the littoral zone, and changes in shoreline conflguration.

(g) The Delaware-Maryland-Virginia shoreline from Cape Henlopen to Cape Charles is currently under study. Data compilation for this reach is essentlally completed and the report is under preparation.

(2193) SHORE PROTECTION PLANNING AND DESIGN.

(b) Laboratory project.

(d) Design. 
(e) To supplement and revise the Coastal Engineering Research Center's (formerly Beach Erosion Board) Technical Report No. 4, "Shore Protection Planning and Design" as new data and techniques are developed for use in the solution of coastal engineering problems.

(g) This report was reprinted in October 1961.

(2195) RE-EXAMINATION OF ARTIFICALLY NOURISHED AND CONSTRUCTED BEACHES.

(b) Laboratory project.

d Fleld investigation; applied research.

(e) To study the behavior of beach fills placed to restore or nourish a beach sector and the effect of the fill on adjacent shores. A selected number of beach fills are being re-examined.

(g) Data collected at Seaside Park, Sherwood Island State Park, and Hammonasset, Conn.; Key West, Fla.; and Presque Isle, Pa. are being compiled to be published as Technical Memoranda.

(2660) STUDY OF QUANTITY OF SEDIMENT IN SUSPENSION IN THE SURF ZONE (INCLUDING TEMPERATURE EFFECTS).

(b) Laboratory project.

(d) Experimental; basic research.

(e) To determine the relationship between wave, water, and sand characterlstics, and the amount of material maintained in suspension and, hence, avallable for longshore transport by currents.

(g) Plans are in progress to collect surf zone suspended sediment samples in the area of Nags Head, North Carolina in early 1964. The surf zone suspended sediment samples will be part of a more comprehensive project to secure coastal data on ocean waves at the coastal site selected. The data will include observations and measurements of the wave characteristics. The observations and measurements will be analyzed for correlation to the suspended sediment concentrations found and compared to concentrations of suspended sediment which have been measured in the CERC laboratory facilities.

(2661) WAVE RUN-UP ON SHORE STRUCTURES.

(b) Laboratory project.

d) Experimental; desion.

(e) Wave run-up is determined experimentally for various waves for different types of shore structures. Effect of both structure roughness and permeability is being investigated.

(g) Wave run-up testing was carried out at a small scale on some stepped-seawall designs. The tests re-affirmed previous conclusions that artificial roughening of sloped seawalis by steps materially decreases the mun-up below that which could be expected on a smooth slope. Tests were made for both 1 on 2, and 1 on 3 slopes. Tests were made for vertical steps and also for re-entrant type steps. Essentially the same run-up was obtained for both types of steps, although there is an indication that slightly lesser run-up may occur with the re-entrant type step. This indication is masked within the general scatter of data for both types.

(3228) MODEL TESTS OF WAVE SETUP ON BEACHES.

(b) Laboratory project.

(d) Experimental; basic research.

(e) To relate increase in water level at the shore due to wave action alone, to the incident wave characteristics and shore hydrography.

(3897) RADIOACTIVE TRACERS FOR BEACH STUDIES.

(b) Laboratory project.

d Experimental; research.

(e) A simulated sediment (glass containing a radioisotope was dispersed along a 16-inch wide strip normal to the waterline in the Shore Processes Test Basin. Waves and waveinduced currents transported the sediment and simulated sediments. Periodically, the beach and offshore zones were monitored with appropriate detection instmuments and tinespace histories of the labelled particles were determined.

(g) Two laboratory tests were completed during the late summer of 1962 . It was found that the sediments moved alongshore and also toward deeper water. The transport may have been pulsating in character. A possible onshore-offshore oscillatory motion was also noted.

(4760) EXPERIMENTAL STUDY OF DUNE BUILDING WITH SAND FENCES.

(b) Laboratory project.

d Experimental; design.

(e) The experimental study consists of the construction of various types and arrangements of sand fences to determine the fence type and arrangement most effective in building a dune by trapping and holding wind-blown sand. Slat-type snow fencing and locally constructed brush fencing have been used in straight, straight-with-side spurs, and zigzag configurations. The study is being conducted on the outer Banks of North Carolina between Cape Hatteras and Cape Lookout.

(4762) CORREIATION OF STORM WAVE ATTACK AND BEACH EROSION.

(b) Laboratory project.

d) Field and offlce investigation to develop quantitative correlation between storm violence and shore erosion.

(e) Repetitive profiles are taken at selected beach areas. The storm wave action between surveys is analyzed and correlations between the wave action and observed profile changes are established.

Repetitive profile lines were established in November 1962 at nine locations between Delaware Bay and Cape Cod. These profiles are resurveyed at weekly or bi-weekly intervals. Storm wave action is measured by the Beach Erosion Board Ocean Wave gages, and storm surges by U.S.C. \& G.S. tide gages.

(4763) OFFSHORE SAND SOURCES.

(b) Laboratory project.

d) Field investigation; applied research.

(e) To develop data on of fshore deposits of material along the U. S. coasts that could be used in beach fili or nourishment projects.

(g) Map study has been made to locate possible source areas. A pilot operation utilizing a "sparker" type sounder to indicate depth of deposit was carried out off the Florida coast. Plans for a dredging operation using a dredge with pump-out capability are underway to study feasibility and costs.

(4764) MODEL TESTS - PROPOSED LOS ANGELES - SANTA MONICA CAUSEWAY.

(b) Los Angeles District, Corps of Engineers, U. S. Army (for State of California).

(d) Experimental; basic research.

(e) An offshore sand barrier has been proposed for a causeway across a portion of Santa Monica Bay. One proposal involves a rock barrier, submerged perhaps 15 feet (to prevent damage to swimmers and small craft) to hold the seaward end of the sand barrier. It thus eliminates the large quantity of sand otherwise necessary to form the toe of the sand barrier. A few large scale (waves 3- 6 feet in height) tests have been made to give an indication of possible quantity of scour shoreward of the rock barrier induced by $1 t$, and the relative proportion of this scour material which might be moved seaward across the rock barrier crest and become 
unavallable for further nourishment and protection of the sand barrier.

(f) Completed.

(g) The test series was quite abbreviated, and a much fuller set of data would be desirable should this proposal ever reach design stage. However, the tests indicated that the amount of scour depends quite critically on wave height, and the direction of movement of the scoured material depends primarily on sand size (being greater in the offshore direction with finer sands) and wave period (being greater in an of shore direction with shorter periods).

(h) Final report furnished the Los Angeles District.

(5079) WAVE HEIGHT PREDICTION FOR WAVE MAKERS IN SHALLOW WATER.

(b) Laboratory project.

d Theoretical and experimental; basic research. By equating the volume of water displaced in half a period by a displacement-type wave maker to the volume of water raised above mean water level in a sine-shaped wave, a simple relation results for shallow water waves which gives wave height as a function of wave length, wave maker stroke, and wave maker geometry. For shallow water, this relation agrees with hydrodynamic theory for piston-type and flap-type wave makers, and with published and unpublished data for waves generated by displacement-type wave makers in absolute water depths ranging from 0.5 feet to 13 feet.

(f) Completed.

(B) The helght of wave generated by displacement-type wave makers in shallow water is approximately equal to $2 \pi \mathrm{S} / \mathrm{L}$ times an appropriate dimension of the wave maker. S is ihe stroke of the wave maker, $L$ is the wave length given by small amplitude theory, and the wave maker dimension 1 s measured perpendicular to the direction of $S$. This relation agrees with the hydrodynamic theory for piston and flap-type wave makers over the range of depths usually used in coastal engineering experiments, and it is supported by data from 4 piston-type and 2 plunger-type wave makers for depths satisfying the condition

$$
\frac{2 \pi \mathrm{d}}{\mathrm{I}}<1 \text {. }
$$

(5080) MODEL STUDY OF OFFSHORE WAVE TRIPPER FOR TEXAS CITY, TEXAS, HURRICANE PROTECTION.

(b) Laboratory project.

d) Experimental; applied research.

(e) A laboratory study was made of the effectiveness of a submerged breakwater in causing the breaking offshore of the larger waves. A bottom profile of $f$ Texas City, Texas, was modeled to a 1:50 scale. Both vertical faced and rubble mound offshore wave trippers were tested. Two elevations were tested for each wave tripper; one at 9 feet, and one at 13 feet below the still water level. Two types of shoreline conditions were tested. one consisted of a smooth concrete slope of the modeled profile, extended to still water level, with a rubble absorber landward of that point. The other had a rather steeply faced rubble seawall that extended landward from 8 feet below to a point 15 feet above the still water level. Wave helghts were measured at several locations both shoreward and seaward of the tripper.

(f) Completed.

(g) Both types of submerged breakwaters caused a reduction in wave helght. Percentage wave height reduction increased with increase in helght of the incident waves, and with increase in the elevation of the offshore structures. The rubble mound type of wave tripper construction was more effective in reducing wave height than the vertical faced type for the same elevation. Reflection from both types of onshore structures was significant, but seaward reflection from both types of offshore wave trippers was negligible. (h) To be published in the Annual Bulletin of the Beach Erosion Board, 1963.

(5081) WAVE OVERTOPPING, CURVED SEAWALL.

(b) Laboratory project.

d) Experimental; applied research.

(e) Laboratory tests of wave overtopping are being carried out for a curved seawall similar to the Galveston wall, with a normal beach fronting seawall, and with a large scour hole immediately in front of and adjacent to the wall. The beach profile for the latter case is essentially that of the post Hurricane Carla survey in 1961 in the Galveston area.

(B) Tests indicate that the depth over the offshore bar coupled with the reflection characteristics of the seawall cause partial or entire breaking of waves with dissipation of energy over the bar and in the area between the bar and the seawall, particularly at the instant the incoming wave meets the seaward moving reflected wave; and that consequently the depth of the scour hole immediately adjacent to the seawall is relatively unimportant in affecting the degree of wave overtopping.

(5082) EFFECTIVENESS OF LOW CRESTED OR SUBMERGED BREAKWATERS.

(b) Laboratory project.

d Experimental; applied research.

(e) To determine the relative effectiveness of low-crested and submerged rubble mound breakwaters. Measurements have been made in the laboratory of the transmission of wave energy over and through both permeable and impermeable rubble mound breakwaters of varying crest width, crest elevation, and water level elevation. Tests were made at both small scale (maximum $6^{17}$ wave) and large scale (maximum 3-foot wave).

U. S. ARMY ENGINEER DISTRICT, CORPS OF ENGINEERS, Portiand.

Inquiries concerning Projects Nos. $3577,3578,4504$, 4505 , 5068 to 5071 , inclusive, should be addressed to the District Engineer, U. S. Army Englneer, Dist., Walla Walla, Bullding 602, City-County Airport, Walla Walla, Wash. 99362.

(3577) GENERAL MODEL STUDY OF LOWER MONUMENTAL DAM, SNAKE RIVER, WASHINGTON.

(b) U. S. Army Engineer District, Walla Walla, Corps of Engineers, Walla Walla, Wa shington.

(d) Experimental; for design.

(e) An undistorted, fixed-bed, 1:100-scale model reproduced approximately 2.4 miles of Snake River bed and overbank topography at the dam site. The dam axis is 41.5 river miles upstream from the confluence of the Snake and Columbia Rivers and about 60 miles from the city of Pasco, Washington, studies were made to determine flow conditions during various construction stages and after completion of the project.

(f) Tests have been completed.

(g) After verification of the model, studies of successive construction stages were made. It was found that proposed limits for excavation along the right bank were inadequate, revisions in alignment and height of first-step cofferdam cells were needed, and problems concerning fish passage would arise during each phase of construction. Numerous conferences and demonstrations held on the model helped solve problems regarding fish migrations. Final designs for all features of the project were developed and tested under anticipated prototype operating conditions. Then the model was revised for studies of cofferdams to protect the work area during stilling basin repairs at Ice Harbor Dam. Tests showed cofferdams would be adequate. 
(h) Final report is in preparation.

(3578) MODEL STUDY OF FISH LADDERS FOR JOHN DAY DAM, COLUMBIA RIVER, OREGON AND WASHINGTON.

(b) U. S. Army Engineer District, Walla Walla, Corps of Engineers, Walla Walla, Washington.

(d) Experimental; for design.

(e) A 1:10-scale model was used for tests of the 24-ft-wide, 1-on-10 sloped f1sh ladders for John Day Dam.

(f) Tests have been completed.

(g) Velocities, flow patterns, and flow characteristics were determined for typical fixed weirs of several alternative designs. A design was developed in which flow conditions were comparable to those within a 24-ft-wide fish ladder sloped 1 on 16. The north fishway exit, orifice control section, and elght typical weirs downstream from the control section were investigated for a maximum varlation of $11 \mathrm{ft}$ in forebay level. A slot-type counting station for the south flsh ladder was satisfactory in all respects.

(h) Final report is in preparation.

(3900) MODEL STUDY OF DOWNPULL FORCES ON EMERGENCY CLOSURE GATES.

(b) Office of the Chief of Engineers, Department of the Army, Washington, D. C.

(c) Division Engineer, U. S. Army Engineer Div., North Pac1fic, Corps of Englneers, 210 Custom House, Portland, Oregon 97209.

(d) Experlmental; applied research.

(e) This is a general study of various sluice coaster gate bottom and lip shapes, and includes downpull and discharge measurements as affected by angle of gate bottom, length of gate lip extension, control valve opening, number of control valves operated, and condition of air vents (open or closed). A 1:25-scale model reproduces a level approach to an intake tower with vertical headwall normal to intake center line, two three-sided bellmouth intakes, a 20-ft.-w1de by 22 -ft.high emergency gate (tractor type), two

10-ft. -w1de by 15-ft.-h1gh control, valves (tainter), and a 22-ft.-diam. outlet tunnel. Hydraulic downpull forces are computed from pressures at 21 critical locations on the emergency gate.

(f) Tests have been completed.

(g) Downpull forces were measured on a tractortype emergency closure gate with bottom beam sloped $30,37.5$, and 45 degrees and with lip extensions of $0,3.5,8$, and 12 in. under heads between 50 and $300 \mathrm{ft}$. Downpull forces were highest with the 30-degree bottom and lowest with the 45-degree bottom. Although lip extensions reduced the downpull, their effectiveness decreased as the bottom slope was increased.

(h) "Downpull Forces on Emergency Closure Gates," U.S. Army Engineer Division Hydraulic Laboratory, Bonneville, oregon. Tech. Report No. 106-1, September 1963 - (Ava1lable on loan). Final report covering the test results.

(4380) MODEL STUDY OF SPILLWAY FOR GREEN PETER DAM, MIDDLE SANTIAM RIVER, OREGON.

(b) U. S. Army Eng1neer District, Portland, Corps of Engineers, Portland, Oregon.

(c) U. S. Army Englneer District, Portland, Corps of Engineers, 628 P1ttock Block, Portland, Oregon 97205.

(d) Experimental; for design.

(e) The 2-bay spillway, flanking abutments, outlet conduits, stiliing basin, fish collection system, powerhouse tallrace, and about 1540 ft and $1620 \mathrm{ft}$ of spillway approach and exit channels, respectively, were reproduced in a 1:50-scale model. The model was used to check the adequacy of designs for the spillway crest, plers, abutments, and gate trunnion supports, outlet eyebrows, stilling basin, and tralning wall between the stlling basin and powerhouse tailrace. (f) Tests have been completed.

g) Improved designs for the abutments, training walls, and st1ling basin were developed. Tests of the fish iadder auxill.lary water intake, fishway entrance, and powerhouse tallrace were made with powerhouse discharges between 950 and 4500 cf's. The best method for coordinated operation of the spillway, powerhouse, and fish facilities were determined.

(h) Final report is in preparation.

(4504) GENERAL MODEL STUDY OF IITTLE GOOSE LOCK AND DAM, SNAKE RIVER, WASHINGTON.

(b) U. S. Army Engineer District, Walla, Corps of Engineers, Walla Walla, Washington.

(d) Experimental; for design.

(e) A flxed-bed model constructed to an undistorted scale ratio of $1: 100$ reproduces the Snake R1ver bed and pertinent overbank topography between river miles 68.3 and 71.6 . The dam axis is at mile 70.3. The original layout consists of a stralght, 8-bay, gravity-type spillway controlied by 50 by 59-ft talnter gates, a powerhouse for $\mathrm{six}$ Kaplan turbines (initial installation three units), an 86- by 675-ft navigation lock having a maximum lift of $101 \mathrm{ft}$, concrete nonoverflow sections, rockfill abutments, and facilities for passing migratory fish over the dam. The initial power installation w1ll produce $405,000 \mathrm{kll}$ owatts. Purposes of the model are to check the structures layout and flow conditions affecting cofferdam placement, power generation, navigation, and flish passage.

(g) Studies of various plans for the first and intermediate stage cofferdams were completed in 1963. Base tests of the original structures are in progress.

(4505) MODEL STUDY OF FISHWAY DIFFUSERS FOR LOWER MONUMENTAL DAM, SNAKE RIVER, WASHINGTON.

(b) U. S. Army Engineer D1strict, Walla Walla, Corps of Engineers, Walla Walla, Wash.

(d) Experimental; for design.

(e) An existing 1:8-scale flshway diffuser model was revised so that two diffusion chambers were supplied by a single riser from the conduit. Included in the model were diffusers 3 and 4 and the common distribution well, the supply conduit, and a portion of the 16-ft-wide south shore fish ladder that carried all flow which passed through the diffusion chambers. In the original design, a 7-1n.-Wide control orifice was locíted $3.5 \mathrm{ft}$ above the diffuser well floor, and 1.5-ft-high ports admitted flow into the respective diffusion chambers. The information desired from this model include: the orifice size required to provide $48 \mathrm{cfs}$ through each diffuser with a head of $2 \mathrm{ft}$ (supply condult grade line minus tallwater elevation), a submergence of $4 \mathrm{ft}$ (supply conduit grade line minus elevation of downstream welr adjacent to diffuser 3), and a conduit flow of 500 cfs; a family of rating curves for heads of from $0.5 \mathrm{ft}$ to $6.0 \mathrm{ft}$ and various submergences; and the effect on diffuser discharge of varylng the conduit flow from about 50 cfs (only one diffuser) to $750 \mathrm{cfs}$ while a constant head is maintained on the test diffuser.

(f) Tests have been completed.

(g) Two diffuser floor plans and 12 orifice arrangements were tested in efforts to obtain uniform distribution of diffuser flow into the $\mathrm{f} 1 \mathrm{sh}$ ladder. The most sat1sfactory arrangement was selected from the test results.

(h) Final report $1 \mathrm{~s}$ in preparation.

(4506) MODEL STUDY OF FINGERLING COLLECTOR FOR GREEN PETER DAM, MIDDIE SANTIAM RIVER, ORE.

(b) U. S. Army Engineer District, Portland, Corps of Englneers Portland, oregon.

(c) U. S. Army Engineer District, Portiand, 
Corps of Engineers, 628 Plttock Block, Portland, Oregon 97205.

(d) Experimental; for design.

(e) Two undistorted hydraulic models are belng used for studies of facilities for downsmigrant fingerling salmon and steelhead trout at Green Peter Dam. The proposed facllity is composed of an entrance horn, vertical adjustable-helght $r i s e r$, separator, flow distribution control device, trough, flexible hose, transverse pipe system, and outlet plpe followed by a flume into the tallwater. The collector will be located on the upstream face of the dam at the focal point of reservolr discharge. Its 20-fthigh horn will collect $\mathrm{flsh}$ near the water surface with a minimum submergence over its top of $5 \mathrm{ft}^{\prime}$ and a maximum submergence at $1 \mathrm{ts}$ bottom of $40 \mathrm{ft}$. About $200 \mathrm{crs}$ will enter the horm and carry migrating fish inward, upward, and across a separator screen ( a 10- by 20-ft perforated plate) covering the compartmented flow distribution device through which from 190 to 194 cfs will pass vertically into a collector well and then be pumped back to the reservolr. Fish in the remaining 6 to 10 cfs will be carried from the separator screen through a flexible hose attached to laterals through the dam and thence by open channel flow to the tallrace. A trash boom at the upstream face of the dam will prevent small floating and suspended debris from entering the fingerling collector.

(g) Two-ft-wide sections of prototype and model separator plates were tested in a flume model as the first step in determining model-prototype similitude relationships. The model perforated plate that reproduced flow conditions over the prototype plate in the most satisfactory manner was used in a $1: 4$-scale model of the entire fingerling collector. Tests of different distributor bar spacings, trough designs, deflector locations, and separator slopes are progressing in the 1:4-scale model.

(5068) MODEL STUDY OF SPILLWAY FOR LITTLE GOOSE DAM, SNAKE RIVER, WASHINGTON.

(b) U.S. Army Englneer District, Walla Walla, Corps of Englneers, Walla Walla, Washington.

(d) Experimental; for design.

(e) The 1:42.47-scale model includes a 3-bay section of the 8-bay spillway and stilling basin. Tests are belng made to evaluate hydraulic performance of the proposed spillway and to develop revisions in design that would increase performance or reduce construction and malntenance costs.

(g) Prescures, head-discharge relationships, and pier contraction coefficlents were determined for free flow over the crest and for unequal openings of adjacent crest gates. Current tests are directed toward development of a satisfactory unpaved stilling basin.

(5069) MODEL STUDY OF LITTLE GOOSE NAVIGATION LOCK, SNAKE RIVER, WASHINGTON.

(b) U.S. Army Englneer District, Walla Walla, Corps of Englneers, Walla Walla, Washington.

(d) Experimental; for design. of the 86-ft-wide by 675-ft-long lock. One model will include the lock chamber, split lateral filling system, river outlet for emptying system, and portions of the upstream and downstream approach channels. The fllling and emptying culverts are located on the river side of the lock chamber for structural and economic reasons. An alternative method for distributing flow to the lateral culverts through a central junction chamber w1ll be evaluated in an auxiliary model before tests in the comprehensive model. Possibility of vortex action over culvert intakes constructed on the same side of a common monolith will be investigated.

(g) Construction of the comprehensive model was completed and preliminary tests begun. Design and construction of the auxiliary model are in progress.

(5070) MODEL STUDY OF SPILLWAY FOR DWORSHAK DAM, NORTH FORK CLEARWATER RIVER, IDAHO.

(b) U.S. Army Englneer District, Walla Walla, Corps of Engineers, Walla Walla, Washington.

(d) Experimental; for design.

e) At present, a 1:50-scale, undistorted, fixedbed model reproduces the river bed and pertinent overbank topography for approximately $3600 \mathrm{ft}$ upstream and $4400 \mathrm{ft}$ downstream from the project axis. After verification studies, the cofferdams, diversion tunnel, and temporary flsh passage facilities will be installed and diversion problems studied. Then the forebay helght w1ll be increased to accommodate the 673-ft-high dam, and the splilway, stilling basin, regulating outlets, fish handling facllities, and log sluices will be installed for tests of these elements.

(g) Verlfication studies are in progress.

(5071) GENERAL MODEL STUDY OF LOWER GRANITE LOCK AND DAM, SNAKE RIVER, WASHINGTON.

(b) U.S. Army Engineer District, Walla Walla, Corps of Engineers, Walla Walla, Wash.

(d) Experimental; for design.

(e) An und1storted, 1:100-scale, f1xed-bed model will reproduce the Snake River bed and pertinent overbank topography for $1.4 \mathrm{miles}$ upstream and 1.7 miles downstream from the project axis ( 107.5 river miles upstream from the junction of the snake and Columbla Rivers). Studies will be made to determine flow conditions during successive construction stages and after proposed structures have been installed.

(g) Site preparation and model design are in progress.

(5072) TESTS OF RUBBER TAINTER GATE SEALS, LIBBY DAM (MONTANA) AND DWORSHAK DAM (IDAHO) PROJECTS.

(b) U.S. Army Englneer District, Seattle, Corps of Englneer's, Seattle, Wash.

(c) District Engineer, U. S. Army Englneer District, Seattle, 1519 South Alaskan Way, Seattle, Wash. 98134.

(d) Experimental; for design.

e Tainter-type slulce valves are being designed for use at Libby and Dworshak Projects. The gates at both projects will operate under a maximum head greater than $260 \mathrm{ft}$. This head is unusually high for this type of gate. Sealing and deformation tests on a 2-in. unclad rectangular rubber seal and a similar seal with "Teflon"-clad sealing surface w1ll be made in a 1:1-scale pressure tank under a head of $300 \mathrm{ft}$. Inltlal tests w11l be made with the upstream face of the seal flush with the gate and with a 3/8-in. gap between the retainer bar and seal plate. Preliminary plans are to make a 30-day deformation test on a Teflon-clad rectangula seal and a 15-day test on an unclad rectangular seal. A Teflon-clad J-type seal will be tested if funds are avallable after tests of the rectangular seals.

(g) The test apparatus was revised and three specimens of rubber seals were obtained.

U. S. ARMY ENGINEER DISTRICT, CORPS OF ENGTNEERS, St. Paul.

(194) A STUDY OF METHODS USED IN MEASUREMENT AND ANALYSIS OF SEDIMENT LOADS IN STREAMS.

U. S. Army Engineer District, St. Paul and U. S. Geological Survey, in cooperation with st. Anthony Falls Hydraulic Laboratory. See St. Anthony Falls Hydraulic Laboratory, page 73. 
U. S. ARMY ENGINEER WATERWAYS EXPERIMENT STATION, CORPS OF ENGINEERS.

Inquiries concerning the following projects should be addressed to the Director, U. S. Army Engineer Waterways Experiment Station, Corps of Englneers, P. 0. Box 631, V1cksburg, Miss. 39181.

\section{(236) MISSISSIPPI BASIN MODEL.}

(b) Office of the Chief of Engineers, Department of the Army, Washington, D. C.

(d) Experimental; for design.

(e) The project provides for construction and operation of a model of the Mississipp1 River watershed including the Missouri, ohio, White, Arkansas, and Red Rivers and the1r principal tributaries. The model area comprises 200 acres and reproduces 1,250,000 square miles of the Mississippi Basin. The topography of the streams and flood plains is reproduced to a horizontal scale of $1: 2,000$ and vertical scale of $1: 100$. All existing and proposed flood-control reservolrs, levees, dikes, floodwalls, and other pertinent works are reproduced. The completed construction consists of the Upper Mississippi from Hannibal, Missouri, to Baton Rouge, Louls1ana; the M1ssouri R1ver from S1oux City, Iowa, to the mouth; the oh1o River from Louisville, Kentucky, to the mouth including the Wabash River below Riverton, Indlana; the Tennessee RIver from P1ckwick Dam, Tennessee, to the mouth; the Cumberland RIver from Old H1ckory Dam, Tennessee, to the mouth; the White RIver from Georgetown, Arkansas, to the mouth; the Arkansas River from Blackburn Damsite, Oklahoma, to the mouth; and the Red River from Alexandria, Loulsiana, to the mouth. Water-surface elevations are measured by electrically operated stage devices with the recorders located in central control buildings. Streamflow is introduced and controlled by automatic instruments called inflow controllers. The model was designed to study coordination of releases from reservoirs, investigate the effect of reservolr operation on flood stages, check the routing of project and other floods, establish and check levee grades, predict stages, and determine the effect of floodways on stage reduction.

(g) The extert of model operation each year is determined by the testing programs directed by the Mississipp1 Basin Model Board and Chief of Engineers and requested by Divisions and Districts that have operable sections on the model. The model was operated as an integrated unit for comprehensive (basinwide) tests. Tests were conducted to verify the Memphis, Tennessee, to Natchez, Mississ1pp1, reach to the 1945, 1950, and 1961 floods. Tests were conducted to determine flow lines on: (1) the Wabash River levees with existing levees and the comprehensive levee system installed; and (2) the Missour 1 River from Boonville to the mouth with the agricultural levee system installed.

(425) COMPREHENSIVE MODEL STUDY, DELAWARE RIVER, PENNSYLVANIA.

(b) District Engineer, U. S. Army Engineer District, Philadelphia, Corps of Eng1neers, Philadelphia, $\mathrm{Pa}$.

(d) Experimental; for design.

(e) To develop and test plans for reduction of shoaling in several ranges of the navigation channel, and to determine the probable effect on the hydraulic and salinity regimen in the estuary that would result from modif1cations of channel depth and alinement and flow regulation, the entire Delaware River estuary from the Atlantic Ocean to Trenton is reproduced in a fixed-bed, silt-injection type model with scale ratios of $1: 1,000$ horizontally and $1: 100$ vertically. T1des and tidal currents are reproduced by automatic t1de generators. Observed prototype salinities are reproduced in the Delaware Bay portion of the model, and provisions made for the injection of silt, and for measuring silt deposits. Studies are also made of salinity intrusion and the dispersion and dilution of wastes discharged into the estuary.

(g) Tests to determine the necessity for rehabllitating all or portions of the Reedy Island Dike, the Pea Patch Island Dike, the Pennsvilie Dike, and the south jetty at Wilmington Harbor, Delaware, indicate that there is no need to rehabilitate any portion of the Reedy Island Dike, and probably none of the Pea Patch Island Dike except possibly the upstream end. The Pennsville Dike should be rehabilitated to about elevation +3 feet $\mathrm{mlw}$, and the gap resulting from fallure of the inshore portion of the south jetty at Wilmington Harbor should be closed.

\section{(993) CAVITATION RESEARCH.}

(b) Office of the Chief of Englneers, Department of the Army, Washington, D.C.

(d) Experimental; applied research.

(e) The cavitation characteristics of such elements as baffle piers, steps in stilling basins, spillway and conduit gate slots, and offset joints are studied in either a vacuum tank or a varlable-pressure, closed-jet water tunnel. The investigation includes a review of literature to evaluate the many varlables that affect cavitation results. A highvelocity water facility is being used to study resistance of concrete and protective coatings to cavitation.

(994) EFFECTS OF MODEL DISTORTION.

(b) Office of the Chief of Engineers, Department of the Army, Washington, D.C.

(d) Experimental; applied research.

(e) This is a general study to determine the hydraulic effects of various types and degræs of model scale distortion on velocity distribution and other hydraulic conditions, with the ultimate alm of establishing $11 \mathrm{mits}$ of permissible distortion for the various types of models. A rectangular flume having a 90-degree bend with provisions for changing the vertical scale to provide distortions of 0 to 101 s used in the study.

(f) Suspended.

(998) WAVE FORCE ON BREAKWATERS.

(b) Office of the Chief of Engineers, Dept. of the Army, Washington, D. C.

(d) Experimental; applied research.

(e) This is a general investigation to obtain data from which the magnitude and elevation of wave forces on a vertical wall can be predicted. The specific purposes of the study are to (1) study existing literature and testing equipment; (2) verify experimentally the clapotis pressure theory; and (3) determine maximum shock-type pressures, delineate the critical conditions necessary to create the extremely high shock pressures, and determine the magnitude of pressures due to partially breaking waves. The literature study and adaptation of existing test equipment have been completed, and measurements of wave-pressure distribution on a vertical wall resulting from breaking waves is in progress in a 1.5 - by 94 -foot wave flume. Test waves are generated by a piston-type generator placed in one end of the flume. Wave helghts and pressures are measured electrically.

(999) STABILITY OF RUBBLE-MOUND BREAKWATERS.

(b) Office of the Chief of Engineers, Department of the Army, Washington, D.C.

(d) Experimental; applied research.

(e) Rubble-mound structures are studied in a 5by 4 - by 119 -foot and $12.5-$ by $4-$ by $119-$ foot wave flumes to develop design procedures and formulas, supported by experimental data, 
from which the design of safe and economical breakwaters can be determined. In addition to quarrystone, tetrapods, tetrahedrons, tribars, quadripods, modified cubes, and other specially molded armor units are being studied.

(1002) EFFECTS OF SCALE AND OPERATING TECHNIQUES ON HARBOR WAVE ACTION MODELS.

(b) Office of the Chief of Engineers, Department of the Arrny, Washington, D.C.

(d) Experimental; applied research.

(e) Tests are conducted in flumes and harbor model basins to obtain information that will allow more accurate determination of optimum scales for wave models, and the effects of different scales and operating techniques on the accuracy of model results.

(f) Inactive.

\section{(1004) INSTRUMENTATION.}

(b) Office of the Chief of Engineers, Department of the Army, Washington, D.C.

(d) Experimental; development.

(e) Various types of measurement and control equipment for use in hydraulic studies are being developed. The se include improvements in a remote-control system for a model towboat, a hawser-stress transducer for measuring model lock tow hawser forces, and a revolutionsensing and remote-indicating device for velocity meters. A pilot study of a turbulence meter, and a feasibility study for a portable salinity meter for model use were begun.

(1467) DEVELOPMENT OF HYDRAULIC DESIGN CRITERIA.

(b) Office of the Chief of Engineers, Dept. of the Artny, Washington, D. C.

(d) Analytical (model and prototype); for design.

(e) A general study to develop, analyze, and disseminate to Army Corps of Engineers establishments hydraulic design criteria to ensure adequate capacity, economy of design and constmetion, and safe and satisfactory operation of large hydraulic structures. Criteria are developed from model and prototype tests relating to the design of spillways, outlet works, gates and valves, channels, and navigation structures.

(g) An analytical procedure was developed which permitted correlation of empirical discharge data for vertical-lift gates independent of the crest geometry and approach conditions. This procedure involves the ratios of gate discharge to uncontrolled discharge versus a function of a head-gate opening parameter. An analytical procedure was also developed which permits the correlation of empirical pressure data for spillway flip-bucket and toe curves. This procedure relates the discharge, curve radius, and total head to the boundary surface pressure and its location on the bucket or toe curve.

(h) "Turbulent Boundary Layer Development on Spillways" and "Discharge Rating Curves for Vertical Lift Gates on Spillway crests." U. S. Army Engineer Waterways Experiment Station Miscellaneous Papers Nos. 2-587 and 2-606, July and October 1963, respectively. (Avallable on loan.)

"Nonuniform Flow Functions--Circular Section." U. S. Army Engineer Waterways Experiment Station Miscellaneous Paper No. 2-601, Sept. 1963. (Avallable for purchase or on loan.)

(b) Office of the Chief of Engineers, Department of the Army, Washington, D.C.

(d) Experimental; applied research.

(e) The study of erosion characteristics of various sizes of riprap and gravel material is being performed with a view to securing adequate protection at minimum cost. Measure. ments of velocity and depth at which movement of material begins will be made. Data collected on models of speciflc structures are beling analyzed in an effort to generalize the test results. 
(1988) WATER TEMPERATURE EFFECTS ON BED FORMS AND ROUGHNESS.

(b) Office of the Chief of Engineers, Department of the Army, Washington, D.C.

(d) Experimental; applied research.

(e) A laboratory flume, in which water temperatures can be varled to simulate normally experienced summer and winter temperatures, is being used to Investigate the effects of water temperature on streambed forms and roughness of various types of bed materials. Preliminary tests with fine sand have been completed and tests with crushed coal undertaken.

(f) Suspended.

(2428) MODEL STUDY OF SAVANNAH HARBOR, GEORGIA.

(b) District Engineer, U. S. Army Engineer District, Savannah, Corps of Engineers, Savannah, Georgia.

(d) Experimental; for design.

(e) The investigation was conducted in a model which reproduced the following: 1) that portion of the Atlantic Ocean, adjacent to the harbor entrance, from Calibogue sound on the north to Wassaw sound on the south; 2) the Savannah River and 1ts flood plain to the head of tide at Ebenezer Landing; and 3 ) that portion of the Intracoastal Waterway which crosses the area included in the model. The model was of fixed-bed construction with scale ratios, model to prototype, of $1: 800$ horizontally and 1:80 vertically. Automatic tide generators were used to reproduce tides and tidal currents throughout the harbor, and salt water was used in the model ocean to reproduce the effects of density difference on current velocities and distributions. Shoaling studies were made by injecting finely ground gilsonite into the model to reproduce the patterns of shoaling as observed in the prototype, following which the effects of proposed improvement plans on shoaling patterns were observed and evaluated. Studies were also made of the effects of proposed improvement plans on dispersion and dilution of contaminants discharged into the harbor. Refinements of plans for reducing and locallzing shoaling were tested for conditions of recently recommended changes in project channel width and depth.

(f) Tests completed; preparation of section 4 of final report in progress.

(g) The results of model tests indicate that construction of a sediment trap and tide gate in lower Back River will effectively eliminate shoaling in lower front River for conditions of the proposed wider and deeper channels throughout the harbor. Tests indicate that this plan offers the greatest benefit in reducing the cost of maintenance dredging In the harbor.

(h) "Savannah Harbor Investigation and Model Study," Volume III, "Results of Model Investigations"; Section 3, "Results of Supplemental Tests." U. S. Army Engineer Waterways Experiment Station Technical Report No. 2-580, November 1963. (Avallable on loan.)

(2673) MODEL STUDIES OF BARKIEY LOCK AND DAM, CUMBERLAND RIVER, TENNESSEE.

(b) District Engineer, U.S. Army Engineer District, Nashvilie, Corps of Englneers, Nashville, Tennessee.

(d) Experimental; for design.

(d) A $1: 120$ model, reproducing the cumberland River from mile 29.4 to 32.2 , the lock, dam, and powerhouse, was used to investigate flow characteristics in the approaches to the lock. A $1: 36$ model, reproducing the riverward downstream lock wall including the culvert manifold which discharges into the spillway stilling basin, five spillway bays, 324 feet of approach channel, and 596 feet of exit channel, was used to investigate flow characteristics in the stilling basin and exit channel. The emergency lock gate was studied in a $1: 25$ model which reproduced the gate, gate sill, and portions of the upstream lock approach and the lock chamber downstream from the gate. This model was used to determine: 1) hydraulic forces on and stability of the emergency gate under various flows including free flow over the lock miter sill; 2) hydrostatic forces on the gate in various positions; 3 ) gate wheel reactions and sill roller reactions at given positions; and 4) head loss through the bridge decking.

(h) Final report in preparation.

(2678) MODEL STUDY OF NAVIGATION CONDITIONS, MCALPINE LOCKS AND DAM, OHIO RIVER.

(b) D1strict Engineer, U. S. Arrny Engineer District, Loulsville, Corps of Engineers, Louisville, Kentucky.

(d) Experimental; for design.

(e) A fixed-bed, 1:120 model reproduced a sixmile reach of the Ohio River including adjacent overbank areas, the locks and dam structures, and all bridges and other structures that might affect flow conditions. Purposes of the model study were to: determine the effects of location, size, and alinement of the dam on stages and currents in the upper pool; determine the effects of location, size, and alinement of a new approach channel on navigation and surge conditions; determine the best location for a new navigable span on the Pennsylvania Rallroad bridge; determine a method of operating the dam for optimum navigation conditions; study navigation conditions in the lower approach as affected by flow through dam, powerhouse, and lock-emptying system; and provide a mears for navigation interests to satisfy themselves as to the acceptability of the proposed pları by observing the model in operation.

(g) Satisfactory plans were developed covering composition and location of dam, upper and lower approach channels, and lock filling and emptying. Tests of various gated sections of the dam provided data for use by the District office in developing discharge rating and stage-duration curves. Data were also obtained on the effects of various dam designs on head at the hydroplant, and on velocities along the Indiana shore.

(h) Final report in preparation.

(2680) MODEL STUDY OF HURRICANE TIDES IN NARRAGANSET BAY, RHODE ISLAND.

(b) Division Engineer, U. S. Army Englneer Division, New England, Corps of Engineers, Boston, Massachusetts.

(d) Experimental; for design. l:100 vertically, reproduces all of Narragansett Bay and an adjacent portion of the Atlantic ocean. An automatic tide generator reproduces normal tides throughout the model, and a separate, manually operated generator reproduces hurricane tides of the desired characteristics at the bay entrance. Numercus barrier plans for prevention of hurricanetide damage have been proposed. The relative and absolute effectiveness of these plans in reducing hurricane-tide elevations throughout the bay system were determined and the effect of the best plan on such important factors as tidal circulation, pollution, salinity, and shoaling for normal conditions were investigated. Fresh water only is used in the model during tests of the proposed barrier plans, but both salt and fresh water are used in tests to determine the effects of barrier plans on all significant factors for normal conditions. Model appurtenances consist of automatic tide gages to record both hurricane-tide and normal-tide elevations at critical points, recording salinity meters, recording dye meters for observing pollution and/or flushing characteristics, current velocity meters, 
and equipment for simulating shoaling of the channels and other navigation facilities.

(g) Results of supplemental tests indlcate that the flood-control effectiveness of the Lower Bay Barrier plan would not be impaired by eliminating the spur dike on the west side of the East Passage Barrler opening, nor by conversion of the navigation opening of the Sakonnet RIver Barrier from a gated to an ungated type.

(2681) SCALE-EFFECT TESTS OF RUBBLE-MOUND BREAKWATERS.

(b) Offlce of the Chlef of Englneers, Department of the Army, Washington, D.C.

(d) Experimental; applied research.

e) Tests are being conducted by the coastal Englneerling Research Center, under the supervision of the Waterways Experiment Station, to investigate the effects of model scale on the results of experimentally determined criteria for the design of rubble-mound breakwaters. Stabll1ty tests have been made of a breakwater slope of 1 on $1-1 / 2$ using wave periods of $2.61,3.75,7.87$, and 11.33 seconds. Tests in the coastal Engineering Research Center wave flume (15 feet by 20 feet by 635 feet) using a linear scale of 7.5 to 1 based on the tests conducted in the Waterways Experiment Station $5-$ by $4-$ by $119-$ foot wave flume were temporarliy suspended. Stabllity tests have also been conducted in the Waterways Experiment Station small wave flume ( 1 foot by 1.5 feet by 94 feet) using a scale of 0.5 to 1 based on tests conducted in the $5-$ by $4-$ by $119-$ foot wave flume. Therefore, data on the stability of mubblemound breakwaters will be avallable for three different linear scales, 0.5 to 1 , 1 to 1 , and 7.5 to 1 . Test data from the Coastal Engineerling Research Center wave flume will be correlated with data from the Waterways Experiment station flumes. Analys1s of data was in progress.

\section{(2925) ULTRASONIC FLOW MEASUREMENT.}

(b) Offlce of the Chief of Engineers, Department of the Army, Washington, D.C.

(d) Experimental; development.

(e) Various types of acoustic flowmeter equipment for discharge measurement in closed rectangular and circular condults were investigated for proposed fleld application in large condults and tunnels. Both line and point transducers were evaluated.

(f) Discontinued.

(2931) MODEL STUDY OF SOUTHWEST PASS, MISSISSIPPI RIVER.

(b) District Englneer, U. S. A mmy Engineer District, New Orleans, Corps of Engineers, New Orleans, Loulsana.

(d) Experimental; for design.

(e) To determine the effectiveness of proposed improvement works (jetty extensions, channel realinements, and contraction works) in el1minating or reducing the periodic maintenance now required in order for deep-draft vessels to navigate the jetty and bar channels of Southwest Pass, the lower 12 miles of the Pass and the adjacent area of the Gulf of Mex lco were reproduced in a $\mathrm{f} 1 \mathrm{xed}-\mathrm{bed}$ model to scale ratios of $1: 500$ horizontally and 1:100 vertically. Tides, t1dal currents, littoral currents, and wave action in the Gulf of Mexico, and saltwater and freshwater flows in Southwest Pass and the bar channel were reproduced in the model. Shoaling studies were made by introducing various mixtures of plastic materlals into the model to slmulate prototype shoaling materlals and thus reproduce in the model the patterns and distribution of shoaling that occur in the prototype.

(h) Final report in preparation.

(2932) MODEL STUDY OF SHOAIING, HUDSON RIVER, N. Y. (b) Distrlct Engineer, U. S. Amy Englneer Distr1ct, New York, Corps of Engineers, New York, N. Y.

(d) Experimental; for design.

(e) A comprehensive, flxed-bed model, constructed to linear scales of $1: 100$ vertically and $1: 1,000$ horlzontally, 1s belng used to determine the source of materlal shoaling the Hudson River in the vicinity of Edgewater and Weehawken plers and the most effective means of reducing or eliminating this shoallng. The model reproduces Upper and Lower New York Bays, Raritan Bay, Hudson RIver to Hyde Park, East RIver to Throgs Neck, and tributaries flowing into the modeled bodies of water. Provisions are included for reproducing tides, freshwater discharge, salinity intrusion, and shoaling. Another model, reproducling the Hudson R1ver between pler 21 (Duane Street) and West 158th Street, Manhattan, to scales of $1: 100$ vertlcally and 1:300 horlzontally, and including provisions for simulating tides, tidal currents, and shoaling of navigation slips is being used to determine the causes of shoaling in the pier slips in New York Harbor, and to develop plans for alleviating this shoaling.

(g) Tests in the comprehensive model Indicated that the best plan 1nvolving 1ncreasing the river cross section at the George Washington Brldge would decrease shoaling of the navigation channels by about 25 percent and would decrease shoaling of the slips by about 15 percent. Fleld and offlce studies indicate that a control structure in the Harlem River is technically infeasible, although model tests show that such a structure would slgniflcantly reduce shoaling both in the navigation channels and in the slips. Tests show that deepening the channel through Haverstraw Bay would not reduce shoaling of channels or slips. A sediment trap in the upstream end of the 30-foot project channel would reduce shoaling in the remalnder of this channel, although similar reduction can be attained by overdredgling the area involved at frequent intervals. Tests in the pier slip model indicate that approximately 25 percent of any dredge spoil free-dumped in the nav1gation channel would return to and deposit In the slips. These tests also show that free-dumping, if permitted, should not be done within 500 feet of the plerhead line.

(3236) MODEL STUDY OF MAXWELL LOCKS AND DAM, MONONGAHEIA RIVER, PENNSYLVANIA.

(b) District Engineer, U. S. Army Engineer Dist., Plttsburgh, Corps of Englneers, Pittsburgh, Pennsylvania.

(d) Experimental; for des1gh. reproducing about 2.5 miles of the

Monongahela River and the locks and dam structures, was used to study approach cond1tions under various river flows and methods of operation oi control gates; to determine effects of design modifications; to develop modiflcations required to overcome any undesirable conditions; and to demonstrate to navigation interests the acceptability of the proposed design from a navigation standpoint.

(g) Tests indicated that modification of the left abutment of the dam and the left bank improved current alinement along the left side of the channel and reduced velocities in the lower lock approach. Modification of the right bank downstream of the lower gulde wall provided additional maneuver area without appreciably affecting navigation conditions. Tests also indicated the maximum discharges which could be passed w1thout overtopping the cofferdams during various phases of construction, velocities with the cofferdams in place, and the effects of the cofferdams on navigation during construction. (h) Final report in preparation. 
(3243) MODEL STUDY OF LOCKS AND DAM NO, 4, MONONGAHELA RIVER.

(b) District Engineer, U.S. Army Engineer District, Pittsburgh, Corps of Engineers, Pittsburgh, Pennsylvania.

(d) Experimental; for design.

(e) A 1:120 fixed-bed, comprehensive model reproducing about 2.5 miles of the Monongahela RIver and the locks and dam structures was used to determine the effects of modifications to the existing locks and dam on navigation conditions, and to develop modifications required to overcome any undesirable conditions.

(h) Final report in preparation.

(3581) MODEL STUDY OF LAKE PONTCHARTRAIN, LOUISIANA.

(b) District Engineer, U.S. Army Engineer District, New Orleans, Corps of Engineers, New Orleans, Louisiana.

(d) Experimental; for design.

(e) The investigation was conducted in a fixedbed model that reproduced to scales of $1: 2,000$ horizontally and $1: 100$ vertically, Mississippi Sound west of Grand Island, and Lakes Borgne, Pontchartrain, and Maurepas, together with significant tributaries. The model reproduced the tides, tidal currents, salinities, and freshwater discharges of the prototype. The purpose of the study was to determine the effect of proposed hurrlcanesurge control structures across the connections between Lake Borgne and Lake

Pontchartrain upon the hydraulic and salinity regimens of the area landward from the structures.

(f) Completed.

(g) Test results indicate that the proposed gated control structures in the Rigolets and Chef Menteur Passes, which would reduce the existing cross-sectional area of the passes by about 75 percent, would have no signif1cant effects on the present salinity regimen of the lakes or on the passage of floods when the Bonnet Carre spillway is in operation. Complete closure of all structures during a hurricane would not cause adverse salinity conditions or increase the highwater elevation by more than 1.4 feet msl. It was concluded from the tests that freshwater inflow must be given equal consideration with any plan for modification of the salinity regimen of the lake system.

(h) "Effects on Lake Pontchartrain, La., of Hurricane Surge Control Structures and Mississippi River-Gulf outlet Channel. Hydraulic Model Investigation." U. S. Army Englneer Waterways Experiment Station Technical Report No. 2-636, November 1963. (Avallable on loan.)

(3584) MODEL STUDIES OF RED ROCK DAM, DES MOINES RIVER, IOWA.

(b) District Engineer, U. S. Army Engineer Disrict, Rock Island, Corps of Engineers, Rock Island, Illinols.

(d) Experimental; for design.

(e) A 1:50 model that reproduced 900 feet of the approach channel above the spillway, an 825-foot-wide section along the dam, the spillway, conduits, stilling basin, and 575 feet of the outlet channel, and a $1: 16$ model that reproduced one conduit and a 16 -footwide portion of the spillway and stilling basin were used to study flow conditions in the approach, particularly at the abutments, to verify stiling basin and training wall design, to evaluate reduction in conduit flow during combined operation, to determine the need for armor plate at the outlet portal, and to study the effects of deflectors above the conduit outlet portals.

(g) Tests on the L:16-scale model indicated that during combined operation, simulating spillway and conduit flow at maximum reservoir

elevation, pressures within the conduit and the outlet portal were positive. "Eyebrows" or deflectors above the portal increased conduit flow and dropped the grade line within the conduit. The Folsom Dam highlevel conduit, reproduced in the model, verified prototype cavitation-damage areas and furnished a basis for interpretation of Red Rock condult test results. The general model provided information on spillway capacity as affected by abutment changes; velocities in the approach, particularly against the dam; optimum basin elevation consistent with safety and economy; basin elements of minimum size; and bottom velocities in the exit channel.

(h) Final report in preparation.

(3586) MODEL STUDY OF HOPPER DRAGHEA.

(b) District Engineer, U.S. Army Engineer District, Philadelphia, Corps of Engineers, Philadelphia,Pennsylvania.

(d) Experimental; for design. attain a greater rate of intake of solids when dredging mud and silt mixtures (soft materials) and dredging densely packed, fine sand (hard materlal), an investigation was conducted in a 60- by 10-foot flume containing various types of bed material. The draghead and suction line, constructed to a scale of 1:6, were connected to a suction pump mounted on a double carriage that provides travel, both longitudinally and transversely, along the top of the flume.

(h) Final report in preparation.

(3590) EFFECTS OF HURRICANE BARRIER ON NAVIGATION CONDITIONS IN EAST PASSAGE, NARRAGANSETT BAY, RHODE ISLAND.

(b) Division Engineer, U.S. Army Engineer Division, New England, Corps of Engineers, Waltham, Massachusetts.

(d) Experimental; for design.

(e) A barrier across East Passage has been proposed to limit the quantity of water entering Narragansett Bay from hurricane surge. A $1: 150$ model of East Passage was used to examine ship navigation conditions with respect to barrier location and its navigation opening under current, wave, and wind conditions created by astronomical tides and hurricane surges. A self-propelled, radio-controlled, model alrcraft carrier, dynamically similar to 1 ts prototype, was used Ir. the tests. Two-dimensional flume tests were conducted to investigate the effect of roughness on the discharge through the proposed barrier opening. Calibration tests were conducted on a roughened overflow section of the barrier in the East Passage model. Comprehensive velocity measurements were taken on the East Passage model for a neap tide condition.

(f) Tests completed; final report in preparation. Tests showed that a velocity of 3.5 knots through the roughened barrier is produced by a head differential of 0.5 foot across the barrier. This is equivalent to the maximum differential caused by a 2.8-foot tide range.

(3592) MODEL STUDY OF TYPICAL NAVIGATION DAM, ARKANSAS RIVER.

(b) District Englneer, U.S. Army Englneer District, Ilttle Rock, Corps of Englneers, Little Rock, Arkansas.

(d) Experimental; for design.

(e) The Arkansas River multipurpose project includes the development of river navigation from the Mississippi River to the general area of Tulsa. Present plans for navigation include construction of several navigation locks and dams. A movable-bed model constructed to linear scales of 1:120 horlzontally and 1:40 vertically, reproducing a 5-mile reach of a typical stream having characteristics generally similar to reaches of the Arkansas River and including a typical 
Arkansas River lock and dam structure, was used to invest1gate various problems that occur in the vicinity of the structures.

(f) Completed.

(g) Tests 1ndicated that: navigation conditions in the upper approach would be affected by high-velocity currents and crosscurrents near the end of the upper guard wall of the lock at the location tested; conditions in the upper approach could be Improved by extending the contraction works in the upstream bend to reduce flow across the bar and by moving the lock and dam structure farther downstream; shoaling would occur in the lower approach channel which could be reduced by means of low wing dikes extending from the end of the lower guard wall; the sandbar in the bend upstream would extend toward the dam and tend to reduce flow through the bays near the abutment on the barside of the channel; deposition would occur over the dam gate $s 111$ and in the stilling basin, but the shoaling should not affect the operation of the gates or the stilling basin.

(h) "Navigation and Sedimentation Conditions at Typlcal Lock and Dam, Arkansas RIver, Arkansas and Oklahoma; Hydraul1c Modél Invest1gat1on." U. S. A my Eng1neer Waterways Experiment Station Techn1cal Report No. 2-623, Apr11 1963. (Avallable on loan.)

(3596) HYDRAULIC STUDIES FOR IMPACT ENERGY DISSIPATOR DESIGN.

(b) Office of the Chief of Englneers, Department of the Army, Washlngton, D.C.

(d) Experimental; applied research.

e) A general investigation to determine the energy loss coefflclent of an Impact energy dissipator of variable helght and depth for varying slopes, diameters, and energy of flows of the Incoming p 1 pe was conducted on a 1.0-foot-diameter impact energy dissipator. The dissipator consisted of a vertical section of c1rcular plpe affixed to the outlet end of a storm drainage outfall, termed a stilling well. The energy of the influx was determined from measurements of the discharge and the hydraulic gradient, and the energy of the efflux from measurements of the water surface above the top of the well. The slope and size of the 1ncoming plpe were varied to determine the effect of each upon the energy dissipated. For a particular slope and diameter of the incoming plpe and a particular helght and depth of the dissipator above the invert of the incoming plpe, the relative energy content of the efflux to the Influx was determined for a range of Reynolds numbers to ascertain the effect of Reynolds number upon the energy loss in the dissipator. Completed.

(g) Test results indicate that there is an opt1mum depth of the stllling well below the Invert of the incoming pipe, dependent on the slope of the incoming pipe. Limited tests Indicated that there is also an optimum helght of the well above the plpe invert for each given set of conditions. In regard to energy dissipation, test results show that the smaller the ratio of the diameter of the incoming plpe to that of the stilling well and the flatter the slope of the Incoming plpe, the greater the value of the energy loss coefficlent. The energy loss coefficlent is less for full pipe flow than for partlal plpe flow. Discharge coefflclents for a clrcular stilling well were determined for both partial and full plpe flows and free outflow conditions, and empirical equations were developed.

(h) "Impact-Type Energy D1ssipator for StormDralnage Outfalls; Stilling Well Design." U. S. Army EngIneer Waterways Experiment Station Technical Report No. 2-620, March 1963. (Avallable on loan.)

(3597) CORRUGATED PIPE ROUGHNESS STUDY.

(b) Office of the Chlef of Englneers, Department of the Army, and Bureau of Public Roads, Department of Commerce, Washington, D.C. (d) Experimental; applied research.

(e) Th1s was a general investigation to determine a resistance coefficient and the law of velocity distribution for flow in structuralplate corrugated p1pe. A fiber-glass test section reproducing a 5-foot-diameter standard corrugated plpe at a scale of $1: 4$ was tested in order to obtain additional data on the resistance coefflclent and velocity distribution and to correlate model work with full-scale tests. F1ber-glass test sections reproducing a 5-foot-, 10-foot-, and 20-footdiameter structural-plate pipe at scales of $1: 2.2,1: 8$, and $1: 16$, respectively, were tested to determine the effect of relative roughness upon the resistance coefflclent and velocity distribution. The hydraulic gradient and the energy loss through 20- to 80-dlameter lengths of test section were established by plezometers located at 5 -foot intervals. These plezometers were $1 / 8$ inch in dlameter, on center of the crests of the corrugations, and four in number around the perlphery of the plpe. Velocity traverso were made by means of calibrated pitot tubes at several locations along the test section for determination of the velocity di stribution.

(h) Final report in preparation.

(3902) RADIOACTIVE TRACER TESTS OF SEDIMENT, GALVESTON BAY, TEXAS.

(b) District Englneer, U.S. Army Englneer District, Galveston, Corps of Englneers, Galveston, Texas.

(d) Experimental; field Investigation.

(e) The movement of sediment in the vicinity of the Galveston Bay jetty was Investigated by use of radloactive gold-1mpregnated glass. The glass was ground to the particle size of the natural sediment. In the flrst serles of tests, the activated, gold-impregnated glass was deposited at three locations on the north side of the Jetty, and the paths of the particles were traced by instruments from a small boat. Readings were procured over a perlod of about one week. It was expected that the tidal action, littoral current, and wind waves would move the materlal around the end of the jetty and/or through the jetty. In a second series of tests, the tracer material was deposited at five additional locations north of the north jetty. These locations extended the area under study beyand the end of the jetty. A third series of tests was conducted in which materlal was placed at three locations outside the south jetty.

(f) Tests completed; final reports in preparation.

(g) In the first series of tests, some of the radloactlve materlal passed through a small boat opening in the jetty, and further tests were needed to determine whether any materlal passes around the end of the jetty. In the second series of tests, the bulk of materlal deposited near the end of the jetty swept around the end into the ship channel and was randomly distributed over the area between the jettles. In the third series of tests, that materlal placed off the south jetty remained. outside the jetty with movement generally east and south.

(3903) MODEL STUDY OF TSUNAMIS AT HILO HARBOR, HAWAII .

(b) DIstrict Engineer, U.S. Army Englneer District, Honolulu, Corps of EngIneers, Honolulu, Hawa11.

(d) Experimental; for design.

(e) A comprehensive, flxed-bed hydraulic model w1ll be constructed by the U. S. Army Engineer District, Honolulu, to determine the optimum plan of protection for H1lo Harbor from attack by tsunamis, dangerous surges, and short-period waves. Remedial works in the form of breakwaters are proposed. The 
Waterways Experiment Station's part in the comprehensive $\mathrm{H} 110$ Harbor investigations being conducted by the Honolulu District is to: (1) design the tsunami generator, (2) establish model and pit limits for Phase I and II of the study, (3) suggest and procure instrumentation for the model, and (4) design the wave filter for Phase II of the investigation. To this end a pilot model study to investigate model distortion and scale effects was conducted. Design of the Phase. I model is in progress. Flume tests are being conducted to determine the design of a wave filter for the Phase II model. Tests to determine the design parameters of a bore generator are being conducted in a small flume.

(g) Tests performed in the pilot model show that the Hilo tsunami model can be distorted as much as 3 to 1 , vertical to horizontal.

(3905) KELIEYS ISLAND HARBOR STUDY, IAKE ERIE, OHIO.

(b) State of onio.

d) Analytical; for design.

(e) An analysis was performed to estimate the magnitude and duration of waves which approach the North Bay area of Kelleys Island, and determine the type, length, and orientation of breakwaters and wave absorbers required to provide good entrance conditions and adequate protection to boats moored in the proposed harbor of refuge. Use was made of wavehindcast methods, wave refraction and diffraction theories, and model data and design procedures developed at the Waterways Experiment Station for evaluation of the stability characteristics of rubble-mound breakwaters and wave absorbers.

(f) Completed.

(g) Results of the analysis indicated that (1) waves about 6 feet in helght will reach the proposed harbor site occasionally;

(2) the harbor entrance should open to the west to ensure adequate inner-harbor protection from waves having the greatest magnitudes and frequency of occurrence, and the littoral drift resulting therefrom; and (3) one of the harbor and breakwater systems investigated will provide sufficient protection to ensure that waves exceeding 0.5 foot in height inside the harbor will occur only rarely.

(h) "Estimate of Wave Action Conditions and Selection of Optimum Plan for Proposed Harbor of Refuge, Kelleys Island, Ohio; Analytical Investigation." U. S. Army Engineer Waterways Experiment Station Miscellaneous Paper No. 2-560, March 1963. (Available on loan.)

(3906) POWER PLANT TRANSIENTS TESTS, GARRISON AND OAHE DAMS, MISSOURI RIVER, NORTH DAKOTA.

(b) Division Engineer, U.S. Army Engineer Division, Missouri River, and District Engineer, U.S. Army Engineer District, Omaha, Corps of Engineers, Omaha, Nebraska.

(d) Field investigations; applied research and design.

(e) Hydraulic prototype measurements of power plant transients at Oahe and Garrison Dam have been made to evaluate results of a comprehensive digital computer study made by the sponsoring offices, and to determine extent to which operation corresponds to design in order to develop a solution of the entire problem of power plant transients, with primary emphasis on governing stability. For different plant loadings, instantaneous pressure values at a number of locations in the power tunnel, the surge tank system, turbine scroll case, and draf't tube were obtained simultaneously with instantaneous values of tunnel velocity, reservolr and tailwater elevations, turbine speed and gate opening, power output, and other elements (including governor system). Pressure and water level were measured with electrical pressure transducers, velocities were measured with pressure transducers mounted in probes projecting into the flow and connected to pitot-static tubes on cross struts in the penstock, and mechanical and electrical values were obtained with appropriate transducers. Measurements were recorded on about 90 channels of oscillograph and magnetic tape recorders. Data are being digitized by the Omaha District for computer analyses.

\section{(3907) SHOALING PROCESSES.}

(b) Office of the Chief of Engineers, Department of the Army, Washington, D.C.

(d) Experimental; for design.

(e) The annual cost to the Federal Government of maintaining navigable channels in tidal waterways is estimated to be of the order of $\$ 60,000,000$. The Corps of Engineers Committee on Tidal Hydraulics has concluded that a thorough study of shoaling processes in tidal waterways would lead to improvements in channel design, dredging, and spoiling practices, and other maintenance techniques which would reduce this large expenditure. The Committee concludes that the following program of research is essential in arriving at the objective of reducing maintenance cost: (1) Flume studies to determine the basic laws involved in the movement and deposition of muddy sediments; (2) flume studies to determine effects of repetitive scour and deposition on sedimentation; (3) the development of techniques for using radioactive tracers for observing the movement and deposition of sediments in nature; (4) the development of a simple and accurate instrument for in-place measurement of turbidity; (5) a study of the physical, chemical, and hydraulic factors involved in the stabilization of deposits in navigable channels; (6) determination of the effects of floccu lation on shoaling; (7) prototype studies aimed at correlation of sedimentation phenomena in tidal waterways with physical, chemical, hydraulic, salinity, and other significant factors; and (8) classification of the sediments which constitute all major repetitive shoals in tidal waterways. Item (1) above was completed under terms of a contract between the University of California and the U. S. Army Engineer District, San Francisco, and all pertiment reports have been published; item (2) is presently inactive; 1tem (3) is in active status by the U. S. Army Engineer Waterways Experiment Station and U. S. Army Engineer Districts, Galveston and Wilmington; item (4) is presentiy inactive; item (5) is being investigated under terms of a contract between the University of Calif and the U. S. Army Engineer Waterways Experiment Station; item (6) is under study by the Committee on Tidal Hydraulics and the U. S. Army Engineer Waterways Experiment Station, and a research program has been formulated; and items (7) and (8) are in progress by the U. S. Army Engineer Waterways Experiment Station. No definite conclusions have yet been reached as a result of these studies.

\section{(3908) ARKANSAS RIVER NAVIGATION MODEL.}

(b) District Engineer, U.S. Army Engineer District, Vicksburg, Corps of Engineers, Vicksburg, Mississippi.

(d) Experimental; for design.

(e) A fixed-bed model reproducing to scales of 1:600 horizontally and $1: 100$ vertically about 33 miles of the Mississippi River near the mouths of the White and Arkansas Rivers, 57 miles of the lower Arkansas River, 12 mile of the lower White River, and the major portion of the White-Arkansas River backwater area was used for the investigation. The model was used to demonstrate alternate routes for the entrance to the Arkansas River navigation project, flow patterns, nature of overbank flow, effect of Arkansas-White Cutoff, and problems related to the location 
and alinement of the navigation entrance to the Arkansas River from the M1ss1ssipp1 River.

(h) Final report in preparation.

(3909) MODEL STUDY OF HANNIBAL (FORMERLY OPOSSUM CREEK) LOCKS AND DAM, OHIO RIVER.

(b) D1strict Engineer, U. S. Army Engineer D1strict, P1ttsburgh, Corps of Eng1neers, P1ttsburgh, Penna.

(d) Experimental; for des1gn.

(e) A 1:120, fixed-bed, comprehensive model reproducing about 4 miles of the oh1o R1ver and the lock and dam structures $1 \mathrm{~s}$ be1ng used to study navigation conditions in the approaches to the locks, determine sultability of the selected site, and develop modiflcations required to overcome any undesirable conditions found.

(8) Effects of modified excavation in the upper lock approach were determined, and tests of the effects of submerged dikes in reducing velocities indicate that a reduction in velocities in the upper approach could be obtalned with submerged dikes designed to deflect flow after 1t passes the bend upstream.

(3911) MODEL STUDY OF MATAGORDA SHIP CHANNEL, TEXAS.

(b) D1strict Engineer, U.S. Army Engineer District, Galveston, Corps of Englneers, Galveston, Texas.

(d) Experimental; for design.

(e) The fixed-bed model, corstructed to scale ratios of $1: 1,000$ horlzontally and $1: 100$ vertically, reproduced about 800 square miles of prototype area, including all of Matagorda Bay, part of the connecting bay system, and a portion of the Gulf of Mexico adjacent to Pass Cavallo. T1des and tidal currents were reproduced by one primary and one secondary tide generator, and fresh-water discharges of tributaries, together w1th the rainfall over the area, are introduced by means of welrs and flowmeters. Salt water was used in the model gulf to reproduce the prototype salinitv reoimen, and provisions were made for the injection of silt in the model for measurements of deposits on the bed of the model. Studies were made to determine: (1) The best location for the entrance channel; (2) the best route for the channel from the entrance to Polnt comfort; (3) such protective works as may be required in the interests of navigation and maintenance of the channel; and (4) the effects of the deep-draft navigation channel on the salinity regimen of the bay system.

(h) Final report in preparation.

\section{(3912) MODEL STUDY OF GALVESTON BAY, TEXAS.}

(b) Distrlct Englneer, U.S. Army Englneer

District, Galveston, Corps of Eng1neers, Galveston, Texas.

(d) Experimental; for design.

(e) A movable-bed model, with scale ratios of 1:500 horlzontally and 1:100 vertically, reproduces about 174.5 square miles of prototype area, including a small portion of Galveston Bay and a portion of the Gulf of Mexico extending 8 miles north of the north jetty, 6-1/2 miles south of the south jetty, and off shore to about the 50-foot contour of depth. T1des, tidal currents, l1ttoral currents, and wave action in the Gulf of Mexico are reproduced. Studies are be1ng made to determine: (i) Plans for relocation and stab1lization of the jetty channel on an al1nement and depth su1table for nav1gation of supertankers; (2) means of protecting the north jetty from undermining action of tidal currents; (3) shoaling characterlstics of the relocated and deepened jetty (1nner bar) channel and plans for minimizing shoaling; and (4) shoaling characteristics of the deepened outer bar channel.

(8) Test results 1ndicate that the plan 2 channel realinement is the best of those tested to date, including the existing alinement. Results of tests of jetty modiflcations are belng analyzed, but no conclusions have been reached.

(3913) MODEL STUDY OF GULF OUTLET CHANNEL, LOUISIANA .

(b) District Eg1neer, U.S. Army Engineer District, New Orleans, Corps of Englneers, New Orleans, Loulsiana.

(d) Experimental; for design.

(e) The investigation was conducted in a f1xed-bed extension of the Lake Pontchartrain model and $1 \mathrm{n}$ confunction with that model study. Reproduced was that area eastward of New Orleans to Breton Sound and south of Lakes Pontchartrain and Borgne to include the connecting watemways between those lakes and the Gulf outlet Channel, now under constmuction. Scales are $1: 2,000$ hor1zontal and $1: 100$ vertical. Tides, t1dal currents, salinities, and water exchange through the connecting waterways are simulated. Purpose of the study was to determine the effect of the channel on the salinity regimens of Lakes Pontchartrain and Borgne, which will be connected to the channel by existing waterways.

(f) Completed.

$(\mathrm{g})$ Test results indicated that the Gulf outlet Channel, with no control over 1ts connection to Lake Pontchartrain through the Inner Harbor Navigation Canal, would cause a large increase in the present salinity of the lake. However, a gated control structure installed near the junction of the channel and Lake Pontchartrain could be used, in conjunction with accurate freshwater inflow predictions, to maintain the salinity level in Lake Pontchartra1n at the desired concentration. Tests w1th the Bonnet Carre sp1llway discharging the design flow and with both the Gulf outlet channel connected and hurricane surge structures installed in Chef Menteur and R1golets showed that high-water elevatio in Lake Pontchartrain would be raised to a maximum of 1.4 feet $\mathrm{msl}$.

(h) "Effects on Lake Pontchartrain, La., of Hurricane Surge Control structures and M1ss1ss1pp1 R1ver-Gulf outlet Channel; Hydraul1c Model Investigation." U.S. Army Engineer Waterways Experiment Station Techn1cal Report No. 2-636, November 1963. (Avallable on loan.)

(3914) MODEL STUDY FOR MODERNIZATION OF EXISTING LOCK, MCALPINE LOCKS, OHIO RIVER.

(b) District Englneer, U.S. Army Engineer District, Loulsville, Corps of Engineers. Loulsvilie, Kentucky.

(d) Experimental; for design.

(e) A 1:25 model which reproduced the f1lling and emptylng system was used to develop feasible modifications which will improve prototype performance.

(h) Final report in preparation.

(3915) MODEL STUDY OF DROP STRUCTURE, GERING VALLEY PROJECT, GERING VALLEY, NEBRASKA.

(b) District Engineer, U.S. Army Engineer D1strict, Omaha, Corps of Eng1neers, Omaha, Nebraska.

(d) Experimental; for design.

(e) The Gerlng Valley project in western Nebrask w1ll consist of low rectangular drop structures designed for alluvial channels, a serles of which w1ll be located in the maln Gering drain as well as in the tributarles. Structure w1dths w11l vary from 6 to 33 feet and lengths from 16 to 47 feet, with drop helghts of 5 and 10 feet. A 1:12-scale model and a 1:33-scale model were used to examine the hydraulic performance of the drap structures with particular interest in basin performance, d1 scharge capac1ty, and the extent and size of riprap required upstream 
and downstream of structure. Each model reproduced a typlcal drop structure, adjacent overbank areas, and about 300 feet of the approach and ex1t areas. The smaller scale model permitted more rapld modifications of the structure. Tests were conducted of 15 drop structure designs. These tests Involved: (1) observation of flow conditions and Investigation of scour tendencles above and below the structures; (2) effect of such factors as basin length, basin elements, and sill helght and basin wall position; and (3) determination of riprap size and placement.

(g) Famliles of curves were developed that permitted drop structure design based on drop helght and discharge conditions. Design criterla based on 1nvestigation of structures having a 5-foot drop helght were applicable to structures w1th drop helghts up to 10 feet. A satisfactory plan for placement of riprap material in the vicinity of the structure was developed.

(3916) MODEL STUDY OF OAHE RESERVOIR SPILLWAY, MISSOURI RIVER, SOUTH DAKOTA.

(b) District Engineer, U.S. Army Englneer District, Omaha, Corps of Engineers, Omaha Nebraska.

(d) Experimental; for design.

e) A 1:50 model reproduced the remote, gated control structure which will serve as the splilway, the stilling basin, and approximately 1,700 feet of approach and 1,200 feet of exit channel. The model study was concerned with: (1) flow characteristics In the approach and exit channels; (2) discharge dsta for the splliway gates w1thout downstream submergence; (3) the shape, arrangement, 'and locations of baffles for dispersal of energy downstream from the gate structure; (4) feasibility of a simple type of transition between the structure snd the discharge channel; snd (5) velocities on the apron below the struccure and in a portion of the unlined exit channel.

(g) Test results indicated that, wh1le the spiliwsy as originally designed functioned satisfactorily, a conventional-type stilling basin was not approprlate because of the lack of residual tall-water to force a hydraulic jump. A shsllow, depressed basin was developed which dispersed the smalier flows and eliminsted surface waves noted at the larger flows with the orlginal design basin. A schedule for use in operation of the spili. way gates was developed. This schedule when used in conjunction with the depressed basin was the optimum method of dissipating flows on the apron until downstream submergence occurred. Tests of the exit channel indicated that sector walls could replace the concrete transitions below the rectangular section of the basin. The paved apron could be reduced in length some 45 feet, and the riprap section could be reduced to 160 feet in length.

(h) Final report in prepsration.

(3917) GENERAL SPILLWAY MODEI TESTS.

(b) Offlce of the Chief of Englneers, Department of the Army, Washington, D.C.

(d) Experimental; for design.

(e) Tests are made on various elements of spillways to develop 1 mproved designs and to better define values of coefficients used in design formulas. A fiume 70 feet lons by 6 feet wide and 6 feet high comprises the test facllity. Section models designed for study of particular elements of splilways are installed in the test flume. A series of tests was conducted on welrs of varlous heights to determine optimum shape from a consideration of discharge coefficlents and pressures.

(g) The desirability of a welr crest shspe tangent to the upstream face of the welr has been established. This applies to welrs with sloping and vertical upstream fsces.
(3918) MODEL TESTS FOR TYPICAL FLOOD- AND WATERCONTROL STRUCTURE.

(b) District Engineer, U.S. Army Engineer District, Jacksonville, Corps of Engineers, Jacksonville, Florida.

(d) Experimental; for design.

(e) A 1:16 model, reproducing 384 feet of the approach channel, an 81.33-foot-w1de 3-bay structure, the spillway, stilling basin, and 192 feet of the outlet channel, was used to Investigate discharge character1stics of typical structure, and determine discharge coefficlents for open and partialiy open gates through a range of headwater and tallwater conditions.

(f) Completed.

(g) As expected, results indicated that the greater the depth of approach and/or difference in elevation between weir crest and exit channel, the greater the discharge coefficlent for all flow conditions. The effects of both on the discharge coefficlents are shown by means of graphical plots. Expressions describing free and submerged controlled and uncontrolled flow conditions and psrameters that w1ll define the limits of each of the four possible flow conditions were determined.

(h) "Typlcal Splliway stmucture for central and Southern Florlda Water-Control Project; Hydraul1c Model Investigation." U. S. Army Engineer Waterways Experiment Station Techn1cal Report No. 2-633, September 1963. (Avallable on loan.)

(4382) HYDRAULIC PROTOTYPE TESTS.

(b) Office of the Chief of Engineers, Department of the Army, Washington, D. C.

(d) Field investigations for applied research and design.

(e) The hydraulic prototype testing program of the corps of Engineers is coordinated for complete coverage of needed testing, prevention of unnecessary duplication of testing facilities and tests, recommendations of instrument installations at projects where physical and hydraulic conditions will be sultable for obtaining data, and investigation of prototype hydraulic performance. Personrel and equipment are msde avallable to corps of Engineers Districts conducting hydraulic fleld tests. Assistance also is given in planning test facilities, analyzing data, and preparing reports. Hydraulic prototype tests related to and conducted partly under this study are described in 1tem 4397 on McAlpine Lock emergency gate tests; 1tem 3906 on power plant translents tests; Prototype Hawser-Stress Measurements, Jackson Lock, Tomb1gbee R1ver, Ala.; Culvert Pressure Tests, Greenup Locks and Dam, Oh1o River, Ky. and Oh10; and Prototype Pressure Tests, Nolin Dam, Nolin River, Ky.

(4383) MODEL STUDY OF TURTLE CREEK CHANNEI IMPROVEMENT, PENNSYLVANIA.

(b) District Eng1neer, U.S. Army Engineer D1strict, P1ttsburgh, Corps of Englneers, P1ttsburgh, Pennsylvania.

(d) Experimental; for design.

(e) To evaluate proposed channel improvements and determine the necessity for ralsing bridges and modifying plers and abutments, a 1:50 model reproducing the lower 7,700 feet of Turtle Creek channel was used. The model included provisions for testing plans with the existing and Improved channels in the lower, 1,500-foot reach of the channel.

(g) Tests indicated that the proposed channel was adequate to carry the design discharge, although low-level rallroad bridges in the reach would project into the flow. Add1tional reduction in stages and improvement in flow conditions could be obtained by realinement of the lower 800 feet of channel to eliminate projecting plers and abutments, and by removing projections and obstructions 
remaining in the channel upstream.

(h) Final report in preparation.

(4384) MODEL STUDY OF SPILLWAY, PROCTOR RESERVOIR, LEON RIVER, TEXAS.

(b) District Engineer, U.S. Army Engineer District, Fort Worth, Corps of Engineers, Fort Worth, Texas.

(d) Experimental; for design

(e) A $1: 40$ model reproducing a center bay and adjacent half bays of the spillway and stilling basin, and 400 feet of approach and exit areas, was used to verify discharge coefficients and pressure conditions on the low ogee weir with sloping upstream face and to determine the effect of varying the depth of approach on these factors. Results will will be utilized for this and other projects in the Fort Worth District.

(h) Final report in preparation.

(4385) MODEL STUDY OF BELIEVILIE LOCKS AND DAM, OHIO RIVER, OHIO AND WEST VIRGINIA.

(b) District Engineer, U.S. Army Engineer District, Huntington, Corps of Engineers, Huntington, west Virginia.

(d) Experimental; for design.

(e) The project involves construction of a nonnavigable-type dam with parallel locks; the main lock will be 1,200 feet by 110 feet and the auxiliary lock 600 feet by 110 feet. A 1:120 fixed-bed model reproducing about 3 miles of the river was used to study navigation conditions in the lock approaches and the effects of the structures on flood stages.

(f) Suspended.

(4386) MODEL STUDY OF HOLT LOCK AND DAM, WARRIOR RIVER, ALABAMA.

(b) District Engineer, U.S. Army Engineer District, Mobile, Corps of Engineers, Mobile, Alabama.

(d) Experimental; for design.

(e) A 1:80 model, reproducing the structures, 4,800 f'eet of the approach channel and 4,800 feet of the exit channel, was used to study flow conditions in the lock approaches and in the approach and exit channels for all arrangements of the structures. A $1: 36$ section model reproducing one full bay and two adjacent half bays of the spillway and stilling basin was utilized for studies of the adequacy of the weir and stilling basin design. A 1:25 model reproducing 800 feet of the lock approach channel, intake manifolds, the 670-foot lock chamber, culverts, bottom laterals, outlet stilling basin, and 730 feet of the downstream exit channel was used to study various types of filling and emptying systems to determine the most advantageous system from the standpoints of rate of operations, degree of turbulence, and economy. A $1: 15$ model of a culvert valve was used to study proposed valve designs.

(h) Final report in preparation.

(4387) MODEL STUDY OF WILIOW SPRINGS AND SAG JUNCTION DIVERSIONS, CHICAGO SANITARY AND SHIP CANAL, ILLINOIS.

(b) Metropolitan Sanitary District of Greater Chicago, Chicago, Illinols.

(d) Experimental; for design.

(e) Tests were conducted on two 1:60 models, reproducing the diversion channels and a portion of the Sanitary and Ship Canal at each location, to determine the effect of crosscurrents on navigation and to verify or further develop the hydraulic design of the diversion channels and appurtenant hydraulic structures. A $1: 16$ section model was used for study of control strictures.

(h) Final report in preparation.
(4388) SECTION MODEL STUDY OF LOCK AND DAM NO. 6 , ARKANSAS RIVER, ARKANSAS.

(b) District Engineer, U.S. Army Engineer District, Little Rock, Corps of Engineers, Little Rock, Arkansas.

(d) Experimental; for design,

e) A $1: 25$ section model, reproducing a 5-foot depth of approach channel, one 60-foot gate bay and two adjacent half bays, the spillway stilling basin, and outlet channel, was used to determine the optimum parabolic shape of the downstream face of the gate sill, the dimensions and elevation of the stilling basin, the shape of the gate piers, the spillway rating curves with full and partially opened gates, and the minimum riprap requirements for various elevations of the exit channel.

(h) Final report in preparation.

(4390) MODEL STUDY OF CANNELTON LOCKS AND DAM, OHIO RIVER, INDIANA AND KENTUCKY.

(b) District Engineer, U.S. Army Engineer District, Louisvilie, Corps of Engineers, Louisvilie, Kentucky.

(d) Experimental; for design.

(e) The project involves the construction of a nonnavigable dam with parallel locks, the main lock to have clear dimensions of 1200 by 110 feet and an auxiliary lock, 600 by 110 feet. A 1:120 model reproducing about 9 miles of the river is used for

investigation of navigation conditions in the lock approaches, effects of the structures on flood stages, to obtain data for development of rating curves, and to determine the effect of powerhouse installation on flow and navigation conditions. A $1: 25$ model, reproducing 500 feet of the lock approach channel, intake manifolds, the 1270-foot lock chamber, culvert, sidewall port manifolds, outlets, and 200 feet of the downstream exit channel is being used to determine the suitability of a sidewall port fllling system under heads and submergences which will obtain at other locks on the Ohio River.

(g) Plans to reduce the swellhead caused by the powerhouse installation and to improve flow distribution in the approach to the powerhouse were developed. Tests in the $1: 25-$ scale lock model have resulted in a satisfactory filling and emptying system for Cannelton, Uniontown, and Hannibal Lock conditions. Satisfactory hawser stresses as well as turbulences obtained with the type 45 port arrangement, which consisted of 25 type A ports spaced 28 feet center to center in each wall with the most upstream port in the left wall 344 feet below the upstream miter gate pintle. The type 45 arrangement al so included is-foot- by $15-$ foot by 4 -foot-high angular deflectors at the twelve upstream ports in each wall.

(4391) MODEL STUDY OF LOCK AND DAM NO. 3, ARKANSAS RIVER, ARKANSAS.

(b) District Engineer, U.S. Army Engineer District, Little Rock, Corps of Engineers, Little Rock, Arkansas.

(d) Experimental; for design.

(e) A movable-bed model reproducing about 13 miles of the Arkansas River and adjacent overbank area, constructed to a scale of 1 to 120 horizontally and 1 to 80 vertically, is being used to determine the suitability of the proposed site for the lock and dam structure, the effects of proposed regulating works in the vicinity including a cutoff', and modifications which might be required to provide adequate channel depths in the lock approaches and safe navigation conditions with minimum maintenance.

(g) Tests indicated that the number of gate bays could be reduced from 22 to 18 and the elevation of the gate sills could be the same across the channel without any 
appreciable effect on channel development or swellhead at the dam. Plans which would tend to reduce shoaling in the lower lock approach would produce currents which might be objectionable to navigation.

(4392) EXTENSION OF LA GUARDIA FIELD RUNWAY, NEW YORK.

(b) Port of New York Authority.

d Experimental; for design.

(e) The existing New York Harbor model is being used for tests to determine the effects of certain proposed fills in East River, for the purpose of extending the North-South runway at La Guardia Airport, on the hydraulic and flushing characteristics of the surrounding areas.

(i) Inactive.

(4393) MODEL STUDY OF STABILITY OF SOUTH JETTY, SIUSLAW RIVER, OREGON.

(b) District Engineer, U.S. Army Engineer District, Portland, Corps of Engineers, Portland, Oregon.

(d) Experimental; for design.

(e) Stability tests were conducted in two wave flumes 119 feet long, 5 feet deep, and 4 feet wide on section models of the jetty constructed to a linear scale of $1: 50$ to determine experimental coefficients $\left(K_{\Delta}\right)$ in the Waterways Experiment station breakwater stability equation for design of repairs of the south jetty at the river mouth. Design criteria were also desired for both the head and trunk of the stmucture for the conditions of (1) waves breaking directly on the stmicture, (2) special placement by crane of selected iong-axis stones above low tide, (3) angles of wave attack of $O$ and 90 degrees, and (4) pell-mell placement by crane of cover-layer stones from toe of jetty to crest.

(f) Completed

g) It was found that values of $K_{\Delta}$ vary only slightly with the angle of wave attack. Also, it was found that the stablilty of the jetties could be improved by placing longaxis stones so that the long axes were normal to the brealwater slope. Design coefficients for the jetty head and trunk sections situated in water depths of 14,21 , 30 , and 40 feet were determined.

(h) "Stability of South Jetty, Siuslaw River, Oregon; Hydraulic Model Investigation." U. S. Army Engineer Waterways Experiment Station Technical Report No. 2-631, July 1963. (Available on loan.)

(4395) DISPERSION STUDIES IN NEW YORK HARBOR MODEL.

(b) Interstate Sanitation Committee.

d) Experimental; for design.

(e) The existing New York model is being used for a comprehensive study of the diffusion pattems from most of the major sewer outfalls in New York Harbor. Model tests are conducted using conservative fluorescent dyes as tracers, and the results will be used for planning the construction of additional sewage treatment facilities. Results are being analyzed by the Interstate Sanitation Commission.

(f) Inactive.

(4396) MODEL STUDY OF COLUMBIA RIVER, OREGON AND WASH INGTON

(b) District Engineer, U.S. Army Engineer District, Portland, Corps of Engineers, Portland, Oregon.

(d) Experimental; for design.

(e) The model reproduces the lower 52 miles of the Columbia River and pertinent offshore areas to linear scales of 1:500 horizontally and $1: 100$ vertically. Tides and tidal currents, density currents, waves, and other phenomena significant to the movement and deposition of sediments are reproduced and studied. Some portions of the model are of the flxed-bed type, while other portions are of the movable-bed type.

The purposes of the study are to determine the need for and to develop optimum plans for rehabilitation of existing jetties and proposed additional improvements; to investigate future shoaling developments in the entrance channel and in the reach between the entrance and oak point, and means of alleviating such shoaling; and to investigate existing and proposed spoil-disposal areas to establish locations that will not permit movement of material back to the channel.

\section{(4397) MCALPINE LOCKS EMERGENCY GATE PROTOTYPE TESTS}

(b) District Engineer, U.S. Army Engineer Dist., Loulsville, Corps of Engrs., Louisville, Ky.

(d) Experimental; for design. on the downstream leaf of a two-leaf, vert1cal-lift emergency gate ( 531 kips dry weight) were made to determine acceptability of the gate under flowing water conditions. Measurements included tension in the dead end of the hoist fall lines, gate-end elevations, and gate vibration. The prototype downpuil and gate vibration were compared with the results of a model study.

(g) Results of the tests Indicated stable gate operation under relatively severe flow conditions. Gate vibration was very low with no tendency to increase, indicating no elastic resonance with any fluctuating hydraulic load. Good agreement was found between prototype observations and results of a model study of the gate. Gate hoist loads were somewhat higher in the prototype than in the model, the variation being attributed to differences in gate constmuction or higher seal and reaction-roller friction in the prototype.

(h) Final report in preparation.

(4398) MODEL STUDY OF AMISTAD DAM SPIILWAY, RIO GRANDE.

(b) District Engineer, U.S. Army Engineer District, Fort Worth, Corps of Engineers, Fort Worth, Texas.

(d) Experimental; for design.

(e) A 1:70 model reproducing one-half of the river for a distance of 1,500 feet upstream and 2,500 feet downstream, one powerhouse, and one-half of the 950-foot-wide, 16-bay structure including the spiliway and stiling basin was used to determine spillway rating curves, flow conditions at the abutments and training. walls, pressures on weir crest, lateral pressures on pler subjected to unbalanced flow, and stiling basin action.

(f) Tests completed.

(4399) MODEL STUDY OF STABILITY OF BREAKWATER, TSOYING HARBOR, TAIWAN.

(b) District Engineer, U.S. Army Engineer District, Okinawa, Corps of Engineers, San Francisco, California.

(d) Experimental; for design.

(e) Stability tests were conducted in a concrete wave flume 119 feet long, 12.5 feet wide, and 4 feet deep on section models of the breakwater constructed to linear scales of $1: 47.6$ and $1: 58.6$ and to obtain data from which alternate designs could be developed for construction of the proposed breakwater. Design criteria for both the head and trunk of the breakwater were desired. Cover layers of both quarrystones and quadripod armor units were tested.

(f) Completed.

(g) Test results indicated that the stability of breakwater sections constructed of quarrystone cover layers is more dependent upon the roughness and shape of the stone used than upon the method of placing the stones 
In the cover layers. Breakwater head and trunk sections constructed of 25- to 35-ton quarrystones would be stable for the 27-foot design wave height. For these conditions the slopes of the head and trunk sections were $1: 4.5$ and $1: 3.5$, respectively. Breakwater head and trunk sections, constructed of 32ton quadripods, would be stable for the design wave height of 27 feet. For these conditions, varlable width berms were used in the design, and the effective side slope of the trunk and the head section was $1: 6$.

(h) "Designs for Rubble-Mound Breakwater Construction, Tsoyling Harbor, Taiwan; Hydraulic Model Investigation." U. S. Arny Engineer Waterways Experiment Station Technical Report No. 2-640, in publication.

(4593) MODEL STUDIES OF MILIERS FERRY LOCK AND DAM, ALABAMA RIVER, ALABAMA.

(b) District Engineer, U. S. Army Engineer Dist. Mobile, Corps of Engineers, Mobile, Ala.

(d) Experimental; for design.

(e) The project will include a nonnavigable dam with a gated and an overflow section, a lock on the left bank having clear dimensions of 600 by 84 feet, and a powerhouse. A 1:100 model, reproducing about 3.1 miles of river, will be used to investigate navigation conditions through an existing bridge and in the lock approaches, the effects of the structures on flood stages, and the effects of powerhouse operations on navigation conditions. A 1:50 model of a section of the gated portion of the dam, reproducing 600 feet of the approach channel, a 50-foot-wide gate bay with piers and 28.5 feet of each adjacent gate bay, a 125-foot-wide section of the stilling basin, and 700 feet of the extt area, was used to determine flow characteristics over the spillway and verify the adequacy of the stllilng basin design. A l:25 model reproducing 700 feet of the lock approach channel, the 600- by 84-foot lock chamber, the entire culvert system, and 800 feet of the downstream exit channel is being used to study the suitabllity of the longltudinal floor culvert system for fllling and emptying the lock under heads and submergences which will obtain at the site.

(g) Results in the general model indicate that a dike would be required along the upper lock approach channel to overcome the adverse currents with the hydroplant in operation, and that a dike would be required along the left overbank below the bridge to eliminate currents from the overbank when powerhouse is not in operation. Modiflcation of the left bank would be required to Improve navigation in the lower approach. In the spillway section model it was found that the downstream face of the gate sill should be shaped to the equation $\mathrm{X}^{2}=40 \mathrm{Y}$ in order to cause flow to follow along the gate sill and not override the stilling basin. A stilling basin consisting of a horlzontal apron and sloping end sill was found to be adequate for energy dissipation. In the lock studies satisfactory designs were developed for connections between the main culverts and the floor culverts. Although tests still were in progress for development of an optimum arrangement for the floor culverts, results to date indicate that the lock can be filled in about 11 minutes with the longltudinal floor culvert system.

(4594) MODEL STUDY OF SPILLWAY, SHELBYVILLE DAM, KASKASKIA RIVER, ILLINOIS.

(b) District Engineer, U. S. Army Engineer Dist., St. Louls, Corps of Engineers, St. Louls, Missouri.

(d) Experimental; for design.

(e) A 1:40 model that reproduces 1,550 feet of the approach channel, the gated spillway with sloping chute leading to a conventional hydraulic-jump type stilling basin, a portion of the earth embankment on each side of the spillway, outlet works through the embankment consisting of a double-barrel sluice discharging into the spillway stilling basin, and 1,150 feet of the exit channel is being used to study the overall hydraulic performance of the spillway and outlets of the sluices, and to verify chute and stilling basin designs.

(f) Suspended.

(g) Foundation considerations governed the elevation of the stilling basin. Basin elements of minimum size and a basin apron of minimum length were developed. A sluice outlet in the left training wall was developed which resulted in more effective dispersion of sluice flows by the baffle plers.

(4595) MODEL STUDY OF COLUMBIA LOCK AND DAM, OUACHITA RIVER, LOUISIANA.

(b) District Engineer, U. S. Army Engineer'Dist., Vicksburg, Corps of Engineers, Vicksburg, Mississippi.

(d) Experimental; for design.

(e) The project involves construction of a cutoff channel about 5,600 feet long with a bottom width of 564 feet, a gated structure (consisting of four talnter gates each 50 feet wide and 26 feet high) located about midway of the cutoff, a 200-foot-wide navigable pass on the right of the dam, and a 600- by 84-foot lock on the left. A l: 100 model, reproducing about 2.6 miles of the river, was used to investigate navigation conditions in the approaches to the lock and navigable pass, and the effects of the structures on flood stages.

(f) Tests completed.

(g) Tests with the right abutment of the navigation pass replaced with a concrete piertype abutment wall 8 feet by 39 feet, and a wall 1 foot thick with the top at elevation 22.0 extending from the abutment wall to the right bank, showed that the right abutment of the navigation pass could be modified as indicated without producing any adverse effect on navigation in the approaches to the pass.

(h) Final report in preparation.

(4596) MODEL STUDY OF OVERFLOW EMBANKMENTS FOR LOW HEAD DAM ON ARKANSAS RIVER, ARKANSAS.

(b) District Engineer, U. S. Army Engineer Dist., Little Rock, Corps of Engineer's, Little Rock, A rkansas.

d) Experimental; for design.

e) A 1:4 model reproducing a 40-foot-wide section including 90 feet of approach channel the embankment with upstream and downstream slopes of 1 on 3 and 1 on 4 , respectively, and crown widths of 20 and 35 feet, and 100 feet of exit channel was used to verify the adequacy of proposed designs utilizing four gradations of riprap on the downstream slope of both an access and nonaccess type overflaw embankment for unit discharges ranging from 5 to 60 cubic feet per second per foot width.

(g) The model indicated the transition riprap placed between the roadway and the larger stone on the downstream slope was inadequate, and that the stone used on the downstream slope should be extended to the edge of the roadway. Relations between headwater and tall-water elevations, with respect to the crown, at which each of the four types of protective stone failed for the range of unit discharges investigated were determined. Although attempts to generalize test results have been unsuccessful, the prime requirements for design of the overflow embankments have been satisfied.

(h) Final report in preparation.

(4598) MODEL STUDY OF DROP STRUCTURE, CAYUGA INIET, ITHACA, NEW YORK.

(b) District Engineer, U. S. Army Engineer Dist., Buffalo, Corps of Engineers, Buffalo, N. Y. 
(d) Experimental; for design.

(e) A 1:20 model, reproducing 300 feet of the trapezoidal approach channel, the rectangular, 80-foot-wide drop structure, the 60-foot-long basin with baffle piers and end sill, and about 400 feet of trapezoldal exit channel, was used to confirm the sultability of the drop structure, and if indicated, to develop advantageous modifications thereto. of particular concern was the magnitude of channel velocities below the stmucture.

(f) Tests completed.

(g) Tests demonstrated that the original design structure was unsatisfactory as little or no energy dissipation occurred at low and intermediate flows. The length of the structure was reduced and baffle plers eliminated in the basin. A 3-foot-high sill was added to the weir crest to reduce velocities in the channel upstream from the structure. Use of a 12-foot-radius abutment wall improved entrance conditions to the structure and reduced construction costs.

(h) Final report in preparation.

(4599) MODEL STUDY OF CONTROL STRUCTURES, LITTLE SIOUX RIVER, LITTLE SIOUX, IOWA.

(b) District Engineer, U. S. Army Engineer Dist. Omaha, Corps of Engineers, Omaha, Nebraska.

(d) Experimental; for design.

(e) The structure will consist of a low, 50-footwide, rectangular drop located in the control channel with rock protection downstream and on adjacent berms. A 1:30 model, reproducing about 700 feet of the approach channel and berms upstream of the structure with portions of the adjacent levees, the drop structure, and about 1,300 feet of the channel and berms below the structure was used to study the placement of riprap materials in the vicinity of the structure, and the discharge capacity of the structure.

(f) Tests completed.

(g) As the design of the drop structure for Little Sloux was based on the successful design of the Gering Valley structure, and as initial observations revealed satisfactory performance of the structure from a hydraulic standpoint no changes were made to the drop structure during the course of the model study. Model tests were mainly concerned with the determination of an adequate riprap plan to protect the structure and obtain the most economical use of the rock. Calibration data for submerged and unsubmerged flows were obtained. It was determined from the model study that while the overall performance of the structure was excellent, and the dimensions of the drop structure based on the Gering Valley tests were satisfactory, certain modifications to the structure would improve hydraulic performance and effect economies in construction.

Tests Indicated that stone sizes in the orlginal riprap plan were larger than necessary and smaller sizes could be used with a resulting saving in construction costs. Tests also indicated that approximately 150 feet of riprap protection on the channel banks upstream from the structure could be eliminated. The capacity of the control structure was found to be adequate.

(h) Final report in preparation.

(4600) RADIOACTIVE TRACER TESTS OF SEDIMENT, CAPE FEAR RIVER, NORTH CAROLINA.

(b) District Engineer, U. S. Army Engineer Dist., Wilmington, Corps of Engineers, Wilmington, North Carolina.

(d) Experimental; field investigation.

(e) The movement of material from dredge spoil areas was investigated using labeled sediment to determine if spoil material moves into the wharf areas at Sunny Point Army Terminal.

The sediment was labeled using auric chloride (Gold-198) solution adsorbed on existing sediment. Material was placed at four locations under two extreme tide conditions.
Movemenc of sediments was observed for two weeks using instruments on a small boat.

(g) Test results showed that significant amounts of the spoil material are transported into the north and center wharf basins, regardless of whether the material is placed during rising or falling tide.

(h) Final report in preparation.

(4601) MODEL STUDY OF POLUTION, CONEY ISLAND CREEK, NEW YORK.

(b) New York City Department of Health, New York, New York.

(d) Experimental; for design.

(e) An existing model of N ew York Harbor is being used to investigate diffusion patterns from sewage treatment plant outfalls and combination sewer and storm outfalls with special attention to contamination of bathing beaches and other recreational facilities. Plans for diverting pollution away from certain critical areas are also being investigated.

(f) Inactive.

\section{(4602) LOCK FILLING AND EMPTYING SYSTEM.}

(b) office of the Chief of Engineers, Dept. of the Army, Wa shington, D. C.

(d) Experimental; applied research.

(e) A 1:15 valve model used to develop the vertically framed Holt Lock valve was utilized to compare the performance of this valve with that of the McNary type valve. The Holt valve was 12.5 by 12.5 feet and the McNary valve was 11 feet wide by 12 feet high. Therefore, for tests of the McNary valve the valve was expanded to 12.5 by 12.5 feet by additions of 1.5 feet in width and 0.5 foot in helght to the center portions of the valve.

(h) Preparation of final report in progress.

(4603) MODEL STUDY OF FILLING AND EMPTYING SYSTEM FOR LOW-IIFT LOCKS, ARKANSAS RIVER, ARKANSAS.

(b) District Engineer, U. S. Army Engineer Dist., Little Rock, Corps of Engineers, Little Rock, Arkansas, and other interested Corps of Engineers offices.

(d) Experimental; for design.

(e) A l:25 model, reproducing 700 feet of lock approach channel, intake manifolds, a 670foot-long lock chamber, culvert, sidewall port manifolds, outlet manifold, and 700 feet of downstream channel is being used to determine an optimum port arrangement for the filling and emptying system for low-lift locks. An intake is to be developed for use in all tests. Then optimum shape, size, number, spacing, and location of the ports in the lock chamber as related to culvert size will be determined for a full range of heads and submergences. The Little Rock District is sponsoring the first phase of the tests in which a 12- by 12-foot culvert will be used. Tests of other size culverts will be sponsored by interested Corps of Engineers of fices for the purpose of standardizing lock design for $600-$ by 110 -foot locks.

(g) Tests with type A port design installed at $24-, 26-, 28-$, and 32-foot centers in the lock chamber walls indicated that with $28-$ foot spacing turbulence appears to be well distributed across the lock chamber. A location at least 70 feet below the filling valves was selected for positioning the first port of the culvert manifold due to pressure conditions in the culvert. Tests with 2-foot-deep recesses in front of the port as well as with angled ports (type c) were also completed during the year. These systems have been documented for a full range of submergences and heads. A satisfactory 8-port sidewall intake manifold was developed for certain of the low-lift locks.

(4604) MODEL STUDY OF INTAKE AND FLOOD-CONTROI OUTLET, DEGRAY DAM, CADDO RIVER, ARKANSAS. 
(b) District Englneer, U. S. Army Englneer Dist., Vicksburg, Corps of Englneers, Vicksburg, Mississippi.

(d) Experimental; for design.

(e) A 1:23 model reproducing the intake tower and a portion of the reservolr, the diversion tunnel, stilling basin, and 240 feet of the exit channel is being used to develop a conventional hydraulic jump-type stilling basin, and to study flow through the intake tower, elbow, tunnels, and at the flowcontrol device at the end of the rloodcontrol tunnel.

(g) A stiling basin necessitating minimum excavation was developed.

(4605) MODEL STUDY OF BREAKWATER, KAHULUI HARBOR, HAWAII.

(b) D1strlct Engineer, U. S. Army Engineer D1st., Honolulu, Corps of Englneers, Honolulu, Hawa11.

(d) Experimental; for design.

(e) Stability tests were conducted in a concrete wave flume 119 feet long, 12.5 feet wide, and 4 feet deep, on section models of both the east and west breakwater heads, and sections of the trunk of the east breakwater constructed to a linear scale of $1: 68.5$ to develop designs for repalr of the damaged breakwater heads and trunks. Tests conducted were concerned with the stability of 35- and 50-ton tribars.

(h) Final report in preparation.

(5228) DESIGN OF SMALL-BOAT HARBORS.

(b) Office of the Chief of Englneers, Dept. of the Army, Washington, D. C.

(d) Experimental; applied research.

(e) Theoretical and experimental studies are being conducted to develop equations and experimental coefficients for use in predicting the motion of small boats moored to floating docks under the action of progressiveand standing-wave systems. A study of waveinduced oscillations of small moored vessels is being made under contract by the California Institute of Technology, Division of Engineering and Applied Science.

\section{(5229) GENERAL COASTAL INIET STUDIES.}

(b) Office of the Chlef of Engineers, Dept. of the Amy, Washington, D. C.

(d) Experimental; applied research.

(e) Th1s is a general study to develop means for computing discharge and velocity distribution through tidal inlets, leading to determination of tidal prisms and water-surface elevations in Inner bay systems; and to determine the factors involved in both inner and outer bar formation, the shoaling of inlet channels, and the stability of inlet shape and location. The project will consist of the following three phases: (1) Tests in rour generalized test facilities, three of which will be located at the Waterways Experiment Station and the fourth at the coastal Engineering Research Center; (2) analysis of results of these tests by the Waterways Experiment Station, the Coastal Englneering Research Center, and the committee on Tidal Hydraulics; and (3) rield observations under sponsorship of the Committee on Tidal Hydraulics to confirm the principles developed. Design of the three racilities to be located at the Waterways Experiment station is in progress; the facility at the Coastal Engineering Research center is already in existence.

(5230) MODEL STUDY OF NAVIGATION CONDITIONS, LOCK AND DAM NO. 4, ARKANSAS RIVER.

(b) District Engineer, U. S. Army Englneer Distrlct, Iltte Rock, Corps of Englneers, Little Rock, Arkansas.

(d) Experimental; for design.

(e) A 1:120 fixed-bed model, reproducing about 5 miles of the Arkansas River and adjacent overbank areas, the lock and dam structures, and all bridges and other stmuctures that might affect flow conditions, is being used to determine the sultablilty of the proposed site for the lock and dam structure, the effects of regulating works in the lower approach, and to develop modiflcation which might be required to overcome any undesirable navigation conditions.

(g) Results indicated that the location of the dam and upper navigation approach conditions are satisfactory. The riverside location of the 600-foot guide wall would provide better navigation conditions in the upper lock approach than the landside location. Installation of fenders at Rob Roy Bridge would produce some increase in velocities through the navigable span with no appreciable change in alinement of the currents. Navigation conditions in the lower lock approach were satisfactory.

(5231) MODEL STUDY OF NAVIGATION CONDITIONS, OZARK LOCK AND DAM, ARKANSAS RIVER.

(b) Distrlct Engineer, U. S. Army Englneer District, Ilttle Rock, Corps of Englneers, Little Rock, Arkansas.

(d) Experimental; for design.

(e) A 1:120, flxed-bed model, reproducing about 3 miles of the Arkansas River, adjacent overbank areas, the lock and dam structures, and all bridges and other structures that might affect flow conditions, is being used to determine the suitabllity of the proposed site for the lock and dam structures, and to develop modiflcations which might be required to overcome any undesirable navigation conditions.

(5232) MODEL STUDY OF STILLING BASIN, HUNTINGTON RESERVOIR, WABASH RIVER.

(b) Distrlct Engineer, U. S. Army Englneer District, Louisville, Kentucky.

(d) Experimental; for design.

(e) A gated spiliway with $\mathrm{six}$ condults through the spillway section is proposed for Huntington Dam. A 1:60 model of a 60-footwide section of the spillway and stilling basin and 500 feet of the exit channel was used in the study. The splllway gate piers and conduits through the spillway were not reproduced; however, the model was adjusted to simulate the increased head that would have obtalned with crest piers and abutments present. The purposes of the study were: (1) To insure good energy dissipation in the stilling basin at low and intermediate flows, and safe conditions at high flows: (2) to study the effect of the flatter than usual downstream splilway slope ( 10 horizontal to 12 vertical) on basin action; and (3) if the originally proposed basin design was found to be unsat 1 sfactory, to make revisions necessary to secure the desired results.

(f) Tests completed.

(g) Tests with a roller bucket basin indicated that, while the splilway weir of original design runctioned satisfactorily, tailwater depths were insufficient for satisfactory performance or the bucket-type energy disslpator. An alternate basin design incorporating a horlzontal apron with baffle plers and an end sill performed adequately.

(h) Final report in preparation.

(5233) MODEL STUDY OF SUBMERGED SILLS, ST. CLAIR RIVER.

(b) District Engineer, U. S. Army Engineer District, Detroit, Corps of Engineers, Detroit, Michigan.

(d) Experimental; for design.

$\{$ e Construction of submerged sills at the head of the St. Clair River is proposed as a means of raising the level of Lake Huron. A $1: 60$, flxed-bed model w111 reproduce 3 miles or the river from lake Huron downstream, 
and will have provisions for simulating sediment movement and shoaling. This model will be used to study effects of one or more submerged sills at different locations on backwater effect, to study sedimentation characeristics, and to study velocities and current directions. A large-scale model will be installed in a flume to study various methods of sill construction.

(5234) MODEL STUDY OF SEAWALL, TEXAS CITY, TEXAS.

(b) District Engineer, U. S. Army Engineer District, Galveston, Corps of Engineers, Galveston, Texas.

(d) Experimental; for design.

(e) A levee and seawall system has been proposed to protect Texas City and adjacent areas of the shore of Galveston Bay from flooding caused by hurricanes. To develop designs for (1) vertical-faced seawalls, (2) mubble-mound structures to protect the natural ground at the base of a vertical wall on its bayside, and (3) mubble-mound armor layers to protect the bayside slope and crown of an earth levee, $1: 35$ section models of the structures are being tested in a concrete flume 119 feet long, 5 feet wide, and 4 feet deep. Model waves are generated by a plunger-type wave machine, and measured and recorded electrically.

(g) Stability tests of a mubble-mound seawall revealed that a single layer of 8-ton armor stones on a 1:2 slope on the bayside of the structure would be stable under the attack of 6-second waves somewhat larger than 16 feet. On the landside, a single layer of 3.3-ton stones scotched by two rows of 6 -ton stones placed in a trench would be stable under the attack of 6-second, 15-foot waves.

(5235) MODEL STUDY OF BESSIE CUTOFF, MISSISSIPPI RIVER.

(b) District Engineer, U. S. Army Engineer District, Memphis, Corps of Engineers, Memphis, Tennessee.

(d) Experimental; for design.

(e) The proposed Bessie Cutoff would eliminate the river bend at New Madrid, Mo., and shorten the river about 20 miles. A model, reproducing 85 miles of the river to a horlzontal scale of $1: 500$ and a vertical scale of $1: 100$, is being used to obtain indications of the probable effects of various degrees of cutoff development on velocities, current directions, watersurface profiles, navigation depths, channel meandering tendencies, and general navigability of the affected reach. The model is of the fixed-bed type with provision for converting to a movable bed the reaches expected to be affected appreciably by the cutoff

(5236) MODEL STUDY OF LOWER ATCHAFALAYA RIVER BASIN, LOUISIANA.

(b) District Engineer, U. S. Army Engineer District, New Orleans, Corps of Engineers, New Orleans, Louisiana.

(d) Experimental; for design.

(e) The Mississippi River flood-control model was used to determine the effects of dredging, side-channel closures, and levee extensions proposed to enlarge the main channel through the lower Atchafalaya River basin, and thus increase its flood-carrying capacity, on slopes and velocities within the main channel. The model is of the fixed-bed type with a horizontal scale of $1: 2,000$ and a vertical scale of 1:100. It reproduces the Mississippi River from Helena, Ark., to Donaldsonville, La., the Arkansas-Wh1te, Yazoo, and RedOuachita backwater areas, the Old River Channel from Angola to Barbre Landing, La., the Atchafalaya River and Basin to the Gulf of Mexico, and the Morganza and West Atchafalaya Floodways.

(f) Completed. (g) Results consisted of data on stages, veloc1ty measurements within the basin, and directions of flow within the various channels and along the overbank for use by design engineers in establishing dredging and side-channel closure program and priorities.

(5237) WAVE ACTION, HALF MOON BAY HARBOR, CALIFORNIA。

(b) District Engineer, U. S. Army Engineer District, San Francisco, Corps of Engineers, San Francisco, Calif.

(d) Experimental; for design.

(e) Half Moon Bay Harbor is partially protected from severe storms by a 2,620-foot-long west breakwater and a 4,420-foot-long east breakwater which enclose a 245-acre area with 6-foot or greater water depths, and form a 600-foot-wide entrance channel 24 feet deep. During storms, a severe concentration of wave energy at the entrance travels into the inner harbor, creating intolerable anchorage conditions. A model study is being conducted to determine: (1) The relative influence of the waves that approach the harbor from the several storm directions; (2) the effects of surge action inside the harbor believed to result from wave energy passing through the volds in the breakwaters in addition to that through the entrance; and (3) the most feasible of several plans proposed for reducing the effects of wave and surge action now prevailing. The 1:100 model, covering an area of about 13,000 square feet, reproduces all the inner harbor, breakwater system, and sufficient bay area to permit simulation of waves from all critical storm directions. Waves are generated by a $60-$ foot-long, plunger wave machine, and are measured and recorded electrically.

(g) Test results indicate that during storms from the southwesterly to south directions, severe wave action obtains inside the harbor at the docks and plers as alleged. The shoals southerly of the harbor entrance cause a concentration of wave energy at and in the present harbor entrance. Several breakwater plans studied adequately reduce the wave energy entering the harbor during severe storms. Preliminary analysis of test results indicates that extending the west breakwater 800 to 1,000 feet southeasterly or a similar revision at the harbor entrance will reduce wave action inside the harbor to an acceptable level.

(5238) MODEL STUDY OF SPILLWAY, STOCKTON DAM, SAC RIVER, MISSOURI.

(b) District Engineer, U. S. Army Engineer District, Kansas City, Corps of Engineers, Kansas City, Kansas.

(d) Experimental; for design.

(e) A 4-gated, ogee spillway and one 45,000kilowatt powerhouse unit located in a concrete nonoverflow section adjacent to the spillway are proposed for Stockton Dam. A 1:60 model reproducing 1,700 feet of the approach area, the entire spillway and powerhouse, the stilling basin, and 1,100 feet of the exit channel will be used to investigate the hydraulic adequacy of the spillway, stilling basin, and appurtenances, and determine any desirable modifications for various operating conditions.

(5239) MODEL STUDY OF WAVE ACTION, MARINA DEL REY, VENICE, CA LI FORNIA.

(b) District Engineer, U. S. Army Engineer District, Los Angeles, Corps of Engineers, Los Angeles, California.

(d) Experimental; for design.

(e) Marina Del Rey is a smali-craft harbor consisting of eight lateral basins off a main channel which opens 1nto Santa Monica Bay. A $1: 175$ model of the entire harbor area was used to study wave action within the project area and to investigate and 
develop remedial plans for alleviating adverse wave and surge action presently restricting full usage of the harbor. Waves were generated with a 40-foot-long, vertical-plunger wave machine, and were measured and recorded electrically.

(f) Tests completed.

(g) Final analysis of model test data indicated that an offshore breakwater, 2,325 feet long, constructed 640 feet seaward of the ends of the channel jetties, would reduce wave action within the harbor to an acceptable level.

(h) Final report in preparation.

(5240) MODEL TESTS FOR HURRICANE BARRIERS, WAREHAMMARION, MASSACHUSETTS.

(b) Division Engineer, U. S. Army Engineer Division, New England, Corps of Engineers, Waltham, Massachusetts.

(d) Exper1mental; for design.

(e) The hurricane protection plan for the area including Wareham and Marion, Mass., consists principally of 50- and 100-foot-w1de, ungated barriers across the mouths of the Weweantic and Wareham Rivers, and a 100-foot-wide, gated barrier across the mouth of onset Bay which will permit navigation during normal tides. The barriers will reduce the entry of flood surges into the waterway areas behind them during hurricanes and other severe storms. A $1: 25$ model, reproducing a 400-foot-wide section including 750 feet of approach channel, each nav1gation opening and allied barrier, and 750 feet of exit channel, was used to determine the discharge characteristics of the barriers and the maximum current velocities through the navigation openings. The cover stone of the barrier and the rock sill of each navigation opening were simulated with properly scaled model stone to provide the effect of roughness.

(f) Tests completed.

g) D1scharge coefficlents applicable to the structures for both free and submerged flows, the limits of each type of flow regime, and velocities in the navigation openings were determined.

(h) Final report in preparation.

(5241) MODEL STUDY OF WAVE ACTION AND SHIP MOORING, POINT LOMA, CALIFORNIA.

(b) Department of the Navy.

d) Experimental; for design.

e) The Navy Electronics Laboratory desires to use an aircraft carrier, moored behind a protective breakwater about 4,000 feet offshore, in the design and development of electronic equipment. A 1:100 model reproducling about 4.4 square miles of the locality, and a $1: 100$ model of an Essex class alrcraft carrier are being used to: (1) Determine wave-action conditions that will obtain within the ship mooring area; (2) study variations in design and location of the breakwater: (3) secure data on actual movement of the moored ship due to wave action; (4) investigate the feasibility of a proposed floating causeway shoreward from the sh1p; and (5) study adequacy of design of a proposed small-craft landing area shoreward from the ship. Waves are generated by a 60-foot-long wave machine, and are measured and recorded electrically.

(g) Model tests and moving p1ctures of the floating causeway showed conclusively that this structure would develop more movement from expected wave action than could be tolerated, and this portion of the project was abandoned.

(5242) PROTOTYPE CULVERT PRESSURE TESTS, GREENUP LOCKS AND DAM, OHIO RIVER, KENTUCKY AND OHIO.

(b) District Engineer, U. S. Army Engineer District, Huntington, Corps of Engineers, Huntington, West Virginia. (d) Experimental; for design.

(e) The filling and emptying system of the main, 110 - by 1,200-foot lock cons1sts of two culverts and a split-lateral system. Prototype pressures in this filling and emptying system and water-surface elevations in the lock chamber were measured for comparison with model results and for further development of lock design criteria. Pressures in all parts of both lock culverts, and water-surface elevations in both pools and the lock chamber were measured with electrical transducers connected to plezometers by a1r-purged lines. Positions of the filling and emptying valves during filling and emptying with one and both valves were determined using circular potentiometers. All data, accompanied by a common time indication, were recorded on light-beam oscillographs. Pressure data points were digitized for reduction and plotting with an electronic computer.

(5243) PROTOTYPE TESTS, GATED INTAKE AND TUNNEL, NOLIN DAM, NOLIN RIVER, KENTUCKY.

(b) District Engineer, U. S. Army Engineer District, Louisvilie, Corps of Engineers, Louisvilie, Kentucky.

(d) Experimental; for design.

(e) The Nolin Dam outlet works consist of a three-gated intake structure and horseshoeshaped tunnel having a capacity of 16,000 cubic feet per second. It is planned to measure the tunnel hydraulic grade line and gate-holst cylinder pressures, and from these measurements to evaluate tunnel friction and intake losses and compute gate forces, Test facilities will include five pairs of sidewall piezometers connected to a manifold. Pressures at full tunnel flow will be measured by means of the air-purge technique, using mercury manometers. Pressure taps are provided in the operating gateholst cylinder to measure gate forces during partial gate opening operations.

(5244) MODEL TESTS OF ENERGY DISSIPATOR, J. PERCY PRIEST DAM (STEWARTS FERRY).

(b) District Engineer, U. S. Army Engineer District, Nashvilie, Corps of Engineers, Nashville, Tennessee.

(d) Experimental; for design.

(e) The J. Percy Priest Dam spillway will be 213 feet long and w1ll be surmounted by 4 tainter gates 45 feet wide by 41 feet high. A $1: 36$ model of a 90-foot-wide section of a revised bucket and 300 feet of the exit channel was used to study the adequacy of the revised bucket design in dissipating the energy of flows ranging from 17,000 to 256,000 cubic feet per second.

(f) Completed.

(g) Tests of the revised bucket indicated that for normal tallwater conditions, energy was dissipated by roller action throughout the range in discharge. Submergence of roller action would not occur in the range of tallwaters 1nvestigated (up to elevation 475), and spray action occurred only at tallwater levels 5 to 13 feet below normal. As the tests were concermed only with two-dimensionel flow, the effect of lateral flow on bucket action is not known. Although no tests were conducted with the spillway gates in operation, 1t is recommended that whenever possible all gates be opened equally in order to distribute flow uniformly over the entire bucket and prevent the occurrence of lateral eddies.

(h) "J. Percy Priest (formerly Stewarts Ferry) Dam, Stones River, Tennessee; Hydraulic Model Investigation, Appendix A: Revised Spillway Bucket." U. S. A rmy Engineer Waterways Experiment Station Technical Memorandum No. 2-239, June 1963. (Avallable on loan.) 
(5245) MODEL STUDY OF HOUSTON SHIP CHANNEL, TEXAS.

(b) District Engineer, U. S. Army Engineer District, Galveston, Corps of Engineers, Galveston, Texas.

(d) Experimental; for design.

(e) Houston Ship Channel is a 52-mile reach extending from the Gulf of Mexico across Galveston Bay to the Turning Basin at Houston. A model study is being conducted to determine if the present cost of maintenance dredging in the channel can be reduced by proposed plans of channel realinement, partial or complete diking of connecting bays, sediment traps, dikes in Galveston Bay, local contractions, enlargements, and other remedial measures. The model reproduces a portion of the Gulf of Mexico outside the entrance to Galveston Bay; all of Galveston and Trinity Bays; Dickinson Bay and Clear Creek to the head of project; the tidal portion of Trinity River; the Houston Ship Channel in its entirety; and Buffalo Bayou from the Turning Basin to the confluence of White Oak Bayou. The model is of fixed-bed construction with scale ratios, model to prototype, of $1: 600$ horizontally and 1:60 vertically. Tides and tidal currents are reproduced by a tide generator located in the Gulf of Mexico portion of the model, and the salinity of the model Gulf is reproduced to scale so that the effects of salinity differences on the vertical distribution of current velocities, as well as salinity concentrations throughout the model, accurately reproduce those of the prototype. The model will be used to establish the effects of all proposed improvement works on tidal current velocities current patterns, and salinities in all critical areas. All hydraulic and salinity data obtained from the model will be quantitative and can be applied directly to the prototype. Shoaling studies will be made by injecting finely ground gilsonite into the model to reproduce the patterns of shoaling as observed in the prototype, following which the effects of proposed improvement plans on shoaling patterns may be observed and evaluated from a qualitative viewpoint.

(5246) MODEL STUDY OF NAVIGATION CONDITIONS, UNIONTOWN LOCK AND DAM, OHIO RIVER.

(b) District Engineer, U. S. Army Engineer Dist., Louisville, Corps of Engineers, Louisville, Kentucky.

(d) Experimental; for design.

(e) The project includes a nonnavigable, gated structure and two parallel locks. A $1: 120$ model, reproducing about 8.6 miles of the Ohio River and adjacent overbarik areas, the lock and dam structures, and the lower reach of the Wabash River, is being used to investigate navigation conditions with the proposed structures, to determine the effects of modifications in the composition and arrangement of the structures, and to develop any modifications considered desirable.

(5247) MODEL STUDY OF FILLING AND EMPTYING SYSTEM, JONESVILIE LOCK AND DAM, OUACH ITA-BLACK RIVER, LOUISIANA.

(b) District Engineer, U. S. Army Engineer District, Vicksburg, Corps of Engineers, V1cksburg, Mississippi.

(d) Experimental; for design.

(e) A 1:25 model, reproducing 750 feet of the lock approach channel, intake manifold, the 84by 600-foot lock chamber, culvert, sidewall port manifolds, outlets, and 650 feet of the exit channel, is being used to develop the optimum side port filling and emptying system for the lock.

(g) The type 3 arrangement, which consisted of 17 type A ports spaced 20 feet on centers in each lock wall, performed satisfactorily. The most upstream port was in the left wall at station $2+03.29$. Recesses in front of the eight upstream ports were angled upstream. Data for a six-barge tow with submergences of 14,20 , and 30 feet and heads of $15,20,25,30$, and 40 feet were obtained. A satisfactory arrangement of type A ports at 20 -foot spacing and without floor recesses was also determined. This arrangement, type 19, consisted of 17 ports in each wall with the most upstream port in the left wall at station $1+63.29$. Data similar to that described for type 3 were obtained.

(5248) MODEL STUDY OF FLOATING BREAKWATER, SMALL BOAT BASIN NO. 2, JUNEAU, ALASKA.

(b) District Englneer, U. S. Army Engineer District, Alaska, Corps of Engineers, Anchorage, Alaska.

(d) Experimental; for design. protect Small Boat Basin No. 2 from stormwave action. To determine wave attenuation characteristics of a floating-log breakwater, tests were conducted in a concrete wave flume 119 feet long, 5 feet wide, and 4 feet deep. Models of a 30-foot-long section of the breakwater were reproduced at a linear scale of $1: 6$. The breakwaters simulated 3- and 4-foot-diameter logs spaced on $4.0-, 5.7-$, and 8.2 -foot centers. Vertical barrier plates were attached to the faces of the logs to increase the effective depth of rlotation of the logs. Model waves were generated by a plungertype wave machine, and measured and recorded electrically.

(f) Tests completed.

(g) It was found that 3-foot-diameter logs spaced from 5.5 to 6.0 feet on centers would provide sufficient protection to the boat basin, based on the criterion of a transmitted wave height $\left(\mathrm{H}_{\mathrm{T}}\right) \leq 0.5$ foot, if it is considered feasible to add vertical plates to the seaside face of the logs extending to a depth of 4 feet below the stillwater level.

(h) Final report in preparation.

(5249) PROTOTYPE HAWSER-STRESS MEASUREMENTS, JACKSON IOCK, TOMBIGEE RIVER, ALABAMA.

(b) District Engineer, U. S. Arny Engineer District, Mobile, Corps of Engineers, Mobile, Alabama, and office, Chief of Engineers, Washington, D. C.

(d) Experimental; for design.

(e) The Jackson Lock chamber is 110 feet wide by 670 feet long and has a 34 -foot maximum lift. Reverse tainter valves control flow in two 12.5-foot-square culverts, each of which has 6 intake ports in the upper approach walls, 14 side ports to the lock chamber, and an outlet discharging outside the lower lock approach. Measurements of prototype hawser loads resulting from hydraulic forces acting on a tow of loaded barges were made to obtain data for comparison with model test results. Both rigid and flexible connections between the tow and floating mooring bitts were used in the tests. The rigid connections, containing callbrated dynamometers, were installed fore and aft on the portside of the tow and connected to floating mooring bitts in the lock land wall. One connection measured longitudinal hawser forces, and the other measured transverse forces. Potentiometers were mounted on the culvert-valve operating arm to measure valve opening. Differentialtype pressure transducers were used for measuring the slope of the water surface in the lock chamber, and absolute pressure transducers were used for drawdown measurements of the water surface in the approach channel. Potentiometers also were installed on the land-wall floating bitts to measure tow movement during the rigid connection tests. For the flexible-connection tests, 
the rigid connections were replaced by

flexible hawsers of l-inch-diameter wire rope, and callbrated dynamometers were installed in the hawsers at each corner of the tow and connected to floating bitts in both lock walls. Other instrumentation was identical with that of the rigid connection tests.

(f) Tests completed.

g) Good agreement was found between the prototype cable hawser measurements and the model results with maximum longitudinal forces of about 4 tons and maximum transverse forces of about 1-1/2 tons. Unscheduled overfilling of the lock chamber, resulting from the momentum of the flow in the fllling system, forced the upstream miter gates to open near the end of the 4-minute valve test, causing longitudinal forces of 8 tons. Prototype hawser loads in the rigid-connection tests were much higher than in the flexibleconnection tests because allowable clearances between the floating mooring bitt rollers and guides permitted the tow to move freely about 2 inches, resulting in impact-type loads.

(h) Final report in preparation.

(5250) PROTOTYPE SPILLWAY TESTS, ANALYSIS AND REPORT, FORT RANDALL DAM, MISSOURI RIVER, SOUTH DAKOTA.

(b) District Engineer, U. S. Army Engineer District, Omaha, Corps of EngIneers, Omaha, Nebraska.

(d) Experimental; for design

(e) The Fort Randall Dam spililway is a 1,000-footwide concrete chute, with a design capacity of 620,000 cubic feet per second. Discharge is controlled by twenty-one 29- by 40-foot tainter gates. Two test series, one in 1960 and one in 1962, have been conducted to obtain vertical velocity distribution and water-surface depths on the splliway chute for use in checking desion resistance coefficlent assumptions and computing discharge over the spillway. These data will assist in eliminating a deficiency in the information on full-scale chute spillway flows used in design of such structures. To obtain the measurements, two pitot piers were fabricated and installed on the spillway chute. The pitot piers instrumentation consisted of elght total-head tubes to measure vertical velocity distributions. Watersurface measurements along the splilway length were made with wire-welght gages. Visual observations and photographic records of flow conditions were also made. Data were obtained at seven average flow depths up to 3.5 feet with velocities up to 45 feet per second.

(i) Tests completed.

g) Flow-depth measurements indicate that essentially normal depth obtained in the vicinity of the pitot piers. Vertical velocity distributions are well described by a logarithmic equation. The tests indirate a somewhat higher resistance cocoefficient than assumed for design.

(h) Final report in preparation.

(5251) MODEL STUDY OF NAVIGATION CONDITIONS, ROBERT S. KERR LOCK AND DAM, ARKANSAS RIVER.

(b) District Engineer, U. S. Army Engineer District, Tulsa, Corps of Engineers, Tulsa, Oklahoma.

(a) Experimental; for design.

(e) The project will consist of a nonnavigable dam, a 110- by 600-foot lock, and a powerhouse. A 1:120 model, reproducing about 3.2 miles of the Arkansas River and the lock and dam structures, w11l be used to study navigation conditions in the approaches to the lock, determine suitability of the selected site, and develop modiflcations required to overcome any undesirable conditions. The model will be of the fixed-bed type with provision for a movable-bed section below the dam for use in developing channel configurations in the reach.
U. S. DEPARTMENT OF COMMERCE, BUREAU OF PUBLIC ROADS.

(856) HYDROLOGY OF STORM DRAINAGE SYSTEMS IN URBAN AREAS .

Cooperative with the Johns Hopkins University. See page 44.

(1591) DETERMINATION OF WATERWAY AREAS.

Cooperative with the University of Illinols. See page 37 .

(2435) HYDRAULICS OF PIPE CULVERTS.

Cooperative with the National Bureau of standards. See page 166.

(2839) HYDRAULICS OF RIVER FLOW UNDER ARCH BRIDGES.

Cooperative with Purdue University. See page 66.

(3597) CORRUGATED PIPE ROUGHNESS STUDY.

Cooperative with U. S. Army Engineer Waterways Experiment Station. See page 154.

(3805) INVESTIGATION OF SUPERCRITICAL FLOW CHANNEL JUNCTIONS.

Cooperative with oregon State college. See page 61 .

(4101) UNSTEADY FREE SURFACE FLOW IN A IARGE STORM DRAIN.

Cooperative with Colorado State University. See page 21 .

(4617) MECHANICS OF LOCAL SCOUR.

Cooperative with Colorado State University. See page 24.

U. S. DEPARTMENT OF COMMERCE, NATIONAL BUREAU OF STANDARDS, Fluid Mechanics Section.

\section{(1478) WIND WAVES.}

(b) Office of Naval Research, Dept. of the Navy.

(d) Experimental and theoretical; basic research.

(e) Includes mathematical and experimental studies of (1) wind tides (setup), (2) growth of wind waves, and (3) surface traction of wind on wavy surfaces.

(h) Report in preparation.

(2435) HYDRAULICS OF PIPE CULVERTS.

(b) Bureau of Public Roads.

(d) Experimental; applied research.

(e) To determine hydraulic characteristics of various types of culvert entrances and to develop inlets of improved design.

(h) "Tapered Inlet Structures for Plpe Culverts," by John L. French, reprinted from the American Soclety of Civil Engineers Journal of the Hydraulics Division, Vol. 90, No. HY2, March 1964, Part I.

(2436) FLOW OVER HYDROPHOBIC MATERIALS.

(b) Office of Naval Research, Dept. of the Navy.

a) Experimental; applied research.

(e) To determine augmented dissipation of hydrophobic disks and plates oscillated in various fluids.

(h) "Friction at Menisci on Hydrophobic Surfaces", by G. H. Keulegan and M. R. Brockman, (In press).

(3250) INERTIAL FORCES IN UNSTEADY FLOW.

(b) Office of Naval Research, Dept. of the Navy.

(d) Experimental; basic research.

(e) Determination of inertia and drag coefflcients of cylinders and plates when 
subjected to a varying monotonically varying flow.

(h) Report in preparation.

(4400) MOTION AROUND A BODY IN A STRATIFIED FLUID.

(b) Office of Naval Research, Dept. of the Navy.

(d) Theoretical and experimental; basic and applied research.

(e) A study is made of the internal waves produced by the horizontal motion of threedimensional objects of revolution through a stably stratified liquid.

(4891) WAVE PROPAGATION IN A TURBULENT LIQUID.

(b) Office of Naval Research, Dept. of the Navy.

(c) Dr. G. Kulin, Hyaraulic Engineer.

d) Experimental; basic research.

(e) A study is being made of additional gravity wave damping due to turbulence.

(h) Report in preparation.

(4892) TURBULENT SHEAR FLOW THROUGH COMPLIANT WALLED TUBES.

(b) Office of Naval Research, Dept. of the Navy.

c) Dr. G. Kulin, Hydraulic Engineer.

d) Experimental; basic research.

(e) Investigation of effect of compliancy of boundaries on a turbulent flow with a view toward possible damping of turbulence and potential reduction in wall shear stress.

(5252) WIND ACTION ON PRE-EXISTING WAVES.

(b) Office of Naval Research, Dept. of the Navy.

c) Dr. G. Kul1n, Hydraul1c Engineer.

d) Experimental; basic research.

(e) Investigation of effect of a following wind on a mechanically produced swell, with emphasis on changes in wave damping and on hydraulic roughness of the resulting surface.

U. S. DEPARTNENT OF COMNERCE, WEATHER BUREAU.

Inquiries concerning the following projects, except as Indicated, should be addressed to Mr. William $\mathrm{E}$. H1att, Chlef, Hydrologic Services DIvision, Weather Bureau, U. S. Dept. of Commerce, Washington, D. C. 20235 .

(1015) MEASUREMENT OF EVAPORATION.

(b) Laboratory project.

(d) Theoretical and field investigation; applied research

(e) Studies are directed toward the derivation of reliable procedures for estimating evaporation from reservolrs (existing and proposed) and land surfaces, utilizing readily available meteorological data and pan evaporation observations.

(g) Work will continue in Fiscal Year 1964 on the project to develop a realistic soll molsture accounting model. The main purpose of the soll molsture accounting is to provide a more reliable index of antecedent soil conditions for use in computation of runoff from rainfall for river forecasting. The technique is being tested on 5 basins with different climatic regime.

Meteorological data have been complled and punched on cards for approximately 70 firstorder Weather Bureau stations and daily potential evapotranspiration 1 s belng computed. An improved IBM 1620 computer program has been developed for computation of the potential evapotranspiration. A computer program has also been developed for estimation of solar radiation from percent sunshine.

It had been planned to initiate in F1scal Year 1963 a project to compare the U.S. Class A evaporation pan and Soviet GGI-3000 and $20 \mathrm{~m}^{2}$ tanks in accordance w1th the recommendation of the World Meteorological organization's Commission for Instruments and Methods of Observation. The program could not be carried out due to lack of specifications required to build the Soviet evaporation tanks. Arrangements have been made to purchase the GGI-3000 tanks and specifications for the $20 \mathrm{~m}^{2}$ tank should be available soon. It is hoped that the tests can be started in the Spring of 1964. The joint project of the Weather Bureau and Forest Service to study the effect of elevation, aspect and exposure on evaporation has completed the second year of its observational program. The installation consists of 13 Class A evaporation pan stations at various elevations ( 4300 to 9000 feet) located on the windward and lee sides of the Wasatch Range near Farmington, Utah. The observational program will be continued in 1964 and analyses of avallable data have been started.

(h) "Appraisal of Seasonal Variation in Pan Coefficients," by T. J. Nordenson and "Evaporation Rates in Mountalnous Terrain", by E. L. Peck and D. J. Pfankuch presented at 13th General Assembly of IUGG, Berkeley, Cal1f., August 19-31, 1963.

(1744) DEVELOPMENT OF RIVER FORECASTING METHODS.

(b) RIver Forecast Centers for: Lower Ohio River Basin, Cincinnati, Ohio, Upper Ohio River Basin, P1ttsburgh, $\mathrm{Fa} . ;$ Susquehanna and Delaware River Basins, Harrisburg, Pa.; Missouri River Basin, Kansas Clty, Mo.; Columbia River Basin, Portland, Oreg.; Middle and Upper Mississippi River Basin, St. Louls, Mo.; Arkansas and Red River Basins, Thusa, Okla.; New England and Hudson RIver Basins, Hartford, Conn.; South Atlantic and East Gulf R1ver Basins, Augusta, Ga.; West Gulf Drainage Basins, Ft. Worth, Tex.; and

Middle Atlantic River Basins, Washington, D.C.

(d) Theoretical and field investigation; operation and applied research.

(e) The purpose of these Investigations is to develop modern river forecast procedures for all ranges of flow for varlous streams of each basin. Procedures include: (1) Rainfallrunoff relations involving consideration of the physics of soll moisture, vegetative reception, transpiration, evaporation and geological features of the basins; (2) snowmelt forecasting relations involving consideration of the physics of snow and heat transfer; (3) unit hydrographs; and (4) streamflow routing procedures, based upon adaptations of basic hydraulic principles, using electronic or mechanical analogues.

(g) Forecasting procedures have been developed for key points. Refinement and modification due to reservoir construction, channel improvements and other changes are a continuing project. The Fort Worth River Forecast Center has successfully applied the IBM-1620 electronic computer in river forecast procedure development and in operational flood forecasting. The newest RIver Forecast Center at Sacramento, Calif., was equipped w1th an IBM-1620 computer. The use of an IBM-1620 computer for development and operational forecasting is also avallable to the River Forecast Centers at Portland, oreg., Kansas C1ty, Mo., and Wash1ngton, D. C.

(h) "Role of DI'gital' Computers in Hyarologic Forecasting and Analyses, "by J.R. McCallister and "Rainfall-Runoff Models" by $M$. A. Kohler presented at 13 th Assembly of IUGG, Berkeley, Cal1f., August 19-31, 1963.

(1745) WATER SUPPLY FORECASTS FOR UNITED STATES.

(b) Work being conducted in following fleld of fice River Forecast Center - Portland, Oreg., Water Supply Forecast Unit - Salt Lake C1ty, Utah, R1ver Forecast Center - Kansas City, Mo., River Forecast Center - Sacramento, Calif., River Forecast Center - Hartford, Conn. 
(d) Theoretical and field investigation; operation and applied research.

(e) The purpose of these investigations is the development of precipitation-runof f relations for water supply forecasting utilizing statistical methods to correlate precipitation during the winter with runoff during the melting season.

(g) Water Supply Forecasts are prepared for nearly 400 points in the United States. These forecasts of water-year and residual flow are released in Monthly Water Supply Forecast Bulletins, January through May . This research program is of a continuing nature designed to improve and extend the present forecasting service.

\section{(2437) UNITED STATES STORM CHARACTERISTICS.}

(b) Soll Conservation Service, Department of Agriculture.

(d) Theoretical and field investigation; applied research and design.

(e) Studies to provide rainfall data for design criteria in estimating required capacities of hydraulic structures. Work Includes: (1) Development for the Hawallan Islands and Alaska of a generalized relationsh1p between depth, area, duration and frequency for areas up to 400 square miles, durations of 5 minutes to 24 hours, and return periods from 1 to 100 years; and development of a generalized portrayal of probable maximum precipitation for areas to 400 square miles and durations to 24 hours. (2) survey of maximum observed rainfall amounts for durations from 5 minutes to 24 hours for 296 stations in the United States and analysis of their daily and seasonal distributions, and depth-duration characteristics. (3) Determination of average annual precipitation in the 48 conterminous states from dally amounts of 0.50 Inch or greater, their contribution to the mean annual total precipitation, and the average annual number of days with such arounts. (4) Development for the 48 conterminous states of a generalized relationsh1p between depth, area, duration and frequency for areas up to 400 square miles, durations from 2 to 10 days, and return perlods from 2 to 100 years. (5) Development of relationship between snow depth, water equivalent, area and frequency for March in Great Lakes region.

(f) Items (1) to (3) completed, (4) and (5) active.

(h) "Rainfall-Frequency Atlas of the Hawallan Islands for Areas to 200 Square Miles. Durations to 24 Hours, and Return Periods from 1 to 100 Years" Technical Paper No. 43, U. S. Weather Bureau, 1962.

"Probable Maximum Precipitation and RainfallFrequency Data for Alaska for Areas to 400 Square Miles, Durations to 24 Hours, and Return Periods from 1 to 100 Years" Technical Paper No. 47, U. S. Weather Bureau, 1963. "Maximum Recorded irited states Point Rainfall for 5 Minutes to 24 Hours at 296 FHrstOrder Stations" Technical Paper No. 2, revised 1963.

"Average Annual Precipitation from Dally Amounts of 0.50 Inch or Greater" by J. L. H. Paulhus and J. F. Miller, Monthly Weather Review (1n press).

\section{(2438) STORM TIDE PREDICTIONS.}

(b) Laboratory projects.

c) Mr. D. L. Harris, Project Leader, Storm Surge Research Profect, Meteorological Research, U. S. Weather Bureau, Washington, D. C. 20235 .

(d) Theoretical and fleld investigation; basic and applied research.

(e) The basic research is the numerical approximation to the solutions of the hydrodynamic storm surge equations and is being done to give a better understanding of the physical processes involved in storm surge generation and modification. The applied research is the development of empin lcal methods of forecasting storm surges with the purpose of improving storm tide forecasts.

(g) Empirical methods of forecasting these inundations are being developed and used in the Weather Bureau's hurricane and storm warning service. Continued improvement in these forecasts is expected to result from this research.

(h) "Characteristics of the Hurricane Storm Surge" D. L. Harris, Technical Paper No. 48, U. S. Weather Bureau, 1963.

(2943) METEOROLOGICAI RADAR TRANSPONDER (MRT) FOR REPORTING RAINFALI.

(b) Laboratory project.

(d) Field investigation; development and operation.

(e) A compact device, consisting of a tipping bucket rain gage and transponder, that can be installed in relatively remote areas at an average distance of 70 miles from the radar and up to 140 miles with a mountaintop installation. Activated by a signal from the radar, the MRT transmits a pulsed signal which appears in Binary code on the radar scope indicating the accrued amounts of precipitation. Investigations are continuing for application to reporting of river and tide stage, and snow water-equivalent data.

(g) MRT-1 now operational; as of July 1963 ten MRT-2's have been installed with twenty remaining installations to be completed.

(h) "Profect Report on the Weather Bureau's Radar Hydrology Program (MRT-2)" by A. F. Flanders, Proceedings of the Tenth Weather Radar Conference, pp 280-281, April 1963.

(3251) PRECIPITATION DISTRIBUTION AS DETERMINED BY WSR-57 RADAR.

(b) Laboratory projects at Weather Bureau off1ces In Detrolt, Mich., Evansville, Ind., Kansas C1ty, Mo., Missoula, Mont., Oklahoma C1ty, okla., Sacramento, Callf., St. Louls, Mo., and Wich1ta, Kansas.

(d) Theoretical and fleld investigation, operation and applied research.

(e) Studies are being made to relate, within 100 N.M. of the radar, the intensity and duration of weather echoes with observed rainfall. Estimates of rainfall can be determined by use of the callbrated attenuators on the radar and converting these $\mathrm{db}$ values to theoretical rainfall rates by means of a rainfall rate-echo intensity graph. This use of radar has application to flood forecasting, water supply forecasting and will also be used to determine a radar range correction value.

(g) Preliminary results indicate that by averaging point radar estimates of rainfall over a river basin and comparing them with obsemed averaged rainfall over the same basin favorable correlations within 10 percent are possible under certain weather regimes. Data collection being continued.

(h) "Report of U. S. Weather Bureau Studies in Radar Hydrology" by A. F. Flanders, 13th General Assembly of IUGG, Committee on Precipitation, Berkeley, Calif., Aug. 1963.

(3601) STUDY OF TECHNIQUES FOR MEASURING RATNFALI BY REFERENCE TO RADAR ATTENUATION.

(b) Laboratory project in cooperation with Stanford Research Institute, Menlo Park, Calif.

(d) Experimental; development and applied research.

(e) By measuring the attenuation of short wave length radar signals over a flxed course and relating it to the measured precipitation along the path of the radar beam, a relationshio can be established enabling 
an instrument (specifications being written) to monitor areas above damsites and small headwaters for the purpose of alerting downstream interests to heavy rainfall.

(5) Completed.

(g) The project was carried out from 1960 to 1963 using a $.87 \mathrm{~cm}$ pulsed radar from which energy was reflected over a fixed path (approximately $8 \mathrm{KM}$ long) by a series of passive reflectors. Reductions in signal strength due to attenuation by rain were compared with records from a network of conventional raingages. The results indicate that its application is best for use in the detection of rain likely to cause flash floods over small drainages.

(h) "Study of Techniques for Measuring Rainfall by Reference to Radar Attenuation" by Collis, Honey and Fernald, Final Stanford Research Report on Weather Bureau Contract 10488, June 1963 .

(3602) EXTENSION OF RATING CURVES.

(b) Laboratory project.

(d) Field investigation; operation and applied research.

(e) The flood forecasting procedures used by the Weather Bureau are primarily based on discharge. However, the flood warnings to be of any value must be in terms of stage (or elevation). This is accomplished by use of U.S. Geological survey rating curves relating discharge to stage. Rating curves are defined only to the maximum observed stage of record. Therefore, it is imperative to devise a reliable method of extending rating curves in order to issue accurate stage predictions for the rocord breaking flood.

(f) In abeyance, work being done by U.S. Geological Survey.

(h) "Extension of Rating curves by Fleld Surveys" by W. T. Sittner, Journal of the Hydraulics Division, ASCE, Vol. 89, No. HY2, Proc. Paper 3444, pp 1-9, March 1963.

(3920) FLOAT-TYPE RESISTANCE RIVER GAGE.

(b) Laboratory project.

d) Experimental; development. A device employing a Helipot (multi-turn potentiometer) operated by a float or connected to an existing river gage and linked by wire or radio to an observation point (up to 3 miles by wire and 50 miles by radio). A reading is obtained by balancing the resistance in the system with a similar unit at the observation point. May be operated on AC or DC power.

(g) Fleld installation of units linked by land lines now operational; radio link still under development.

(3921) PUNCHED-TAPE RECORDING, WEIGHING-TYPE PRECIPITATION GAGE WITH TELEMETERING CAPABILITY.

(b) Laboratory project.

d) Experimental; development.

(e) A twenty-inch capacity, welghing-type battery-operated precipitation gage providing a punched tape record which can be machine processed, capable of over one month's unattended operation. Gage so designated that data can be telemetered through use of a "black box" attached to recording mechanism.

(g) Initial gages procured and undergoing laboratory and field tests. Installation and fleld testing began sept. 1963.

(4401) BINARY-DECIMAL TRANSMITTER FOR USE WITH ANALOG-DIGITAL RECORDER.

(b) Laboratory project in cooperation with Fischer \& Porter Co.

(d) Experimental; design development.

(e) Black-box attachment for Analog-Digital Recorder (ADR) permitting interrogation by telephone or radio of river stage data.

(g) Initial installations undergoing field test.

(4402) RADAR PRECIPITATION INTEGRATOR.

(b) Laboratory project in cooperation with Stanford Research Institute, Menlo Park, Calir.

(d) Experimental and field investigation, applied research and development.

(e) A system for measuring precipitation by Sband radar, employing six levels of intensity on the log recelver, which quantizes the received radar signal from selected grid locations. The accrued precipitation is recorded on paper tape as well as displayed in units of depth by a series of electro-mechanical counters set in a map corresponding to the 140 grid locations. Because of the pulsed digital nature of the readout it is possible to transmit the signal by narrow bandwidth links. An evaluation of the system is in process utilizing a dense network of recording raingages operated by the Agriculture Research Service near Norman, Okla.

(f) Construction phase completed. Evaluation phase active.

(g) The system has been installed at the Weather Bureau's Weather Radar Lab, Norman, Okla.

(h) "Construction of prototype," by Ronald $\mathrm{T}$. H. Collis, Final SRI Report on phase II of contract CWB-10282, April 1963.

(4765) THE ANARTIC CIRCUMPOLAR CURRENT.

(b) Laboratory project (supported by National Sclence Foundation).

(c) Mr. F. Ostapoff, Polar Meteorological Research Project, U. S. Weather Bureau, Wash. 25, D. C.

(d) Theoretical and field investigation; basic and applied.

(e) Attempts have been made to assess quantitatively the meridional and vertical velocity components of the Antarctic Circumpolar Current, an important problem in the study of oceanic circulation around Antartica and its interaction with the atmosphere.

(g) Transverse and vertical velocity components were computed from hydrographic data along meridional cross-sections through the Antarctic Circumpolar current. Results indicate the existence of a well-defined convergence zone lying north of the primary polar front.

(h) "On Frictionally Induced Transverse Velocity Components in the Antarctic Circumpolar Current," Dent. Hydro. Zeit., vol. 15, No. 3, pp. 103-113, 1962.

(4766) OCEAN-ATMOSPHERE INTERACTION

(b) Laboratory Project.

c) Dr. Kirk Bryan, General Circulation Research Laboratory, U. S. Weather Bureau, Wash. 25, D. C.

(d) Experimental, theoretical; basic.

(e) As part of the fundamental investigation of atmospheric processes by the General Circulation Research Laboratory, work has been initiated to study the large-scale aspects of the interaction of the ocean with the atmosphere. The problem of the response of a simplified ocean model to wind stress was chosen as a starting point. Numerical solutions for this problem incorporate a much more detalled treatment of the non-linear terms than has been possible in previous studies. Model and boundary refinements will be made to check whether the results could be explained by aspects other than the pattern of wind stress.

(g) Preliminary conclusions drawn from calculations indicate that details of the observed pattern of wind stress are very important for explaining many features of the Gulf Stream and Kuroshio systems

(h) "A Numerical Investigation of a Nonlinear Model of a Wind-Driven Ocean," by K. Bryan 
to be published in Journal of the Atmospheric Sclences.

(4767) PROBABLE MAXIMUM PRECIPITATION IN THE HAWAIIAN ISLANDS.

(b) Corps of Engineers, Department of the Army.

(d) Applied research and design.

(e) Estimates of probable maximum precipitation for durations up to 24 hours for the Hawa11an Islands.

(f) Completed.

(h) "Probable Maximum Precipltation in the Hawallan Islands," U. S. Weather Bureau, Hydrometeorological Report No. 39, Washington, May 1963.

\section{(4768) STORM WINDFLOW OVER CALIFORNIA.}

(b) Corps of Englneers, Department of the Army.

(d) Applied research.

(e) Determine windflow in precipitation storms for purposes of estimating design storms and forecasting precipitation.

(f) Completed.

(h) "Three-Dimensional Wind Flow and Resulting Precipitation in a Northern California Storm," Weather Bureau Research Paper No. 44, Washington, August 1963. Supt. of Documents, Washington, D. C. 35 cents.

(5012) PROBABLE MAXIMUM PRECIPITATION FOR THE U.S PACIFIC NORTHWEST (COLUMBIA RIVER DRAINAGE).

(b) Corps of Engineers, Dept. of the Army

(d) Applied research.

(e) Six- to 72-hour probable maximum precipitation for basins up to $1000 \mathrm{sq}$. m1. In extent, for each month. Includes temperature and winds for several days prior to and during storm. Estimates used in design of flood control structures.

(h) Unpublished preliminary report.

U. S. DEPARTMENT OF THE INTERIOR, GEOLOGICAL SURVEY.

(2688) MECHANICS OF AQUIFERS.

(b) Laboratory project.

c) Mr.J.F. Poland, U.S. Geologlcal survey, Sacramento, California.

(d) Field investigation; basic and applied research.

(e) To determine the principles and factors involved in the strain, deformation, and compaction of water-bearing rocks resulting chiefly from changes in hydrologic environment.

(h) "Physical and Hydrologic Properties of WaterBearlng Deposits from Core Holes in the Los Banos-Kettleman C1ty area, Cal1f." by A. L. Johnson, and D. A. Morris, 1962a; U. S. Geol. Survey open-file rept., multilithed, 182 p., 26 flgs., 10 tables. (To be combined with similar reports on two other areas for publication as Prof. Paper.)

"Subsidence in the Santa Clara Valley--A progress report," J. F. Poland and J.H. Green, 1962, U. S. Geol. Survey Water-Supply Paper 1619-C, 16 p., 12 flgs.

"Tectonic Control of Interior Drainage, San Joaquin Valley, Calif.,"G. H. Davis, and J. H. Green; Art. 146 in U. S. Geol. Survey Prof. Paper 450-D, p. D89-D9l. "Compaction of the Aquifer System and Land subsidence in the Santa Clara Valley, Cal1f." J. H. Green, 1962: Art. 172 in U. S. Geol. Survey Prof. Paper 450-D, p. Dl75-Di78. "An Automatic Recording Liquid-Level Tiltmeter / abs./," F. S. R1ley, 1962: Am. Geophys. Union Trans., v. 43 , no. 4, p. 427.

"Relation of the Pore Volume of silty sed1ments to overburden Load, Particle size, and Sorting," R. H. Meade, 1963: Art. 210 in U. S. Geol. Survey Prof. Paper 450-E, p. El11Ell4.

"Relation of Core Expansion to the Laboratory Determination of Porosity of Alluvial sediments /abs./," J. F. Poland, 1963, Am. Geophys. Union Trans., v. 44 , no. 1 , p. 46.

(2689) DIFFUSIONAL PROCESSES AND HYDRODYNAMICS OF SALT-FRESH WATER INTERFACE IN AQUIFERS.

(b) Laboratory project.

(c) Mr.H.H. Cooper, Jr., U.S. Geol. Surv., Tallahassee, Florida.

(d) Field and laboratory investigation; basic and applied research.

(e) To determine the factors affecting the distribution of salt water in coastal aquifers subject to salt water encroachment.

(h) "Bank Storage and Ground-Water Movements Caused by Flood Waves in surface streams," H. H. Cooper, Jr., M. I. Rorabaugh, 1963, U. S. Geol. Survey Prof. Paper 475-A. "Type Curves for Nonsteady Radial Flow in an Infinite Leaky Aquifer in short Cuts and special Methods in Aquifer Tests," H. H. Cooper, Jr., 1963, U. S. Geol. Survey WaterSupply Paper 1545-C. (In press.)

"Ground-Water Movements and Bank Storage Due to Flood stages," H. H. Cooper, Jr., M. I. Rorabaugh, 1963 , U. S. Geol. Survey Water-Supply Paper 1536-J. (In press.)

(2695) CONTINUOUS DISCHARGE RECORDS IN TIDAL STREAMS.

(b) Laboratory project

(c) Dr. Chintu La1, USGS, washington 25, D. C. that describes the flow pattern and related channel characteristics for a tidal stream, and to develop methods for determining the discharge in the reach.

(g) Basic partial differential equations for tidal flow were derlved. These equations were transformed into characteristics equations and then organized into difference equations sultable for electronic digital computer. Trial mus have indicated satisfactory results. Another approach to the solution of partial differential equations by implicit method is under study.

(h) "Flows of Homogeneous Density in Tidal Reaches, by Method of Characteristics," by Chintu La1 (in review).

(2703) EVAPORATION SUPPRESSION.

(b) Cooperative with Bureau of Reclamation and Texas $A$. and $M$. College.

(c) Mr. G. E. Koberg, U. S. Geol. Surv., Denver, Colorado.

(d) Field investigation; applied research.

(e) The purpose of the project is to improve the techniques for measuring evaporation from open water surfaces both in instrumentation and theory. To develop methods for reducing evaporation which are both economical and practical for field application.

(h) "Evaporation Control, 1959-60," G. E. Koberg, R. R. Cruse, and C. L. Shrewsbury, U. S. Geol. Survey Water supply Paper 1692, 55 p., 10 figs., 1963.

(2948) ANALOG MODEL ANALYZER FOR STEADY-STATE GROUND-WATER FLOW PROBLEMS.

(b) Laboratory project.

(c) Mr. R. W. Stallman, U.S. Geol. Surv., Denver, Colo.

(d) Theoretical study and instmument development.

(e) Use of a varlable-resistance glrd analyzer in analyzing steady-state ground-water flow problems in which the transmissiblilty varies In space.

(h) "Orlentation of Axes for Calculating Distribution of Transmissiblilty from WaterLevel Alt1tudes," R. W. Staliman, 1963 , U. S. Geol. Survey Prof. Paper 450-E, p. 165-166.

"Calculation of Resistance and Error in an Electric Analog of Steady Flow Through Nonhomogeneous Aquifers," R. W. Stallman, 1963 , U. S. Geol. Survey Water-Supply Paper $1544-G$. 
(2949) ULTRASONIC FLOW METER.

(b) Laboratory project.

(c) Mr. E. G. Barron, U. S. Geological Survey, Columbus 12, Ohio.

(d) Experimental; instrument development.

(e) The objective is to measure the average velocity in a natural channel by acoustic means.

(g) Two sets of instruments have been constructed on basis of new design concepts. The instruments are being tested in the field.

(2950) SEDIMENT TRANSPORT AND CHANNEL ROUGHNESS IN NATURAL AND ARTIFICIAL CHANNELS.

(b) Laboratory project.

(c) Mr. Thomas Maddock, Jr., U. S. Geological Survey, Washington 25, D.C.

(d) Basic research.

(e) Field and laboratory studies, original and other investigations will be analyzed in terms of sediment movement, channel roughness, shear distribution in channel prism and other effects on shape of natural channels.

(g) Sand channel reach with controlled flow on the Rio Grande below El Paso selected for concentrated study.

(3253) CHANNEL STABILITY IN AN EPHEMERAL STREAM.

(b) Laboratory project.

(c) Dr. Luna B. Leopold, U. S. Geological Survey, Washington 25, D. C.

(d) Field investigation; basic research.

(e) In an ephemeral stream (arroya), measurements are being made on the following: Stress on rocks during a flow; movement and location of rocks after flow; extent of scour and fill; movement of bars; changes in cross sections at certain locations; erosion on slopes; mass movement of solis; and soll wash.

(h) Report in preparation. Paper on downstream scour and fill to be presented at second National Conference on Sedimentation in Jan. 1963.

(3260) SOIL-MOISTURE EQUIPMENT.

(b) Laboratory project.

(c) Mr. A. I. Johnson, Chief, Hydrologic Laboratory, U.S. Geological Survey, Denver, Colo.

(d) Laboratory and field investigation; applied research.

(e) Laboratory model and field comparative study of techniques and of various commercially available instruments for measuring soll molsture. New equipment may also be designed as result of study.

(g) Fleld and laboratory calibrations of neutron meter, tensiometers, molsture blocks and sampling equipment. Evaluation of neutron meter. Deslgn of small-diameter fast-response tensiometer. Library research.

(h) "A Field Method for Measurement of Infiltration," by A. I. Johnson, U. S. Geol. Survey Water-Supply Paper 1544-F.

(3263) SPECIFIC YIELD AND RELATED PROPERTIES.

(b) Cooperative with the State of Califormia.

(c) Mr. A. I. Johnson, Chief, Hydrologic Laboratory, U.S. Geological Survey, Denver, Colo. or Mr. Fred Kunkel, District Geologist, U. S. Geological Survey, Sacramento, Calif.

(d) Laboratory and fleld investigation; basic and applied research.

(e) Theoretical, laboratory and field study of specific yield, and related properties, such as molsture equivalent, field capacity, molsture tension, unsaturated permeability and time-drainage relationships, as related to ground-water storage. Evaluation of existing, and possible development of new methods for determing these properties.

(g) Library research, laboratory study in progress or completed of factors affecting column drainage, centrifuge moisutre equivalent, moisture tension and unsaturated permeability.

(h) "Specific y1eld--Column drainage and centrifuge mo1sture content," by A. I. Johnson,
R. C. Prill, and D. A. Morris: U. S. Geol. Survey open-file report; also U. S. Geol. Survey Water-Supply Paper 1662-A (i963). "Centrifuge Technique for Determining Time-Drainage Relations for a Natural Sand," by R. C. Prill and A. I. Johnson: U. S. Geol. Survey Prof. Paper 450-E (1963). "Research on Specific Yield," (abstract), by A. I. Johnson and D. A. Morris,

California Association Engineering Geologisto Meeting, October 1961; U. S. Geol. Survey open-file rept. (1961).

(3264) SUBSURFACE EXPLORATION EQUIPMENT AND TECHNIQUES.

(b) Laboratory project.

(c) Mr. A. I. Johnson, Chief, Hydrologic Laboratory, U. S. Geological Survey, Denver, colo.

(d) Laboratory and field investigation; applied research.

(e) Evaluate and adapt subsurface exploration equipment and techniques, such as gamma ray and electric loggers, fluid velocity and conductivity loggers, temperature loggers, power augers and core samplers, for solving ground water occurrence problems

(g) Portable temperature logger nearly completed; core samplers designed and commercial models procured and compared under field conditions; power augering equipment and techniques evaluated; evaluation in progress of gamma-ray conductivity and temperature logging equipment for salt-water encroachment and waste disposal problems. Library research in progress.

(h) "Selected References on Laboratory and Field Methods in Ground-Water Hydrology," by A. I. Johnson, U. S. Geological Survey Water-Supply Paper.

"Training Aids: Hydrologic Laboratory; Symbols and Definitions from Soll Mechanics and Soll Physics; Design of Well screen and Filter Pack; Portable Equs.pment for Borehole Exploration; Modifled Parshall Flume," by A. I. Johnson, U. S. Geol. Survey Open-file Rept.

"Geophysical Logging of Boreholes for Hydrologic Studies," by A. I. Johnson, U. S. Geol. Survey open-File Rept.

"Outiline of Equipment for Hydrologic Studies", by A. I. Johnson, U. S. Geol. Survey openFile Rept.

"Geophysical Exploration of Wells as an Aid in Location of Salt-Water Leakage, Alameda Plain, California," by R. P. Moston and A. I Johnson, U. S. Geol. Survey Professional Paper 424-D, p. 262-264.

(3265) INVESTIGATION OF VADOSE FLOW THROUGH HOMOGENEOUS ISOTROP IC MEDIA.

(b) Laboratory project.

(c) Mr. A. I. Johnson, Chief, Hydrologic Laboratory, U. S. Geological Survey, Denver, Colo.

(d) Experimental; basic and applied research.

(e) Laboratory model study of infiltration of fluids from surface pits into a thick unsaturated zone above the water table.

(g) Model tank designed and constructed; several test mus with beads of different particle size completed; library research; test runs photographed by slide and movie.

(3939) STUDY OF RADIOACTIVE WASTES, CLINCH RIVER, TENNESSEE.

(b) Atomic Energy Commission.

(c) Mr. P.H. Carrigan, U. S. Geological Survey, Oak Ridge, Tennessee.

(d) Field investigation; applied research.

e) Purpose is to undertake a comprehensive study of the entry, movement, location and fate of radioactive wastes discharged into the Clinch River by the Oak Ridge National Laboratory.

(g) Laboratory flume study conducted in addition to field investigations. 
(3953) BASIC RESEARCH IN VEGETATION AND HYDROLOGY.

(b) Laboratory project.

c) Dr. R. S. Sigafoos, USGS, Arlington, Va.

d Field investigation; applied research

The overall objective of this project is to better understand the relationships between wild vegetation and the hydrologic environment. The immediate objectives are to develop methods of analyzing vegetation to find evidence of hydrologic events, to increase the record in time and space and to relate vegetation to differences in the physical environment and to the history of the area.

(g) Four reports in preparation or scheduled.

(3954) CHARACTERISTICS OF GLACIER-FED STREAMS

(b) Laboratory project

c c Dr. R. K. Fahnestock, USGS, Fort Collins, Colo.

d Field invest1gation.

(e) The purpose of this project is to study the channel characteristics of streams below active glaciers, especially those camylng substantial amounts of debris which 1 s sorted and transported by meltwater. It should assist developing an understanding of glacial outwash deposits, both present and past, in other areas. This study should also add to both the knowledge of the influence of diurnal fluctuations in flow on the characteristics of alluvial channels and to the knowledge of long term response of stream channels to glacler fluctuations. The project is carried on at White River below Emmons Glacier, Mt. Ra1nier, wash., flume studies are carried out at Colorado' state University.

(f) Suspended.

(3955) DOWNSTREAM EFFECT ON DAMS, DIVERSIONS AND IRRIGATION DRAINS ON ALLUVIAL CHANNELS.

(b) Laboratory project.

(c) Dr. M.G. Wolman, Johṇs Hopkins University, Baltimore, Md.

(d) Field Investigation; applied research.

(e) The purpose of the project is to determine the downstream effect of dams, diversions and irrigation drains on alluvial channels. All avallable data are to be gathered and summarized on channel surveys before and after construction. Th1s will be accomplished insofar as possible by correspondence with State, Federal, and local agencles.

(f) Completed.

(h) Manuscript in preparation.

(3956) LONG-TERM HYDROLOGIC TRENDS AS INDICATED BY GIACIERS.

(b) Laboratory project.

c) Dr. M.F. Meler, USGS, Tacoma, Washington.

d Field investigation; basic research. In general, this continuing program seeks to improve our knowledge and understanding of high mountain and glacier hydrology, and to develop and test means for analyzing quantitatively the response of a glacier to changes in climate. Immediate objectives are to determine the complete water- and massbudgets, and the time-varlations in these budgets for a glacierized basin, and to test and refine current theories of the response of a glacier's surface profile to a perturbation in climate.

(h) "Proposed Definitions for Glacier Mass Budget Terms," M. F. Melr, Jour. Glaciology, v. 4, No. 33 , p. 252-261, 3 f1gs., 1962.

"The Kinemat1c Wave on N1squally Glacier, Washington (Abstract)," M. F. Meler and J. N. Johnson, Jour. Geophys. Research, v. $67, \mathrm{p}$.
886,1962 .

"Recent Varlations in Mass Net Budgets of Glaciers in western North Amer1ca," M. F. Meler and A. S. Post. Internat. Assoc. of Sc1. Hydrology, Obergurgl Symposium, Pub. 58, p. $63-77,8$ figs.

"Mechanics of Response of Glaclers to climatic Change--a Progress Report," M. F. Me1er, Geol. Soc. America Annual Meeting, Houston, Texas,
Nov. 12-14, 1962, Special Session on Quant1tat1ve Approach to Geomorphology. Review by Alfred A. Knopf of "The World of Ice," by J. L. Dyson, New York, 292 p., Art1c, p. 32l-322.

(3957) THE HYDROLOGY OF A PORTION OF THE HUMBOLDT RIVER VALLEY.

(b) State of Nevada and U. S. Bureau of Reclamation.

(c) Mr. T.W. Robinson, USGS, Menlo Park, Cal1f.

(d) Field investigation.

The purpose of this project is to determine how the avallable water in Humboldt RIver valley might better be utilized. The following hydrologic data w1ll be collected and studied: (I) Runoff characteristics and magnitude of use of surface waters; (2) the specific yleld of sediments in the flood plain and the magnitude and extent of water-level fluctuations in the groundwater reservolr; (3) the use of water by greasewood and willows; (4) variations in chemical quality of the water in the flood plain; (5) amount of underflow at comus and Rose Creek to be determined by means of pumping tests of exploratory holes; and (6) amount of ground water from tributary valleys, to be determined on the basis of chemical analyses and low-flow measurements. The General Hydrology Branch has furntshed the project leader and will determine the amount of water used by greasewood and w1llows by use of tanks (lysimeters) similar to those used in the Buckeye project. Site is near Winnemucca, Nevada, in the Humboldt River Valley.

(g) Quantitative data obtained on the annual rate of use by w1llow and greasewood. However, the use by greasewood was abnormal (low) due to the concentration of boron in the root zone, causing defollation during the latter part of the 1962 growing season. Leaching of the tanks by back-washing, to remove most of the boron appears to have been successful. Samples of soll inside and outside the tanks and samples of the effluent leach water were collected and analyzed for boron and other constituents. Follage volume measurements were made of all species except rabbltbmush, which was not mature, and photographic records of growth were made at 4 to 6 week 1ntervals. Replanting of some of the rabbltbmush to replace seedlings planted in April 1962 that did not survive.

(h) "Research Studies on the Use of Water by Phreatophytes," T. W. Robinson, Nevada state Dept. of Conv. 3rd Progress Report, Humboldt River Research Project, 1962.

(3958) THE EFFECT OF EXPOSURE ON SLOPE MORPHOLOGY.

(b) Laboratory project.

c Mr. R. F. Hadley, USGS, Denver, Colo.

d Fleld investigation; applied research. The purpose of this project $1 \mathrm{~s}$ to determine the morphologic and hydrologic differences existing among slopes of various exposures and to measure the resulting effects on erosion, soll molsture, and vegetational cover. Also, the effect of differential exposure on drainage-basin evolution w1ll be investigated. Sites for study are several selected small areas in wyoming, Colorado, and New Mexico.

(3959) LONG-TERM CHRONOLOGIES ON HYDROLOGIC EVENTS.

(b) Laboratory project.

c Mr. W. D. Simons, USGS, Tacoma, Washington.

d Field investigation.

e) The purpose of this project is to provide information on flood and drought frequencies and other critical hydrologic events from the history of major river basins. Data w1ll be sought to evaluate long-term fluctuation in water supply to determine whether or not there has been elther an upward or downward trend during the last 
2 or 3 centurles. Such data w1ll include crop records, news 1tems, historical records, tree-ring data and lake levels. Efforts w1ll be made to obta1n useful data rrom anthropological research studies in the Pac1f1c Northwest. Th1s study would provide add1tional knowlege on probable frequency and duration of critical hydrologic events especially droughts for each major river basin. The first 1nvestigation would be in the Columbia River basin.

(3961) USE OF WATER BY SALTCEDAR.

(b) Bureau of Reclamation.

(c) Dr. T. E. A. vanHylckama, USGS, Phoen1x, Arizona.

(e) The purpose of this project is to measure the use of ground water by saltcedar in evapotranspirometers and to evaluate these data against those obtained by energy budget and mass transfer methods. Est1mates can then be made of the quantity of water salvageable by control or eradication of saltcedar. Large evapotranspirometers have been constructed in an env1ronment of saltcedar and planted at the same density as in the surrounding area. The use of water from these tanks will be measured and the effect of maintaining ground water at different levels studied.

(h) "Buckeye Project - water Use by Saltcedar," T. W. Robinson and C. W. Bowser, U. S. Geol. Survey and U.S. Bur. Reclamation, $26 \mathrm{p}$. 59-3 Phreatophyte Subcomnlttee meeting Pác. S. W. Inter-Agency Comm., 1959.

"Measuring Water Use by Saltcedar," T. E. A. van Hylckama, Proc. 4th Ann. Arlzona Watershed Sympos1um p. 22-26; Ar1z. Water Resources Comm. and State Land Dept., State of $\operatorname{Ar1z}, 1960$.

"Use of Water by Saltcedar (Tamarix Pentandra) as Measured by the Water-Budget Method (a preliminary report)," T. E. A. van Hylckama, 23 p., abstract in Jour. Geophys. Research, v. 67, p. $3535,1962$.

(3962) RESEARCH IN PHREATOPHYTES.

(b) Laboratory project.

c Mr.T. W. Robinson, USGS, Menlo Park, Cal1f.

d Field invest1gation; applied research.

(e) The purpose of this project is to provide a more complete understanding of the factors affecting the occurrence and use of ground water, by species, of phreatophytes, the areal extent of the widespread species, the magnitude of the phreatophyte problem; and the development of information and techniques for salvaging the consumptively wasted water.

(h) "Glossary of Terms Relating to the Phreatophyte Problem," T. W. Robinson, Duplicated report for the Subcommittee on Phreatophytes, Pac1f1c Southwest Inter-Agency Comm1ttee, 1962.

(3963) EVAPOTRANSPIRATION THEORY AND MEASUREMENT.

(b) Laboratory project.

c) Mr. O. E. Leppanen, USGS, Phoen1x, Ar1zona.

d Field investigation.

(e) The long term goals of the project are to develop methods to determine evapotranspiration losses from hydrologically important areas. These methods should preferably be Independent of detalled ground water, so1l mo1sture, and surface water data. Inmedlate objectives are the development of so1l mo1sture measurement methods, determination of practical methods of measuring and computing heat exchange over vegetated areas, and development of a mathematical model to describe the hydrologic behavior of a reach of river channel subject to large evapotranspiration losses.

(h) "A Test of the Energy Budget Method of Measuring Evapotranspiration," O. E. Leppanen and G. E. Warbeck, Jr., Internat. Assoc. Ac1. Hydrology, Publ. 53, p. 428-437, 1960.
"Methods for Study of Evapotransp1ration," o. E. Leppanan, U. S. Geol. Survey, Pror. Paper 424-B (U. S. Geol. Survey Research 1961) p. $43-45$.

(3965) HYDROLOGIC EFFECT OF VEGETATION MODIFICATION.

(b) Laboratory project.

c Mr. R. M Myrlck, USGS, Tuscon, Arlzona.

d) Field 1nvest1gation.

(e) The purpose of this project is to evaluate the change in water yleld produced by the vegetation modification and to develop a more comprehensible understanding of the function of vegetation, w1thin the hydrologic reglme, under semiarid conditions. Substitution of short-rooted grass for deeprooted trees is the basis for this study. The study has been divided into two parts; (1) The determination of the changes in water yield produced by a pinon-juniper eradication program on a dra1nage area of 200 square miles; and (2) the intensive study of 2 palrs of small watersheds to evaluate the hydrologic processes involved and alterations that occur as a result of vegetation modification. Correlations of munoff, using precipitation will be used for (1). In part (2) an attempt will be made to evaluate the major portions of the hydrologic cycle and to define the interrelationsh1ps. Study site 1 s Carrizo and Corduroy Creek basins in the Fort Apache Ind1an Reservation, Arizona.

(h) "Hydrolog1c A spects of the P1nyon and Jun1per Eradication Project on the Fort Apache Ind1an Reservation, Ar1zona, "R. M. Myr1ck and M. R. Collings, New Mexico Geolog1cal soc., Th1rteenth Fleld Conference, Mogolion Rim Region, 1962.

(3966) EFFECTS OF SEDIMENT CHARACTERISTICS OF FLUVIAL MORPHOLOGY AND HYDRAULICS.

(b) Laboratory project.

c Dr. S. A. Schumm, USGS, Denver, Colo.

d Field 1nvest1gation; applied research. The purpose of this project is to collect data on the physical properties of sediments forming the perlmeter of alluvial channels, and to determine the effect of sediment type on fluvial morphology and hydraulics. The physical and chem1cal properties of alluvial materials and their relations to and effects upon fluvial morphology are not well enough understood and require considerable research. Basic data are collected at about 200 cross-sectional sites on as many as possible of the following: channel shape, dimensions, gradient, pattern, and roughness: channel and bank vegetation; stream discharg velocity of flow; suspended and bed sediment loads; and the types of sediment forming the cross-sectional perimeter of the channels "S1nuosity of Rivers," S. A. Schumm, (abs.): Geol. Soc. Am., Special Paper, 1963.

(3968) STUDY OF CHANNEL CHARACTERISTICS AND FLOODPLAIN AGGRADATION, TUSAYAN WASHES, ARIZONA.

(b) Laboratory project.

c) Mr. R.F. Hadley, USGS, Denver, Colo.

d) F1eld 1nvest1gation.

(e) The purpose of this project $1 \mathrm{~s}$ to determine the physical and hydraulic factors that control channel characteristics in aggrading and degrading alluvial channels in the sem1ar1d and ar1d Southwest. An understanding of these processes is needed in order to plan conservation practices in a logical and economic fashion. The project includes study of aggradation occurring naturally as well as aggradation induced by channel structures. Studies are in the drainage basins of Polacca, Ora1b1, Jeddito, Dinnebito Washes, all tributary to L1ttle Colorado River near Winslow in northeastern Arizona.

(h) "Influence of Riparian vegetation on Channel Shape Northeastern Ar1zona," R. F. Hadley, 
U. S. Geol. Survey Prof. Paper 424-C, Art. 156,1961 .

"Characteristics of Sediment Deposits Above Channel structures, Polacca Wash, Arizona," R. F. Hadley, 2nd Federal Interagency Sedimentation Conference, Dept. Agric. Misc. series, 1963.

(3969) GENERAL STUDIES OF EROSION AND SEDIMENTATION.

(b) Laboratory project.

c) Mr. R. F. Hadley and Mr. N. J. King, USGS, Denver, Colo.

(d) Field investigation; applied research.

(e) The purpose of this project is to investigate the basic processes of erosion in a semiarid and arid environment. Studies fall into three general groups: (1) Quantitat1ve measurements of gully growth, channel widening, and channel erosion; (2) measurements of rates of upland erosion; and (3) detalled studies of a particular erosion process in a selected area. The quantitative measurements will be ut1lized to ald in design of soll and water conservation measures. Studies are being made in several areas in Montana, Wyoming, Utah, New Mexico, and Arizona.

(3970) HYDROLOGIC EFFECTS OF URBANIZATION.

(b) Laboratory project.

c Mr. W. Hofman, USGS, Menlo Park, Californ1a.

d) Field investigation.

(e) The purpose of this project is to evaluate the hydrologic effects of changes in land use associated with development of suburban, industrial and urban communities; also included is a study of hydrologic problems in storm dralnage in urban areas. Changes in land use associated with urban development affect local hydrologic factors such as munoff, flood frequency, recharge, channel stability, sediment production and the interrelationship between surface and ground water. Data on stream flow, precipitation, soll molsture and related hydrologic and climatologic data, topographic effects, and geologic, soils, and ecologic information, together w1th documentation of changes in land use as they occur, are needed for proper evaluation. The study area, San Francisquito Basin at Stanford University, Palo Alto, California.

(3971) THE HYDROLOGY OF PRAIRIE POTHOLES, NORTH DAKOTA .

(b) Research Section of Bureau of Sport Fisheries and W1ldlife.

(c) Mr. Wm. S. Eisenlohr, Jr., U.S.G.S., Denver, colo.

(d) Field investigation; applied research.

(e) The purpose of this project is to study the processes by which water enters and leaves prairie pothole ponds, and the causes of variation in the chemical quality of the water. The immediate objective is to find methods by which to determine the activity of the various hydrologic processes operating in the potholes.

(g) Collection of data continued on the original group of potholes and several others were selected and instrumented.

(h) "Current Studies of the Hyorology of prairie Potholes, "J. B. Shjeflo and others, U. S. Geol. Survey Circular 472, 1962.

(3972) STUDY OF WATER APPLICATION AND USE ON A RANGE WATERSPREADER IN NORTHEASTERN MONTANA .

(b) Laboratory project.

(c) Dr. F. A. Branson, Mr. I. S. McQueen, and Mr. R. F. M1ller, USGS, Denver, Colo.

(d) Field investigation; applied research.

(e) The purpose of this project is to evaluate the use of a waterspreader on forage yields. Little information is avallable on amounts of water applied to and used by waterspreaders or on the amounts of water needed for successful waterspreaders. As water becomes more in demand, information on the efficiency of water used by waterspreaders becomes increasingly important. Water applied to the spreader is measured by means of a water-stage recorder which determines the duration of flow through a pipe into the spreader and by means of a rain gage. Plant measurements are being made by the Montana Agricultural Experiment station. Study site is the Willow creek area near Fort Peck, Mont.

(g) Data on so1l mo1sture storage and use have been obtalned for three years (1959-61) when water was applied to the spreader. Analyses are being made of the differences in storage and use on the three major sollvogetation types included in the spreader.

(h) Progress report in preparation.

(3975) STUDY OF EFFECTS OF GRAZING IN BADGER WASH AREA, COLORADO.

(b) U. S. Bureau of Land Management, Reclamation, Forest Service, and Fish and Wildlife Service.

(c) Mr. G. C. Lusby, USGS, Denver, Colo.

d Field investigation; applied research.

(e) The purpose of this project is to determine runoff and sediment yields from small watersheds representing Mancos shale areas of the colorado Plateau and to determine the effects of grazing exclusions on runoff and sediment ylelds. An associated objective is to evaluate effects of a system of reservoirs.

(g) Fleld records were obtalned and computed for munoff and sediment yleld at 18 reservoirs and for precipitation at 10 recording rain gages. Periodic measurement of infiltration rates was begun at 8 locations.

(h) "Hydrologic and Blotic Characteristics of Grazed and Ungrazed Watersheds of the Badger Wash Basin in Western Colorado, 1953-58," G. C. Lusby, G. T. Turner, J. R. Tompson and V. H. Re1d, U. S. Geolog1cal Survey water-Supply Paper 1532-B.

(3976) EVALUATION OF SEDIMENT BARRIER ON SHEEP CREEK, NEAR TROPIC, UTAH.

(b) Laboratory project.

c) Mr. G. C. Lusby, USGS, Denver, Colo.

d) Field investigation; applied research.

(e) The purpose of this study is to determine the effect of a small barrier dam on sheep creek on channel aggradation. A qualitative evaluation of land-treatment practices may be possible.

(g) Collection and computation of field data was cont1nued. Surveys of the reservolr body and channel upstream and downstream from the reservoir were made and computed. Samples of reservoir sediments were obtained and size analyses were made.

(h) Progress report in preparation.

(3978) EFFECTS OF MECHANICAL TREATMENTS ON ARID LANDS IN WESTERN UNITED STATES.

(b) Laboratory project.

c) Mr. A. Branson, Mr. I. S. McQueen, and Mr. R. F. Miller, USGS, Denver, Colo.

(d) Field investigation; applied research.

(e) The purpose of this project is to determine the effects of different mechanical treatments on arid lands. Several small basins on land administered by the Bureau of Land Management in central Montana, eastern New Mexico, and western Colorado, are the study sites. Some reservolrs have been, and others are to be constructed in each of these basins, and runof $f$ and sediment yield is being and has been determined before treatments are applied. Among the treatments applied after precalibration are the following: spike-tooth pitting, eccentric-disc pitting, and contour furrowing (w1th furrow intervals determined on the basis of computed furrow water-storage capacity). Other measurements made would include: vegetation 
kinds and quantities before and after treatment, so1l-mo1sture storage and seasonal and annual changes.

(h) "Effects of Land Treatment Practices on Erosion and Vegetation on Range Lands in Parts of Arizona and New Mexico," $\mathrm{H}$. V. Peterson and F. A. Branson, Jour. of Range Management, v. 15, no. 4, p. 220-226, 1962. "Effects of Contour Furrowing, Grazing Intensities and Solls on Infiltration Rates, Soll Molsture and Vegetation Near Fort Peck, Montana," F. A. Branson, R. F. Miller and I. S. Mcqueen, Jour. of Range Management, v. 15, no. 3, p. 151-158, 1962.

(3979) GENERAL EVALUATION OF SOIL AND MOISTURE TREATMENT PRACTICES.

(b) Laboratory investigation.

c) Mr.K. R. Melin, USGS, Denver, colo.

(d) Field investigation.

The purpose of this project is to appraise the structures and treatment practices used in soll molsture conservation to determine their effectiveness in accomplishing the purposes for which they were designed. The fleld studies include maintenance of records on munoff, erosion and sedimentation to determine the effects of the structures or practices at several areas in colorado, Utah, Arizona, Wyoming, Montana, and New Mexico.

(3980) HYDROLOGY OF DEATH VALLEY.

(b) Laboratory project.

(c) Mr. T. W. Robinson, U. S. G.S., Menlo Park, Calif. and Mr. C. B. Hunt, U.S.G.S, Denver, Colo.

(d) Field investigation.

(e) The purpose of this report is to study the various phases of the hydrology of Death Valley. Data on evaporation, wind movement, humidity and temperature are being obtalned under informal agreement w1th the National Park Service. Relations of plants to salinity and effects of salinity on evapotranspiration also are being investigated.

(f) Completed.

(g) Report on the hydrology of Death Valley in preparation.

(3981) PLEISTOCENE LAKES OF THE GREAT LAKES BASIN.

(b) Nevada State Eng1neers.

c Mr. C. T. Snyder, USGS, Menlo Park, Calif .

d Field investigation.

(e) The purpose of this project is to prepare a map based on data gathered during soll and Molsture Conservation investigations showing the Pleistocene Lakes in the Great Basin area. Further refinements can now be made to Lakes Lahounta and Bonneville and the assoc1ated smaller lakes that existed concurrently. An additional large Pleistocene lake recently discovered is included.

(f) Completed.

(3984) WATER AND SOIL RELATIONSHIPS AS INDICATED BY PLANT SPECIES OR PLANT COMMUNITIES.

(b) Laboratory project.

(c) Dr. F. A. Branson, Mr. I. S. McQueen and Mr. R. F. Miller, USGS, Denver, Colo.

(d) Field investigation.

(e) The purpose of this project is to determine whether or not phonological development of vegetation differs for communities having the same macroclimate but different solls. Plants have been used as indicators of conditions, processes and uses for many years. Where plants can be used as indicators of soll conditions, expensive measurements of physical and chemical properties can be reduced. Plant spectes or communities may be used as indicators of potential production to be expected from land management and treatment practices. Research sites are near Golden, Colorado. Other sites will be selected. (h) "So1l Water Availability and Use by Grasslands on Adjacent Stony and Shale-derived Solls in Colorado," F. A. Branson, R. F. Miller and I. S. McQueen, U. S. Geol. Survey Prof. Paper 425-C, p. 251-253, 1961.

(4404) EROSION, SEDIMENTATION, AND LAND-FORM DEVELOPMENT IN ARID AND SEMIARID REGIONS.

(b) Laboratory project.

(c) Messrs, Garald G. Parker, Reuben C. Miller, and Irel S. McQueen, USGS, Denver, Colo.

(d) Field investigation; both basic and applied research.

(e) Purpose is to ascertain the causes and forces that separate soll and/or rock particles from their sources, and to study the resultant land forms for geomorphic analyses. Field study areas have been selected in several western States, and a primary field research station has been established at the Warbonnet Ranch, 13 miles north of Harrison, Nebr., where all factors relating to erosion and sedimentation are being measured both automatically by specialized recording instruments and manually. The warbonnet research station has been established for a minimum 10-year project life.

(4405) PIPING, AN EROSIONAL PHENOMENON IN CERTAIN SILTY SOILS OF ARID AND SEMIARID REGIONS.

(b) Laboratory project.

(c) Messrs. Garald G. Parker, Reuben C. Miller, and Irel S. McQueen, USGS, Denver, Colo.

(d) Field investigation; both basic and applied research.

(e) Purpose is to ascertain the causes of piping and thus enable fleld engineers and geologists to control this form of destructive erosion. Soils chemistry and physiology will be thoroughly investigated, the atmospheric and other environmental factors related to piping will be determined, and long-term (10 years, at least) observational records will be kept on several areas where piping is a prominent form of erosion. Primary study areas are near chinle and Cameron in Arizona; Cuba, New Mexico; and Panquitch, Utah.

(4408) ANALOG MODELS OF HYDROLOGIC PHENOMENA.

(b) Laboratory project.

(c) Mr. Rolland W. Carter, U. S. Geological Survey, Washington, D. C.

(d) Basic and applied research

(e) Investigation of applicability of analog computer technique to solve problems involving either hydrologic data in general or surface-water flow in particular.

(g) Results to date indicate concept and approach are valid. Additional methods and instrumentation being investigated.

(h) "Use of Hydrologic Models in the Analysis of Flood Runoff," by John Shen (in press).

(4410) BANK SEEPAGE DURING FLOOD FLOWS.

(b) Laboratory project.

c) Mr. M. E. C. Pogge, U. S. Geological Survey, Iowa Clty, Iowa City, Iowa.

(d) Field Investigation; applied research for doctoral thesis.

(e) Purpose is to understand the mechanics of seepage flow into and from bank storage along a channel in response to movement of flood waves through a channel reach.

(g) Program expanded to include study of origin of base flow. Objective now to determine interrelationships between ground and surface water for understanding hydrologic character istics of streams. Observation well and stream gaging stations installed in snall study basin in Central Iowa. Additional wells installed in Missouri Valley for pumptest determination of hydraulic characteristics of outwash aquifer. 
(4411) LIQUID MOVEMENT IN CLAYS.

(b) Laboratory project.

c Dr. H. W. Olsen, USGS, Washington 25, D.C.

(d) Experimental and theoretical study; basic research.

(e) To study the nature of liquid movement through clays in response to gradients of electrical potential, ionic concentration, and temperature; and to relate the movement to such factors as the mineralogical and chemical composition of the clay and pore liquid.

(4770) STUDIES IN GEOMORPHOLOGY.

(b) Laboratory project.

c) Dr. A. V. Jopling, Harvard University, Cambridge, Massachusetts.

(d) Basic and applied research.

e) The purpose of the project is as follows: (1) To carry out fundamental research on the erodibility characteristics of cohesive materlals under a fluid shear stress. Erodibility will be interpreted in terms of the physicochemical properties of the materials under investigation. (2) To determine the effect of size, shape, density, and surface texture on the static angle of subaqueous repose for cohesionless granular materials. (3) To study the transition from a ripple (dune) to a plane-bed regime in a verry narrow $(1 / 2$ in.) laboratory flume. Particle movement will be studied by photographic techniques. (4) To study the effect of partial stabilization on the hydraulic geometry of a meandering laboratory stream.

(4779) LARGE-SCALE ROUGHNESS.

(b) Laboratory project.

c) Mr.J. Davidian, USGS, Washington 25, D. C.

d) Fleld investigation; applied research.

(e) Purpose is to study energy losses produced by large-scale roughness resulting from channel alignment and configuration.

(g) Bed-particle samples have been collected on 64 streams in three different parts of the country. A relation between Manning's roughness coefficient, particle size, and size distribution has been found and is being refined.

(4782) WATER MANAGEMENT.

(b) Laboratory project.

c Mr. C. W. Reck, USGS, Washington 25, D. C.

d) Experimental; applied research.

(e) Purpose is to develop hydrologic principles and methods of water-resources appraisal that can be used for water management.

(f) Suspended.

(4784) FLOW LOSSES IN EPHEMERAL STREAM CHANNELS.

(b) Cooperating Agent - Bureau of Land Management.

c) Mr. R. F. Hadley, U.S.G.S., Denver, Colo.

d) Fleld investigation, basic research.

e) Measurement of surface flow losses in an ephemeral stream channel and determination of whether or not the absorbed water reaches a ground-water reservor will be evaluated on the San Ysidro Wash in Sandoval County, New Mexfco. Secondly, these studies will furnish an opportunity to determine changes in channel and hydraulic geometry in a "losing" reach of channel.

(g) Channel controls and gaging stations were completed in the study reach. Six creststage gages were installed in the study reach. Two recording rain gages were installed in the drainage basin. Surveys were made of the longltudinal profile and several channel cross sections to observe changes during the course of the study.

(4785) THE VIGIL NETWORK.

(b) Laboratory project. (c) Dr. L. B. Leopold, U.S.G.S., Washington 25, D. C.

(d) Field investigation; basic research.

(e) To determine the changes with time on a number of small watersheds (from 1 to 10 square miles) in the vegetation, the channels, the biota, and the overall landscape.

(g) Progress has been made on choossing a serles of small watersheds along a line or transect stretching in an east-west direction between the major mountain masses on the North American continent. Later it is hoped to have a similar series of watersheds in a north-south line through the central part of the United States where the topography is relatively flat. The north-south transect, then would give a representation of the effect of latitude uninfluenced by major differences in Topography.

(4786) EVALUATION OF HYDROLOGIC FEATURES CONCERNING GROUND-WATER CONTAMINATION.

(b) Laboratory project

(c) Mr. H. E. LeGrand, U.S.G.S., Washington 25, D. C.

(d) Field investigation; basic research.

(e) To put into hydrologic perspective the various problems of ground-water contamination. To identify and classify both the contamination problems and their major geologic settings.

(g) Progress is being made on classifying the hydrogeologic framework in which contamination occurs.

(h) "Management Aspects of Ground-Water Contamination," by H. E. LeGrand, American Water Works Association Journal, in press.

(4787) MECHANICS OF FLUID FLOW IN POROUS MEDIA.

(b) Laboratory project.

c) Dr. Ak1o Ogata, U. S. Geological Survey, Honolulu, Hawail.

(d) Experimental tnd theoretical study; basic research.

(e) Theoretical and laboratory study of microscopic and macroscopic aspects of flow through porous media.

(4789) THE EFFECT OF PHREATOPHYTE CLEARTNG, MIDDLE GILA RIVER VALIEY, SAN CARLOS INDIAN RESERVATION, ARTZONA.

(b) Laboratory

c) Mr. R. C. Culler, U.S.G.S., Tucson, Ariz.

d) Field investigation, basic research.

e) To evaluate the change in evapotranspiration produced by the eradication of phreatophytes and the substitution of a beneficial vegetation. A water budget evaluation will be made of 16 miles of the flood plain of the G1la River, within the San Carlos Indian Reservation, Arlzona. The water budget will be kept with the phreatophytes undisturbed for the calendar years 1963 to 1966 . In 1967 the phreatophytes will be removed and a sultable replacement vegetation will be established. From 1967 to 1970 the water budget will be evaluated for the replacement vegetation.

(g) Four gaging stations on the Gila River and 63 stations on tributaries were installed. Installation of observation wells and soll molsture meter access pipes was started. other instrumentation was completed.

(5073) STATISTICAL DERIVATION OF THE VELOCITY PROFILE FOR TURBULENT FLOW.

(b) Laboratory project.

(c) Mr. N. C. Matalas and Mr. W. J. Conover, U. S. Geological Survey, Washington, D. C.

(d) Theoretical; basic and applied research.

e) A statistical model of turbulence, based on a random walk process, is developed to represent two-dimensional flow. This model is used to derive a mathematical form of the velocity profile across the turbulent fleld.

(f) Completed. 
(g) The velocity profile is defined as a three parameter hyperbolic function, with two parameters reflecting the effect of bed roughness and fluid viscosity on the shape of the velocity profile and the fluid parameter being the mean velocity across the turbulent fluid. This profile is shown to provide as good and in some cases a better fit to observations than the logarithmic velocity distribution.

(h) "Derivation of the Velocity Profile From a Statistical Model of Turbulence," by N. C. Matalas and W. J. Conover (in review).

(5074) DISPERSION IN OPEN CHANNELS.

(b) Atomic Energy Commission.

(c) Dr. N. Yot sukura, U. S. Geological Survey, Wa shington, D. C.

(d) Theoretical and laboratory investigation; basic research.

(e) To relate longitudinal dispersion to channel geometry, boundary roughness, and flow characteristics.

(f) Completed.

g) Longitudinal dispersion is strongly influenced by velocity transport, and its coeff. relative to lateral diffusion coeff. is a function of friction factor, which depends on Reynolds number and boundary roughness.

(h) "Model Studies of Dispersion in Open Channels," by N. Yot sukura, G. F. Smoot, and D. I. Cahal, U. S. Geological Survey Professional Paper (in draft).

"Numerical Solution to a Dispersion Equation," by N. Yotsukura and M. B. Flering, ASCE Journal (in press).

(5075) DOPPLER VELOCITY METER.

(b) Laboratory project.

(c) Mr. E. G. Barron, U. S. Geological Survey, Columbus, Ohio

(d) Experimental; instrument development.

(e) The objective is to measure the instantaneous local velocity by means of the Doppler frequency shift of an ultrasonic signal reflected by minute particles of suspended sediment.

(g) Model undergoing laboratory and field tests.

(5076) DISTRIBUTION AND CONCENTRATION OF RADIOACTIVE WASTE IN STREAMS BY FLUVIAL SEDIMENT.

(b) U. S. Geological Survey for Atomic Energy Commision.

(c) Mr. William W. Sayre, Project Chief, U. S. Geological Survey, c/o Engineering Research Center, Foothills Campus, Colorado State University, Fort Collins, Colorado 80521.

(d) Experimental and theoretical; basic and applied research.

(e) A significant fraction of the low level liquid radioactive wastes which are discharged into surface streams is often sorbed by bed material and fine material sediment particles. Consequently the manner in which these sediments are transported is a significant factor in determining the distribution of radioactive wastes in the stream environment. The project is devoted to investigating the dispersion and transport of both fine and bed material sediment particles. Experiments are being conducted in natural streams and in laboratory flumes. Radioactive tracer techniques, fluorometry and nephelometry are among the experimental techniques being employed. Analytically and experimentally the phenomenon of sediment transport is being treated from a Lagrangian point of view.

(g) The transport of bed material particles can be described as an alternating sequence of steps and rest periods in which the step lengths and rest period durations are exponentially distributed. In stochastic processes this would be known as a compound Poisson process. This yields a concentration distribution function which agrees with distributions of concentrations of radioactive tracer particles observed in the North Loup R1ver, Nebraska, and in a laboratory flume.

Radioactive tracer techniques provide a

feasible method for determining bed material discharge averaged over a period of time. The longitudinal dispersion of dye and fine suspended sediment particles in a wide rectangular open channel with a rough boundary follows closely the prediction of the Taylor-Elder theory in which a virtual coefficient of longitudinal dispersion is computed using the velocity distribution and the Reynolds analogy concerning the equivalence of mass and momentum transfer. Also in such a channel, experiments to date indicate that at large distances from the source the rate of lateral dispersion from a continuous point source is essentially constant over most of the flow depth.

(h) "Transport and Dispersion of Labeled Bed Material, North Loup Bed River, Nebraska," by W. W. Sayre and D. W. Hubbell, U. S. Geological Survey Open File Report, Fort Collins, Colorado, 112 p., April 1963. "Application of Radloactive Tracers in the Study of Sediment Movement," by D. W. Hubbell and W. W. Sayre, prepared for presentation at Federal Inter-Agency Sedimentation Conference, Jackson, Miss., January 28 - February 1, 1963, 30 p. "Uptake and Transport of Radionuclides by Stream Sediments," by W. W. Sayre, H. P. Guy and A. R. Chamberlain, U. S. Geological Survey Professional Paper 433-A, U. S. GPO, Washington, 35 p., 1963.

"Transport of Radionuclides in Fresh water: Dispersal of Bed Sediments," by W. W. Sayre and D. W. Hubbell, in Transport of Radionuclides in Fresh Water Systems, U. S. A tomic Energy Commission, Report No. TID7664, pp. 327-352, July 1963.

(5077) ARTIFICIAL CONTROLS FOR ALLUVIAL CHANNEL STREAMS.

(b) U. S. Geological Survey .

(c) Mr. F. A. Kilpatrick, Project Chief, U. S. Geological Survey, c\% Engineering Fesearch Center, Foothills Campus, Colorado State University, Fort collins, Colorado 80521. (d) Tield investigation; applied research. program of the U. S. Geological Survey for sand bed channels is in need of improvement. Such channels have unstable stage-discharge relationships. Thus effort is being made to develop control designs and construction methods suitable for alluvial channels. Methods for improving the stability will be designed and then tested in the laboratory and field. Careful consideration will be given to construction techniques in order to minimize costs to the data collection program.

(5078) ALLUVIAL CHANNEL HYDRAULICS.

(b) U. S. Geological Survey.

(c) Mr. H. P. Guy, Acting Project Chief, U. S. Geological Survey, c/o Engineering Research center, Foothills Campus, Colorado State University, Fort collins, Colorado 80521.

(d) Laboratory investigation; basic research.

(e) A laboratory study of resistance to flow, sediment transport and related problems in alluvial channels.

(g) Five different bed materials ranging in size from 0.19 millimeters to 0.93 millimeters have been studied. The forms of bed roughness which occur and their relation to sediment transport and resistance to flow have been studied and described. The effect of large concentrations of suspended fine sediment (clay), the viscosity of the water and the specific weight and gradation of the bed material on the mechanics of flow and on sediment transport in alluvial channels have also been investigated.

(h) "A Preliminary Study of the Effect of Gradation of Bed Material on Flow Phenomena 
in Alluvial Channels," by N1wat Daranandana, Ph.D. DIssertation, Colorado State Un1v., May 1962.

"Control structures in Alluvial Channels," by Frederick C. Stepanich, M. S. Thesis, Colorado State University, October 1962. "An Investigation of Total Sediment D1 scharge in Alluvial Channels," by Feng-Ming Chang, Ph.D. Dissertation, Colorado State Univ., December 1962 .

"Electrokinetic-Probe Response to Vortexstreet Frequency," by Hing Chuang, paper to be published in the Journal of Fluid Mechanics, colorado State University Civil Engineering Report No. CER62HC55, September 1962.

Discussion of Francis M. Henderson's paper "Stability of Alluvial Channels," by D. B. simons, published in the Journal of the Hydraulics Division, Proceedings of the Amerlcan Soclety of Civil Englneers, Vol. 88, No. HY4, July 1962.

Closure to "Forms of Bed Roughness in

Alluvial Channels," by D. B. Simons and E. V. Richardson, published in the Journal of the Hydraulics Division, Proceedings of the Amelican Soclety of Civil Engineers, Vol. 88 , No. HY4, July 1962 .

"A Study of Varlables Affecting Flow Characteristics and sediment Transport in Alluvial Channels," by D. B. Simons and E. V.

Richardson, presented at the Federal InterAgency Sedimentation Conference, Jackson, Miss.

"Control Structures for Sand Bed Channels," by F. C. Stepanich, D. B. Simons, and E. V. Richardson, presented at ASCE Water Resources Conference, Milwaukee, W1 sconsin. Discussion of "Depth Discharge Relations in Alluvial Channels," by D. B. Simons, E. V. RIchardson and W. L. Haushild, ASCE Hyd. Div. Journal.

"The Dissimilarity Between spacial and Velocity-Weighted Concentrations," by H. P. Guy and D. B. Simons, (a short paper), U. S. Geological Survey Proressional Paper 475-D.

U. S. DEPARTMENT OF THE INTERIOR, BUREAU OF MINES, Morgantown Research Center.

\section{(4436) FLOW PROPERTIES OF COAL-WATER SLURRIES.}

(b) Laboratory project--information for general public use.

(c) Mr. J. P. McGee, Research Director, Morgantown Research Center, Morgantown, West Virginia.

(d) Experimental; applied research

(e) The object of the project is to establish friction factor-Reynolds number relationships for coal-water slurries of various concentrations with coals of different ranks and size analyses. Work 1 s being done with $1 / 2$ inch, $3 / 4$ inch, and 1 inch pipes. Data are processed on an IBM-1620 computer

(g) Preliminary results show a change in rheological classification at or above 45 percent coal concentrations.

(h) "Aqueous Slurries of Coal and Granular Materials; A Bibliography," by L. F. Wilmott, W. R. Huff and W. E. Crockett, Bureau of Mines Inf. Circ. 8165, 1963.

(4790) DIEIECTRIC SEPARATION OF PARTICLES FROM SUSPENSIONS OF FINE COAL IN OIL.

(b) Laboratory project.

(c) Mr. J. P. McGee, Research Director, Morgantown, Research Center, Morgantown, W. Va.

(d) Experimental; applied research for a M.S. thesis at West Virginia University.

(e) The purpose of the project is to explore the feasibility of separating solld particles in nonpolar liquids by the application on a nonuniform electric field to a flowing stream of the suspension and in particular the separation in an oll vehicle of fine coal from its ash constituents.

(g) Capacitance cells have been constructed for determining the dielectric constants of the solids fractions and the olls in the suspensions.

U. S. DEPARTMENT OF THE INTERIOR, BUREAU OF RECLAMATION

Inquiries concerning the following projects should be addressed to Chief Englneer, Bureau of Reclamation, Denver Federal Center, Denver, Colo. 80225.

(2457) EROSION AND TRACTIVE FORCE STUDY OF UNLINED AND EARTH-LINED CANALS.

(e) Three fleld test reaches have been selected for study and for verification of laboratory studies in order to establish critical tractive force criterla for design of canals. A laboratory flume is being callbrated for determining tractive forces that erode soll in terms of standard soll properties.

(h) "Studies of Tractive Forces of Cohesive Solls in Earth Canals," by E. J. Carlson and P. F. Enger, Hydraulics Branch Report No. Hyd-504, October 1962.

(2719) GLEN CANYON DAM SPILLWAY.

(f) Tests completed.

(h) Report in preparation.

(2953) STUDIES OF WTND WAVES ON CANALS.

(e) A soil classifled as a fine silt having practically no cohesive qualities was subjected to surface water waves generated in a laboratory flume to determine 1 ts resistance to erosion.

(f) Tests completed.

(g) The relationsh1p of bank erosion to wave length, wave perlod, wave helght, and time of exposure to waves was determined.

(h) "Canal Bank Erosion by Surface Water waves Generated in a Laboratory Flume," by R. A. Dodge, Jr., Hydraullcs Branch Report No. Hyd-506, June 1963.

(2959) STILLING BASINS FOR SLIDE GATE CONTROLLED OUTLET WORKS.

(f) Tests in progress.

g) Data were taken for two types of stilling basins for high-head slide gates. Prellminary design curves were developed for the usual hydraulic jump basin and for a simple plunge-type basin.

(h) Progress report in preparation.

(2960) FLAMING GORGE DAM SPILLWAY.

(f) Tests completed.

$\left(\begin{array}{l}\text { f } \\ \text { h }\end{array}\right.$ Report in preparation.

(3267) CANAL INLET AND OUTLET TRANSITION STUDIES.

(f) Inactive.

(g) Losses for a variety of conventional, open, broken-back transitions were found to be 0.6 to $0.7 \Delta$ hfor outlet service and 0.4 $\Delta \mathrm{h}_{\mathrm{v}}$ for inlet service. Scour was slightly reduced with the closed condult transitions.

(h) "Progress Report 1 -- Research Studies on Inlet and outlet Transitions for Small Canals," by W. P. Simmons, Hydraulics Branch Report No. Hyd-492, July 1962 .

(3271) CHANNELIZATION IN ALLUVIAL RIVERS USING STEEL JACKS AND JETTIES.

(f) Laboratory tests completed, field data to be analyzed progressively as obtalned.

(h) "Control of Alluvial Rivers by Steel Jetties" by E. J. Carlson and R. A. Dodge, Jr., Hydraulics Branch Report No. Hyd-503, Oct. 1962.

(3274) CONSTANT HEAD ORIFICE TURNOUT. 
(f) Tests completed.

(h) Report in preparation.

(3275) FRICTION FACTOR TESTS IN LARGE PRESSURE CONDUITS--EKLUTNA TUNNEL, ALASKA.

(f) Tests and data analyses completed.

(h) Results are presented in revised edition of Bureau of Reclamation Engineering Monograph No. 7, "Friction Factors for Large Conduits Flowing Full," November 1962.

(3278) CAVITATION OF CONCRETE SURFACE IRREGULARITIES.

(h) "Use of an Electronic Computer to Obtain Flow Nets for a Channel with a 900 of set," by H. T. Falvey, Hydraulics Branch Report No. Hyd-500, November 1963. Additional reports to be prepared.

(3611) ADJUSTABLE WEIR.

(f) Single weir investigation completed.

(h) Report in preparation.

(3612) DISCHARGE COEFFICIENTS FOR RADIAL GATES.

(b) Laboratory project.

(d) Experimental, laboratory and field investigations; applied research.

(e) Radial gates are used extensively in irrigation systems for discharge and water surface level control. Intelifgent operation of the systems requires that the rate of flow passing the gated structure be known. Literature research resulted in an analytical approach and adjusted equation for the gate capacity with unsubmerged flow.

(8) Extensive model and prototype radial gate data were obtained from the TVA Hydraulic Laboratory. The data are being analyzed to verify the proposed discharge formula and to extend the scope of presently avallable information.

(3614) EXPERIMENTAL STUDY OF SUBCRITICAL FLOW IN CURVED CHANNELS.

(b) Laboratory project.

d Experimental; applied research and design.

(e) A fixed-bed, hydraulic model has been constructed to determine the possibility of reduction in scour and deposition in unlined channels due to secondary currents. A Preston Tube has been constructed and is belng used to measure boundary shear along the curved portion of the trapezoidal model channel.

(f) Tests in progress.

(g) For a given model discharge of 2.85 cfs at a depth of 0.75 feet high boundary shear stresses existed on the outside bank downstream from the curve and to a lesser extent on the inside bank in the leading portion of the curve.

(h) Progress report in preparation.

(3985) DISCHARGE CAPACITY OF IARGE CONCRETE-LINED CANALS.

(b) Laboratory project.

(d) Experimental, laboratory and field 1nvest1gations; applied research and design.

(e) This study is for the purpose of exploring the effects on the hydraulic gradient of the relationship of boundary surface resistance to the cumulative resistance of crossings, inlets, turnouts, checks, and other local items in concrete-lined canals of different sizes, shapes, and grades. This study is part of a program to explain why design procedures used successfully for small and medium sizes of canals may not be adequate for large concrete-lined canals on flat slopes.

(h) Report in preparation.

(3989) YELLOWTAIL DAM SPILLWAY.

(f) Completed. (g) The following were developed during the stud width and alinement of the approach channel; length and shape of the pier at the gate section; discharge calibration; curvature of the tunnel trajectory approaching the comb1nation flip bucket stilling basin; length, depth, and shape of the flip bucket basin; and riprap requirements downstream from basto

(h) Report in preparation.

(3994) HYDRAULIC JUMP CHUTE BLOCK AND BAFFLE BLOCK PRESSURES.

(b) Laboratory project.

(b) Minimum subatmospheric pressures on a squaro edge block are related to tallwater depth for a range of approach velocities.

(h) "Progress Report VI, Research Study on Stiling Basins, Energy Dissipators, and Associated Appurtenances--Section 12, Stilling Basin Chute Block Pressures-(Basin II)," by G. L. Beichley, Hydraulics Branch Report No. Hyd-514, May 1963.

(3996) HIGH HEAD ORIFICE STUDIES.

(f) Tests in progress.

(h) Progress report in preparation.

(4412) OROVILLE DAM DIVERSION TUNNELS AND TAILRACE.

(b) Cal1fornia Department of Water Resources.

d) Experimental; for design.

(e) A $1: 54.63$ scale hydraulic model was used to study complex, high-velocity diversion flows in the two 36-foot-diameter, 4,500-foot-long tunnels and to study surge characteristics of the underground power house whose draft tubes connect to the downstream portion of the tunnels to form the tailrace. A $1: 46.6$ scale air model was used to evaluate various passage configurations for connecting the draft tubes to the tunnels to obtain minimum losses.

(f) Completed.

8) Flow and pressure conditions were satisfactory in the bellmouth inlets, tunnels, and outlet portals for diversion flows. Better river channel flow conditions were obtained with a higher guide wall on the right side of outlet Portal 1, and with the channel upstream from the portals filled to the downstream fac.e of the dam. Other improvements in the river, such as guide walls and the removal of rock outcrops, were not necessary or economically feasible. The design of the complex tall-race system for the underground powerhouse satisfactorily controlled surging for all possible load acceptance or load rejection cycles.

(h) "Hydraul1c Model Studies of the Diversion Tunnels for Oroville Dam," by W. P. Simmons, Hydraulics Branch Report No. Hyd-502, Jan. 1963 .

"Hydraulic Model Studies of the Draft Tube Connections and Surge Characteristics of the Tailrace Tunnels for Oroville Powerplant," by W. P. Simmons, Hydraulies Branch Report No. Hyd-507, April 1963.

(4413) OROVILLE DAM TUNNEL PLUG OUTLET WORKS.

(b) California Department of Water Resources.

d) Experimental; for design.

(e) A $1: 18$ scale model of the tunnel plug outlet works was used to determine the appurtenant structures necessary in the 35-foot-diameter tunnel to adequately dissipate the high energy flow from two 54-inch Howell-Bunger valves discharging under a 670-foot head.

(f) Completed.

(g) A design was developed wh1ch adequately dissipates the high energy flows from two 54-inch Howell-Bunger valves, each discharging 2,700 cfs under a head of 670 feet. The valves are placed 3 feet above the tunnel centerline, and the appurtenances consist of a deflector ring around the 
inside of the tunnel and two rows of baffle plers on the invert downstream.

(h) "Hydraul1c Model Studies of the R1ver outlet Works at Oroville Dam," by D. Colgate, Hydraulics branch Report No. Hyd-508, Oct. 1963.

(4416) BLUE MESA DAM SPILLWAY.

(b) Laboratory project.

d) Experimental; for design.

(e) A 1:32.78 scale model was used to study the radial gate controlled intake, inclined tunnel, and the flip bucket for flows up to 33,650 cfs discharging at a velocity of 113 feet per second at the outlet portal.

(f) Tests completed.

(8) The approach channel shape, tunnel transition section at the intake, inclined tunnel, vertical bend in tunnel, and flip bucket were developed.

(h) Report in preparation.

(4419) WHISKEYTOWN DAM SPILLWAY.

(b) Laboratory project.

(d) Experimental; for design.

(e) A l:32.78 scale model was constructed to study the morning-glory intake, the vertical tunnel bend, the stralght tunnel, the flip bucket, and the downstream river channel for flows up to 28,450 cfs discharging with a maximum velocity of 96 feet per second at the outlet portal.

(f) Completed.

g) The following were developed during the study: Gulde vanes for the crest, a deflector and a1r vent for the vertical bend, shape of the fllp bucket, discharge channel alinement, and head discharge relationsh1ps for the splilway.

(h) "Hyaraul1c Model studies of Whiskeytown Dam Splllway," by G. L. Belchley, Hydraulics Branch Report No. Hyd-498, November 1963.

(4421) SEDIMENT CONTROL AT DIVERSIONS.

(b) Laboratory project.

d) Experimental; for design.

(e) Var1ous devices were studied to develop ways of reducing the amount of bed sediment entering canals.

(f) Completed.

(g) Several arrangements of bottom and surface gulde vanes were tested, and their effectiveness in reducing sediment intake into a canal diverted from a large river was compared.

(h) "Sediment Control at a Headworks Using Guide Vanes," by E. J. Carlson and P. F. Enger, a paper presented at the Federal Inter-Agency Sedimentation Conference, Jackson, M1ss., February 1963. To be published in Conference Proceedings. Ava1lable from U. S. Superintendent of Documents.

(4425) WATER-COLUMN SEPARATION.

(b) Division of Design Profect.

(d) Theoretical and field investigation. applied research.

(e) Field tests are being used to check theoretical developments designed to predict completely the hydraulic transient conditions occurring during separation and rejolning of water columns occurring during separation and rejolning of water columns in pump discharge lines.

(f) Continuing.

$(\mathrm{g})$ Peak pressures higher than predicted were measured in the field.

(h) Report in preparation.

(4791) HIGH-VELOCITY JET ON PROTECTIVE COATINGS.

(b) Laboratory study.

d Experimental; for operation and maintenance. A 100-fps, 1-1nch-dlameter jet was 1 mpinged at 45 degrees on protective coverings proposed for application on concrete surfaces to be subjected to high-velocity flow with sediment laden water.

(f) Conpleted.

(8) All protective coatings tested, in which the surface was unbroken, w1thstood the jet for 4 hours. All coatings tested in which a broken or cut surface extended to the cencrete were ripped from the concrete test blocks in less than 5 minutes.

(h) Report in preparation.

(4792) CANADIAN RIVER AQUEDUCT CHECK TOWERS.

(b) Laboratory project.

d) Experimental; for design.

(e) Laboratory tests are be1ng made to determine the hydraulic losses and alr-entralnment potential of check towers to be installed in the 125-m1le-long Canadian River Aqueduct. The towers and aqueduct are to be so designed that the top of each tower are slightly below the hydraulic gradient. Preliminary studies are with a 90 degree vert1cal bend from the condult alinement, a rising leg, a 180 degree return bend, a descending leg, and a 90 degree vertical bend to return the conduit to the main conduit al1nement. The 1nside diameter of the check tower is the same as the conduit. A1r movement through vertical 4-, 6-, 8-, and 12-1nch vents is being determined.

(f) Continuing.

(4793) ROTATING DISK--PAINT TEST APPARATUS.

(b) Laboratory project.

d) Experimental; development.

(e) A test apparatus cons1sting of four d1sks, each rotating in a separate chamber, was constmucted and tested. Protective coatings will be applied to the disks and to the walls of each chamber, to evaluate the coating's resistance to flowing water.

(i) Completed.

(g) Water veloc1ty and path charts have been prepared for both the rotating disks and the chamber walls.

(h) Report in preparation.

(4794) VERTICAL STILIING WELI.

(b) Laboratory project.

(d) Applied research.

(e) The purpose is to obta1n the opt1mum s1ze, depth, and intermal configuration of vertical stilling wells for high-head discharges. The test installation has a 4 -foot by 4 -foot-square well 6 feet deep, followed by a canal with a 4-foot bottom width and 1-1/2:1 side slopes. An adjustable downspout $1 \mathrm{~s}$ symmetricaliy located in the well and discharges against the flat floor. Plezometers are located in the floor and lower sidewalls of the well. Adjustable comer flllets provide a means for determining optimum flliet angle, slze, and helght.

(f) Continuing.

(g) The addition of corner fillets to the well results in much smoother water surfaces. The flilets direct the flow from the comers back to the center of the well inducing roller action. Optimum fillet configuration has been determined for one ratio of downspout area to well area. Add1tional studies will determine optimum fillet conf1gurations for larger downspouts.

(4795) SUCTION EIBOWS FOR LARGE PUMPING PLANTS.

(b) Laboratory project.

d) Experimental; research and design.

(e) The purpose is to make a comparative analysis of two suction elbows involving 135 degrees of turn rather than the usual 90 degrees. Tests are being made w1th $1: 9.187$ scale model elbows having $8-1$ nch outlet diameters. one elbow is based on the concept of RV being constant, and the other is based on the concept of a constant radius centerline. The cross sectional areas of both elbows decreas in the downstream direction. Use of elbows 
with 135 degrees of turning results in a shallower forebay with cost saving due to decreased excavation. The shallower forebay prevents "pooling" of water in the forebay and provides a more efficient design because the kinetic energy of the canal flow is maintained. Sediment deposits which often occur in the forebay will also be decreased.

(f) Completed.

(g) Both elbows showed a high degree of efficiency; however, design simplicity dictated the use of the elbow with a constant radius centerline. The velocity distribution at the location of the pump impeller was excellent and the energy loss from forebay to impeller station was 0.10 hv2.

(h) "Model Studies of Suction Tubes for Mile 18 and Forebay Pumping Plants," by T. J. Isbester, Hydraulics Branch Report No. Hyd-513, June 1963.

(4798) DOWNPULL STUDIES OF FIXED-WHEEL GATE FOR RED BLUFF DIVERSION DAM.

(b) Laboratory project.

d) Experimental; for design.

(e) $1: 18.6$ model studies were conducted to determine downpull forces on 18-by 60-foot, upstream seal, fixed-wheel gates for free and submerged flow conditions.

(f) Tests completed.

(g) To reduce downpull during submerged operation the conventional solid-web beams on the downstream face of the gate were replaced with open bow trusses. A combination of welghing and pressure techniques was used to measure total downpull and to separate It Into the forces acting on certain parts of the gate.

(h) "Hydraulic Downpull Studies of the FixedWheel Splllway Gates for Red Bluff Diversion Dam," by R. A. Dodge, Jr., Hydraulics Branch Report No. Hyd-511, Apr11 1963.

(4799) SAN LUIS DAM FOREBAY SPILLWAY.

(b) Laboratory project.

d Experimental; for design.

(e) A $1: 14.83$ scale model was used to study the morning-glory spillway intake, vertical shaft, and vertical bend for flows up to $3,000 \mathrm{cfs}$, dropping approximately 100 feet through the inlet and vertical shaft.

(f) Tests completed.

(g) A deflector, with air vent and guide vanes, was developed for the vertical bend.

(h) Report in preparation.

(4800) SAN LUIS DAM FOREBAY.

(b) Laboratory project.

d Experimental; for design.

(e) A I:22 scale model was used to study the morning-glory inlet, vertical bend, and stilling basin for flows up to 3,600 flowing at approximately 50 feet per second at the tunnel exit portal.

(f) Completed.

(g) Morning-flory-inlet, tunnel, and stilling basin size requirements were determined. A deflector, air vent, and guide vanes were developed for the vertical bend. Pressures in the inlet, vertical bend, and stilling basin were recorded.

(h) Report in preparation.

(4802) STUDIES ON ORIFICES FOR AUTOMATIC RADIAI GATE CONTROLS

(b) Laboratory project.

d Experimental; for design.

(e) A study to determine flow characteristics and coefficlents of discharge of varlous size orifices in floatwell intakes of automatic radial gate controls. Studies have been made of 1 -1nch and 3-1nch oriflces in horfzontal and vertical planes, in nonstandard settings, with different approach and exit conditions at heads from 1 to 100 feet. (f) Inactive.

Although the test arrangements differed substantially from arrangements for which data are presently available, measured coefficients compared closely with existing data.

\section{(4805) CAUSEY DAM OUTLET WORKS.}

(b) Laboratory project.

d Experimental; for design.

(e) A $1: 11$ scale model was used to observe hydraulic performance of the slide gate controlled outlet works. The features included: Symmetrical wye branch upstream from gates, chute, hydraulic jump stilling basin, and a portion of the downstream river channel.

(f) Completed.

$\{\mathrm{g}$ All features of the design were found to be acceptable. Pressures and head losses in the wye branch were determined and hydraulic jump data were taken for use in future designs.

(h) "Hydraulic Model Studies of Causey Dam outlet Works," by D. L. King, Hydraulics Branch Report No. Hyd-496, April 1963.

(4806) NORTON DAM OUTLET WORKS.

(b) Laboratory project

d Experimental; for design.

(e) A 1:8.75 scale model was used to study the hydraulic characteristics of the chute and stilling basin for the slide gate controlled outlet works.

(f) Completed.

(g) All features of the design were found to be acceptable. Pressures on the chute and in the hydraulic jump stilling basin were recorded and configuration of the hydraulic jump was measured for varying heads and discharges.

(h) "Hydraulic Model Studies of Norton Dam outlet Works," by D. L. King, Hydraulics Branch Report No. Hyd-497, October 1963.

(4807) MORROW POINT DAM SPILLWAY AND OUTLET WORKS.

(b) Laboratory project.

d) Experimental; for design.

e) A 1:24 scale model was constructed to aid In the development of the unusual design of the splilway and outlet works for the thinarch concrete dam. The orlginal design, consisting of a free overfall splilway and an outlet works located near the bottom of the dam, was abandoned because of undesirable flow conditions in the artif1clally formed stilling pool at the base of the dam. The present design includes four flxed-wheel gate controlled condults near the top of the dam which pass the combined splilway and outlet works discharge of 38,100 cfs, allowing 1t to fall approximately 400 feet to the stilling pool.

(f) Tests in progress.

g) Model studies have proven the acceptability of the present design. Design of the control weir which forms the stiling pool was modified and the two inside spillway conduits were tipped downward to provide more even distribution of impact of the free-falling jets.

(4808) JOES VALIEY DAM SPILLWAY.

(b) Laboratory project.

d) Experimental; for design.

(e) A 1:20 scale model was used to study hydraulic features of the morning-glory spillway. The model included the spiliway entrance, a portion of the reservolr topography surrounding the entrance, the vertical bends, and a portion of the horizontal tunnel.

(i) Completed.

(g) Minor modifications were made to the preliminary design to correct undesirable flow conditions which prevalied for the 
maximum discharge of 5,000 second-feet. Appurtenant devices were developed to control the vortex which formed durling submerged operation and Improve flow conditions during unsubmerged operation.

(h) Report in preparation.

(4947) OROVILIE DAM INCLINED POWERPLANT INTAKE TOWERS.

(b) Cal1fornia Department of Water Resources.

(d) Experimental; for design.

(e) Head loss, air entralnment, and other hydraulic phenomena of the unique Inclined intake towers are being studied in a $1: 24$ scale model. Gates are arranged on the towers so water can be drawn from selected levels in the reservolr to maintain desired river temperatures for Irrigation and $\mathrm{flsh}$ propagation. Differential pressures across these very large gates, and any tendencles for hydraulic instabllity during operation, are also being studied.

(f) Tests in progress.

(4948) OROVILIE DAM SPIILWAY.

(b) Cal1fornia Department of Water Resources.

(d) Experimental; for design.

(e) A 1:78 scale model is being used to study the hydraulic features of the preliminary design. The model contalns five flood control outlets flanked on each slde by four gated splllway sections, the splliway approach channels and surrounding topography, the concrete-lined apron and excavated channel downstream from the spillway and outlets, and a portion of the Feather River Channel.

(f) Inactive.

(g) Tests showed that acceptable flow conditions occurred only when a very long converging apron was used. Attempts to reduce the apron to an economical size produced unacceptable flow conditions, and the preliminary design was abandoned. Testing will resume on a modifled design of the splilway.

(4949) HYDRAULIC DOWNPULL COMPUTATIONS FOR GLENDO DAM FIXED WHEEL GATE.

\section{(b) Laboratory project.}

d) Theoretical computations.

e) Computations were made to determine the effect of rapld closure of the flxed wheel gate under emergency conditions, w1th water standing in the gate well due to initial back pressure.

(f) Completed.

g) Water temporar1ly trapped in the gate well creates an additional head, and hence add1ticnal hydraul1c downpuli, for most of the gate travel when the gate 1 s closed rapidly. However, the peak hydraul1c downpull occurs at small gate openings and is not affected by reasonably rapid gate closure.

(h) Report in preparation.

(4950) NAVAJO MAIN CANAL HEADWORKS.

(b) Laboratory project.

d) Experimental; for design.

(e) A $1: 16$ scale model containing two 9- by 12foot top seal radial gates, a divided underground stilling basin, and a horeshoe-shaped downstream tunnel was constructed to ald in evaluating and improving the stilling basin performance, and to test the unusual appl1cation of radial gates. D1 scharges w111 range from 100 of's to $2,120 \mathrm{crs}$, and heads w111 vary from 21 feet to 132.5 feet.

(f) Tests in progress.

(4951) SAN LUIS OUTLET WORKS EMERGENCY GATES--DOWNPULI STUDIES.

(b) Iaboratory project.

d) Experimental; for design.

(e) A 1:35 scale model of a single intake structure and gate was constructed to study downpull characteristics. The studies were performed under controlled discharge conditions simulating maximum power generation at the powerplant, and under conditions simulating a rupture at the structure or in the downstream tunnel. The study is part of a long-range program to provide sufficlent information to analytically determine downpull forces on large gates.

(g) Modifications, in the form of recesses and offsets in the gate chamber, greatly arfect the flow over the top of the gate, and result In changes in the downpull and uplift characteristics. Also, changes in the ratio of gate lip extension to leaf thickness greatly affect the downpull.

(h) Report in preparation.

(4952) SURGE STUDIES IN IONG, LOW-HEAD PIPELINE SYSTEMS.

(b) Laboratory project.

d Experimental; applied research and design.

e) Laboratory studies $w 111$ be made to verify an electronic computer program for analyzing low frequency surge characteristics of long pipeline systems. The test facllity consists of 1,400 feet of 4 -inch p1pe, a constant head water supply, a constant head terminal reservolr, and a slow closing and opening valve for producing controlled changs in rate of flow. The plpeline is interrupted at 160-foot Intervals with open check stands that divide the line into individual reaches with pressure heads not greater than 2.8 feet. Total drop of the Ine $1 \mathrm{~s} 24$ feet.

(4953) ARBUCKLE DAM OUTLET WORKS.

(b) Laboratory project

(d) Experimental; for design. scale model to determine the hydraulic operating characteristics of the slide gate controlled outlet works and the effects of operation of the hydraulic jump stilling basin on an adjacent splllway stilling basin.

(f) Completed.

(g) All features of the design were found to be acceptable. Some fine material was deposited In the splliway stilling basin during operation of the outlet works alone but no severe eddy currents were observed in the downstream channel.

(h) Report in preparation.

(4954) SAN LUIS FOREBAY PUMPING PLANT INTAKE TRANSITIONS.

(b) taboratory project.

(d) Experimental; for design.

e) A $1: 15$ scale model is being used to compare head loss, veloclty distribution, and flow patterns in various conflgurations of canal transitions to pumping plant intakes.

(f) Tests in progress.

(4955) SAN LUIS FOREBAY CANAI SURGE STUDIES.

(b) Laboratory project.

(d) Experimental; for design.

(e) A $1: 48$ scale model $1 \mathrm{~s}$ being constructed to determine the magnitude and velocity of surge in a pumplng plant supply canal after power fallure and rejection of flow. Effects of blfurcations, curves, and canal structures and methods of relleving the surge will be Investigated.

(4956) YELLOWTAII AFTERBAY DAM SLUICEWAY AND SPIILWAY.

(b) Laboratory project.

(d) Experimental; for design.

(e) $1: 24$ scale models were used to study hydraulic characteristics of the gate-controlled sluiceway and splliway which are designed for a total discharge of $20,000 \mathrm{cfs}$. Flow conditions in the approach channel and through 
the gates, overfalls, and stilling basins were studied.

(1) Completed.

$(\mathrm{g})$ The stilling basins were modified by changing dentate spacing and pier sizes. The tests resulted in more efficient energy dissipation within the basins and an accompanying reduction of erosion in the downstream channel.

(h) Report in preparation.

(4957) BAFFLED PIPE OUTLET ENERGY DISSIPATORS.

(b) Laboratory study.

d) Applied research.

(e) Hydraulic model studies are being made to extend present information concerning this type of impact energy dissipator. Prototype data from existing operating structures will be compared with model data. Investigation of erosion around the structures and in the downstream bed will be stressed.

(f) Tests in progress.

(4958) AIR DEMAND TESTS ON 84-INCH JET FLOW GATE-TRINITY DAM, CALIFORNIA.

(b) Laboratory project.

d) Field investigations.

e) Field measurements were obtained to compare model and prototype air demand for the complete range of gate openings at maximum operating head (369 feet) on the gate.

(f) Completed.

(g) Maximum velocity in the air supply conduit was within design limits.

(h) Report in preparation.

(4959) FLAT BOTTOMED TRAPEZOIDAL VENTURI FLUMES.

(b) Laboratory project.

d) Experimental; for design.

(e) A pilot study of a single flume is being conducted to determine the best approach to a comprehensive program to generalize the design and calibration of this type of water measuring device.

(g) The model study has demonstrated that the particular pilot flume tested is an adequate measuring device.

(h) Report in preparation.

(4960) PROTOTYPE PIEZOMETRIC AND AIR DEMAND MEASUREMENTS OF 4- BY 4-FOOT TANDEM GATE--NAVAJO DAM, NEW MEXICO.

(b) Laboratory project.

d) Field investigation.

(e) To compare the model and prototype, piezometric measurements were obtained for the complete range of gate openings with a head of 164.5 feet. Further tests are planned at heads of about 230 feet and 300 feet to more fully evaluate the hydraulic characteristics of this gate and to check the model scaling.

(4961) USE OF RADIOISOTOPES FOR WATER MEASUREMENT.

(b) Laboratory project.

(d) Field and laboratory investigations of theoretical and experimental nature.

(e) The purpose of the program is to determine the applicability of the use of radioactive 1rotopes to measurement of open channel flows wy the dilution or total count methods. The program is being continued to provide statistical data on the capabilities of the methods.

(h) "Use of Radioisotopes for Open Channel Flow Measurements," a technical paper by L. $O$. Timblin, Jr., and A.J. Peterka.

(4962) LABORATORY INVESTIGATION OF THE REMOVAL OF SALT WATER FROM A TWO-PART AQUIFER USING TILE DRAINS INSTALLED IN THE UPPER MEMBER.

(b) Laboratory project.

d) Applied research.

(e) Tests were performed on a 16-foot-long 1:40 scale model containing a two-part aquifer to determine the hydraulic action of simulated tile ground-water drains placed 0.2 foot below the model surface. The lower aquifer was composed of coarse sand 50 times more permeable than the fine sand in the upper aquifer. For initial conditions the model was charged with salt water, concentration $6,000 \mathrm{ppm} \mathrm{NaCl}$, dyed blue for visual identification.

(f) Completed.

(g) For the given prototype conditions, tile ground-water drains will not intercept and discharge fresh water if the lower aquifer contains salt water. The fresh water tends to drive the salt water ahead of 1 t to the drain.

(h) "Progress Report No. 1--Laboratory Invest1gation of the Removal of Salt Water From a Two-Part Aquifer Using Tile Drains Installed in the Upper Member," by A. J. Peterka and R. E. Glover, Hydraulics Branch Report No. Hyd-520, June 1963.

U. S. DEPARTMENT OF THE NAVY, DAVID TAYLOR MODEL BASIN,

Inquiries concerning the following projects should be addressed to the Comanding officer and Director, David Taylor Model Basin, Washington, D. C. 20007.

\section{(711) CAVITATION RESEARCH}

(b) Bureau of Ships; David Taylor Model Basin.

(d) Theoretical and experimental; applied research.

(e) Research is being conducted on the mechanism and effects of cavitation phenomena in real and ideal fluids. (1) Lineartzed theory is being applied to determine cavity shapes and forces in steady flows. (2) Experimental studies of the growth of cavities on hydrofolls are to be made in both steady and unsteady flows (see project \#3284).

(f) Discontinued.

(g) A better correlation between theoretically and experimentally determined cavity shape has been achieved by modifying linearized cavitation theory to include surface tension effects.

(h) "Surface Tension and Free Surface Effects in Steady Two-Dimensional Cavity Flow About Slender Bodies," by S. H. Schot, TMB Report 1566 (January í962).

\section{(1778) HYDRODYNAMIC NOISE.}

(b) Bureau of Ships; David Taylor Model Basin.

d) Hydrodynamic research.

(e) Investigations of the characteristics of underwater noise associated with various hydrodynamic phenomena such as cavitation, bubble oscillation, and turbulence.

Attention is now being given to measurement of spectra and space-time correlations of pressure fluctuations on walls adjacent to turbulent flaws, such as flat plate boundary-layer flaws, turbulent boundarylayers on gravity propelled bodies, and fully turbulent pipe flaws.

(g) Cross-spectral densities of the pressures at pairs of longitudinally and transversely spored points on a flat plate adjacent to a turbulent boundary-layer in a wind tunnel have been measured. Results obtained for selected ranges of free-stream velocity, boundary-layer thickness, separation of the two points, and for a range of frequency, are expressed non-dimensionally. The data supplement measurements of spectral densities and correlations obtained by others.

(h) "Measurement of Fluctuating Pressures on a Wall Adjacent to a Turbulent Boundary-Layer," Donald W. Jorgensen, David Taylor Model Basin Report 1744, July 1963.

(1783) MATHEMATICAL SHIP LINES.

(b) Bureau of Ships; David Taylor Model Basin.

(d) Theoretical research. 
(e) Development of a suitable method for the mathematical determination of ship lines which can be applied to a wide variety of ship forms especially to those of modern design.

(f) Inactive.

(g) A method has been developed for the mathematical falring of graphical lines. This is a first step toward the development of a flexible system of mathematical ship lines. Future work is directed toward the development of a system of mathematical lines which will permit the derivation of a hull form for a given set of parameters.

(1786) STUDIES OF THE SLAMMING OF SHIPS.

(b) Bureau of Ships; Dav1d Taylor Model Basin.

(d) Experimental and theoretical basic research.

(e) Computations and measurements of the pressure distribution and impact forces on the bottoms of slamming ships for the purpose of developing design criteria to effect their reduction.

(g) A theory which is applicable to almost any practical ship forebody section has been developed for determining impact force and pressures on a ship's bottom during slamming. The theory was applied to three different ship forms ranging from extreme $U$ to extreme $\mathrm{V}$ and pressures, forces and Impulse were compared. A comparison of the theory with two dimensional drop tests using the $\mathrm{V}$-form was also included. In addition, model tests have been conducted on a MARTNER Class ship and bottom pressures measured during slamming in a seaway. Results will be compared with theory.

\section{(2019) SERIES 60 - PROPELLER EXCITED VIBRÁTION.}

(b) David Taylor Model Basin and Society of. Naval Architects and Marine Engineers.

(d) Experimental basic research.

(e) Measurement of propeller induced vibratory forces on a series of models with variations in stern shape.

(i) Completed.

(8) The instrumentation and test techniques for measuring the propeller induced vibratory forces on a single screw ship model has been developed sufficiently to obtain repetitive results. Although there is insufficient information available to permit extrapolation to full scale forces, comparison of test results of models of similar type and dimensions appears valid. During the past year tests were conducted of a serles of 3 models, based on the $0.70 \mathrm{C}_{B}$ series 60 parent form, with variations in stern section shape from $U$ to $V$. Measurement of instantaneous pressure has been made on the hull of the USS TIMMERMAN and on the hull of a 30-foot model of that vessel. Preliminary data indicates that the model measurements when similarly extrapolated also produce higher values than were measured on board ship.

(2229) NEAR SURFACE EFFECTS.

(b) Bureau of Ships; David Taylor Model Basin.

d) Hydrodynamic research.

(e) A mathematical study of the forces and moments acting on bodies due to the proximity of a free surface. The studies include both the case in which the surface is initially undisturbed and the case in which there are disturbances originating at a distance. Experiments are being conducted to verify the theoretical developments.

(g) Methods were developed for computing the forces and moments acting on bodies of revolution, both due to waves generated by the body itself and to regular trains of waves. Experiments with a spherold moving under waves largely confirmed the theory except in following seas. The damping forces on a submerged translating ellipsoid which is oscillating in any of its six degrees of freedom have been developed theoretically. The effect of tank walls has been evaluated theoretically as well.

Theoretical methods have been developed for the determination of wave resistance of floating bodies in steady motion from wave measurements along a parallel cut. The first and second order diffraction and radiation forces acting on a submerged twodimensional circular cylinder have been developed and computations have been made. Analytic expressions have been obtained for arbitrary bodies relating the radiation and diffraction forces to each other.

(h) "The Exciting Forces on Fixed Bodles in Waves," by J. N. Newman, Joumal of Ship Research, Volume 6, No. 3, December 1962. Also available as TMB Report No. 1717 dated May 1963.

"The Determination of Wave Resistance from Wave Measurements Along a Parallel Cut, "by N. N. Newman, paper presented at the Seminar on Wave Resistance Theory at Ann Arbor, August 1963.

"FIrst and Second Order Forces on a Cylinder Submerged Under a Free Surface," by T. Francis Ogilvie, Journal of Fluid Mechanics, Volume 16, Part 3, pp 451-472, 1963.

\section{(2230) THEORY OF SEAWORTHINESS.}

(b) Bureau of Ships; David Taylor Model Basin.

d) Hydrodynamic research.

(e) A theoretical and experimental study of factors affecting the seaworthiness of ships, for the purpose of developing procedures for predicting their motion. The work is oriented in four directions: (1) Finding the equations of motion of a ship in a seaway, with the forces obtained from solutions of the boundary value potential problem. This approach will provide equations which are valid for transient as well as steadystate oscillatory conditions. (2) Validification of the more common technique of assuming that the longitudinal plane motions can be described by a system of linear secord order differential equations with constant frequency dependent coefficients. The coefficients in the equations of motion are determined experimentally, as well as the forces on restrained models in regular waves. The motions of a free model can then be computed and compared with experiments to determine the validity of the theory. Analytical and experimental studies of the damping of ship motions by free surface effects. (4) Determination of the form of a set of equations for the motions of a ship which are more reasonable physically than the second order constant-coefficient equations. Such equations will be derlved in a heuristic manner, and certain parameters will be determined experimentally. The resulting equations should be valid for transient and steady-state sinisoidal motion

(g) A restrained ship model has been towed in regular waves and the force and moment induced by the waves has been measured. Com parison of these data with calculations based on the Froude-Krylov hypothesis shows only qualitative agreement. Calculation of damping coefficients has been completed for series 60 model, yielding generaliy excellent agreement with forced oscillation experiments. A mathematically defined model has been oscillated in pitch and in heave over a range of frequencles and forward speeds, to determine the coefficients for the assumed second order equations of motion. Equations of motion for the oscillating ship have been obtained which remove the necessity for frequency dependent coefficients. These equations include convolution integrals over the past history of the motion, and are completely general.

Mathematical theories have been developed $f o r$ predicting the motions of single and multiple 
spar buoy configurations.
(h) The Motion of a Spar Buoy

(negular Waves, 1963.

(2237) LIFTING SURFACE THEORY OF PROPELIERS.

(b) Bureau of Ships; David Taylor Model Basin.

d Theoretical; applied research.

e) Studies of the corrections on lifting line theory which arise from the finite extent of the blades.

(2471) THEORY OF CONTRAROTATING PROPELLERS.

(b) Cooperative with the Bureau of Ships.

(d) Experimental and theoretical; applied research.

(e) Studies of the theory of contrarotating propellers without assumptions regarding the orientation of the resultant induced veloc1ty. Open water and water tunnel tests to determine, experimentally, the effect of various propeller parameters.

(f) Discontinued.

(g) Application to open water and wake adapted propellers. Latest experiments have shown the performance to be insensitive to spacing between propellers so long as they are operated at their design spacing.

(h) "The Design of Contrarotating Propeliers Using Lerbs' Theory," by W. B. Morgan, SNAME Trans., Vol. 68-1960.

(2472) COOPERATIVE TESTS ON A VICTORY SHIP DESIGN.

(b) David Taylor Model Basin: Skin Friction Committee of the Intermational Towing Tank Conference.

(d) Experimental testing; basic research.

(e) The Investigation was authorized by the International Committee on "Scale Effect on Propellers," and on "Self-Propulsion Factors," as part of the international cooperative test program in ship basins. The International committee will compare the results from the various basins and present a report to the coming International Conference. The tests will be carried out with a wax model of scale 1:23 equipped with different kinds of stimulators. The friction corrections will be calculated by the varlous basins according to their methods.

(f) Completed.

(g) The specified program of model testing has been completed. The required calculation for the power predictions have to be done before the evaluation work can proceed.

(h) Results have been reported to the International Towing Conference. A TMB Report is being prepared comparing TNB results with those of other basins.

(2729) HULL FORM RESEARCH WITH A FLEXIBIE MODEL.

(b) David Taylor Model Basin.

(d) Development and experimental work.

(e) A flexible model which can be quickly changed to have any fullness and any shape of section area curve is to be developed first. The effect of section area curve parameters, such as $t_{F}, t_{A}, C_{P F}, C_{P A}$, $L_{F}$, $\mathrm{LX}_{\mathrm{X}}, \mathrm{X}_{\mathrm{F}}, \mathrm{X}_{\mathrm{A}}$, etc., upon resistance will be systematically investigated by using this flexible model.

(f) Inactive.

(g) The flexible model has been built and experimental test work begun. Thirty resistance tests have been conducted during the past fiscal year. Preliminary work with this flexible model indicates its adaptability for this work 1 s satisfactory. An analysis of the test results has not been completed.

(2730) MOLECULAR - PHYSICAL SKIN EFFECT.

(b) David Taylor Model Basin. (d) Experimental; applied research

(e) The frictional resistance of a "new" plate consisting of a special molecular coating will be compared with the frictional resistance of a hydraulically smooth brass plate and of a mirror smooth glass plate. The test equipment will be designed and constructed to study wave and spray formation for the determination of the true wetted surface. The plate will be tested with maximum speed of 15.0 knots and with various stimulation devices.

(f) Completed.

(g) The Nikuradsi coated plates have been tested. Significant resistance differences between coated and non-coated plates have been measured on a coated brass plate and an uncoated aluminum plate. Since the contours of the leading and trailing edges of the two plates vary considerably doubt is raised at whether the coating or the difference in the contours caused the resistance differences. A stainless steel plate having the same contours and the coated brass plate has been constructed and tested.

(2971) FULL SCALE TRIALS AND MODEL PREDICTION CORRELATION.

(b) Bureau of Ships; David Taylor Model Basin.

(d) Experimental testing and re-evaluation of existing test data.

(e) The accuracy of full scale power predictions from model test results depends upon the proper selection of the correlation allowance $\left(\triangle C_{F}\right)$ to be used in model tests. The results of about 54 correlations of surface ships have been completed and published. The present target is the analysis of correlations submarines, considering all trials conducted, and selecting those most acceptable to this program.

(g) Same analysis has been done in connection with submarines. Further analysis of the data derlved from the surface ship trials is continuing.

\section{(3284) UNSTEADY HYDROFOILS.}

(b) Bureau of Ships; Dav1d Taylor Model Basin.

(d) Experimental and theoretical applied research.

(e) Th1s work w1ll provide hydrofoll design criteria for the Bureau of Ships to be used in designing high speed, sea-going hydrofoll craft. The forces on two-dimensional hydrofolls due to heaving and pitching oscillations of the foil, and due to encounters with regular, head and following waves will be determined experimentally. Both cavitating and non-cavitating conditions will be studied. The data from the experiment will be digitized and then will be analyzed on the IBM 7090 computer using existing thesis.

(g) All of the experimental equipment has been assembled and its operation partially checked. Preliminary experimental muns have been made. A full schedule, exper1mental program will start early in 1964. Preliminary results should follow later in the year. Several equipment and analysis reports are belng prepared for publication.

(h) "Calculated Hydrodynamic Loads on an oscillating Hydrofoll," by T. J. Langan and D. Coder, TNB Report No. 1695 (in review).

(3285) HYDROELASTICITY PROBLEMS.

(b) Bureau of Ships; David Taylor Model Basin. Experimental and Theoret1cal Applied Research.

(e) Investigations to determine the conditions which produce hydroelastic 1nstability of oscillatory hydrofoll systems. The effects of speed, frequencies, mass distribution, cavitation, free surface and waves on the system stability will be studied. This work is related to Unsteady Hydrofolls (Reference No. 3284 .) 
(g) A flutter dynamotor for a two-dimensional, two-degree of freedom hydrofoll has been constructed. Flutter tests of a supercavitating hydrofoll are underway in the 36 Inch Water Tunnel.

(h) "A Simplified Analysis of the Hydroelastic Instability of a Three-Dimensional Hydrofoil," by M. E. McCormick, TMB Report 1555, April 1963.

(3286) SUPERCAVITATING PROPELLER DEVELOPMENT.

(b) Bureau of Ships; David Taylor Model Basin.

(d) Theoretical and experimental; applied research.

(e) Studies and design of propellers designed to operate at high speeds including $1 \mathrm{mproved}$ section shapes for good operating character1stics and better strength capability.

(g) Theoretical series for preliminary design purposes have been computed and published. Crashback and windmilling performance has been experimentally obtained. Experiments with a controllable pitch supercavitating propeller have confirmed the feasibility of this type of propulsion device.

(3287) EFFECT OF STERN MODIFICATION TO A SERIES 60 VESSEI, RESISTANCE, POWERING, WAKE DISTRIBUTION AND PROPELLER INDUCED VIBRATION.

(b) David Taylor Model Basin; Maritime Administration.

(d) Experimental testing and evaluation of data for basic research.

(e) Models representing specific variations in stern shapes and designed for special instrumentation installation will be built. The basic design will be the series 60,0 .70 Block Coefficient Parent. Six other forms will be derived having systematic changes in section shapes (from $V$ to extreme $U$ ) and for variation in waterline endings (from fine to blunt). An attempt $w 11$ l be made to develop formulation to mathematically express the stern varlations from the parent.

(f) Conpleted.

g) The bas1c model has been constructed and powering data has been obtained.

(3292) EXPLORATORY STUDIES AND PLANS AT DTMB FOR MODEL TESTS IN 3-DIMENSIONS.

(b) Bureau of Ships; David Taylor Model Basin.

d Experimental; basic research.

A new seakeeping test facility is now in operation. Techniques for generating irregular short-crested seas and measuring the response of ship models at oblique headings is under development.

(g) Segmented wave generators provide the ability to produce oblique waves. Programming to individual wavemakers results in generation of confused seas of almost any nature. The rectangular basin offers opportunity to test in any relative heading to the waves and even in cross seas. Problems in analysis involve determination of the seaway (in the tank) as a function of frequency and direction. Ship motions in confused seas will be random in nature and w1ll be analyzed by spectrum methods.

(3617) VENTILATED PROPELIER DEVELOPMENT.

(b) David Taylor Model Basin.

(d) Theoretical and experimental; applied research.

(e) Studies and design of ventilated propellers for operation at intermediate speeds.

(g) Experiments on the use of tripping wedge and tripping wire have been performed. The wedge appears to be no better than the wire and causes a loss in performance. Work on measurements of ventilated cavities is progressing.

(3619) VERTICAL AXIS PROPELLER. (b) Bureau of Sh1ps; Dav1d Taylor Model Basin.

d) Experimental and theoretical; applied research .

(e) Theoretical and experimental studies of performance characteristics of various types of vertical axis propellers.

(4426) DEVELOPMENT OF A LOW WAVE DRAG HULL FORM.

(b) Bureau of Sh1ps; David Taylor Model Basin.

d) Basic research.

(e) To establish a series of basic hull forms which can be used as a gulde to evaluate the merlt of future high speed ship designs. The basic test work has been completed. Thirty three models were tested for resistance including 4 defining the parent form and 2 catamarans. Analysis of data for basic serles have been completed. Series is to be extended to determine the effect of a varlation in LVB. The design and construction of these models have begun.

(g) Further expansion of this series may include a variation in $\mathrm{Cp}$.

(h) A paper to be presented to the society of Naval Architects and Marine Engineers is contemplated. An unclassified report will also be published.

(4427) A METHOD OF CALCULATING SPINDLE TORQUE OF CONTROLLABLE PITCH PROPELLERS.

(b) David Taylor Model Basin.

d Theoretical; applied research.

(e) A method of calculating the spindle torque of a controllable pitch propeller over the complete range of operating conditions and a theoretical investigation of the effect of various design parameters upon spindle torque. In order to calculate spindle torque at off design conditions, the off design performance of the controllable pitch propeller must flist be determined.

(g) A method of calculating the spindle torque at design conditions has been completed. The geometric problem of determing the effective distortion of blade sections at off design pitch settings has been solved. The solution has been programmed for the 7090 Computer.

(4428) COMPUTER SOLUTIONS OF FREE SURFACE FORCES.

(b) Bureau of Ships; David Taylor Model Basin.

(d) Hydrodynamic research. oscillating on the free surface will be solved directly on a digital computer by distributing pulsating sources over the surface of the body and calculating the required source density. The individual source potentials are chosen to satisfy the free surface boundary condition.

(g) The integral equations for source density have been formulated for the case of twodimensional bodies with no forward speed. The numerical analysis and programming have been largely completed for this case.

(4429) LATERAI FORCES.

(b) Bureau of Ships; David Taylor Model Basin.

d) Hydrodynamic research.

(e) The lateral force on a translating body which vertically cuts the free surface is being formulated theoretically. Two special cases are included: (a) If the draft is large compared to the length, the body is a stmut with angle of attack. (b) If the draft is very small, the body corresponds to a yawed thin ship.

(g) An integral equation has been derived for the density of a surface distribution of dipoles. such that the boundary conditons are satisfied.

(4809) TURBULENT BOUNDARY IAYERS IN PRESSURE GRADIENTS ON ROUGH SURFACES. 
(b) Laboratory project, David Taylor Model Basin. Theoretical and experimental; basic and applied research.

(e) Research in behavior of turbulent boundary layers in pressure gradients leading to separation. Initial roughnesses will be screens of various gages fastened to wall of wind tunnel. Velocity surveys and turbulence measurements w111 be performed.

(g) Data have been obtained at one non-zero pressure gradient for one wall roughness. Pitot tube and hot wire surveys have been made at seven longitudinal positions on the rough wall. At each position the boundarylayer velocity distribution and turbulence intensities were measured at three tunnel velocities.

(4810) SHIP WAKE SIMULATION STUDIES.

(b) Bureau of Ships; David Taylor Model Basin.

(d) Experimental and theoretical; applied research.

(e) To produce sh1p wake distributions in a ariable pressure water tunnel in order to determine the performance of propellers in non-uniform wake flows.

(g) A theoretical method has been obtained for determining the wire grid geometry necessary to produce arbitrary, steady, three-dimensional flows. Simple experimental confirmation of the method has been obtained.

(h) "A Method of Wake Production in Water Tunnels," by J.H. McCarthy. DTMB Report \#1785, 1963 .

(4811) STEADY-STATE FORCES ON SUPERCAVITATING AND VENTILATED HYDROFOILS.

(b) Bureau of Ships; David Taylor Model Basin. Theoretical and experimental; applied research.

(e) To study the steady-state lift and drag characteristics of supercavitating hydrofoll conflgurations for application to hydrofoll craft and supercavitating propeller design.

(g) Experimental determination of the lift and drag of various three-dimensional supercavitating hydrofolls is in progress. These include folls with 2-term, 5-term and flatfaced sections. The effects of aspect-ratio and taper are belng investigated. Vent1lation by blowing air through holes in the suction surface of the foll is used to extend the range of cavitation number. Future research includes the determination of two-dimensional lift and drag, studies of flap conflgurations and measurement of the interaction of tandem and cascade folls.

(h) "Experimental Determination of the Forces on Supercavitating Hydrofolls with Intermal Ventilation," by N. L. Ficken, Jr. and G. F. Dobay, Proc. of National Meeting of IAS on Hydrofolls and Aerospace Sclences, Sept. 1962. DTMB Report No. 1676.

(4812) PROPELLER AND BODY INTERACTION.

(b) Bureau of Ships; David Taylor Model Basin.

d) Theoretical and experimental; applied research.

(e) Study and development of design criteria for determining propulsion characteristics of submerged bodles and hydrofoll-supported craft.

(g) Axtal clearance between a submerged body of revolution and a stern propeller has been optimized on the basis of propulsive coefficlent. A method has been developed for computing thrust deduction for submerged hydrofoll-propeller arrangements.

(4813) INVESTIGATION OF DUCTED PROPELIERS.

(b) Bureau of Ships; David Taylor Model Basin. Theoretical and experimental; applied research.

(e) To develop a design method for ducted propellers and to conduct a parametric study of ducted propeller performance.

(g) A theory of the ducted propeller with finite number of blades has been developed. From this theory a design method will be developed and then a parametric study of ducted propeller performance will be conducted.

\section{(4814) POWERING IN WAVES.}

(b) Bureau of Sh1ps; David Taylor Model Basin. d) Experimental.

(e) To determine the powering characteristics and speed loss of ships in waves by conducting model tests in regular and irregular waves. Limitations of present procedures for predicting power and speed loss in a seaway from tests in regular waves will be determined and new techniques will be developed where necessary.

(4815) PARAMETRIC STUDIES.

(b) Bureau of Sh1ps; David Taylor Model Basin.

(d) Experimental.

(e) To provide basic information from which the most sultable destroyer form for high sustained sea speeds in a seaway can be established. Model tests will be conducted in regular and irregular seas using a serles of models for which the signiflcant geometric parameters are systematically varied. Motions and powering increase in waves w11l be studied.

\section{(4816) FUNDAMENTAL PROPERTIES OF SH IP ROLLING.}

(b) Bureau of Ships; David Taylor Model Basin.

d) Experimental and theoretical.

(e) Though extensive studies of rolling have been made in recent years, a great deal remains to be learned conceming the fundamental properties of rolling for both surface ships and submarines. Areas which require additional research are (1) applicability of superposition principle for rolling motion especially in short crested waves, (2) unstable rolling motion in oblique regular and in irregular waves, (3) nonlinear roll behavior in rough seas, etc. In order to clarify the fundamental nature of rolling, model tests will be conducted in regular and 1rregular waves at various heading angles. Parametars significant for roll will be investigated.

(5121) SERIES 60 - PROPELIER INDUCED VIBRATION.

(b) David Taylor Model Basin.

d) Experimental; basic research.

(e) Measurement of propeller induced vibratory forces to study the effect of for and aft clearance in the propeller aperture.

(g) The instrumentation is basically the same as previously used in programs of this type. Insufficient information has been obtained upon which to base quantitative conclusions but there is evidence of considerable var1ation in vibratory fuses depending upon clearance from the stern frams.

\section{(5122) FLOW VISUALIZATION STUDIES.}

(b) Bureau of Ships; David Taylor Model Basin.

d) Experimental; applied research.

(e) To visually determine in water the effect of boundary-layer growth and tralling edge geometry on separation, and the mechanism of vortex shedding, from stationary and osc1llating hydrofoll shapes.

(g) The hydrogen bubble visualization technique has been adopted to the 12 -INCH water tunnel and preliminary flow studies have been made on a number of two-dimensional bodies. The experiments are being extended to study vortex shedding from stationary folls having different trailing edge geometrics.

(5123) THE EFFECT OF GAS NUCLAI ON CAVITATION.

(b) Bureau of Sh1ps; David Taylor Model Basin.

d) Experimental; applied research.

(e) To determine the effect of gas nuclas on the 
inception of cavitation.

(8) Acoustic techniques to measure the distri. bution and size of nuclal are being studied, and one will be applied to the water tunnels at DTMB. Cavitation inception studies will be made for a simple body and propellers and the results correlated with gas nuclai content of the water.

(5124) PROPELLER OSCILLATING PRESSURE FIELD.

(b) Bureau of Ships; David Taylor Model Basin.

d) Experimental; applied research. To experimentally determine the oscillating pressure fleld about marine propellers and correlate these measurements with theoretical predictions.

(g) Pressures will be measured on a flat plate parallel to the axis of two propellers, one a propelier of conventional design and the other of double blade thickness, in both uniform and non-uniform flow.

(5125) HYDRODYNAMICALIY EXCITED PROPELLER SINGING.

(b) Bureau of Ships; David Taylor Model Basin.

(d) Experimental; applied research.

(e) To determine the characteristics of flow induced propeller singing and investigate methods to suppress singing.

(g) Tests on a model propeller have demonstrated the feasibility of studying singing at model scale by suitable trailing edge modifications. The investigation will be extended to determine the applicability of two-dimensional flow-excited vibration data to propeller blades and to study the influence of variations in trailing edge geometry and other design parameters on propeller singing.

(5126) CAVITATION INCEPTION ON A ROUGH SURFACE.

(b) Bureau of Ships; David Taylor Model Basin.

d) Experimental and theoretical; applied research. An investigation of cavitation inception over isolated three-dimensional roughness elements on a flat plate as a function of boundarylayer parameters, pressure gradient, geometry and size of the roughness elements, etc. Theoretical studies will attempt to establish sealing laws for cavitation.

(g) Equipment being designed.

(5127) INTERACTION FORCES BETWEEN LIFTING SURFACES.

(b) Bureau of Ships; David Taylor Model Basin.

d) Theoretical; applied research.

(e) A two-dimensional theory for determining the forces and moments acting on two lifting surfaces as one passes through the wake of the other will be developed. This theory will be applied to the prediction of propellerappendage interaction forces on a ship.

(5128) BOUNDARY-LAYER STUDIES.

(b) David Taylor Model Basin; basic and applied research.

(d) Theoretical and experimental; basic and applied research.

(e) Studies of boundary-layer phenomena important to naval hydrodynamics; methods for reducing frictional resistance, improved analytical methods for laminar and turbulent boundarylayers, prediction of transition from laminar to turbulent flow.

(g) A high speed towing $\mathrm{rig}$ is under design and construction.

(h) "The Effect of Fluid Injection on the Drag of Flat Plates at High Reynolds Numbers," by P. S. Granville, International Shipbuilding Progress, Vol. 10, No. 10l. (Jan. 1963).

"The Boundary-Layer and Frictional Resistance of Flat Plates in Non-Newtonian Fluids," by P. S. Granville, David Taylor Model Basin Report No. 1579 (Dec. 1962).

For sponsored projects see the following:

(3026) Ship Resistance in Uniform. Waves as a

Function Wave Steepness.
(3686) Nonlinear Coupled Sh1p Motions.

4570) Pressure Distribution on Semi-submerged oscillating Bodies.

(4971) Ship Resistance in Irregular Waves Wake Characteristics for Bodies of Revolution.

(4974) Turbulence Characteristics of the Wake of a Body of Revolution.

(4677) The Investigation of Two-Dimensional Unsteady Cavity Flows About Fixed Symmetric Bluff Bodies.
(5112)

2603

4199

$(4202)$

(4691)

(4696)

(4699)

$(3826)$

3828

4702

4703

4704

(2155)

(2616)

(3830)

(4220)

(4713)

(5057)

(5060)

(5061)

(5066)

(4716)

$\{5190\}$

(5191)

(5198)

(5199)

(5202)
(3832)

urbulence Measurements in Liquids.

Water Tunnel Air Content Studies.

Geometry of Air Cavities in a Boundary Layer.

Micro Bubble Studies.

A Study of Drag Reduction by the Use of Non-Newtonian Boundary Layer Additives.

theoretical Investigation of Two-

Dimensional Unsteady, Supercavitated

Hydrofoil Flows with Free-Surface

Boundary Conditions.

Force Characteristics of a Cavitating Body in a Compressible Liquid Mixture. Hydrodynamics of Ship slamming.

Studies in Hydroelasticity.

Hydrodynamics of Ship Anti-Roll Tanks .

Vibration of Submerged Elastic Plates.

Vibration of Hydrofoil Structures.

Supercavitating Hydrofoll Theory.

Seakeeping Qualities of Ships at All

Headings to Waves.

The Blade-Frequency Force Generated by

a Propeller on a Body of Revolution.

Acoustic Radiation of a Cylindrical

Bar and an Infinite Plate Excited By

the Field of a Ship Propeller.

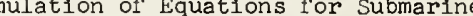
Trajectories with Six Degrees of Freedom. 77 Analytical Investigation of Course Stability and steering Qualities of Ships.

Three-Dimensional Approach to the Gust Problem for a Screw Propeller.

Influence of Afterbody Shape on

Angular Harmonic Content of the Wake

of Single screw Ships.

Flutter of Hydrofolls on Flexible

Structures.

Surface Piercing Hydrofoll Flutter.

Study of the Propeller singing

Phenomenon.

Experimental Study of Propeller-

Induced Vibratory Pressures on Simple

Ship Surfaces.

Unsteady Lifting surface Theory for

a Marine Propeller of Low P1tch Angle

with Chordwise Loading Distribution.

Unsteady Lifting Surface Theory for a

Marine Propeller of an Arbitrary Pitch

Angle with Chordwise Loading Distribu-

tion.

Applications of Unsteady Lifting

Surface Theory Using Weissinger Model.

Deformation of Regular Waves by a

Ship Model.

Dimensional Effects on Hydrophone

Output in the Near Field.

Acoustic Exc1tation of Flow Plates by Turbulent Flow.

Drag Forces in Velocity Gradient Fields. Sound Radiated From a Turbulent Boundary Layer.

Interaction of Distributed Surface

Vibrations with an Adjacent Boundary Layer Flow.

78

78 Hydrofoil.

Theoretical Study of Hydrofoll Flutter Characteristics.

Turbulent Flow Transition Near solid and Flexible Boundaries.

The Low-A spect Ratio Jet Flap Hydrofoll. The Effect of Flow Separation From the Hull on the Stability of a High speed

Determination of Ship Wave Resistance. 
U. S. DEPARTMENT OF THE NAVY, NAVAL BOILER AND TURBINE LABORATORY.

(3623) HIGH PRESSURE-TEMPERATURE WATER FLOW METER CALIBRA TION .

(b) Bureau of Ships; Philadelphia Naval Shipyard (Naval Boller and Turbine Laboratory).

(c) Mr.J. W. Murdock, Associate Technical Director for Applied Physics Division, Naval Boiler and Turbine Laboratory, Phila. Naval Shipyard, Phila. 12, Pennsylvania.

(d) Experimental; applied research

(e) A facility is available for calibrating with water at pressures and temperatures up to 2500 psi and $600 \mathrm{~F}$ respectively. Capacity is $100 \mathrm{gpm}$ at maximum pressure and temperature and greater at lower pressures and temperatures. After flowing through the metering section the water is cooled and welghed. The facility is also used to investigate and verify orifice meter coefficlents at pressures and temperatures above those at which the coefficients in use were established. A number of flow meters which measure the flow in nuclear reactor loops have been callbrated.

(f) Inactive.

(g) A limited amount of test data indicate good agreement between orifice flow rates obtained by calibration at high pressures and temperatures and those obtained by extrapolating from cold water calibrations. Other meter tests show the need to include suitable corrections for change in shape, size, density, etc.

(3624) INVESTIGATION OF ELBOW FLOW METERS.

(b) Bureau of Ships; Philadelphia Naval Shipyard; (Naval Boller and Turbine Laboratory)

(c) Mr. J. W. Murdock, Head, Applied Physics Division, Naval Boiler and Turbine Lab., Phila. Naval Shipyard, Phila. 12, Pa.

(d) Experimental, applied research.

(e) The 90 degree elbow has been proposed for metering flow in shipboard systems. This type meter is attractive since the use of an existing elbow would not require any changes to the piping and would impose no additional pressure drop on the system. In addition, the elbow can meter reverse flow. The chief drawbacks are large variation in elbows and the lack of an exact relationship between flow and differential pressure. Testing was limited to the long turn 90 degree, type A elbows of specification MIL-F-1183 to establish criteria for their installation and use.

(f) Completed.

(g) When certain standards are imposed on the fabrication and measurement of the elbows and a specifled means of computing flow is used, a measurement tolerance of 4 percent can be expected. In control applications the elbow meter was found to have a square root transfer function and a repeatability of $0.2 \%$.

(h) "Elbow Flow Meter Investigation," J. W. Murdock \& C. Gregory, Naval Bolier and Turbine Laboratory report to Bureau of Ships, Washington 25, D. C., 45 pages with 11 11lustrations, December 10, 1962. "Performance Characteristics of Elbow Flow Meters," Paper No. 63-WA-17, presented at ASME annual meeting November 1963.

(4001) HIGH PRESSURE STEAM AND WATER FLOW TESTS.

(b) American Society of Mechanical Engineers. (c) Research Committee on Fluid Meters, American Society of Mechanical Engineers, 345 East Forty-Seventh Street, New York 17, New York.

(d) Experimental; applied research.

(e) Although the ASME Research Committee on Fluid Meters has sponsored many fundamental research programs dealing with the development of basic constants used with primary elements, hardly any of this work has been done on steam flow at high pressures and temperatures. Ne1ther has research been done on high temperature water flow. Analysis of many tests indicate that the basic calibrations obtained with low temperature water (air and gas) could be extrapolated with high accuracy to the measurement of high pressure and temperature steam and water flow provided suitable corrections were made for the change in the shape and size of the primary element, the pipe and the fluid. This procedure has been experimentally verified for steam up to $2000 \mathrm{psi}$ and $1050 \mathrm{~F}$ and for water to $2500 \mathrm{ps} 1$ and $600 \mathrm{~F}$.

(f) Completed.

g) Nozzles and orlfices were calibrated with water at $240 \mathrm{~F}, 2200 \mathrm{psia}$, and with steam at $1050 \mathrm{~F}, 2000$ psia. Pipe Reynolds numbers averaged 600,000 for the water and 4,000,000 for the steam. Coefficients were generally in agreement with ASME predicted coefficients Two and a quarter percent (2 $1 / 4 \%$ ) chromemolybdenum steel proved unsatisfactory for the steam nozzles showing misting and pitting after less than 10 hours. Type 430 stainless steel was substituted and was satisfactory.

(h) Test results reported to ASME as: "Flow Meter Calibrations for the American Society of Mechanical Engineers Research Committee on Fluid Meters," by C. Gregory, 31 oct. 1962. ASNE has not published results.

\section{U. S. NAVAL ORDNANCE LABORATORY.}

(4867) THE HYDROBALLISTICS OF WATER ENTRY.

(b) Bureau of Naval Weapons, Department of the Navy.

(c) Commander, U. S. Naval Ordnance Laboratory White Oak, Silver Spring, Maryland.

(d) Experimental, theoretical, basic and applied research.

(e) The purpose is to study high velocity water entry as related directly or indirestly to the behavior of missiles. The study includes the stability and forces during the entry, cavity development and pressure, and the missile trajectory. A wide range of developmental and research configurations and of esperimental conditions are investigated. Guns are used to launch models into a tank equipped for operation at various pressures.

(h) "Research for Design of a Hydroballistics Tank," by Albert May, NOLTR 63-119, Aug. 30 , 1963. Coples may be obtalned from the Defense Documentation Center.

\section{U. S. NAVAL ORDNANCE TEST STATION.}

\section{(4002) MISSILE BEHAVIOR DURING WATER EXIT.}

(b) Bureau of Naval Weapons, Navy Department.

(c) Commander, U. S. Naval Ordnance Test Station, Attn: Dr. John G. Waugh, Code P8074, 3202 E. Foothill Blvd., Pasadena, California.

(d) Experimental; basic research.

(e) The objectives of this project are as follows (1) To study missile water-exit behavior and associated phenomena under different conditions to determine if problems exist in missile water-exit technology and to establish scaling techniques for modeling missile water-exit behavior. (2) To evaluate qualitatively the inherent value of slenderbody theory in predicting the underwater and water-exit behavior of an underwater launched missile in the presence of various sea states.

(g) Studies have been made on the water-exit behavior of a momentum-propelled 2-inchdiameter hemisphere-head missile under different degrees of cavitation, ranging from fully wetted to fully cavitating, and for a range of trafectory water-exit angles. The results indicate that considerable 
perturbations in missile pitch and pitch velocity take place at water exit, and it is inferred that problems may exist in missile water-exit technology.

The experimental fully-wetted flight and water-exit behavior of a blunt based axisymmetric missile traveling in a standing wave are simulated on an analogue computer using motion equations derived from slenderbody theory. The analytical approach is supplemented by introducing experimental hydrodynamic coefficients and transverse drag terms. The results of the simulation are compared graphically with the experimental behavior to illustrate an upper limit of the accuracy to be expected of slender-body theory.

(h) The following reports are in process of Publication:

"Water-Exit Behavior of Missiles, Part 2, Effect of Cavitation and Exit Angle," by J. G. Waugh and G. W. Stubstad. (NÁVWEPS Report 7735), U. S. Naval Ordnance Test Station, China Lake, Calif.

"Water-Exit Behavior of Missiles, Part 3 , Macroscopic Effects of the Hydrodynamic Flow Pattern," by J. G. Waugh and G. W. Stubstad. (NAVWEPS Report 7735), U. S. Naval Ordnance Test Station, China Lake, Calif.

"A Qualitative Correlation of Theoretically Predicted and Experimentally obtained Underwater-Launched Missile Behavior in the Presence of Waves," by M. L. Sturgeon and J. G. Waugh (in preparation).

\section{(4434) DUCTED PROPELIER DESIGN.}

(b) Bureau of Naval Weapons, Navy Department.

c) Commander, U. S. Naval Ordnance Test Sta., Attn: Mr. J. F. Reynolds, Code P8074,

3202 East Foothill Blvd., Pasadena, Calif.

(d) Theoretical; applied research.

(e) An estimate of the flow through a ducted propeller system involves a solution to the duct boundary condition. This can be determined by reducing the integral form of the boundary condition on the duct to a set of linear algebraic equations relating the Glauert coefficients for a ring vortex density distribution to the Fourier coefficients of radial wash due to the duct camber line and average propeller velocities. A solution to the set of linear algebraic equations has been prograumed on an IBM 7090 computer for any value of the duct chorddiameter ratio. The program also includes a solution to the harmonic coefficients describing circumferential variations in vortex density on a cylindrical vortex surface due to circumferential variations in the flow field induced by the propeller. These hamonic solutions can be used to calculate the pressure fluctuations on the duct surface. The computer program can be used to solve added boundary conditions involving blade surface, duct thickness and central body effects.

(4868) NON-NEWTONIAN FLUIDS.

(b) Bureau of Naval Weapons, Department of the Navy .

(c) Commander, U.S. Naval ordnance Test Station Attn: A. G. Fabula, P5006, 3202 E. Foothill Boulevard, Pasadena 8, California.

(d) Experimental; basic research.

(e) The turbulent flow characteristics of dilute solutions of various high polymers are being studied to understand why they often display anomalous flow behavior.

(g) Plpe flow studies for Reynolds numbers around $10^{5}$ have disclosed some new aspects of the phenomenon (apparently first reported by 3. A. Toms in 1948). To obtain consistent (and more interesting) results, newly mixed solutions have been tested once each in a blow-down type of pipe apparatus and then discarded. In some cases increasing pressure drop per unit length as far as 400 diameters $(400 \mathrm{~cm})$ downstream of an abrupt inlet contraction was observed. This behavior might correspond to macromolecular-coll scission or disentanglement or both. For the polymer solutions tested, there is a correlation between turbulent flow properties and the intrinsic viscosity which is a measure of macromolecular coil size.

(h) "The Toms Phenomenon in the Turbulent Flow of Very Dilute Polymer Solutions," by A. G. Fabula, paper presented at the Fourth International Congress on Rheology, 1963.

(4872) A METHOD FOR COMPUTING TURBULENT BOUNDARY IAYERS BASED ON THE LAW OF THE WALL AND THE LAW OF THE WAKE.

(b) Bureau of Naval Weapons, Navy Department.

c) Commander, U. S. Naval Ordnance Test Station Attn: Mr. David M. Nelson, Code P8074, 3202 E. Foothill Boulevard, Pasadena 8 , California.

(d) Theoretical; applied research.

(e) A method for computing turbulent boundary layers based on the law of the wall and Coles' law of wake is under development. This method is applicable to two dimensional bodies and to bodies of revolution in axialsymmetric flow where the boundary layer thickness is not necessarily small compared to the body radius. A simultaneous solution of the momentum integral equation and the energy integral equation is carried out assuming the mean velocity profiles are given by a universal, two-parameter representation as suggested by coles. The computational procedure will be programmed for ag IBM 7090 computer.

(f) Temporarily suspended.

(4873) RING WING LOADINGS.

(b) Bureau of Naval Weapons, Navy Department.

(c) Commander, U. S. Naval Ordnance Test Station, Attr: J. F. Reynolds, Code P8074, 3202 East Foothili Blvd., Pasadena 8, Calif.

(d) Theoretical; applied research

(e) A study of the effect of the ring wing chord-diameter ratio on lift and pitching moments due to normal forces for isolated three-dimensional wings at angle of attack has recently been published. A second report to be published later includes the effect of axial forces on the total pitching moment and position of the wing aerodynamic center. It was found that, relative to two-dimensioral airfolls, the effective position of aerodynamic center is changed significantly due to curvature of the chord plane and the axial forces due to wing camber and wing half cone angle.

(h) "Lifting Surface Theory Applied to Isolated Ring Wings at Angle of Attack," by Jack F. Reynolds, Navweps 8401 , NOTS TP 3322.

(4918) PROPELLER DESIGN METHOD TREATING THE BLADES AS LIFTING SURFACES.

(b) Bureau of Naval Weapons, Navy Department.

(c) Commander, U. S. Naval Ordnance Test Station, Attn: Mr. David M. Nelson, Code P8074, 3202 East Foothill Blvd., Pasadena, Calif.

(d) Theoretical; applied research. treating the blades as lifting surfaces has been developed and programmed for an IBM 7090 computer. The singularity distributions representing the bound circulation, shed vorticity, and blade thickness are treated as continuous sheets, making it necessary to determine the Cauchy principal value of the improper integrals expressing the induced velocities on the blades. The camber lines and pitch angles are determined from the variation of the normal component of induced velocity across the blade. The method allows for essentially arbitrary spanwise and chordwise distributions of circulation. It is applicable to moderately loaded, non-optimum, 
wake-adapted propellers with or without skew. Th1s work was undertaken to provide a fairly rigorous method of designing propeliers that would not contain the many assumptions and approximations that are found in the existing design methods that can be carried out on a hand calculator

(f) Completed.

(h) "A I ifting Surface Propeller Design Method for High Speed Computers," by D. M. Nelson. NavWeps Report 8442 , NOTS TP 3399 , U. S. Naval ordnance Test Station, China Lake, Calif. (in preparation).

(4919) RELATIVE FLOW AT LIFTING IINE FOR COUNTER ROTATING PROPELLERS.

(b) Bureau of Naval Weapons, Navy Department

c) Commander, U. S. Naval Ordnance Test Station, Attn: Mr. David M. Nelson, Code P8074, 3202

East Foothill Blvd., Pasadena, Calif.

(d) Theoretical; applied research.

(e) A theoretical means for determining the relative flow at the lifting line for counter rotating propellers is being developed and programmed for an IBM 7090 computer. This method is intended to handle non-optimum, wake-adapted propellers. The induced velocities at the lifting line arising from the effect of the front or rear propelier on itself are determined by a silghtly modified version of the induction factor method developed by Lerbs.* The mean axlal velocities at one propeller induced by the other are determined by replacing the finitely bladed propeller by an infinitely bladed propeller having the same radial thrust distribution and operating in the same wake. The mean tangential velocities at the rear propeller induced by the front propeller are determined by Stokes' theorem. The effect of the tapering afterbody on which the propellers are located is approximately accounted for by continuity consideration.

* "Moderately Loaded Propellers with a Finite Number of Blades and Arbitrary Distribution of Circulation," by G. W. Lerbs, Trans. SNAME, Vol. 60,1952 , pp. 73-117.

(g) All theoretical work has been finished and the final check solutions are being mun on the computer.

(4920) UNDERWATER GAS-JET PROPULSION STUDY.

(b) Bureau of Naval Weapons, Dept. of the Navy.

(c) Commander, U. S. Naval Ordnance Test station, 3202 E. Foothili Blvd. Pasadena 8, Calif. Attn: H. V. I. Patrick or T. G. Lang, Code P5006.

(d) Experimental; applied research.

The thrust and efflciency of a submerged supersonic gas-jet propulsion system will be studied on a model propelled by a solld propellant grain generating hot gas at 4,000 psi exhausted through four nozzles along its afterbody. The efflclency of the momentum exchange with the surrounding water will be studied in an effort to increase the normally low propulsion efficlency of high speed jets.

(g) Investigation of supersonic submerged gas jets in a still-water tank showed the jets to be unstable in nature. The jet breaks into small bubbles immediately on exit. The majority of the jet nolse has been found due to the resonant oscillation of these bubbles.

U. S. DEPT. OF THE NAVY, OFFICE OF NAVAL RESEARCH.

For sponsored projects see the following:

Project

Page

$(1548)$

Problems in Hydrodynamics.

$\left\{\begin{array}{l}3377 \\ 3378\end{array}\right.$

Theoretical Studies in Hydrodynamics.

Hydrodynamics of Turbomachines.

Studies in Ventilating Flows and

Model Scaling.

(5036) Hydrodynamics and Thermodynamic Parameters Affecting Cavitation Bubble Grovith and Collapse.
(3677) Annular Nozzle Ground Effect Machine.

4083 Dynamic Interaction Between Ships.

4084 Ships of Minimum Resistance.

4970 Pressures Acting on a Hemisphere

oscillating on a Free surface.

(4093) V1bratory Motions of Floating Bodies. The Discharge of MaJor Western Rivers in Relation to the General Circulation of the Atmosphere.

(73) Measurement of Turbulence in Flowing Water.

(79) Cavitation.

(1875 Characteristics of Stable Eddies.

2091 Research on Ship Theory.

2541 Development of Instmuments For Use In Analyzing Aperiodic Signals.

(2792) The Decay of Turbulence in a Zero Momentum Wake.

(3074) Wake of Zero Momentum flux.

(4149) Drag of Supercavitating Bodies of Revolution.

(2801) Interaction of Waves with submerged and Floating Bodies.

(3444) Effects of Basin Geometry and V1scous Damping on the Amplitude of Resonant oscillations in Harbors.

(4160) Motion of Submerged Bodies Below a Free Surface.

(4655) Entrainment of Cohesive Sediments.

4494) The Transition Between Two Phase Slug and Annular Flow.

(4983) Detemination of the state of the Art in Two-Phase Gas-IIquid Flow Phenomena.

(4985) The Flow Properties of Bubbly Mixtures.

(3120) Offlce of Naval Research Atmosphere Interaction and Wave Project.

(2144) Experimental and Analytical studies of Hydrofolls.

(3153) Flow About Bodies at Small Cavitation Numbers.

(4200) Investigation of the Forces and Interference Effect of Tandem Flat Hydrofolls.

(4700) Osc1llatory Ifft and Drag Forces on Ventllated Hydrofolls in Regular Waves. 72

(4502) Swell Attenuation Studies.

(5010) Laboratory Study of the Runup and Reflection of Iow-Steepness Waves.

(4917) Mechanisms Involved in Wind-Generated Waves.

(2154) Investigation of High speed Ship Forms.

(4221) Unsteady Forces and Motions on a Hydrofoll Moving Under an Irregular Sea.

(4226) Investigation of Surface-plercing Fully Ventilated Dihedral Hydrofolls. Smooth Water Behavior of SurfacePlercing Hydrofoll Vessel.

(4229) The Boundary Layer Under Progressive and Standing Waves.

(4709) Surface Plercing Hydrofoll Flutter.

4711 Study of the Propeller Singing Phenomenon.

(4712) Interference Effects of a Submerged Hydrofoll on a surface-Plercing Strut.

(5063) Wave-Resistance Reduction of NearSurface Bodies.

(5065) A Study of Ship Forms at High Froude Numbers.

(4737) Experimental Hydrodynamics of Rotating System.

(4738) Synoptic Oceanography-Surface Effects.

Forces and Moments on an Oscillating Hydrofoll.

Theoretical Study of Hydrofoll

Flutter Characteristics.

special Problems in Fluid Dynamics.

The Effect of Flow separation from the Hull on the stability of a High Speed Submarine.

(1478) Wind Waves.

Flow over

Inertial Forces in Unsteady Flow. Motion Around a Body in a Stratified Fluld.
12 15

15 16 22 41 41 41 41 

Turbulent Shear Flow Through Compliant Walled Tubes.

(5252)

TENNESSEE VALIEY AUTHORITY, Engineer1ng Laboratory.

Inquirles concerning the following projects should be addressed to $\mathrm{Mr}$. Rex A. Elder, Director, TVA Englneering Laboratory, P. O. Box 37, Norris, Tenn.

(3629) LOW POWER VHF RADIO GAGES FOR REPORTING RA INFALL AND STREAM LEVEL DATA.

(d) Development

(e) Transistorized radio components powered from nickel cadimum batteries, which will be charged by thermoelectric generators and/or solar cells, will be used. Data in gray blnary code will be transmitted by audio tone pulses. Unattended operation of long duration is a primary objective in the design of these stations.

(g) A model of the electronics between the digital shaft position encoder and the gaging station transmitter has been assembled and is now undergoing test. Design of the decoding electronics at the recelving station is essentially complete.

\section{(4439) DENSITY UNDERFLOW WITHDRAWAL STRUCTURES.}

(d) Experimental; applied research.

(e) A three-dimensional model was used to develop the basic relationship involved in the design of skimmer wall structures used to insure the withdrawal of the bottom layer in a two-layered, density stratified reservolr.

(f) Laboratory study completed.

g) Design curves were developed which will permit design of structures which will insure withdrawal of only the bottom layer or of withdrawal of the bottom layer plus 1 percent, 2 percent or 5 percent of the flow from the top layer.

(h) A technical paper describing the results was presented at the A.S.C.E. National Conference, Hydraulics Division, held at Pennsylvania State University, August 6-9, 1963, by the authors Mr. Rex A. Elder and Dr. D. R. F. Harleman.

(4441) MEASUREMENT OF KAPLAN TUREZNE DISCHARGES USING OTT CONPONENT CURRENT METERS.

(d) Equipment development and fleld measurement operation.

(e) A measuring technique is being developed with which the flows through Kaplan type turbines can be accurately measured by use of ott component type current meters which can vertically traverse the flow at the turbine intake gate slots. These measurements, made at several fixed discharges, will be used to calibrate winter-Kennedy scroll case pressure taps. The WInter-Kennedy taps w1ll then be used, with suitable measuring equipment, to determine the discharge for any turbine loading.

(g) The carriage framework upon which the ott component type current meters will be mounted, along with their assoclated lifting devices, and the necessary recording instrumentation has been deslgned, constructed and fleld tested. Development of the actual measuring techniques is now in progress.

(4878) PARADISE STEAM PLANT, AIR DUCT STUDIES.

(d) Experimental; for design.

(e) Model studies were conducted on a 1:8 scale model of the forced draft blower and the appurtenent duct work beginning with the fan silencers and extending through the first pass of a four pass tubular pre-heater to:

(1) obtain uniform velocity distribution into the pre-heater, and (2) reduce head loss in the duct system.

(g) Vane designs were developed which materlally Improved the flow distribution without appreciably increasing the head loss in the system.

(h) Internal report in preparation.

(4880) VIBRATION STUDIES OF STEAM PLANT AIR AND GAS DUCTS.

(d) Experimental; for basic and applied research. Studies are being made to extend our knowledge relating to flow induced duct vibrations and to apply the findings to present and future installations. Duct vibrations which are believed to stem from the highly turbulent flows created by the forced draft fans and by the various duct confligurations have been experlenced in the duct work of some plants. These turbulent conditions create pressure fluctuations which could lead to wall vibrations.

(f) Suspended.

(4881) BASIC STREAM AND RESERVOIR HEAT BUDGET STUDIES.

(d) Experimental; for basic and applied research

(e) This is a study to develop the basic temperature prediction equations for a stream or reservolr into which a volume of water at a different temperature 1 s injected. All known variables such as stream flow characteristics, meteorological conditions and thermal characteristics will be included. Theoretical studies, field tests, and possible laboratory studies will be combined to produce verified equations.

(g) A basic heat budget equation has been developed which relates mean water temperature to meteorological, hydraulic, and thermal characteristics. The equation can be used to predlct mean water temperature as a function of distance below a steam plant, using 24-hour time averages. To date this equation has been proved for the completely mixed non-recirculating river flow case.

(4882) GUNTERSVILLE MAIN LOCK INTAKE DESIGN.

(d) Experimental; for design. wide $x 600$ foot long, 45 foot lift, new lock are of the multiple opening type located in an extension of the two lock walls. The design is being studied by means of a $1: 24$ scale model to determine (1) if each entrance opening carries its share of the discharge, and (2) that no objectionable vortices occur.

(f) Model testing completed.

(g) An effective operating design was developed which produced no objectionable vortices during lock filling operations and essentially balanced flows in both culverts.

(h) An intermal report has been issued.

(4883) GUNTERSVILIE MAIN LOCK DISCHARGE STRUCTURES.

(d) Experimental; for design.

(e) The discharge stmuctures for the 110 foot wide $x 600$ foot long, 45 foot lift, new lock are to be located immediately below the downstream miter gate and will consist of multiple horlzontal openings across the width of the approach channel at river bed level. Each culvert will have its own discharge system. The 1:24 scale model test are to determine the actual outlet configuration required to furnish satisfactory navigation conditions near the outlet area.

(f) Model testing completed.

(g) A design was developed which produced satisfactory downstream navigating conditions.

(h) Internal report in preparation.

(5002) BULL RUN, UNIT I, AIR AND GAS DUCT STUDIES. 
(d) Experimental; for design.

(e) Tests using a 1:16 scale model were conducted to develop the most favorable overall operations of the a1r and gas duct systems under varlous operating conditions. The ducts studied extended from the 1nlet to the outlet of the breeching sections into the chimney. Studies were also conducted using a 1:30 scale model of the breechings and the chimney to develop a deflector design in the chimney base to eliminate surging and to reduce pressure losses.

(f) Completed.

(g) The flow distribution patterns in the duct systems were sultably modifled at critical polnts (by means of vanes and perforated screens) to provide the type of distribution required for optimum operation. It was found that excessive pulsations could develop throughout the a1r and gas systems w1thout a satisfactory deflector structure in the base of the chimney. A design which eliminated this surging was developed.

(h) Internal reports issued.

(5003) TELLICO PROJECT, NAVIGATION CHANNEL IMPROVEMENTS.

(d) Fleld Investigations and model tests; for planning design and operations.

(e) Tests were conducted on a distorted scale model with a horlzontal scale of $1: 250$ and a vertical scale of $1: 50$ and fleld measurements were taken at the proposed project site for purposes of determining the effect of power peaking releases from the Ft. Loudoun and the proposed Tellico projects upon navigation conditions downstream from these facllities. Th1s problem was envisioned primarliy because of the proximity of the two hydro facilities. Ft. Loudoun is situated on the Tennessee River just 1.2 miles upstream from its confluence with the Little Tennessee River and the proposed Tellico Project is tentatively proposed to be located on the L1ttle Tennessee River only 0.3 miles upstream from this confluence.

(f) Model tests completed.

(g) Model tests proved the presence of a severe cross-current problem at the confluence, occurring during peaking or steady state discharges. This could be eliminated by the addition of a gulde wall structure at the confluence of the two rivers and the adoption of an operating program which would speclfy the conditions under which the two hydroelectric facllities might be operated in concert.

(h) Advance report 1ssued.

(5004) NICKAJACK PROJECT.

(d) Experimental; for design.

(e) Model studies are belng conducted on a distorted model, $1: 150$ horlzontal scale by $1: 90$ vertical scale, representing an area of approximately 3 miles $1 n$ length by 1 mile In width at the river site. Three baslc dam layouts were tested and the test results studied to determine the most advantageous design based on economy and performance. The hydraulic problems assoclated with each phase of the construction program are also studied.

(h) Two internal reports have been issued to date, dealing with varlous phases of the design, construction and the interim operations of this facllity.

(5005) WHEELER PROJECT, TURBINE UNITS 9, 10 and 11 , VIBRATION STUDIES.

(d) Field 1nvestigations; applied research. Severe vibrations of these flxed-blade turbines has lead to instrumentation of one unit to study the inter-relationships of the hydraulic forces and the unit vibrations. Pressures are measured in the scroll case at 3 locations, on the head cover at one location and at 5 locations in the draft tube. Vibrations are measured at 8 radial polnts on the shaft and at one vertical point. A measurement is also taken at one polnt under the generator thmust bearing support bracket.

(5006) WIDOWS CREEK STEAM PIANT, CONDENSER WATER INTAKE, UNITS $7 \& 8$, ENTRANCE CONDITION AND TRASH STUDY.

(d) Experimental; for mechanical design.

(e) Tests were conducted using'a $1: 40$ scale model to determine the modifications necessary to produce good flow conditions into the intakes for the condenser water pumps for Units 7 and 8 and to provide, at the same t1me, for maximum protection from floating or submerged trash which had tended to collect at the intake openings. The remedies would have to be external to the already constructed intake structure.

(f) Completed.

g) The studies indlcated the need for two modifications to the present intake. These were: (1) the removal of a dike and anchor cell which extended approximately 36 feet into the river 110 feet upstream from the Intake structure, and (2) the addition of a rounded 90 degree cormer, 13 feet in radius, on the upstream corner of the Intake structure.

(h) Internal report in preparation.

( $(707)$ STUDIES OF BEND LOSSES AND VANING IN LARGE CONDUITS.

(d) Experimental; baslc research and applied research.

(e) These studies are to develop baslc deslgn criterla for alr and gas duct systems for steam plants, w1th particular reference to methods of vaning for optimum flow conditions and minimum head loss characteristics and to the effects of multiple bends on the loss characterlstics of the system. The first phase of these studies will deal w1th duct sections having helght to width ratios of $2: 1$. Other phases will deal with more complex duct shapes and bends. The data w1ll be developed ent1rely by laboratory testing. The study is being conducted on a limited basis in 1964 and W1ll be expanded In 1965.

(f) Temporarily suspended.

(5008) STUDIES OF THE EFFECTS OF TURBULENCE ON JET DISPERSION.

(d) Experimental; basic and applied research.

(e) To determine the effect of the turbulence in the discharging jet from a chimney on the rise of the plume above the stack, measurements of the turbulence characteristics of several TVA stacks will be made and by means of model comparisons, the mixing characteristics of the jet will be compared with those for an ideal discharge condition. These data will then be combined by the D1vision of Health and Safety with other field data from the same plants to develop an overall plume rise equation. This study is co-sponsored by TVA and USPHS. Fleld and model studies will be conducted during 1964 and 1965 .

(5009) MODEL-PROTOTYPE COMPARISON OF LOCK HAWSER PULL FORCES.

(d) Experimental fleld Investigations for applied research.

(f) Completed.

g) The results from these model-prototype comparison studies indicate that the hawser force is a poor varlable to use in lock design evaluation due to the extreme difflculties encountered in making these type measurements. The results indicated, however, that in well deslgned locks the hawser forces are directly related to the water surface slopes.

(h) Report in preparation. 
TENNESSEE VALIEY AUTHORITY, Hydraul1c Data Branch.

Inquiries concerning projects should be addressed to Mr. James W. Beverage, Chief, Hydraulic Data Branch, Tennessee Valley Authority, Knoxville, Tenn. 37902.

(765) EVAPORATION IN THE TENNESSEE BASIN.

(d) Field investigation; applied research.

e) To provide data for estimating reservoir losses and derive a general rule, applicable to the Basin, permitting computation of evaporation from pans at $s 1 x$ locations in Basin, together with standard meteorological readings.

(h) Results published in monthly and annual bulletins, "Precipitation in Tennessee River Basin" (Project 768).

(768) PRECIPITATION IN TENNESSEE RIVER BASIN.

(d) Field investigation; basic research.

(e) A comprehensive study of rainfall and other weather phenomena for purposes of water dispatching and improvements in water control; storm studies as related to maximum precipitation, rainfall-munoff, splliway design and operation, etc.

(h) Monthly and annul bulletins, "Precipitation in Tennessee River Basin."

(769) RESERVOIR AND STREAM TEMPERATURES.

(d) Fleld investigation; basic research.

e) study of water utilization and water movement as concerns industrial plant locations and stream pollution. Variations in temperature from surface to bottom in reservolrs throughout the year are determined by soundings, and by continuous recording gages in natural streams.

(771) GALIERY DRAINAGE IN LARGE DAMS.

(d) Field investigations; design.

(e) Weirs are placed in main galleries and dralnage measured as check on tightness and stability.

(779) MAXIMUM POSSIBIE PRECIPITATION IN TENNESSEE VALLEY.

(b) Cooperative with U. S. Weather Bureau.

d) Theoretical; applied research.

(e) Hydrometeorological analysis of large storms with upward adjustments of controlling factors to maximum limits as applied to the Tennessee valley and subdivisions.

(g) Results to be published as one of current series of hydrometeorological reports by the U.S.W.B. and cooperating agencies.

(780) PERIODIC EVALUATION OF GROUND-WATER STORAGE.

(d) Theoretical; operation.

(e) By analysis of current records of stream discharge, the volumes of runoff in groundwater and channel storage are determined for use in operation of multi-purpose reservoirs.

(g) Results reported monthly and weekly within the orgainzation.

(785) SEDIMENTATION OF EXISTING RESERVOIRS.

(d) Field investigation; basic research.

(e) Selected ranges in reservolrs are probed and sounded, volumetric samples are collected and analyzed, quantity and distribution of sediment are computed to determine deposition by stream, probable life of reservolr, effect of sediment storage on navigation channels and sedimentation of down-stream reservoirs, and probable sedimentation in future reservolrs.

(3306) COOPERATIVE RESEARCH PROJECT IN WESTERN NORTH CAROLINA.

(b) Project conducted in cooperation with North Carolina State College of Agriculture and Engineering. (d) To determine water-land relationships for some of the principal solls used for agricultural purposes in western North Carolina under Important vegetative covers. Observations include rainfall, munoff, sollmo1sture, potential evapotranspiration, and actual evapotranspiration.

(e) A statistically designed rotation of four covers on four small watersheds and a separate evaluation of deep-rooted crop on a fifth watershed.

(f) Field studies of the deep-rooted crop, alfalfa, have been discontinued.

(g) Results to date are summarized in annual reports on the project.

(h) "Water Use by several crops in a Welghing Lysimeter," by C. B. England, Agronomy Journal, Vol. 55:239-242, 1963.

(3307) PARKER BRANCH PILOT WATERSHED RESEARCH PROJECT.

(b) Project conducted in cooperation with North Carolina state College of Agriculture and Engineering.

(d) To determine the effects upon the hydrology of the watershed of an intensive farm development program designed to give the optimum economic well-belng of the people using the land. Rainfall, runoff, suspended and deposited sediment are observed, periodic solls-land-use and inventories are made and records of income summarles and public and private investments are maintained.

(e) Project activities are divided into calibration, action, and evaluation phases.

(f) Agricultural economics portion of project terinlnated June 30, 1962; hydrologic portion terminated september 30, 1962 .

(g) Results are summarized in annual reports on the project.

(h) "Parker Branch Research Watershed--Project Report, 1953-1962," TVA report, Knoxville, Tennessee, 1963.

(3308) WHITE HOLLOW WATERSHED.

(d) To study the effect of changes in the vegetal cover on a watershed taken out of cultivation on the hydrologic factors of runoff and soll erosion.

(e) Continuous record from 1935 of rainfall, runoff, and suspended sediment, and period1c determination of vegetal cover indexes.

(f) Trees have been marked for selective cutting which will be accomplished in 1963.

(g) During the 24-year period 1935-1958, the forest cover improvement in the watershed resulted in greater watershed protection with no measurable change in water yleld, no change in volume of elther surface runoff or ground-water munoff, marked reduction in summer peak rates of discharge with lesser reduction in winter rates, a prolongation of the period of draining of surface munoff from the channel system, and a 96 percent reduction in the sediment load.

(3309) PINE TREE BRANCH WATERSHED.

(d) To determine the effects upon the hydrology of the watershed by reforestation and erosion control measures.

(e) Continuous record from 1941 of rainfall, runoff, ground water, and sediment loads.

(f) Trees have been marked for selective cuting which will be accomplished in 1963.

(g) During the 20-year period 1941-1960, the cover improvement and erosion control in the watershed resulted in a decrease in surface munoff volumes and an increase in groundwater discharges, marked reductions in summer and winter peak flood discharges, a reduction in overland surface velocities, a prolongation of the period of draining of surface munoff from the channel system, an appreciable decrease in water yield, and a 96 percent reduction in sediment load.

(4011) NORTH FORK CITICO CREEK RESEARCH WATERSHED. 
(b) Project conducted in cooperation with U.S. Forest Service.

(d) Field investigation; basic research.

(e) To determine the effects of normal, highstandard National Forest Multiple-use management upon the hydrology of the area. observations include rainfall, munoff, air and water temperature, and humidity.

Timber inventories, soll surveys, wildilfe inventories, and evaluations of soll disturbances will be made. Project activities are divided into calibration, development, and evaluation phases.

(g) Results are published in annual reports distributed to cooperating agencies.

(4884) UPPER BEAR CREEK EXPERIMENTAL PROJECT.

(b) TVA Tributary Area Development project cooperative with U. S. Forest Service and Auburn University.

(d) Quantitative determination of the effect of soil type, slope, and vegetative cover upon munoff, peak discharge, and erosion on small watersheds progressing to large watersheds. Development of procedures to make data usable in projecting effects from small watersheds to larger drainage areas and to transfer results of the study to ungaged areas.

(e) Four general types of land cover and use will be considered in the study of the watersheds that progress downstream from areas of several hundred acres through intermediatesized watersheds to a drainage area of 143 square miles.

(f) The instrumentation phase of the project was nearly completed in 1963.

(g) Results will be published in annual reports. 
H. G. ACRES \& COMPANY LIMITED, Hydraulic Laboratory.

Inquiries concerning the following projects should be addressed to Mr. F. H. Jonker, Head, Hydraulic Department, H. G. Acres and Company Limited, Consulting Engineers, Nlagara Falls, Canada.

(5083) SPILLWAY MODEI FOR THE WOODSTOCK FLOOD CONTROL RESERVOIR.

(b) Vance, Needles, Bergendoff and Smith Limited, Consulting Englneers, Woodstock, ontar1o.

(d) Experimental; design.

(e) Tests were performed on a 1:50 scale movable bed model, to determine rating curves for the sector gates, and to develop the dimensions of the downstream stilling basin.

(f) Tests completed.

g) The model tests indicated that the major dimensions of the stilling basin and the downstream slope protection were determined by the asymmetrical flow conditions which occurred when only one or, two of the gates were operated.

(h) Report submitted to client.

(5084) DIVERSION STRUCTURE MODEL FOR THE MACTAQUAC HYDRO-ELECTRIC DEVELOPMENT.

(b) The New Bmanswick Electric Power Commission.

d) Experimental; design.

(e) Tests were carried out on 1:75 and 1:120 scale movable bed models to determine the most efficient configuration of the upstream approaches, the required dimensions of the diversion structure, and the required apron level and appurtenances for the downstream stilling basin to provide adequate energy dissipation.

(f) Tests completed.

(g) The test results indicated that to minimize contraction losses at the diversion structure, a spur dyke was required, constructed out from the upstream cofferdam, to deflect the river flow and turn it through a large radius arc. Eneggy dissipation was achieved by using 17.5 feet baffle plers and a 9.5foot dentated end sill in a 255-foot long stilling basin.

(h) Report submitted to, client.

(5085) MODEL TESTS FOR THE PROPOSED MACTAQUAC HYDROELECTRIC DEVELOPMENT.

(b) The New Brunswick Electric Power Commission.

d) Experimental; design.

(e) Model tests were made using a 1:120 scale movable bed model of the project area to determine; the optimum configuration of the approach channel to the main spillway and powerhouse; and the dimensions of the downstream roller bucket. Tests were also completed to determine the most efficient location for log booms to permit passage of 200,000 cords of pulpwood in a 3-day period and for fish ladders to handle up to 10,000 salmon in a six-month period.

(f) Tests completed.

(h) Report submitted to cllent.

(5086) MODEL TESTS OF A HORIZONTAL MOVEMENT INDICATOR FOR THE GRAND RAPIDS GENERATING STATION.

(b) Manitoba Hydro-Electric Commission.

d) Experimental; design.

(e) A study to determine the accuracy with which horizontal movement of the intake structure could be measured was carried out using a $1: 3$ scale model. The sensitivity to temperature variation and local vibration of a submerged float which will be anchored by a wire to sound bedrock at the bottom of a 100-foot shaft was investigated.

(f) Tests completed.

g) The test results indicated that such an instrument was not affected by local vibration but that it accurately recorded any movement of the structure due to thermal expansion and contraction and would therefore require field calibration before horizontal movement of the structure can be evaluated. (h) Report submitted to client.

(5087) EFFECTS OF THE LOCATION OF A TAILRACE WEIR ON TURBINE EFFICIENCY.

(b) Corporacion Autonoma Regional Del Cauca, Cal1, Colombia.

(d) Experimental; design.

e) The tallrace for the Calima II Hydro-Electric Project will discharge into the Rio Calima at right angles to the river. A tallrace weir is located between the draft tube outlets and the river channel. Model tests were carried out on a $1: 10$ scale model of the draft tube and the tailrace configuration, to determine the relative effects on turbine efficiency resulting from a variety of tallrace apron slopes and welr distances downstream from the draft tube exit.

(i) Tests completed.

(h) Report submitted to client.

(5088) MODEL TESTS OF CHUTE SPILLWAY FOR THE CALIMA II HYDRO-EIECTRIC PROJECT.

(b) Corporacion Autonoma Regional Del Cauca, Cali, Colombia.

(d) Experimental; design.

e) Model tests are being carried out on a $1: 32.8$ scale movable bed model to determine: (1) The discharge characteristics of the ogee shaped spillway, which is constructed on an arc. (2) The magnitude and frequency of pressure fluctuations on the 240-metre long chute which drops 46 metres. (3) The optimum shape of the downstream flip bucket.

UNIVERSITY OF AIBERTA, Hydraulics Laboratory.

(4921) IABORATORY MODEL STUDIES OF SEA WATER INTRUSION.

(b) Govermment of Barbados and University of Alberta.

(c) Prof. J. P. Verschuren, Dept of Civil Engineering, Univ. of Alberta, Edmonton, Alberta, Canada.

(d) Laboratory study, master's thesis.

(e) Study of fresh water - salt water interface location under pumping and non-pumping conditions. Two different size models were used and results plotted non-dimensionally. Test will be carried out in the field to check results and in laboratory using bigger models.

(B) Under certain conditions the Ghyben-Herzberg relation does not hold. The inverted cone of depression of the interface is not symmetrical under influence of the horizontal velocities of the fresh water. Pumping at more points with lower rates reduces the salt water intrusion and loss of fresh water to the ocean.

(h) "Two Density Subsoll Flow in a Coastal Aquifer," H. A. Sealy, M.Sc. Thesis, 1963.

(4922) ALBERTAN CO-OPERATIVE STUDIES OF RIVER REGIME.

(b) Field research financed by NRC grant.

c) Dr. T. Blench, Dept. of Civil Engineering, Univ. of Alberta, Edmonton, Alberta.

(d) Observational and theoretical basic research.

e) Investigate small gravel river selfadjustment for vanishingly small bed-load charge, relatively steady flow, no suspended load, and limited meandering.

(f) Complete part of continuing program by cooperating group.

(g) Confirmed laboratory finding that $F_{p o}$ depends on relative stone size, within limits, as well as on stone size. Confirmed utility of Wolman method of estimating gravel size. Suggested that, for depth very small relative to stone size and for unduned bed-movement, behavior might be explained in terms of a fourth root friction factor combined with a relation between tractive force and stone size as in non-moving bed. Laboratory 
demonstration of building up of gravel river followed by degradation when bed-load ceased. (h) "Gravel Rivers with Low sediment Charge," Rolf Kellerhals, dipl.ing.ETH. M.Sc. Thesis, University of Alberta, 1963.

\section{UNIVERSITY OF BRITISH COLUMBIA, Hydraulics Lab.}

(4451) HEAD LOSS IN SPHERICAL AND CONVENTIONAL WYES.

(b) Laboratory project.

(c) Dr. E. Ruus, Dept. of Civil Engineering, University of British Columbia.

(d) Applied research.

(e) The spherical wye due to its small d1mensions is particularly suitable as a wyebranch in large penstocks under high head. A Lucite model of a spherical wye was constructed and the head losses measured. Models for conventional type of wyes are under construction. For all wyes the inside diameter of the main pipe and the branch pipes are $51 / 4$ and $33 / 4$ inches respectively. Several modifications such as tapered outlets, rounded corners and different sphere diameters are being investigated.

(h) Report in preparation.

(4902) FLOOD SYNTHESIS AND FORECASTING FOR THE FRASER RIVER.

(b) British Columbia Disaster Relief Fund Committee.

(c) Dr. M. C. Quick, Dept. of Civil Engineering.

(d) Mainly theoretical, using existing meteorological and hydrological data, but some extra fleld and laboratory work is being undertaken.

(e) Starting with meteorological data, an attempt has been made to synthesise the 1948 Fraser Flood. Data for other peak flow years has also been examined. From this study a method is being developed to assess the probability of certain peak flows. The present experimental project is concerned with soil temperature gradients and freezing levels under the snow.

(h) Preliminary report in preparation.

(4903) FORCES ENCOUNTERED BY A CYLINDER IMMERSED IN FLOWING WATER.

(b) Laboratory project.

(c) Dr. M. C. Quick, Dept. of Civil Engineering, Univ. of British Columbia.

(d) Experimental and theoretical; basic research. Much of the experimental work 1 s being done by an M.A.Sc. student.

(e) The maln purpose is to study the varlation of lateral and drag forces with the permitted amplitudes of vibration of the cylinder. Various methods of stabilizing the cylinder to reduce or remove the osclliating forces, are being investigated.

(4904) FISH PASSAGE THROUGH HYDRAULIC TURBINES INFLUENCE OF INJECTION OF COMPRESSED AIR ON FISH MORTALITY.

(b) Laboratory project.

(c) Dr. E. Ruus, Dept. of Civil Engineering, Univ, of British Columbia.

(d) Experimental; applied research. Much of the experimental work is being done by an M.A.Sc. student.

(e) Cavitation is considered as a major factor contributing to the mortality of fish passing through a hydraulic turbine. Injection of compressed air in the regions of maximum cavitation results in a significant reduction in cavitation. This project is being undertaken to determine the extent of reduction in fish mortality resulting from the injection of compressed alr Into the penstock or draft tube. In a serles of tests young salmon will be injected into the penstock and will pass through a $10 \mathrm{In}$. dia. four-bladed model propeller wheel. The turbine will operate under different conditions of speed, gate opening and sigma.

ECOLE POLYTECHNIQUE, Department of C1Vil Engineering,

(4043) STUDY OF THE RELIABILITY AND OPERATION OF BACK-WATER VALVES ON PLUMBING SYSTEMS AGA INST FLOODING BY PUBLIC SEWERS.

(b) C1ty of Montreal, C1ty Planning Department, Inspection Division.

(c) Professor Raymond Boucher, Director, Hydrodynamics Laboratory, Ecole Polytechnique, 2500 Marle-Guyard Avenue, Montreal 26, Quebec, Canada.

(d) Experimental; applied research.

(e) A full scale three-story plumbing system has been erected in the Hydrodynamics Laboratory of Ecole Polytechnique. The diameter of the pluvial column, the soll stack and the drain is 4 inches. The drain has many sections of pyrex glass to permit observations at critical points. A system of valves and of cross-connections on the vents lends to various combinations of tests. The back-water valves have a transparent lucite cover to enable visual observations. As air entrainment has a great importance on the venting capacity, the rate of air entrained in the vertical columns is measured at the inlet by means of a hotwire alr-meter. Various flooding conditions of the public sewers are simulated by a tank in which the water level can be controlled by gate valves. This research is aimed at determining whether back-water valves can offer home dwellers a reliable protection against flooding due to any overload of combined sewers. If this method is not satisfactory, an improved design of plumbing system may be suggested.

(f) Reactivated.

(g) The mechanism of air entrainment has been studied and tests have revealed the best position for some of the vents.

(h) Interim report entitled "Étude expérimentale des soupapes de sûreté contre les surcharges d'égout" submitted to sponsor.

(5089) MODEL TESTS OF THE PILLUR DAM SCOUR VENT FOR THE KUNDAH HYDRO-ELECTRIC PROJECT, INDIA.

(b) Canadian Vickers Iimited.

c) Professor Raymond Boucher, Director, Hydrodynamics Laboratory, Ecole Polytechnique, 2500 Marie-Guyard Ave., Montreal 26, Quebec, Canada.

(d) Experimental; applied research. the hydraulic performance of a scour vent for different headwater and tallwater conditions. The model built to a scale of $1: 20$ comprises a hydraulic inlet flared in three directions, a vertical lift emergency gate, a radial type control gate and an energy dissipator.

The experimental investigation is primarily concerned with (1) the development of cavitation free entrance shapes, (2) the determination of the hydraulic thrust on the emergency gate for different openings and discharge conditions, (3) the observation of mechanical vibrations on the gates, and (4) the performance of the energy dissipator.

THE HYDRO-EIECTRIC POWER COMMISSION OF ONTARIO, Hydraulic Model Laboratory.

Inquiries concerning the following projects should be addressed to Mr. J. B. Bryce, Hydraulic Engineer, Hydraulic Generation Department, 620 University Avenue, Toronto 2 , Ontario, Canada.

(3324) ST. IAWRENCE RIVER MODEL - OGDENSBURG TO 
LEISHMAN'S POINT.

(b) Ontario Hydro and the Power Authority of the State of New York.

(d) Experimental; for design, development and operation.

(e) A 1:500 × 1:100 scale model of St. Lawrence River between Ogdensburg and Leishman's Point, a distance of 16.1 miles, was constructed to determine the design of channel enlargements, the location of the Iroquols during construction of the St. Lawrence Power Profect. The locations and conditions for a series of six ice booms for ice control were determined.

(f) Work is completed and model removed.

g) Channel enlargements were developed which met the criteria stipulated by the International Joint Commission with respect to navigation and ice-forming velocities and the seaway navigation channel was located. The optimum arrangements and location for the Iroquois Control Dam was determined. A plan of river control during construction was developed. Log booms for ice control have been successful since their installation in the prototype.

(4026) NIAGARA RIVER MODEL.

(b) ontario Hydro.

d Experimental; for design and operation.

e) An existing 1:250 x 1:50 scale model reproducing five miles of the Niagara River from Buckhom Island to below the Cataracts is being used to determine the operational characterlstics of the Niagara River Control Structure under developed conditions. This model was previously used to investigate the remedial works necessary for the Preservation and Enhancement of Niagara Falls and for the location of the intakes and necessary river improvements of both ontario Hydro and the Power Authority of the State of New York. To fully realize the terms of the 1950 Niagara Treaty, additional remedial works have been designed. These include a five-gate extension to the existing 13-gate control structure as well as a system containing an upstream accelerating wall, a downstream training wall and overflow weir for the safe passage of ice past the various intakes along the Canadian shore of the river above the Falls. The sequence of construction of these works and the conditions during their construction were determined in the model. Rating of the structure under cofferdammed conditions was obtained. An echo-sounding survey with electronic fixing was made in the field in 1962 and portions of the model re-contoured. Certain river improvements were designed and executed to assist in the passage of ice floes.

(4454) ONTARIO POWER GENERATING STATION - INTAKE AND WEIR MODEL.

(b) Ontario Hydro

d Experimental; for design and operation.

(e) A l:50 scale model was built of the ontario Power outer forebay intake wall and a portion of the downstream training wall and overflow weir, which are a part of the extension to the Niagara River additional remedial works. The design of the weir and wall as developed in the distorced Nlagara Model was checked in this natural scale model.

(f) Work is completed and model removed.

(g) The requirement of the International Joint Commission that the downstream training wall be covered by water during the Tourist season Days, was fulfilled.

\section{(4455) ARROW LAKES DAM - COLUMBIA RIVER.}

(b) British Columbia Hydro and Power Authority.

d) Experimental; for design and operation.

(e) An 1:80 scale model of the Arrow Lakes and dam and environs was built to determine the detailed location and adequacy of the water passages in a concrete structure and the energy-dissipating works necessary to ensure the protection of an associated earth dam. Numerous tests have been made with a movable bed of fine sand to determine erosion characteristics and navigation velocities upstream and downstream of a lock situated between the concrete structure and the earth dam.

A l:50 scale model was tested in a flume to determine the hydraulic design of the tunnel ports in the concrete structure and to develop the assoclated energy-dissipating work. Rating of these ports was obtained as well as the hydraulic loadings on the port gates. A 1:60 scale model of one of the four sluiceways is being tested in the flume to determine the rating of the sluice and the hydraulic loadings on the sluice gate. Plezometers are being used to determine under varying conditions of flow, the rollway pressures as well as the pressures at selected locations in the energy-dissipating bucket and associated tooth-like projections of the dissipatar.

\section{(4508) LITTLE LONG MAIN DAM MODEL.}

(b) ontario Hydro.

d) Experimental; for design and operation. A I:80 natural scale model was constructed of the main dam containing two submerged tunnel ports and five sluiceways with staggered sill elevations. Discharge capacities of these components were determined as well as several schemes of closure in raising the head pond. Conditions dowmstream of the structure at several access bridge piers were studied.

(f) Work is completed, and model removed.

(в) Headpond was filled during spring freshet this year as per model schedule.

\section{(4509) HARMON GENERATING STATION MODEL.}

(b) Ontario Hydro.

(d) Experimental; for design and operation. of the main dam, two submerged ports and two sluiceways. A diversion channel was designed with associated cofferdams for use during construction. Capacities of ports and sluices were determined. Location of downstream access bridge plers was determined. A ski-jump type energy dissipator for the sluiceways was also designed.

(f) Model is still active.

(4510) DOUGLAS POINT CIRCULATION MODEL.

(b) Atomic Energy of Canada Limited.

(d) Experimental; for operation. scale model was constructed of an area oneand-a-half miles by three miles of Lake Huron in the vicinity of the Douglas Point nuclear plant intake and outfall. The circulation of the cooling water from the outfall with respect to the intake was investigated with littoral drifts of different velocities and opposite directions, as well as no drift.

(f) Work is essentially completed, but model is still active.

\section{(45II) CLATREVILLE DAM MODEL.}

(b) Metropolitan Toronto and Region Conservation Authority.

(d) Experimental; for design

e) A 1:40 natural scale model of the dam and its environs was built and the capacity and rating of the five sluiceways determined. Schemes of various energy dissipators were investigated and a design recommended.

(f) Work is complete, and model removed. g) Sluiceway capacity was determined and a

(4512) WESTERLY WATER PURIFICATION PLANT MODEL. 
(b) The municipality of Metropolitan Toronto.

(d) Experimental; for design.

(e) A 1:8 plastic model of one of the bays of a water purification plant was constructed. It contaired the main manifold with 1 ts assoclated laterals and the filter and backwash cycles will be checked to ensure as uniform a distribution of flow as possible through the lateral beds.

(f) Work $1 \mathrm{~s}$ completed and model inactive.

(g) The head losses in the main manifold and distribution system were obtalned for both filter and backwash cycles. A report of the findings was made to the consulting engineering flirm.

(4963) KIPLING GENERATING STATION MODEL.

(b) Ontario Hydro.

d) Experimental; for design.

(e) A $1: 80$ scale comprehensive model has been constructed of the main dam containing two submerged tunnel ports and two sluiceways to determine the dewatering arrangement for construction, cofferdam location and elevations, velocities during closure of cofferdam and the rating of the diversion ports during construction of main dam and sluiceways.

(4964) LAKEVIEW THERMAL GENERATING STATION RECIRCULATION STUDY OF CONDENSER COOLING WATER.

(b) Ontario Hydro.

d Experimental; for design and operation.

(e) A 1:24 natural scale model is being constructed of the intake channel and pump wells for the condenser cooling water of the elght 300-megawatt thermal units. A study will be conducted to determine the best method of introducing warm condenser recirculation water upstream of the pump wells to prevent ice difficulties at the travelling seasons.

(f) Model is under construction.

LASALLE HYDRAULIC LABORATORY LTD.

(4456) VELOCITY AND DIRECTION OF CURRENT RECORDER.

(b) Laboratory Project.

d) Experimental - development of instmument for hydrographic and oceanographic research for acquisition of datum in computable form (punched tape).

(e) Recording of velocity by impulse counter for propeller type current-meter. Recording of direction by reading an encoder monitorized by a marine compass. Instrument must be: 1) rugged, 2) simple and easy to maintain, 3 very low power drain for long perlods. (recording up to 6 months under ice).

(g) Prototype routine tests equivalent to 2 years without fallure have been carried out. These prototypes are under construction and will be tested at sea early in 1964. Depth up to 2000 feet. Patent pending.

(4517) MONTREAL - SOREL SHIP CHANNEL.

(b) Department of Transport.

d) Theoretical and experimental: design.

(e) Two models representing a section of the St. Lawrence River from Laprairle Basin including Montreal Harbour to Sorel Islands were built at a scale $1 / 150$ vertically and $1 / 600$ horizontally.

The purpose of the model was to study the improvement of a a gation in this section of the St. Lawrence River.

(4521) MANICOUAGAN 5: BOTTOM OUTLET

(b) Quebec Hydro and Surveyer, Nenniger and Chenevert.

(d) Experimental; design.

(e) A $1 / 60$ scale model was bilt to study the best design for the bottom outlet with regard to the erosion downstream of the structures. This model was also used for pressure measurements on the structures.

(f) Completed.

(h) Report submitted to sponsor.

(4522) BRAZEAU OUTLET WORKS PROJECT.

(b) Dominion Bridge Co. Ltd.

d) Experimental; design.

(e) Study on a $1 / 36$ scale model of the hydraullc forces and possibility of vibration of the headgates provided at the entrance of the pump turbine units and operated against direct or reverse flow.

(f) Completed.

(h) Report submitted to sponsor.

(4523) PERFORATED BREAKWATERS.

(b) Laboratory project.

(d) Basic research.

(e) Theoretical and model study of swell reflexion against vertical perforated breakwaters. A serles of tests were conducted in a two-dimensional wave flume at a $1 / 30$ scale in order to obtain a better understanding of the advantages, limitations and possible use of perforated breakwaters.

(f) Completed.

(h) The Englneering Journal.

(4965) ST. TIMOTHEE REACH.

(b) Hydro - Quebec

(d) Experimental; design.

(e) Study on an undistorted $1 / 100$ scale model of the water level control in the St. Timothee Reach.

(4966) WHITESHELL NUCLEAR RESEARCH ESTABLISHMENT.

(b) Atomic Energy of Canada, and Shawinigan Engineering Co. Ltd.

(d) Experimental; design.

(e) A $1 / 7$ scale model was used to study the proper design of the water intake pump of the main pumping station in order to ensure a good operation of the pumps.

(f) Completed.

(g) Report submitted to sponsor.

(4967) OAKVILLE REFINERY WHARF.

(b) Foundation of Canada Englneering Corp.

d) Experimental; design.

(e) The study concerns the stability of cells which are subjected to severe erosive action of waves. Tests with $1 / 30$ scale cell were conducted in a 16 foot wave flume.

(f) Completed.

g) Report submitted to sponsor.

(4968) RAPIDE BIANC PROJECT.

(b) Shawinigan Engineering Co. Ltd.

d Experimental; design.

(e) Study on a $1 / 48$ scale model of the modifications to be made on Spillway No. 1 in order to suppress the large vibrations which appear when the gate is partlally opened.

(f) Completed.

(h) Report submitted to sponsor.

(4969) BIG CHUTE LOCK.

(b) Department of Transport.

d Theoretical and experimental; design.

(e) A $1 / 20$ scale model of this lock, which forms part of the Trent River navigation facilities, was used to determine filling and emptylng conditions, intake and outlet flow characteristics as well as the hydraulic flow conditions along the whole water conducting circuit.

(f) Completed.

(h) Report submitted to sponsor. 
UNIVERSITY OF MANITOBA, Hydraul1es Laboratory.

Inquirles concerning the following projects should be addressed to Professor E. Kulper, Department of Clvil Englneering, University of Manitoba, Fort Garry, Manitoba, Canada.

(4548) SOUTH SASKATCHEWAN RESERVOIR SEDIMENTATION.

(b) Prairle Farm Rehabilitation Administration, Regina.

(d) Experimental project to determine nature of deposition of sediment.

(e) The upper 80 miles of the South Saskatchewar Reservolr were reproduced as a length ratio of 1:15,000; a width ratio of 1:1500; and a depth ratio of $1: 40$; resulting in a model that was 30 feet long, 4 feet wide and 3 feet deep. The model was operated in accordance with the prototype fluctuations in discharge, sediment transport and reservolr level. The purpose of the tests was to study the pattern of deposition in longitudinal direction.

(f) Testing is completed on deposition of uniform material. The model 1 s now being used for tests to determine the deposition pattern of sand and silt; and the behaviour of density currents.

(g) Regarding deposition of uniform material it was found that the slope of the delta surface between the upper and lower reservoir levels approximates the slope of the river bed. The slope below $1 \mathrm{~s}$ substantially steeper. The slope above follows the backwater curve towards normal depth.

(4550) RED RIVER FLOODWAY INLET MODEI.

(b) Water Control Branch, Province of Manitoba.

(d) Experimental project to aid in the design of the inlet works of the Red River Floodway.

(e) The upper end of the Floodway, the control dam with dmum gates, and two miles of Red River Channel were reproduced at a hor zontal scale of $1: 120$ and a vertical scale of $1: 60$, resulting in a model of $40 \times 160$ feet. Tests were conducted with artiflcial surface $1 \mathrm{ce}$ to study the formation and behaviour of $1 \mathrm{ce}$ Jams at critical points in the river system.

(f) Tests completed.

(g) Tests indlcated what places in the river system were most susceptible to 1 ce Jams and what size of lce floes were critical for the formation of lce Jams.

(h) Report under preparation.

(4551) MEANDERING OF ALIUVIAI RIVERS.

(b) University of Manitoba.

(d) Basic research in the hydraulics laboratory towards a masters degree.

(e) Verification of established river regime under available laboratory conditions. Plans are being made for a study of sediment movement in river bends.

(f) Tests are being continued.

(5253) WAVE RUN-UP ON SMOOTH AND ROUGH SLOPES.

(b) University of Manitoba.

(d) Basic research in the hydraulics laboratory towards a master's degree.

(e) Tests were conducted in a flume of 3 feet wide, one to two feet deep, and 44 feet long. A wave generating mechanism produced waves of 0.08 to 0.58 feet in helght. The wave period could be changed from one to four seconds. Smooth and rough slopes were tested, ranging from vertical to 1.8 .

(f) Tests completed.

(b) An inltial series of tests verifled previous tests performed by R. P. Savage and reported in the Proceedings of the ASCE. Subsequent tests were conducted with extra large riprap, having the same dimensional range as the Impinging wave height. Charts were produced establishing the relations between wave helght, wave perlod, diameter of rip rap, and wave uprush.

(h) "A Model Study of Wave Run-up on Smooth and
Rough Slopes," by Kenneth M. Adam. Part requirement for degree of M.Sc. from Univ. of Manitoba.

(5254) WIND SET UP ON LAKES.

(b) UnIversity of Manitoba.

(d) Basic research in the hydraulics laboratory towards a masters degree.

(e) Tests were conducted in a flume of 3 feet wide, and 44 feet long. The depth of water was a few Inches. The alr space above the water surface was one foot. WInd setup was determined for different wind velocities, different plan shapes, different proflles, and different bottom roughness.

(f) Tests completed.

(g) Data are being analysed.

(h) Report under preparation.

(5255) MOVABIE BED MODEL SCAIES.

(b) University of Nanitoba.

(d) Basic research in the hydraulics laboratory towards a masters degree.

(e) Tests are being conducted in a movable bed channel, 4 feet wide, 1 foot deep, and 20 feet long. Erosion patterns are being studied, resulting from a coffer dam that blocks of $\mathrm{f}$ alf of the channel cross-section. Tests will be conducted how the same erosion pattern can be produced with smaller models, and different bed materials.

(f) Tests are belng conducted.

MCGIII UNIVERSITY, Department of C1V1l Engineering and Applied Mechanics.

(4545) BREAKUP OF SOLITARY WAVE.

(b) Laboratory project.

(c) Dr. A. J. Reynolds, Dept. of Civil Engineering and Applied Mechanics, McGill University, Montreal 2, P.Q., Canada.

(d) Experimental; basic research.

(e) Examination of disintegration of a solitary wave in shallow water on encountering deep water.

(f) Apparatus constmucted.

(4546) CAVITATION AT HIGH-HEAD SLUICE GATES.

(b) Laboratory project.

(c) Dr.A.J. Reynolds, Dept. of Civil Engrg. arr Applied Mechanics, McG1ll Un1v., Montreal 2, P. Q., Canada.

(d) Experimental; applied research, for Master's degree.

(e) Study of pressure fluctuations on wall behind an obstruction which produces cavitation.

(f) Smali syphon tunnel built.

(4923) DIVISION OF OPEN-CHANNEI FLOW.

(b) National Research Counc1l, Canada.

(c) Dr. A. J. Reynolds, Dept. of Civil Engineering and Applied Mechanlcs, McGill UnIv., Montreal 2, P.Q., Canada.

(d) Experimental; basic research, for Master's degree.

(e) Detalled examination of flow at junction between stralght channel and a branch at $90^{\circ}$.

(4924) WAVES IN AND NEAR PACK ICE.

(b) Defence Research Board, Canada.

c Dr. A. J. Reynolds, Dept. of Civil EnglneerIng and Applied Mechanics, MeGill Univ., Montreal 2, P.Q., Canada.

(d) Theoretical and experimental; basic and applied research, for Master's degree.

(e) Study of fundamental mechanical processes of interaction between surface waves and floating elastic bodies.

(h) Internal reports: "Wave celerity in a Floating, Elastic Plate", "The Energy of Waves in 
NATIONAL RESEARCH COUNCIL, Division of Mechanical Engineering.

Inquiries concerning the following projects should be addressed to Dr. D. C. MacPhail, Director, Division of Mechanical Engineering, National Research Council, Montreal Road, Ottawa, Ontario, Canada.

(4047) BAIE CONEAU, PROVINCE OF QUEBEC.

(b) Department of Public Works, Canada.

d) Experimental; for design.

(e) The new development of the harbour is completed. It involves a perforated verticalwall breakwater, $1000 \mathrm{ft}$. long, $60 \mathrm{ft}$. w1de, $56 \mathrm{ft}$. high, built as the extension to an existing wharf.

(g) Observations have shown the breakwater to perform in a satisfactory manner during storms. The wave run-up appears to be suppressed and no erosion can be observed at the toe. The breakwater can thus provide berthing facllities as well as harbour protection.

(4464) RUSTICO HARBOUR, PRINCE EDWARD ISLAND.

(b) Department of Public Works, Canada.

d) Experimental for design.

(e) A $1: 150$ by ':30 wave and tidal model with movable bec of crushed bakelite was made to study harbour inlet instability and to determine suitable remedial measures.

(f) Model study completed and recommendations issued to sponsor

(8) Shallow water interaction between waves and currents found to be responsible for instability rather than littoral drift.

(h) "Basic Experiments on the Development of Coastal Inlets W1 th and Without Wave Action," K. L. Philpott, Proc. Xth I.A.H.R. Congress, pp. 303-310, London, September 1963.

(4466) AIR BUBBLERS.

(b) Laboratory project.

d) Experimental; field investigations. Fleld measurements and laboratory tests were performed to determine the mechanism whereby an air bubbler prevents 1 ce formation in an oceanic environment.

(g) Field measurements afforded a clear picture of the mechanism and heat balance of the air bubbler operation. In most oceanic environments the air bubbler will be effective with varying degrees of efficiency.

(4525) FORMATION OF ICE IN RIVERS.

(b) Laboratory project.

d) Experimental; field investigations.

(e) Water temperatures are being recorded in the St. Lawrence River between Kingston, ontario, and Three Rivers, Quebec, to obtain information on heat losses.

(g) Preliminary calculations show satisfactory agreement between measured and computed heat losses. For closer correlation more precise measurement of meteorological conditions- particularly radiation- will be necessary.

(4527) TIDE PROPAGATION IN AN ESTUARY.

(b) Laboratory project.

d) Theoretical and experimental.

(e) During the last 25 years, several structures have been built in the estuary of the Fraser River, B.C., to increase locally the depth of the navigation channel. A $1: 1440$ by $1: 144$ fixed-bed model of the entire tidal section has been constructed to determine the actual effect of such structures on the tidal propagation.

(g) The model has been calibrated for different
(4528) EFFECT OF EARTH'S ROTATION ON RIVER FLOW.

(b) Laboratory project.

d) Theoretical and experimental.

(e) Considerations of gravity and coriolis forces acting in fast-flowing, straight rivers of small slope indicate that considerable spiral flow is possible. A small rotating table has been constructed to study flow in channels in a rotating system.

\section{(5090) CODROY HARBOUR, NEWFOUNDLAND.}

(b) Department of Public Works, Canada.

d) Experimental, for design.

(e) A $1: 180$ by $1: 120$ fixed-bed wave and current model of the harbour has been constructed to investigate silting conditions in the harbour entrance and to devise remedial works.

(5091) ST. BRIDES HARBOUR BREAKWATER, NEWFOUNDLAND.

(b) Department of Public Works, Canada.

d) Experimental for design.

e) A $1 / 36$ scale model of a proposed partially submerged breakwater was tested in a wave flume to determine its effectiveness in providing protection seaward of an existing structure.

(f) Completed, results reported to sponsor.

(5092) BRANCH HARBOUR, NEWFOUNDLAND.

(b) Department of Public Works, Canada.

d) Theoretical for design.

(e) A study of methods of reducing or eliminating the need for regular maintenance dredging, by making use of a river for flushing combined with reduction of littoral drift passing the harbour entrance.

(5093) GENERAL HARBOUR STUDIES.

(b) Laboratory project, sponsored in part by Dept. of Public Works, Canada.

(d) Field and theoretical, applied research.

(e) A general study of the hydraulic aspects of harbour design with the eventual objective of standardizing procedures and, if possible, designs, for relatively simple situations nơ requiring model studies. The first stage concerns evaluation of design conditions and in this connection a method of processing wind data for estimation of wave probabilities is under study.

(5094) PERFORATED VERTICAL-WALL BREAKWATER.

(b) Laboratory project.

d) Experimental and theoretical.

(e) Two-dimensional flume experiments are being made to determine the behaviour of an erodible bed in front of the breakwater.

(g) Results obtained hitherto indicate that, for a non-cohesive bed, no erosion develops at the toe of the breakwater regardless of the wave height or period.

(h) A report will be prepared.

(5095) DINGWALL HARBOUR, NOVA SCOTIA.

(b) Department of Public Works, Canada.

d) Experimental.

(e) Model study of a harbour subject to heavy sedimentation (sand) induced by waves.

(f) The model study has been completed, but the study is still active.

(g) The harbour entrance has been rebuilt. It involves four rubble-mound breakwaters forming a wave energy trap. Results indicate that no shoaling of the entrance occurs.

(h) Report is in preparation.

(5096) SAULNIERVILLE HARBOUR, NOVA SCOTIA.

(b) Department of Public Works, Canada. 
(d) Theoretical and field investigation.

(e) Development of a new harbour involving a perforated vertical-wall breakwater.

$$
\text { - - - }
$$

(g) Water table depths were determined with the resistivity method in glac1o - lacustrine sands. A report is in preparation.

(3660) RAINFALI-DEPTH-AREA-INTENSITY REIATIONSHIPS IN CENTRAL ONTARIO.

\section{ONTARIO AGRICULTURAL COLIEGE.}

(2492) RUNOFF FROM SMALL WATERSHEDS.

(b) Laboratory project.

(c) Prof. H. D. Ayers, Ontario Agricultural College, Guelph, Ontario, Canada.

(d) Experimental; applied research.

(e) The relationship of precipltation and snowmelt to runoff characteristics on four watersheds of 20 acres each, under various land use practices, is being evaluated.

(g) Winter surface runoff from watersheds with good grass-legume cover is greater than from watersheds plowed during the winter season. Negligible surface runof f from watershed in trees and pasture.

(2740) MAIN TILE DRAIN SIZES FOR COMPOSITE DRAINAGE OF BROOKSTON CIAY SOIL.

(b) Laboratory project.

(c) Prof. F. R. Hore, Ontario Agricultural College, Guelph, Ontario, Canada.

(d) Fleld investigation; applied research.

(e) Discharge measurements from lateral tile drains in Brookston clay soll are being made to determine the proper drainage coefficlent to use in the design of main tile drains and to determine the effect of lateral tile drain spacing on the drainage rate.

(g) Preliminary frequency analyses have been made on runoff data collected over a 5-year period.

(h) "Flow Characteristics of Tile Drains in Fine-Textured Solls," by F. R. Hore. Can. Agric. Engr., Vol. 5, No. i, pp 17-i8;20,38. 1963.

\section{(3363) HYDROLOGIC CHARACTERISTICS OF ORGANIC SOIL.}

(b) Laboratory project.

c) Prof. R. W. Irwin, ontario Agricultural College, Guelph, Ontario, Canada.

(d) Fleld investigation; applied research.

(e) The study is belng carrled out to establish criterla to be used in the development and operation of a water control project for organic solls. In the investigation, an attempt will be made to establish a hydrologic water balance for the field area by measuring, recording, and analyzing so far as possible the evaporation, seepage, transpiration, precipitation, water table elevation and ground water discharge through tile drains.

(g) Data collection is continuing. The physical properties of the organic soli have been determined and the results are presently being analyzed.

(h) "Determination of a Procedure for the Measurement of Subsidence of Organic Soll," C. Mirza. M.S.A. thesis on file in Massey Library, ontario Agricultural College, 1963.

"Progress Report on Hydrologic Investigation of Organic Soll," R. W. Irwin. Proc. 9th Canadlan Muskeg Research Meeting, N.R.C., Quebec C1ty, 1963.

"A1r and Soll Temperature Study of Organic Soll", R. W. Irwin. Eng. Tech. Pub. 9, Dept. of Enginearing Sclence, Ontario Agricultural College, Guelph, 1963.

(3658) THE RESISTIVITY METHOD OF GROUND WATER PROSPECTING.

(b) Laboratory project.

(c) Mr.G. J. M. Wessels, Ontario Agricultural College, Guelph, Ontario, Canada.

(d) Field investigation; appiled research.

(e) The objective is to investigate the appl1cation of the resistivity method to subsurface exploration for ground water under the geological conditions found in southern ontario.

(b) Laboratory project.

(c) Pror. H. D. Ayers, Ontanio Agricultural College, Guelph, Ontario, Canada.

(d) Field investigation; appiled research.

(e) A dense network of standard and recording rain gages has been established in the Guelih area with the cooperation of the Meteorololos1cal Branch, Department of Transport. The network 1 s over an area of approximately 12 square miles with an average gage density of 1 per square mile. The purpose of this study is to obtain detailed information on summer precipitation characteristics for use in the hydrologic design for small drainage basins.

(g) Analysis of data shows that for 8 years intensity-frequency relationships are different from nearby stations with longer record.

(3662) POTENTIAL EVAPOTRANSPIRATION AND CONSUMPTIVE USE OF WATER BY CROPS.

(b) Laboratory project.

(c) Dr.K. M. King, Department of Solls, Ontario Agricultural College, Guelph, Ontario, Can.

(d) Field investigations; basic research.

(e) The purpose of this investigation is to evalu ate the factors influencing evapotranspiratio by the use of a specially designed floating lysimeter. Study is being conducted on the effect of soll molsture on the heat budget and evapotranspiration for crops.

(g) Errors due to temperature variations in zinc chloride filled floating lysimeters were found to be much more serious than those in water filled floating lysimeters.

(4052) COVER MATERIALS FOR TIIE DRAINS.

(b) Laboratory project.

(c) Prof. F. R. Hore, Ontario Agricultural College, Guelph, Ontario, Canada.

(d) Experimental and fleld investigation; applied research.

(e) Th1s study is being made to determine the effect of several cover materials on soll movement and water discharged into a tile drain. Laboratory studies of some relatively new glass fiber materials have been completed and a fleld experiment based on those results was installed in the fall of 1960.

(g) Yearly sampling of sediment from drains at the field experimental site are belng continued but no conclusions can be drawn as yet.

(4054) RUNOFF FROM FLAT LAND.

(b) Laboratory project in cooperation with Water Resources Division, Department of Northern Affairs and National Resources.

(c) Prof. F. R. Hore, Ontar10 Agricultural College, Guelph, Ontario, Canada.

(d) Field investigation; appiled research.

(e) Four 2 to 10 square mile flat watersheds of fine-textured solls are to be studied to determine the relationship between preclpitation, snowmelt, watershed characteristics and runoff. Hydrologic data on this type of watershed are being sought for the establishment of criteria for the design of hydraulic structures. The installation of gaging stations is complete.

(4925) MECHANICAL DRAINAGE' OF AGRICULTURAL LANDS.

(b) Laboratory project.

c) Prof. R. W. Irwin, ontario Agricultural College, Guelph, Ontario, Canada.

(d) Fleld investigation; applied research.

(e) Discharge measurements and stage measurements from three pump drainage sites are being recorded together with precipitation values, 
(g) Data collection is continuing.

(h) "Pump Drainage outlet," R. W. Irwin, Can. Agr. Eng. 4: 10-11, 1962 .

"Ditch Storage for Farm Drainage Pumping

Plants," R. W. Irwin. Agr. Eng. 44: 548-549, 1963.

QUEEN'S UNIVERSITY AT KINGSTON, Hydraulic

Laboratories.

(3364) LITTORAL DRIFT AND ITS EFFECT ON THE HARBOURS ON THE NORTH SHORE OF IAKE ONTARIO.

(b) The National Research Council of Canada.

(c) Dr. A. Brebner, Ellis Hall, Queen's Univ., Kingston, Ontario, Canada.

(d) Experimental and field; basic and applied.

e Fleld and laboratory: 3-dimensional models.

(h) Model tests on the Relationship between Deepwater Wave Characteristics and Longshore Currents", by Dr. A. Brebner and J.W.

Kamphuis, Queen's University, Civil Report

No. 31. Available from Queen's University.

"A Model Study of the Breaking of Waves at an Angle with the Shoreline," by Dr. A.

Brebner and J. W. Kamphuis. Proc. 10th Congress of I.A.H.R. London, 1963.

(4057) THE TRANSPORT OF LOGS OR SUSPENDED SOLIDS THROUGH PIPELINES.

(b) The National Research Council of Canada.

c) Dr. A. Brebner, Ellis Hall, Queen's Univ., Kingston, Ont., Canada.

(d) Laboratory investigation but to almost fullsize scale.

(e) The head losses associated with two-phase flow of wood-chips and water.

(g) Wood-chips pumped through $400 \mathrm{ft}$. of 4 "line with good success.

(4468) CRITERIA FOR THE INCIDENCE OF TURBULENCE.

(b) National Research Council.

(c) Prof. R. J. Kennedy, Queen's Univ., Kinston, Ont. Canada.

(d) Basic research.

(e) An apparatus to produce plane Couette flow is used. Both shear intensity and distance between boundaries are independently variable.

(4530) THE VERTICAL PUMPING OF MINE PRODUCTS.

(b) Ontario Mining Association.

(c) Dr. A. Brebner, Ellis Hall, Queen's Univ., Kingston, Ontario, Canada.

(d) Applied research in laboratory.

(e) To establish co-relation between head losses in vertical pumping and particle size, speciflc gravity, concentration, etc.

(g) Work progressing.

UNIVERSITY OF TORONTO, Department of Mechanical

Engineering.

(1.298) DISCHARGE CHARACTERISTICS OF WEIR-TYPE SPILLWAYS.

(b) Laboratory project.

(c) Prof. L. E. Jones, University of Toronto, Toronto 5, Canada.

(d) Experimental; applied research for master's theses.

(e) A long-term research carried out with a view to systematizing discharge characteristics for spillways having various pier spacings and proportions.

(f) A computer project is being undertaken to review all numerical work and to utilize appropriate statistical procedures in the function-fitting.

(g) Significant correlations obtained via special plotting techniques.

(h) Report in preparation.

(3003) ROUGHNESS PHENONENA IN OPEN CHANNEL FLOW. (b) Laboratory project.

(c) Prof. L. E. Jones, University of Toronto, Toronto 5, Canada.

(d) Experimental and analytical; basic research for doctoral thesis.

(e) Critical analysis of the hydraulic radius concept and the effect of cross-section geometry on the resistance to flow in conduits. Detalled evaluation of mean flow parameters such as friction coefficients, static pressures, velocities, and wall shear stresses. The channel under study was 70 feet long and had a variable rectangular cross-section of $3 \times 1,3,9$ inches, respectively, and used air as the fluid medium.

(f) First project completed.

(g) Friction coefficients plotted as function of bulk Reynolds number exhibit a trend similar to but not identical with the circular pipe resistance law. The local velocities correlate well in the form of the inner law provided the local shear velocity is used. The appropriate velocity scale for the outer law correlation is the average shear velocity, but this correlation is not established for Reynolds numbers below $10^{5}$. Static pressures increase toward the center of the ducts.

(h) "The Effect of cross-Section Geometry upon the Resistance to Flow in Conduits," by H. J. Leutheusser, Ph.D. thesis, University of Toronto, October 1961.

"Turbulent Flow in Rectangular Ducts," by H. J. Leutheusser, Journal of Hyd. DIV., May, 1963.

(3368) DIFFUSION OF GASEOUS PLUMES.

(b) Laboratory project.

c) Prof. W. D. Baines, University of Toronto, Toronto 5, Canada.

(d) Experimental and analytical; basic research for Master's thesis.

(e) A jet of air is injected at various angles into a uniform cross-flow. From photographs of the jet containing smoke, and velocities determined with a hot-wire anemometer the shape of the jet and the pattern of dispersin are being studied.

(g) Momentum equations yield parametric relationships for the shape of the jet which have been used to define the path of a jet injected at 90 degrees to the cross-flow. Experiments are in progress with jets entering at other angles.

(h) "The Round Turbulent Jet in a Cross-Wind," by J. F. Keffer and W. D. Baines, Journal of Fluid Mechanics, vol. 15, no. 4, April 1963.

(4064) EFFECT OF GROINS ON LITTORAL TRANSPORT.

(b) Laboratory project.

c) Prof. G. Ross Lord, University of Toronto, Toronto 5, Canada.

(d) Experimental and analytical; applied research for master's thesis.

(e) The motions of individual sediment particles of various sizes and densities were studied on a solid plane beach of $1: 10$ slope at 45 degrees to the wave direction. Direction and magnitude of the particle velocities and the effect of groins upon particle motion were studied.

(g) Wave induced currents have been analyzed and compared with experimental results. After minimizing the effects of nearshore circulation, equations are derived for littoral transport velocities of spherical particles for the given beach and wave configuration. Modification of existing refraction theories is proposed.

(h) Report in preparation.

(4065) EFFECTS OF VELOCITY DISTRIBUTION ON WIND LOADS ON BUILDINGS.

(b) Division of Building Research, National Research Council of Canada.

(c) Prof.W. D. Baines, University of Toronto, Toronto 5, Canada. 
(d) Experimental; applied research for design information.

(e) An artificlally thickened boundary layer has been created in a wind tunnel. Mean and fluctuating pressure distributions around typical shapes are being measured.

(g) Measurements of the effect of parapets on different shape of bulldings indicate that, in general, for higher parapets the peak suction is less but the average lift on the roof is greater.

(h) "Effect of Velocity Distribution on wind Loads and Flow Pattems Around Buildings" W. D. Baines, Proceedings, Symposium on wind Effects on Buildings and Structures, National Physical Laboratory, Teddington, June 1963.

(4469) DIFFUSION OF MONENTUM AND ENERGY IN NONCIRCULAR DUCTS.

(b) Laboratory project.

(c) Prof. W. D. Baines, University of Toronto, Toronto 5, Canada.

(d) Experimental, research for master's theses.

(e) The role of secondary currents in the diffusion of heat from the wall of a square duct is being studied. Comparisons are being made with the turbulent heat transfer rates.

(g) Temperature distributions are very similar to velocity distributions across the section but are more uniform.

(4470) CHARACTERISTICS OF TURBULENT WALL JETS.

(b) Laboratory project.

(c) Prof.W. D. Baines, University of Toronto, Toronto 5, Canada.

(d) Experimental; applied research for master's thesis.

(e) The flow in a two-dimensional wall jet is being studied to determine the conditions under which flow similarity is maintained at successive stations.

(g) Jets along rough and porous walls do not display the same similarity as for a smooth wall. Furthermore, a reversal in wall pressure gradient has been found which cannot be explained.

(h) "Flow Characteristics of wall-Jets on Smooth, Rough and Porous Walls, "Y. L. Lau, M.A.Sc. Thesis, University of Toronto, October 1963.

(4472) SURGES IN AIR VENTS.

(b) Laboratory project.

(c) Prof. L. E. Jones, University of Toronto, Toronto 5, Canada.

(d) Experimental; applied research for master's thesis.

(e) Investigation of mixed regime conditions due to sudden discharge changes in a horizontal condult equipped with air vent and surge tank.

(g) Experimental, photographic and computer data have been assembled in the mixed-regime analysis for head-gate closure and for condult refiling. Significant data have been established on the surge front profile and the phenomenon of air-entrapment.

(h) "Transient Hydraulic Phenomena in a Horizontal Conduit -- Air Vent -- Surge Tank Supply System," by R. Abel, M.A.Sc. thesis, University of Toronto, September 1962.
(4888) HYDRAULIC TRANSIENTS IN AN AIR VENT - SURGE TANK ASSEMBLY.

(b) Laboratory project.

(c) Prof.H.J. Leutheusser, University of Toronto, Toronto 5, Canada.

(d) Experimental, basic research for master's thesis.

(e) Using an existing small-scale replica of a schematic penstock-inlet, air entrainment and pressure conditions due to various modes of gate and valve closure are belng investigated.

(4889) UNSTEADY LAMINAR FLOW IN SHORT, CLOSED CONDUITS.

(b) Laboratory project.

(c) Prof. H. J. Leutheusser, University of Toronto, Toronto 5, Canada.

(d) Experimental and analytical, basic research for master's thesis.

(e) Various cases of unsteady (oscillating) laminar flow as encountered in typical viscous damping devices are being investigated.

(4890) CHARACTERISTICS OF FLOW OF FLUID-SEDIMENT MIXTURES.

(b) Laboratory project.

(c) Prof. H. J. Leutheusser, University of Toronto, Toronto 5, Canada.

(d) Experimental, basic research.

(e) Evaluation of mean flow parameters such as friction coefficients, static pressures, veloclties and wall shear stresses in closed conduits.

(5256) OPTIMUM HEIGHTS OF CHIMNEYS.

(b) The Municipality of Metropolitan Toronto, Department of Works.

(c) Prof. G. R. Lord, University of Toronto, Toronto 5, Canada.

(d) Experimental, applied research for design information.

(e) Models of various configurations of blocktype bulldings, equipped with smoke stacks of variable height are being investigated in a low-speed wind tunnel at a ratio of gas emission speed to wind velocity equal to unity. Objective of study is to derive rules for the proper height of chimneys resulting in reduced aerodynamic downwash of the stack gases.

(5257) CHARACTERISTICS OF FLOW IN A SEWER DROP SHAFT.

(b) M. M. Dillon and Co., London, ontario.

(c) Prof. H. J. Leutheusser, Univ. of Toronto, Toronto 5, Canada.

(d) Experimental, applied research for design information.

(e) Model (1:12) investigation of a particular drop shaft design from the viewpoint of flow configuration, energy dissipation, passage of debris and detergent content in the fluid.

(f) completed. 
Accelerated motion

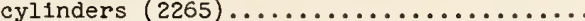

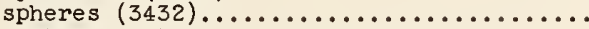

Alr entrainment

Intake towers, Oroville Dam (4947).......

Apparatus

portable 1rrigation sprinkler (4368)......

rainfall simulator $(2596) \ldots \ldots \ldots \ldots \ldots \ldots$ sediment sampler $(194) \ldots \ldots \ldots \ldots \ldots \ldots \ldots \ldots \ldots \ldots$

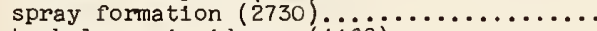

turbulence incidence (4468)...............

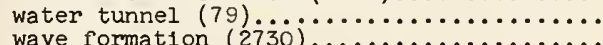

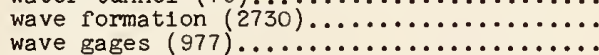

Aquifers

recession hydrographs (5037)........... two-part, salt water removal $(4962) \ldots \ldots$.

Baffle piers

basic research (993).................. cavitation $(993) \ldots \ldots \ldots \ldots \ldots \ldots \ldots \ldots \ldots$

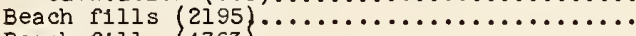

Beach fills $(4763) \ldots \ldots \ldots \ldots \ldots \ldots \ldots \ldots \ldots \ldots$

Beaches

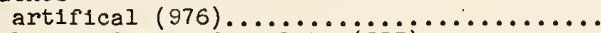

by-passing sand, inlets $(975) \ldots \ldots \ldots \ldots \ldots$

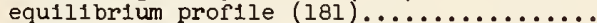

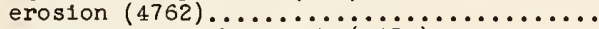

erosion, So. Lake Worth $(4474) \ldots \ldots \ldots \ldots$

littorai movement $(3897) \ldots \ldots \ldots \ldots \ldots \ldots \ldots$

particle movement $(3897) \ldots$ profiles, vertical walls $(4935) \ldots \ldots \ldots \ldots \ldots$

profiles, vertical walls $(4935) \ldots \ldots \ldots \ldots \ldots$
sand movement $(4930) \ldots \ldots \ldots \ldots \ldots \ldots \ldots$

wave action $(181) \ldots \ldots \ldots \ldots \ldots \ldots \ldots \ldots \ldots \ldots \ldots \ldots$

wave action 660$\} \ldots \ldots \ldots \ldots \ldots \ldots \ldots \ldots$

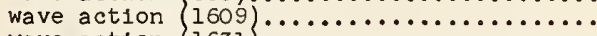

wave action 1631$\} \ldots \ldots \ldots \ldots \ldots \ldots \ldots \ldots \ldots$

Bends

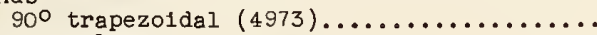

Boundary layer

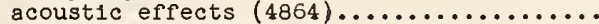

Interfacial $(3674) \ldots \ldots \ldots \ldots \ldots \ldots \ldots \ldots$

instability $(5109) \ldots \ldots \ldots \ldots \ldots \ldots \ldots \ldots$

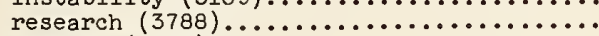

studies (5128).

Boundary resistance

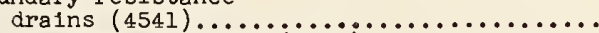

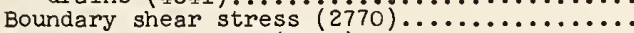

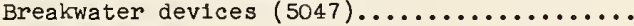

Breakwaters

Kahulu1 Harbor, Hawa11 (4605) ...........

low crested $(5082) \ldots \ldots \ldots \ldots \ldots \ldots \ldots \ldots \ldots \ldots$

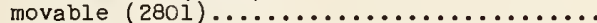

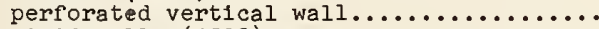

rigid walls $(4908) \ldots \ldots \ldots \ldots \ldots \ldots \ldots \ldots$

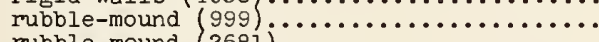

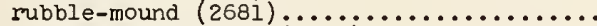

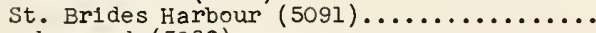

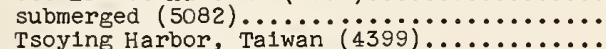

vertical perforated $(4523) \ldots \ldots \ldots \ldots \ldots \ldots$.

wave forces $(998) \ldots \ldots \ldots \ldots \ldots \ldots \ldots \ldots$.

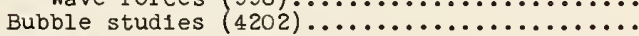

Bubbles

liquid shear flows $(5195) \ldots \ldots \ldots \ldots \ldots \ldots$

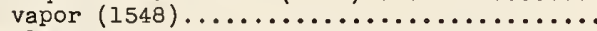

Canals

1rrigation, Bentonite sealing (3704)......

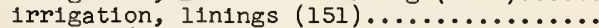

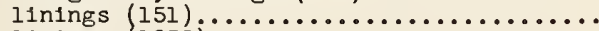

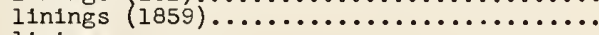

linings

seepage (1859)

sediment control

Canals, concrete-lined

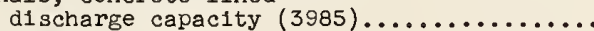

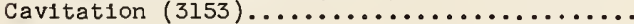

Cavitation

baffle piers (993).

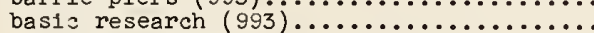

basic research

Calif. Inst. of Tech. (1548) $\ldots \ldots \ldots \ldots$

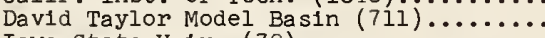

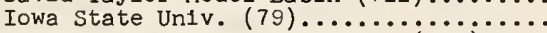

Waterways Experiment Station (993)....

bubble collapse $(5036) \ldots \ldots \ldots \ldots \ldots \ldots \ldots$.

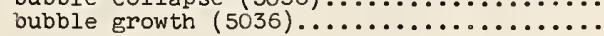

Cavitation

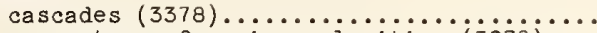

concrete surface irregularities (3278)....

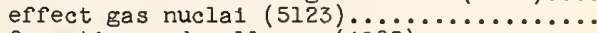

formation and collapse $(4082) \ldots \ldots \ldots \ldots$.

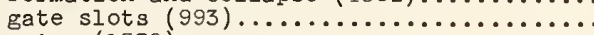

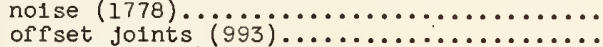

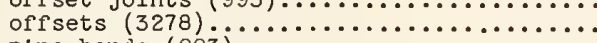

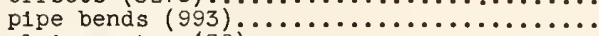

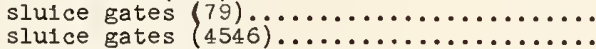

sluice gates $(4546) \ldots \ldots \ldots \ldots \ldots \ldots \ldots \ldots \ldots \ldots \ldots \ldots \ldots \ldots \ldots \ldots$
stilling basin steps $(993) \ldots \ldots \ldots \ldots \ldots \ldots$

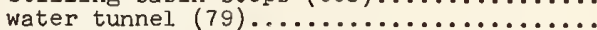

Waterways Experiment Station (993)...........

Cavitation Characteristies

simple liquids (3807).

Cavitation research

inception on rough surface $(5126) \ldots \ldots \ldots$

Channel improvement

flood control, Middle Miss. River (236)...

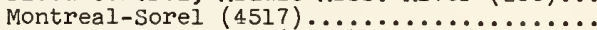

St. Lawrence River
shoaling processes $\left(\begin{array}{l}3324 \\ 3907\end{array}\right\} \ldots \ldots \ldots \ldots \ldots \ldots \ldots \ldots$

shoaling processes (3907)

Turtle creek (4383) $\ldots \ldots \ldots \ldots \ldots \ldots \ldots$

Willow springs $(4387) \ldots \ldots \ldots \ldots \ldots \ldots \ldots \ldots$

Channel stabilization $(4284) \ldots \ldots \ldots \ldots \ldots \ldots \ldots \ldots \ldots \ldots$

Channel stabilization

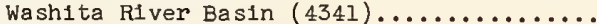

Channels

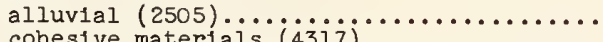

cohesive materials $(4317) \ldots \ldots \ldots \ldots \ldots \ldots$.

conservation linings $(1723) \ldots \ldots \ldots \ldots \ldots \ldots$

conservation linings $(3804\} \ldots \ldots \ldots \ldots \ldots \ldots$

critical flow $(4542) \ldots \ldots \ldots \ldots \ldots \ldots \ldots \ldots \ldots$
effect flood flows $(4283) \ldots \ldots \ldots \ldots \ldots \ldots$

ephemeral stream flow losses $(4784) \ldots . .$.

seepage flow $(4410) \ldots \ldots \ldots \ldots \ldots \ldots \ldots \ldots$

stability $(4316) \ldots \ldots \ldots \ldots \ldots \ldots \ldots \ldots \ldots \ldots \ldots$

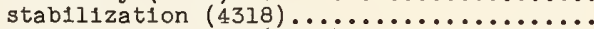

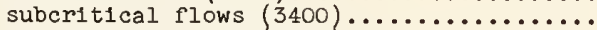

subcritical flows $(4296\} \ldots \ldots \ldots \ldots \ldots \ldots \ldots \ldots$

thalweg profile studies $(425 i) \ldots \ldots \ldots \ldots$

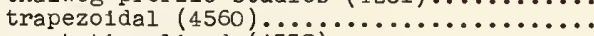

vegetation lined $(4337) \ldots \ldots \ldots \ldots \ldots \ldots . . . . . . .$.

Channels, alluvial

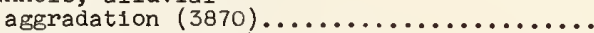

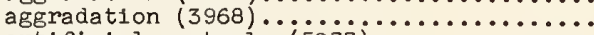

artificial controls $(5077) \ldots \ldots \ldots \ldots \ldots \ldots$

bar migration study $(5179) \ldots \ldots \ldots \ldots \ldots$

degradation $(3870) \ldots \ldots \ldots \ldots \ldots \ldots \ldots \ldots \ldots \ldots$

degradation $3968, \ldots \ldots \ldots \ldots \ldots \ldots \ldots \ldots \ldots \ldots \ldots \ldots$

effect dams $(3955)$ effect diversion $(3955) \ldots \ldots \ldots \ldots \ldots \ldots \ldots \ldots \ldots \ldots \ldots \ldots$

effect diversion (3955) .. $39 \ldots \ldots \ldots \ldots \ldots$

flood waves $(4358) \ldots \ldots \ldots \ldots \ldots \ldots \ldots \ldots$.

hydraulics of $(5078) \ldots \ldots \ldots \ldots \ldots \ldots \ldots \ldots \ldots \ldots$.

meandering $(4551) \ldots \ldots \ldots \ldots \ldots \ldots \ldots \ldots$

Channels, artificial

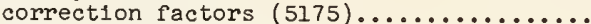

Channels, curved

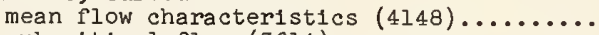

subcritical flow $(3614) \ldots \ldots \ldots \ldots \ldots \ldots \ldots$.

turbulence characteristics (4148)............

Channels, steep

surface characteristic (3824)............

Climatological data

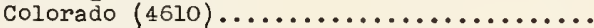

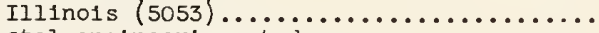

Coastal engineering study

Cedar Key Highway Dock (4900) ............

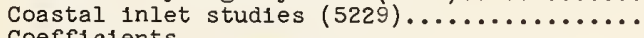

oefficients

hydrophoblc disks and plates (2436)......

roughness, streams $(5181) \ldots \ldots \ldots \ldots \ldots \ldots$

Conduits

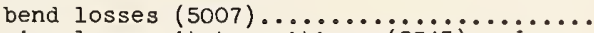

circular, exit transitions $(2543) \ldots \ldots \ldots$

exit pressure distributions (2543)........

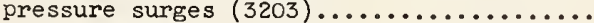

two-phase flow $(4235) \ldots \ldots \ldots \ldots \ldots \ldots$.

Conduits, closed

flow characteristics of foams (5099)......

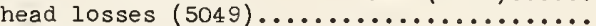

laminar flow $(4889) \ldots \ldots \ldots \ldots \ldots \ldots \ldots \ldots \ldots \ldots \ldots \ldots \ldots$

mean flow parameters $(4890) \ldots \ldots \ldots \ldots \ldots \ldots \ldots$

188

149

199

197

155

193

57

158
103

118

12
113

(13

61

38
103

176

175

113

19

106

43

118

112

173

177
62

112

173
172

172

172

125

177
200

60

43

179

43

71

23

28

162

166

62

193

46
46

46
16

84

17

26
204

204 
Conduits, noncircular

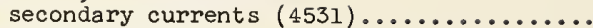

Conduits, pressure

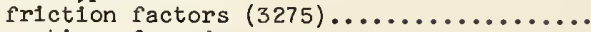

Convection, forced

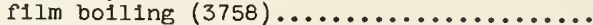

Coriolis

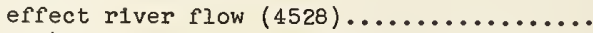

Culverts

discharge characteristics (2435)..........

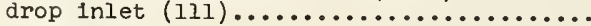

Culverts, box

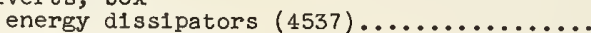

Culverts, outlets

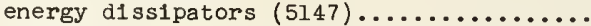

currents

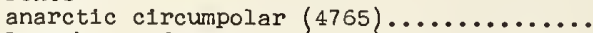

longshore, formation $(4158) \ldots \ldots \ldots \ldots \ldots \ldots$

Cylinders

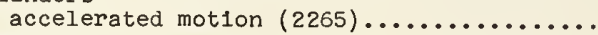
Dams

gallery drainage (771)

Density current studies $(4657) \ldots \ldots \ldots \ldots \ldots$

Density currents

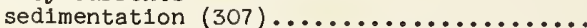

shallow water bay systems $(4233) \ldots \ldots \ldots \ldots$

tidal estuaries $(1986) \ldots \ldots \ldots \ldots \ldots . . . . . . .$.

Diffusers, annular

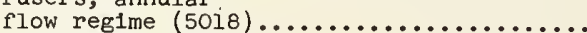

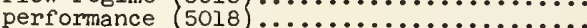

Diffusers, conical

flow regime $(5017) \ldots \ldots \ldots \ldots \ldots \ldots \ldots$ Diffusion

atmospheric $(3398) \ldots \ldots \ldots \ldots \ldots \ldots \ldots \ldots$

atmospheric $(3708) \ldots \ldots \ldots \ldots \ldots \ldots \ldots \ldots \ldots \ldots \ldots$

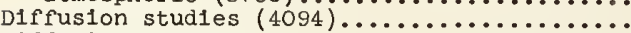
Diffusion studies

open channel flow (4931)

Diffusion, turbulent

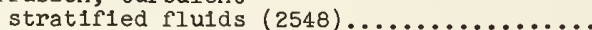

Disks, rotating resistance of $(3749)$.............

Dissipators

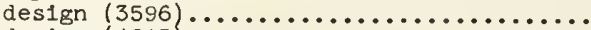
design (4245)

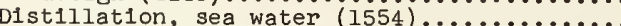

Distribution systems Drag

low Reynolds numbers (4174)

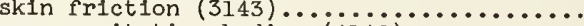

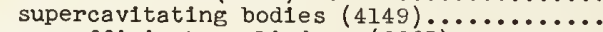

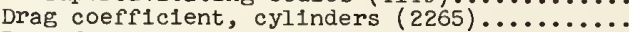
Drag forces

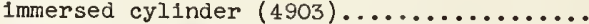
osc1llating hemisphere $(4970) \ldots \ldots \ldots \ldots \ldots . . . . . . .$. velocity gradient flelds $(4716) \ldots \ldots \ldots \ldots . .$.

Drag measurement $(4558) \ldots \ldots \ldots \ldots \ldots \ldots \ldots \ldots$

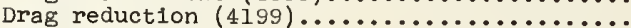

Drag reduction $(4556) \ldots \ldots \ldots \ldots \ldots \ldots \ldots \ldots \ldots \ldots \ldots \ldots \ldots$

Drag reduction

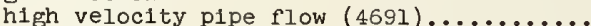

Drag resistance

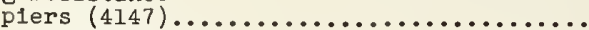

submerged objects $(5 i 34) \ldots \ldots \ldots \ldots \ldots \ldots . . . . . . . . .$.

Drag, hemisphere

3-dimensional finite flow fleld (5137)....

Drain tile

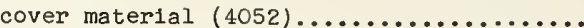

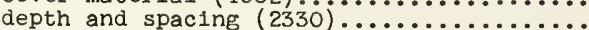

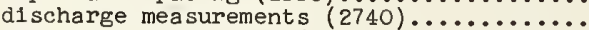

flow characteristics $(3490) \ldots \ldots \ldots \ldots \ldots \ldots$. gravel fllters $(4114) \ldots \ldots \ldots \ldots \ldots \ldots \ldots \ldots$

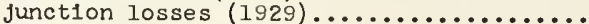

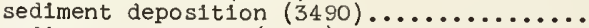
sediment movement $(3490) \ldots \ldots \ldots \ldots \ldots \ldots \ldots$.

Drainage, by pumping $(2350\} \ldots \ldots \ldots \ldots \ldots \ldots \ldots$ Drainage

effect, solonetzic solls (4987)..........

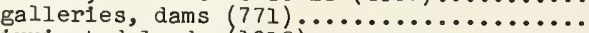
irrigated lands $(1819) \ldots \ldots \ldots \ldots \ldots \ldots \ldots \ldots$ mechanical, agricultural lands $(4925) . .$. . salt affected solls (4831)............... subsurface $(4183) \ldots \ldots \ldots \ldots \ldots \ldots \ldots \ldots \ldots \ldots \ldots$

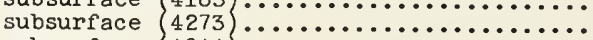
subsurface $(4844\} \ldots \ldots \ldots \ldots \ldots \ldots \ldots \ldots \ldots$

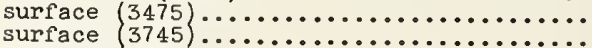
$\left.\begin{array}{l}\text { surface } \\ \text { surface }\end{array} \begin{array}{l}3745 \\ 3867\end{array}\right\} \ldots \ldots \ldots \ldots \ldots \ldots \ldots \ldots \ldots \ldots \ldots \ldots$ surface $(4273\} \ldots \ldots \ldots \ldots \ldots \ldots \ldots \ldots \ldots \ldots \ldots \ldots \ldots$
Dra1nage, subsurface

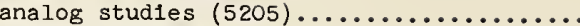

rainage, surface

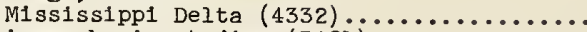

Drainage basin studies $(3421) \ldots \ldots \ldots \ldots \ldots \ldots$

Drainage effluent

quality of $(5161) \ldots \ldots \ldots \ldots \ldots \ldots \ldots$

Drainage 1mprovement, surface (2333).........

Drainage investigations $(5033) \ldots \ldots \ldots \ldots \ldots$. rainage materials

durability and effectiveness (5218)...... Drainage methods

nonirrigated areas of Lower Rio

Grande Valley $(4849) \ldots \ldots \ldots \ldots \ldots \ldots \ldots$

Drainage practices

development of techniques (4819)..........

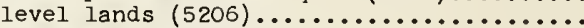

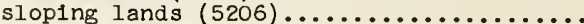

Drainage systems

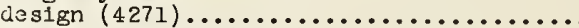
design criteria $(4353) \ldots \ldots \ldots \ldots \ldots \ldots \ldots$

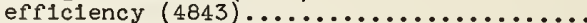

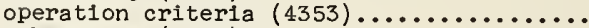
subsurface $(5176) \ldots \ldots \ldots \ldots \ldots \ldots \ldots \ldots$. Drains

plastic lined (4681)

83

150

Drains, filter operational characteristics (3060)........ Drains, subsurface

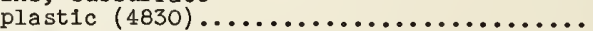

Duct studies

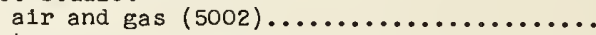

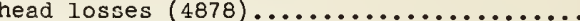

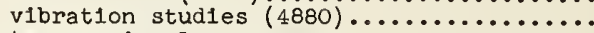
Ducts, noncircular

diffusion momentum and energy (4469).....

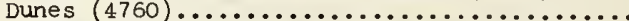

Eddles, effect of boundary geometry (i875)... Energy dissipation transition of pipe to open channel

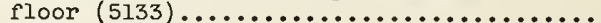

Energy losses bends (3441). slug flow (4939)

Energy losses, frictional gas-1iquid, two-phase (4938).......... Erosion

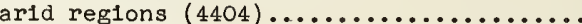

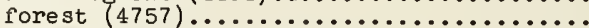
ranges $(4757) \ldots \ldots \ldots \ldots \ldots \ldots \ldots \ldots \ldots \ldots \ldots \ldots$.

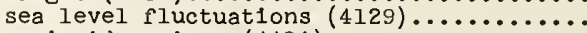

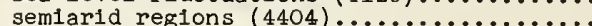
Erosion control

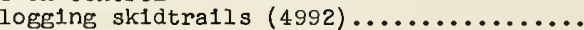

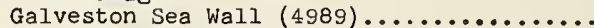

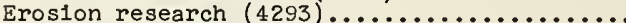

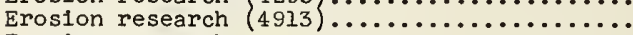
Erosion research

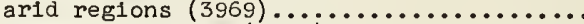

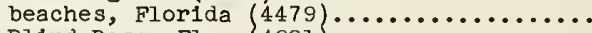

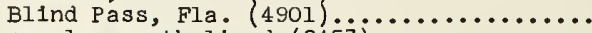
canals, earth lined $(2457) \ldots \ldots \ldots \ldots \ldots \ldots$

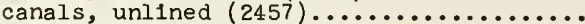
cell stability $(4967) \ldots \ldots \ldots \ldots \ldots \ldots \ldots \ldots$

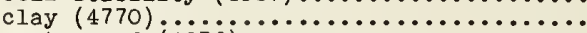

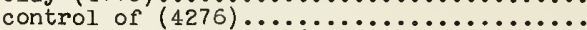
eastern South Dakota $(4282) \ldots \ldots \ldots \ldots \ldots$ eastern South Dakota $(4817) \ldots \ldots \ldots \ldots \ldots$ Exner equation $(5183) \ldots \ldots \ldots \ldots \ldots \ldots \ldots \ldots$ Florida inlets $(3413, \ldots \ldots \ldots \ldots \ldots \ldots \ldots \ldots \ldots \ldots$ forest influences $(380) \ldots \ldots \ldots \ldots \ldots \ldots \ldots$

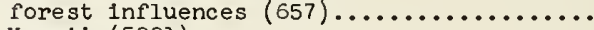

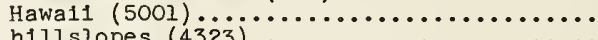

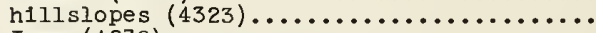
Iowa $(4279) \ldots \ldots \ldots \ldots \ldots \ldots \ldots \ldots \ldots \ldots \ldots$

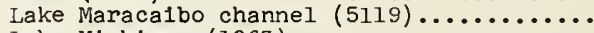

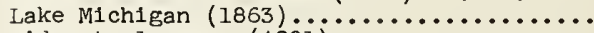

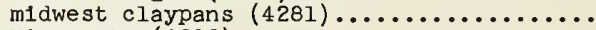

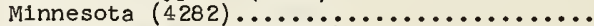

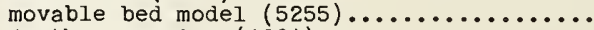
Northeast solls $(4294) \ldots \ldots \ldots \ldots \ldots \ldots \ldots$ piping phenomenon $(4405) \ldots \ldots \ldots \ldots \ldots \ldots$.

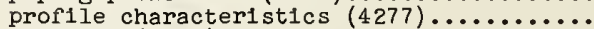

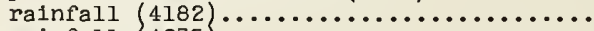
rainfall $(4275) \ldots \ldots \ldots \ldots \ldots \ldots \ldots \ldots \ldots \ldots \ldots \ldots$ munoff $(4275) \ldots \ldots \ldots \ldots \ldots \ldots \ldots \ldots \ldots \ldots \ldots \ldots \ldots \ldots$ runoff $(4276) \ldots \ldots \ldots \ldots \ldots \ldots \ldots \ldots \ldots \ldots \ldots \ldots \ldots$ 121

105

106

106

100

120

117

120

61 
Erosion research

sediment yield $(4303) \ldots \ldots \ldots \ldots \ldots \ldots \ldots$

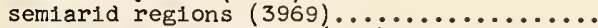

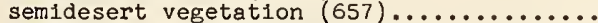

sheet runoff $(4182) \ldots \ldots \ldots \ldots \ldots \ldots \ldots \ldots \ldots$

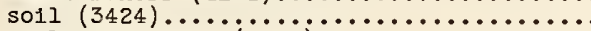

soll properties $(4277) \ldots \ldots \ldots \ldots \ldots \ldots \ldots$

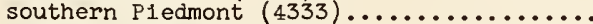

volume of erosion $(5207) \ldots \ldots \ldots \ldots \ldots \ldots$.

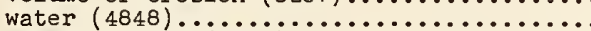

water control $(4295) \ldots \ldots \ldots \ldots \ldots \ldots \ldots \ldots$

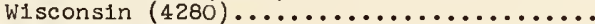

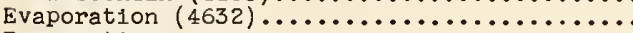

Evaporation

effects of elevation (4994).............

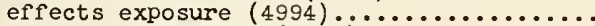

effects topography $(4994) \ldots \ldots \ldots \ldots \ldots \ldots$

evapotranspiration $(3662) \ldots \ldots \ldots \ldots \ldots \ldots$.

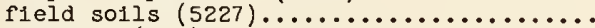

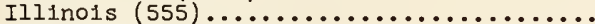

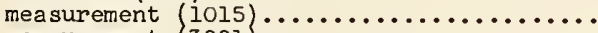

measurement $(3881\} \ldots \ldots \ldots \ldots \ldots \ldots \ldots \ldots \ldots \ldots$

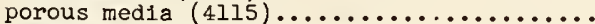

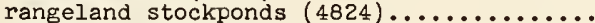

reduction $(2828) \ldots \ldots \ldots \ldots \ldots \ldots \ldots \ldots \ldots \ldots \ldots \ldots \ldots$

reduction 3508$\} \ldots \ldots \ldots \ldots \ldots \ldots \ldots \ldots \ldots \ldots$

reduction $(4634) \ldots \ldots \ldots \ldots \ldots \ldots \ldots \ldots \ldots$

reservolrs $(765) \ldots \ldots \ldots \ldots \ldots \ldots \ldots \ldots \ldots$

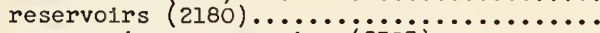

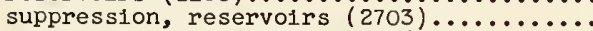

watersheds, Tennessee Basin (765)........

Evapotranspiration

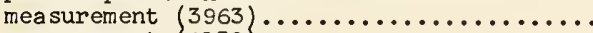

measurement $4138, \ldots \ldots \ldots \ldots \ldots \ldots \ldots \ldots \ldots \ldots$

measurement $(4833, \ldots \ldots \ldots \ldots \ldots \ldots \ldots \ldots$

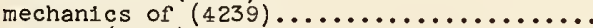

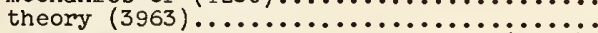

watersheds, Central and so. Calir. (485ij).

Film boiling

horizontal flow fields (4942)............

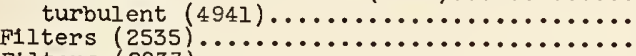

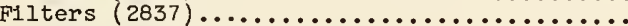

Fish ladders

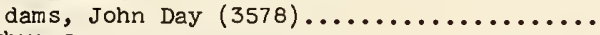

F1 shways

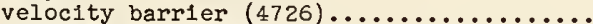

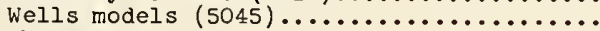

Flashboards

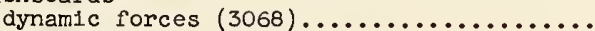

Flood control

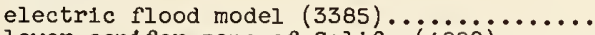

lower conifer zone of Calif. (4998)...........

Moosic project $(5178) \ldots \ldots \ldots \ldots \ldots \ldots \ldots$ rivers

Mississippi Basin (236).............

Flood forecasting

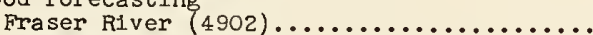

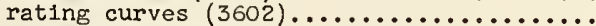

Flood hydrographs

agricultural watersheds $(4311) \ldots \ldots \ldots \ldots$.

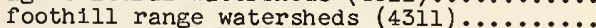

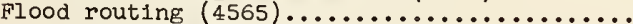

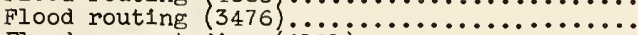

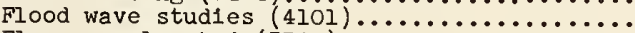

Flow, accelerated $(3740) \ldots \ldots \ldots \ldots \ldots \ldots \ldots \ldots \ldots \ldots$

Flow, accelerated $(3782\} \ldots \ldots \ldots \ldots \ldots \ldots \ldots$

Flow

cavity (4677).

conducting fluids $(4980) \ldots \ldots \ldots \ldots \ldots \ldots$

Flow, fluids

packed beds (5170)

Flow, free surface $(468 \dot{8}) \ldots \ldots \ldots \ldots \ldots \ldots \ldots \ldots$

Flow, free surface $\left(\begin{array}{l}419 \\ 4\end{array} \ldots \ldots \ldots \ldots \ldots\right.$

Flow

gases in liquids $(4188) \ldots \ldots \ldots \ldots \ldots \ldots$ granular media $(4695) \ldots \ldots \ldots \ldots \ldots \ldots \ldots \ldots \ldots$

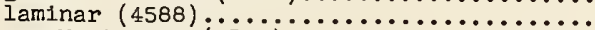

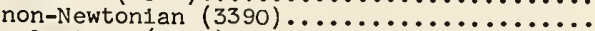
pulsating $(3689) \ldots \ldots \ldots \ldots \ldots \ldots \ldots \ldots \ldots \ldots \ldots \ldots \ldots$ pulsating $(4859\} \ldots \ldots \ldots \ldots \ldots \ldots \ldots \ldots \ldots \ldots \ldots \ldots$

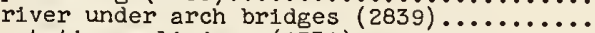
rotating cylinders $(4734) \ldots \ldots \ldots \ldots \ldots \ldots$ single and two-phase in tube $(2374) \ldots \ldots \ldots$

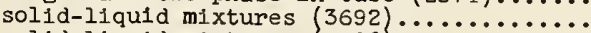

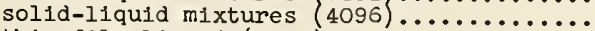

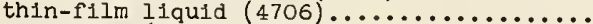
two-phase $(4165) \ldots \ldots \ldots \ldots \ldots \ldots \ldots \ldots$ two-phase, one-component $(4984) \ldots \ldots \ldots \ldots$

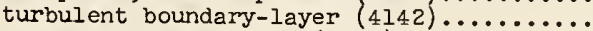
unsteady free surface $(4667) \ldots \ldots \ldots \ldots \ldots$.
Flow, accelerated curvilinear pressure distribution $(5136) \ldots \ldots \ldots \ldots \ldots .68$ velocity distribution $(5136) \ldots \ldots \ldots \ldots \ldots$

Plow, annular

two-phase $(4486) \ldots \ldots \ldots \ldots \ldots \ldots \ldots$

Flow, divided

mechanics of (3743)

Flow, gas-liquid

two-phase (4936).

Flow, laminar

rigid tubes (5016).

tube entrance (5150).

Flow, nonisothermal

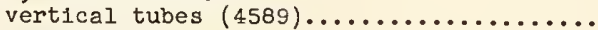

Flow, overland

hydraulics of $(4676) \ldots \ldots \ldots \ldots \ldots$

Flow, potential

unisotropic singularities $(4487) \ldots \ldots \ldots$.

Flow, pulsating

tubes (4690)

Flow, separated

body of revolution (5199)

Flow, supercritical

transitions (5182)

Flow, turbulent

condut1s (4937)

shear (4892)

vorticity $(4568) \ldots \ldots \ldots \ldots \ldots \ldots \ldots \ldots \ldots$

Flow, two-phase

gas-liquid $(5149) \ldots \ldots \ldots \ldots \ldots \ldots \ldots \ldots \ldots \ldots \ldots \ldots \ldots \ldots \ldots$

regime boundaries $(4494) \ldots \ldots \ldots \ldots \ldots \ldots$

Flow, unsteady

inertial forces $(3250) \ldots \ldots \ldots \ldots \ldots \ldots$.

Kutta condition $(5107) \ldots \ldots \ldots \ldots \ldots \ldots \ldots$

Flow development, secondary $(4586) \ldots \ldots \ldots$.

Flow fields

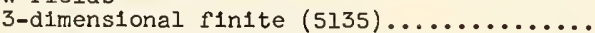

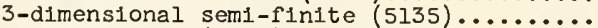

visualization $(4498) \ldots \ldots \ldots \ldots \ldots \ldots \ldots$.

Flow mea surement $(2925\} \ldots \ldots \ldots \ldots \ldots \ldots \ldots \ldots \ldots \ldots$

Flow measurement

irrigation water $(5164) \ldots \ldots \ldots \ldots \ldots \ldots \ldots$ open channels $(5164) \ldots \ldots \ldots \ldots \ldots \ldots \ldots \ldots$.

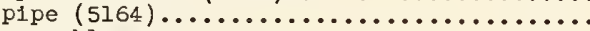

Flow problems

vascular system (4643)

low properties

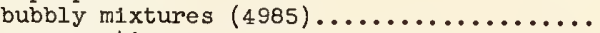

Flow separation

geometric characteristics (4151).........

Flow stability

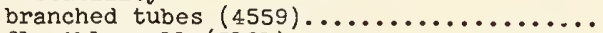

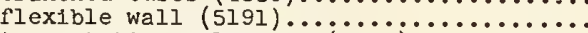

two rotating cylinders $(4641) \ldots \ldots \ldots \ldots$.

Flow studies

partially saturated $(4627) \ldots \ldots \ldots \ldots \ldots$

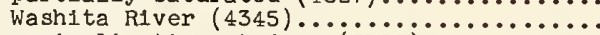

iluid flow

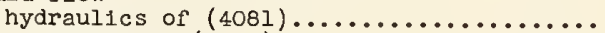
mechanics of (4123)

111

13

Fluid mechanics

educational films (3739)

Fluids

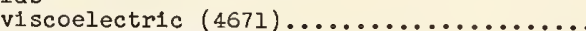

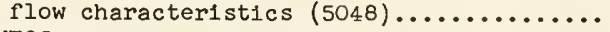
Flumes

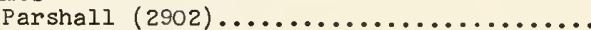

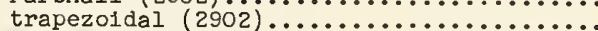

Flumes, metering calibration (3848)

lumes

venturi, calibration (4959)............ venturi, design $(4959) \ldots \ldots \ldots \ldots \ldots \ldots \ldots$ Forces

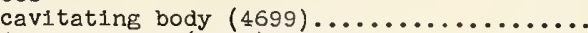
free surface $(4428) \ldots \ldots \ldots \ldots \ldots \ldots \ldots \ldots \ldots$

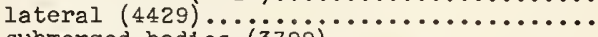

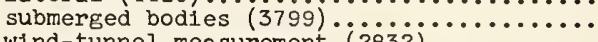
wind-tunnel mea surement $(2832) \ldots \ldots \ldots \ldots .$.

Frictional effects

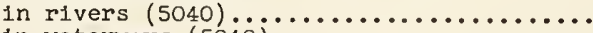

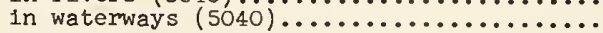
Gage slots

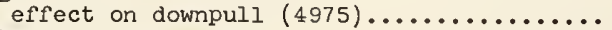
Gates

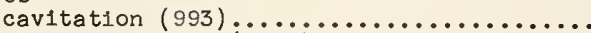
downpull forces $(4798) \ldots \ldots \ldots \ldots \ldots \ldots \ldots \ldots$

lock $(1474) \ldots \ldots \ldots \ldots \ldots \ldots \ldots \ldots \ldots$. 
Gates

pressure distribution $(4146) \ldots \ldots \ldots \ldots \ldots$ Navajo Dam, New Mexico $(4960)$.............. Trinity Dam air demand tests $(4958) \ldots . .$. . Gates, fixed wheel

Glendo Dam (4949)..................

Gates, tainter

mubber seals $(5072) \ldots \ldots \ldots \ldots \ldots \ldots \ldots \ldots$

Gates, vertical

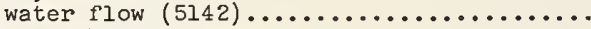

Gates, vibration

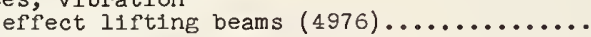

Groundwater

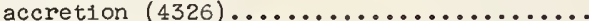

accretion and movement $(4290) \ldots \ldots \ldots \ldots$

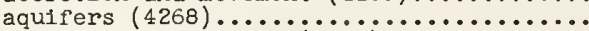

aquifers, evaluation $(3733) \ldots \ldots \ldots \ldots \ldots$

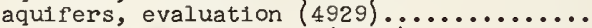

aquifers, mechanics of $(2688) \ldots \ldots \ldots \ldots \ldots$

acquifer productivity $(3731) \ldots \ldots \ldots \ldots \ldots$ aquifers, salt water encroachment (2689).. aquifer-streamflow relation $(4346) \ldots \ldots \ldots$ aquifer-streamflow relationship $(5224) \ldots$.

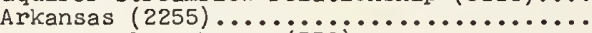
artificial recharge $(559) \ldots \ldots \ldots \ldots \ldots \ldots$ artificial recharge $(2255) \ldots \ldots \ldots \ldots \ldots \ldots$ basin management $(4932) \ldots \ldots \ldots \ldots \ldots$

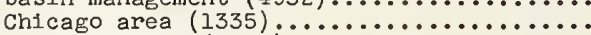

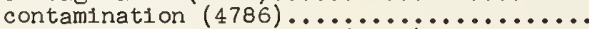
density-stratified flow $(5013) \ldots \ldots \ldots \ldots \ldots$ dynamic storage of $(5185) \ldots \ldots \ldots \ldots \ldots \ldots$ East st. Louis area $(561) \ldots \ldots \ldots \ldots \ldots \ldots \ldots \ldots$ electronic analog model $(4544) \ldots \ldots \ldots \ldots \ldots$

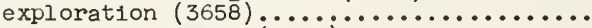
flow in sediments $(3524) \ldots \ldots \ldots \ldots \ldots \ldots \ldots$

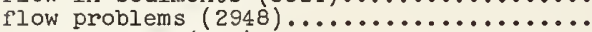
fluctuations $(821) \ldots \ldots \ldots \ldots \ldots \ldots \ldots \ldots \ldots$

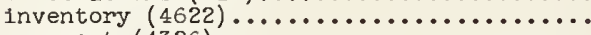
movement $(4326) \ldots \ldots \ldots \ldots \ldots \ldots \ldots \ldots \ldots \ldots$

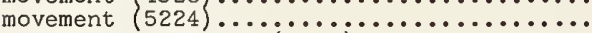
movement by tracer $(4628) \ldots \ldots \ldots \ldots \ldots \ldots \ldots$ movement, laminar $(5158) \ldots \ldots \ldots \ldots \ldots \ldots \ldots$ movement, model studies $(4630) \ldots \ldots \ldots \ldots \ldots$

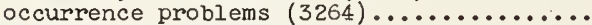

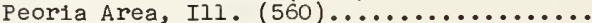
pressure measurement $(5030) \ldots \ldots \ldots \ldots \ldots \ldots$

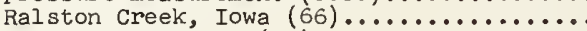

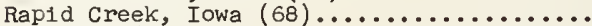

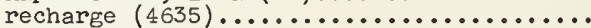

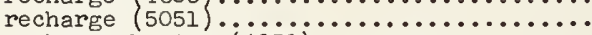
recharge basins $(4850) \ldots \ldots \ldots \ldots \ldots \ldots \ldots \ldots$ Red River valley, No. Dak. $(32 i j) \ldots \ldots \ldots . . . .$. reservoir characteristics $(4106) \ldots . . . \ldots$. resource evaluation $(4536) \ldots \ldots \ldots \ldots \ldots \ldots$

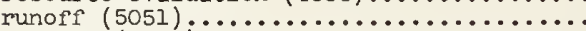

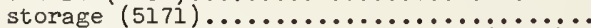
studies of westem desert, U.A.R. (4631).. Tennessee valley $(780) \ldots . . \ldots \ldots \ldots \ldots \ldots$ unglaclated Allegheny Plateau $(4268) \ldots . .$.

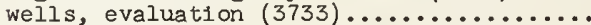
Ground-water basin

hydrologic characteristics $(4624) \ldots . .$. . Ground-water storage (3263) .................. Harbor improvement

Bale Comeau, Que. (4047)..............

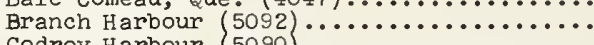

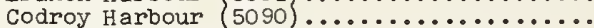
Dingwall Harbour, Nova Scotia (5095)......

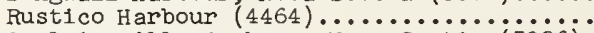
Saulnierville Harbour, Nova Scotia ( 5096$)$.

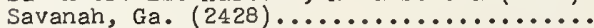
Harbor models

Burns Waterways Harbor, Ind. (4899)......

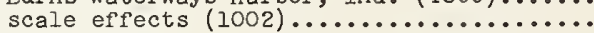
Harbor studies design (5093

Harbor study

Kelly's Island, Lake Erie (3905).......... Harbors

small-boat, design of $(5228) \ldots \ldots \ldots \ldots \ldots$

Head loss

spherical wyes $(4451) \ldots \ldots \ldots \ldots \ldots \ldots$

Head losses

intake towers, oroville Dam (4947).......

Headgates, irrigation

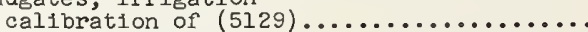

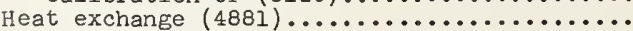
Heat exchanger

pressure loss $(4172) \ldots \ldots \ldots \ldots \ldots \ldots \ldots$
Heat transfer

electromagnets $(4490) \ldots \ldots \ldots \ldots \ldots \ldots \ldots$ fluldized beds $(3474) \ldots \ldots \ldots \ldots \ldots \ldots$ hot-wire characteristics $(5110) \ldots . . .$. multiple-channel systems $(4979) \ldots \ldots \ldots \ldots$.

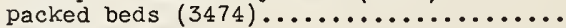

Highway drainage culverts $(111) \ldots \ldots \ldots \ldots \ldots \ldots \ldots \ldots \ldots \ldots$ culverts $(1591) \ldots \ldots \ldots \ldots \ldots \ldots \ldots \ldots \ldots \ldots \ldots \ldots . \ldots \ldots \ldots$

Hydraulic conductivity mechanisms of $(4186) \ldots \ldots \ldots \ldots \ldots \ldots$ Hydraulic control systems

valves $(2335) \ldots \ldots \ldots \ldots \ldots \ldots \ldots \ldots \ldots \ldots \ldots$

valves $(4499) \ldots \ldots \ldots \ldots \ldots \ldots \ldots \ldots \ldots \ldots$

Hydraulic cyclone $(4743) \ldots \ldots \ldots \ldots \ldots \ldots \ldots$ Hydraulic jump $(2161) \ldots \ldots \ldots \ldots \ldots \ldots \ldots \ldots$ Hydraulic jump $3994\{\ldots \ldots \ldots \ldots \ldots \ldots \ldots \ldots \ldots$ H ydraulic jump $\{4540\} \ldots \ldots \ldots \ldots \ldots \ldots \ldots \ldots \ldots$ Hydraulic jump $(5165) \ldots \ldots \ldots \ldots \ldots \ldots \ldots$ Hydraulic lines, dynamics $(4197) \ldots \ldots \ldots \ldots$. Hydraulic prototype tests $(4382) \ldots \ldots \ldots \ldots \ldots$ Hydraulic systems analysis (4933)......... Hydrodynamic forces

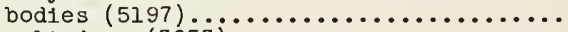
cylinders $(3853) \ldots \ldots \ldots \ldots \ldots \ldots \ldots \ldots \ldots$

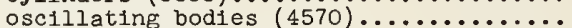
underwater bodies $(2746) \ldots \ldots \ldots \ldots \ldots \ldots$ vibrating body $(4573) \ldots \ldots \ldots \ldots \ldots \ldots \ldots \ldots$ Hydrodynamics $(4642) \ldots \ldots \ldots \ldots \ldots \ldots \ldots \ldots \ldots$ Hydrodynamics flow studies $(3377) \ldots \ldots \ldots \ldots \ldots \ldots \ldots$ rotating systems $(4737) \ldots \ldots \ldots \ldots \ldots \ldots \ldots$ Hydrofoll structures

vibration of $(4704) \ldots \ldots \ldots \ldots \ldots \ldots$ Hydrofolls

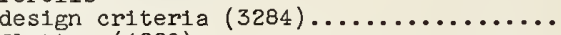

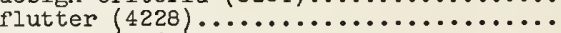

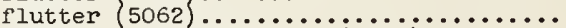
flutter characteristics (5193)......... flutter speed $(4928) \ldots \ldots \ldots \ldots \ldots \ldots \ldots \ldots$

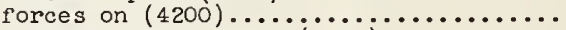

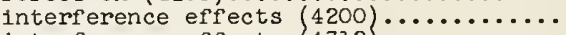
interference effects $(4712) \ldots \ldots \ldots \ldots \ldots$

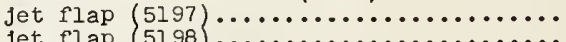
measured flutter speed $(4 \not \ddot{i} \dot{j}) \ldots \ldots \ldots \ldots \ldots$

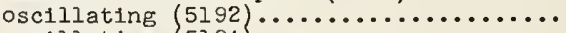
oscillating $(5194) \ldots \ldots \ldots \ldots \ldots \ldots \ldots \ldots$ predicted flutter speed $(4709) \ldots \ldots \ldots \ldots$ study $(2144) \ldots \ldots \ldots \ldots \ldots \ldots \ldots \ldots \ldots \ldots \ldots$ supercavitating $(42 i 9) \ldots \ldots \ldots \ldots \ldots \ldots \ldots$ supercavitating $\{4693, \ldots \ldots \ldots \ldots \ldots \ldots \ldots$ supercavitating $(4696\} \ldots \ldots \ldots \ldots \ldots \ldots$ supercavitating $(4811) \ldots \ldots \ldots \ldots \ldots \ldots \ldots$ surface-piercing $(4227) \ldots \ldots \ldots \ldots \ldots \ldots$ three-dimensional $(4226) \ldots \ldots \ldots \ldots \ldots \ldots$ unsteady forces and motions (4221)...... ventilated $(4700) \ldots \ldots \ldots \ldots \ldots \ldots \ldots \ldots \ldots$ ventilated $(4811) \ldots \ldots \ldots \ldots \ldots \ldots \ldots \ldots \ldots$ ventilating flows $(4073) \ldots \ldots \ldots \ldots \ldots \ldots \ldots$

Hydrofoils, models testing (3828)

Hydrofolls, teed

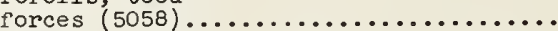

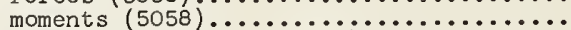
Hydrograph laboratory $(4820) \ldots . . \ldots \ldots \ldots$ Hydrograph Studies synthetic unit graph methods (4150) .....

Hydrologic characteristics organic soil $(3363) \ldots . . \ldots \ldots \ldots \ldots \ldots \ldots$ playa sedimentary formations (5215)..... Hydrologic data

analyses $(5138) \ldots \ldots \ldots \ldots \ldots \ldots \ldots \ldots$ compilation and publication of $(4823) \ldots$

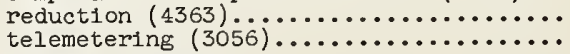
Hydrologic studies

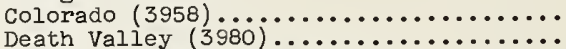
Death Valley $(3980) \ldots \ldots \ldots \ldots \ldots \ldots \ldots \ldots$ effects urbanization $(5050) \ldots \ldots \ldots \ldots \ldots$ flood frequency $(3953) \ldots \ldots \ldots \ldots \ldots \ldots \ldots$ forest development $(3953) \ldots \ldots \ldots \ldots \ldots$ Humboldt River Valley $(3957) \ldots \ldots \ldots \ldots \ldots$ Missour1 watersheds $(5204) \ldots \ldots \ldots \ldots \ldots$ New Mexico $(3958) \ldots \ldots \ldots \ldots \ldots \ldots \ldots \ldots$

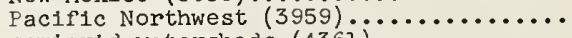
semiarid watersheds $(4361) \ldots \ldots \ldots \ldots \ldots$ Waller creek watershed $(2162) \ldots . . \ldots \ldots$. 
Hyarologic studies

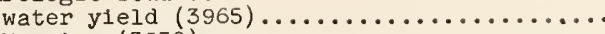

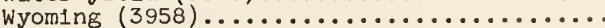

Hydrologic systems

nonlinear analysis $(5145) \ldots \ldots \ldots \ldots \ldots \ldots \ldots$

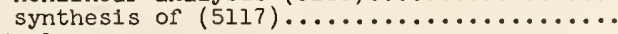

Hydrology

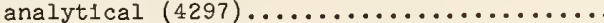

research $(4322) \ldots \ldots \ldots \ldots \ldots \ldots \ldots \ldots \ldots$

research, Great Salt Lake (5139)......... untt hydrograph $(4732) \ldots \ldots \ldots \ldots \ldots \ldots \ldots \ldots$ water source $(4997) \ldots \ldots \ldots \ldots \ldots \ldots \ldots \ldots \ldots$

Hydrophones $(4863) \ldots \ldots \ldots \ldots \ldots \ldots \ldots \ldots \ldots \ldots \ldots$

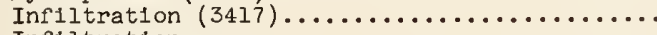

Infiltration

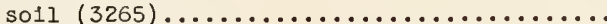

Infiltration rates

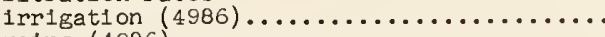

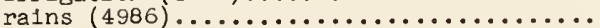

Inflltration studies $(3507) \ldots \ldots \ldots \ldots \ldots \ldots \ldots$

Inlets

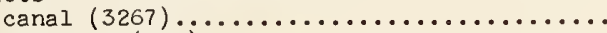
culverts $(111) \ldots \ldots \ldots \ldots \ldots \ldots \ldots \ldots \ldots \ldots \ldots \ldots$

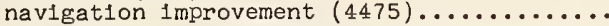

Instruments

evaporator, fluid mechanics study (4982)... nuclear radiation equipment (4373)......... prec1p1tation gage, we1ghing-type (3921)...

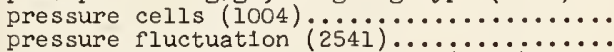

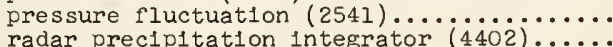

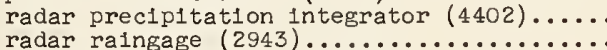

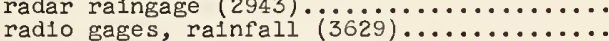

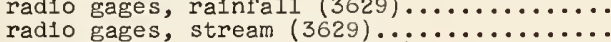
radlo1sotope snow gage $(5168) \ldots \ldots \ldots \ldots \ldots \ldots$ ra1ngage, study of $(5052) \ldots \ldots \ldots \ldots \ldots \ldots \ldots$ rainstorm simulator $(5223) \ldots \ldots \ldots \ldots \ldots \ldots \ldots$ river gage, float-type $(3920) \ldots \ldots \ldots \ldots \ldots \ldots$ servomotors, design $(4981) \ldots \ldots \ldots \ldots \ldots \ldots \ldots$ so1l mo1sture $(3260) \ldots . \ldots \ldots \ldots \ldots \ldots \ldots \ldots$ velocity meter $(1004) \ldots \ldots \ldots \ldots \ldots \ldots \ldots \ldots \ldots$

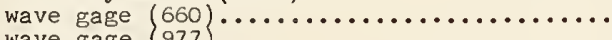

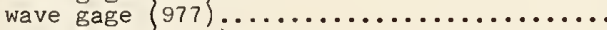

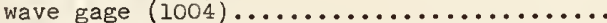

Intakes

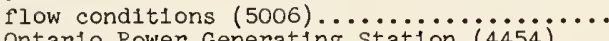
Ontar1o Power Generating Station (4454)...

Interfaclal effects

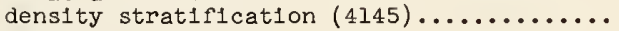

Irrigation

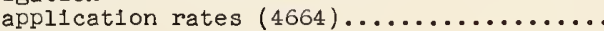
canals

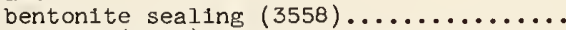

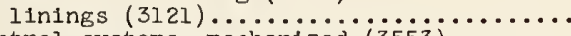

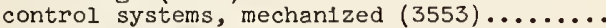
cut-back furrow $(5177) \ldots \ldots \ldots \ldots \ldots \ldots \ldots$ design sprinkler systems $(43 i j) \ldots \ldots \ldots \ldots \ldots$

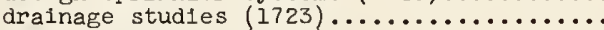

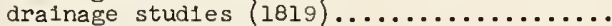
dralnage studles $(2651) \ldots \ldots \ldots \ldots \ldots \ldots \ldots \ldots$

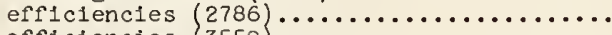

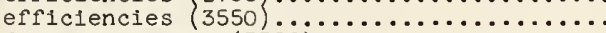
farm structures $(3556) \ldots \ldots \ldots \ldots \ldots \ldots \ldots \ldots$ flow characteristics $(4270) \ldots \ldots \ldots \ldots \ldots \ldots$

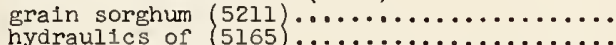

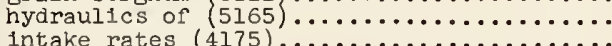

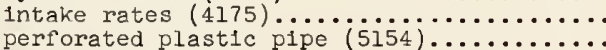
radial gates $(3612) \ldots \ldots \ldots \ldots \ldots \ldots \ldots \ldots \ldots \ldots \ldots$ sprinklers $(3470)$.

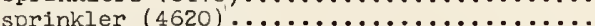
sprinkler (462l) sprinkler, portable $(4840) \ldots \ldots \ldots \ldots \ldots \ldots$

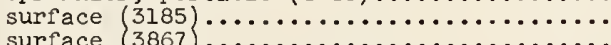
$\ldots \ldots \ldots \ldots \ldots$ surface, hydraulics of $(3552) \ldots \ldots \ldots \ldots \ldots$ underground perforated tubes $(4489) \ldots \ldots \ldots$

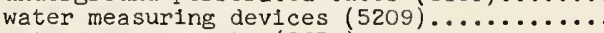
water measurements $(2650) \ldots \ldots \ldots \ldots \ldots \ldots \ldots \ldots$

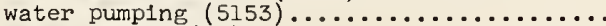

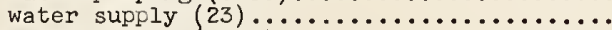

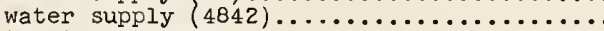

Irrigation systems

deslgn data $(4828) \ldots \ldots \ldots \ldots \ldots \ldots \ldots \ldots . \ldots . \ldots$ efflc1ency $(4827) \ldots \ldots \ldots \ldots \ldots \ldots \ldots \ldots \ldots \ldots \ldots$

Jets $(3854) \ldots \ldots \ldots \ldots \ldots \ldots \ldots \ldots \ldots \ldots \ldots \ldots \ldots \ldots \ldots \ldots \ldots \ldots$ Jets

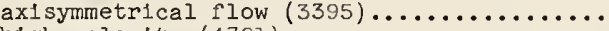

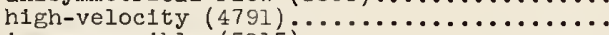

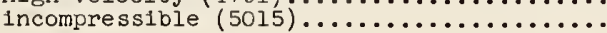

107

114

89

136

32

171

37

37
75

178

69
27

54

129

169
150

41

169

192

192

32
36

128

169

53

150

143

144

193

198

42

56

124

59

61

111

99

123

31
110

124

100

121

24
59

5
179

179
56

1

112

86

103

110
47

112

5

117

109

109
93

19

180
69
Jets

mercury, instabil1ty (5108)...........

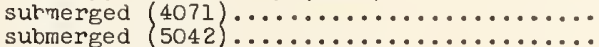
Jets, dispersion

effects of turbulence $(5008) \ldots \ldots \ldots \ldots \ldots$.

Jets, gas

underwater propulsion study $(4920) \ldots . . .$.

Jets, wall

turbulent $(4470) \ldots \ldots \ldots \ldots \ldots \ldots \ldots \ldots$

Jetties

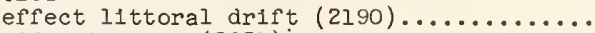

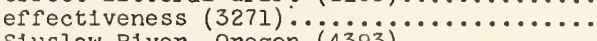
S1uslaw River, Oregon (4393)............

Lakes

application monolayer-forming

materlals $(5132) \ldots \ldots \ldots \ldots \ldots \ldots \ldots \ldots \ldots \ldots$

Laminar flow

liquids (4095)

Lquid tensions

measurement (5106)

Iiterature search

two-phase, gas-liquid flow (4983).......

Locks

discharge structures (4883)............ emergency gates, McAlpine Locks (4397) ....

filling, emptying systems

Arkansas River Dam No. 6 (4388)...... Arkansas R1ver Dam No. $3(4391) \ldots \ldots$....

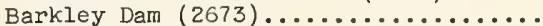

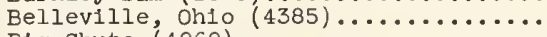

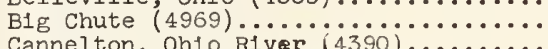
Cannelton, Ohio River $(4390) \ldots \ldots \ldots \ldots$ Jackson Lock, hawser-stress

mea surements $(5249)$................ Jonesville Lock and Dam $(5247) \ldots . . . .$. low lift $(4603) \ldots \ldots \ldots \ldots \ldots \ldots \ldots . . \ldots$

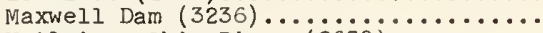

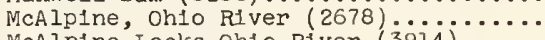
McAlplne Locks ohto River (3914)......

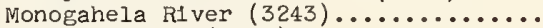
valve studies $(4602)$...

hawser pull forces $(5009) \ldots \ldots \ldots \ldots \ldots \ldots \ldots \ldots$

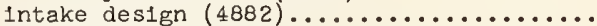

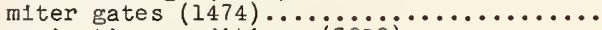

navigation conditions $(3909) \ldots \ldots \ldots \ldots \ldots$.

Meteorological observations $(2760) \ldots \ldots \ldots \ldots$.

Meteorological observations $(5162) \ldots \ldots \ldots \ldots$ Meters

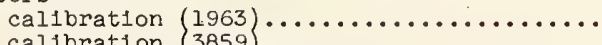

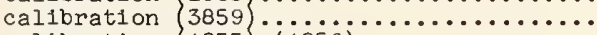
calibration 4255$)(4256) \ldots \ldots \ldots \ldots \ldots$ calibration $(4746) \ldots \ldots \ldots \ldots \ldots \ldots \ldots \ldots$ Meters, current

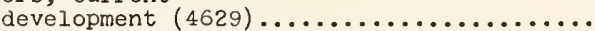

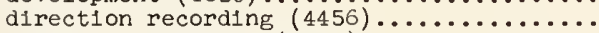
veloc1ty recording $(4456) \ldots \ldots \ldots \ldots \ldots \ldots$ Meters

Doppler, veloc1ty $(5075) \ldots \ldots \ldots \ldots \ldots \ldots \ldots$

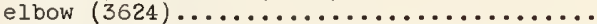
elbow, dynamic similarity $(3872) \ldots \ldots \ldots \ldots$

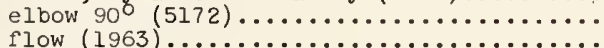

Meters, flow

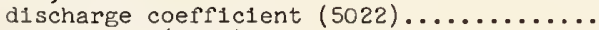
ultrasonic $(2949) \ldots . . \ldots \ldots \ldots \ldots \ldots \ldots . . . \ldots$ Meters

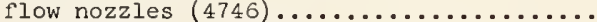
high pressure-temperature $(3623) \ldots \ldots \ldots \ldots$ Model analog studies river basins ( 5140$)$.

Model distortion (994)..... Model laws

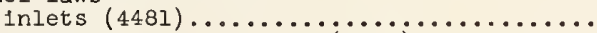
scale effects, harbors $(1002) \ldots . . . \ldots . . . .$.

Model studies

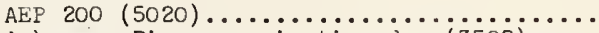
Arkansas R1ver, navigation dam ( 3592$) \ldots \ldots$. barrage at Muscoda $(4735) \ldots \ldots \ldots \ldots \ldots \ldots$ Bessie Cutoff, Miss. River $(5235) \ldots \ldots \ldots \ldots$

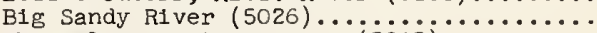

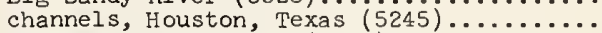
Chong Pyong Spillway (4739)............ Chong Pyong Hydroelectric project $(4740) \ldots$ Columbia Lock and Dam $(4595) \ldots . . . . . .$.

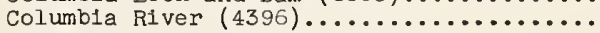
control structures, Little Sioux River $(4599) \ldots \ldots \ldots \ldots \ldots \ldots \ldots \ldots \ldots . . \ldots \ldots$
151

158
199

158

164

165

165

161

152
151

156

153

161

193

150

156

18
24

95

95

95

199

199

177

189

124

47
95

95
171

95

189

149

27

150

95
153

155

94
163

96

165

95
95

160

159

161 
Model studies

Cornwall Development $(5024) \ldots \ldots \ldots \ldots \ldots \ldots$

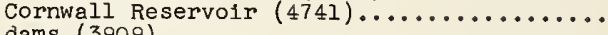

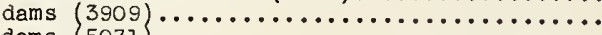

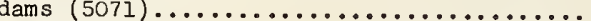

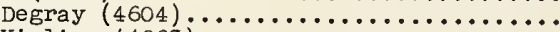

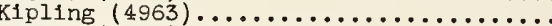

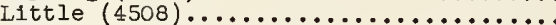

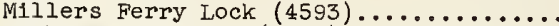
Nickajack Project $(5004) \ldots \ldots \ldots \ldots \ldots \ldots \ldots$ Opossum Creek, Ohio River (3909)........

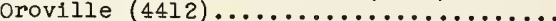

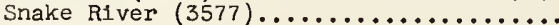

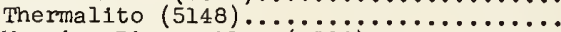
Warrior River, Ala. $(4386 j \ldots \ldots \ldots \ldots \ldots \ldots$

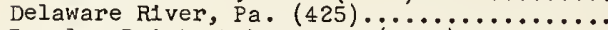

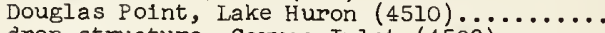
drop structure, Cayuga Inlet (4598)....... energy dissipators, outlet pipe (4957) .....

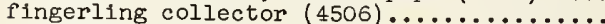
flshway diffusers (4505).............. flood control

low Atchafalaya RIver Basin, La. (5236).

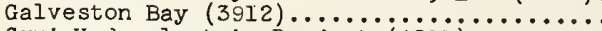
Grui Hydroelectric Project $(4201) \ldots \ldots \ldots \ldots$ Gulf outlet Channel, La. (3913)............

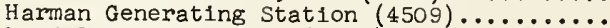
head losses in bends $(3441) \ldots \ldots \ldots \ldots \ldots \ldots$

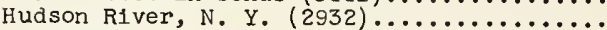
hurricane structures, Lake Pontchartrain,

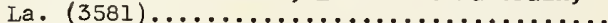
inlet structures, Uttarbhag Pumping

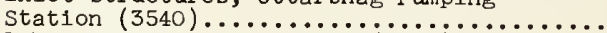
lake circulation patterns $(5120) \ldots \ldots \ldots \ldots . . . . . .$. Lakeview themal generating station (4964): Iittle Goose Lock and Dam 4504$). . . . . . .$.

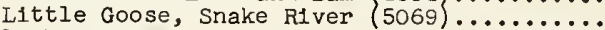
lock and dam No. 4, Arkansas River (5230)...

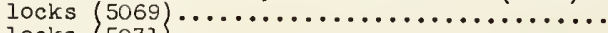

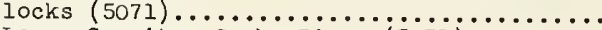
Lower Granite, Snake River (5071).......... Matagorda Bay $(3911) \ldots . \ldots \ldots \ldots \ldots \ldots . . \ldots \ldots$

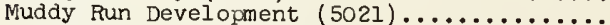
navigation conditions

Kerr Lock and Dam $(5251) \ldots \ldots \ldots \ldots \ldots$

Uniontown lock and dam $(5246) \ldots \ldots \ldots \ldots$. Niagara River control structure $(4026) \ldots . .$. Opossum Creek, ohio River $(3909) \ldots \ldots \ldots \ldots \ldots$ Ozark Lock and Dam, Arkansas River (523i)... Palo Seco Steam Plant (5025)............

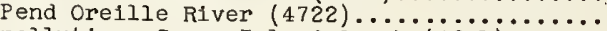
pollution, Coney Island Creek $(460 i j \ldots \ldots . . .$. Red River floodway inlet (4550)...........

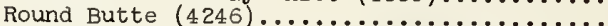

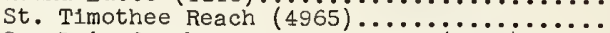
San Luis forebay pumping plant $(4954) \ldots . .$. seawall, Texas City, Texas (5234)......... sea water intrusion $(4921) \ldots \ldots \ldots \ldots \ldots \ldots$

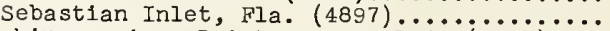
ship mooring, Point Loma, Calif. (524i).... sluicegates, downpull forces $(3900) \ldots . .$. . spillways

Oahe Reservoir, Mo. River, So.

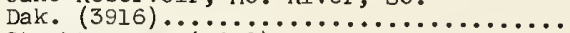

Stockton Dam $(5238) \ldots \ldots \ldots \ldots \ldots \ldots \ldots \ldots \ldots . \ldots \ldots \ldots$

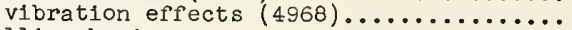
stilling basin

Huntingt on Reservoir, Wabash River (5232) submerged sills, St. Clair River (5233).... tunnel rock traps $(5046) \ldots \ldots \ldots \ldots \ldots \ldots . . . \ldots$

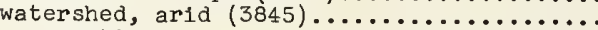
wave action

Half Moon Bay Harbor, Calif. (5237).....

Marina Del. Rey, Venice, Calif. (5239)...

Point Loma, Calif. (5241)............. Whiteshell Nuclear Research Establish-

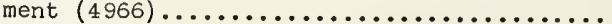

Model tests

diversion structure $(5084) \ldots \ldots \ldots \ldots \ldots$ energy dissipator

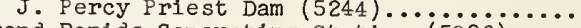
Grand Rapids Generating Station ( 5086$) \ldots . .$. hurricane barriers, Wareham-Marion,

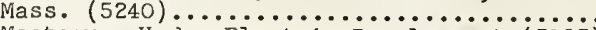
Mactaquac Hydro-Electric Development ( 5085 ) pillur dam scour vent $(5089) \ldots \ldots \ldots \ldots \ldots \ldots \ldots$ spillway, Calima II Hydro-Electric

Project $(5088) \ldots \ldots \ldots \ldots \ldots \ldots \ldots \ldots \ldots \ldots \ldots$
Model tests

spillways, general tests (3917).........

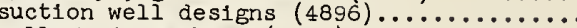
Wells Hydrocombine $(4724) \ldots \ldots \ldots \ldots \ldots \ldots \ldots$ Woodstock flood control reservolr (5083).. Model verification

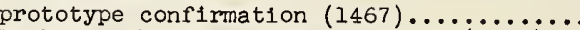
Rocky Reach Site, Columbia River (263i)... Southwest Pass, Miss. River (2931).......

Moisture regimes $(4327) \ldots \ldots \ldots \ldots \ldots \ldots \ldots \ldots \ldots$ Motions, nonlinear liquid $(4927) \ldots \ldots \ldots \ldots \ldots$ Noise, hydrodynamic $(1778) \ldots \ldots \ldots \ldots \ldots \ldots$

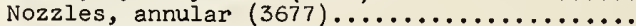
open channels

boundary layer growth $(5131) \ldots \ldots \ldots \ldots \ldots$ control cross waves $(4715) \ldots \ldots \ldots \ldots \ldots \ldots$ correction factors $(5175) \ldots \ldots \ldots \ldots \ldots \ldots \ldots$

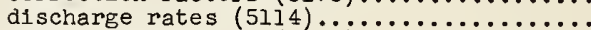
dispersion studies $(5074) \ldots \ldots \ldots \ldots \ldots \ldots \ldots \ldots$

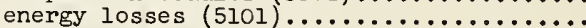
flow measurements $(4961) \ldots \ldots \ldots \ldots \ldots \ldots \ldots \ldots . . \ldots \ldots$ flow problems $(4076) \ldots \ldots \ldots \ldots \ldots \ldots \ldots \ldots \ldots$

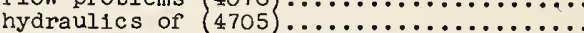
influence of roughnesses $(458 i j \ldots \ldots \ldots \ldots$ interference effects $(4692) \ldots \ldots \ldots \ldots \ldots \ldots$

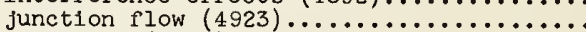

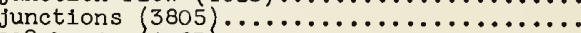

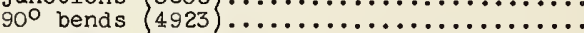

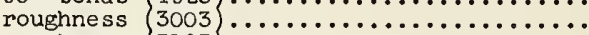

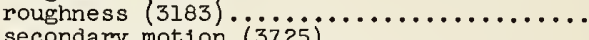

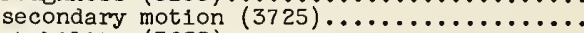

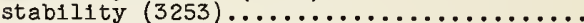
structure boundary growth $(5131) \ldots \ldots \ldots \ldots$

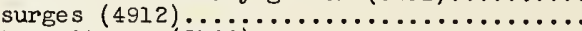

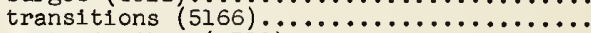

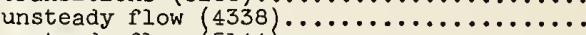
unsteady flow $(5144) \ldots \ldots \ldots \ldots \ldots \ldots \ldots \ldots$ velocity distribution $(2083) \ldots \ldots \ldots \ldots \ldots \ldots \ldots$
velocity profiles $(5101) \ldots \ldots \ldots \ldots \ldots \ldots \ldots \ldots$

orifice studies high head $(3996) \ldots \ldots \ldots \ldots \ldots \ldots \ldots \ldots \ldots \ldots$

orifices

basic research $(149) \ldots \ldots \ldots \ldots \ldots \ldots \ldots$

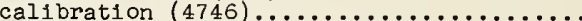
constant head turnout $(3274) \ldots \ldots \ldots \ldots \ldots$ discharge coefflcient $(5011) \ldots \ldots \ldots \ldots \ldots \ldots$

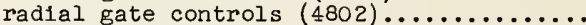

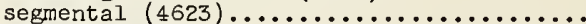

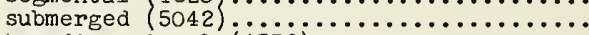

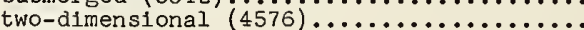
vortex flow $(1181) \ldots \ldots \ldots \ldots \ldots \ldots \ldots \ldots \ldots \ldots \ldots$ outlet works dams

Arbuckle $(4953) \ldots \ldots \ldots \ldots \ldots \ldots \ldots$

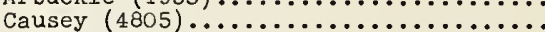

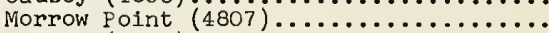

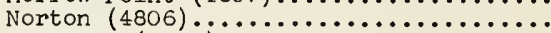
oroville $(4413) \ldots \ldots \ldots \ldots \ldots \ldots \ldots \ldots \ldots \ldots \ldots \ldots$ prototype tests, Nolin Dam $(5243) \ldots . .$. gate vibrations $(4522) \ldots \ldots \ldots \ldots \ldots \ldots \ldots \ldots \ldots$

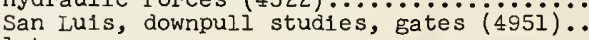
outlets

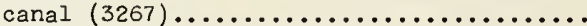

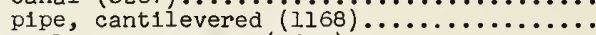

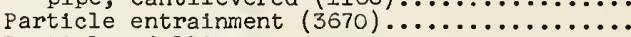
Particle, falling

Stokes drag (4173)

Particle measurement

light scattering $(4166) \ldots \ldots \ldots \ldots \ldots \ldots \ldots$

Particle study

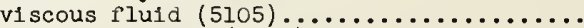

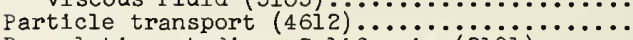

Percolation studies, California $(2 i 8 i j \ldots \ldots \ldots$

Pipe fittings

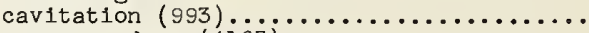
pressure drop $(4 i 67) \ldots \ldots \ldots \ldots \ldots \ldots \ldots \ldots \ldots \ldots$

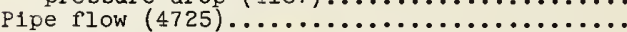

Pipeline systems

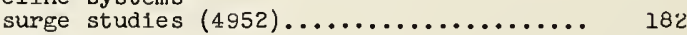
Plpes

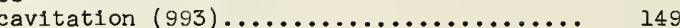

corrosion, prevention $(4135) \ldots \ldots \ldots \ldots \ldots \ldots$ flow measurement $(3525) \ldots \ldots \ldots \ldots \ldots \ldots \ldots \ldots$ flow of mixtures, liquid-solid $(227 \bar{j}) \ldots \ldots$

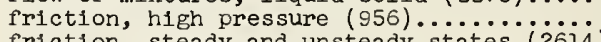

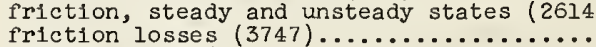
joint leakage $(5100) \ldots \ldots \ldots \ldots \ldots \ldots \ldots \ldots \ldots \ldots$

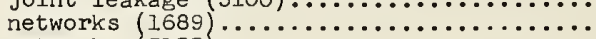

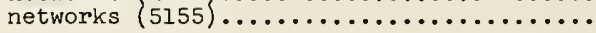

157 
P1pes

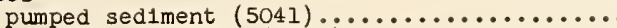

resonance studies $(4946) \ldots \ldots \ldots \ldots \ldots \ldots \ldots$

sand-water m1xtures $(4564) \ldots \ldots \ldots \ldots \ldots \ldots$. . . .

turbulent flow $(4640) \ldots \ldots \ldots \ldots \ldots \ldots \ldots \ldots \ldots$

unsteady flow $(5029) \ldots \ldots \ldots \ldots \ldots \ldots \ldots$

Pipes, corrugated

roughness study $(3597) \ldots \ldots \ldots \ldots \ldots \ldots \ldots$

Playa survey $(5216) \ldots \ldots \ldots \ldots \ldots \ldots \ldots \ldots \ldots \ldots \ldots \ldots$ Plumbing

backflow prevention $(4043) \ldots \ldots \ldots \ldots \ldots \ldots$

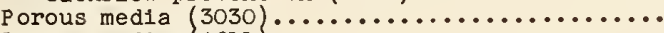

Porous medla $(4611\} \ldots \ldots \ldots \ldots \ldots \ldots \ldots \ldots \ldots \ldots \ldots \ldots \ldots \ldots$

Porous media

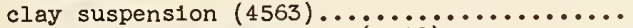

dispersion, mechanics of $(3748) \ldots \ldots \ldots \ldots \ldots$

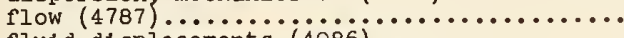

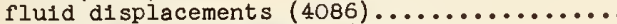

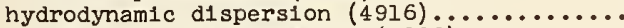

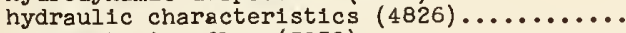

non-Newton 1 an flow $(5038) \ldots \ldots \ldots \ldots \ldots \ldots \ldots$

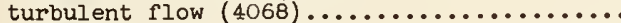

unsteady flow $(4736) \ldots \ldots \ldots \ldots \ldots \ldots \ldots$

unsteady flow equations $(5039) \ldots \ldots \ldots \ldots \ldots$

Porous medium

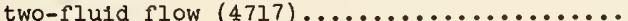

Precipltation

disposition, small watersheds (4836)........

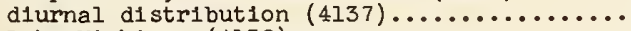

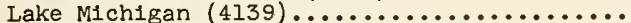

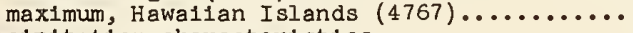

Precipitation characteristics

effect hydrology $(5222) . \ldots \ldots \ldots \ldots \ldots \ldots$.

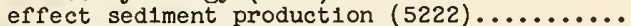

Precipitation distribution

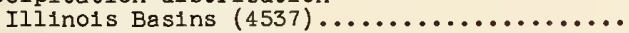

Pressure distribution

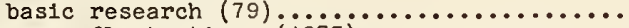

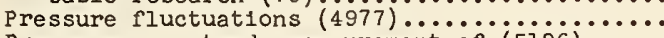

Pressures, unsteady measurement of $(5186) \ldots . .$. Propellers

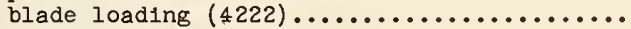
counter rotating

relative flow at lifting line (4919)....

design method $(4918) \ldots \ldots \ldots \ldots \ldots \ldots \ldots \ldots$

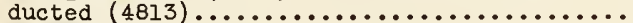

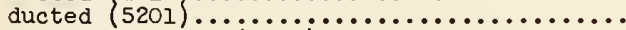

flow distortion $(3487) \ldots \ldots \ldots \ldots \ldots \ldots \ldots$

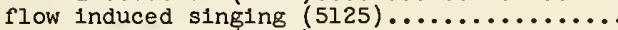

low p1tch angle $(5057) \ldots \ldots \ldots \ldots \ldots \ldots$

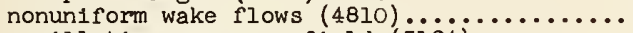

oscillating pressure field $(5 i 24) \ldots \ldots \ldots \ldots$.

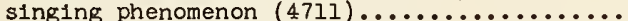

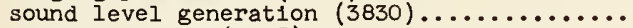

spindle torque $(4427) \ldots \ldots \ldots \ldots \ldots \ldots \ldots$

study of induced vibratory forces $(5 i 2 i) . .$. .

supercavitating $(3286) \ldots \ldots \ldots \ldots \ldots \ldots \ldots \ldots$

torque $(5061) \ldots \ldots \ldots \ldots \ldots \ldots \ldots \ldots \ldots \ldots \ldots$

transient forces $(2616) \ldots \ldots \ldots \ldots \ldots \ldots \ldots \ldots$

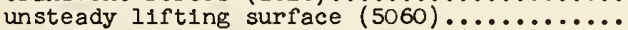

unsteady lifting surface theory (5057)......

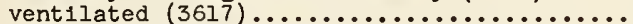

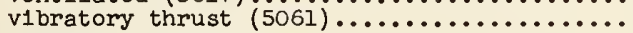

Propellers, ducted

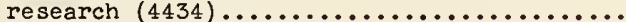

stern-mounted $(5200) \ldots \ldots \ldots \ldots \ldots \ldots \ldots \ldots \ldots$

Propellers, theory

lifting (2237)

Propellers, vertical axis

performance characterist1cs (3619).........

Prototype check tests

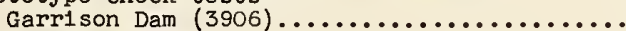

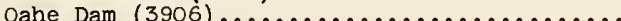

Pump systems

dredge $(4156) \ldots \ldots \ldots \ldots \ldots \ldots \ldots \ldots \ldots \ldots \ldots \ldots$

Pumps

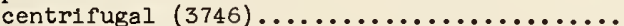

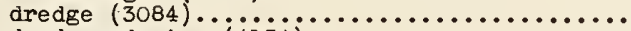
dredge, design $(4 i 54) \ldots \ldots \ldots \ldots \ldots \ldots \ldots \ldots \ldots$

Pumps, dredge

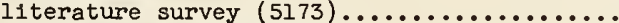

performance study $(5174, \ldots \ldots \ldots \ldots \ldots \ldots \ldots \ldots$

Pumps, 1mpeller design $(3442) \ldots \ldots \ldots \ldots \ldots \ldots \ldots$

Pumps, jet, for sediment $(3673) \ldots \ldots \ldots \ldots \ldots \ldots$.

Pumps, water-column separation (4425)..........

Pumps, dredging

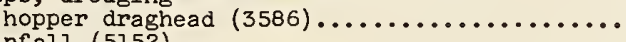

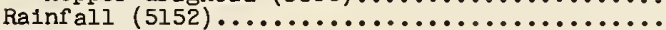

Rainfal

collection ano storage (3873)
Rainfall

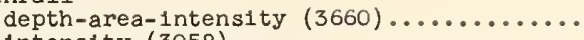

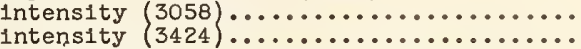

intensity-kinetic energy relation-

ship (4278)

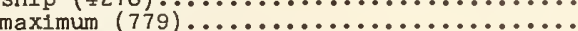

maximum (2788)

ralnfall-munof $(68) \ldots \ldots \ldots \ldots \ldots \ldots \ldots \ldots$ rainfall-runoff

rainfall-runoff

rainfall-munoff

rainfall-runoff

rainfall-runoff

rainfall-runoff

rainfall-runoff

rainfall-munoff

768

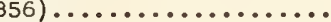

$2162) \ldots \ldots \ldots \ldots \ldots \ldots \ldots$

$2561, \ldots \ldots \ldots \ldots \ldots \ldots \ldots$

3808
4054

$4054, \cdots \cdots \cdots \cdots \cdots \cdots$

$\left(\begin{array}{l}408 \\ 4348, \ldots \ldots \cdots \cdots \cdots \cdots \cdots \cdots \cdots\end{array}\right.$

$4352\}$

rainfall-runof $f$ relations (2397) .........

records (2534) . .......

Tennessee River Basin $(768) \ldots \ldots \ldots \ldots \ldots \ldots$

Rainfall measurements

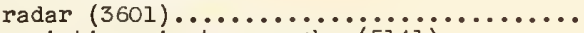

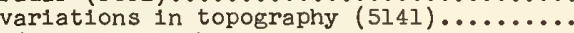

Rainfall, research

Intensity $(3251) \ldots \ldots \ldots \ldots \ldots \ldots \ldots \ldots \ldots \ldots \ldots \ldots$

Intensity $(3419)$........ 3 orth Central wisconsin $(4733) \ldots \ldots \ldots \ldots$

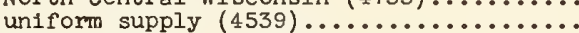

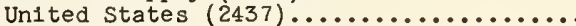

Rainfall-munof $f$

frequency relationship $(4910) \ldots \ldots \ldots \ldots$

Reservolrs

application monolayer-forming

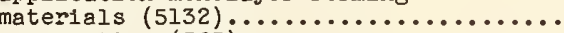

evaporation $(765) \ldots \ldots \ldots \ldots \ldots \ldots \ldots \ldots \ldots \ldots$

evaporation $(2180) . . . \ldots \ldots \ldots \ldots \ldots \ldots$.

evaporation $(4234) \ldots \ldots \ldots \ldots \ldots \ldots \ldots$

evaporation, retardation (2532)......... retarding-type $(4305) \ldots \ldots \ldots \ldots \ldots \ldots$

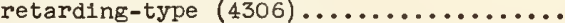

sediment distribution (4306)..............

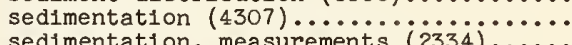

sedimentation, measurements $(2334)$......

silting

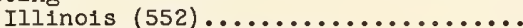

temperature gaging (769).............

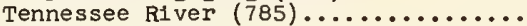

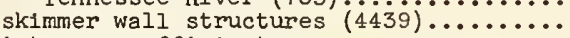
Resistance coefficients

drains (4541)..........

River regime characteristics (3031).......

River regime studies (4922)................. Roughness

artificial channels (2950).............

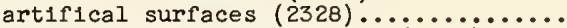

effect of water temperature (i988)........... Runoff

off

changes in meadow

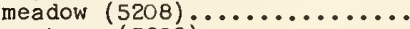

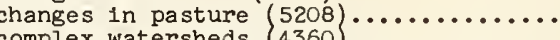
conservation farmed watersheds $(4300) .$. control $(4323)$........................... conventionally farmed watersheds (4300).

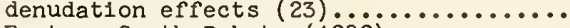

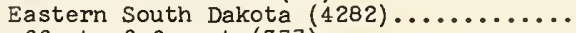
effect of forest $(377) \ldots \ldots \ldots \ldots \ldots \ldots$ loss mea surement $\left\{\begin{array}{l}4286 \\ 4357\end{array} \ldots \ldots \ldots \ldots \ldots \ldots \ldots \ldots \ldots\right.$

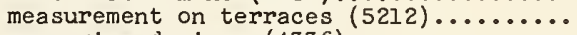

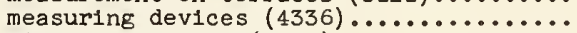
m1dwest claypans $(4281) \ldots \ldots \ldots \ldots \ldots \ldots \ldots$

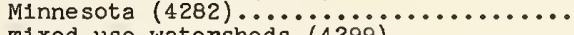

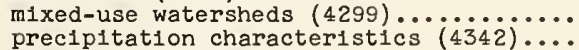

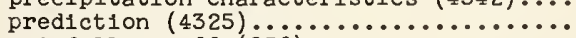
rainfall-runoff $(856) \ldots \ldots \ldots \ldots \ldots \ldots$

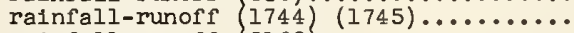
rainfall-runoff $\left\{\begin{array}{l}2162 \\ 2331\end{array} \ldots \ldots \ldots \ldots \ldots \ldots \ldots\right.$ rainfall-runoff $2331, \ldots \ldots \ldots \ldots \ldots \ldots$ $\begin{aligned} & \text { rainfall-munoff } \\ & \text { rainfall-runoff }\end{aligned} \quad 2334, \ldots \ldots \ldots \ldots \ldots \ldots \ldots \ldots$ rainfall-runoff rainfall-munoff relations $(2397) \ldots . . . \cdots$ rangeland $(4301) \ldots \ldots \ldots \ldots \ldots \ldots \ldots \ldots$

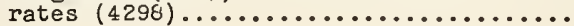
rates $(4330) \ldots \ldots \ldots \ldots \ldots \ldots \ldots \ldots \ldots \ldots \ldots$.

202

101

194

34

41
194

44

83

54

202

22
119

120

84

194

194

168

168

34
94

38

168

39

88

194

84

33

113

108

108
102

40

32

194

192

38

18
196

171

41

151

176

116

110

110

107

114

107

102

138

104

120

122

118

102

102

107

119

114 
Runoff

semiarid watersheds $(4359) \ldots \ldots \ldots \ldots \ldots \ldots$ small areas $(1946) \ldots \ldots \ldots \ldots \ldots \ldots \ldots \ldots \ldots$

small watersheds $(2492) \ldots \ldots \ldots \ldots \ldots \ldots \ldots$

small watersheds $(2841) \ldots \ldots \ldots \ldots \ldots \ldots \ldots$

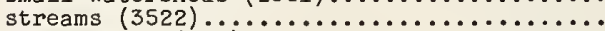

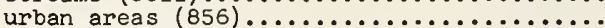

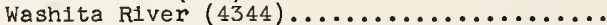

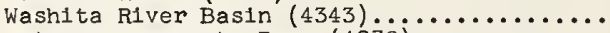

water management, Iowa $(4279) \ldots \ldots \ldots \ldots \ldots$

watersheds $(4344) \ldots \ldots \ldots \ldots \ldots \ldots \ldots \ldots$.

watersheds

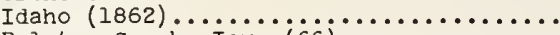
Ralston Creek, Iowa $(66) \ldots \ldots \ldots \ldots \ldots \ldots$

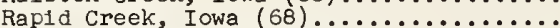

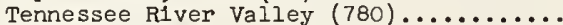

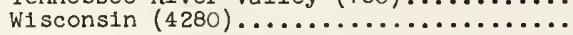
Runoff measurement

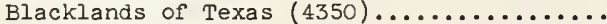

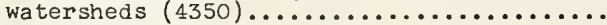
Runoff production

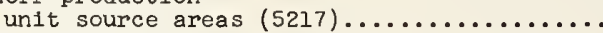
Runoff studies

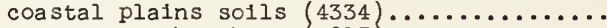
Eastern South Dakota $(4817\} \ldots \ldots \ldots \ldots \ldots \ldots$ southern Piedmont $(4333) \ldots \ldots \ldots \ldots \ldots \ldots \ldots$.

Salt infiltration

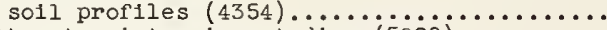

Salt-water intrusion studies $(5028) \ldots \ldots \ldots \ldots$. Salt-water intmusion studies

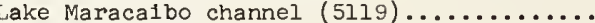

Sand transport

by winds $(4895) \ldots \ldots \ldots \ldots \ldots \ldots \ldots \ldots \ldots$

scour

bridges (4626).

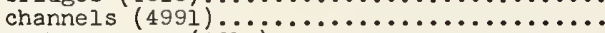
Sediment

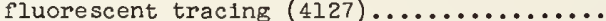

mechanics of dune $(5118) \ldots \ldots \ldots \ldots \ldots \ldots$

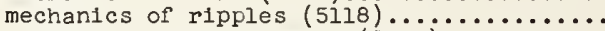

radioactive tracer tests (3902)............

radioactive tracer tests $(4600) . . . \ldots$.....

radio-carbon dating $(5210) \ldots \ldots \ldots \ldots \ldots \ldots . . . . . . .$.

reduction sediment load $(482 i) \ldots \ldots \ldots \ldots \ldots$.

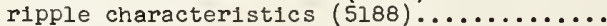

routing $(4320) \ldots \ldots \ldots \ldots \ldots \ldots \ldots \ldots \ldots \ldots$

Sediment barrier

Sheep Creek, Utah (3976)...............

sediment, cohesive

scour resistance (2874)................

Sediment control

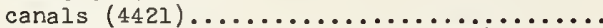

lower conifer zone of Calif. (4998).........

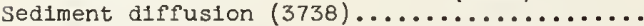
Sediment, fluvial

distribution, radioactive wastes (5076)....

sediment measurement

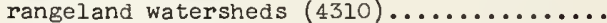
watersheds $(5207) \ldots \ldots \ldots \ldots \ldots \ldots \ldots \ldots$.

sediment movement

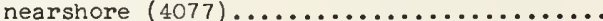

sediment particles, movement $(4625) \ldots \ldots \ldots \ldots$.

Sediment particles

velocities (4064)

sediment, removal

muddy playa lake water $(5214) \ldots \ldots \ldots \ldots$...

Sediment, suspended

Washita River Basin, Okla. (4340)........

Sediment transport $(3675) \ldots \ldots \ldots \ldots \ldots \ldots \ldots \ldots$

Sediment transport $\{3871\} \ldots \ldots \ldots \ldots \ldots \ldots \ldots \ldots \ldots \ldots$

Sediment transport $5_{034}\{\ldots \ldots \ldots \ldots \ldots \ldots \ldots \ldots \ldots$

Sediment transport $(5165) \ldots \ldots \ldots \ldots \ldots \ldots \ldots \ldots \ldots$

Sediment transport

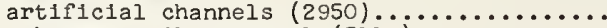

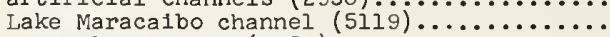

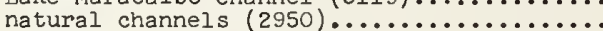

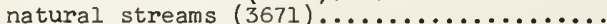

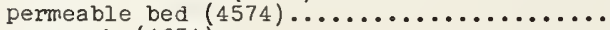

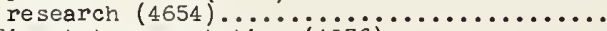

sediment transportation $(4076) \ldots \ldots \ldots \ldots \ldots . . . . . .$.

Sediment transportation

bed load, wave action, effect (1823).......

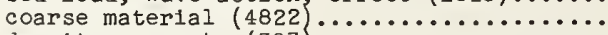

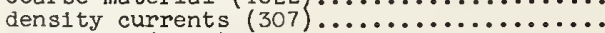

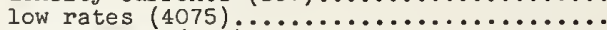

measurement $(194) \ldots \ldots \ldots \ldots \ldots \ldots \ldots \ldots$.

suspended load, measurement $(i 9 i j \ldots \ldots \ldots . . . . . .$.

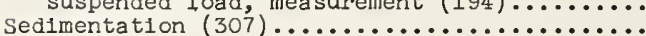

Sedimentation $(4190) \ldots \ldots \ldots \ldots \ldots \ldots \ldots \ldots$

arid regions (4404)....................

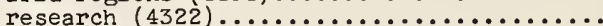

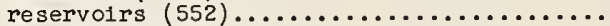

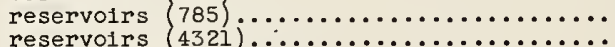

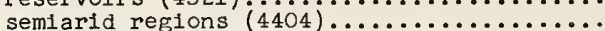

So. Saskatchewan Reservoir (4548)..........

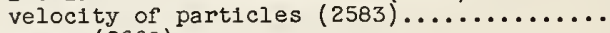

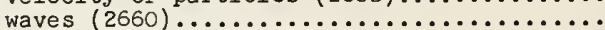

Sedimentation basins $(3541) \ldots \ldots \ldots \ldots \ldots \ldots$.

sedimentation basins

flow stability (4669)..................

Sedimentation studies

Sabetha Lake watershed $(4304) \ldots \ldots \ldots \ldots$...

sediments, cohesive

entrainment (4655)....................

Seepage

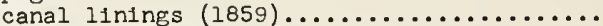

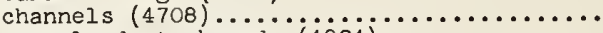

rangeland stockponds $(4824) \ldots \ldots \ldots \ldots \ldots$.

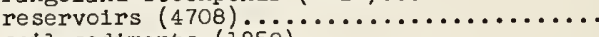

soil sediments $(1859) \ldots \ldots \ldots \ldots \ldots \ldots \ldots \ldots$

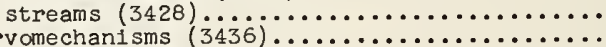

Servomechanisms

underwater missile (4678)

Sewer drop shaft

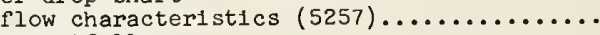

sewer outfalls

ocean (3678)

Sewerage systems

Ships

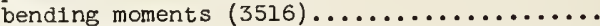

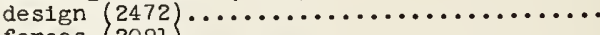

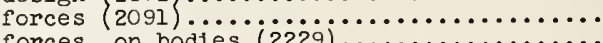

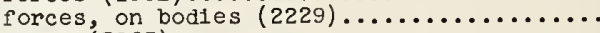

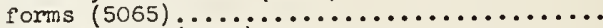

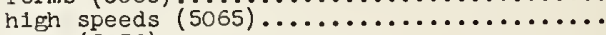

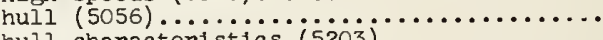

hull characteristics $(5203) \ldots \ldots \ldots \ldots \ldots \ldots$

hull form design $(4426) \ldots \ldots \ldots \ldots \ldots \ldots$.

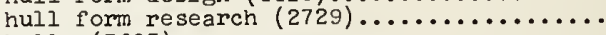

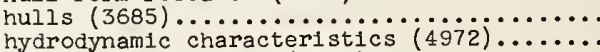

hydrofoll supported $(4812) \ldots \ldots \ldots \ldots \ldots \ldots$

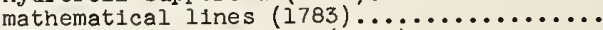
model testing facility $(3292) \ldots \ldots \ldots \ldots \ldots \ldots$

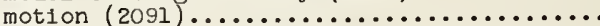
motion $2154\{(2155) \ldots \ldots \ldots \ldots \ldots \ldots \ldots \ldots \ldots$ motion $3686\{\ldots \ldots \ldots \ldots \ldots \ldots \ldots \ldots \ldots \ldots \ldots$ motion $4083\{\ldots \ldots \ldots \ldots \ldots \ldots \ldots \ldots \ldots \ldots \ldots \ldots$

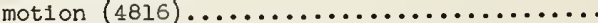

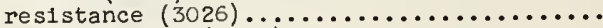
seaworthiness $(2230) \ldots \ldots \ldots \ldots \ldots \ldots \ldots \ldots \ldots$. slamming (1786)

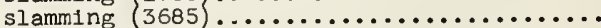

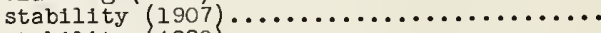
stability $(4220) \ldots \ldots \ldots \ldots \ldots \ldots \ldots \ldots \ldots \ldots \ldots$ stabilization tanks $(4702) \ldots \ldots \ldots \ldots \ldots \ldots \ldots$

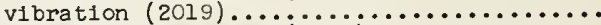

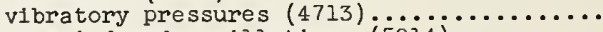

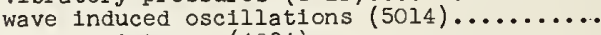
wave resistance $(4084) \ldots \ldots \ldots \ldots \ldots \ldots \ldots \ldots$

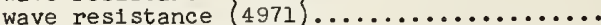
wave resistance $5055, \ldots \ldots \ldots \ldots \ldots \ldots \ldots$. wave resistance $5056\{\ldots \ldots \ldots \ldots \ldots \ldots \ldots \ldots \ldots$ wave resistance $(5202\} \ldots \ldots \ldots \ldots \ldots \ldots \ldots \ldots \ldots$ wave tests $(1907) \ldots \ldots \ldots \ldots \ldots \ldots \ldots \ldots$.

Ships, hull

wave-resistance reduction $(5063) \ldots \ldots \ldots$. Ships

motion, investigation of (5064)...........

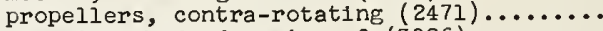

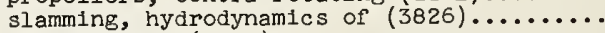
Shore processes $(2192) \ldots \ldots \ldots \ldots \ldots \ldots \ldots \ldots \ldots \ldots$. Shore protection

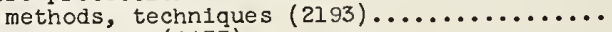
structures $(4477) \ldots \ldots \ldots \ldots \ldots \ldots \ldots \ldots \ldots$.

silting

harbors north shore of Lake ontario (3364). reservolrs

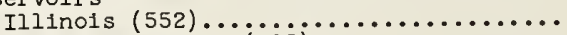

Tennessee Valley $(785) \ldots \ldots \ldots \ldots \ldots \ldots$ Siphons

terraces $(5212) \ldots \ldots \ldots \ldots \ldots \ldots \ldots \ldots \ldots \ldots$.

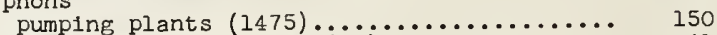

sluice gates, cavitation $(79) \ldots \ldots \ldots \ldots \ldots \ldots \ldots . .41$ 
Sluice gates

Lockport

$(3425)$

Sluiceways

dams

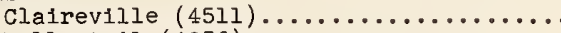

Yellowtail $(4956) \ldots \ldots \ldots \ldots \ldots \ldots \ldots$

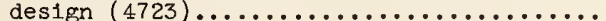

slurries

coal-water $(4436) \ldots \ldots \ldots \ldots \ldots \ldots \ldots \ldots$

Snow surveys $(3895) \ldots \ldots \ldots \ldots \ldots \ldots \ldots \ldots \ldots \ldots$

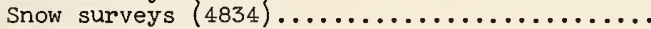

Snow surveys

accumulation $(4837) \ldots \ldots \ldots \ldots \ldots \ldots \ldots$

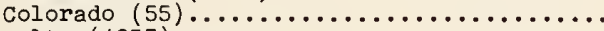

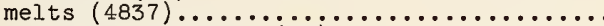

runoff forecasting $(55) \ldots \ldots \ldots \ldots \ldots \ldots$

Snow water content

measurement $(3416)$...

Snowmelt characteristics

western white pine forest (4993).........

Soll molsture

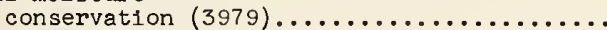

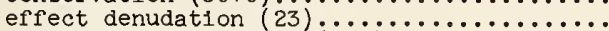

effect timber cutting $(377) \ldots \ldots \ldots \ldots \ldots \ldots . .$.

forest influences $(380) \ldots \ldots \ldots \ldots \ldots \ldots \ldots \ldots$

forest influences $(657\} \ldots \ldots \ldots \ldots \ldots \ldots \ldots \ldots$

movement $(3079) \ldots \ldots \ldots \ldots \ldots \ldots \ldots \ldots \ldots$

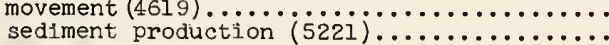

semiarid rangeland hydrology $(522 i) . . . \ldots$.

semidesert vegetation $(657) \ldots \ldots \ldots \ldots \ldots$

Soll molsture level

effect on evapotranspiration (4845) ........ plant growth $(4328) \ldots \ldots \ldots \ldots \ldots \ldots \ldots \ldots$

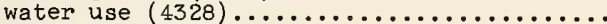

Soll molsture regimes

unglaciated Allegheny Plateau (4269)......

Soll mo1sture study $(4752) \ldots \ldots \ldots \ldots \ldots \ldots$

Solls

unsaturated flow characteristics (5220)...

Spheres

accelerated motion $(3432) \ldots \ldots \ldots \ldots \ldots \ldots$

Spillways

calibration, Rock Island Dam (4721).......

dams $(5068) \ldots \ldots \ldots \ldots \ldots \ldots \ldots \ldots \ldots \ldots \ldots$

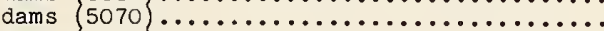

dams $(5113$ )

dams

Amistad (4398)

Angat (4694)

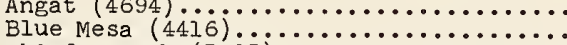

Chief Joseph (3085)

Flaming Gorge (2960) $\cdots \cdots \cdots \cdots \cdots \cdots$

Fort Randali Dam $(5250) \ldots \ldots \ldots \ldots \ldots$.

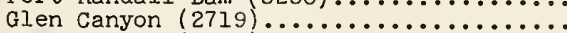

Joes Valley $(4808) \ldots \ldots \ldots \ldots \ldots \ldots \ldots \ldots \ldots \ldots$

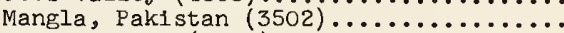

Morrow Point $(4807) \ldots \ldots \ldots \ldots \ldots \ldots \ldots$

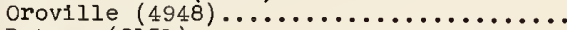

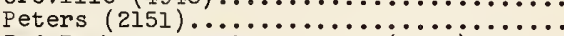

Red Rock, Des Moines River $(3584) \ldots . .$.

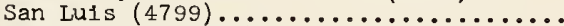

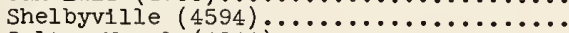

Sultan No. I $(4244) \ldots \ldots \ldots \ldots \ldots \ldots \ldots . . .6$.

Wells $(3534)$

Whi skeytown $(4 i 19 j \ldots \ldots \ldots \ldots \ldots \ldots \ldots \ldots \ldots \ldots \ldots \ldots$

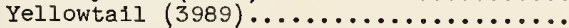

Yellowtall (4956)

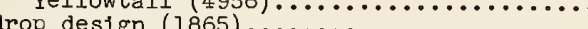

$\ldots \ldots \ldots \ldots$

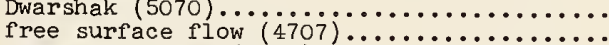

Green Peter Dam $(4380) \ldots \ldots \ldots \ldots \ldots \ldots \ldots$

Karnafuli (4697)

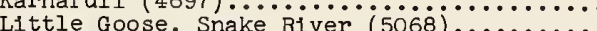

Mossyrock $(5113) \ldots \ldots \ldots \ldots \ldots \ldots \ldots \ldots \ldots$

Proctor Reservoir $(4384 j \ldots \ldots \ldots \ldots \ldots \ldots \ldots$

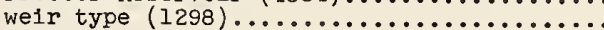

spur dikes

design criteria $\left\{\begin{array}{l}3086 \\ \text { design criteria }\end{array}\left(\begin{array}{l}4645 \\ \ldots\end{array} \ldots \ldots \ldots \ldots \ldots \ldots \ldots \ldots \ldots\right.\right.$

Stilling basins

dams, San Luis $(4800) \ldots \ldots \ldots \ldots \ldots \ldots \ldots$

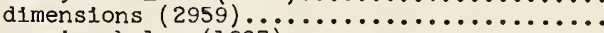

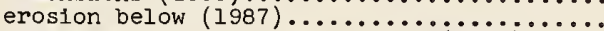

performance, Navajo Main Canal $(4950) . .$. ...

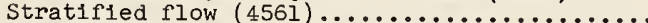

Stratifled flow

mechanics of (307)

Stratified fluids

flow (4252)
198

182

90

178

141.

111

111
18

111

18

31

131

175

138

141

139

1

128

139

121

115

115

100

130

128

42

90

148

148

159

72

180
46

178

166

178

181

181

182

75
153

181

160

90

180

179

182

33
148

76
147

147

148

91
158

203

181

178
150

182

48

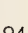

94
Stream gaging

Tennessee Valley $(769) \ldots . . \ldots \ldots \ldots \ldots \ldots$

194

reambeds, salmon-producing

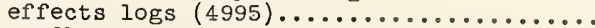

134

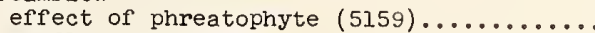

Streamflow, low flows

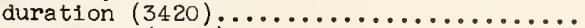

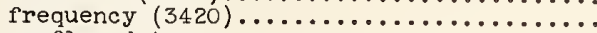

Streamflow data

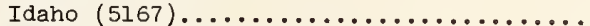

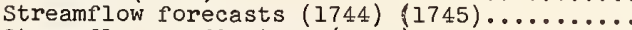

Streamflow predictions $(4313) \ldots \ldots \ldots \ldots \ldots \ldots$.

Stream flow studies

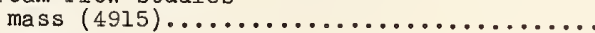

Streams

bed material $(4730) \ldots \ldots \ldots \ldots \ldots \ldots \ldots$

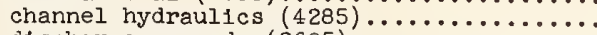

discharge records $(2695) \ldots \ldots \ldots \ldots \ldots \ldots \ldots \ldots \ldots$

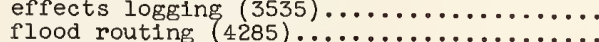

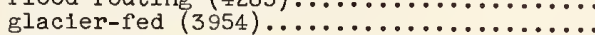

stage discharge, Iowa $(67) \ldots \ldots \ldots \ldots \ldots . . . .$.

Structures

conservation $(1723) \ldots \ldots \ldots \ldots \ldots \ldots \ldots$

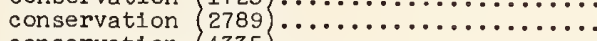

conservation $(4335, \ldots \ldots \ldots \ldots \ldots \ldots \ldots \ldots$

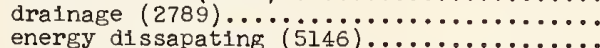

energy dissapating $(5 i 46) \ldots \ldots \ldots \ldots \ldots \ldots$

farm irrigation $(5130) \ldots \ldots \ldots \ldots \ldots \ldots \ldots .$.

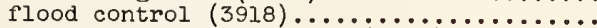

flood control, design of $(5012) \ldots \ldots \ldots \ldots$

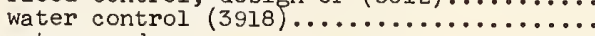

structures, drop

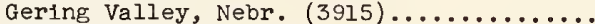

surface water

storage, farms $(4841) \ldots \ldots \ldots \ldots \ldots \ldots \ldots$

supply, farms (4841)

Surge studies

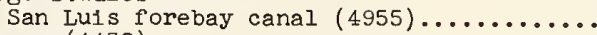

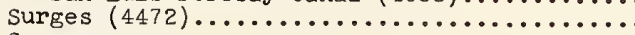
surges

dry bed (5143)

Tidal flow

bays ( 4701 )

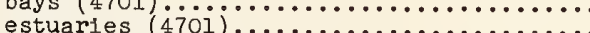

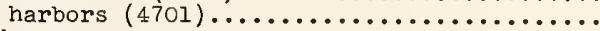

Tides

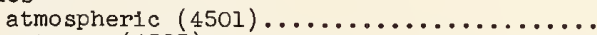

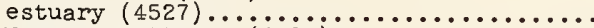

Narragansett Bay $(2680) \ldots \ldots \ldots \ldots \ldots \ldots$

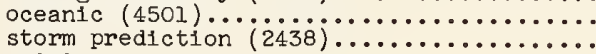

Transition

laminar and turbulent $(5098) \ldots \ldots \ldots \ldots$.

supercritical velocities $(2386) \ldots \ldots \ldots \ldots$.

Transpiration retardation $(3732) \ldots \ldots \ldots \ldots$.

Transport processes

atmosphere $(5160) \ldots \ldots \ldots \ldots \ldots \ldots \ldots \ldots$

Tubes $(3689) \ldots$
Tubes, vertical

condensation (5151)

Tunnel boundaries

effect on measured forces $(4181) \ldots \ldots \ldots$.

Tunnels

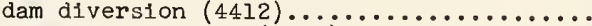

water air content $(2603) \ldots \ldots \ldots \ldots \ldots \ldots \ldots$

Turbines

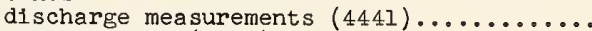

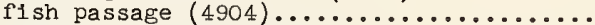

vibration studies $(5005) \ldots \ldots \ldots \ldots \ldots \ldots \ldots$.

Turbulence, controlled $(5169) . . . \ldots \ldots \ldots \ldots \ldots$

Turbulence

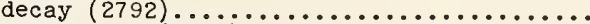

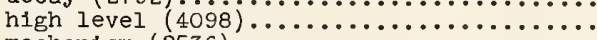

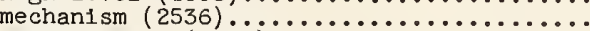

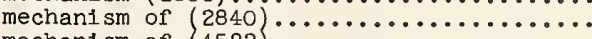

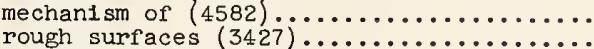

rough surfaces $(3427) \ldots \ldots \ldots \ldots \ldots \ldots \ldots \ldots$
structure $(4582) \ldots \ldots \ldots \ldots \ldots$

structure of $(4606) \ldots \ldots \ldots \ldots \ldots \ldots \ldots \ldots \ldots . .$.

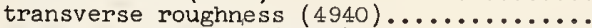

water measurements $(3486) \ldots \ldots \ldots \ldots \ldots \ldots$.

Turbulence entrainment $(3670) \ldots \ldots \ldots \ldots \ldots \ldots . . . . . . .$.

Turbulence, generation

pulsating viscous flow $(3780) \ldots \ldots \ldots \ldots$.

Turbulence intensity,

mea surement of (4656).

Turbulence levels

mea surement of (3539)

34

32

167

111

92

170

92
103

172

41

99

36
118

118
36

10

88

157
170

157

156

116

116

182

204

10

74

74
74

73

201

151

73
168

17

70
35

124

16

30

64 
Turbulence measurement

apparatus $(73) \ldots . .$.

Turbulence measurements

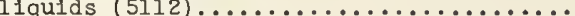

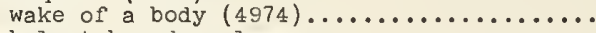

Turbulent boundary layers

computat1on method $(4872) \ldots \ldots \ldots \ldots \ldots \ldots$

rough surfaces $(4809) \ldots \ldots \ldots \ldots \ldots \ldots \ldots \ldots$

sound radiation $(5190) \ldots \ldots \ldots \ldots \ldots \ldots \ldots \ldots$

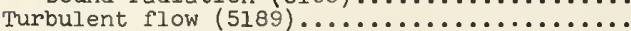

Turbulent flow

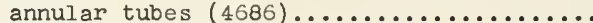

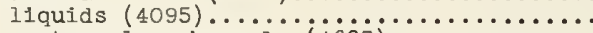

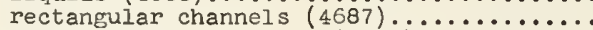

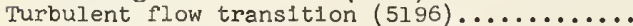

Turbulent liquids

gas absorpsion mechanism (4988).........

Turbulent structure

generated wake separating boundary

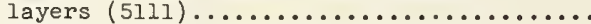

Turbulent transfer mechanics $(4649) \ldots \ldots \ldots \ldots$

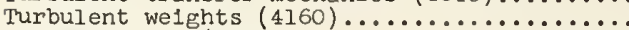

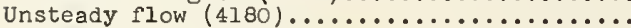

Velocity distribution

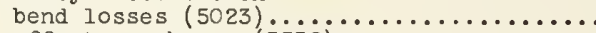

effect roughness $(3539) \ldots \ldots \ldots \ldots \ldots \ldots \ldots \ldots$

Veloclty measurement $(3074) \ldots \ldots \ldots \ldots \ldots \ldots \ldots$

Velucity measurement

electro-magnet1c $(73) \ldots \ldots \ldots \ldots \ldots \ldots \ldots$

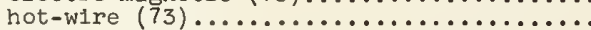

Velocity profile

turbulent fllow $(5073) \ldots \ldots \ldots \ldots \ldots \ldots \ldots \ldots$

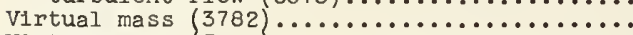

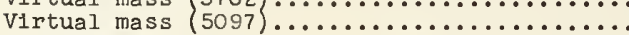

Virtual mass

partly submerged bodies $(4170) \ldots \ldots \ldots \ldots$. .

Vortex, drain-hole

formation (4945)

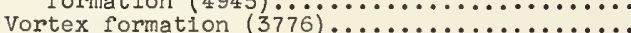

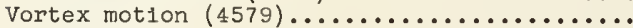

Vortex motion

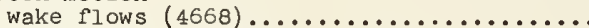

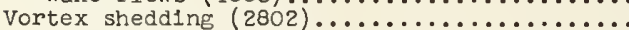

Vortex stretching $(4579) \ldots \ldots \ldots \ldots \ldots \ldots \ldots \ldots$

Vortices

outlet works $(5187) \ldots \ldots \ldots \ldots \ldots \ldots \ldots \ldots$

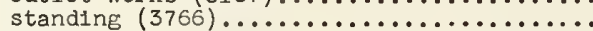
Water

structure of $(4569)$.

Water conservation $(3057) \ldots \ldots \ldots \ldots \ldots \ldots \ldots \ldots \ldots \ldots \ldots \ldots \ldots \ldots \ldots \ldots \ldots \ldots$

Water conservation facilities

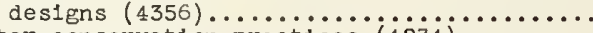

Water conservation practices $(4274) \ldots \ldots \ldots \ldots$

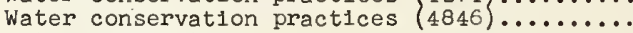

Water consumption

residential ( 3437 )

Water, consumptive use

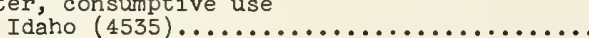

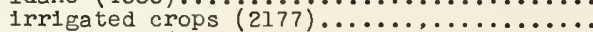

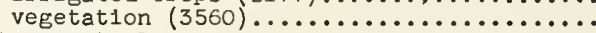

Water control

southern Pledmont $(4331) \ldots \ldots \ldots \ldots \ldots \ldots$

Water control facilities, design $(i 723) \ldots . .$.

Water discharge measurements

chemlcal traces $(5219) \ldots \ldots \ldots \ldots \ldots \ldots \ldots$

Water distribution systems $(4538) \ldots \ldots \ldots \ldots \ldots$

Water entry

high velocity $(4867) \ldots \ldots \ldots \ldots \ldots \ldots \ldots \ldots$

Water exit

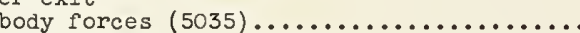

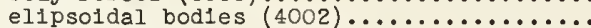

Water flow tests

h1gh pressure $(4001) \ldots \ldots \ldots \ldots \ldots \ldots \ldots \ldots$

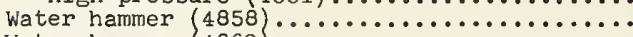

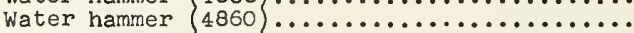

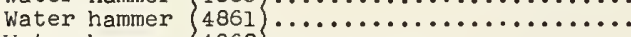

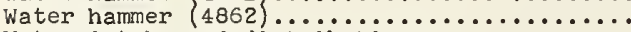

Water intake and distribution

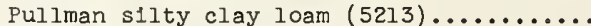

Water loss

brushland solls $(5000) \ldots \ldots \ldots \ldots \ldots \ldots \ldots \ldots$

Water management

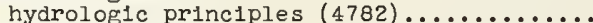

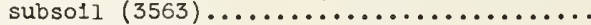

Water measurement

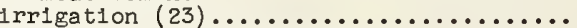

northwestern range watersheds $(4312) \ldots \ldots$

rangeland watersheds $(4310) \ldots . . \ldots \ldots \ldots . . .$.

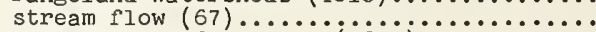

water movement, flow $\mathrm{i}$ aws $(4679) \ldots \ldots \ldots \ldots \ldots$
68

16
68

97

59

67

50
50

63

95

93

41

41

176
Water movement

recharge installations $(4592) \ldots \ldots \ldots \ldots \ldots$

marshlands $(3530) \ldots \ldots \ldots \ldots$

Water resources englneering $(4572) \ldots \ldots \ldots \ldots$

water resources planning $(5115) \ldots \ldots \ldots \ldots \ldots \ldots$

Water resources problems

Latin America (5116)

Water resources system $(4543) \ldots \ldots \ldots \ldots \ldots \ldots \ldots \ldots$ Water storage

brushland solls (5000).

Water, surface

characteristics $(3059) \ldots \ldots \ldots \ldots \ldots \ldots \ldots \ldots$

diversions $(4838) \ldots \ldots \ldots \ldots \ldots \ldots \ldots \ldots$

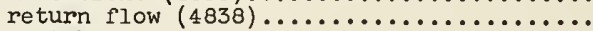

Water table

falling $(4832) \ldots \ldots \ldots \ldots \ldots \ldots \ldots \ldots \ldots \ldots$

Water tunnel

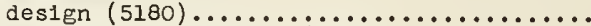

1sotropic-turbulence $(4580) \ldots \ldots \ldots \ldots \ldots \ldots$

Water use, industrial $(3734) \ldots \ldots \ldots \ldots \ldots \ldots$

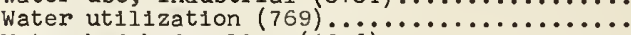

Watershed hydraulics $(4906) \ldots \ldots \ldots \ldots \ldots \ldots \ldots$

Watersheds

precipitation characteristics (4265).....

Watershed management

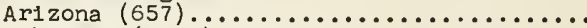

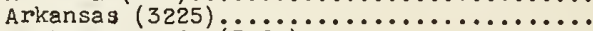

Baltimore, Md. $(3567) \ldots \ldots \ldots \ldots \ldots \ldots \ldots \ldots$

Continental Divide $(377) \ldots \ldots \ldots \ldots \ldots \ldots \ldots \ldots$

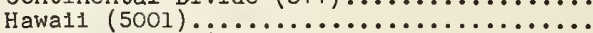

Laramie, wyo. $(3569) \ldots \ldots \ldots \ldots \ldots \ldots \ldots \ldots$

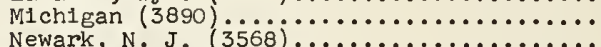

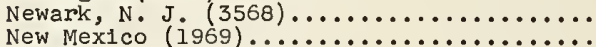

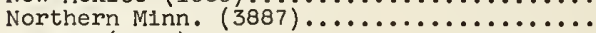

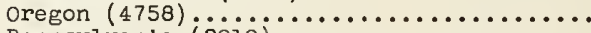

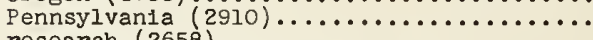

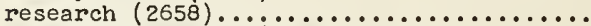

snowpack research $(4996) \ldots \ldots \ldots \ldots \ldots \ldots$

Southeastern United States $(380) \ldots \ldots \ldots \ldots$

Southwestern United States $(4999) \ldots \ldots \ldots \ldots$

Southeastern W1sconsin $(3889) \ldots \ldots \ldots \ldots \ldots$.

strip mined lands $(4753) \ldots \ldots \ldots \ldots \ldots \ldots \ldots$

Syracuse University $(4756) \ldots \ldots \ldots \ldots \ldots \ldots \ldots$

Tallahatchee Research Center $(29 i 4) \ldots \ldots \ldots$

Watershed management research

Fort Collins, Colorado (3896)............ 144

watershed studies

Blacklands of Texas $(4349) \ldots \ldots \ldots \ldots \ldots \ldots$

Blacklands of Texas $\{4351\} \ldots \ldots \ldots \ldots \ldots \ldots$

central Florida $(4329) \ldots \ldots \ldots \ldots \ldots \ldots \ldots$

effects logging $(2654) \ldots \ldots \ldots \ldots \ldots \ldots \ldots \ldots$

forest influences $(377) \ldots \ldots \ldots \ldots \ldots \ldots \ldots \ldots \ldots$

forest influences $(380) \ldots \ldots \ldots \ldots \ldots \ldots \ldots \ldots$

forest influences $(1188) \ldots \ldots \ldots \ldots \ldots \ldots \ldots$

hydrologic cycle $(2162) \ldots \ldots \ldots \ldots \ldots \ldots \ldots \ldots$

1deal flow field $\{5157\} \ldots \ldots \ldots \ldots \ldots \ldots \ldots \ldots$

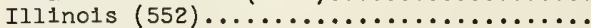

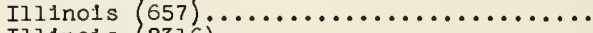

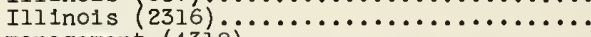

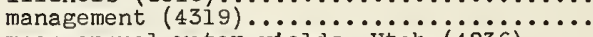

mean annual water yields, Utah $(4236) \ldots .$.

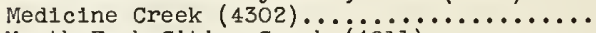

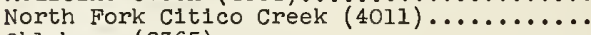

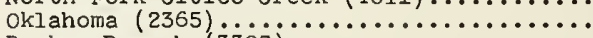

Parker Branch $(3307) \ldots \ldots \ldots \ldots \ldots \ldots \ldots$

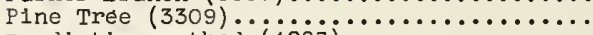

prediction method $(4287) \ldots \ldots \ldots \ldots \ldots \ldots \ldots$

Ralston Creek, Iowa $(66) \ldots \ldots \ldots \ldots \ldots \ldots \ldots \ldots$

Rapld Creek, Iowa $(68) \ldots \ldots \ldots \ldots \ldots \ldots \ldots$

Red Prairle of okla. (4339) .............

Reynolds Creek $(4314) \ldots \ldots \ldots \ldots \ldots \ldots \ldots$

munoff yields $(4364) \ldots \ldots \ldots \ldots \ldots \ldots \ldots \ldots \ldots \ldots$

sediment movement $(4365) \ldots \ldots \ldots \ldots \ldots \ldots \ldots$

sediment production $(4913) \ldots \ldots \ldots \ldots \ldots \ldots$

sediment ylelds $(4364) \ldots \ldots \ldots \ldots \ldots \ldots \ldots \ldots$ semlarid

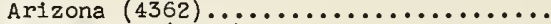

New Mexico $(4362) \ldots \ldots \ldots \ldots \ldots \ldots \ldots \ldots \ldots$

Sleepers river $(4288) \ldots \ldots \ldots \ldots \ldots \ldots \ldots \ldots$

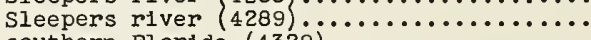

southern Florida $(4329) \ldots \ldots \ldots \ldots \ldots \ldots \ldots \ldots$

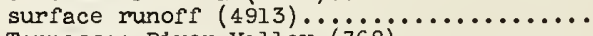

Tennessee Rlver Valley $(768) \ldots \ldots \ldots \ldots \ldots \ldots$

Tennessee River valley $(780) \ldots \ldots \ldots \ldots \ldots \ldots$

tracer techniques $(4324) \ldots \ldots \ldots \ldots \ldots \ldots \ldots$

turbulence structure $(41 j 0) \ldots \ldots \ldots \ldots \ldots$

unglaclated Allegheny Plateau $(4266) \ldots \ldots$

unglaciated Alleghey Plateau $(4267) \ldots \ldots$.... 
Watershed studies

Upper Bear Creek (4884) ............... 195

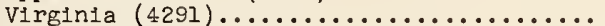

W. Va. Appalachian Valieys and

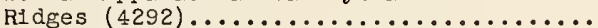

White Hollow $(3308) \ldots \ldots \ldots \ldots \ldots \ldots \ldots \ldots . \ldots \ldots$

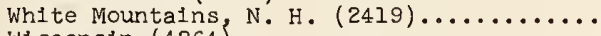

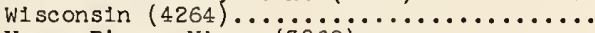

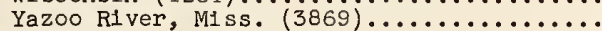

Watersheds

rainfall-munoff $(4907) \ldots \ldots \ldots \ldots \ldots \ldots$

Wave action

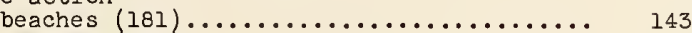

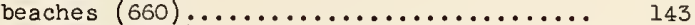

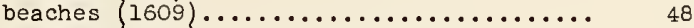

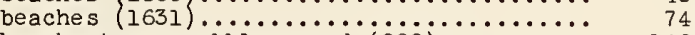

breakwaters, mubble-mound $(999) \ldots \ldots \ldots \ldots . . . . . . . . . . .149$

East Passage, Narragansett Bay (3590)..... 153

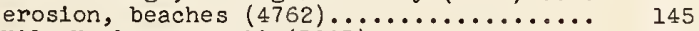

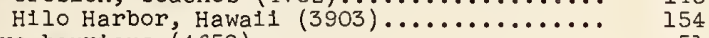

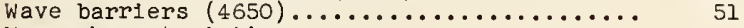

Wave characteristics

shoaling water (4990)................ 85

Wave forces

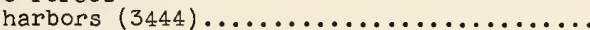

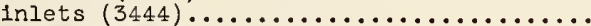

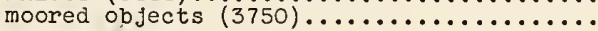
Wave overtopping

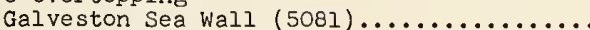

Wave propagation

turbulent l1quid $(4891) \ldots \ldots \ldots \ldots \ldots \ldots \ldots$

Wave run-up

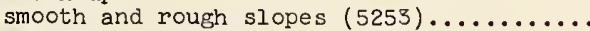

Wave setup

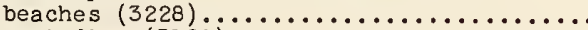

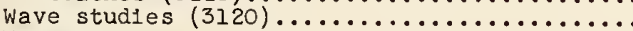

Waves

attenuation studies $(4502) \ldots \ldots \ldots \ldots \ldots \ldots$ energy dissipation $(5032) \ldots \ldots \ldots \ldots \ldots \ldots \ldots$ forces, submerged structures $(4728) \ldots . . . .$.

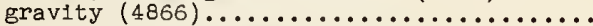

interaction problems $(5104) \ldots \ldots \ldots \ldots \ldots \ldots$

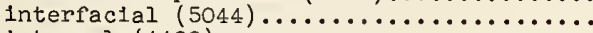

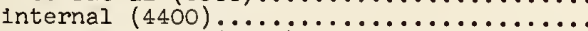

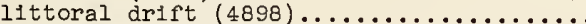

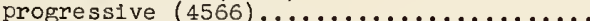

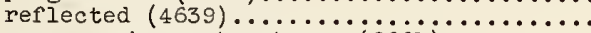

run-up, shore structures $(266 i) \ldots \ldots \ldots \ldots$

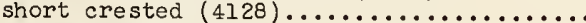

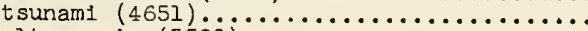

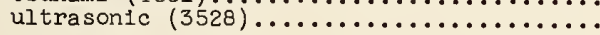

Waves, gravity

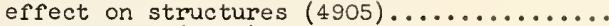

reflections $(4644) \ldots \ldots \ldots \ldots \ldots \ldots \ldots \ldots \ldots$

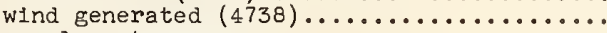

Waves, low steepness

reflection $(5010) \ldots \ldots \ldots \ldots \ldots \ldots \ldots \ldots$

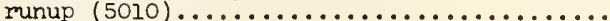

Waves, ocean

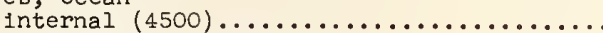

Waves, regular

deformation of (5066)

Waves, shallow water

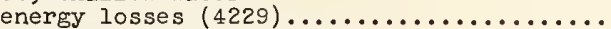

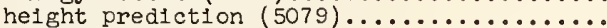

Waves, solitary

breakup $(4545) \ldots \ldots \ldots \ldots \ldots \ldots \ldots \ldots \ldots$

Waves, surface

characteristics, observed $(660) \ldots \ldots \ldots \ldots$

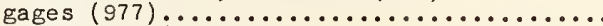

generation $(4) \ldots \ldots \ldots \ldots \ldots \ldots \ldots \ldots \ldots \ldots \ldots \ldots \ldots \ldots$

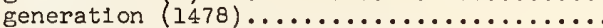

interaction of floating elastic

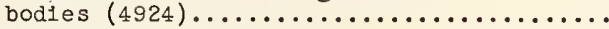

Waves, wind generated

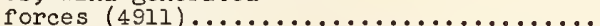

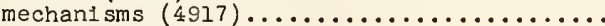

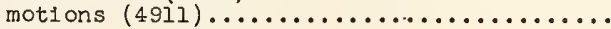

Weirs

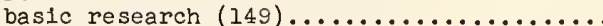

tailrace, effects on turbine

efflc1ency $(5087) \ldots \ldots \ldots \ldots \ldots \ldots \ldots \ldots \ldots$

Weirs, adjustable, discharge capacity $(36 i i j$.

We1rs, sharp-crested, flow (4088)........... Wells

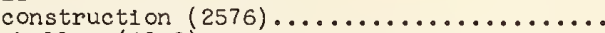

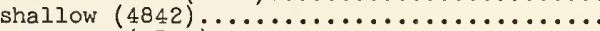

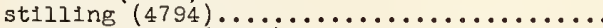

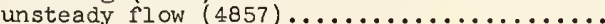

Wind action, pre-existing waves (5252).......

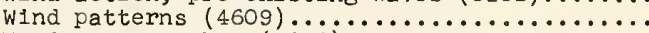

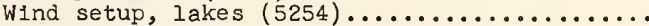

Wind tunnel tests

aerodynamic downwash of gases (5256)......

Wind, velocity $(4102) \ldots \ldots \ldots \ldots \ldots \ldots \ldots . . . \ldots$

Wind waves

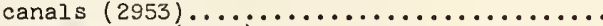

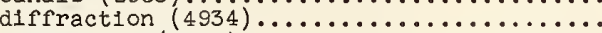

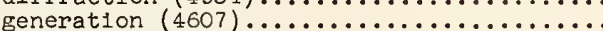

refraction $(4934) \ldots \ldots \ldots \ldots \ldots \ldots \ldots \ldots \ldots$

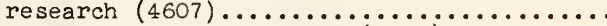

Windflow, stom, california $(4768) \ldots \ldots \ldots \ldots$ 



\section{Hydraulic Research in the United States}

Guides to projects conducted by various hydraulic and hydrologic laboratories in the United States and Canada during 1962 and 1963. Project reports cover work done at 86 private or State laboratories in the United States, 32 Federal laboratories, and 12 Canadian laboratories. These publications outline individual projects on nearly 200 subjects in the field.

Order:

NBS Miscellaneous Publication 245, Hydraulic Research in the United States, 1962, 196 pages. Price: $\$ 1.00$.

NBS Miscellaneous Publication 249, Hydraulic Research in the United States, 1963, 210 pages. Price: $\$ 1.00$. 
